\title{
Paulo-Guilherme D'Eça Leal: reflejos en la cultura visual portuguesa
}

Rute Sofia Pereira Bastardo Pinto

Director:

Dr. D. Carlos Plasencia Climent

Departamento de Dibujo

Facultad de Bellas-Artes de San Carlos

Universidad Politécnica de Valencia

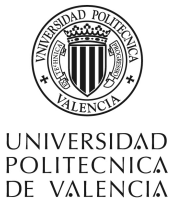




\section{Abstract - español}

La presente investigación está dedicada al estudio monográfico de la actividad del artista multidisciplinar Paul Guilherme D'Eça Leal (1932-2010), una personalidad polifacética que realizó una obra enorme, diversa y que constituye un importante legado para patrimonio artístico-cultural de los portugueses. El trabajo de campo, con la recopilación, inventario y estudio de los trabajos que constituyen el conjunto de su obra, permite dar a conocer su personalidad y evaluar sus aportaciones desde las influencias, experiencias, tendencias, métodos y limitaciones, así como analizar críticamente los aspectos más relevantes de su producción en las diferentes áreas artísticas a las que este versátil autor se dedicó durante seis décadas. Este estudio pone en valor la obra de este artista en el contexto del panorama artístico portugués del siglo XX, y la proyecta al XXI revelando informaciones inéditas de un autor cuyo trabajo no es lo suficientemente reconocido, ya que una parte significativa del mismo, nunca fue adecuadamente difundida. De este modo, tratamos de contribuir a la difusión de su obra, recopilándola y analizando su cuerpo principal, y defendiendo su consecuente preservación. Una parte importante de la investigación observa y analiza la interdisciplinariedad y transversalidad de los trabajos de Paul Guilherme D'Eça Leal, promoviendo la comprensión e interés de su producción en el contexto del panorama artístico de su época, evaluando su contribución y aportación a la cultura visual portuguesa del siglo XX. Examinar y advertir los aspectos claves de los proyectos y trabajos de este artista que se convirtieron en factores determinantes en la evolución de la imaginería moderna portuguesa, así como detectar los momentos y las obras principales donde se operaron sus cambios de estilo y sus procesos evolutivos. 


\section{Abstract - português}

A presente investigação dedica-se ao estudo monográfico da actividade do artista multidisciplinar Paulo Guilherme D'Eça Leal (1932-2010), uma personalidade multifacetada que realizou uma obra vasta, diversa e que constitui um importante legado para o património artístico-cultural português. $\mathrm{O}$ trabalho de investigação, pela compilação, inventário e estudo dos trabalhos que constituem o conjunto da sua obra, permite dar a conhecer a sua personalidade e avaliar as suas contribuições desde as influências, experiências, tendências, métodos e condicionalismos, assim como analisar criticamente os aspectos mais relevantes da sua produção nas diferentes áreas artística a que este autor polivalente se dedicou durante seis décadas. Este estudo objectiva valorar a obra deste artista no contexto do panorama artístico português do séc. XX e projectá-la para o séc. XXI, revelando a informação inédita de um autor cuja obra não é suficientemente reconhecida, uma vez que uma parte significativa desta, nunca foi devidamente difundida. Deste modo, contribuímos com a difusão da sua obra, reunindo e analisando o seu corpus e defendendo a sua consequente preservação. Uma parte importante da investigação observa e analisa a interdisciplinaridade e transversalidade da obra de Paulo Guilherme D’Eça Leal, promovendo a compreensão e interesse da sua produção no contexto do panorama artístico da sua época, aferindo a sua contribuição na cultura visual portuguesa do séc. XX. Analisar e advertir os apectos chave dos projectos e trabalhos deste artista que se tornaram factores preponderantes de evolução na imagética moderna portuguesa, bem como detectar os momentos e as obras principais que operaram mudanças de estilo e consequentes processos evolutivos. 


\section{Abstract - valencià}

La present investigació està dedicada a l'estudi monogràfic de l'activitat de l'artista multidisciplinari Paul Guilherme D'Eça Lleial (1932-2010), una personalitat polifacètica que va realitzar una obra enorme, diversa $i$ que constitueix un important llegat per a patrimoni artístic-cultural dels portuguesos. El treball de camp, amb la recopilació, inventari i estudi dels treballs que constitueixen el conjunt de la seva obra, permet donar a conèixer la seva personalitat i avaluar les seves aportacions des de les influències, experiències, tendències, mètodes i limitacions, així com analitzar críticament els aspectes més rellevants de la seva producció a les diferents àrees artístiques a les quals aquest versàtil autor es va dedicar durant sis dècades.

Aquest estudi posa en valor l'obra d'aquest artista en el context del panorama artístic portuguès del segle XX, i la projecta al XXI revelant informacions inèdites d'un autor, el treball del qual no és prou reconegut ja que una part significativa del mateix, mai va anar adequadament difosa. D'aquesta manera, tractem de contribuir a la difusió de la seva obra, recopilant-la i analitzant el seu cos principal, i defensant la seva conseqüent preservació.

Una part important de la investigació observa i analitza la interdisciplinarietat i transversalitat dels treballs de Paul Guilherme D'Eça Lleial, promovent la comprensió i interès de la seva producció en el context del panorama artístic de la seva època, avaluant la seva contribució i aportació a la cultura visual portuguesa del segle XX. Examinar i advertir els aspectes claus dels projectes i treballs d'aquest artista que es van convertir en factors determinants en l'evolució de la imatgeria moderna portuguesa, així com detectar els moments i les obres principals on es van operar els seus canvis d'estil i els seus processos evolutius. 


\section{Abstract - inglès}

This research aims the monographic study of the multidisciplinary activity of the artist Paulo Guilherme D'Eça Leal (1932-2010), a multifaceted personality who made a vast and diverse work, which has been an important legacy to the Portuguese artistic and cultural heritage. The research, with the compilation, inventory and study of his entire work, is able to acquaint his personality and evaluate his contributions from the influences, experiences, trends, methods and constraints, as well as to analyze critically the most relevant aspects of his production in the different artistic areas, this versatile author devoted himself for six decades.

This study has the purpose to appraise the work of this artist in the Portuguese art scene context of the $20^{\text {th }}$ century and project it to the $21^{\text {st }}$ century, revealing unheard information of an author whose work is not sufficiently recognized, since a significant portion of it was never diffused properly. Thus, we contribute to the diffusion of his work, gathering and analyzing its corpus and defending its consequent preservation.

An important part of the research observes and analyzes the interdisciplinary and the transversality of Paulo Guilherme D'Eça Leal's work, promoting the understanding and interest of its production in the art scene context of his time, measuring his contribution in the Portuguese visual culture of the $20^{\text {th }}$ century. To analyze and to notice the key aspects of this artist projects and work that became predominant factors in the evolution of Portuguese modern imagery, as well as to detect the moments and main works that originated styling changes and consequent evolutionary processes. 


\section{Agradecimentos}

Agradeço:

- Aos meus pais pelo amor e dedicação com que me educaram e pelo apoio incondicional que sempre me prestaram na minha formação académica.

- Ao meu irmão e ao meu Zé por serem grandes apoios na minha vida, pela compreensão e pelo espírito vencedor incutido.

- À minha amiga Goreti pela paciência, disponibilidade e carinho.

- Ao meu orientador Prof. Dr. Carlos Plasencia pela paciência, apoio, generosidade e pela partilha do seu saber ao longo deste trabalho.

- À Julia Correia e ao Francisco D’Eça Leal por toda a amizade, carinho e por me terem como parte da família.

- Aos meus amigos Jorge Silva e Prof. Bartolo pela amizade e conselhos dispensados.

- Aos meus amigos: Áurea Regina e seu marido Jorge, Carina Jerusa, Emanuel Peres, Ermelinda Moras, João Pavão, Jorge Rocha, Leandro Gomes, Maximino Bessa, Biatriz e Sara Tavares, Tânia Rocha e Teresa Veiga pelo apoio, amizade e disponibilidade que sempre me concederam.

- Aos meus amigos Nuno Ribeiro e Zita Silva pela amizade e por me acolherem no seu lar tornando-o o meu porto de abrigo.

- Aos meus amigos Luís Filipe Teixeira e Pedro Cavaco pela ajuda apaixonada e profissional prestada na realização do vídeo documental.

- Aos meus eternos amigos da faculdade Silvia Ferreira, Isabel Santos, Bruno Ferreira e Sergio Alecrim pelo facto de estarem sempre presentes na minha vida, pela partilha e apoio.

- Ao meu amigo Miguel e parceiro desta viagem do doutoramento pelo apoio e amizade. 
- Aos entrevistados Luis filipe de Abreu, Cândido Mota, Maria das Neves, Nuno Nazareth Fernandes, Cruzeiro Seixas, Luis Miguel Rosa Dias, Laranjeira Santos e Fernando Dacosta pela generosidade e tempo despendido.

- A todos os meus amigos que de uma forma indirecta me ajudaram.

- Ao Laboratório de Comunicação e Multimédia da Universidade Trás-os-Montes e Alto Douro por todo o material concedido.

- À Universidade Politécnica de Valência pelo acolhimento.

Agradeço claro, a Paulo Guilherme por me ter ajudado, por me ter acolhido em sua casa, por ter confiado em mim sem me conhecer, por ter partilhado a sua vida e a sua sabedoria, por ter cuidado de mim e me ter deixado cuidar dele. Agradeço pela lição de humildade que me deu e por me ter feito viver uma verdadeira aventura. 
...e onde estão os heróis da minha vida? Onde estás Paulo-Guilherme? 


\section{Indice}

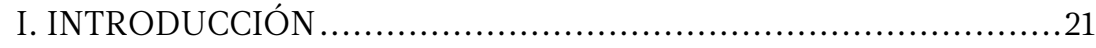

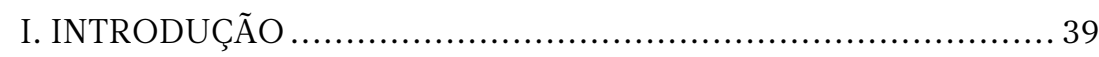

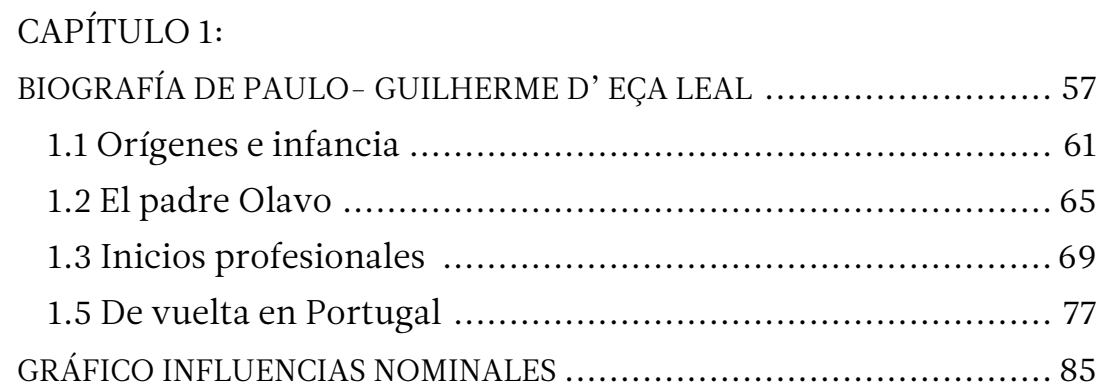

\section{CAPÍTULO 2:}

LA SOCIEDAD PORTUGUESA EN EL SIGLO XX: CONTEXTO HISTÓRICO -

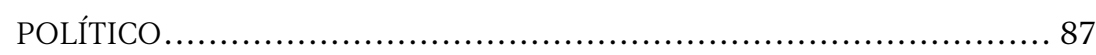

2.1 Estado Nuevo y la política del Espíritu ............................ 88

2.2 El estancamiento de la prosperidad de la posguerra............. 94

2.3 Las políticas del régimen y el culto a la personalidade de

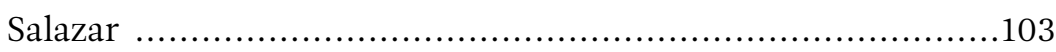

2.4 El golpe de estado y sus implicaciones políticas ...............108

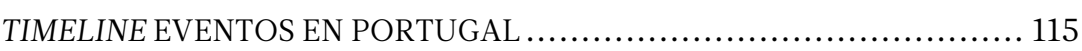

CAPÍTULO 3:

LA ARTE EN PORTUGAL DEL SIGLO XX Y SUS PROTAGONISTAS..........117

3.1.1 "Orphismo" al Modernismo .................................. 121

3.1.2 Las influencias de Amadeu de Sousa Cardoso ................ 125

3.1.3 Almada Negreiros, la nueva vanguardia .................... 127

3.2 La $2{ }^{a}$ generación .................................................. 131

3.2.1 António Ferro, “Arte del Régimen” ...........................135

3.2.2 Olavo D’Eça Leal ..............................................139 
3.2.4 Neo-Realismo ............................................ 155

3.2.5 Surrealismo .............................................. 161

3.2.6 Exposición del Mundo Portugués, 1940 .................... 165

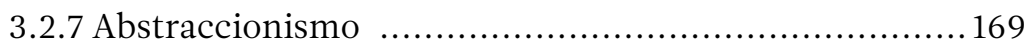

3.2.8 La Fundación Calouste Gulbenkian ........................ 173

3.3 El principio del final del "Arte del Régimen” ................ 177

3.3.1 Años 50 y 60 - nuevos factores ......................... 179

3.3.2 El advenimiento de la ruptura - últimas manifestaciones

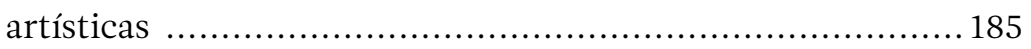

3.3.3 El “Arte del Régimen” Democrático - primeiras asimilaciones 189

3.4 Últimas décadas del siglo XX -implicaciones y consolidaciones

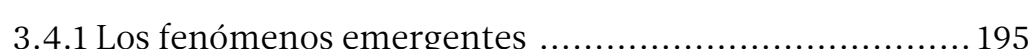

3.4.2 Fotografía - ruta y participaciones ........................ 199

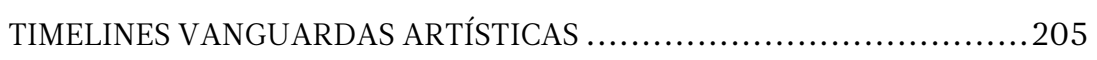

CAPÍTULO 4:

OBRA DE PAULO-GUILHERME D'EÇA LEAL ......................... 207

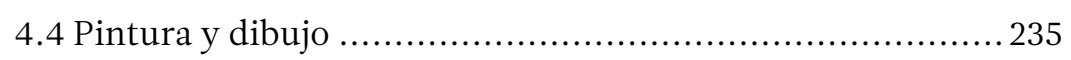

4.5 Escultura y tapices ...................................... 247

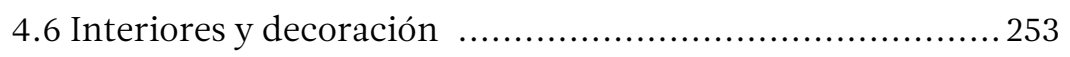

4.6.1 Restaurante Bachus ...................................... 267

4.6.2 Misión de Macau ........................................... 271

4.7 El aeropuerto de Portela - ANA Aeropuertos ............... 297

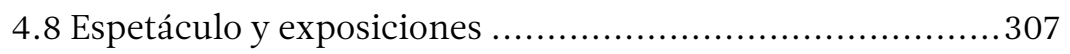

4.8.1 Cabaretíssimo .......................................... 311

4.8.2 Exposicione Paulo-Guilherme D’Eça Leal etcétera y tales, 2000 ....................................................... 317

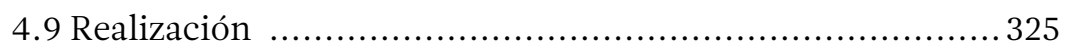

4.9.1 OAlquimista .............................................. 327

4.9.2 Iratan e Iracema, los chicos más traviesos del mundo 333 


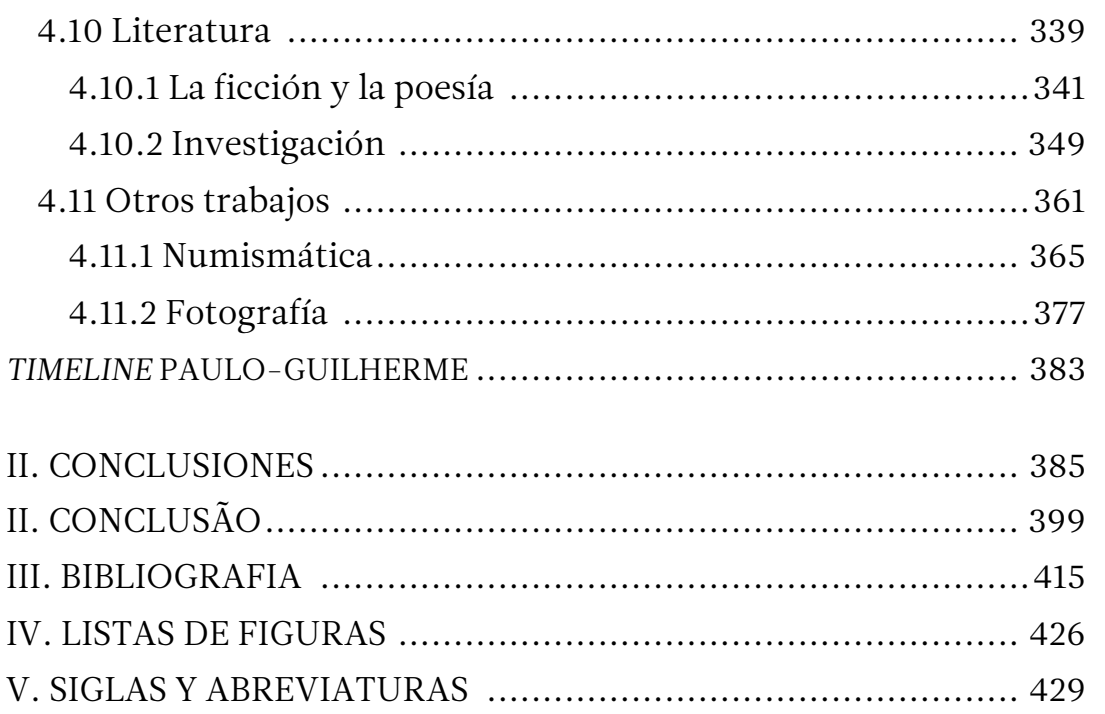




\section{Introducción}

«La historia del arte, a pesar de ser una búsqueda teórica revestida de innumerables dificultades, ocupa un papel cada vez más importante en la producción artística, ya que reflexiona sobre su Pasado, intenta superarlo, establecer brechas y crear obras que constituyan indagaciones a su respecto.. $\gg^{1}$

Para comprender hacen falta datos que nos permitan generar una imagen de lo que la realidad nos trasmite. En consecuencia, para entender la historia es necesario dar un significado a cualquier información que pueda ser utilizada en favor de su conocimiento. Los hechos principales, los agentes protagonistas y sus obras, deben ser difundidos y explicados con objeto de que pueda ser evaluado su interés desde perspectivas de conocimiento diversas.

La cultura visual portuguesa se debe, como es obvio, al resultado del trabajo de muchos artistas. Autores que, en su conjunto, generaron una obra notable e influyente que terminó por permitir conformar la matriz de nuestra cultura visual, y por extensión, de nuestra historia cultural. El estudio crítico de su trabajo, la divulgación de su obra y la puesta en valor del resultado de sus esfuerzos, es fundamental a la hora de generar procesos de conocimiento que

\footnotetext{
1 Traducción libre de: MARQUILHAS, Maria Beatriz; O Declínio da Arte: Morte e Transfiguração (II), [disponible en: http://www.artecapital.net/opinioes.php?ref=115] [consultado en 20/06/12, 18:18:00]
} 
permitan sustanciar y ubicar en la historia aquellos hechos que hagan posible reconocernos en lo que somos como pueblo.

Contribuir a sumar a esa memoria colectiva, hechos pasados que por su significación e interés creemos que deben ser rescatados para conocimiento de generaciones futuras, es lo que, modestamente, pretende esta tesis en su objetivo principal.

La presente investigación tiene por objeto ofrecer un estudio (con un fuerte componente historiográfico) de la vida y obra del artista Paulo-Guilherme D'Eça Leal (a partir de ahora, también PG), y de su contribución a la historia artístico-cultural portuguesa del siglo XX. El convencimiento, afirmado en el activo proceso de identificar, aislar y vincular coherentemente los datos de la investigación, de que se trata de uno de los artistas principales de la segunda mitad del s.XX portugués, ha sido el estímulo principal a la hora de superar las dificultades y esfuerzo que ha supuesto este trabajo, y la constatación de ello en el contexto de la cultura visual portuguesa, la aportación que sometemos a juicio en esta tesis.

«Una investigación de arte en cuanto instancia de mediación, del hombre y de las imágenes reales producidas por él en cuanto a ser intrínsecamente histórico, reclama una visión de esta en cuanto experiencia mutante, ya que la realidad y el hombre dentro de ella, son también entidades marcadas por constantes mutaciones. La experiencia del hombre que habita en un mundo, su mundo, se convierte en una experiencia exteriorizable, lo que nos permite una visión de la obra, por sí misma, teniendo que ser pensada en cuanto creación cuyo origen es la experiencia de la subjetividad. Arte es hoy la emanación de mí, un yo marcado por coordenadas espacio-temporales. Las obras de arte desde sus inicios, deben ser abordadas en su totalidad, en cuanto proceso de auto-aprendizaje por parte del ser humano, reflejándose, en su totalidad el camino recorrido por la especie humana en su búsqueda 
para capturar lo real y manifestar la experiencia vivida por aquel que lo habita. Si el espíritu de la obra es inalienable cuando se piensa en el Arte, tenemos como resultado que vivimos en un momento en que lo real se hace añicos; y la imposibilidad de encontrar una continuidad en las manifestaciones sensibles que se van presentando refleja precisamente la complejidad del presente y las lagunas de "nuestra historia": el espíritu de nuestro tiempo está fragmentado.» ${ }^{2}$

Nuestra preocupación se ha centrado mucho en pensar, reflexionar, realizar balances de situaciones que permitieran evaluar objetivamente la interacción de la actividad del artista con el campo en el que se desarrolla, señalando hechos concretos, rupturas, sinergias y discontinuidades. Por otra parte hemos tenido presente siempre que, para esta investigación era fundamental comprender (entendiendo esta facultad como un proceso activo que exige medios concretos), observar y analizar extensamente las particularidades de la interdisciplinariedad y actividad transversal de este artista en las diferentes áreas de trabajo en las que se implicó, haciendo posible el análisis de sus manifestaciones en el contexto del panorama artístico de la época, y evaluando su importancia para la construcción de la cultura visual portuguesa, no en vano la condición multifacética de la personalidad artística de Paulo Guilherme, es una de las variables principales de su actividad creativa, y explica su diversidad expresiva.

\footnotetext{
2 Traducción libre de: MARQUILHAS, Maria Beatriz; O Declínio da Arte: Morte $e$ Transfiguração (II), [disponible en: http://www.artecapital.net/opinioes.php?ref=115] [consultado en 20/06/12, 18:18:00]
} 


\section{I.II Motivación y justificación}

El motivo que se encuentran en el origen de esta investigación surge de un trabajo previamente realizado, titulado Los gráficos portugueses, cubiertas de libros de las décadas 50's y 60's. Esta investigación reunió un amplio y vasto conjunto de portadas de libros, en la búsqueda de reunir una variedad de soluciones gráficas y conceptuales, en un esfuerzo por captar lo que podríamos denominar «la imagen del libro» durante ese significativo periodo de tiempo. Situado en un contexto histórico concreto, con referencias económicas, políticas, sociales y artísticas tan particulares, se identificaron técnicas, influencias, experiencias, tendencias, métodos y condicionantes, así como a algunos de los protagonistas de lo que fue, una inmensa y magnifica producción de diseño gráfico desde la perspectiva de crear un estilo portugués del mundo editorial de esas décadas, particularmente en la producción artística relacionada con el mundo editorial y concretamente con las portadas de libros. Vitor Palla, Sebastião Rodrigues, António Garcia, António Domingues, Luís Felipe Abreu, João da Câmara Leme y Paulo-Guilherme, fueron algunos de los muchos artistas de que contribuyeron a la renovación del diseño portugués del momento, de su mercado y de su público. Todos ellos participaron con un legado vasto y diversificado que terminó por ser relevante en el patrimonio artístico-cultural portugués. Protagonistas de una amplia y multifacética obra, fueron indudablemente nombres de fuerte presencia del mundo editorial, especialmente en la producción de cubiertas de libros, y el resultado de su estudio se convirtió en un incentivo dada la dimensión e importancia que terminamos por darle al tema y el interés que entendimos podría 
tener, profundizar en la ámbito contributivo de algunos de los protagonistas en la conformación de la cuestión principal: la promoción de una cultura visual portuguesa que se convirtió en referente para las generaciones siguientes.

Con este trabajo se logró dimensionar la importancia de los estudios monográficos realizados, especialmente el de Antonio Garcia (Tesis de Maestría en Museología y Museografía; Zeitgeis - El Espiritu del Tiempo António Garcia - Diseño y Arquitectura en las décadas de 50 - 70 del siglo XX, de Ana Sofia Pessoa Matos) y el de Vítor Palla (Tesis de Maestría Un inventario critico de la obra de Vitor Palla, Diseño y Cultura Visual” de João Palla y Carmo Reinas Martins), investigaciones que permitieron una mejor comprensión de la historia reciente de la gráfica portuguesa, y que ayudaron a generar y soportar nuevos planteamientos y teorías acerca de su evolución. Para nosotros, una vez excluidos de la nómina de artistas los ya estudiados Antonio Garcia y Vítor Palla, los criterios de selección fueron obvios. ¿Qué argumentos nos llevaron elegir al artista Paulo Guilherme D’Eça Leal, de entre los restantes?, pues, por una parte por la calidad que otorgábamos a su obra así como por el reconocimiento del evidente interés que apreciábamos, tanto en su trabajo como en su personalidad, y por otra (y no menos importante) por la posibilidad del contacto personal, una circunstancia fundamental a la hora de abordar el trabajo de campo que exigía el planteamiento de nuestra investigación, que obviamente podía verse notablemente favorecida por ello, al permitirnos una mayor y mejor recopilación, y estudio del material que haría posible nuestro acercamiento a los fundamentos de la cuestión principal y facilitaría la exigencia de rigor que nos imponíamos. Significar en este punto, hasta qué punto el conocimiento personal de Paulo-Guilherme y el compromiso que adquirimos con él, ha significado un estímulo que nos ha permitido 
mantener viva la motivación inicial que nos llevó a plantear esta investigación, y a superar las lógicas dificultades a las que nos hemos enfrentado. La obra de Paulo-Guilherme D'Eça Leal es referenciada en numerosos artículos, crónicas, críticas de periódicos, revistas de la época o catálogos de exposiciones. Sin embargo, toda la información disponible está dispersa, sin analizar y sin conformar un corpus que permitiera ponerla en valor en su conjunto y divulgarla adecuadamente. Si se ha puesto al alcance del público ha sido de una manera atomizada y superficial. No se ha estudiado en profundidad, ni interpretado con el nivel adecuado (no ha sido filtrada por teorías establecidas o aceptadas) para que pueda informar y llegar a ser entendida, ni siquiera, por aquellos colectivos interesados en este tipo de conocimiento. En consecuencia, la recolección y compilación de los diferentes componentes que constituyen la obra de Paulo-Guillherme D'Eça Leal permite generar la oportunidad de dar a conocer el material que la integra en su conjunto, las técnicas y la particularidad de su empleo, las influencias, las experiencias, el seguimiento de tendencias, los métodos y condicionantes que la hicieron posible, y estudiar los aspectos más relevantes de su producción en conjunto. Este estudio pretende desde una perspectiva de análisis general y distanciado sobre la producción de este arquitecto, artista gráfico, fotógrafo, ensayista, escultor, pintor, medallista, escenógrafo, realizador, escritor, poeta e ilustrador, mostrar y hacer accesible el conocimiento de su obra en términos objetivos, y en contexto en el que se generó. Como resultado, esta investigación también pretende ser útil de cara a abordar con extensión el panorama artístico portugués de la segunda mitad de s.XX y de su proyección en el arranque del s.XXI, porque, entre otras cosas, va a revelar información adicional, inédita, sobre la producción de un autor cuya obra no fue suficientemente conocida (y en consecuencia, 
reconocida) en su momento, una vez que parte significativa de la misma no fue debidamente difundida, bien porque se hizo por gente no experta que la simplificó en exceso, bien porque se realizó de una forma parcializada. A pesar del ingente trabajo de Paulo Guilherme a lo largo de su vida, siempre centrado en el gusto de experimentar actuando en hábitos creativos y expresivos diversos, innovando en las artes gráficas, en la edición y producción de libros, en la ilustración de cubiertas, en la fotografía y en la arquitectura, etc., nunca se preocupó por su difusión.

\section{I.III Contextualización y marco teórico}

La contextualización de la cuestión principal de la investigación y de sus hipótesis deben tener en cuenta la Historia del Diseño Portugués, un ámbito de estudio en gran medida, en estado latente o embrionario. La disciplina como tal, está ausente de los planes de estudios de Diseño en la Educación Superior, se imparte en un único curso universitario de la Universidad de Aveiro. Se infiere, la no tradición del estudio de estas cuestiones específicamente en el contexto portugués.

Académicamente y como regla general, se basa en el conocimiento de la historia del Diseño o de la Teoría del Diseño en el ámbito universal, sufriendo, en el caso portugués, de una patología disfuncional. Al estudio exhaustivo de los recursos de la biblioteca en cuanto al diseño portugués, pronto induce su ausencia, dándole el enfoque a ser un no-problema en la masa cultural y la cultura portuguesa en sí mismo. 
Los estudios de diseño portugués son escasos, discontinuados y sobre monografías individuales, sin embargo empiezan a surgir teorías que reflejan su historia, estudios acerca de su origen, su desarrollo y su momento actual, estudios que nos pueden permitir una comprensión general de su ámbito de aplicación y de las correlaciones de los diversos elementos existentes dentro de ella. Sobresalen los escritos de críticos y académicos como Mario Moura, José Bartolo (con asidua contribuciones en sus blogs Ressabiator y Reactor, respectivamente, de notoriedad nacional), la profesora e investigadora Maria Helena Souto, y el diseñador Jorge Silva (conocido por el encomiable esfuerzo de compilación de los máximos exponentes del diseño gráfico portugués, una antología editada por Imp. Nacional Casa da Moeda, intitulada Collection D). Sobre estas contribuciones, se sentó en el análisis, la crítica y la reconstrucción de la historia del diseño portugués que también pasa por los artículos en periódicos, revistas y libros especializados de proyección nacional e internacional. El lento surgimiento de centros de Investigación en Diseño (ID+, Instituto de Investigación en Diseño, Medios de Comunicación y Cultura, Instituto de Investigación en Arte, Diseño y Sociedad; UNIDCOM, Unidad de Investigación y Capacitación en Diseño y Comunicación; i2ADS, Instituto de Investigación en Arte, Diseño y Sociedad FBAUL y CIFAD, Centro de Investigación en Diseño y Comunicación, etc.), su dispersión, y la ausencia de revistas científicas, complica la tarea de efectuar un flujo estable y autorizado de información que fomente la conciencia colectiva del diseño portugués. Y es que «la historia del diseño portugués no se lleva a cabo de forma sistemática $y$ coherente, aunque hoy en día hay contribuciones importantes a la comprensión, incluso a través masters y tesis doctorales» ${ }^{3}$.

${ }^{3}$ Traducción libre de: BARBOSA, Maria Helena Ferreira Braga; História do Design Português [disponível em: http://www.ua.pt/PageDisc.aspx?id=2470\&b=1] [consultado em 06/10/12, 16:50:00] 
El aumento del número de estudiantes de maestría y doctorado en la última década ha permitido un crecimiento del trabajo académico en torno a la historia del diseño en Portugal. Algunas tesis han dado lugar a publicaciones como el reciente Diseño Gráfico en Portugal de Margarida Fragoso, o disponibles on-line o en otras bibliotecas que revelan un enfoque particular en los estudios monográficos (Sebastião Rodrigues, Víctor Palla, Antonio García, Maria Keil, Fred Kradolfer, etc.). Tesis como la de Maria Helena Souto (Historia del diseño en Portugal) resuelven una historia ya más sistemática de diseño portugués en el siglo XX o incluso la tesis de Ana Catarina Oliveira Redol titulado La influencia de la abstracción geométrica en Diseño Gráfico en los años 60. Para un enfoque en Portugal, que aborda la influencia evidente de la abstracción geométrica, teorías internacionales como De Stijl, la Bauhaus, el constructivismo ruso y la «Nueva Tipografía» en Portugal.

Se refiere a los personajes y vehículos que proporcionan no sólo las teorías asociadas con estos movimientos (el comienzo de siglo), sino también el panorama artístico de la abstracción geométrica. En el contexto de la abstracción geométrica en Portugal fueron protagonistas destacados Fernando Lanhas y Nadir Afonso así como en portugués de diseño gráfico Rodrigues Sebastião, Antonio García, Palla Victor, João Câmara Leme y Paulo Guilherme, éstos como los principales artistas y representantes de la «generación de oro», dejando un legado histórico invaluable y visual del diseño gráfico influenciado por una fuerte componente geométrico y estructural, único y raro en el panorama portugués. Este estudio es de los pocos que clasifica a Paulo Guilherme D'Eça Leal como una referencia en diseño gráfico portugués junto a otros grandes nombres. Su acercamiento a estos casos es también a causa de su trabajo interdisciplinar para incorporar una origen similar en cuanto a cualidad como es la multidisciplinariedad, la 
transversalidad y el eclecticismo. Pero esta similitud y en forma comparativa con otros artistas como Victor Palla, Antonio García, Luís Filipe de Abreu (los autores estudiados y de reconocido mérito ), nos hace cuestionar por qué Paulo Guilherme no se ha estudiado, no se conoce. ¿No tiene Paulo Guilherme importancia para la cultura visual del siglo XX portugués?

La contextualización del problema y la investigación de sus supuestos, permiten la estructuración del pensamiento en un sentido pragmático. De ese modo, las referencias existentes como plataformas teóricas para su fundamentación, se centran en el estudio de la historia personal y profesional de PG, de su tiempo, de su formación personal y la artística, así como en el estudio de su obra. Desde ahí se considerarán sus artículos y crónicas en periódicos y revistas importantes de la época, sus catálogos, dos libros de investigación, una novela e incluso dos libros de poemas. Para un mejor y más completo entendimiento de lo que fue y de su aportaciones a la cultura visual portuguesa, también será importante considerar no solo el contexto artístico sino el políticosocial y el económico del momento, así como los principales protagonistas, sus acciones y su impacto social, las influencias ejercidas, las experiencias acumuladas y la correlación de todos esos datos. Igualmente importante será la valoración de PG por parte de los artistas de su generación y los testimonios acumulados de todos aquellos que compartieron con él, el arte y la vida. 


\section{I.IV Objetivos de la Investigación}

El objetivo general de esta tesis es, como apuntábamos al principio, la realización de un estudio monográfico que ponga en valor la obra de Paulo Guillherme D'Eça Leal, que faculte su comprensión e importancia, y que contribuya a su divulgación dentro del contexto del arte y la historia del diseño portugués, y que esto sea posible a través de nuestra contribución crítica, así como de las diversas aportaciones biográficas, bibliográficas y visuales desconocidas que hacemos públicas en el presente trabajo.

Al tratarse de una personalidad multifacética y dado el universo y extensión del material existente, el interés principal recae en las obras clave encuadradas en momentos específicos para establecer una visión crítica de la evolución de su autor en base al análisis de dichas obras y del contexto en el que fueron creadas.

Con el propósito de contribuir a una mejor documentación de la Historia del Diseño en Portugal en lo que se refiere a la identificación, reunión de documentación y testimonios disponibles, la investigación realizada pretende generar nuevos conocimientos con la análisis, reflexión y comprensión en la historiografía portuguesa. Esta base teórica se destina a generar un nuevo conocimiento para el dominio público, con especial atención a los estudiantes y profesionales de esta área.

Dentro de lo que podríamos denominar objetivos específicos, este estudio pretende también obtener como resultado: 
1. Establecer, en base al estudio y análisis exhaustivo de la vida y obra de Paulo-Guilherme, relaciones de dependencia o interacciones de interés destinadas a hacer posible una mayor compresión de su trabajo creativo.

2. Realizar una recopilación gráfica razonada lo más completa posible que reúna e ilustre la parte más destacable de la producción artística del autor, en función de los momentos clave de su evolución.

3. Dentro de su diversidad, contextualizar conceptual y técnicamente su trabajo, y subrayar las posibles aportaciones en ese sentido.

4. Contribuir al debate en torno a la valorización de este autor, desde lo que entendemos es una contribución importante a la conformación de una hipotética cultura visual portuguesa.

La investigación, la reflexión y la sistematización que se proponen, aspiran a servir de referencia a futuras investigaciones, ya sea a propósito del propio PG como para eventuales evaluaciones de otros autores que compartan la misma matriz cultura y visual, suministrando pistas y material para completar con ello la historiografía portuguesa. 


\section{I.V Estructura de la Tesis}

El corpus de esta memoria de tesis se divide en cuatro capítulos cuya línea rectora principal tiene que ver con la vida de PauloGuilherme D'Eça Leal (I), con el contexto histórico-político de la sociedad portuguesa de la segunda mitad del siglo XX (II), con el arte portugués y sus protagonistas a lo largo de ese mismo período de tiempo (III), y con obra de Paulo-Guilherme D'Eça Leal (IV), seguidos por un capítulo de conclusiones en base a los resultados del proceso de investigación, una bibliografía y una serie de anexos con materiales complementarios.

En el capítulo I, destinado a tratar biográficamente la vida de Paulo-Guilherme D'Eça Leal, presenta, en general, la genealogía de este artista, su formación, su trayectoria y sus influencias principales. La primera aproximación al tema de estudio hemos entendido que debía de ser necesariamente a un nivel personal, antes de entender al artista hay que ver al hombre y sus circunstancias. Sabemos que el enfoque puede ser polémico porque lo que importa realmente es la personalidad estética y no la empírica, pero aunque centremos parte de nuestra atención en el hombre que vive una existencia cotidiana, es el creador de obras artísticas el que, definitivamente, constituye el núcleo principal de nuestra investigación. Así que este capítulo da una visión general de sus antecedentes, experiencias e influencias que terminaron por dar forma a su personalidad y a su trayectoria vital, y que terminaron por sustanciarse en su actividad artística. En este contexto es fundamental destacar la figura de su padre Olavo, que fue su punto de referencia principal y cuya influencia es determinante para una mejor comprensión de los aspectos distintivos de PG como artista. 
En resumen, y pese a la advertencia apuntada más arriba, podríamos decir que el contenido de este capítulo se basa en el conocimiento del «hombre» con el fin de deducir las diversas variables existenciales que le definen como «ser».

En el segundo capítulo realizamos una revisión del contexto social, político y económico, lo que entendemos hace posible una comprensión general de la cuestión principal de la investigación en base a los hechos más relevantes y las acciones más importantes que ocurrieron durante las cinco décadas (de los años 30 a los 80) de su transcurso. Se centra en los principales actores y en los acontecimientos que ocurrieron en los diversos ámbitos de la sociedad portuguesa de ese tiempo. Su objetivo es llevar a entender que el comportamiento de un individuo tiene condicionantes y no sólo de orden psicológico, sino también determinados por la situación histórica y social. La situación portuguesa del s. XX pondrá de relieve la influencia de fenómenos perturbadores. La «Gran Guerra» (1914-1918), la crisis de 1920, la dictadura de Salazar a lo largo de 40 años, la guerra colonial (1961-1974), la Revolución de Abril (1974), transición abrupta a la democracia, datos son informativos para la comprensión de los efectos inversos el desarrollo general del país y en particular el las prácticas artísticas en Portugal.

Forma parte de este capítulo, una línea de tiempo (timeline) para hacer posible una visualización gráfica de estos acontecimientos.

En el tercer capítulo se lleva a cabo una revisión general del estado del arte portugués en el s. XX y sus protagonistas principales, es decir, trata de ofrecer una visión histórica del arte en Portugal en varias áreas de acción que permitan una comprensión general de las corrientes, los movimientos y sus manifestaciones e implicaciones, con la evidente intención de contextualizar la obra y 
aportaciones de PG. Se identifican y describen los actores culturales y sus intereses en diversos sectores estableciendo las correlaciones de estos agentes, las áreas y el impacto de todo ello en el desarrollo artístico portugués. Personajes de gran interés cultural, autores de una obra relevante y notable, protagonistas de acciones indudables en la cultura y las artes, son sin duda los autores de nuestra historia. En resumen: dar a conocer los movimientos artísticos más prevalentes y sus influencias teniendo en cuenta lo individual y lo colectivo, y estableciendo relaciones diversas. El énfasis discursivo se encuentra también en algunos individuos que son referencias fundamentales ya que fueron determinantes para que la historia fuera tal y como la conocemos, por lo que son fundamentales para su estudio e interpretación. También en este capítulo tiene cabida una línea de tiempo (timeline) destinada a hacer más fácil una visión general de estos acontecimientos.

Es el cuarto capítulo donde realizamos la recopilación de toda la obra de PG, con el fin de contribuir a la descripción y comprensión de su acerbo contributivo a la cultura visual de Portugal. El capítulo está dividido en nueve áreas: artes gráficas, pintura y dibujo, escultura y tapicería, interiores y decoración, arquitectura, espectáculos y exposiciones, intervenciones artísticas, literatura y, por último, otros trabajos. En su recorrido se pretende observar y analizar ampliamente su actividad interdisciplinar y transversal de PG en las diferentes áreas donde desarrolló su actividad, promoviendo la comprensión de sus trabajos en el panorama artístico de la época y valorando su importancia, así como el nivel de su contribución a la construcción de la cultura visual portuguesa del s.XX. En consecuencia, el análisis y evaluación crítica de todos los aspectos de la acción y la obra de este artista. que se convirtieron en factores predominantes en la evolución de las imaginario portugués, así como la detección de los 
momentos, los cambios operados y las interrupciones en esta evolución, tienen lugar en esta parte de la memoria de tesis. También en este apartado introducimos una línea de tiempo para seguir ofreciendo la posibilidad de una visualización general su obra en relación a su trayectoria vital.

Los cuatro capítulos enunciados ofrecen nuevos datos interpretativos y tras las pertinentes conclusiones, añadimos la bibliografía y los anexos. Los archivos adjuntos en soporte DVD nos permiten ofrecer un material importante para la investigación, principalmente fotográfico $\mathrm{y}$ audiovisual (conferencias $\mathrm{y}$ entrevistas), que permiten enriquecer y completar la visión de la vida y obra de PG. También adjuntamos una película documental que hemos realizado sobre la vida y obra de PG cuyos protagonistas son personajes principales del ámbito cultural portugués.

\section{I.V Metodologías}

La presente investigación se basó en la narrativa y descripción de los elementos esenciales y estructurales de la obra de Paulo Guilherme D’Eça Leal. Se investigó exhaustiva y ponderadamente con la intención de localizar y reunir la mayor cantidad de obras, y sobre todo, las más significativas, permitiendo con ello la construcción de un conjunto que transmitiera un visión global y lo más completa posible del trabajo desarrollado por el artista PG, en términos cualitativos y cuantitativos. La investigación contiene una serie de testimonios orales y datos biográficos contrastados, 
también prototipos, artefactos, dibujos técnicos, así como referencias bibliográficas, documentales, etc. de gran riqueza. Y de ella surge un primer inventario, clasificación, investigación cronológica de la obra de PG, así como una estructuración de sus diferentes áreas de intervención, notaciones de referencias bibliográficas e iconográficas, diversas entrevistas y contactos personales que han terminado por ser fundamentales para el éxito de esta tesis.

Forman parte del proceso investigativo de esta tesis instrumentos metodológicos como:

a) Recolección, selección y ordenación de toda la información documental existente sobre la vida y obra de Paulo-Guilherme D'Eça Leal.

b) Fundamentación teórica de cuanto permitió el diseño de una estructura organizativa y selectiva del material más relevante desde los objetivos que perseguía la investigación.

c) Contratación y verificación de las influencias nacionales e internacionales que han podido mostrar los orígenes de los intereses artísticos y visuales del autor.

d) Análisis crítico de los textos escritos por o sobre el autor, y concretamente aquellos que ayuden a aclarar desde su perspectiva la problemática de la cultura visual portuguesa.

e) Examen iconográfico de las obras consideradas clave para dimensionar las contribución de PG a la cultura visual portuguesa.

f) Entrevistas a personas relacionadas con el artista y/o con el medio artístico de la época estudiada.

Para terminar este proemio explicativo, subrayar nuestra intención a lo largo de este estudio, de no entrar en el enigma del artista, es 
decir, de no condicionar desde una perspectiva psicológica nuestra aproximación a la personalidad artística de PG, sino hacerlo, si acaso, desde una visión sociológica que entendemos más próxima a nuestra competencia. Ello nos permite no condicionar desde la apología o desde posibles prejuicios, los hechos biográficos del artista a los que hemos tenido alcance, y atender con exclusividad aquellos aspectos que desde lo que es estrictamente artístico y desde la consideración de sus propios contemporáneos, pueden ser relevantes para nuestra área de intereses.

Hemos renunciado, también, a la realización de una memoria de tesis gruesa y cargada de notas que hubiera sido lo normal en relación al volumen de documentación al que hemos tenido acceso, en favor de una economía expositiva que se centrara principalmente en aquello que entendemos sustantivo. Con ello, no pretendemos limitar nuestra responsabilidad acerca de los resultados, sino ser fieles a nuestra intención de no dar juego a especulación alguna, o pecar de pretenciosos intentando dar un carácter definitivo a nuestras apreciaciones en base a evaluaciones puramente cuantitativas. 


\title{
I. Introdução
}

\begin{abstract}
«A história de arte, ainda que seja hoje uma busca teórica revestida de inúmeras dificuldades, ocupa uma função de crescente importância na produção artística, pois que esta reflecte sobre o seu Passado, tenta superá-lo, estabelecer rupturas e criar obras que constituam indagações a seu respeito $\gg^{4}$
\end{abstract}

Para compreensão da História fazem falta dados que nos permitam gerar uma imagem do que a realidade transmite. Em consequência, para entender a história é necessário dar significado a qualquer informação que pode ser utilizada em favor do seu conhecimento. Os feitos principais, os agentes protagonistas e suas obras, devem ser difundidos e explicados com objectivo de ser avaliado seu interesse sob as diversas perspectivas de conhecimento.

A cultura visual portuguesa deve-se, como é óbvio, ao resultado do trabalho de muitos artistas. Autores que, em seu conjunto, geraram uma obra notável e influente que terminou por permitir conformar a matriz da nossa cultura visual, e por extensão, a nossa história cultural. O estudo crítico de seu trabalho, a divulgação de sua obra e a definição do valor do resultado dos seus esforços, é fundamental na hora de produzir processos de conhecimento que permitam fundamentar e localizar na história aqueles factos que tornam possível o reconhecimento do que somos como povo.

\footnotetext{
${ }^{4}$ MARQUILHAS, Maria Beatriz; O Declínio da Arte: Morte e Transfiguração (II), [disponível em: http://www.artecapital.net/opinioes.php?ref=115] [consultado em 20/06/12, 18:18:00]
} 
Contribuir para o aumento da memória colectiva, factos passados que por sua significação e interesse acreditamos que devam ser resgatados para o conhecimento de gerações futuras, isto é, modestamente, o objectivo principal desta tese.

A presente investigação tem por objectivo oferecer um estudo (com uma forte componente historiográfica) da vida e obra do artista Paulo-Guilherme D’Eça Leal (a partir de agora, também PG), e da sua contribuição para a história artístico-cultural portuguesa do século XX. A crença, declarou no processo activo de identificar, isolar e vincular coerentemente os dados da investigação, de que se trata de um dos artistas portugueses principais da segunda metade do século XX, tendo sido o principal estímulo na hora de superar as dificuldades e o esforço que representou este trabalho, a constatação deste no contexto da cultura visual portuguesa, contribuição que submetemos a julgamento nesta tese.

«Uma indagação da arte enquanto instância de mediação, bem como do homem enquanto ser intrinsecamente histórico e das imagens do real por ele produzidas, reclama uma visão desta enquanto experimentação permanente, mutante pois que o real e o homem dentro dele também seres marcados por constantes mutações. A experiência do homem que habita um mundo, o seu mundo, torna-se experiência exteriorizável, o que nos impede um olhar sobre a obra, per se, tendo esta de ser pensada enquanto criação cuja origem é a experiência de uma subjectividade. Arte é hoje tela de emanação do eu, um eu marcado por coordenadas espácio-temporais. As obras de arte, desde os seus primórdios, devem então ser abordadas, na sua totalidade, enquanto processo de auto-aprendizagem por parte do ser humano, reflectindo-se, nessa totalidade, o caminho percorrido pela espécie humana no seu apelo para apreender o real e manifestar a experiência vivida por 
aquele que o habita. Se um zeitgeist é inalienável quando se pensa a Arte, tiramos a consequência de que vivemos num tempo em que o real está estilhaçado; e a impossibilidade de encontrar uma continuidade nas manifestações sensíveis que se vão apresentando reflecte precisamente a complexidade do Presente e os hiatos de significância de que a "nossa história" está repleta: o espírito do nosso tempo é o do fragmentário.» ${ }^{5}$

A nossa preocupação centrou-se muito, no pensamento, na reflecção, na realização de balanços de situações que permitem avaliar objectivamente a interacção da actividade do artista com o campo em que se desenvolve, assinalando factos concretos, rupturas, sinergias e descontinuidades. Por outra parte temos tido sempre presente que, para esta investigação era fundamental compreender (o entendimento dessa habilidade como um processo activo que requer meios específicos), observar e analisar extensamente as particularidades da interdisciplinaridade e a actividade transversal deste artista nas diferentes áreas de trabalho em que se implicou, fazendo a possível análise das suas manifestações no contexto do panorama artístico da época, avaliando a sua importância para a construção da cultura visual portuguesa. Não é em vão a condição multifacetada da personalidade artística de Paulo-Guilherme, é uma das variáveis principais de sua actividade criativa e explica a sua diversidade expressiva.

\footnotetext{
${ }^{5}$ MARQUILHAS, Maria Beatriz; O Declínio da Arte: Morte e Transfiguração (II), [disponível em: http://www.artecapital.net/opinioes.php?ref=115] [consultado em 20/06/12, 18:18:00]
} 


\section{I.I Motivação e justificação}

As motivações que serviram de inspiração à presente investigação, advêem da trabalho de investigação anteriormente efectuado intitulado Grafismos Portugueses, capas de livros das décadas 50/60. Este trabalho de investigação reuniu um conjunto amplo e abrangente de capas de livros, na procura de recolher variadas abordagens, soluções gráficas e conceptuais, no esforço de captar a essência do livro. Inserido no contexto histórico, com referências do panorama económico, político, social e artístico, identificaramse técnicas, influências, experiências, tendências, métodos, condicionalismos e alguns dos seus intervenientes de uma imensa e magnífica produção de Design Gráfico, numa perspectiva de criar um estilo português dessas décadas do mundo editorial, particularmente na produção artísticas de capas de livros.

Victor Palla, Sebastião Rodrigues, António Garcia, António Domingues, Luís Filipe Abreu, João da Câmara Leme, PauloGuilherme, foram alguns exemplos entre muitos que contribuíram para uma renovação do Design Português, do seu mercado e dos seus públicos. Participaram com um vasto, diversificado e relevante legado no património artístico-cultural português. Protagonistas de extensa e multifacetada obra, foram indubitavelmente nomes de forte presença no mundo editorial, nomeadamente na produção de capas de livros. O resultado do seu estudo, converteu-se num incentivo, dada a dimensão e importância que julgamos dar ao tema e o interesse que entendemos poder ter, aprofundar o âmbito contributivo de alguns dos protagonistas na definição da questão principal: A promoção de uma cultura visual portuguesa que se torna referência para as gerações seguintes. 
Com este trabalho dimensionou-se a importância dos estudos monograficos já realizadas, nomeadamente de António Garcia (tese de Mestrado em Museologia e Museografia; Zeitgeist - O Espírito do Tempo António Garcia - Design e Arquitectura nas décadas de 5070 do século XX, de Ana Sofia Pessoa Matos) e Victor Palla (tese de Mestrado "Um inventário crítico da obra de Vítor Palla, Desenho e Cultura Visual” de João Palla e Carmo Reinas Martins) investigações que permitiram uma melhor compreensão da história recente do design gráfico português, ajudando a gerar e suportar novas abordagens e teorias sobre a sua evolução. Para nós, uma vez excluído a lista de artistas já estudados Antonio Garcia e Victor Palla, os critérios de selecção foram óbvios. Que argumentos nos levaram a eleger o artista Paulo-Guilherme D'Eça Leal dentro dos demais? Por uma parte, a qualidade que concedemos à sua obra assim como pelo reconhecimento do evidente interesse que apreciámos, tanto em seu trabalho como em sua personalidade, e por outro lado (e não menos importante) pela possibilidade do contacto pessoal, uma circunstância fundamental na hora de enfrentar o trabalho de campo que exigia a abordagem da nossa investigação. Obviamente podia ver-se por isto notavelmente favorecida, ao permitir-nos uma maior e melhor recompilação e estudo do material que faria possível a nossa aproximação aos fundamentos da questão principal e facilitando a exigência de rigor a que nos impúnhamos. Significa, neste ponto, em que medida o conhecimento pessoal com Paulo-Guilherme e o compromisso que adquirimos com ele se tornou um estímulo que nos permitiu manter viva a motivação inicial levando-nos a apresentar esta investigação e superar as lógicas dificuldades enfrentadas.

A obra de Paulo-Guilherme D'Eça Leal é referenciada em artigos, crónicas, críticas de jornais, revistas da época ou catálogos de exposições. Contudo o seu trabalho e toda informação disponível 
encontra-se dispersa, não analisada e sem conformar um corpus que permita valorar o seu conjunto e divulga-la adequadamente. Se foi posta ao alcance do público foi de uma fragmentada e superficial. Não foi estudado em profundidade, e interpretado com o nível adequado (no foi filtrado por teorias aceites e estabelecidas) para que se possa informar e chegar a ser entendida, nem sequer, por aqueles colectivos interessados neste tipo de conhecimento. Consequentemente, a recolha e compilação dos vários componentes que constituem o obra de Paulo-Guilherme D’Eça Leal permite gerar a oportunidade de dar a conhecer o material que a integra em seu conjunto, as técnicas e a particularidade de seu emprego, as influencias, as experiências, o seguimento de tendências, os métodos e condicionantes que tornaram possível o estudo dos aspectos mais relevantes da sua produção em conjunto.

Este estudo pretende a partir de uma análise geral e distanciada sobre a produção deste arquitecto, artista gráfico, fotografo, ensaísta, escultor, pintor, medalhista, cenógrafo, realizador, escritor, poeta e ilustrador, dar a conhecer e tornar possível o conhecimento de sua obra em términos objectivos no contexto em que se gerou.

Como resultado, desta investigação também pretende ser útil no futuro na abordagem em extensão no panorama artístico Português da segunda metade do séc. XX e sua projecção no arranque do séc. XXI, porque, entre outras coisas, revela informação adicional, inédita, sobre a produção de um autor cuja obra não foi suficientemente conhecida ( e em consequência reconhecida) em seu momento, uma vez que parte significativa da mesma não foi devidamente difundida, ou porque ele fez por pessoas nãoespecialistas, excessivamente simplificado, ou porque se realizou de uma forma parcializada. Apesar de Paulo-Guilherme ter exposto ao longo da sua vida, não teve como preocupação a sua divulgação, fez 
obra pelo gosto de experimentar, actuou em vários domínios, inovou nas artes gráficas, na edição e produção de livros, na ilustração de capas, na fotografia, e na arquitectura, etc.

\section{I.II Contextualização do problema}

Na contextualização da problemática e na investigação dos seus pressupostos deve-se ter em conta a História global do Design Português que em boa medida, encontra-se por fazer num estado de latência ou embrionária. A disciplina da História do Design Português é ausente dos currículos dos cursos de Design no Ensino Superior, está integrada apenas num único curso superior (Universidade de Aveiro). Infere-se, a não tradição do estudo de tal matéria especificamente no contexto Português. Academicamente é revelado, por norma, o conhecimento da história do Design ou Teoria do Design em âmbito universal sofrendo o caso Português de uma patologia disfuncional.

Pelo levantamento exaustivo dos recursos bibliográficos no que toca ao Design Português, logo se induz a sua inexistência, dando o enfoque de tal ser um não assunto na massa cultural e na própria cultura portuguesa.

As abordagens do Design Português são escassas, descontinuadas e individuais, contudo começam a emergir as teorias que reflectem a sua história, a informação cognitiva dos seus antecedentes, desenvolvimento e o momento actual de modo a permitir o entendimento geral do seu campo de acção e as correlações dos 
vários elementos existentes dentro deste.

Das abordagens individuais salientam-se os escritos dos críticos docentes universitários Mário Moura e José Bartolo (com contribuições assíduas nos seus Blogs Ressabiator e Reactor, respectivamente, de notoriedade nacional), a docente e investigadora Maria Helena Souto, e o Designer Jorge Silva (com o conhecido esforço louvável da compilação dos expoentes máximos do Design Gráfico Português na colectânea Colecção D editado pela Imprensa Casa da Moeda). Contribuições estas, debruçadas na análise, crítica e na reconstrução de História do Design Português que passam também por artigos em jornais, revistas e livros da especialidade de projecção nacional e internacional. O moroso aparecimento de centros de Investigação na área do Design (ID+, Instituto de Investigação em Design, Media e Cultura; Instituto de Investigação em Arte, Design e Sociedade; UNIDCOM, Unidade de Investigação e Formação em Design e Comunicação; i2ADS, Instituto de Investigação em Arte, Design e Sociedade da FBAUL e CIFAD, Centro de Investigação em Design e Comunicação) bem como a ausência de revistas científicas na área, dificulta a missão de se efectivar uma corrente de informação dinamizadora da consciência colectiva do Design Português.

É que «A História do Design Português ainda não está feita de modo sistemático e consistente apesar de existirem, hoje, contributos importantes para a sua compreensão, nomeadamente através de teses de mestrado e doutoramento.» ${ }^{6}$

O aumento do número de alunos de mestrado e doutoramento ao longo da última década potenciou um crescimento de trabalhos académicos no âmbito da história do design em Portugal. Algumas teses resultaram já em publicações, como o recente “Design Gráfico

${ }^{6}$ BARBOSA, Maria Helena Ferreira Braga; História do Design Português [disponível em: http://www.ua.pt/PageDisc.aspx $? \mathrm{id}=2470 \& \mathrm{~b}=1$ ] [consultado em 06/10/12, 16:50:00] 
em Portugal” de Margarida Fragoso ou outras disponíveis on-line ou em bibliotecas que revelam uma particular atenção aos estudos monográficos (Sebastião Rodrigues, Victor Palla, António Garcia, Maria Keil, Fred Kradolfer, etc.). Teses como a de Maria Helena Souto apresentam já de forma mais sistematizada a história do design português no início do século XX ou até mesmo a Tese de Ana Catarina de Oliveira Redol, intitulada "A influência do abstracionismo geométrico no Design Gráfico nos anos 60. Para uma abordagem em Portugal”, que aborda a evidente influência do abstraccionismo geométrico manifestado a nível internacional que patenteia teorias De Stijl, da Bauhaus, Construtivismo Russo e da Nova Tipografia em Portugal. Remete para as figuras de destaque e para os veículos que proporcionaram não só as teorias associadas a estes movimentos (do início do século), como também o panorama artístico do abstraccionismo geométrico. No âmbito da abstração geométrica em Portugal foram protagonistas proeminentes Fernando Lanhas e Nadir Afonso bem como no design gráfico português Sebastião Rodrigues, António Garcia, Victor Palla, João Câmara Leme e Paulo Guilherme estes como representantes e principais obreiros da geração de ouro, deixando um legado histórico e visual de grande valor para o design gráfico, influenciados por uma vertente geométrica e de rigorosa incidência estrutural, únicas e escassas no panorama Português. Este estudo, é dos únicos estudos efectuados que posiciona PG como referencia no Design Gráfico Português ao lado de outros grandes nomes de referência nacional portuguesa. A sua aproximação com estes casos faz-se também pelo facto do seu trabalho incorporar uma matriz semelhante no tocante a qualidades, como multidisciplinariedade, transversalidade e ecletismo. Mas esta semelhança e numa base comparativa com outros artistas como Victor Palla, António Garcia, Luís Filipe de Abreu, autores estudados, referenciados, de 
reconhecido mérito, confunde a razão, pois PG não foi estudado, quase nunca referenciado ou conhecido. Não será legítimo também poder afirmar-se que PG contribuiu para a Cultura Visual Portuguesa do séc. XX?

A contextualização da problemática e a investigação dos seus pressupostos, permitem a estruturação do pensamento num sentido pragmático. Desse modo, as referências existentes, que são as plataformas teóricas para a fundamentação, concentra-se na compreensão da história de vida de PG, o seu tempo, a formação pessoal e artística e a sua obra. Deste plinto, salientam-se os artigos, crónicas, criticas de jornais e revistas da época, um catálogo de exposição, dois livros de investigação, um livro género "romance" e dois livros de poemas. Para rigorosa compreensão, importante será também o entendimento do contexto político, social, económico e o contexto artístico bem como os principais protagonistas, suas acções e impactos, influências exercidas, experiências acumuladas e a correlação de todos os dados. Igualmente importante, serão os artistas contemporâneos de PG, os seus depoimentos, a partilha comum na arte e na vida.

\section{I.III Objectivos da Investigação}

O objectivo geral desta tese é, como se aponta no início, a realização de um estudo monográfico que coloque em valor a obra de PauloGuilherme D'Eça Leal, facultando a sua compreensão, importância e que contribua para a sua divulgação dentro do contexto da arte e da 
história do design português. E que isso seja possível através desta nossa contribuição crítica, bem como os diversos contributos biográficos, bibliográficos e visuais desconhecidos do público que fazemos no presente trabalho.

Tratando-se de uma personalidade multifacetada e dado o universo e extensão do material existente, o principal interesse recai nas obras-chave enquadradas em momentos específicos para estabelecer uma visão crítica da evolução com base na análise das ditas obras e do contexto em que foram criadas.

Com o objectivo de contribuir para melhor documentação da cultura visual Portuguesa no que diz respeito à identificação, reunião de documentação e testemunhos ainda disponíveis, a investigação efectuada pretende salvaguardar espécimes e gerar novo conhecimento com a análise, reflexão e compreensão da mesma. Esta base teórica destina-se a gerar novo conhecimento para o domínio público, com especial enfoque nos estudantes e profissionais desta área.

No que pode ser chamado de objetivos específicos, este estudo também visa obter como resultado:

1. Estabelecer, com base no estudo e análise exaustiva da vida e obra de Paulo-Guilherme, relações de dependência ou interacções de interesse destinadas a fazer possível uma maior compreensão de seu trabalho criativo.

2. Realizar graficamente uma compilação fundamentada e o mais completa possível que reúna e ilustre a parte mais destacável da produção artística do autor em função dos momentos chaves da sua evolução.

3. Contextualizar, dentro de sua diversidade, conceptualmente e tecnicamente seu trabalho e 
destacar as possíveis contribuições nesse sentido.

4. Contribuir para o debate em torno da valorização deste autor, pelo que entendemos ser uma contribuição importante para a formação de uma hipotética cultura visual portuguesa;

A investigação, reflexão e a sistematização que agora se propõem, aspiram a servir de referência a futuras investigações, e sejam a prepósito do próprio PG como para eventuais avaliações de outros autores que partilham a mesma matriz cultural e visual, fornecendo pistas e material para completar com ele a historiografia portuguesa.

\section{I.IV Estrutura da tese}

O corpus desta memória de tese divide-se em quatro capítulos cuja linha de orientação principal é sobre a vida de Paulo-Guilherme D’Eça Leal (I), com o contexto histórico - político da sociedade portuguesa na segunda metade do séc. XX (II), com a arte portuguesa e seus protagonistas ao longo desse mesmo período de tempo (III), e com a obra de Paulo-Guilherme D’Eça Leal (IV), seguidos por um capítulo de conclusões tendo por base os resultados do processo da investigação, uma bibliografia e uma série de anexos com materiais complementares.

No capítulo I, destinado a tratar biograficamente a vida de Paulo-Guilherme D’Eça Leal, apresenta-se, em geral, a genealogia 
deste artista, sua formação, sua trajectória e suas principais influencias. A primeira aproximação ao tema de estudo, entendemos que deveria ser necessariamente a nível pessoal, antes de compreender o artista há que entender o homem e suas circunstâncias. Sabemos que o enfoque pode ser polémico porque o que importa realmente é a personalidade estética e não a empírica, mas, embora centremos parte da nossa atenção no homem que vive uma existência quotidiana, é o criador de obras artísticas o que, definitivamente, constitui o núcleo principal da nossa investigação. Assim este capítulo dá uma visão geral dos seus antecedentes, experiencias e influencias que determinam por conformar a sua personalidade, a sua trajectória de vida acabando por sustentar a sua actividade artística. Neste contexto é fundamental destacar a figura de seu pai Olavo, que foi seu ponto principal de referencia e cuja influencia é determinante para uma melhor compreensão dos aspectos que distinguem PG como artista. Em resumo, e apesar da observação acima indicada, poderíamos dizer que o conteúdo deste capítulo se baseia no conhecimento do «homem» com o fim de deduzir as diversas variáveis existenciais que o definem como «ser».

O capítulo I versa a vida de Paulo-Guilherme D’Eça Leal, apresenta de um modo geral: a genealogia deste artista, a sua formação, o seu percurso e as suas influências. A primeira abordagem ao tema de estudo teria forçosamente de ser a um nível pessoal, antes de entender o artista entender o homem e os circunstancialismos que o formaram tal e qual como foi. Dar uma perspectiva das suas origens, vivências e influências que teve exposto e de que modo isso moldou a sua personalidade e o seu percurso enquanto pessoa e artista.

Nesta explanação é realçada a figura de seu pai Olavo pelo marco que foi e pelas opções de vida que induziu, determinante para a 
melhor compreensão da personalidade de PG.

O teor deste capítulo assenta no conhecimento pragmático e circunstancial sobre o "Homem" com o propósito de se inferirem as várias variáveis existenciais definidoras enquanto "Ser".

No segundo capítulo realizamos uma revisão do contexto social, político e económico, que entendemos possibilitar uma compreensão geral da questão principal da investigação com base nos factos mais relevantes e nas acções mais importantes que ocorridas durante cinco décadas (dos anos 30 aos 80) no seu decurso. Centra-se nos principais actores e nos acontecimentos que ocorreram nos diversos âmbitos da sociedade portuguesa dessa tempo. Seu objectivo é levar a entender que o comportamento de um indivíduo tem condicionantes e não só de ordem psicológica, mas também determinados pela situação histórica e social. Na situação portuguesa do séc. XX destacam-se a influencia de fenómenos perturbadores. A “Grande Guerra” (1914-1918), a crise de 1920, os 40 anos de ditadura Salazarista, a guerra colonial (19611974), a Revolução de Abril (1974), a transição abrupta para a democracia, são dados informativos para a compreensão dos efeitos inversos ao desenvolvimento geral do país e em particular as práticas artísticas em Portugal.

Constitui parte deste capítulo, uma linha do tempo (timeline) tornando possível uma visão geral e gráfica destes fenómenos.

No terceiro capítulo leva-se a cabo uma revisão geral do estado da Arte portuguesa no séc. XX e os seus principais protagonistas, ou seja, fornece uma contextualização histórica da Arte em Portugal nas mais diversas áreas de actuação permitindo um entendimento geral dos percursos, dos movimentos, dos fenómenos, das manifestações e implicações, com a evidente intenção de contextualizar a obra e contribuições de PG.

São identificados e descritos os agentes culturais e suas 
participações nas diversas áreas de actuação estabelecendo-se as correlações desses agentes, dessas áreas e as repercussões no desenvolvimento artístico português. Personagens com grande carácter cultural, autores de obra relevante e marcante, protagonistas de acções indubitáveis, na cultura e no meio artístico, são indiscutivelmente os autores da nossa história.

Em resumo: dar a conhecer os movimentos artísticos que mais sobressaem e suas influencias tendo em conta o individual e o colectivo, estabelecendo as várias relações. A ênfase discursiva encontra-se também em alguns indivíduos que são referencias fundamentais já que foram determinantes para que a história fora tal como a conhecemos, pelo que são fundamentais para o seu estudo e interpretação. Também este capítulo tem uma linha do tempo (timeline) destinada a tornar mais fácil uma visão geral destes acontecimentos.

É no quarto capítulo que realizamos a compilação de toda a obra de PG, com o fim de contribuir para a descrição e compreensão do seu acervo contributivo para a cultura visual de Portugal. O capítulo está dividido em nove áreas de actuação: Artes Gráficas; Pintura e desenho; Escultura e tapeçaria; Interiores e decoração; Arquitectura; Espetáculos e exposições; Realização; Literatura e, por último, Outros trabalhos. Na sua forma pretende-se observar e analisar amplamente a sua actividade profissional interdisciplinar e transversal de PG nas diferentes áreas de actuação onde desenvolveu sua actividade, promovendo a compreensão dos seus trabalhos no panorama artístico da época e valorar a respectiva importância e contribuição que teve na construção da cultura visual portuguesa do séc.XX. Em consequência, a analisar e avaliação crítica de todos os aspectos da acção e da obra deste artista que se tornaram factores preponderantes de evolução na imagética Portuguesa, bem como detectar os momentos e as obras que 
operaram mudanças e rupturas nessa evolução, ocorrendo nesta parte da memória de tese. Também neste capitulo, apresentamos uma linha de tempo (timeline) oferecendo a possibilidade de uma visualização geral da sua obra em relação à sua trajectótia de vida.

Os quatro capítulos enunciados potenciam novos dados interpretativos, procedidos das pertinentes conclusões, agregandose a este ponto, a bibliografia e anexos. Os anexos têm a forma de DVD's e oferecem material importante para a investigação, principalmente fotográfico, audiovisual (palestras e entrevistas) que permitem enriquecer e completar a visão da vida e obra de PG. Também se anexa um filme documental que realizamos no âmbito da vida e obra de PG cujos protagonistas são principalmente personagens integrantes da massa cultural portuguesa.

\section{I.V Metodologia}

A presente investigação fundamentou-se na narrativa e na descrição dos elementos essenciais e estruturais da obra de Paulo Guilherme D'Eça Leal. Investigou-se exaustiva e ponderadamente com a intenção de localizar e reunir o maior número de obras, e sobretudo, as mais significativas, permitindo com elas a construção de um conjunto que transmitirá uma visão global, e o mais completa possível, do trabalho desenvolvido pelo artista PG em termos qualitativos e quantitativos. A investigação contém uma série de testemunhos orais, dados biográficos reconhecidos, protótipos, artefactos, desenhos técnicos, assim como referências 
bibliográficas, documentos, etc. de grande riqueza. Daqui surge um primeiro inventário, a classificação, a investigação cronológica da obra de PG, assim como uma estruturação das diferentes áreas de intervenção, notas de referencia bibliográfica e iconográficas, diversas entrevistas e contactos pessoais que foram determinantes para o sucesso desta tese.

Foram parte do processo investigativo desta tese instrumentos metodológicos como:

a) Recolha, selecção e ordenação de toda a informação documental existente sobre a vida e obra de PauloGuilherme D’Eça Leal.

b) Fundamentação teórica sobre o que levou à concepção de uma estrutura organizativa e selectiva do material mais relevante desde os objetivos que perseguiam a investigação.

c) Levantamento e verificação das influências nacionais e internacionais, que possam indiciar as raízes visuais do autor.

d) Análise critica dos textos escritos pelo ou sobre o autor, e concretamente aqueles que ajudem a esclarecer na perspectiva da problemática da cultura visual;

e) Análise iconográfica das obras consideradas chave no dimensionamento das contribuições de PG na cultura visual portuguesa;

f) Entrevistas a pessoas relacionadas com o artista e/ou com meio artístico da época em estudo.

Para concluir este prefácio explicativo, sublinha-se a nossa intenção ao longo deste estudo, de não entrar no enigma do artista, isto é, não condicionar a nossa aproximação a uma perspectiva psicológica 
à personalidade artística de Paulo-Guilherme, mas fazê-lo, desde uma visão sociológica que entendemos mais próxima à nossa competência. Esta, permite não nos condicionar desde a apologia até preconceitos possíveis. Os factos bibliográficos do artista a que tivemos alcance dão a entender com exclusividade os aspectos, que vão do que é estritamente artístico até à consideração de seus próprios contemporâneos que podem ser relevantes para a nossa área de interesse.

Renunciamos, também, à realização de uma memória de tese densa e carregada de notas que teria sido normal em relação ao volume de documentação a que tivemos acesso, em favor de uma economia expositiva que se centra principalmente naquilo que entendemos que é substantivo. Com isto, não pretendemos limitar nossa responsabilidade sobre os resultados, se não ser fiéis à nossa intenção de não dar azo a qualquer especulação, ou sermos pretensiosos intentando dar um carácter definitivo às nossas apreciações com base em avaliações puramente quantitativas. 


\section{Capítulo 1: Biografía de Paulo- Guilherme D' Eça Leal / Biografia de Paulo- Guilherme D’Eça Leal}

«Paulo-Guilherme D’Eça Leal. Desde logo, a saga trágico-épica do clã: rezam as estórias da História que o primeiro dos Eças foi o neto de Pedro e Inês. Depois, a progenitura notável: Olavo D’Eça Leal, o pai, foi homem sobre quem se recorda o génio. Na escrita e na vida. Paulo-Guilherme chegou ao mundo carregado de responsabilidade. $\mathrm{E}$ a verdade é que podia não ter corrido bem. Acontece nas melhores famílias. Foi o contrário. Correu-lhe, a ele e a todos nós que beneficiámos com isso, tão bem, tão espantosamente bem, que a narrativa sobre os seus feitos e venturas se torna tão improvável como um filme fantasioso, demasiado optimista. Se não, tomemos os factos. Paulo Guilherme foi, é: emérito ilustrador, prolífero decorador, autor de arquitecturas memoráveis, pintor, escultor, fotógrafo, cineasta, cenógrafo, gráfico, dramaturgo, produtor teatral, investigador esotérico, poeta, cozinheiro, diseur, barman. Enfim inclassificável na diversidade das suas competências, voraz na curiosidade, demolidor na paixão criadora, impressionante na capacidade de trabalho. Um sobredotado com a inevitável dificuldade na fixação de interesses. «Sempre adorei fazer o que nunca fiz. E uma das minhas poucas virtudes é uma tenacidade doentia».» ${ }^{7}$

Despreocupado em construir uma carreira, ter um título ou profissão fixa, Paulo Guilherme procurou na sua vida adeterminação, a aventura, a experimentação, o novo.

${ }^{7}$ PINHEIRO, Paula Moura. Revista Elle n ${ }^{o} 138$, p. 84 


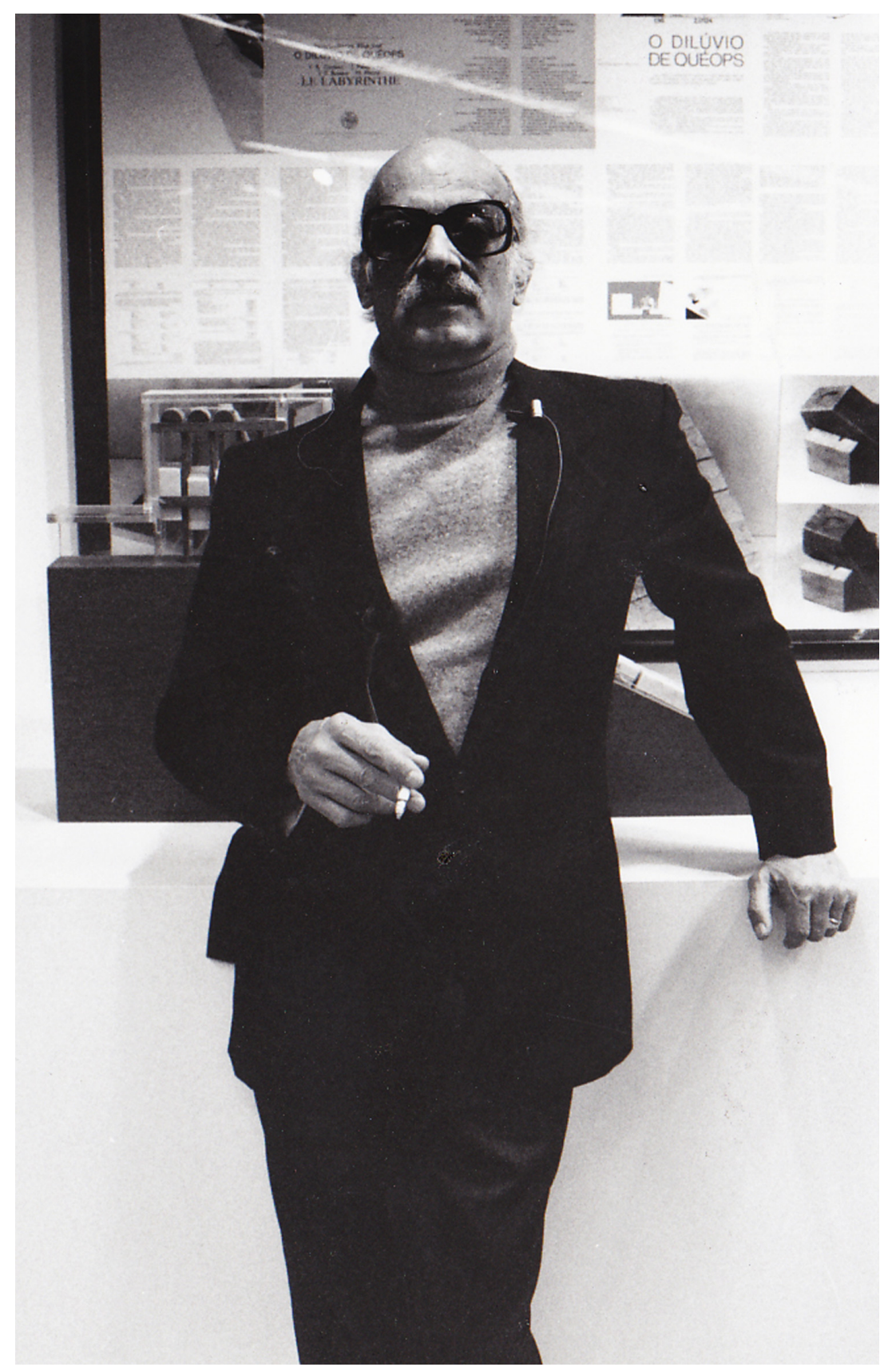

Figura 1. Fotografia de Paulo-Guilherme, 1991 
O espírito auto didacta, a persistência, a teimosia, características intrínsecas definem-no como homem e como artista.

«(...) não faço questão nem nunca fiz questão de ser escritor ou pintor, ou isto ou aquilo, eu gosto de criar... criar é um passo de mágica, é fazer aparecer qualquer coisa onde dantes não existia e isso fascina-me. Tanto faz (...) é preciso é criar coisas como não sou fanático de ser um grande pintor ou um grande escritor, ou um grande isto, quero é ser o melhor PG possível.» ${ }^{8}$

José Augusto-França, no catálogo da exposição retrospectiva Paulo-Guilherme d'Eça Leal d'Etcetera e Tal 2000, salienta: «(...) a relação entre as coisas que exibes é o que elas têm de melhor, porque o que foste mudando, aqui e acolá, na exposição como na vida, na superfície da tua acção, todo o resto logo alterou sempre outro que foste sendo» ${ }^{9}$.

«O apego desmedido à liberdade de acção, o destino do visionário comprido a todo o custo, a incapacidade de integrar limites, as regras dos outros, fizeram do Paulo Guilherme um criador em todas as frentes, no «espírito de todas as artes». ${ }^{10}$

\footnotetext{
${ }^{8}$ LEAL, Paulo-Guilherme. CRUZ, Carlos. (Prod.) (25/12/1991). Carlos Cruz Quartafeira [video VHS]. RTP

9 D'EÇA LEAL, Paulo-Guilherme. Paulo-Guilherme d'Eça Leal d'Etcetera e Tal 2000 Exposições -Lisboa, Arte ibérica, 2000,p.9

${ }^{10}$ PINHEIRO, Paula Moura. Revista Elle n ${ }^{\circ} 138$, p. 84
} 


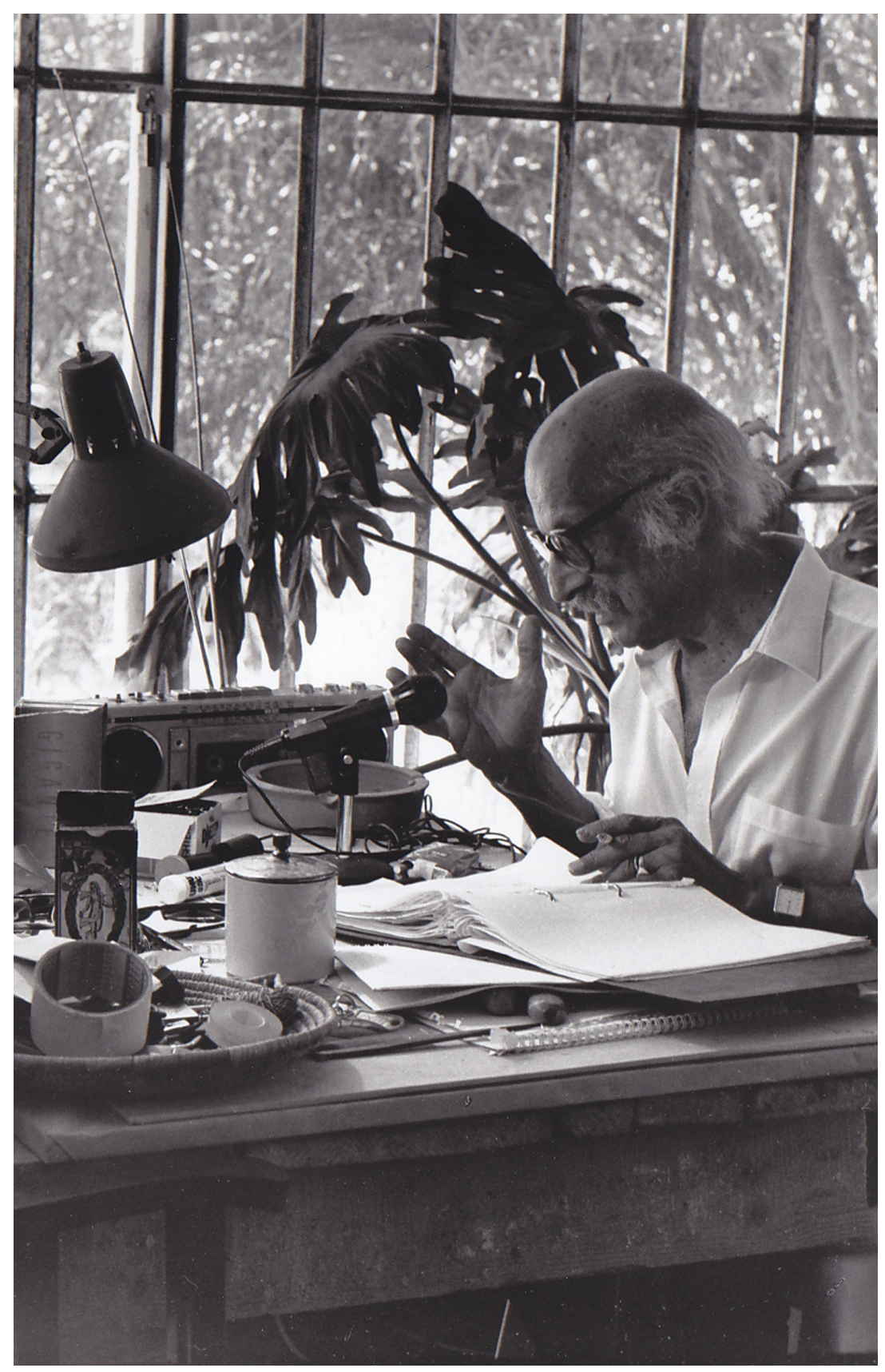

Figura 2. Fotografia de Paulo-Guilherme, 1995 


\subsection{Orígenes e infancia / Origens e infância}

Paulo-Guilherme Tomaz Dúlio Ribeiro D’Eça Leal, nasce a 21/7/1932 na Rua Alexandre Herculano, em Lisboa. Seu avô Thomaz D'Aquino Pereira D’Eça e Albuquerque Leal, fora poeta, sua avó Flávia Correia Leite D’Eça Leal dramaturga e poetisa, sua mãe Luiza Maria Dúlio Ribeiro D’Eça Leal música e professora de línguas e seu pai Olavo correia Leite D’Eça Leal locutor da Emissora Nacional e artista com vasta obra que se estende por vários domínios como a poesia, ficção, artes plásticas, teatro radiofónico e cinema. PG enquanto criança era uma figura franzina, tímida, insegura atrás de uns grandes óculos de massa com lentes muito graduadas. Descendente de uma família repleta de artistas, PG, o mais velho dos seus irmãos, cresceu no meio de artistas e viveu profundamente imbuído nesse mundo.

«Tive uma sorte espantosa de nascer num meio de artistas. Até certa idade, tinha a impressão de que toda a gente era ou pintora, ou escultora, ou artista plástica, etc.» ${ }^{11}$

A família de Paulo-Guilherme era muito abastada, mas no ano de seu nascimento perdera tudo, dinheiro, luxo, propriedades, restou apenas a educação refinada e o bom gosto. O palacete na Rua Júlio Dinis, no bairro Azul, onde morava com a sua família era frequentado por inúmeros escritores, pintores, músicos e intelectuais. Ofélia Marques ${ }^{12}$, Bernardo Marques ${ }^{13}$, Carlos Queiroz ${ }^{14}$,

\footnotetext{
${ }^{11}$ CEGONHO,Pedro.’Um bairro à imagem de Montmatre".Revista Santo Condestável, Julho a Dezembro de 2008, pág.8

${ }^{12}$ Primeira mulher de Bernardo Marques (1902-1952), pintora e ilustradora de grande sensibilidade preferia temas ligados à infância. Ganhou em 1942 o prémio Amadeu de Sousa Cardosa com o retrato Luísa Maria D’Eça Leal (mãe de PG)

${ }^{13}$ Personagem fascinante, (1899-1962) verdadeiro príncipe das artes, deu impulso decisivo nas artes gráficas portuguesas. Grande ilustrador, recebeu a Ordem de Santiago em 1942.
} 


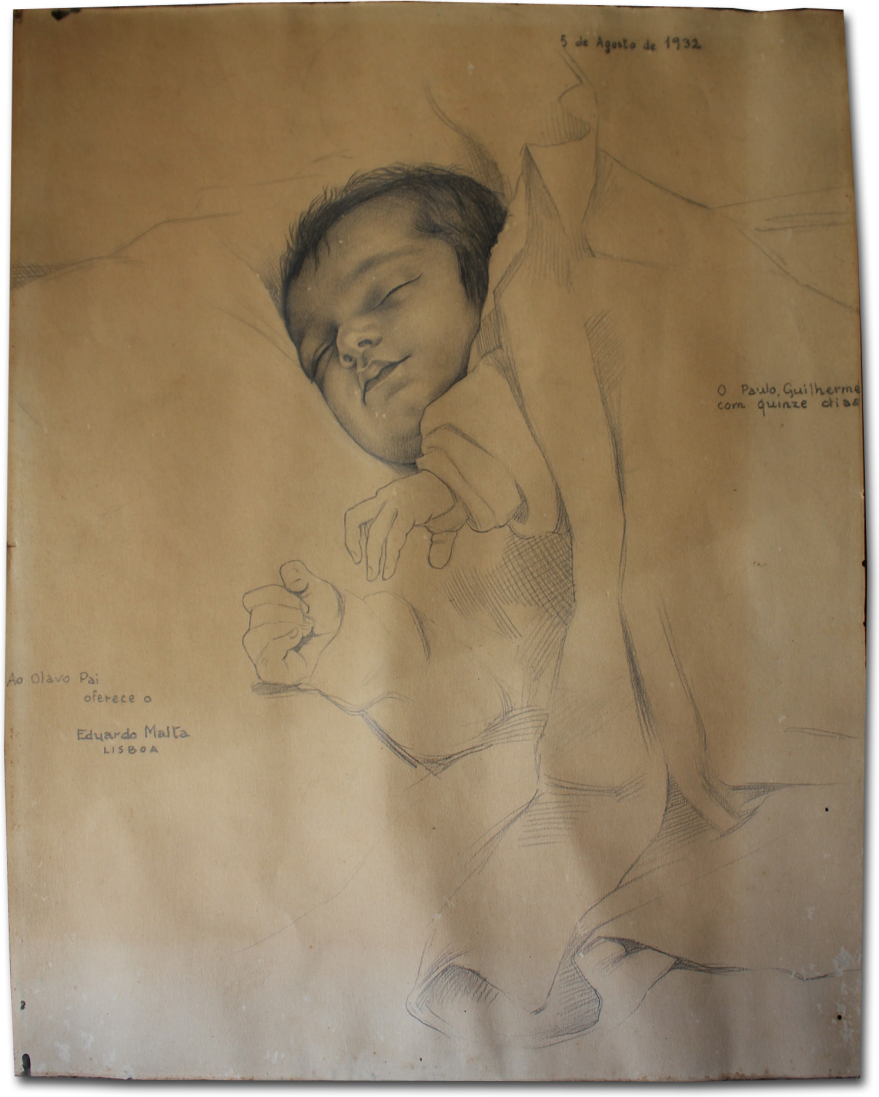

Figure 3. Retrato de Paulo-Guilherme por Eduardo Malta, 1932

${ }^{14}$ Poeta (1907-1949) de tendência intelectualista, ensaísta, crítico de arte. O seu primeiro livro publicado, "Desaparecido", obteve o prémio Antero de Quental de 1935. O seu ultimo livro foi "Breve tratado de não versatificação" (1938). A sua obra encontra-se dispersa por jornais e revistas literários. Colaborou na Presença de Coimbra, Variante e Sudoeste. Dirigiu a revista Litoral e Panorama editada pelo SNI. Funcionário da Emissora Nacional organizou muitos programas de rádio principalmente consagrados à poesia, literatura e teatro. 
José Régio ${ }^{15}$, Almada Negreiros ${ }^{16}$, Fernando Pessoa ${ }^{17}$ entre muitas outras ilustres personalidades que foram presenças assíduas na casa e na infância de Paulo-Guilherme.

«(...)o princípio foi assim: quatro anos depois de ter nascido comecei a fazer bonequinhos, como todas as crianças. E como todas as crianças tinha pais, tios e primas que achavam que o menino tinha muito jeitinho. Só que há meninos que acreditam e outros que não, e eu acreditei, portanto nunca mais desisti. Ainda por cima lá em casa toda a gente desenhava bem... toda a gente tocava bem, escrevia bem... e pensava bem. Porque uma das heranças que tive do meu pai foi um bom nome que tenho feito os possíveis por manter e, muito principalmente, um círculo de amizades. $\gg^{18}$

PG frisa ainda a quantidade, a diversidade e a qualidade superior dos artistas que o rodeavam na sua infância e acrescenta até que: «...uma criança é uma espécie de mata borrão que apanha as influências que tem ao pé.» ${ }^{19}$

Fruto do seu seio familiar, do meio artístico em que nasceu e se viu envolvido, Paulo Guilherme foi irremediavelmente influenciado pela geração de seu pai, uma das suas máximas referências enquanto artista. Por outro lado o seu próprio pai era já também fruto dessas influências.

\footnotetext{
15 José Régio (1901-1969), escritor cujo pseudónimo José Maria dos Reis Pereira, foi possivelmente o único escritor em língua portuguesa a dominar com igual mestria todos os géneros literários: poeta, dramaturgo, romancista, novelista, ensaísta, cronista, jornalista, crítico, epistológrafo, historiador de literatura... editor e diretor de influencia revista Presença, desenhador, pintor e colecionador de arte Sacra e Popular

16 Almada Negreiros (1893- 1970), impulsionador do futurismo em Portugal, pintor fez os Murais das Gares Marítimas de Alcântara e da Rocha de Conde de Óbidos. Os vitrais da igreja de Fátima, o Mural da fundação Gulbenkian. Poeta, novelista e dramaturgo. Grande estudioso de estética e história de Arte, grande geómetra.

${ }^{17}$ Fernando Pessoa (1888-1935) grande poeta, desdobrado em múltiplos heterónimos, é o mais influente pensamento na literatura portuguesa. Lançou a revista Orpheu com Mário de Sá Carneiro e Luís de Montalvor e ganhou em 1934 o prémio Antero de Quental com o seu livro "Mensagens".

${ }^{18}$ LEAL, Paulo-Guilherme, cit in "Paulo-Guilherme, Je ne regrette rien!", jornal SI ,1980, p.24

${ }^{19}$ Idem
} 

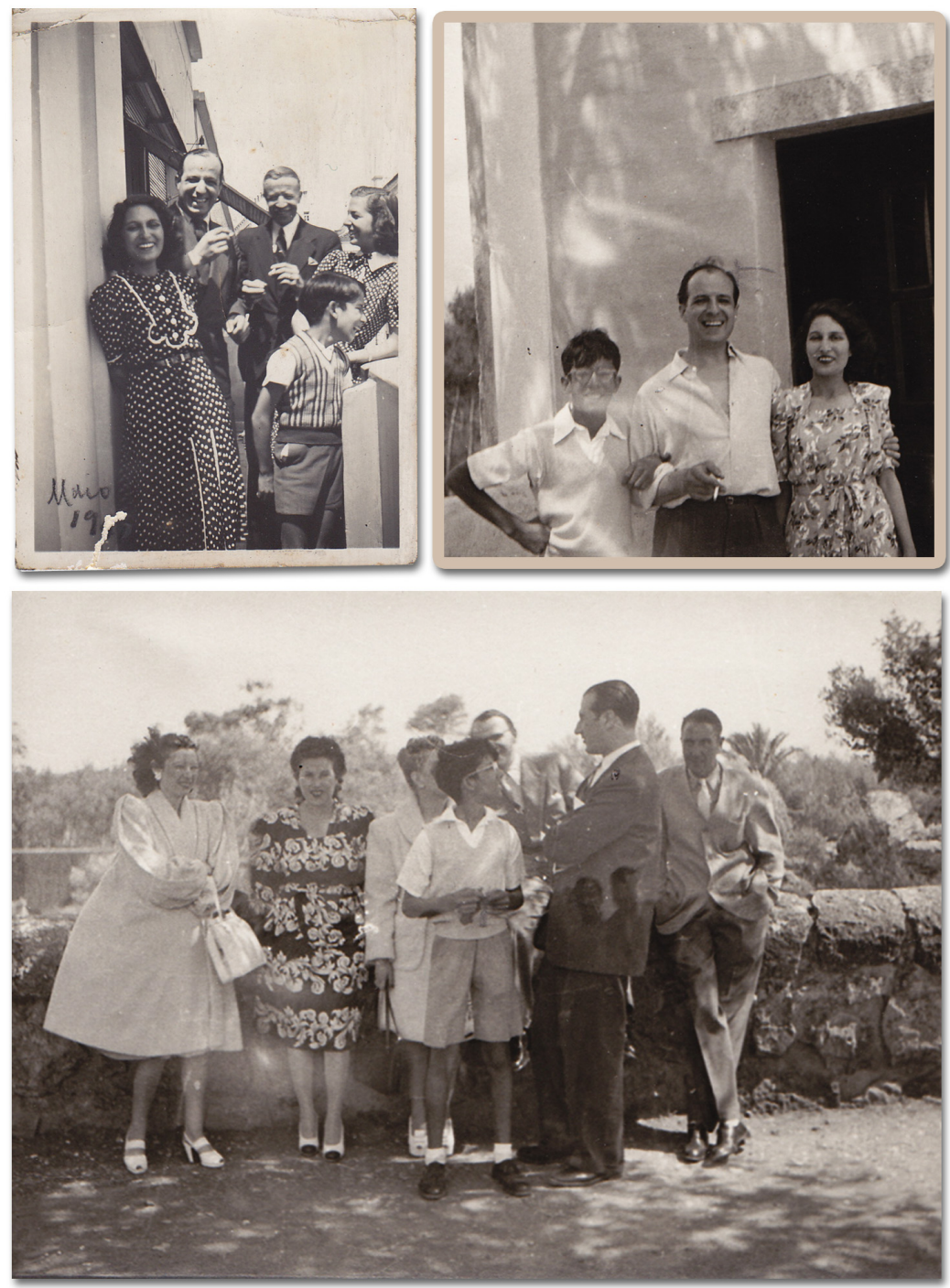

Figure 4. Conjunto de fotografias familiares 


\subsection{El padre Olavo / O pai Olavo}

Como pai, Olavo D' Eça Leal foi uma referencia constante na vida de seu filho Paulo-Guilherme. Homem extremamente trabalhador, dividiu o seu tempo numa diversidade de profissões e actividades: colaborações em revistas com artigos, contos, poemas, artigos e desenhos; escritor dos seus próprios livros; artista gráfico; ilustrador; professor de desenho; Actor de cinema e teatro; assistente de realização em filmes portugueses; realizador de anúncios televisos; locutor; etc.

Olavo Correia Leite D' Eça Leal nasceu a 31/07/1908, em Lisboa. Filho da dramaturga e poetisa Flávia Correia Leite D’Eça Leal e do poeta Thomaz D'Eça Leal, tem o privilégio de crescer num ambiente familiar culto e economicamente favorecido.

Olavo era um homem de grande sucesso, tinha uma cultura de cariz clássica, foi educado em Paris sabia o Corneille ${ }^{20}$ e o Racine $e^{21}$ de cor e salteado também como todos os clássicos portugueses.

Paulo Guilherme foi criado nesse meio em que o pai, culto e também polivalente, convivia com grandes personalidades da cultura portuguesa da época: Sarah Afonso, Ofélia e Bernardo Marques, Abel Manta. Jean Cocteau e José Régio eram alguns dos que se correspondiam com o pai Olavo, no auge da sua carreira. De seu pai guarda, da infância, grandes debates com o Almada. Olavo, desde muito jovem movimentava-se num círculo de amigos

\footnotetext{
${ }^{20}$ Pierre Corneille, mais conhecido por Corneille (1606-1684) foi um dramaturgo de tragédias. Ele foi um dos três maiores produtores de drama na França, durante o XVII, ao lado de Moliére e Racine. Era chamado de "fundador da tragédia Francesa" e escreveu peça por mais de quarenta anos.

${ }^{21}$ Jean Baptiste Racine (1639-1699) foi um poeta dramaturgo, matemático e historiador francês. É considerado, juntamente com Pierre Corneille, como um dos maiores dramaturgos clássicos de França.
} 


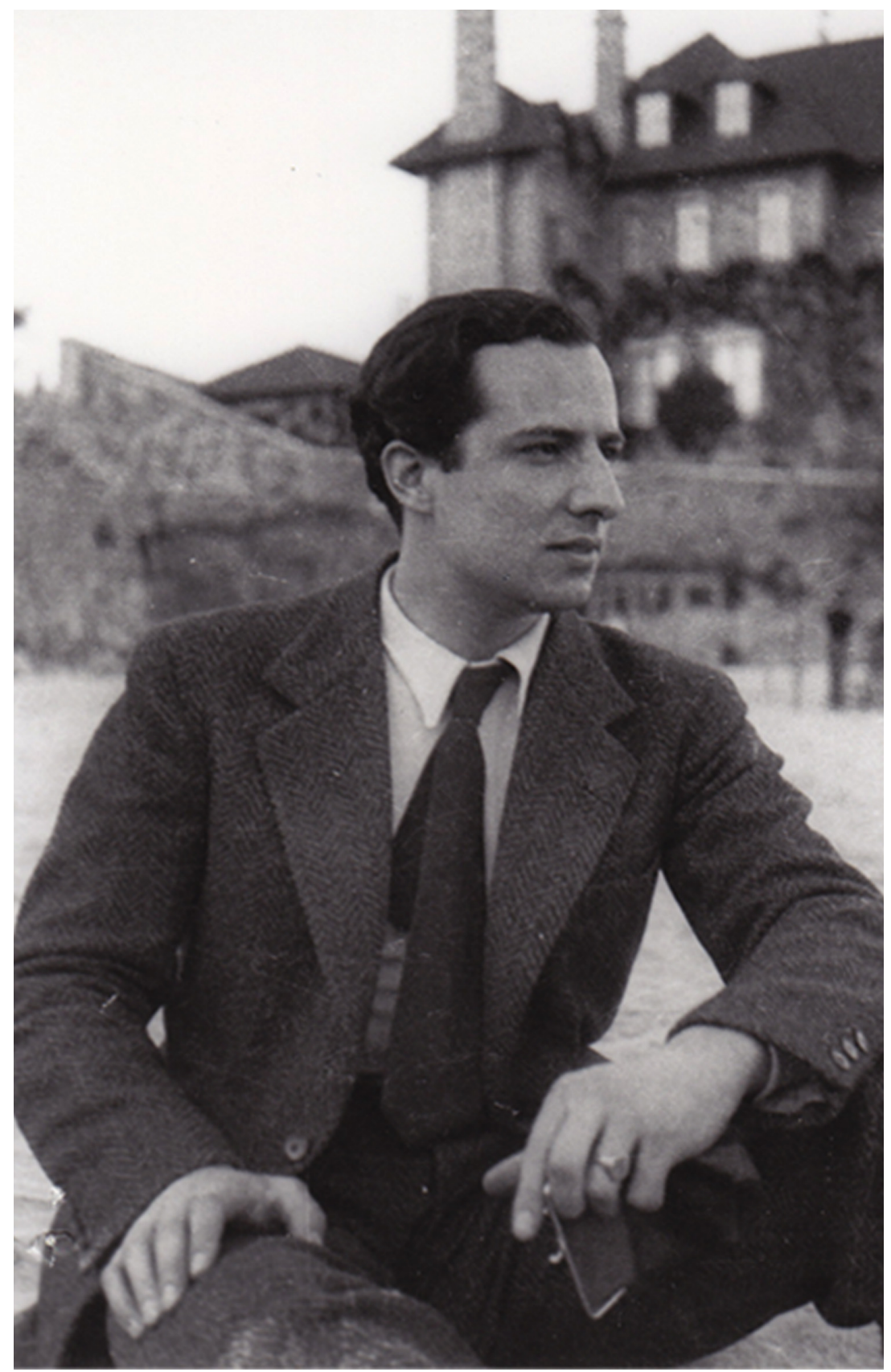

Figura 5. Fotografia de Paulo-Guilherme, 1991 
intelectualmente brilhantes e a sua vida contava com uma faceta mundana e boémia, sendo frequentador assíduo do Maxime, do Arcádia e do Retiro da Severa.

Esta figura paternal muitas vezes ausente mantinha uma forte imagem no seio familiar, em que a sua educação, cultura, intelecto e universo causava respeito, deslumbramento. PG referia-se sempre com admiração aos feitos de seu pai, suas ilustrações, seus desenhos, suas poesias, suas obras literárias, etc.. As qualidades que lhe reconhecia foram sempre de estímulo, brio, responsabilidade, profissionalismo, perfeccionismo e competitividade, incentivo a tornar-se igual ou a superá-lo.

Paulo-Guilherme sempre tivera uma relação atribulada com o seu pai, fruto das vincadas personalidades de ambos e dos fortes ideais divergentes. A sua relação quotidiana era displicente, pouco afectiva, de grande independência, tratavam-se de modo igual, como colegas ou amigos. As discussões eram permanentes mas somente discutiam sobre as do ponto de vista artístico, intelectual ou literário. Discutiam muito, mas sempre mantiveram um grande respeito pela opinião um do outro.

«Tanto assim que toda a sua vida uma vez que fazia um programa de televisão ou de rádio, mais importante, mesmo que tivéssemos zangados, a primeira pessoa a quem ele telefonava a pedir a opinião era a seu filho.» ${ }^{22}$ comenta Paulo Guilherme numa entrevista a Carlos Cruz.

Respeitavam-se e admiravam-se mutuamente chegando até a fazer algumas parcerias em trabalho. Contudo desde cedo Paulo Guilherme sempre quisera afirmar-se pelas suas qualidades e competências não querendo viver na sombra do bom nome D’Eça

${ }^{22}$ LEAL, Paulo-Guilherme. cit in CRUZ, Carlos. (Prod.) (25/12/1991). Carlos Cruz Quarta-feira [video VHS]. RTP 


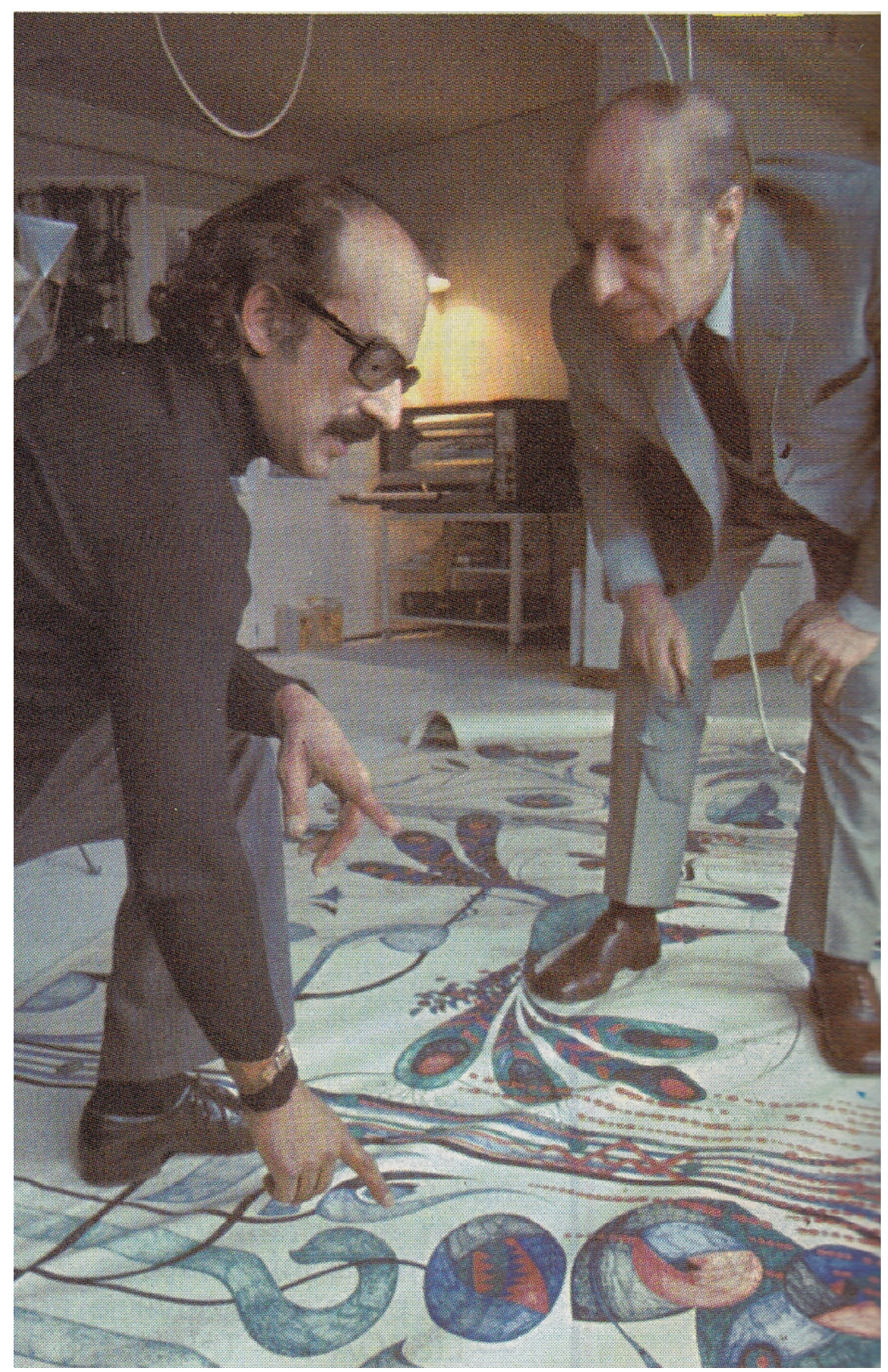

Figura 6. Fotografia de Paulo-Guilherme e Olavo, 1974 
Leal. Opta precocemente pela rubrica, Paulo-Guilherme com a qual identificou toda a obra não fosse ser confundido com o seu pai, não querendo tirar qualquer dividendos de tal facto. Tinha mesmo que se afirmar pelo seu próprio mérito. Excepção feita na obra realizada no Brasil, período compreendido entre 75 a 80, onde assinou D’Eça Leal por este nome não ser identificável.

A obra artística de Paulo Guilherme foi assim profundamente influenciada pelos anos 40 e 50 do século passado. Da mãe, recorda o facto de ter sido muito bem educada, tocava guitarra e falava línguas. Em sua casa a cultura e o sucesso eram o ambiente do seu crescimento.

\subsection{Inicios profesionales / Início profissional}

Olavo incutiu no seu filho o hábito de desenhar, dando-lhe um rolo de papel de máquina por dia com a obrigação borrar as 500 páginas todas, o que desenvolveu extraordinariamente a sua capacidade de desenho e refinamento de traço.

É pela pintura que o gosto criativo lhe chega primeiro. Aos oito anos pinta já para a Exposição do Mundo Português. Começa a "trabalhar semi-profissionalmente" muito cedo: aos 11, 12 anos já tinha ilustrações publicadas e bastantes. Decidiu depois voar pelos seus próprios meios.

Aos 12 anos de idade, realiza a sua primeira colaboração regular como ilustrador no Semanário Acção! ${ }^{23}$, Viriam o Diário Popular²4,

\footnotetext{
${ }^{23}$ O semanário Acção!, dirigido por Manuel Múrias, contou com a colaboração de muitos ilustradores prestigiados como Emmérico Nunes.

${ }^{24}$ O Diário Popular foi um jornal diário, Lisboeta e vespertino, fundado em 1942 de grande tiragem em Portugal.
} 


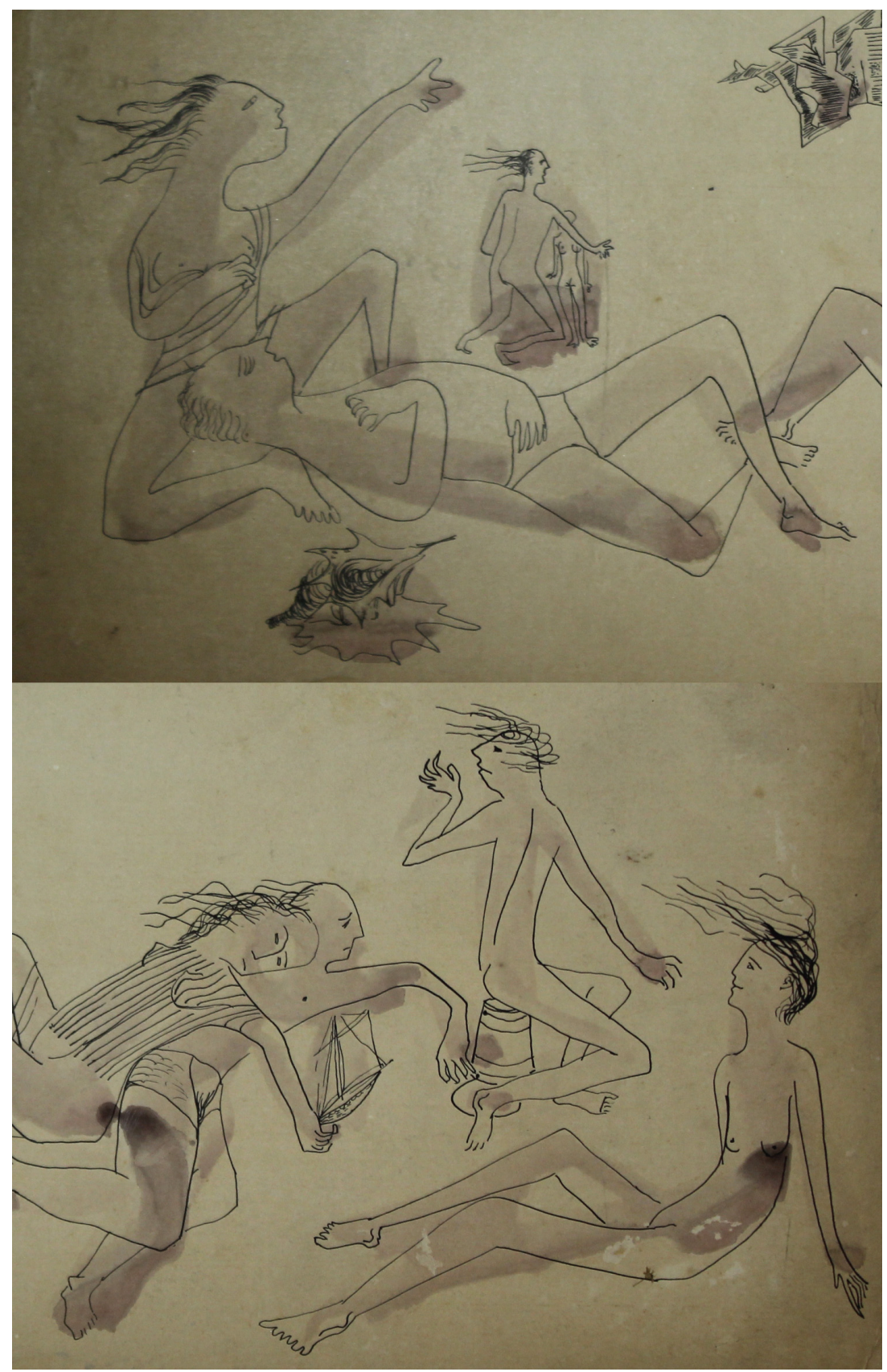

Figura 7. Desenhos de Paulo-Guilherme, 1948

70 
o Diário de Notícias ${ }^{25}$, O Século ${ }^{26}$.

Após a 4 classe, PG frequenta o Colégio Inglês e posteriormente o liceu Pedro Nunes (fez muitos anos de liceu, mais do que aqueles que era suposto), ingressou no curso de pintura na escola de Belas Artes de Lisboa (1951), não o tendo concluído por precocemente assumir a sua total independência.

Antes de sair de casa já trabalhar num atelier Estúdio de Artes Gráficas, Arquitectura e Decoração de Carlos Ribeiro onde aprendeu, chamemos-lhe assim, "a carpintaria da arte": esbatidos, pintura de letras, maquetas, stands, etc.... o que mais tarde todo este aprendizado lhe é útil. PG considerava Carlos Ribeiro um dos seus principais mestres. $\mathrm{O}$ atelier era de grande prestígio no meio e acolhia muitos outros profissionais, entre eles, Roberto de Araújo, António Garcia, Rogério Amaral, Sena da Silva, vários arquitectos e designers. Não significa isto, que o trabalho era comum com todos estas figuras mas por vezes propiciava-se a troca, fusão de ideias e opiniões, em grande espírito de camaradagem. O ambiente era excelente, de grande amizade, de entreajuda, de partilha e de aprendizado. Ambiente próspero para crescer profissionalmente. Por volta dos 16 anos teve uma discussão familiar com seu pai por causa das Pièces noires de Anouilh ${ }^{27}$. Paulo Guilherme saiu de casa e foi para a Rua da Arrábida. Alugou um quarto e começou a fazer trabalhos de publicidade, simultaneamente com ilustrações. Fez tantas, que por volta de 1970 , festejou a sua $5000^{a}$ ilustração.

\footnotetext{
${ }^{25}$ Jornal Nacional, de grande tiragem, fundado em Dezembro de 1864.

${ }^{26}$ O Século foi um jornal Nacional, diário matutino de Lisboa fundado em 1880.

${ }^{27}$ Jean Anouilh (1910-1987) é um dramaturgo francês. Na sua obra é patente a herança de certos elementos de tradição romântica, presentes tanto nas comédias como nos melodramas. Manifesta um notável pessimismo sobre a condição humana, mas fá-lo com um critério de medida e de grande exactidão formal; neste sentido; é um brilhante artífice teatral e um dramaturgo tipicamente burguês que goza de grande aceitação. Ele mesmo agrupa as suas obras em virtude do seu caracter: obras negras "Piéces Noires"; obras rosas "Piéces Roses"; obras brilhantes "Piéces Brillantes"; obras sibilantes "Piéces Grinçantes"; etc.
} 
Tratou-se de um corte umbilical com o lar, apenas no aspecto físico porque o contacto e as discussões foram constantes ao longo de toda a vida. Já com 16 anos de idade, trabalhou em Paris aproximadamente um ano numa marcenaria onde se faziam cadeiras Luís XV e paralelamente produzia pinturas aguareladas que vendia em cafés.

«Em 1948 está em Paris, a festejar os seus 16 anos. Vai direito ao Quartier Latin. Vive da venda de quadros seus, com amigas que também pintam. Regressará muitas vezes à Cidade-Luz: «É a 'Brasileira' da Europa», diz, e ri-se da própria definição, que compara a metrópole francesa com o café cosmopolita de Lisboa. Abandona, entretanto, o curso de pintura e segue o seu próprio destino: «Defendo a liberdade a todo o custo. Não é a questão da política, pois sigo por outros caminhos. Os 'ismos' não acontecem comigo, com certeza». Os tais «ismos» passam-lhe pela pintura, mas vão sendo abandonados, sempre em nome da liberdade. O neorealismo é o primeiro: «Aos 16 anos éramos todos neo-realistas. Eu pintava umas coisas horríveis!» Inspiração transversal dos muralistas mexicanos e da sua influência no nosso país. Abre os olhos: «Comecei a olhar para o Kandinsky e a seguir outros rumos. Os meus 'mestres' zangaram-se comigo.» A linha evolutiva tomou o rumo do surrealismo, do qual partiu para as tendências figurativas. Segundo diz, foi a vez dos surrealistas se ressentirem. ${ }^{28}$ Mais tarde, voltou para Portugal, e colaborou com quase todas as revistas da época: fazia 3 ou 4 ilustrações por dia durante aproximadamente um ano. Fixou-se no País e torna-se decorador. Pôs boîtes a funcionarem só com discos, sugeriu pormenores tão simples como o de trazer o whiskey no copo, associando novas estéticas aos lugares noctívagos.

${ }^{28}$ LEAL, Paulo-Guilherme. cit in“As sete portas das Artes”, JL,19 de Novembro de 1997, p. 23 
Nos finais dos anos 50, PG era já um profissional com grande actividade em várias áreas principalmente no design gráfico, na ilustração e design de interiores (decoração como era designado). A vida ensinou PG a contornar a sua timidez e insegurança tornandoo num grande orador (com uma certa prosápia), um gentleman requintado.

«Entrar na Cinecittà era agora o seu grande sonho. Procurou Francesco Zarelli, um operador de câmara italiano que conhecera em Portugal quando trabalhou na cenografia de dois filmes («Sangue Toureiro» e «Perdeu-se um Marido»). Acabou por númera-lo. Não vai para a Cinecittà, mas arranjou emprego na $\mathrm{FAO}^{29}$, como ilustrador.» ${ }^{30}$

«Em Itália, com 25 ou 26 anos, (...) acabou a cantar o fado num restaurante (...) Recebeu um telefonema do pai para o vir ajudar com o suplemento Século Ilustrado, partindo lentamente para Portugal, via Barcelona. Em Lisboa regressa ao mesmíssimo quarto que tinha deixado vago antes de partir na Praça João do Rio, perto do Areeiro. Antes de vir para Campo de Ourique, vivia num quarto andar em S. Mamede, numa casa onde eram presenças habituais José Régio e Almada Negreiros. ${ }^{31}$

Assim, em 1960, PG e seu pai trabalhavam ambos n’O Século. Mais tarde a sua colaboração com o jornal estendeu-se ao Século Ilustrado e ao Pim-Pam-Pum.

O acordar cedo era imperativo. PG necessitava de poucas horas de sono o que lhe permitia despender de mais horas de trabalho.

\footnotetext{
${ }^{29}$ A Organização para a Alimentação e Agricultura das Nações Unidas é uma agencia especializada que lidera os esforços na luta contra a fome. Servindo tanto países desenvolvidos e em desenvolvimentos, a FAO actua como um fórum neutro, onde todas as nações se reúnem como iguais para negociar acordos e debater políticas. É também uma fonte de conhecimento e informação e ajuda os países em desenvolvimento e em transição a modernizar e melhorar a agricultura, silvicultura e pescas práticas.

${ }^{30}$ LEAL, Paulo-Guilherme. cit in “As sete portas das Artes" ;JL;Quarta-feira, 19 de Novembro de 1997, p. 24

${ }^{31}$ CEGONHO, Pedro.'Um bairro à imagem de Montmatre".Revista Santo Condestável, Julho a Dezembro de 2008, pág.9
} 
Mesmo quando os tempos exigiam trabalhar pela noite dentro (p.e tempos do Snob, Snobíssimo, tempos que dirigiu gráfica e literariamente jornais, etc.). Tempos em que tinha forçosamente hábitos noctívagos, continuava surpreendentemente madrugador.

«(...) podia surpreender de manhã cedo com soluções para problemas mal iniciados na véspera. Tirava do bolso um papel amarrotado: Já está! Já sei! Já vi como hei-de... ${ }^{32}$

Teve muitas casas e ateliers em diversos sítios mas sempre criava neles ambientes muito próprios, com gosto e criatividade. Tornavaos em espaços únicos mesmo que fosse por tempos relativamente curtos. Salienta-se a grande facilidade de se ajustar às mudanças da vida.

A vida sentimental de PG também o ocupava. Aos 28 anos casou-se com Maria Helena Galhardo, não voltando a casar. Contudo teve vários relacionamentos, destacando-se um com a actriz, modelo e artista plástica Júlia Correia. Foi pai de 3 filhos: João, Margarida e o mais novo Francisco D'Eça Leal.

Por arrasto com a modificação de sua vida fez ao lado de sua casa um bar que ainda hoje existe: O Snob. Já fizera, anteriormente, decorações de boîtes, restaurantes, cenários para teatro, cenografias para três filmes, etc.

Entretanto, decidiu ir viver para Cascais, onde montou um restaurante: o Snobíssimo.

Aos 41 anos (1973) realizou um grande trabalho na cidade do Porto, a sede do Banco Pinto \& Sotto Mayor.

Ao longo da sua vida pintou de forma ininterrupta, mas na sequência de um acidente de automóvel, a 11 de Novembro de 74, viu comprometido o seu futuro com pincéis e deitou a mão ao papel. A pintura acontecia esporádicamente.

${ }^{32}$ ABREU, Luís Filipe, Entrevista sobre Paulo-Guilherme, [disponível na integra em anexo], 10/06/2012, p.1 
1.4 Descubriendo Brasil / À descoberta do Brasil

Em 1975, Brasil foi a paragem seguinte. Ali, a sua apetência pelo divertimento aumenta e relata como sendo uma aventura espantosa e maravilhosa. No Rio de Janeiro volta a montar o Cabaretíssimo, que fica em cartaz durante oito meses e é um sucesso. Mas a sorte deixou de o acompanhar. O Rio sofreu as maiores chuvas dos últimos 200 anos. O sucesso do espectáculo sentiu um revés, era preciso recomeçar tudo de novo. Foi para Curitiba, onde decorou um hotel. Quando terminou o trabalho, meteu-se no táxi, sem dinheiro para o pagar. Pelo caminho, descobriu um pequeno café à venda. Resolveu comprá-lo e pagou as primeiras prestações (e a factura de táxi) com os primeiros pastéis por si confeccionados. Regressou ao Rio de Janeiro, onde montou um restaurante de luxo, o La Bohème. Segundo o próprio, esta foi uma época de grandes oportunidades para os portugueses que chegavam ao Brasil, eram vistos como 'russos brancos', ao contrário do que se pensava, eram cultos, civilizados e falavam línguas.

Fez no Rio de Janeiro uma exposição individual na galeria Nouvelle Dezon, outra na galeria Acaiaca, em Curitiba e ainda uma no museu de Arte Contemporânea no Panamá. No Brasil encontra-se representado nas colecções particulares de: Afonso P. De Magalhães, Caetano B. Da Veiga, Joacy Goês, Karl Neuman, Carlos Jung, Arthur Campos, Arice Buschman, Victorina Sagboni, José Campos, Nagem Nahas e Winfred Blum. Esta actividade da pintura ocupou grande parte do tempo que passou no Brasil, podendo contar assim com 248 quadros produzidos, adicionando 


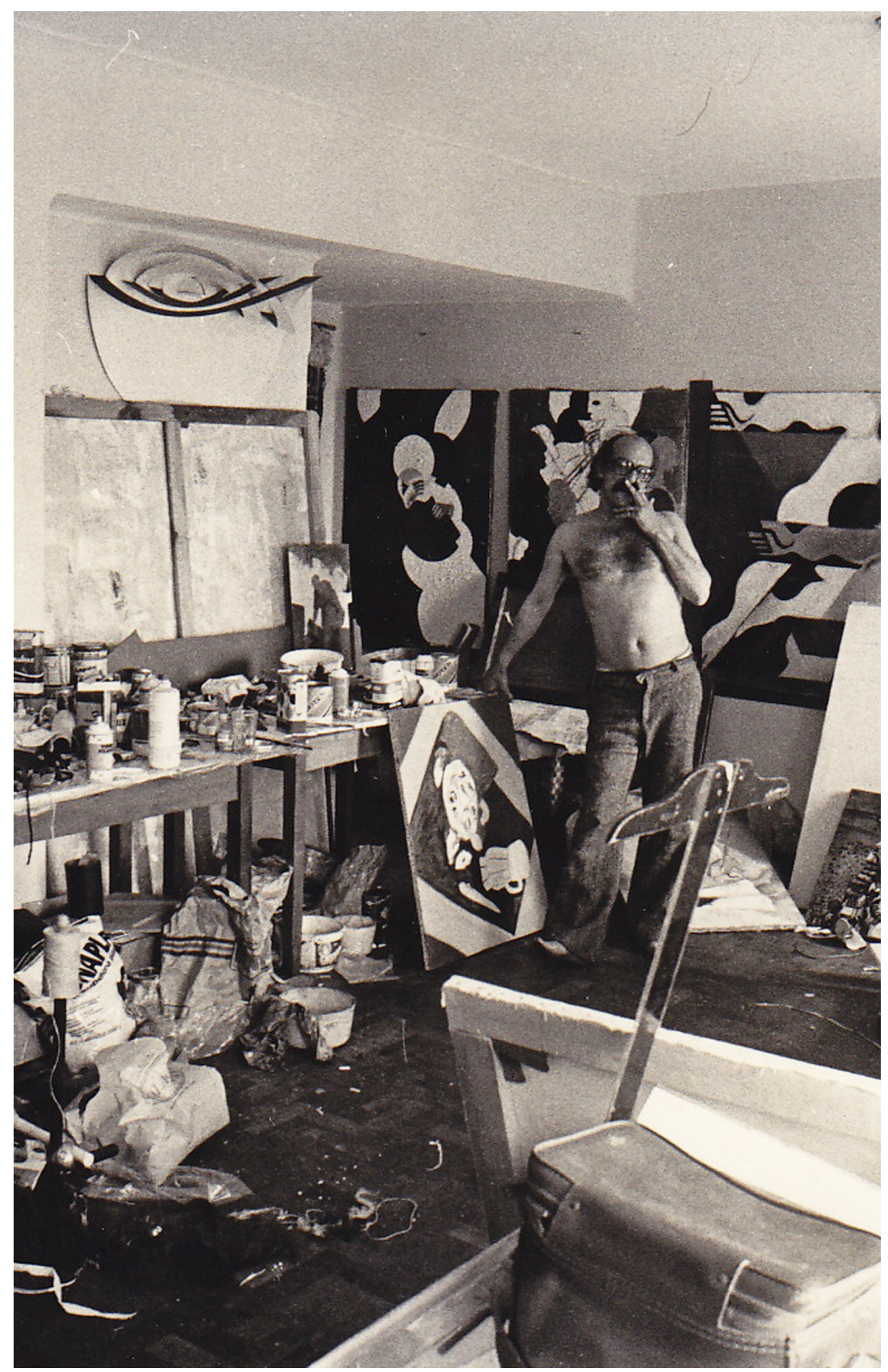

Figura 8. Fotografia de Paulo-Guilherme no atelier em Brasil, 1975 
irremediavelmente um «...um sabor tropicalista à sua prática pictórica.» ${ }^{33}$

Realizou também tapeçarias para os escritórios de Nagem Nahas em São Paulo $(5 \times 2 \mathrm{~m})$, assim como para a sua residência $(1,20 \times 2 \mathrm{~m})$ e para a Sede do Banco Real de S. Paulo (Curitiba) (2x1,5m). Projetou um edifício para a Avenida Paulista, em São Paulo, e um bar em Uberlândia. Teve uma secção de cinco páginas na revista "Casa e Decoração" e o interesse pelas Pirâmides de Quéops foi despertado a propósito de uma série de textos que lhe encomendaram sobre as sete maravilhas do Mundo. Acredita que foi o trabalho mais sério que fiz até então. Começa a estudá-lo do ponto de visto geométrico e matemático. Esta nova paixão, despertada no Brasil, acompanhou-o para o resto da sua vida e deu origem a outras investigações. Afirma fazer tudo isto por ter uma enorme capacidade de aprender e de mudar de profissão. Apesar de admitir ser um homem vaidoso, considera-se um frívolo, não se leva a sério, e não gosto que o façam.

O desejo de regressar voltou pois sentiu terríveis saudades da pátria.

\subsection{De vuelta en Portugal / Regresso a Portugal}

«Regressado à pátria após intensa actividade de decorador, pintor, desenhador e escultor, novas aventuras o esperavam: a do cinema, com a realização do filme Iratan e Iracema, Os Meninos Mais Malcriados do Mundo, segundo o livro homónimo paterno, e da curta-metragem $\mathrm{O}$ Alquimista; a de investigador esotérico de

${ }^{33}$ SANTOS, Rui Afonso, Paulo-Guilherme d'Eça Leal d'Etcetera e Tal, Arte Ibérica n ${ }^{\circ} 43$, Abril 2000, p. 28 
matriz geométrica e matemática, com sensacionais deduções sobre a esquecida ciência egípcia e os construtores da Pirâmide de Quéops, o tesouro dos Templários ou, tal como o seu velho amigo Almada a Fortuna dos painéis de Nuno Gonçalves; a de romancista e poeta com obra publicada, a de arquitecto e designer do Aeroporto de Lisboa (1983-88), onde realizou o grande hall com cobertura metálica e a ampla rotunda cuja articulação entre o tambor e a cúpula sugere as proporções romanas do Panteão; ${ }^{34}$

No ano de 1983 encontra-se a decorar o Aeroporto de Lisboa, dedicando_dez anos da sua vida em sucessivos projetos de ampliação, volumetria arquitectónica e decoração. O Alquimista das ideias como já lhe chamaram interessava-se pela ficção científica, pelo maravilhoso, por viagens extraordinárias. Autores como Júlio Verne, Mark Twain e Emily Brontë com O Monte dos Vendavais, entre outros, foram grande estímulo que o levou, anos mais tarde, a interessar-se pelo esoterismo e pela geometria sagrada. Nos anos 80 , começou a fazer estudos de geometria sagrada por influência de uma recolha, feita por Lima de Freitas, da obra do Almada Negreiros através de exposições suas e do seu livro Almada e o Número. Sentiu-se completamente envolvido e fascinado. Paulo-Gilherme dedica-se à escrita, abordando temas como Pirâmide de Quéops. O interesse não era novo, já o despertara no Brasil. Simultaneamente com os trabalhos de decoração aprofunda o estudo sobre a pirâmide de Quéops, ao qual já se dedica cerca de 15 anos. Este estudo leva-o a crer que se tratava de uma máquina de funcionamento inesperadamente hidráulica que fora criada para que um único homem detentor do saber egípcio, sobrevivesse a um hipotético dilúvio. Encerrava outros aspectos curiosos e relevantes, como o de reunir em si todo um conceito matemático

${ }^{34}$ SANTOS, Rui Afonso, Paulo-Guilherme d'Eça Leal d'Etcetera e Tal, Arte Ibérica nº43, Abril 2000, p.28 
extremamente simples. O resultado desta investigação surge na forma de livro O Dilúvio de Quéops em 1993, onde pretende mostrar como foi construído o monumento egípcio. O estudo destas investigações tiveram também o formato de diversas palestras abertas ao público em vários locais sendo uma delas na Fundação Calouste Gulbenkian. Seguiu-se, em 95, As Sete Portas de Arsenise, onde mistura realidade e ficção sob o género de romance. $O$ interesse pela geometria sagrada, pelo esotérico aliado com o fascínio de relacionar dados e criar relações inesperadas, insólitas, corroborar as suas teorias por silogismos, deduções matemáticas e geométricas levam-no a fazer outras investigações que resultam em mais 2 livros publicados.

1.6 Consideración finales / Considerações finais

A sua obra percorre vários domínios, homem holístico entusiasta pelo novo atravessa a ilustração, o design, a pintura, o desenho em várias vertentes, desenho de padrões para murais e tapeçarias, arquitectura, decoração de casas particulares, espaços públicos e comerciais, a escultura, a arte cénica para teatro e cinema, a realização, a fotografia, a filatelia, a numismática, o espectáculo e até literatura.

PG, de espírito aventureiro, tinha gosto pelo novo, pelo espontâneo, ânsia de novas experiencias, novas descobertas. Era um entusiasta em tudo o que fazia. Trabalhador incansável foi sempre acompanhado por novas ideias, novos pensamentos, novos 

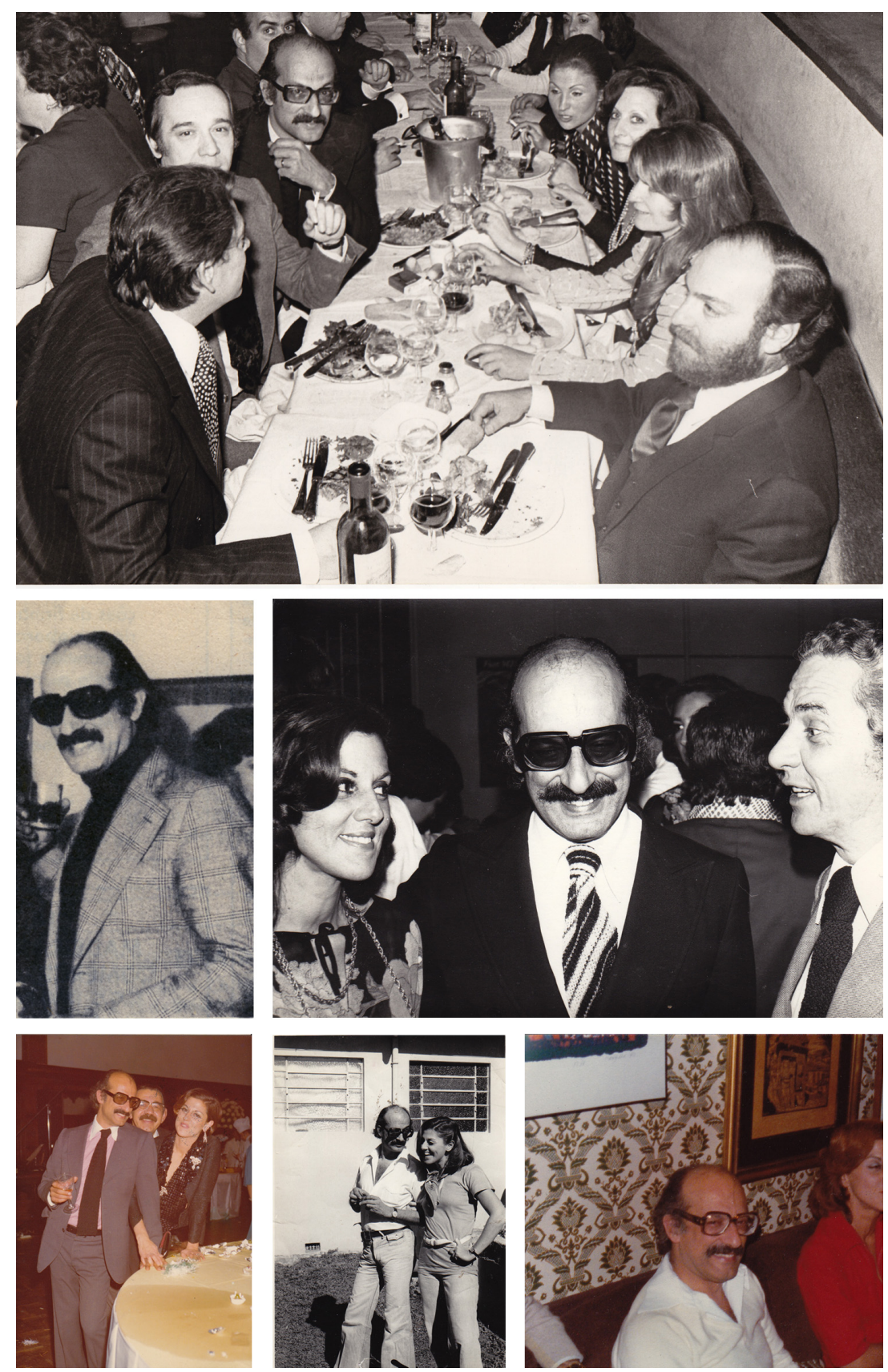

Figura 9. Conjunto de imagens da vida social de Paulo-Guilherme 
projectos. Vence a timidez e a insegurança que carregara em criança e torna-se num comunicador envolvente e exuberante.

Amante da vida, não esconde que a Paris artística e boémia deixou marcas na sua personalidade. Levou uma vida sob holofotes, desde inúmeras entrevistas a canais televisivos, jornais e revistas, como participações em programas de televisão, palestras e eventos sociais.

«PG tinha um enorme ego. Uma necessidade de afirmação, pela positiva, pela qualidade, mas também pela bravata, moviam toda a sua actuação. O sucesso, qualquer que fosse, embevecia-o. Gabavase sem pudor e só em circuito mais íntimo reconhecia limites ou falhas. As outras pessoas, nem todas compreendiam isso e frequentemente o acusavam de vaidade e de insuportável convencimento. Esse seu discurso de auto-promoção e afirmação foi-se moderando com o tempo e a consolidação do legítimo prestígio. Perdeu aspectos de bravata juvenil, ganhando em experiência muito vasta e autoridade. Mas, infelizmente, persistiram muitos dos efeitos desses títulos negativos, de que ele, aliás, nada se lamentava. ${ }^{35}$

Ao longo da sua vida enfrentou inúmeras provações como várias doenças, roubos e um grande incêndio na sua casa que queimou parte da sua obra, impossível de contabilizar, nunca se teve a noção de quantos desenhos, maquetas, livros, objectos foram perdidos. Quando decidiu assentar escolheu para viver Campo de Ourique em Santo Contestável, na Rua Tomás da Anunciação.

«Freneticamente, tanto quanto o permitia num estado de saúde cada vez mais agravado, continuava a investigar, escrever, desenhar, rabiscar, entre delírios entrelaçados de ângulos e rectas misteriosas e curvas de mulheres sensualmente enigmáticas, sobre

${ }^{35}$ ABREU, Luís Filipe, Entrevista sobre Paulo-Guilherme, [disponível na integra em anexo], $10 / 06 / 2012$ 
as toalhas de papel do restaurante ou do bloco pousado sobre a mesa.» ${ }^{36}$

Dedicou os últimos anos ao livro "Da Geometria se fez Pedra", investigação sobre os valores e tradição da Geometria Sagrada no convento da Batalha, não o chegando a concluir.

«Dependentemente agarrado ao seu último projecto de investigação, "E a Geometria se fez Pedra”, perseguia contudo outro, em que compilava o espólio de seu pai, Olavo d'Eça Leal, espólio riquíssimo, de correspondência trocada com grandes e díspares personalidades com quem convivera, como Régio, Cocteau, Almada, Carlos Queiroz, António Lopes Ribeiro, Aquilino Ribeiro, Henrique Galvão, Bernardo Marques e Mário Eloy, crónicas, desenhos enfim, um sem número de documentos, por si sós, retratado da riquíssima vida cultural e do Modernismo da Europa durante o passado século. $\gg^{37}$

Dia 9 de Outubro de 2010, aos 78 anos de idade, acaba por falecer vítima de doença prolongada, no hospital Egas Moniz em Lisboa.

\footnotetext{
${ }^{36}$ FERNANDES, Nuno Nazareth."'Quem matou Paulo-Guilherme”. Jornal O Diabo, 12 de Outubro de 2010, Ano XXXIII I No 1763 , P. 14

${ }^{37}$ Idem
} 


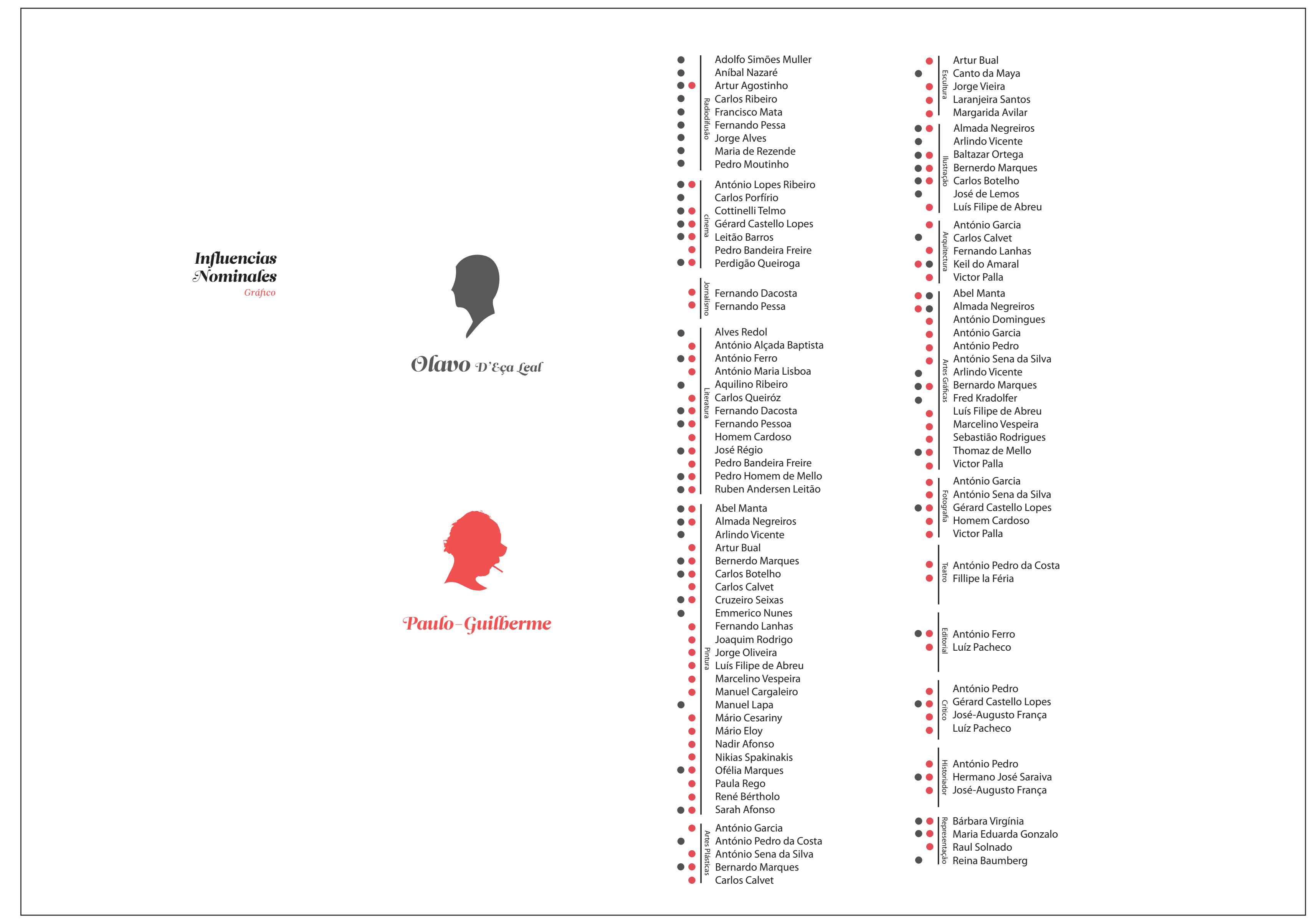




\section{Capítulo 2: La sociedad portuguesa en el siglo $\mathrm{XX}$ : Contexto histórico - político / A sociedade portuguesa no séc.XX: Contexto Histórico - Político}

Os paradigmas formatadores na sociedade portuguesa no seculo XX, têm a sua génese no desenvolvimento da acção política que determina a sua história. Na história deste seculo, são pródigos as nuances e rupturas políticas, desencadeadas por um lado, pelo frágil sistema económico (no inicio do seculo á beira da falência) e por outro pela pretensão do domínio absoluto do poder. Estes dois pilares são os pressupostos determinantes para uma conjuntura histórica politica e social. Nas primeiras três décadas os principais factores de instabilidade no séc. XX caracterizam-se pela implantação da Republica e pelas convulsões que daí decorrem na sua consolidação e também pela $1^{a}$ guerra de 14 a 18 . Da década de 30 a Abril de 74, Portugal sofre também os efeitos da $2^{a}$ guerra, o sistema político de Salazar afirma-se ditatorialmente, usa e abusa do poder, isola-se do mundo, fomenta um país rural, inculto, pobre em todos os aspectos economicamente e culturalmente. A este estado de coisas, acresce ainda 13 anos de guerra colonial, gerador de conflitos sociais e gastador dos dinheiros públicos em detrimento do desenvolvimento. A estagnação a que o país foi votado, o fraco desenvolvimento económico/social, a ausência de liberdade, geram o golpe de militar no 25 de Abril de 74 com o derrube do governo perspetivando a democracia. Contudo, novo período conturbado subsiste na sociedade portuguesa, a consolidação do regime democrático é morosa e tem custos. Deste espectro se infere, que os fenómenos políticos do séc. XX foram enviesados ou contrários ao 
desenvolvimento da sociedade nos fundamentais direitos económicos sociais e culturais, e levará o seu tempo a tudo ser estabilizado.

\subsection{Estado Nuevo y la política del Espíritu / Estado Novo e a} Política de Espírito

O Estado Novo acabava de se implantar. Este período, anos 30, foi marcado pela reestruturação do sistema do estado e do funcionamento da sociedade civil em função do programa político de Salazar, formalizado em 1933, com a aprovação de uma nova constituição, que instituiu 4 órgãos de soberania: Presidente da República, Assembleia Nacional, Governo e Tribunais. A nova Constituição pôs fim à ditadura militar e deu início a um novo regime - o Estado Novo - que durou 40 anos (1933-1974). Esta nova constituição deveria consagrar a divisão dos poderes, o recurso a eleições (para os órgãos de soberania) assim como zelar e respeitar os direitos e liberdades dos cidadãos. Antes porém, fora criada a direcção geral dos edifícios e monumentos nacionais, que o Ministério do Comercio e das comunicações desenvolve desde a sua criação, em 1929, uma politica propagandística, sistematizada, que antecipa a acção desenvolvida a partir de 1932 pela Secretaria de Propaganda Nacional (S.P.N), cujo principal fautor é António Ferro. Embora a intenção fosse de criar um Estado mais livre e democrático este revelou-se tirano: Os direitos e garantias individuais dos cidadãos previstos na Constituição passariam a ser regulados por "leis especiais" que, na prática, os anulariam. Houve 
assim a privação de votar livremente, com eleições controladas e ilegais; O Presidente do Conselho dispunha de poder ilimitado na criação e aprovação das leis sobrepondo-se ao suposto órgão legislativo, Assembleia Nacional. Tornava-se, na prática, mais notável e poderoso que o próprio Presidente da República. Suspendeu-se qualquer tipo de liberdade e criou-se órgãos de repressão: organismos de corporativismo assegurando a ordem social e o controlo dos trabalhadores. Cria-se assim os Sindicatos, as Casas do Povo, as Ordens, etc. que abrangiam as actividades económicas, culturais e morais da Nação e que tinham a seu cargo a defesa dos interesses dos cidadãos. Que, na prática, serviu para o Estado controlar o poder reivindicativo dos trabalhadores, as greves, os conflitos e lutas de classe e possibilitou a subordinação do patronato aos interesses do Estado; a criação de polícia política (a Polícia de Vigilância e Defesa do Estado, mais tarde chamada PIDE, isto é, Polícia Internacional de Defesa do Estado); de prisões políticas (como Peniche); campos de deportação (como o do Tarrafal, em Cabo Verde); estabelecimento da censura (à imprensa, rádio e todo o tipo de espectáculos); proibição dos partidos políticos (apenas se reconhecia a União $\mathrm{Nacional}^{38}$ ); enquadramento e doutrinação da juventude (através da Mocidade Portuguesa ${ }^{39}$ ) e organização de forças paramilitares (como a Legião Portuguesa ${ }^{40}$ ) para a defesa do regime. Esta nova constituição criou também, 1932, o Secretariado de Propaganda Nacional (S.P.N.), mais tarde, 1945,

\footnotetext{
${ }^{38}$ Criada em 1930, a União Nacional foi um movimento de apoio ao governo, uma espécie de partido único, controlada pelo Presidente do Conselho, que tentava anular qualquer possível concorrência, oposição.

${ }^{39}$ Criada em 1936, a Mocidade Portuguesa, de inscrição obrigatória, era destinada a todas as crianças e jovens com o fim de incutir valores patrióticos e nacionalistas do Estado Novo. ${ }^{40}$ Criada em 1936, a Legião Portuguesa, era uma milícia com o objectivo de "defender o património espiritual da Nação" e a ameaça comunista. Nas décadas de 50 e 60 , a sua acção caracterizou-se pela perseguição e repressão a toda a oposição, com um Serviço de Informações e a sua vasta rede de informadores.
} 


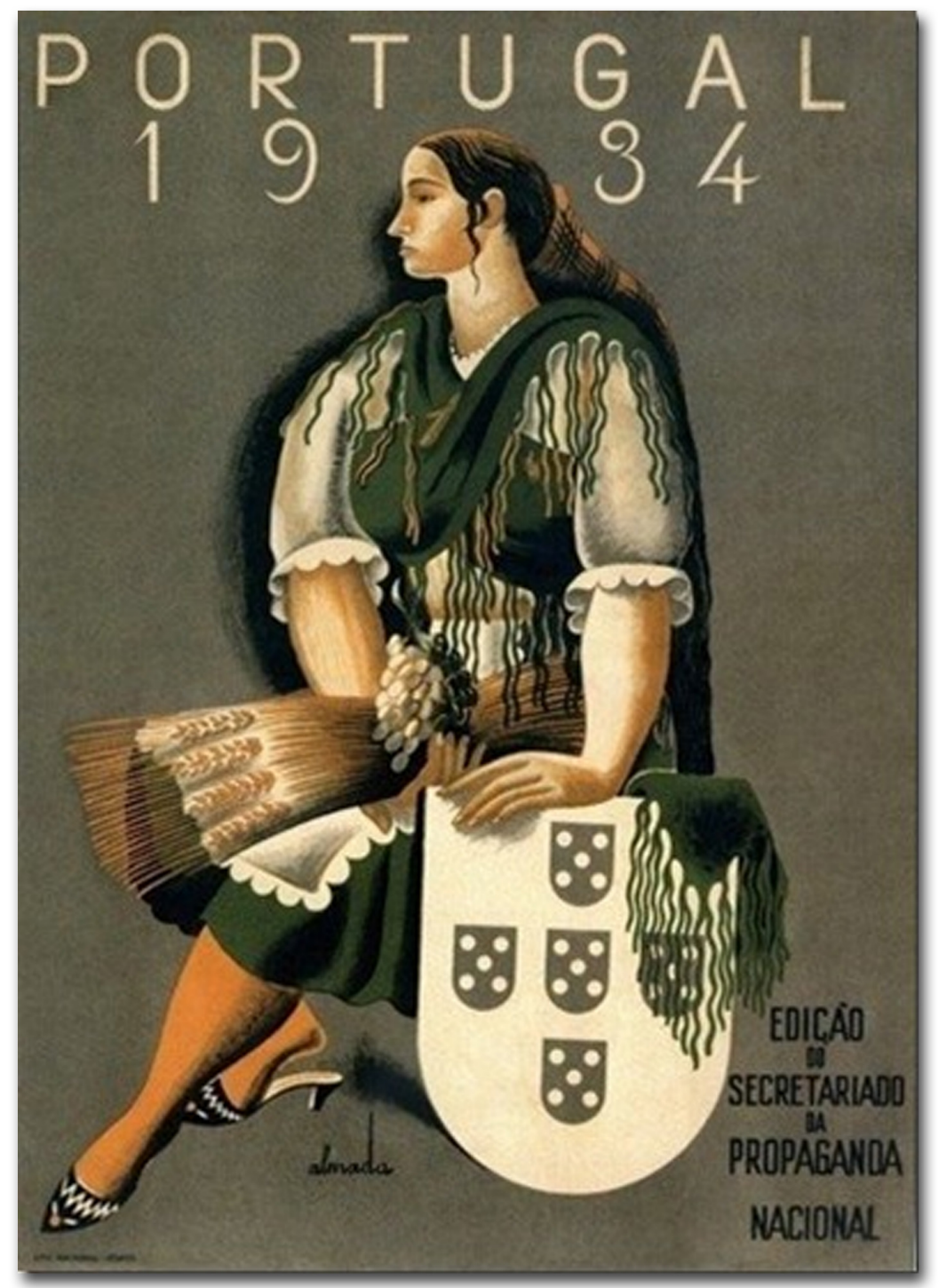

Figura 10. Cartaz de Alamda Negreiros para o SPN, 1934 
chamado de S.N.I. (Secretariado Nacional de Informação), para promover as ideias políticas do regime, chefiado por António Ferro.

Teve um papel preponderante na padronização da cultura e das artes do regime do Estado Novo e na divulgação do ideário nacionalista. O seu modo de acção era através da propaganda das ideias do regime, do turismo e da cultura popular para integração das camadas mais baixas da população.

«Política do Espírito não é apenas, repetimos, fomentar o desenvolvimento da literatura, da arte e da ciência, acarinhar os artistas e os pensadores, fazendo-os viver numa atmosfera em que lhes seja fácil criar Política do Espírito é aquela que se opõe, fundamentalmente e estruturalmente, à política da matéria. Política de Espírito, (...) é estabelecer e organizar, o combate contra tudo o que suja o espírito, fazer o necessário para evitar certas pinturas viciosas do vício que prejudicam a beleza, a felicidade da beleza,como certos crimes e taras ofendem a humanidade, a felicidade do homem. Defender a Política do Espírito é combater sistematicamente, obra da vida ou obra de arte, tudo o que é feio, grosseiro, bestial, tudo o que é maléfico, doentio, por simples volúpia ou satanismo! Política de Espírito é aquela que proclama, precisamente, a independência do Espírito, que o liberta escravidão do materialismo tirânico, insinuante, que pretende constantemente suborná-lo, embriagá-lo...» ${ }^{41}$

Resumia-se assim ao uso da cultura como meio de propaganda, programa este que procurava estabelecer uma cultura nacional e popular com base nas suas raízes e nos ideais do regime; os movimentos culturais deviam ser orientados no sentido de glorificar o regime e o seu chefe; tentavam conciliar as velhas tradições e os antigos valores com a modernidade daquele tempo.

${ }^{41}$ SOUSA, Jorge Pais de. O Fascismo Catedrático de Salazar, das origens na I Guerra Mundial à intervenção militar na guerra civil de Espanha 1914-1939, Imprensa da Universidade de Coimbra, 2011, p.360 
Pretendia-se assim, que a cultura fosse simples, directa e que distraísse o povo. Conseguiu, António Ferro, com esta propaganda nacional demonstrar que era possível as manifestações culturais serem organizadas de modo a predispor, controlar os indivíduos para certas formas de comportamento e pensamento. E, todo o control foi facilitado pela ausência de politicas educativas que elevassem o nível cultural do povo. A principal preocupação de AF era a criação dos meios de ocupação dos tempos livres dos portugueses vistos como uma forma potencialmente perigosa para o poder.

A politica cultural, foi partilhada e prosseguida por vários organismos do estado e o seu principal mentor foi Salazar. Desde os finais dos anos 30 que a colectânea de ideias de A.F era a identidade da cultura portuguesa, percorrendo estas toda a administração pública chegando a ser teorizadas por diversos e reputados intelectuais. No final da década de 40 a política cultural do Estado Novo, estava esgotada, o modelo económico assente no modelo corporativista lembrando as cooperações medievais, é esvaziado de conteúdo embora alimente o imaginário de alguns estudiosos. Em 1936 foi criada na Mocidade Portuguesa (MP) e a Legião Portuguesa (LP). A MP tinha como metas: a formação do carácter e a devoção à pátria, no culto dos deveres morais, cívicos e militares, no gosto da disciplina e da ordem e estimular o desenvolvimento integral da sua capacidade física. A LP tinha por meta defender o património espiritual da Nação e combater a ameaça comunista e o anarquismo. Esta organização passou a estar mais voltada para a defesa civil a partir de 1940. Em 1937 foi fundada a MP feminina, com o intuito de criar uma nova mulher, esposa, mãe, doméstica, cristã preparada para contribuir para o bem comum.

Com afastamento de AF do S.N.I. deu-se a queda total da política cultural do regime, que durou até ao final dos anos 40 e 
ficou conhecida como política do espírito. Portugal, na $2^{\mathrm{a}}$ Guerra Mundial, assumiu uma posição neutra, apagada, o que permitiu a permanência do regime salazarista. No pós-guerra, Portugal mantinha um desfasamento político e económico em relação à Europa. Possuía pequenas actividades produtivas, tecnologicamente pouco avançadas e um sector agrícola de pouco peso. Era um país agrário de fortes contrastes, não só díspar fora das suas fronteiras, mas também de grande assimetria nomeadamente Norte-Sul. No Norte tinham lugar propriedades de reduzida dimensão onde a mecanização não era possível, com muito poucas estradas a servi-los, sem água canalizada nem electricidade. No Sul havia uma maior concentração da população, os habitantes dispunham de estradas e água canalizada, possuíam uma economia mais monetária com salários diários mas as imensas propriedades eram subaproveitadas. Era uma vida difícil, as famílias eram numerosas, privadas de boa alimentação, necessitavam de fazer grandes sacrifícios para sobreviver. As crianças das aldeias eram habituadas a ajudar a família nos trabalhos do campo desde cedo. Dificilmente as crianças tinham a oportunidade de se instruírem, era por isso elevada a taxa de analfabetismo. O ritmo de vida era marcado pelo trabalho agrícola de sol a sol, a terra cultivada pela força braçal e seus animais. As comunicações faziam-se sobretudo verbalmente ou por carta pois os telefones, rádios eram escassos e a televisão inexistente. Apenas se encontrava telefone nas casas mais abastadas e a rádio era uma novidade, que só começou a emitir oficialmente em 1938. O automóvel era reservado a poucos. Frigorífico, televisão, máquinas de lavar, aspiradores apareceriam muito mais tarde, finais dos anos 60. Nas cidades ou nas aldeias, com mais ou menos comodidades a vida era modesta e de forte prática religiosa.

Nos anos 40/45 em plena $2^{\mathrm{a}}$ Guerra Mundial os países 
fornecedores de produtos não puderam satisfazer os pedidos pela sua industria estar orientada para o armamento. Em consequência Portugal começa a produzir os seus próprios bens, e para isso foi criada a lei de fomento e reorganização Industrial, sendo o objectivo substituir as importações. É em 1945 e no final da guerra que o governo português extinguiu o SNI.

\subsection{El estancamiento de la prosperidad de la posguerra} Da estagnação à prosperidade pós-Guerra

O Portugal dos anos 50 era um pais estagnado, imóvel face as possíveis reformas e avanços tecnológicos. Portugal continuava a viver debaixo duma grande deficiência alimentar, as famílias passavam grandes privações, tinham poucas condições de vida. A mortalidade infantil era elevada e a tuberculose persistia. Nem todas as crianças tinham a oportunidade de se instruírem sendo, por isso, levadas a trabalhar muito cedo. Era portanto um país com elevada taxa de analfabetismo. Contudo, o nível geral de instrução aumentou, nos anos 50. Esta tendência também se reflectiu nas universidades, cujo número de estudantes cresceu. Contudo, ainda assim o ensino superior, três Universidades existentes (Lisboa, Porto e Coimbra), eram para pequenas minorias.

Portugal contrastava com os restantes países industriais do pósguerra. Este contraste leva à emigração, procurava-se melhores condições de vida, o país ficava cada vez mais despovoado. Salazar repudiava a ideia de Portugal ser um país industrializado e desenvolvido. Afirmava que perderíamos as pequenas empresas, criaríamos desemprego, que haveria um desenraizamento, que 
perderíamos a vida modesta. A ideia de haver uma abertura económica do país, de um investimento estrangeiro, deita por terra todo o conservadorismo prezado por Salazar, preferindo «formar no espaço português (colónias incluídas) uma economia nacional.» ${ }^{42}$

Portugal não era só um país economicamente estagnado mas também politicamente. A polícia e a censura certificavam que só havia uma opinião política, estimulando assim a subserviência, o servilismo e essencialmente o receio. O clima vivido era de medo e desconfiança daqueles que são capazes de fazer denúncias por um emprego, privilégio, por um negócio ou qualquer outra coisa.

«Claro está que também há uma dose de frustração pela oposição, sem poder ter opinião pública contra o Salazarismo. O pensamento português era assim controlado pelo regime. Completamente moldado ou abafado. A forte mão da censura, coordenada por coronéis na reforma, alastrou-se até à imprensa (livros, revistas, jornais...), à rádio aos cinemas, ao teatro, à música, à literatura, à televisão e até mesmo às escolas. Nas escolas, palco priveligiado, tínhamos uma forte presença de Salazar onde se enaltecia e se ensinava os valores defendidos pelo Estado Novo: "a glorificação da obra do Estado Novo e do seu líder, Salazar; o papel subalterno da mulher, limitada à função de esposa e mãe; a caridade que, quantas vezes, substitui a função social do Estado; a catequese, incutindo os rudimentos da doutrina católica; a gloriosa história pátria que transforma Portugal na Nação mais bela do mundo e de que o Estado Novo é o mais legítimo herdeiro.» ${ }^{43}$ Não havia direito à liberdade de expressão.

Inúmera leitura foi cortada ou interdita, inúmeras peças são

\footnotetext{
${ }^{42}$ Vieira, Joaquim. Portugal século XX: Crónica em imagens 1950-1960,1 ${ }^{\text {a }}$ ed. [S. 1.]: Bertrand Editorial, 2006, pág.20

${ }^{43}$ A lição de Salazar [disponível em]

http://www.esfcastro.pt:8079/users/franciscosilva/salazar.html [consultado em] 20/08/09; 17:30
} 
impedidas de subir aos palcos. A censura não poupava ninguém nem mesmo as mais altas figuras. Tudo era controlado para assegurar estabilidade ao governo de Salazar, todas as possíveis críticas que pudessem abalar por pouco que fosse o sistema eram impedidas.

«Como os Glaciares, porém, a nação portuguesa também se move, e se isso é imperceptível à superfície, há uma possante corrente subterrânea em vias de alterar toda a estrutura da sociedade. Apesar da relutância salazarista, a industrialização, mais rápida ou mais lenta, é um facto inelutável. Portugal vive num sistema de relações e interdependências que não lhe permite ficar imune à prosperidade dos anos $50 .{ }^{44}$

Afligidos pela crise económica da viragem do século e cientes que o desnível com a Europa provocaria inevitavelmente uma crise social o que seria muito mais grave do que o tão indesejado progresso industrial, tentaram assim fazer uma modernização do país minimizando a discrepância com o resto da Europa. Com certeza, que depois de tanto esforço fizeram-no de forma a salvaguardar a estabilidade e o regime até então conseguido pelo Estado Novo.

Os planos de Fomento com a duração de seis anos tinham como objectivo central a modernização do país. O I plano de Fomento (1953-1958) consistia num conjunto de investimentos públicos orientados para a construção de infra-estruturas. Preocupa-se assim com industrialização como com a rentabilidade agrícola. Pretendia-se que a industrialização passasse a ser um instrumento de protecção do mercado interno, através da dimensão mínima das unidades produtivas e de condições técnicas de funcionamento. Era projecto de transição de uma sociedade rural para uma sociedade moderna.

Em 1957, os defensores da industrialização tentam acelerar o

\footnotetext{
${ }^{44}$ Vieira, Joaquim. Portugal século XX: Crónica em imagens 1950-1960,1ª ed. [S. 1.]: Bertrand Editorial, 2006, pág. 25
} 
ritmo do desenvolvimento. Coordenada por Caetano, estas novas exigências constituem o II plano de Fomento (1959-1964). Apresentando-se como "um programa de política económica", tem como objectivos as preocupações adiantadas no plano anterior, passando agora o sector industrial a ser prioritário, tentando livrar a economia da burocracia e do sistema corporativista. Seria na entrada em vigor do II Plano de Fomento que Portugal viria a aderir à maioria dos acordos e organizações económicas internacionais.

No fim da década de 50, o Governo português adere à Associação Europeia de Comercio Livre (EFTA) que consiste num grupo de países que procura eliminar as barreiras alfandegárias, propiciando que Portugal comece a procurar novos mercados. Assim a expansão fabril bem como a construção civil e o sector energético fazem com que haja a tal receada quebra das pequenas empresas em prol das grandes indústrias. Ruma assim a população para as grandes cidades em busca de emprego, tornando-se a população mais urbana e com melhor rendimento. Proporciona-se melhores condições de vida, mais informação o que diminui as taxas de natalidade e mortalidade, envelhecendo a população.

Apesar de todo este desenvolvimento e mudanças, o país ainda está aquém do resto da Europa. Todos estes processos são lentos bem como o ajuste que todo o Estado Novo teria que fazer para acompanhar os novos tempos: necessário ajuste do sistema político, a abertura do regime, a renovação do pessoal dirigente e o aumento da participação dos cidadãos.

Depois de Galvão um dissidente do regime, em 1958, Humberto Delgado, general da Força Aérea candidata-se à Presidência da República. Demonstra que a paciência do povo tivera esgotado e estava ansiosa e desejosa por mudanças.

Começa a ser cada vez mais notório todos os sinais de descontentamento, saturação e até mesmo do desvanecimento dos 


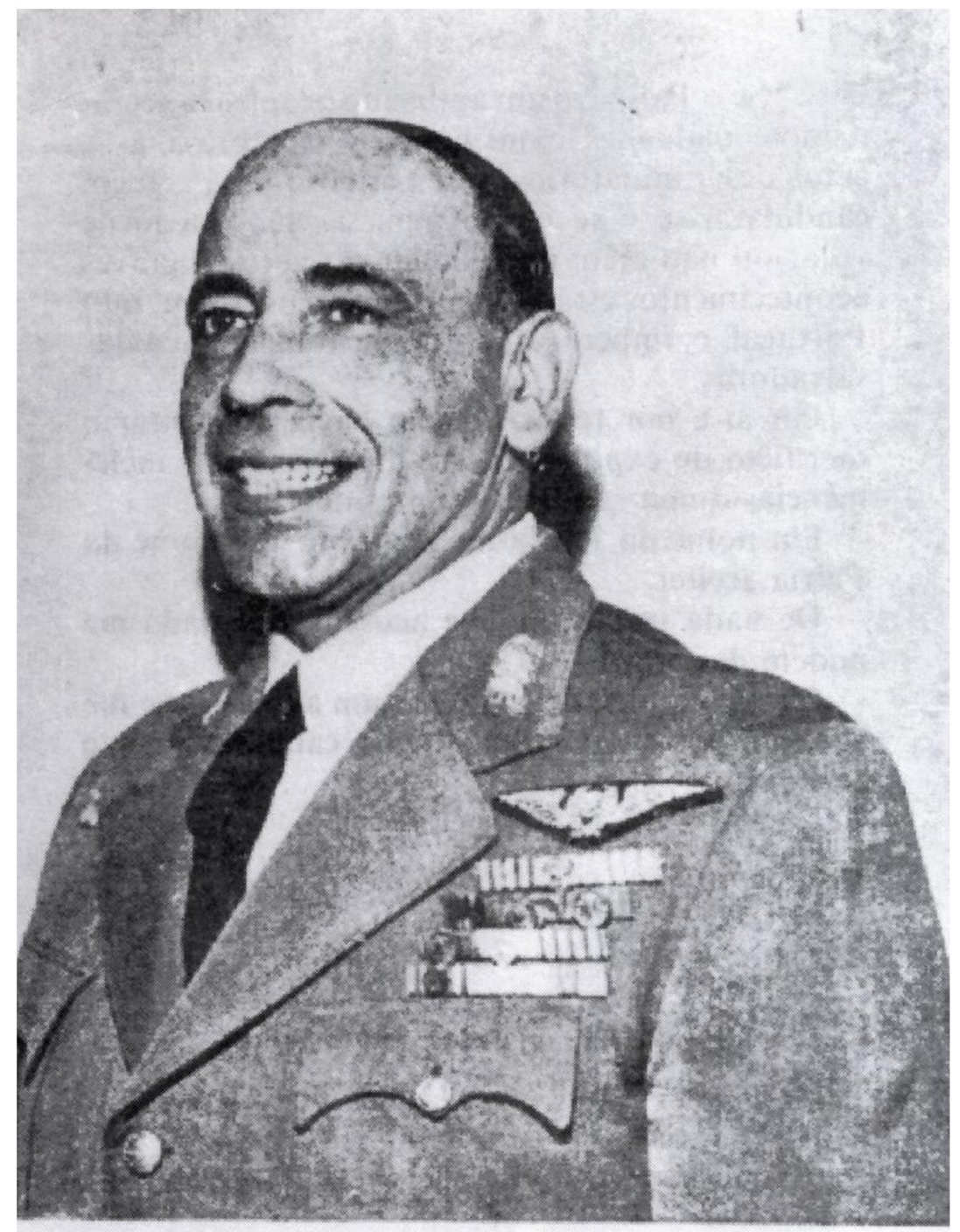

GENERAL HUMBERTO DELGADO Candidato Nacional à Presidência da Repubblica

Figura 11. General Humberto Delgado, 1958 
dois pontos basilares do Estado Novo: as Forças Armadas e a Igreja Católica. Com um regime controlador, o entretenimento popular era simples, recatado, tranquilo, conformista.

«Consagra-se por estes tempos a fórmula dos três efes com que se diz apaziguar o regime os Portugueses: Fado, Futebol e Fátima.» ${ }^{45}$ enquanto que para o governo as palavras chave eram Deus, Pátria e Família.

Fátima transforma-se nos anos 50 num centro de atracção anual de dezenas de milhares de peregrinos.

O Futebol criava heróis nacionais e fazia a representação da nação em termos simbólicos (na questão do patriotismo e sobretudo na questão da multirracionalidade). As canções, os festejos dos santos populares eram aguardadas o ano inteiro onde a diversão era realmente grande. O humor viveu tempos difíceis, por mais tímida que fossem as referências políticas, económicas ou sociais dos portugueses, estava sob o traço pesado e implacável do lápis azul, ou seja a censura.

Os anos 50, na prosperidade do pós-guerra, abrem-se as portas à industrialização e à sociedade de consumo. É um período onde as longas fases de recessão económica que intercalam guerras e crises conduzem a um amadurecimento das leis de produção de massa e de concorrência comercial. Surge a linguagem comercial, a publicidade, rompendo com a arte oficial e seus academismos. As campanhas publicitárias começam a fazer parte do quotidiano português. São campanhas maioritariamente constituídas por ilustrações. As ilustrações são alegres, muitas delas com humor, acompanhadas de um slogan de fácil identificação e memorização. Fortes ilustrações, de cores vivas e apelativas, alusivas aos tempos modernos forram as ruas e alteram toda a percepção das cidades.

\footnotetext{
${ }^{45}$ Vieira, Joaquim. Portugal século XX: Crónica em imagens 1950-1960,1 ${ }^{\mathrm{a}}$ ed. [S. 1.]: Bertrand Editorial, 2006, pág.78
} 


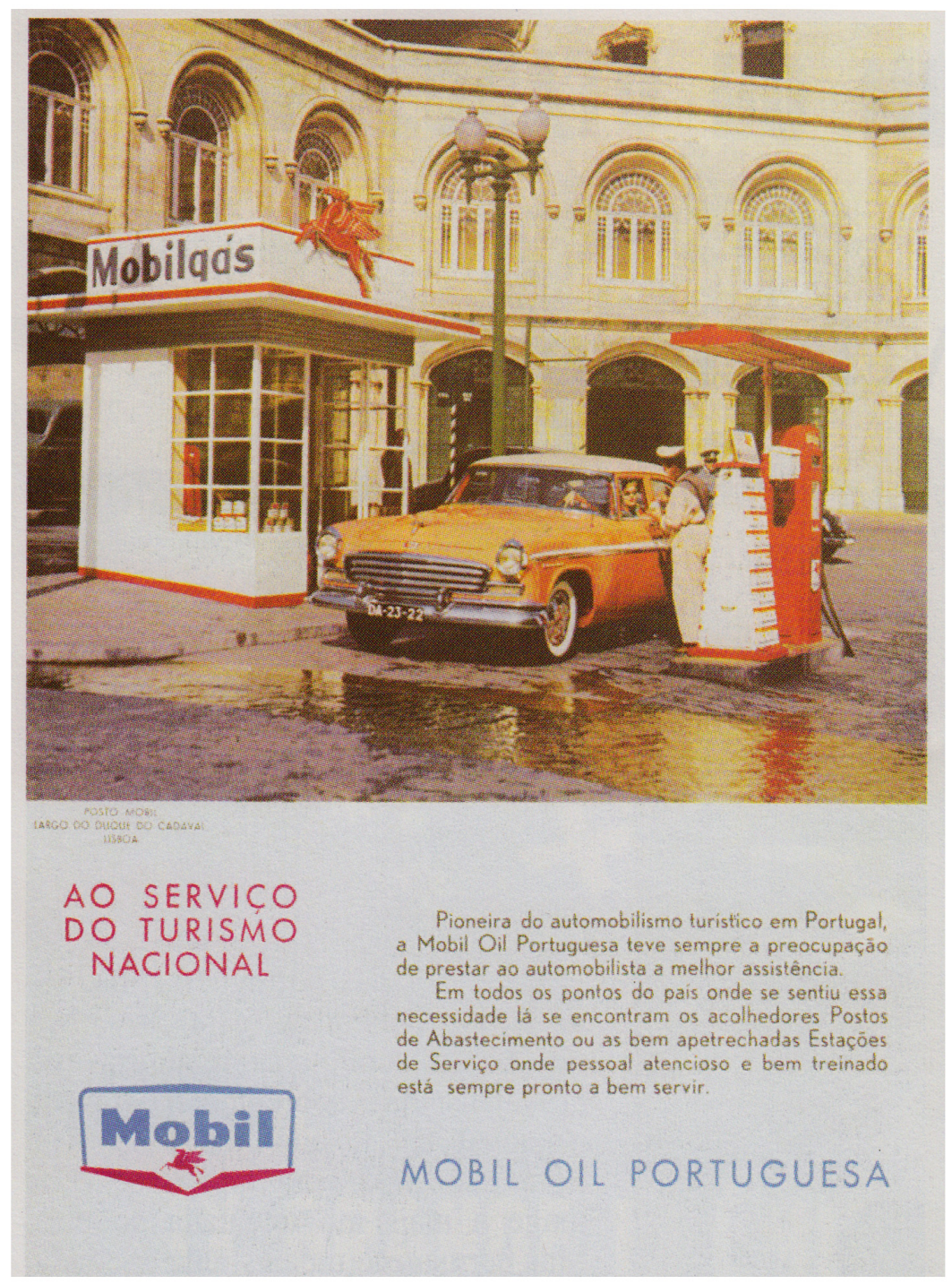

Figura 12. Publicidade da marca de Combustível Móbil,1957 
Inevitavelmente, muito lentas e silenciosas transformações operaram-se a partir dos anos 50 na sociedade. A partir dos meados dos anos 50, começa-se a sentir uma melhoria significativa das condições de vida. O uso da electricidade, do gás canalizado começou a expandir-se pelas cidades permitindo maior comodidade. Isto deu espaço aos frigoríficos e os fogões a gás e a electricidade em detrimento dos fogões a lenha.

O automóvel é a confirmação dos novos tempos, do estatuto social por parte de quem o compra. A maioria dos portugueses não pode aspirar à adesão de ter um transporte como o automóvel, embora o país esteja a crescer ainda é uma sociedade semiindustrial aquém do resto da Europa. Poucos automóveis, eram vistos o que até era um ponto positivo pois o país não tinha estradas preparadas. A estética dos automóveis dos anos 50 (influenciada pela aviação, turbina a jacto, velocidade) resultou em formas aerodinâmicas e angulosas com uma maior variedade de cores até então oferecida. Outro fascínio protagonizado pelo automóvel são as grandes competições internacionais. Vila Real, Vila do Conde, Porto, Matosinhos, Boavista, entre outras são cidades que acolheram as corridas. Divertiam e fascinavam os populares e atraíam estrangeiros arrastando multidões. Fomentou o crescimento de inúmeras marcas (Sacor, combustíveis e lubricicantes, Mobil, combustíveis, etc).

Automóveis em número significativo apareceram a partir do início dos anos 60 - é dessa época o começo da montagem de automóveis em Portugal. No decorrer dos anos os automóveis tornam-se cada vez mais acessíveis, práticos, mais resistentes e duráveis, sendo que o seu número cresceu de modo vertiginoso nas ruas portuguesas. Encurtava as distâncias, minimizava as diferenças e possibilitava "apagar" fronteiras nacionais e internacionais.

Com o pós-guerra, a Mocidade portuguesa moderou a sua 
ambição de controlar e moldar as mentes juvenis. Não deixando de ser uma sociedade altamente controladora e moralizante os jovens sentiam-se mais livres.

«Apesar da Mocidade Portuguesa e da rígida moral vigente, a juventude dispõe dos meios que lhe permitem criar o seu próprio imaginário.» ${ }^{46}$

Com o aumento da escolaridade, a descida do analfabetismo, com a expansão da leitura de revistas de banda desenhada ou por a influência da rádio os jovens ganham uma nova capacidade de sonhar e de desenvolver o seu imaginário. De vários formatos, de vários géneros (western, ficção científica, guerra...) fazem parte do universo literário infantil e inserem vida ao quotidiano infantil português, revistas quinzenais de histórias aos quadradinhos como O Mosquito (1939) com ilustrações de Eduardo Teixeira Coelho; O Diabrete (1941) com Fernando Bento a ilustrar; O Mundo de Aventuras (1949); Cavaleiro Andante (1952); Como não poderia deixar foram também alvo da censura. A televisão aparece em 1958, em que numa primeira fase (quando os aparelhos eram caros para a maioria das bolsas), havia congregado os espectadores nos cafés e sociedades recreativas. Conforme o nível de vida subia possibilitava às famílias possuir o seu aparelho, motivo para não se sair de casa à noite. As vedetas passam a ser da televisão, dos concursos, dos programas de culinária ou de comunicação.

\footnotetext{
${ }^{46}$ Vieira, Joaquim. Portugal século XX: Crónica em imagens 1950-1960,1ª ed. [S. 1.]: Bertrand Editorial, 2006, pág.121, ISBN 972-25-1533-0
} 
2.3 Las políticas del régimen y el culto a la personalidade de Salazar / As políticas do Regime e o Culto da Personalidadde de Salazar

«Para «aportuguesar» o império, a emigração é canalizada para África, que emerge como terra fácil e grandes oportunidades. ${ }^{47}$

A questão das colónias é sagrada e intocável para o regime salazarista. Os anticolonialistas sofreram várias represálias mas a sua força obriga a uma revisão constitucional em 1951, onde as colónias passariam a chamar-se províncias ultramarinas ou ultramar numa tentativa de extinguir o "Acto colonial" de 1930. Banem todas as referências pejorativas com receio de reacções por partes nacionais e internacionais. Nos campos a situação alterou-se: muitos jovens vieram do interior para as cidades para integrarem os contingentes que eram enviados para a guerra em África; outros, dado as más condições de vida emigravam para a Europa. Ao contrário da antiga emigração para o Brasil ou África em que o emigrante lá permanecia, agora esta permitia com mais frequência o regresso a casa relatando as novas vivências e cultura adquirida. Entre muitas outras influências, muda também a paisagem rural construindo casas inspiradas pela arquitectura dos países que os acolheram. Portugal, durante do decénio investe em trocas comerciais, no desenvolvimento do ultramar, promove a fixação de emigrantes europeus, intensifica-se o investimento público e privado. Facilitase a entrada a companhias de países aliados de Portugal. Libertam-se verbas para a construção urbana e de infra-estruturas. Cria-se uma

${ }^{47}$ Ibidem, p.177 
nova sociedade colonial, com vida descomplicada, despreocupada, tranquila. Uma época de prosperidade construída às custas da mãode-obra indígena brutalmente maltratada e escravizada. Com a revolta da população pelo descontentamento de lhes tirarem a terra, pelos conflitos raciais e escravidão, surgem greves, protestos salariais e revoltas que fazem crescer grupos nacionalistas clandestinos: União dos Povos de Angola (UPA), 1954, o Partido Africano para a Independência da Guiné e Cabo Verde (PAIGC), 1956, Movimento Popular para a Libertação de Angola (MPLA), 1956 e núcleos moçambicanos em 1959. Em boa parte, foram vários os factores poíticos designadamente a repressão à liberdade de expressão e de manifestação, a má gestão de dinheiros públicos e a ausência de políticas educativas que geraram antecipadamente a guerra colonial.

Rotulado como "candidato independente", avança com ideias republicanas: instauração da liberdade, reforma da polícia ultramarina e realização a prazo de eleições legislativas livres após conquistada a presidência. Humberto Delgado, pela primeira vez mostra que Salazar não é divino, eterno e insubstituível. Nasce assim por todo o país um clima anti-salazarista, um fervoroso clima de optimismo e confiança na mudança, na libertação, potenciado também pelo cansaço e saturação de um regime opressor. Com o povo de seu lado, minimiza os actos policiais que tentam intimidar e controlar a população ganhando força e poder nas massas. Um acontecimento único no que respeita à mobilização popular. O Estado Novo é profundamente abalado e tenta desesperadamente controlar a situação evitando qualquer perturbação de ordem pública e ambientes propícios a actos de carácter subversivo. Começam os entraves à campanha de Delgado, a intensificação da acção policial, a censura entre outras manobras que o levam à sua derrota nas eleições. Dizendo-se vítima de fraude eleitoral, Delgado 
fica isolado e Salazar retoma aos poucos o controlo da situação. Apesar do grande movimento audaz e conformista de Delgado ter desvanecido, nada fica como antes, porque agora, desmistificou-se a figura intocável de Salazar e que o regime já não é inabalável, já não é indestrutível.

«No rescaldo da campanha de Delgado, o regime descobre a perda de apoios tradicionais, como parte da opinião pública católica.» ${ }^{48}$ Contudo Delgado, assim como Galvão, não se livram de um ajuste de contas, de uma perseguição séria sofrendo inúmeras represálias o que faz com que acabem por pedir exílio às embaixadas do Brasil e Argentina, respectivamente. Mesmo exilado no Brasil, o general lidera a luta contra o Salazarismo.

Ambiente amargo e pessimista, dá espaço à emigração de trabalhadores para outros países. A política sombria, no campo diplomático com poucos apoios, caminha para o isolamento. Sem grandes entusiasmos tomam medidas para evitar possíveis sobressaltos entre as quais problemas internos do governo bem como uma nova revisão institucional, com um novo sistema de eleição do chefe de Estado. Passava assim o presidente a ser escolhido por um colégio eleitoral de deputados e os mais ilustres do regime. Tornando-se cada vez menos democrático, fugindo assim à opinião do povo.

Desvanece o apoio de alguns monárquicos e da maioria da igreja católica acusando de perversão autoritária, injustiça social, falta de liberdade, opressão dos pobres e divórcio do país fazendo avisos públicos sobre a má gestão e conduta do regime. Esta rebeldia da opinião católica despertou inúmeros incidentes desde processoscrimes instaurados pela PIDE, conspirações de vários activistas católicos que acabam muitos deles em exílio, instalando um

\footnotetext{
${ }^{48}$ Vieira, Joaquim. Portugal século XX: Crónica em imagens 1950-1960,1 a ed. [S. 1.]: Bertrand Editorial, 2006, pág.199
} 
desconforto geral entre o regime e a igreja. Fracassos atrás de fracassos na tentativa de derrubar o regime de Salazar pelos comunistas e até a oposição não-comunistas faz intensificar a acção policial. No final dos anos 60 consegue-se de novo a estabilidade do regime, com inúmeras detenções, desmantelamentos de partidos e com uma atitude de conformismo generalizada.

O estado Novo ficou caracterizado pela sua Ideologia Oficial, pelo culto da personalidade de Salazar ("Salvador da Pátria"), pelo nacionalismo ${ }^{49}$ (exaltação do passado, da história portuguesa para engrandecimento e orgulho da Nação) ou até mesmo a construção de obras públicas (pontes, estradas, tribunais, escolas) que constituiriam um motivo de orgulho. No início dos anos 60, o regime investe em obras públicas e inaugurações, pontes, barragens, monumentos e transportes, etc. sinais de progresso e melhoramentos. O regime conseguia através da igreja, da "política", da censura, da propaganda e também com o número de presos exilados (políticos) manter uma paz aparente até finais da década de 60.

A proliferação das escolas industriais e comerciais, na área do ensino técnico tinha como finalidade qualificar a mão de obra, a formação de profissionais mais aptos, forneceria ao sector económico um trabalho qualificado com o objectivo do desenvolvimento.

A emigração foi um fenómeno de grande vulto, nesta época. Deu um contributo enorme à economia, mas apenas com o se não de ser um elemento desagregador da família e a perda de mão de obra para um país que precisa urgentemente de se desenvolver e afirmar-se alem fronteiras. «A ideia de mudança foi uma ideia quase de todo ausente na universidade portuguesa nas três décadas que se

${ }^{49}$ SALAZAR, António de Oliveira. Discursos e notas Políticas, Coimbra Editora, $2^{\mathrm{a}}$ ed., vols. II, 1946, p. 132 
seguiram a 1930.» ${ }^{50}$

«As bibliotecas quase não eram frequentadas. A investigação científica como actividade colectiva era quase inexistente. A palavra seminário não tinha uso na universidade (...). Em particular a universidade estava em absoluto separada das escolas do ensino médio (os estudantes de dois tipos de escolas eram considerados como de duas classes sociais diferentes)». ${ }^{51}$

A estrutura da universidade manteve-se na prática inalterada na década de 60, contudo esta década foi o palco das reivindicações dos estudantes portugueses. O poder dos catedráticos foi abalado e estava em franco recuo. O movimento estudantil, ao longo desta década, assentou na liberdade e na igualdade de ideais e no final desta faziam despertar um movimento contra a opressão do regime Salazarista, a par da contestação "silenciosa" da guerra colonial esta mais para os finais da década.

A agitação estudantil entre 62 a 65 o movimento associativo 65 a 68, em que a associação de estudantes eram autênticos sindicatos, obrigavam os professores ao dialogo, pois o controlo mais difícil era no interior das universidades. As criticas no plano pedagógico degeneraram em reivindicações de facilitismo. Mesmo assim o ditador, António Oliveira Salazar conseguiu até finais da década de 60 controlar e assegurar que o país vivia de maneira recatada e controlada de modo a que a sua imagem e poder fosse intocável.

\footnotetext{
${ }^{50}$ BROTAS, António, Ensino Superior e projecto de Sociedade, Sistema de Ensino em Portugal, fundação Caloust Gulbenkian Lisboa, Junho 1981, p.623

${ }^{51}$ Idem
} 


\subsection{El golpe de estado y sus implicaciones políticas / O}

Golpe de Estado e as suas implicações políticas

Salazar em 1968 cai de uma cadeira fica mentalmente afectado, diminuído, sendo substituído por Marcelo Caetano, e morre em Julho de 1970.

Com entrada de Veiga Simão para Ministro da Educação, assiste-se a uma maior abertura do sistema, foram tomadas várias medidas e fizeram-se algumas reformas de forma a responder às situações de censura. A contestação da guerra colonial aumentava. Em 1973 foi publicada a lei de bases do sistema educativo, procurando mostrar uma faceta liberal e foi criado por decreto uma rede de escola superiores, mas surgiram já numa fase de ruptura muito tardiamente.

Cada vez é maior a contestação social à guerra colonial, os resultados começam a ser catastróficos e sem fim à vista, já são quase treze anos de guerra é um pesadelo para os jovens e suas famílias. Em 1974 reina um descontentamento bastante grande no seio das forças armadas. Em 11 de Março dá-se o primeiro movimento das Forças Armadas (FA) para derrubar o governo, mas esta intentona resulta num fracasso total e na prisão dos oficiais responsáveis. Foi o prenúncio da Revolução de Abril.

Em 25 de Abril, os militares (Capitães de Abril) fazem um novo golpe, "Revolução dos cravos" (pela força pacífica) derrubam o governo, constituem a Junta de Salvação Nacional para sustentar o novo Governo do Estado Português. Após a Revolução de Abril (74/75) o povo até então estivera oprimido, liberta-se, ganhava a liberdade de expressão e o direito à participação na causa pública. Gera-se uma forte movimentação politica e social, dá-se o 
desmantelamento dos principais grupos económicos como a Companhia União Fabril $(\mathrm{CUF})^{52}$, os grupos Champalimaud e Espírito Santo etc., através das nacionalizações. O estado fica em posse de 1300 empresas. É extinta a LP e MP pela Junta Nacional no próprio dia 25 de Abril através de Decreto. Dá-se o processo de descolonização das províncias ultramarinas da qual resulta o regresso e integração de meio milhão de pessoas. Estamos no Período Revolucionário em Curso (PREC), um movimento impulsionado por partidos e organizações de esquerda e extrema esquerda que terminara com o 25 de Novembro de 75 . Este foi um período muito conturbado "o povo é quem mais ordena" os muitos partidos de esquerda e extrema esquerda querem ganhar o seu espaço, fazer vingar as suas ideias. Alem das nacionalizações foi um período de manifestações, ocupações e governos provisórios.

Vasco Gonçalves foi uma das figuras proeminentes na transição democrática, nos períodos compreendidos entre Julho de 74 e Agosto de 75, homem de esquerda foi ministro em quatro governos provisórios neste mesmo período, alimentava o sonho do socialismo e esteve intimamente ligado às nacionalizações e reforma agrária, de tal ênfase fora a sua participação que o período da sua estada na politica foi cognominado "Gonçalvismo". Este período também se caracterizou pelo regresso, principalmente vindos da Europa dos intelectuais políticos exilados com o destaque para Mário Soares, e Álvaro Cunhal, a libertação dos presos políticos (feitos pela PIDE e pela DGS) e as passagens administrativas no ensino.

Nos finais de 75 o país estava à beira de uma guerra civil, tais eram as convulsões politicas. As forças procomunistas (PCP,

${ }^{52}$ A CUF em 1974 estava fortemente presente: na Banca e Investimentos financeiros; na Indústria de Construção; nos Seguros e Resseguros; Engenharia, organização e consulta; Sector químico; Sector têxtil; Sector de higiene e alimentação; Sector metálico Mecânico; Sector eléctrico; Industrias petroquímicas; Minas; Industria do Papel; Tabaco; Estaleiros Navais; Navegação; Hotelaria e turismo; Aluguer de veículos e empresas diversas. 


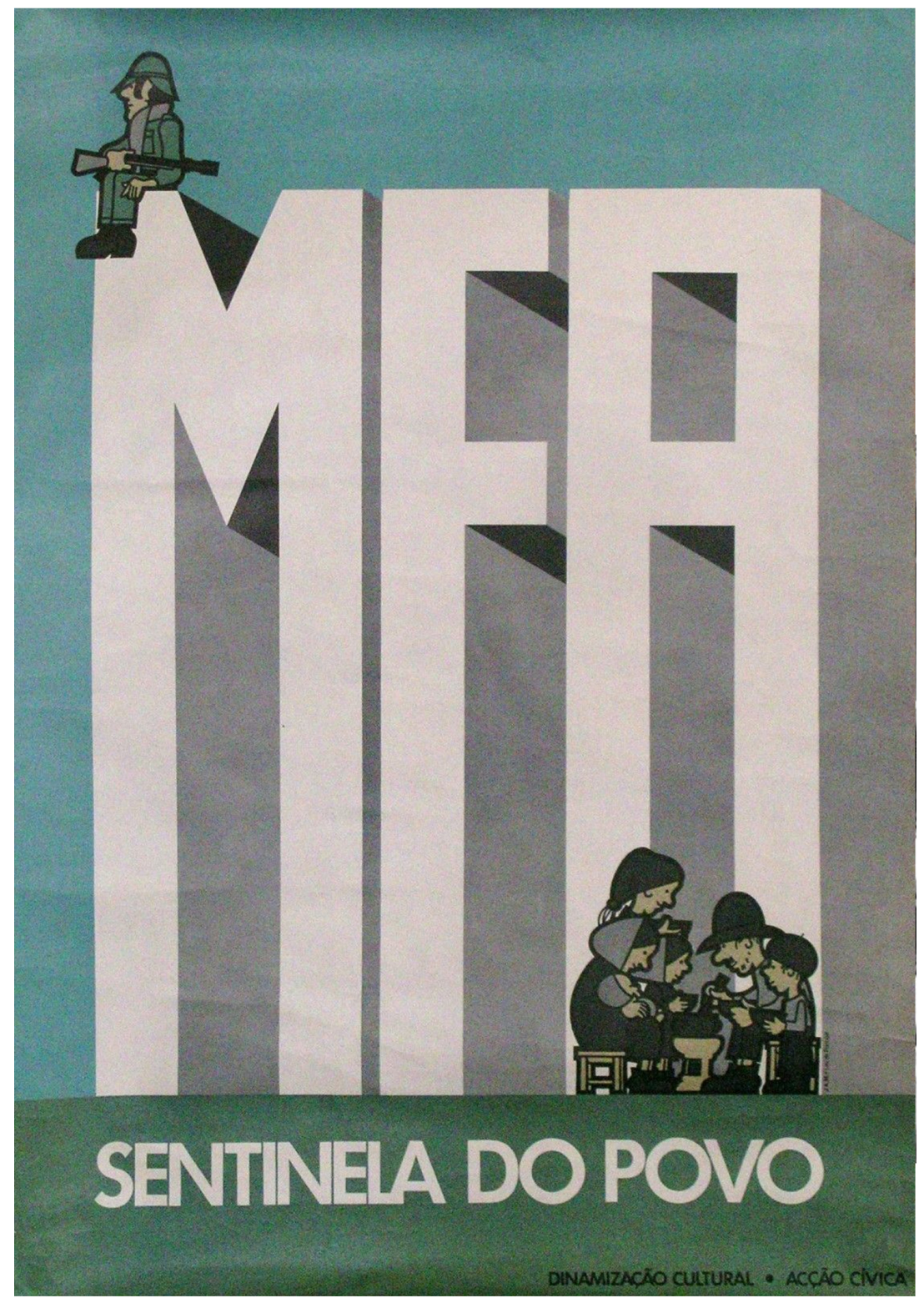

Figura 13. Postal Sentila do Povo de João Abel Manta 
Esquerda Militar e Extrema Esquerda) procuravam impor um regime próximo dos países comunistas enquanto os moderados dos Movimentos das Forças Armadas (MFA), as forças democráticas (CDS, PSD, PS) e a Igreja Católica partilhavam e "lutavam" por uma democracia pró europeu.

Além desta viragem político/económica, começa a sentir-se uma intenção de mudança na política de educação, muito pelo facto da herança educacional em plena remodelação profunda. Logo em 75 é criado o serviço cívico estudantil destinado a candidatos ao ensino superior e preconizava incutir hábitos de trabalho socialmente produtivos e inseridos num programa global de reconstituição do país.

Em 25 de Abril de 1976 dão-se as primeiras eleições livres, abertas a todos os cidadãos com mais de 18 anos, independentemente do seu estatuto social, género ou educação.

«Consolidado o regime democrático, é fundamental que Portugal opte quanto ao seu futuro. Não tanto em termos de corrigir os erros do passado mas, acima de tudo, com o objectivo de acertar o passo pelos parceiros da comunidade europeia a que, por direito, deve e quer pertencer a curto prazo. Isso, porém, só será possível desde que o país forme os técnicos indispensáveis para o seu desenvolvimento, o que obriga a uma urgente reestruturação de todo o ensino, em especial o Ensino Superior. Para tal considera-se fundamental que as opções a tomar, no que se refere à diversificação, expansão e acesso ao Ensino Superior, sejam clara e urgentemente assumidas pelos órgãos de suberania a quem tal compete. ${ }^{53}$

A democratização do ensino pós 25 de Abril despoleta a massificação que conduz à degradação do meio escolar por impreparação e por isso o acesso ao ensino superior foi regulado pelo serviço cívico no

${ }^{53}$ BRAGA, C.Lloyd / GRILO, E. Marçal, Ensino Superior, Sistema de Ensino em Portugal, fundação Caloust Gulbenkian Lisboa, Junho 1981, p.233 
ano lectivo 75/76 também com numerus clausus para alguns cursos. $\mathrm{O}$ ano propedêutico entra em funcionamento em 77/78 e destina-se a preencher o ano lectivo deixado em aberto pela extinção do serviço cívico e estudantil, transformando-se mais tarde no $12^{\circ}$ ano de escolaridade. A partir deste ano lectivo passa a vigorar em definitivo os numerus clausus no acesso ao ensino superior.

Em 1980 Otelo Silva de Carvalho cria o partido Força de Unidade Popular (FUP). Durante a década 80 é acusado de liderar a organização terrorista Forças Populares 25 de Abril conhecidas por “FP-25”, responsável pelo assassinato de 17 pessoas e assaltos a bancos. Esta organização FP-25 é uma organização armada clandestina de extrema esquerda que operou em Portugal até em 1987.

No ano de 80 (Dezembro) morre o primeiro ministro Sá Carneiro e o Ministro da Defesa Adelino Amaro da Costa quando o avião em que seguiam se despenhou (em Lisboa) em circunstâncias ainda por esclarecer.

No ano de 83 foi relançado o ensino técnico profissional e no ano de 89 os cursos tecnológicos e os cursos profissionais.

$\mathrm{Na}$ década de 80 os estabelecimento de ensino publico, na área da educação artística, são em número reduzido, mal instalados e mal equipados com problemas financeiros e o seu estatuto ou é indefinido, ou provisório, ou carece de revisão e actualização. Foi publicada em 1986 a lei de bases do sistema educativo que determinou a reorganização estrutural do sistema educativo, vindo mais tarde a prolongar a escolaridade obrigatória de 6 para 9 anos.

Em síntese: desde os anos 30 que os tempos foram socialmente conturbados, conflituosos e paradoxalmente de apatia, marcadamente pelos objectivos políticos da ditadura salazarista (até 74) e pela transição abrupta para a democracia. Na consolidação e progresso da democracia estiveram ausentes os pressupostos do 
desenvolvimento sócio/económico e cultural. Por tudo isto os pilares da sociedade: justiça, educação e saúde não foram bem alicerçados, fenómeno que se repercute no passado, presente e futuro em todos os campos da sociedade portuguesa. 


\section{Acontecimentos \\ em Portugal}

$1930 \quad 32$

32

$$
44
$$

inicio do Estado
Novo - II República 1) Exposiçăo do Mundo Português 1) revisão constituicional

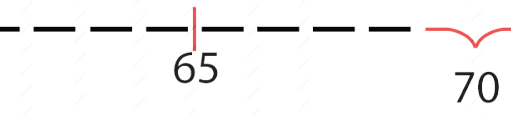

70

Aprovaçao de uma nova
constituicáo em plesbicito
Fim dad Ditadura Militar

1) Proibicião dos partidos
politicos edas associaçōes

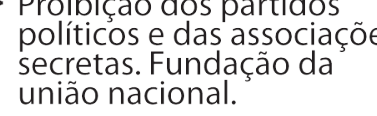

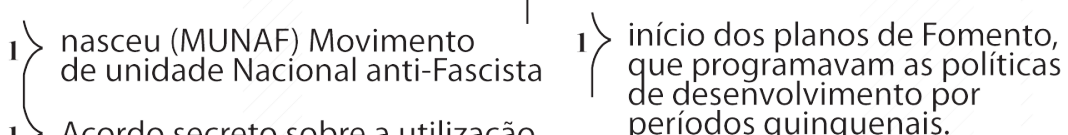

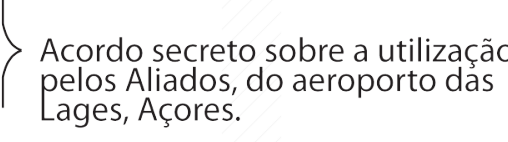

1) entrada de Portugal
na O.N.U

1) Guerra Civil Espanhola

fundação da legião
portuguesa

1) (MUNAF) substituido por

1) Instituicăo da Fundação

1) Inauguracăo da Ponte

Inicio da Guerrilha na Guiné

7475

$78 \quad 80$

83

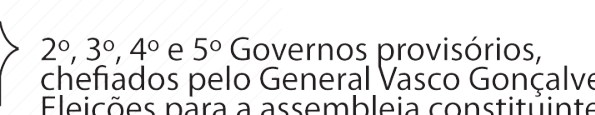

$88 \quad 90$

90

$97 \quad 992000$

Reeleicãao do Dr. Mário Soares
para a Presidência da República

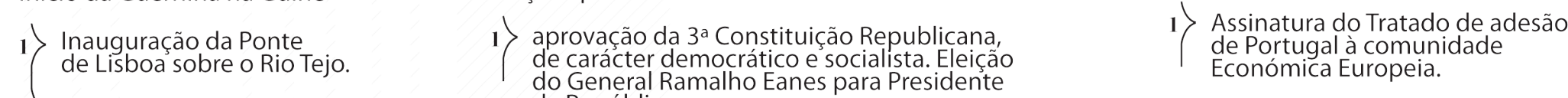

1) Início da Guerrilha em Moçambique da República

1) Reeleicão do General Eanes para
a Presidência da República.

1) Marcelo Caetano

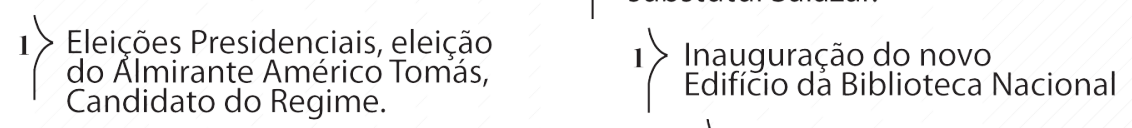

fim da Il Guerra Mundial
1) tentativa de Revolta Militar
(Revolução da Mealhada).

Apoio ao movimento
nacionalista na guerra civil
de Espanta

1) |I Guerra Mundial

Defesa da neutralidade Portuguess'
perante a II Guerra Mudial

Pacto ibérico - Portugal
reconhece o governo do

reconhece o governo do
General renco eassina
coma a Espanha um tratado

1) Fim do MUD

1) Candidatura do General Norton
de Matos à presidencia

1) Candidatura de Humberto
Delgado às Eleiçoes
Presidenciais.

1) Guerra Colonial
(Guerra do Ultramar)

1) Surgiu (MFA) Movimento

1) Crise Mundial

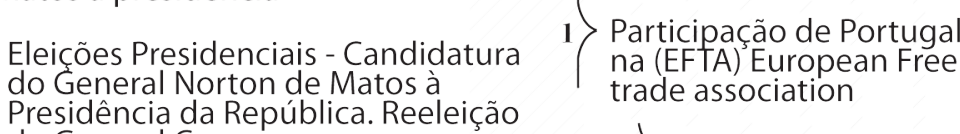

General Carmona.

1) canditura de Quintão Meireles
as eleiçoes Presidenciais

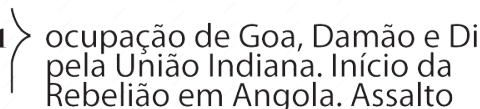

no paquete Santa Maria
nebeliá

1)

1) Fim da Guerra Colon

1) Rendiçăo de Marcelo Caetano

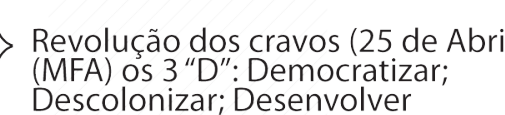

Descoloniza, Desenwiver

7) uma junta da salvacaáa Nacional,

governo e designa Presidente da

Spinola, que renuncia ao cargo em
Setembroe é substituido pelo
General Costo
1) Assinatura do acordo de
Maastricht, ratificadoo pela
assembleia da República

1) Eleição do Dr. Mário Soares 


\section{Capítulo 3: La Arte en Portugal del siglo XX y sus protagonistas / A Arte em Portugal no séc.XX e seus protagonista}

Num contexto cultural e politicamente desfavorável, a modernização nas práticas artísticas em Portugal foi lenta e complexa. O desenvolvimento artístico do seculo XX tem como principais intervenientes artistas da chamada $1^{\mathrm{a}}$ e $2^{\mathrm{a}}$ geração cujas obras são a principal acção dinâmica para novos desenvolvimentos estéticos, promotora de mudanças e reflexões sociais e artísticas. Porem, não se pode escamotear a valorosa participação prestada, do mesmo modo por todos os artistas e intelectuais, organismos e instituições ao longo do seculo, no desenvolvimento e consecução da arte em Portugal. É a este conjunto de actores que se deve a evolução, aprofundamento e a diversidade artística, muitas das vezes sem grandes meios que dependeram apenas da grande força de vontade e do amor-próprio pela arte.

Dos intelectuais do séc. XX, distinguiu-se a figura de António Ferro, pelo modo, participação e pela ratificação do modelo imposto pelo regime e por si, nem sempre nobre nem sempre em prol da arte pela arte como se pode aferir posteriormente.

Outro grande actor da arte no séc. XX foi indubitavelmente o multifacetado artista Fred kradolfer, introdutor das artes gráficas e de uma nova linguagem visual no design gráfico em Portugal. 


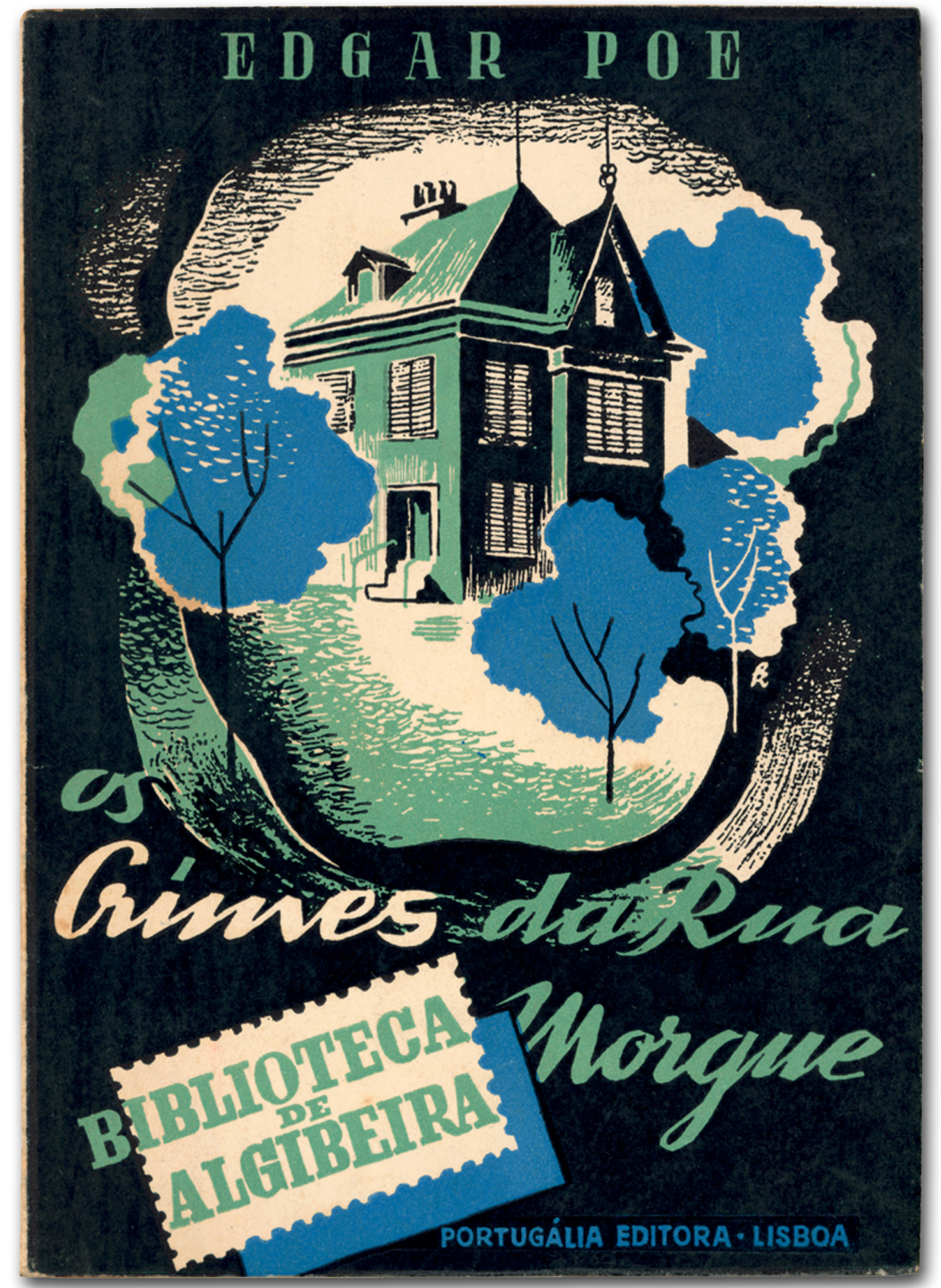

Figura 14. Capa de livro, ilustrado por Fred Kradolfer, 1943 


\subsection{El inicio de la estética Modernista - $1^{\text {a }}$ Generación / Início da Estética Modernista $-1^{\mathrm{a}}$ Geração}

«Quando as distâncias entre os países europeus iniciaram o seu processo de colapso e a circulação da informação se constituiu como parte triunfante do novo mundo, a arte moderna portuguesa desenvolveu-se por episódios singulares e amplas descontinuidades. A reação a este contexto foi a emigração de alguns dos mais relevantes artistas para Paris: primeiro Amadeu de Sousa Cardoso, situação interrompida pela Grande Guerra e sua morte prematura; posteriormente o caso maior e definitivo de Maria Helena Vieira da Silva, a quem Salazar viria a retirar a própria nacionalidade. $>^{54}$

Da revolução republicana, com a instauração da $1^{a}$ república, surge em Portugal o "Modernismo" influenciado pelas grandes correntes estéticas europeias, o futurismo e o expressionismo, resultante do fenómeno das estadias de diversos artistas principalmente em Paris, os quais faziam a ponte com as vanguardas emergentes e proporcionam relevante fluxo de informação e do contributo fundamental da chamada "geração literária" ou "geração Orfeu” do qual faziam parte figuras proeminentes das letras e das artes como Fernando Pessoa, Almada Negreiros, Mário Sá Carneiro ou Santa Rita.

A I exposição de humoristas portugueses teve lugar em Lisboa em 1912. Em 1915, no Porto, emerge o termo modernista do título de uma exposição de humoristas e modernistas.

O Modernismo é a rejeição do tradicional, é perspectivar o futuro

${ }^{54}$ LAPA, Pedro, Arte moderna em Portugal: de Amadeo a Paula Rego [disponível em] http://www.museudochiado-ipmuseus.pt/pt/node/686; [consultado em] 22/06/09, 11:05 


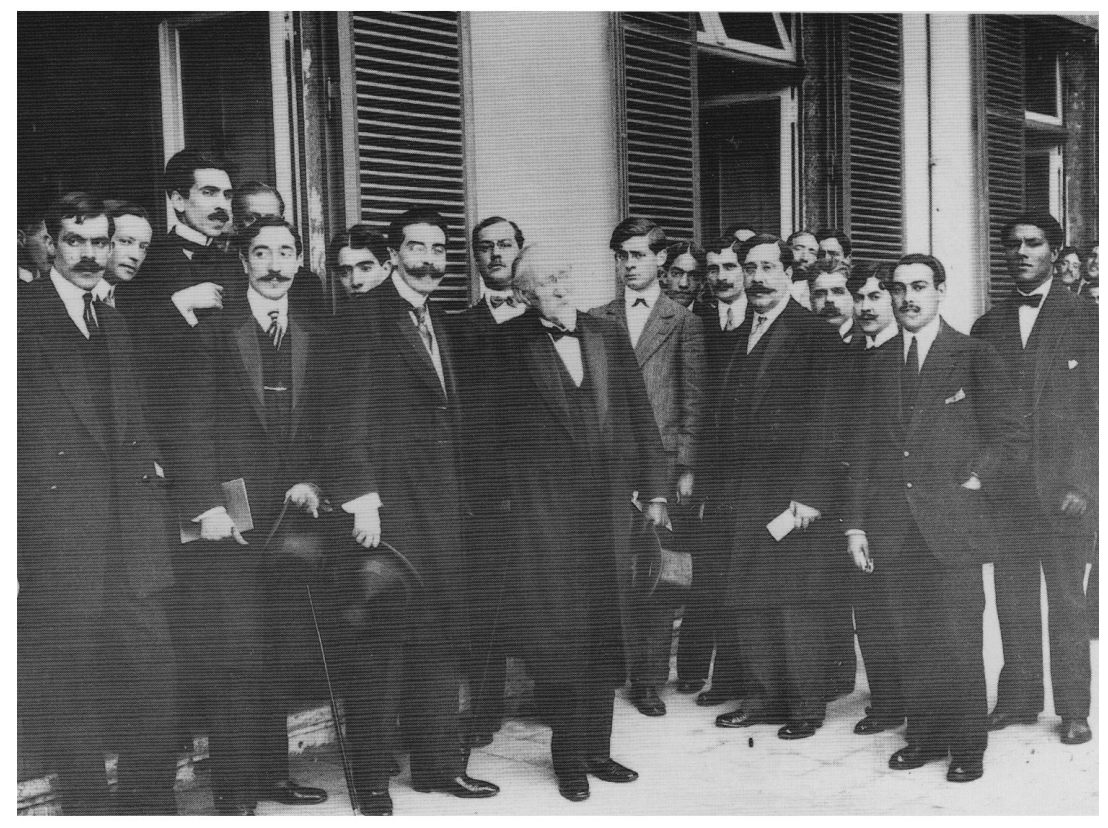

Figura 15. Fotografia I $^{\circ}$ Salão dos Humoristas 
baseado na criação e na inovação, é dar lugar a uma nova cultura. O modernismo é o conjunto de movimentos culturais, (não totalmente convergentes), nomeadamente a literatura a arquitetura, pintura escultura, design, música e teatro que perfilham a mudança, desde os aspectos existenciais, á filosofia e ao comercio, objectivando o progresso, equacionando novas ideias e novas técnicas.

Os movimentos modernistas com os seus estilos, as suas escolas e os diferentes saberes premearam o design e as artes principalmente até aos anos 40 .

\subsection{1 "Orphismo" al Modernismo /}

"Orphismo" ao Modernismo

«Modernismo _ o termo tem sido usado para descrever a arte e a cultura dos últimos cem anos - aparentemente chega ao fim. À medida que vivemos as agitadas consequências morais e intelectuais do que o critico americano Irving Howe chamou o "declínio do novo" (em 1959, no texto Mass society and post-modern fiction), tem-se tornado cada vez mais difícil acreditar na possibilidade da ocorrência de mais uma revolução estilística, de mais um salto para uma forma radical. ${ }^{55}$

O marco da entrada em Portugal do modernismo fez-se com a "revista Orfeu", 1915, apenas com dois números publicados conseguiu exercer tal influencia no movimento intelectual artístico que perdurou no tempo a sua filosofia, acções, ideias e experiencias, é o contraste com a falta de actividade artística de vanguarda, salvo algumas excepções.

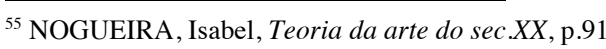


O modernismo dividiu-se em três fases: Orfismo (1915), movimento criado pelos escritores e responsáveis pela revista Orfeu; Presencismo (1927), criação da revista presença, que sem romper com as ideias do orfismo procuravam aprofundar e obter novas formas de expressão que surgiram pelo mundo. Foi a edição crítica cuja intervenção melhor soube dar continuidade e entendimento ao vanguardismo do primeiro modernismo e Neo-Realismo, Movimento que defendeu uma literatura crítica, reformador, ao serviço da sociedade e combate do fascismo (predomínio da prosa).

Fernando Pessoa, Mário Carneiro e Almada Negreiros entre outros, publicaram os primeiros poemas de contestação e intervenção numa nova linha de pensamento e contra a velha ordem (tradicional) literária no primeiro número da Orpheu, enquanto que no segundo número entre outros artigos já continha "pinturas futuristas" de Santa Rita, contudo ambas as edições receberam a troça dos críticos mas provocou um efeito adverso o que reforçou o movimento e o aparecimento de novos criadores.

«Muitas vezes se faz da Renascença o começo dos tempos modernos. Ela marca certamente o início de uma idade nova (que talvez não seja já a nossa), a de um certo número de grandes descobertas. Extremamente desiguais, mas também mais livres, os homens acreditam encontrar, à força de investigações e de discussões, a Verdade. Pelo menos um certo número de verdades. ${ }^{56}$

Fernando António Nogueira Pessoa, simplesmente Fernando Pessoa (1889-1935), foi fazedor de muitos ofícios: empresário, editor, escritor, critico literário, comentador político, inventor, astrólogo publicitário, poeta e tradutor (a principal fonte do seu sustento).

Nasce em Lisboa, vive grande parte da sua adolescência na cidade de Durban, África do Sul, onde concluiu o ensino primário, com dez

${ }^{56}$ NOGUEIRA, Isabel.Teoria da Arte, Imprensa da Universidade de Coimbra, Março 2012, p. 91 
anos de idade ingressa no liceu de Durban sendo um dos melhores alunos. Mais tarde matricula-se na Durban Comercial (ensino noturno) e simultaneamente prepara-se para fazer o exame de admissão á universidade no qual não obtém boa nota mas é o primeiro no "ensaio de estilo Inglês" obtendo o premio Rainha Vitoria. Encerra os seus estudos na universidade em Durban, com a conclusão do "exame intermediário em artes”, com a consecução de uma boa classificação.

Mais tarde, 1906, em Lisboa, matricula-se no curso superior de letras, abandonando-o sem acabar o primeiro ano.

A sua estada desde tenra idade na Africa do Sul, o seu percurso escolar, a educação tipicamente inglesa, bem como o contacto desde cedo com grandes vultos da literatura inglesa (shakespeare, Lorde Byron, Edgar Allen Poe entre outros) permitia-lhe um aprendizado, que lhe confere o domínio absoluto da língua inglesa e o despertar desde tenra idade de uma sensibilidade artística impar na área das letras. Começa a escrever aos sete anos de idade, toda a sua vida foi prosa ou verso. Escreve em inglês, francês e português, mas, na língua materna, apenas publica em vida e obra "Pessoa ele mesmo" em 1934.Dos muitíssimos heterónimos utilizados, entre outros, destacam-se Álvaro Campos, Alberto Caieiro, Ricardo Reis na sua obra poética e Bernardo Soares no livro "Desassossego", tendo porem usado também pseudónimos e o ortónimo Fernando Pessoa.

Pessoa faz parte da "revista literária Orfeu " em 1915, editado em Lisboa, com os seus escritos no $1^{\circ}$ numero e no $2^{\circ}$ número, já é sob a sua direção conjuntamente com Mário Sá-Carneiro. A "Orfeu" embora cause um choque negativo na critica, foi de grande importância pelos movimentos literários que gerou pelo impulsionamento de renovação que cria na literatura portuguesa, e também é agregadora de grande nomes da literatura (como 


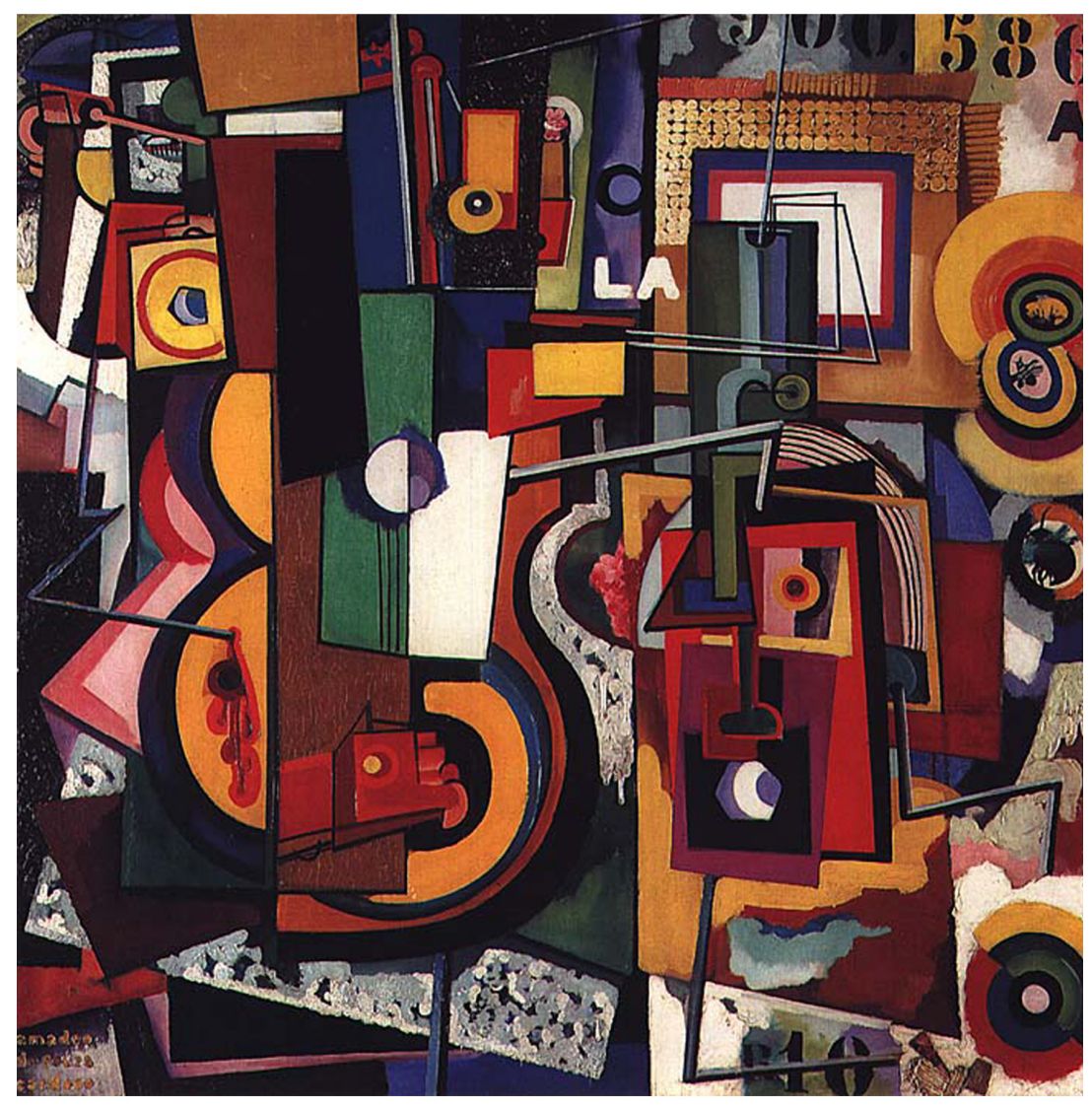

Figura 16. Pintura óleo sobre tela de Amadeu Sousa Cardozo, 1917 
Almada-Negreiros e Santa Rita -pintor) e fundamentalmente introduz em Portugal o modernismo (apenas com dois números editados). Fernando Pessoa por tudo o que constituiu foi um grande nome da literatura, e um dos maiores poetas portuguese, contudo o seu fim dá-se em 1935 sem fortuna nem reconhecimento.

\subsubsection{Las influencias de Amadeu de Sousa Cardoso / As influências de Amadeu de Sousa Cardoso}

Pertencente à primeira geração de pintores modernistas portugueses foi Amadeu de Sousa Cardoso, (n. 1887-1918), viveu em Paris, durante sete anos, (1907-1914) no bairro de Montparnass, lugar de encontro e de convivência dos artistas e intelectuais, regressa à Pátria com frequência promovendo um fluxo de informação com as vanguardas emergentes. Amadeu foi o único artista que participou em importantes exposições de vanguarda internacional (Paris, Berlim, Nova Iorque), foi um dos artistas representados no "Armory Show", (International Exhition of Modern Art), em Nova Iorque em 1913, ficando esta exposição ligada à viragem modernista norte americana. Mas já antes , 1911, tinha privado e exposto conjuntamente com Modigliani, cujo livro de honra é assinado pelo Picasso. Em 1912, reúne desenhos desse e do ano anterior vindo a obter uma grande divulgação e destaque na imprensa portuguesa e na imprensa francesa. Em 1913, expõe em Berlim ( $1^{\circ}$ Salão de Outono Alemão), com outros artistas que também se identificavam com a novíssima pintura. O rebentar da guerra fá-lo regressar a Portugal onde expõe no Porto e em Lisboa, causando aos críticos grande surpresa, por não estarem acostumados com esta vanguarda. Convive com Almada Negreiros e 
membros do Orfeu e em 1917, tem mesmo projectos editoriais com Almada. No seu trabalho individual aprofunda o seu universo pictórico, realizando as experiencias mais radicais sobre a nova concepção deste espaço. Os últimos trabalhos reforçam as associações inesperadas, avolumou-se as complexidades dos processos técnicos, suas misturas, integra elementos iconográficos, típicos da fragmentação cubista, representações físicas ou produtos contemporâneos e formas abstratas e são o reforço do seu estatuto como artista.

Toda a sua obra mostra a coerência interior e indagante. Logo em 1913 experimentou o abstracionismo puro e simples, planos de cor muito próximos do abstracto e naturezas mortas pró-artistas. O princípio da sua investigação faz-se através de uma paleta expressionista por meio de uma geometrização estilizada de motivos naturalistas. As sobreposições de planos, o uso das cores, as colagens e a figuração intersecionados denotam o gosto cubista e mostram bem a profundidade da sua obra e a sua maturidade plástica. Com as suas intervenções planográficas e cubistas, Amadeu, é a maior influência para o Abstraccionismo Geometrico e para a Arte Abstracta em Portugal.

Amadeu conviveu com grandes vultos da arte internacional como Picasso, Braque, Modigliani e o casal de Delaunay. No campo artístico experienciou várias correntes que vão do naturalismo ao cubo-futurismo passando pelo expressionismo e abstracionismo, por isso a sua obra espelha influencias das várias tendências artísticas o que dificulta a sua classificação. 


\subsubsection{Almada Negreiros, la nueva vanguardia / Almada Negreiros, a nova vanguarda}

Começando a actividade de artística seguiu como escritor uma carreira de ruptura intencional e provocatória, sendo entre os "modernos" o que mais se afirmou.

José Almada Negreiros (1893-1970) escritor e artista plástico, pintor, novelista, dramaturgo, romancista, poeta, caricaturista, coreógrafo e futurista, fundador da revista Orpheu, teve longa colaboração com a imprensa, foi uma das figuras chave na introdução no modernismo e foi também um impulsionador do futurismo em Portugal.

O principal tema que desenvolveu foi a geometria (sagrada) e os seus significados. A sua elaborada arte resulta de uma aprendizagem introspectiva e universal. Como pintor passou da representação convencional das primeiras experiencias e do figurativismo para a abstracção geométrica, matemática e numérica característica das ultimas obras. Da sua obra destacam-se os murais das Gares Marítimas, os vitrais da Igreja de Fátima e o mural da Fundação Calouste Gulbenkian e o manifesto Anti Dantas.

O início da década de 1940 ficará marcado pela profunda reformulação do trabalho de Almada Negreiros a partir dos frescos que realiza para as gares marítimas de Alcântara e da Rocha do Conde de Óbidos, em Lisboa. A sua obra, oriunda de uma primeira vanguarda, constituiu um trabalho de refle- xão e aprofundamento de uma síntese do desenho e da procura de um sistema de 

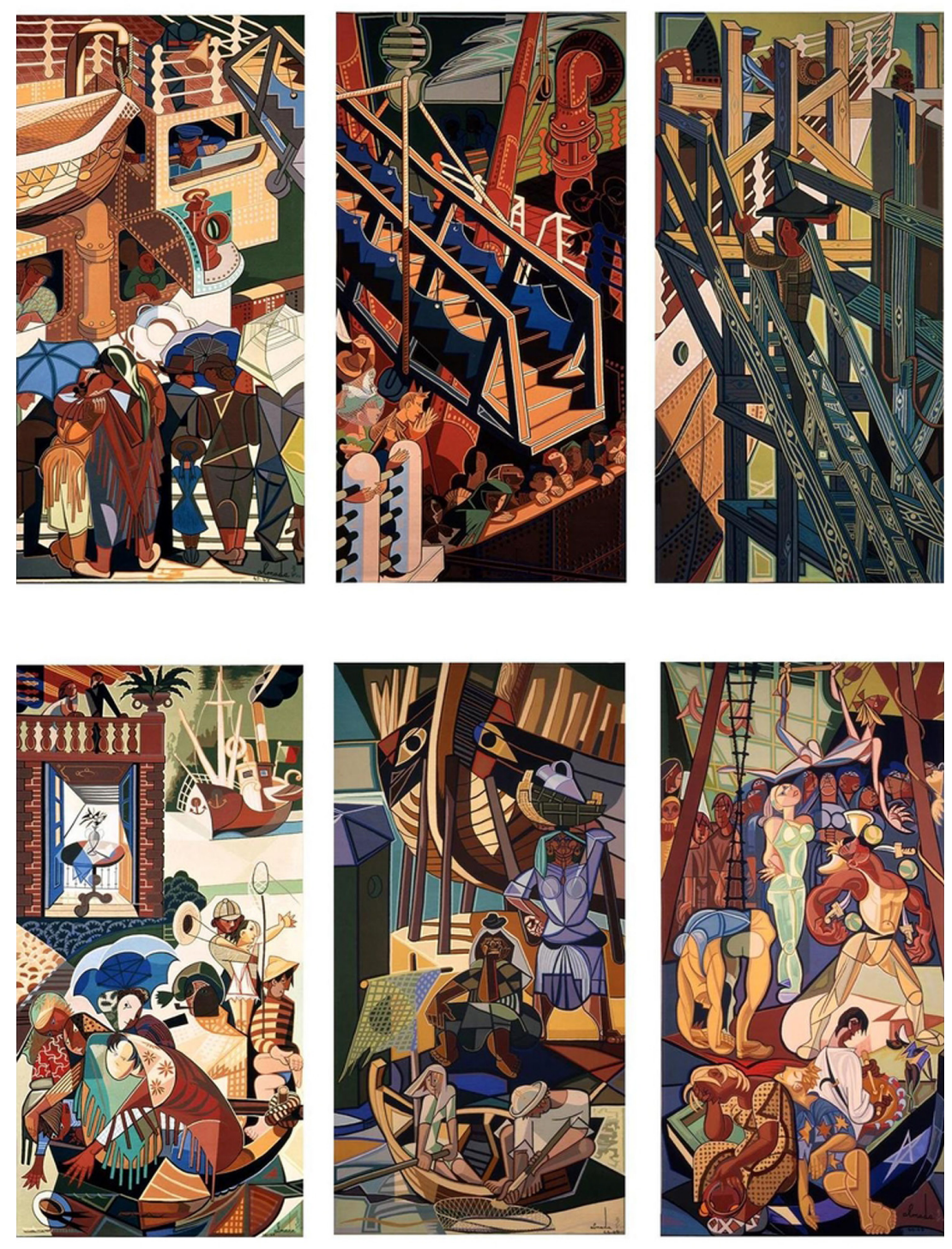

Figura 17. Dois trípticos de Almada Negreiros,1948 
proporções comum à arte ocidental, que neste período conhece novas reformulações radicalizando algumas questões abordadas pelos primeiros modernismos. Almada é assim uma figura tutelar e referencial da vanguarda histórica que se reelabora em sincronia com as jovens gerações interessadas em alterar a modernidade. Almada aproximava-se de questões que motivaram e dividiram novas gerações que nesses anos assumiram importante presença na cena artística nacional.

«Foram de facto os Abstraccionistas, os Neo-realistas e os Surrealistas que produziram essa modernidade prometida por Amadeo de Souza-Cardoso, passada como testemunho por Almada Negreiros e que estes artistas deram corpo e conflitualidade. $\gg^{57}$

Objectivando a modernização dos equipamentos portuários, a criação da Gare Marítima de Alcântara surge num edifício amplo, apresentando um extenso vestíbulo e uma nave alongada de linhas curvas. É neste vestíbulo que são visíveis as pinturas murais de Almada, subdivididas em duas figuras avulsas e dois trípticos. Destes frescos o historiador de arte, crítico, João Pinharanda diz que o modo como dominar esses mecanismos de estilização do desenho e das cores e a própria imaginação gráfica, ajudam-no a libertar-se das amarras naturalistas.

«Foi este um período de intenso e exaltado labor que muitos e muitos estudos das figuras documentam e ainda mais o que dele saiu, um empenho inteiramente renovado de pesquisa formal, na sabedoria de cada traço e da articulação de volumes com a original perspectivação do cubismo, nas condições culturais que vimos». ${ }^{58}$ A gare da Rocha de Conde Redondo de Óbidos foi projectada em 1934 e dela fazem parte a gare que apresenta uma ampla nave e um

\footnotetext{
${ }^{57}$ LAPA, Pedro, Arte moderna em Portugal: de Amadeo a Paula Rego [disponível em] http://www.museudochiado-ipmuseus.pt/pt/ node/686; [consultado em] 22/06/09, 14:00 ${ }^{58}$ FRANÇA, José Augusto, História da Arte em Portugal, o Modernismo,Editorial Presença 2004, p.116
} 
vestíbulo, o qual, Almada animou com pinturas murais as suas paredes. A decoração é composta por dois trípticos, sendo um deles uma só configuração repartida por dois compartimentos. Sobressaindo na obra a estilização gráfica. Os "frescos" que pintou representam a obra primado modernismo e a sua conclusão.

«Com efeito, entre as decorações da Gare de Alcântara e da Rocha, uma fractura nítida e radical e significativa: à arte de extrema e amável habilidade e sensibilidade mundana que vimos perpassar nos desenhos e pinturas e vitrais até então realizados, contrariada embora com exigência dos seus textos, em fúria poética - futurista ou em reflexão místico - filosófica, em épocas diferentes, sucede uma arte empenhada numa renovação estilística que recupera valores estéticos do cubismo da sua geração, (...) e que passa a assumir a responsabilidade das próprias pesquisas forma em termos de geometria estrutural. ${ }^{59}$

Guilherme Santa Rita ou Santa-Rita Pintor foi um escritor e pintor português reputado como o introdutor do futurismo em Portugal. Em oposição ao grupo da revista Orpheu criou e publicou a revista Portugal Futurista cuja a longevidade não passou da primeira edição. O Futurismo em Portugal foi um movimento estético prematuro, principalmente foi o modo e acção de alguns artistas participarem colectivamente.

A questão do futurismo desenvolveu-se inicialmente mais no campo literário.

${ }^{59}$ FRANÇA, José Augusto, História da Arte em Portugal, o Modernismo,Editorial Presença 2004, p.114 


\subsection{La $2{ }^{a}$ generación / A $2^{\mathrm{a}}$ Geração}

Santa-Rita Pintor, afirma em 1916, que Futuristas declarados, em Portugal, há só um, ele próprio. Luigi Russolo (1885-1947) «Indicava que Santa-Rita não apreciava ideias ou assuntos, estando mais preocupado com os estados de espírito do que com concretizações objectivas e formais. ${ }^{60}$

Santa-Rita faleceu no mesmo ano de Amadeu de Sousa Cardozo, 1918, marcando o fim da primeira fase do modernismo Português.

A nova estética internacional, estava a ser mostrada pelos artistas que tinham regressado de Paris, entre outros Mário Eloy, Abel Manta, Diogo Macedo, os irmãos Franco e Almada Negreiros, constituíram a chamada $2^{\mathrm{a}}$ geração de Paris.

«Se Amadeu ou Santa-Rita pela pintura ou pela acção, foram os principais mitos de uma vanguarda portuguesa, esta só foi possível através de influencias internacionais que internamente se consumiram... Internamente a transformação modernista só se podia realizar, não pela pintura, mas pela caricatura e ilustração, como se tais sinais de mudança apenas pudessem representar-se no seio do próprio sorriso cultural.» ${ }^{61}$

Os anos 20 apareceram como uma década de lenta consolidação de modernidade que só se torna aceitável pela alienação culturalmente perturbadora e pela artificialidade dos meios. As mostras "modernistas" eram raras em conteúdo e em quantidade. As Mostras individuais além de escassas são efémeras sem qualquer afirmação de modernidade e apenas as colectivas representavam

\footnotetext{
${ }^{60}$ DIAS, Fernando Rosa, Ecos Expressionistas da Pintura Portuguesa entre Guerras (19141940), p.93

${ }^{61}$ Ibidem, p.109
} 


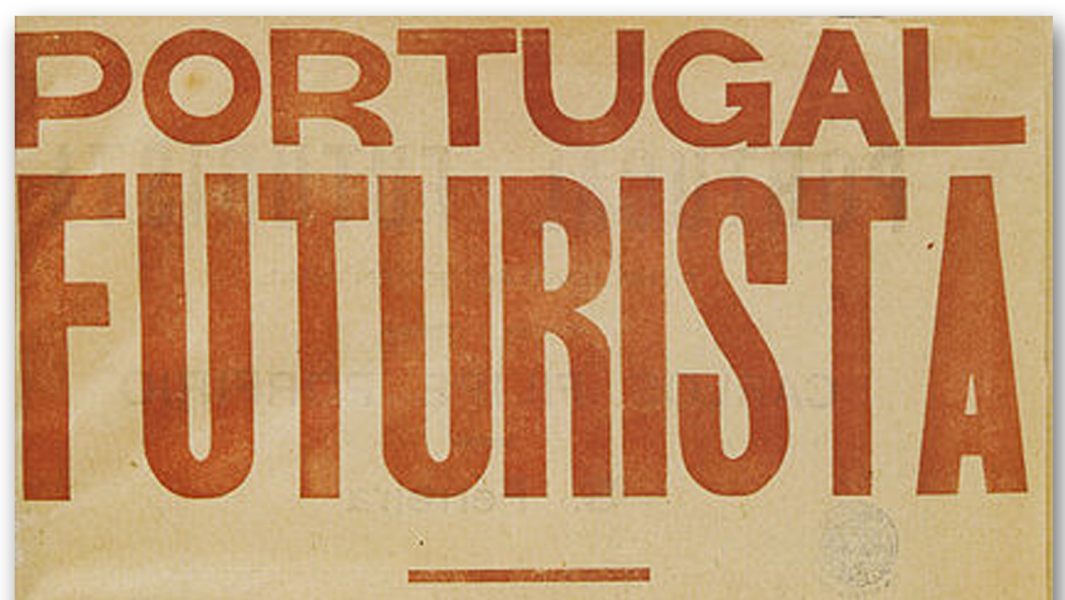

Santa Rita Pintor José de Almada-Negreiros - Amadeo de Souza-Gardoso

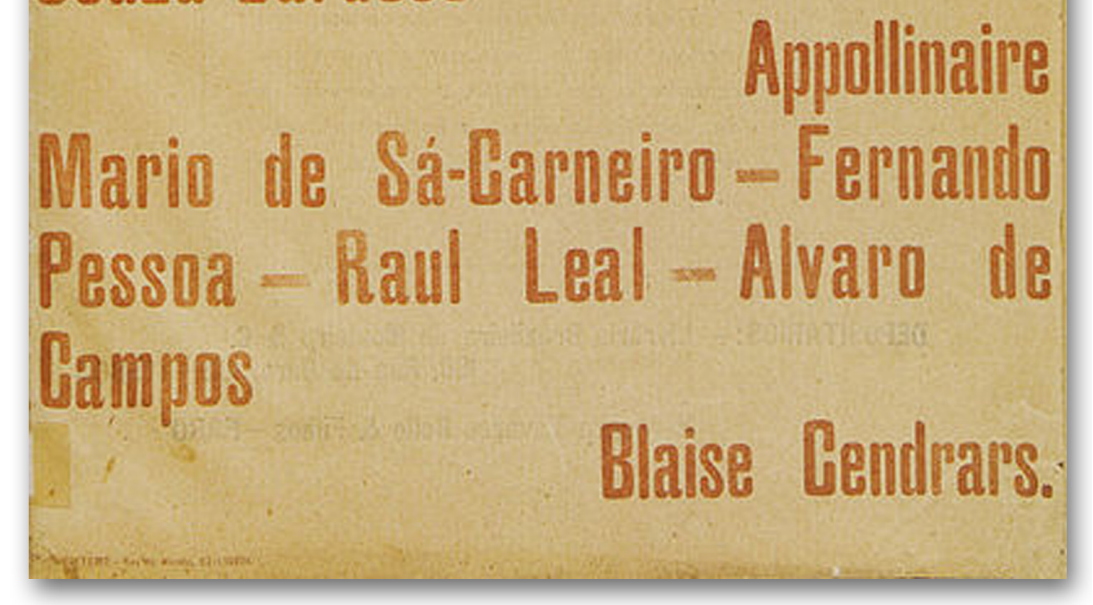

Figura 18. Revista Portugal Futurista, 1917 
alguns motivos representativos dessa modernidade. Neste estado melancólico de modernidade, nesta mundanidade, o expressionismo acontecia sem sentido ou perdia mesmo o sentido e a esperança regressou com o primeiro salão dos Independentes (1930) com o lançamento de novas possibilidades para as artes gráficas portuguesas.

Devido ao desinteresse pelas artes e às limitações impostas pelo regime (1926), pode a arquitectura portuguesa criar alguns projectos. Assim o modernismo português caracterizou-se pela simplificação e geometrização das formas e elementos florais abstractos (no gosto Art Decó), pela libertação das regras da linguagem decorativa clássica, pela busca de originalidade e pela aplicação de princípios funcionalistas e construtivistas de Le Corbusier e do grupo da Bauhaus designadamente na combinação livre e assimétrica das plantas, recaindo na organização das fachadas e dos volumes bem como a utilização de novos materiais. Usou também elementos padronizados para tornar mais barato o custo de produção e assim tornar possível o aumento da construção nomeadamente da habitação social. Estas características foram aplicadas na arquitectura e urbanismo mas também nas artes decorativas e gráficas. Com origens na arte nova valorizava as formas geométricas, tendo o cubismo por inspiração e desvalorizava as linhas orgânicas. De forte influencia cubista possui elemento estéticos do De Stijl e da Bauhaus e inclui referencias assírias e azetecas e egípcias; relâmpagos, raios de sol, obliscos e pirâmides. Foi um movimento internacional que nasce nos anos 20 em Paris que influencia o design, as artes plásticas, a moda, a publicidade e arquitectura, cujas particularidades principais são a utilização de cores fortes, as formas angulares e extremamente geométricas. 


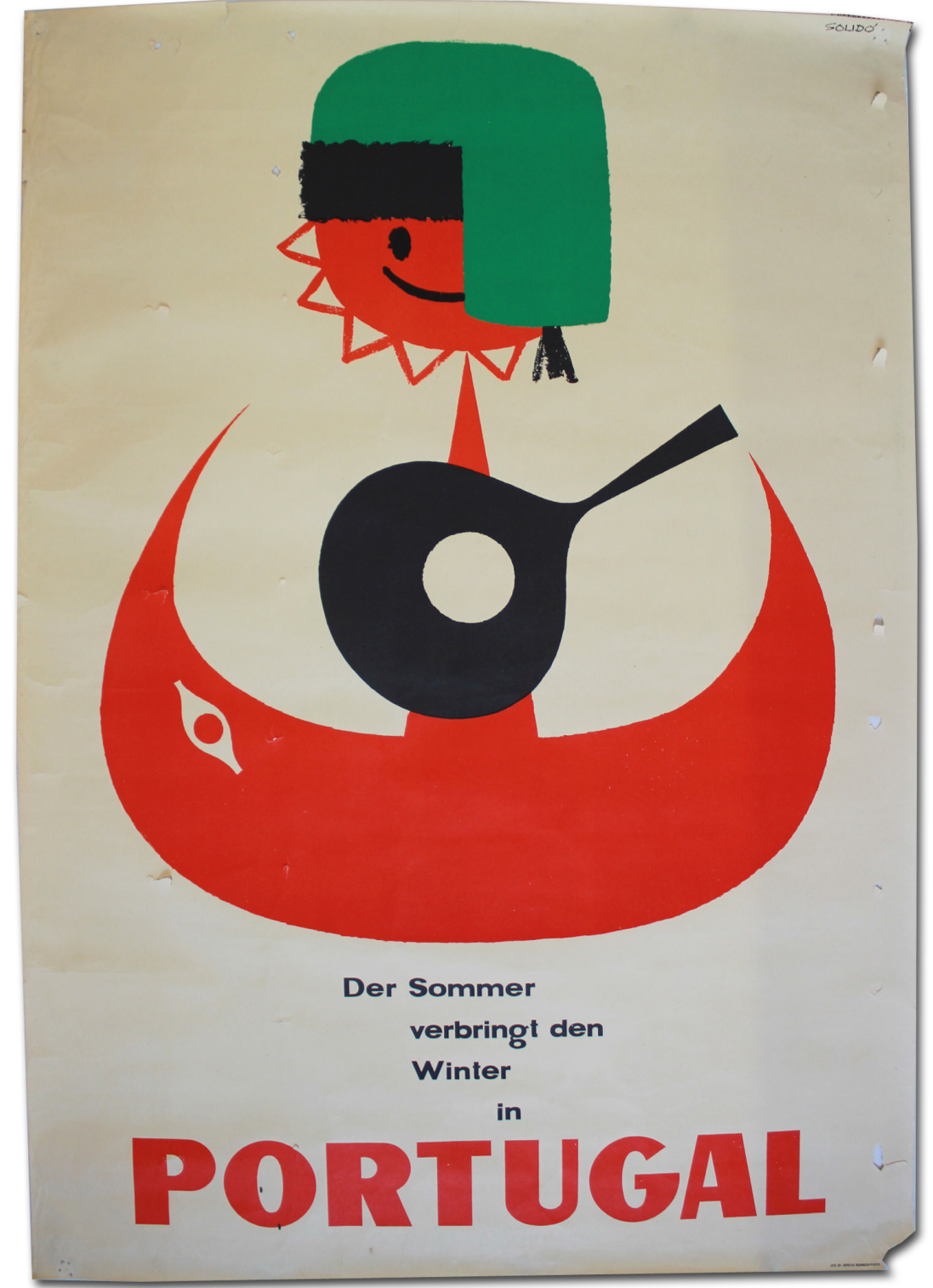

Figura 19. Cartaz de Paulo-Guilherme (SNI), 1963 


\subsubsection{António Ferro, "Arte del Régimen" / António Ferro, a "Arte do Regime"}

No advento dos anos 30 Portugal vive uma paz e uma felicidade aparente, apesar da repressão do Estado Novo, os portugueses vivem alheados dos problemas por culpa de António Salazar.

Simpatizante dos regimes autoritários nomeadamente do regime Fascista, António Joaquim Tavares Ferro ou simplesmente António Ferro (AF), 1895-1956, jornalista moderno, cronista espirituoso, foi editor da Revista Orpheu, jornalista de O Século e do Diário de Lisboa, redactor principal do diário O jornal (1919), colaborou nas revistas Alma Nova (1914 - FARO), publicou o manifesto modernista Nós (1921), publicou conferências, reportagens, entrevistas, contos, o romance Fragmentário, Leviana (1921), o livro de Aforismos e Paradoxos, teoria da Indiferença (1920), diretor da revista Ilustração Portuguesa e repórter internacional do Diário de Notícias que lhe permite entrevistar figuras nacionais e internacionais como: Marinetti, Mussolini, D’Annunzio Pio XI, etc. e o próprio Oliveira Salazar (1932), que lhe valeu o cargo de diretor do SPN/SNI. Investido pelo regime, $\mathrm{AF}$, intelectual brilhante, de tal modo administra dez anos de atividade (1933-1945), que cimenta a imagem "modernista” de um regime de ideário integralista, ruralista e retrógrado.

«A arte, a literatura e a ciência constituem a grande fachada duma nacionalidade o que se vê lá de fora» ${ }^{62}$

Através do SPN mais tarde SNI promoveu a denominada "política de espírito" cuja marca era a unicidade. AF toma a cultura como ardil

${ }^{62}$ FERRO, António. Os 40 anos da Arte Portuguesa Fundação Calouste Gulbenkian, Lisboa 1982, p. 190 
para a construção de um estilo empolado e guindado em favor e ao serviço do estado, harmonizando os conflitos sociais em volta dos grandes projectos nacionais.

«A formação modernista de Ferro tornara-o apto (o que não era muito comum entre os intelectuais portugueses, a compreender a importância do cinema não só como veículo de propaganda, mas também como veículo cultural. (...) o cinema estava longe de ser considerado arte menor quer influências de teorias das vanguardas artísticas que nos anos 20 e 30 tinham entrevisto, ou visto, as possibilidades da chamada $7^{a}$ arte nas «aventuras do imaginário». Dotado nos anos 30 de infra-estruturas algo ambiciosas (Tóbis, Lisboa Filme, Ulysseia) o cinema podia arrancar em três direcções priveligiadas pelas instâncias oficiais: a comédia populista, (...); o filme de exaltação nacionalista, (...); atransposição cinematográfica de obras literárias conhecidas. O primeiro género foi o mais fértil em sucessos, permitindo ao cinema português dos princípios dos anos 40 um «boom» espectacular sem precedentes nem prolongamentos. ${ }^{63}$

António Ferro enquanto director do SPN recruta alguns dos melhores artistas modernos, forma uma equipa com José da Rocha (1933) para garantir com alguma solidez a modernização das artes em Portugal tendo também outros cooperantes como: Bernardo Marques, Almada Negreiros e Carlos Coelho, pintores de reconhecido gosto gráfico. Assim, impulsiona a área de publicidade com a apresentação de vários trabalhos como as exposições internacionais de Paris, em 1937 e de Nova Iorque, em 1939, que serviram para firmar o bom gosto português. Nos meados da década de 1930 ocorre uma assimilação superficial da modernidade, então definida por António Ferro, o seu promotor oficial consentido pelo fascismo, promovendo sempre o equilíbrio e a compatibilidade

${ }^{63}$ COSTA, João Bénard. Os anos 40 no cinema, Os 40 anos na arte portuguesa, Fundação Calouste Gulbenkian, Lisboa 1982, p.183 
entre o regime e a arte moderna.

Contagiado pela sua experiencia além fronteiras, nos anos 30, Almada Negreiros regressa e desenvolve um retorno ao classicismo de matriz picassiana, iniciando uma pesquisa sobre o cânone ocidental.

Ocorreram simultaneamente outras tentativas dispersas de reformulação do modernismo com novas propostas integradas no quadro das vanguardas internacionais. António Pedro, em Paris, retoma a exploração da relação entre palavra e espaço, iniciada com a geração do Orfeu, para seguidamente realizar as primeiras pinturas surrealistas, juntamente com António Dacosta. M. H. Vieira da Silva dá início às suas explorações espaciais a partir de arquitecturas imaginadas ou transfiguradas, tornando-se um dos vultos do abstracionismo.

As secções de artes decorativas, arquitectura e decoração são introduzidas no primeiro salão dos Independentes, (1930), e daí emana um presságio de mudança gráfica. O SPN, ao longo da década organizava as mostras, promovia os artistas, impunha temas e estéticas, envolveu diversos projectos artísticos e arquitectónicos objectivando a propaganda do regime Salazarista.

«A sintonia com a «modernismo» e com a modernidade era evidente". "O período das grandes «obras públicas» do regime haveria de ser um potente motor de renovação na arquitectura» ${ }^{64}$

${ }^{64}$ PEREIRA, Paulo, Arte Portuguesa História essencial, p. 805 

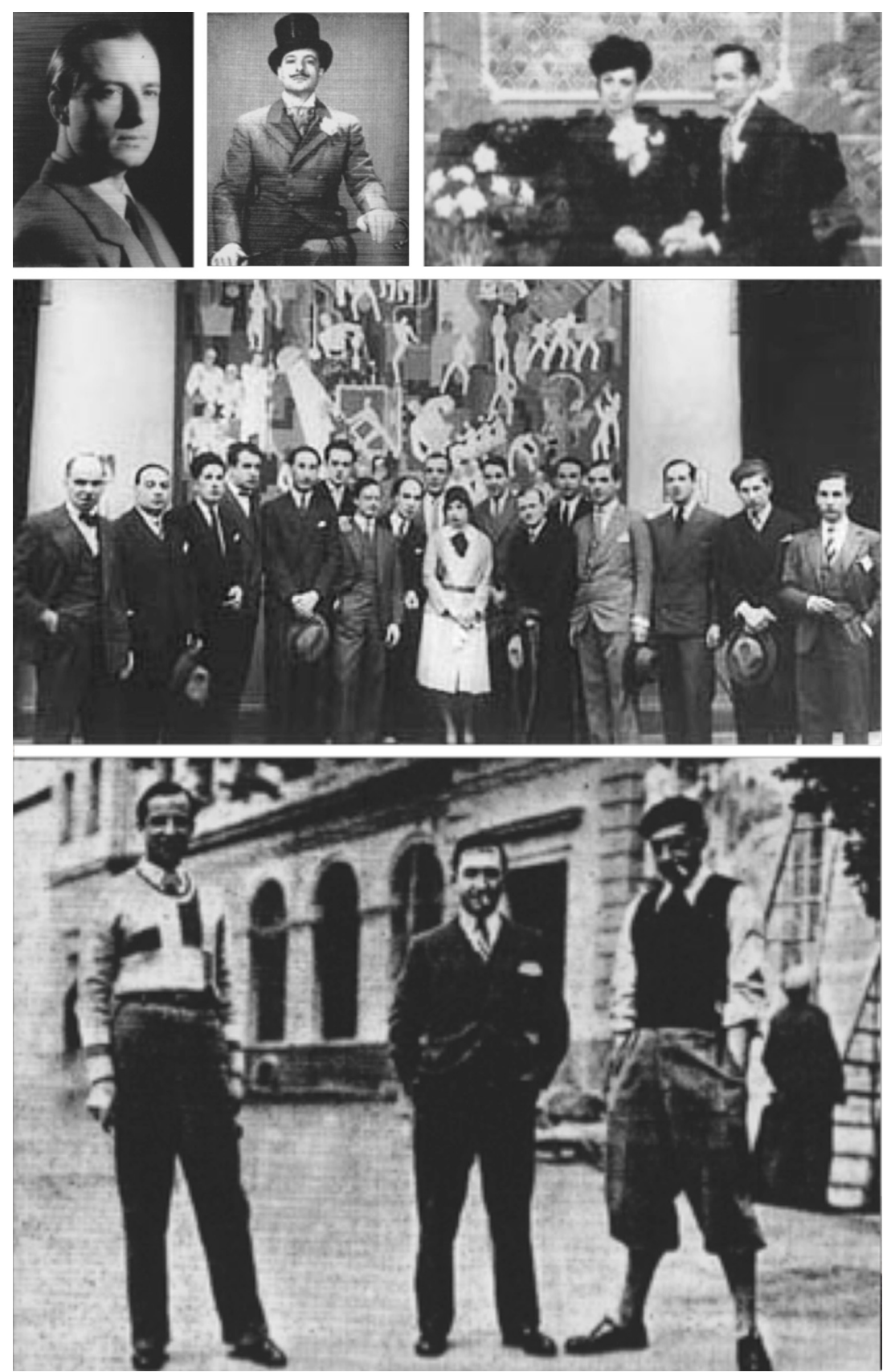

Figura 20. Conjunto de fotografias de Olavo D’Eça Leal 


\subsubsection{Olavo D’Eça Leal / Olavo D'Eça Leal}

Olavo Correia Leite d' Eça Leal (1908-1976), nasceu a 31 de Julho de 1908 em Lisboa. Filho da dramaturga e poetisa Flávia Correia Leite D’Eça Leal e do poeta Thomaz D'Eça Leal, tem o privilégio de crescer num ambiente familiar culto e economicamente favorecido. A sua educação decorreu em diversos colégios, sendo de referir que os seus últimos anos de estudo foram passados na École Pascal em Paris, o que lhe facultou o conhecimento dos autores clássicos franceses.

Com dezoito anos, movimentava-se num círculo de amigos intelectualmente brilhantes, sendo nesse ambiente que o seu espírito criativo se inicia na pintura, na escrita e na poesia. Trabalhou como desenhador no Atelier de Desenhos Animados de André Vigneau.

Após ter percorrido vários países europeus e passado pelo Brasil, regressa a Portugal.

Inicia uma colaboração diversificada com as revistas Seara Nova, Acção, Panorama, Contemporânea, Atlântico e Presença, através de contos, poemas, artigos e desenhos. (Presença - editada por Branquinho da Fonseca - abandona direcção no no 27 (1930) - a partir ${ }^{\circ} 33$ passa a Adolfo Casais Monteiro até 1938).

A revista Presença adquire uma importância fundamental no panorama cultural português. Deu a conhecer os principais autores europeus da $1^{a}$ metade do séc. XX, como Marcel Proust, Perandello e Paul Valery. Era uma publicação que pretendia dar à literatura uma nova dinâmica, no sentido da liberdade e do espírito crítico. Esta era a ideologia dos seus fundadores, como também de Albano Nogueira e Guilherme de Castilho e ainda dos colaboradores 
doutrinários, José Bacelar, Delfim Santos, Saul Dias, Francisco Bugalho e António Botto. Também são de referir o contributo de personalidades como Fernando Pessoa e Afonso Duarte, bem como a colaboração de Olavo D’Eça Leal, António de Sousa, Irene Lisboa (com alguns poemas já em prosa), Vitorino Nemésio e Pedro Homem de Mello, todos eles se destacando sobretudo na poesia.

Paralelamente a iniciativas oficiais, a Presença fomentava um importante intercâmbio entre autores portugueses e brasileiros, com a divulgação de produtos literários dos dois países.

Em 1928, Olavo publicou um livro de contos infantis com ilustrações da sua autoria intitulado Provérbios. Além dos artigos, contos e desenhos com que contribuía em publicações foi ainda redactor e critico de cinema. Passou a colaborar regularmente com as revistas da $7^{\text {a }}$ Arte Imagem e Kino dirigidas por António Lopes Ribeiro e tendo como chefe de redacção Félix Ribeiro. Esta revista surge com a chegada do cinema sonoro tendo-se dedicado à defesa da sua implementação como uma mais-valia inovadora, nem sempre aceite pelas mentalidades mais conservadoras. Foram publicados 53 números (de 1.5.1930 a 30.4.1931). Entre outros, colaboraram nesta publicação, o poeta Carlos Queiroz, Artur Portela, José Gomes Ferreira, Bernardo Marques, Norberto Lopes, Fred Kradolfer e Cottinelli Telmo. Deve-se a este último a realização do $1^{\circ}$ filme sonoro português rodado no nosso País. É ainda nesta revista que Domingos Mascarenhas se inicia como crítico cinematográfico.

Em 1931, Olavo D’Eça Leal e Leitão de Barros facultaram o lugar de repórter gráfico a Baltazar Ortega no Diário Ilustrado, ao mesmo tempo que o motivaram a adquirir formação geral e a frequentar a Sociedade de Belas-Artes. Nascia assim um caricaturista maior, reconhecido até aos nossos dias. Olavo D’Eça Leal, embora sempre envolvido no processo criativo em que era 
brilhante, tinha a sua faceta mundana e boémia, sendo frequentador assíduo do Maxime, do Arcádia e do Retiro da Severa.

Entretanto casou e, desta união nasceu um menino, a quem põe o nome de Paulo Guilherme. Resolveu emigrar para o Brasil em 1933, junto com a família. Foi viver para uma herdade de um primo, em Itapetininga. Aqui dedicou-se à elaboração de cartazes publicitários, montou um gabinete de análises grafológicas, deu lições de desenho a jovens do estado de S. Paulo, mas nenhuma das actividades teve grande sucesso. Regressou a Portugal no ano seguinte. Teve conhecimento da abertura de uma vaga para locutor na Emissora Nacional de Radiodifusão, tendo-se candidatado.

Graças à uma voz saudável, educada, levemente snob e de impecável dicção, conseguiu o lugar.

Nesta altura, nos anos quarenta, a rádio era um meio de informação e entretenimento de enorme poder, pois era o único meio de difusão que acompanhava todas as famílias.

Olavo D’Eça Leal, Jorge Alves, Fernando Pessa, Pedro Moutinho, Artur Agostinho, Mary, Maria de Rezende e tantos outros foram referências radiofónicas incontornáveis.

Foi na Rádio que se consagraram os nomes de realizadores de programas, como Olavo D’Eça Leal, Adolfo Simões Muller, Francisco Mata, Aníbal Nazaré e de locutores como Fernando Pessa, João da Câmara ou ainda Maria Leonor. Embora na actividade radiofónica, continuou a escrever e em 1939 ganhou o prémio Maria Amália Vaz de Carvalho de Literatura infantil, com o livro Iratan e Iracema, Os Meninos Mais Malcriados do Mundo, com ilustrações de Paulo Ferreira e publicado pela Livraria Portugália. História de Portugal para meninos preguiçosos, neste livro encontra-se uma narração diferente e criativa, prendendo o leitor desde o início e com a particularidade de o levar a desejar identificar-se com Iratan e Iracema, ou seja, um menino malcriado . Tudo pode acontecer 

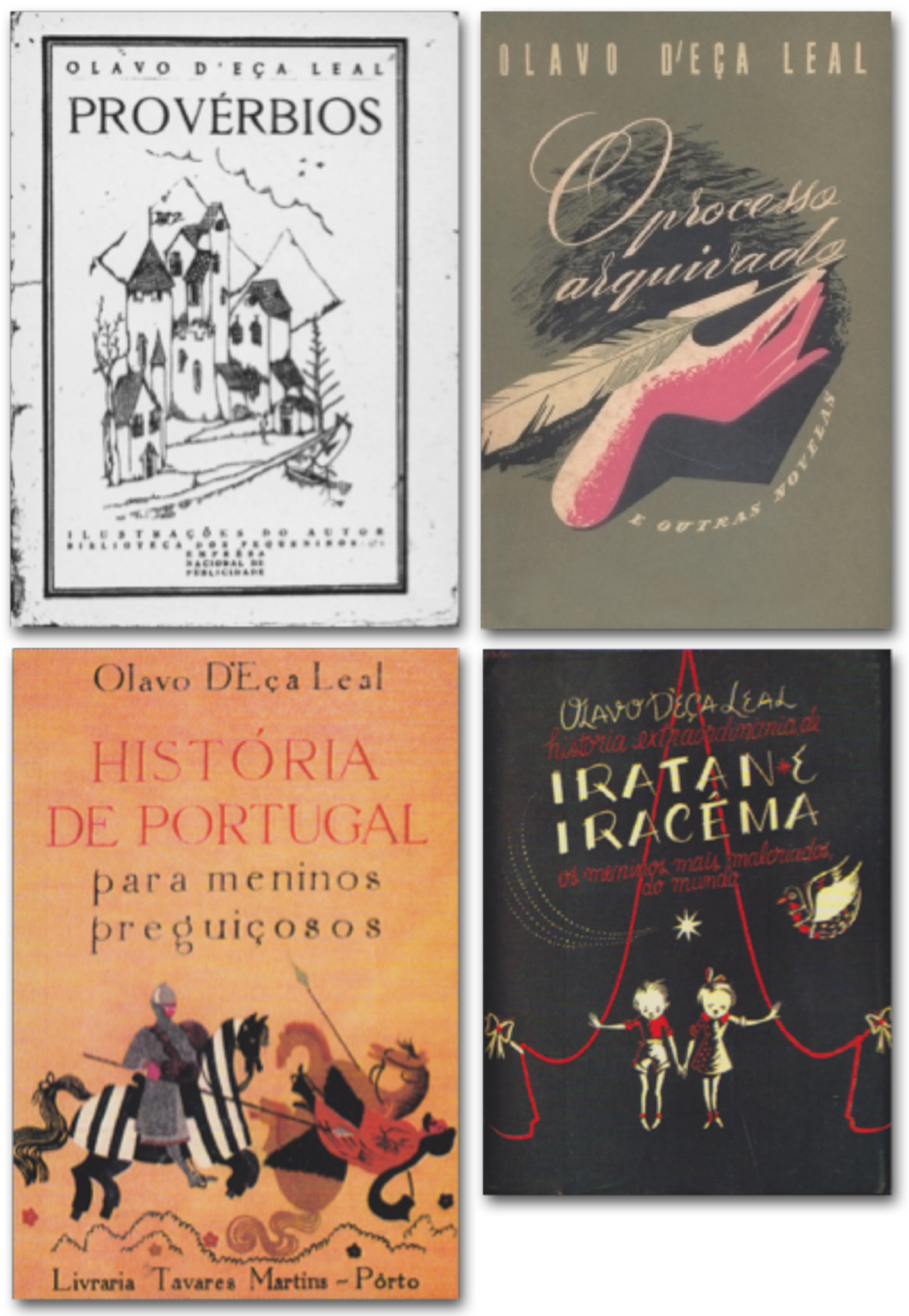

Figura 21. Conjunto de capas do livros de Olavo D’Eça Leal 
nesta aventura de dois meninos malcriados mas dotados de um sentido de humor num mundo onde tudo é sério. É uma viagem pelo maravilhoso na qual os irmãos avistam torres tenebrosas, atravessam a zona da incompreensão encontrando fantasmas e bruxas, cidades de silêncio e palácios de ferro e ainda faquires, lobos, cães de três cabeças e vendedores de memórias. Este livro, Iratan e Iracema, Os Meninos Mais Malcriados do Mundo, foi argumento de um filme com o mesmo nome, realizado em 1987 pelo seu filho Paulo Guilherme. Em 1940, Olavo publicou um livro de novelas, intitulado Fim-de-semana e 3 anos depois, em 1943, ganhou novamente o prémio Maria Amália Vaz de Carvalho, mas desta vez com a História de Portugal para meninos preguiçosos, com ilustração de Manuel Lapa. Olavo D’Eça Leal editou ainda Falar por Falar, (1943), A Voz da Rádio (1944) e Nem Tudo Se Perde no Ar, (1945), diálogos radiofónicos escritos e interpretados por si, para o programa Diálogos de Domingo, que fizeram época na Emissora Nacional.

Entretanto na década de cinquenta, sai da Emissora Nacional. Foi trabalhar noutras rádios, entre as quais na Rádio Clube Português, onde surgiram vários programas de grande sucesso, entre os quais, Quer um conselho ou Diga-me o que lhe aconteceu. Estes programas tinham uma relação muito próxima com os ouvintes, interagindo com os estes abordavam-se problemas quotidianos de maior ou menor importância. Procurava ajudar a resolver questões, aconselhar, formar no domínio das atitudes. Em 1959 já tinha publicado mais de 800 diálogos radiofónicos.

Olavo D’Eça Leal publicou o romance Processo Arquivado, (1948), na Editora Ibérica, com o qual ganhou o prémio Fialho de Almeida, e em 1958 outro romance intitulado Conceituado Comerciante, na Editora Gomes e Rodrigues, com ilustrações e capa do seu filho Paulo Guilherme. Nesse mesmo ano fundou O século de 


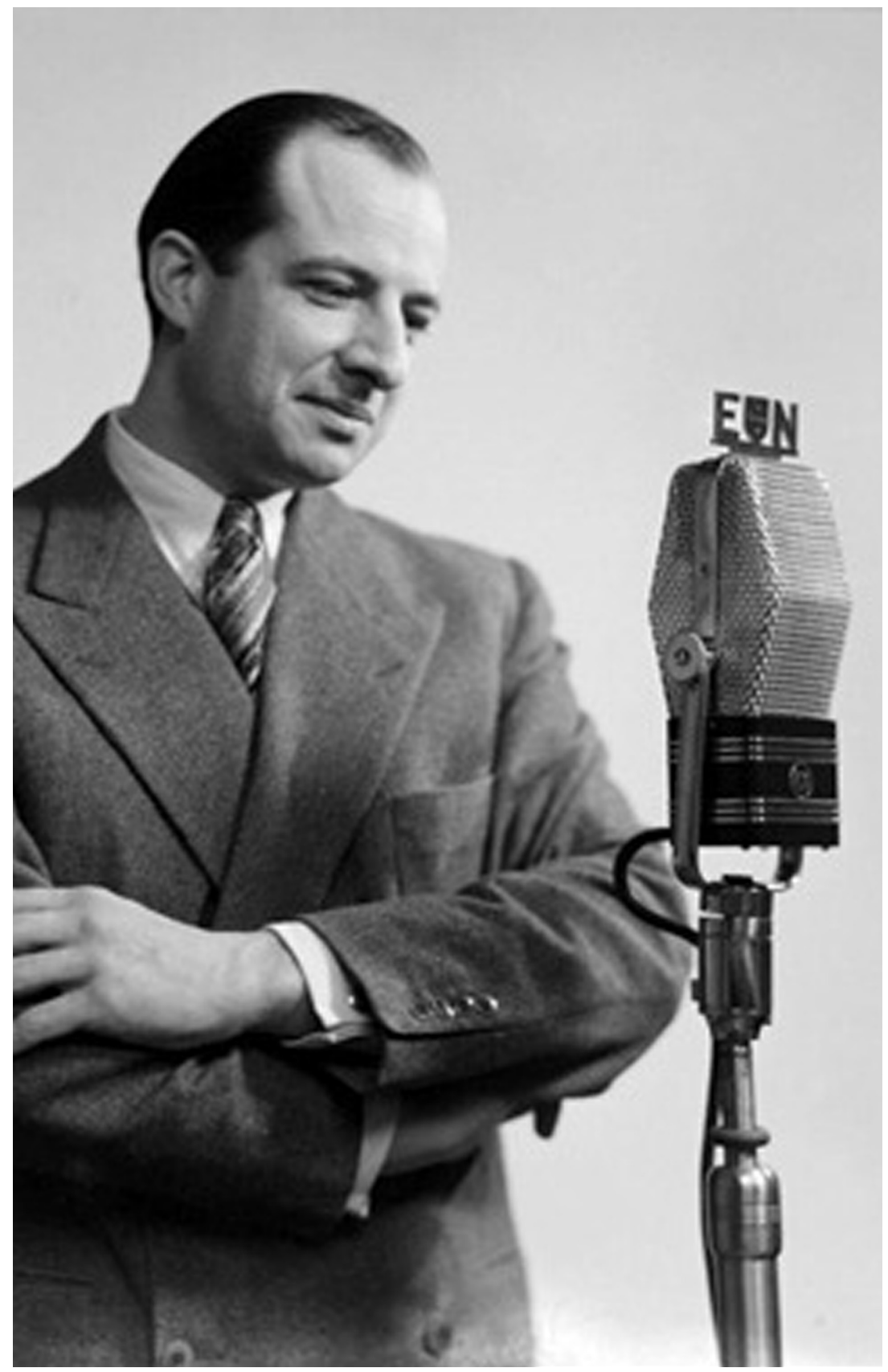

Figura 22. Fotografia de Olavo na Emissora Nacional,anos 40. 
Domingo e em 1959 escreveu A Rapariga do Snack-Bar um extenso poema. Depois de toda a diversidade das produções culturais já referidas, Olavo D'Eça Leal ainda se dedicou ao teatro. A sua primeira peça, o acto em verso Noite de Natal, estreou-se no Teatro do Ginásio no começo dos anos 30 do século passado, ao que se seguiram as peças num acto A casa Encantada e A Rosa Vermelha ou ainda, Um Homem de Génio e Noite de Paz, das quais apenas a última foi apresentada (mas só em 1960) na Televisão. Representadas foram A Taça de Oiro (1953) no Teatro Nacional de D.Maria II e a tragi-farsa - O Amor, o Dinheiro e a Morte, (1960), no Teatro Trindade onde ambas questionam a vida da classe burguesa contudo sem grande aprofundamentos da natureza desses comportamentos.

Como actor, entrou em três ou quatro filmes, entre os quais Ladrão Precisa-se e Sonho de Amor (1945), de Carlos Porfírio, com as actrizes como Reina Baumberg, Maria Eduarda Gonzalo e Bárbara Virgínia. Participou também como assistente de realização nos filmes portugueses Severa de Leitão de Barros e Revolução de Maio, de António Lopes Ribeiro (com argumento conjunto com António Ferro). Enquanto escrevia inúmeras crónicas nos jornais Diário de Notícias, Século, Diário Popular e Diário de Lisboa, fazia também algumas exposições de pintura e filmes de publicidade.

Desenvolveu algumas séries de programas para a Rádio Televisão Portuguesa, destacando-se o Programa dos Inventores. Também neste meio de difusão o seu trabalho realçou as suas qualidades de comunicação e a sua facilidade de diálogo já anteriormente evidenciadas na experiência radiofónica.

$\ll O$ seu estilo muito próprio inconfundível que não poucos tentaram, sem êxito, imitar - a par de uma boa dose de ironia com que sabia "jogar", umas vezes de forma subtil, outras com uma frontalidade provocatória, contribuíram para o sucesso espetacular 
e para a popularidade de alguns programas da época. ${ }^{65}$

Olavo D'Eça Leal faleceu a 17 de Setembro de 1976 em Inglaterra, na localidade de Strafford-On-Haven. Desapareceu então o artista multifacetado com obra reconhecida desde as produções escritas de vários géneros às artes plásticas.

«Olavo D’Eça Leal que foi uma das figuras mais curiosas e fascinantes da nossa cidade. O Olavo não foi apenas um dos homens que marcou uma época muito especial da Rádio Portuguesa. Foi na escrita, e nas artes plásticas, um artista de rara sensibilidade(...) ${ }^{66}$ O seu contributo para a cultura portuguesa foi enorme, deixando um valioso e diversificado legado, uma obra vasta e notável. Olavo foi uma figura proeminente da sua época pelo desempenho e acção no campo social e das artes. Na súmula do seu resgate, abrange e combina áreas como desenhador, ilustrador, jornalista, poeta, escritor, locutor, professor e dentro da cinematografia: produtor, editor, actor, director e argumentista. Tendo o seu tempo sido marcado principalmente pelo áudio-radiofónico, Olavo tornou-se, muito em parte seu carácter na voz de Portugal. Promovendo e desenvolvendo a cidadania, a cultura, servindo e apoiando incondicionalmente milhares de concidadãos das mais variadas formas.

A Câmara Municipal de Lisboa presta homenagem ao escritor Olavo D'Eça Leal, ao atribuir o seu nome a um arruamento de Lisboa, situado na Freguesia de São Domingos de Benfica.

${ }^{65}$ AGOSTINHO, Artur. "O Snob mais simpático da Rádio Portuguesa”. Revista Viva!Avenidas Novas, $\mathrm{n}^{\circ} 2$, julho $1999, \mathrm{p} .53$

${ }^{66}$ Ibidem, p.52 


\subsubsection{Kradolfer, introductor de las Artes Gráficas /}

Kradolfer, introdutor das Artes Gráficas

Fred Kradolfer (Zurique 1903-1968 Lisboa) suíço com formação académica, fixou residência em Portugal em 1927 depois de estar na Bélgica e Paris «a chegada de Fred kradolfer deu ensejo a um movimento..» ${ }^{67}$

Artista multifacetado, mestre incontestado da publicidade artística, ilustrador, pintor e gráfico, sendo o $1^{\circ}$ designer gráfico em Portugal, foi o impulsionador e o grande obreiro do desenvolvimento das artes gráficas. Foi o mentor da publicidade para a $2^{a}$ geração "modernistas".

No seu percurso artístico interveio ativamente em diversas atividades designadamente no vitral, na cerâmica, na decoração, em anúncios luminosos, e no cartaz que foi a sua grande marca na década de 50, devido ao tipo de letra e plasticidade das suas ilustrações, tendo sido o introdutor de uma nova linguagem visual. De 1937 a 1940, fez parte do grupo de decoradores do SPN (de A.F) conjuntamente com Bernardo Marques, Carlos Botelho, Paulo Ferreira, José Rocha, Emmérico Nunes, Tomaz de Mello, incumbidos da realização e decoração do pavilhão Português para a exposição de Paris (1937), para a exposição de Nova Iorque (1939) e para a exposição do Mundo Português em 1940. O trabalho apresentado na exposição de Paris, foi reconhecido internacionalmente como extraordinário quanto à sua execução plástica, tendo sido o líder da equipa Fred Kradolfer. Ainda em 1936 colabora com José da Rocha no Estúdio Teórico de Publicidade

${ }^{67}$ FRANÇA,José Augusto, Historia da arte em Portugal- o modernismo, Editorial Presença 2004, p.63 


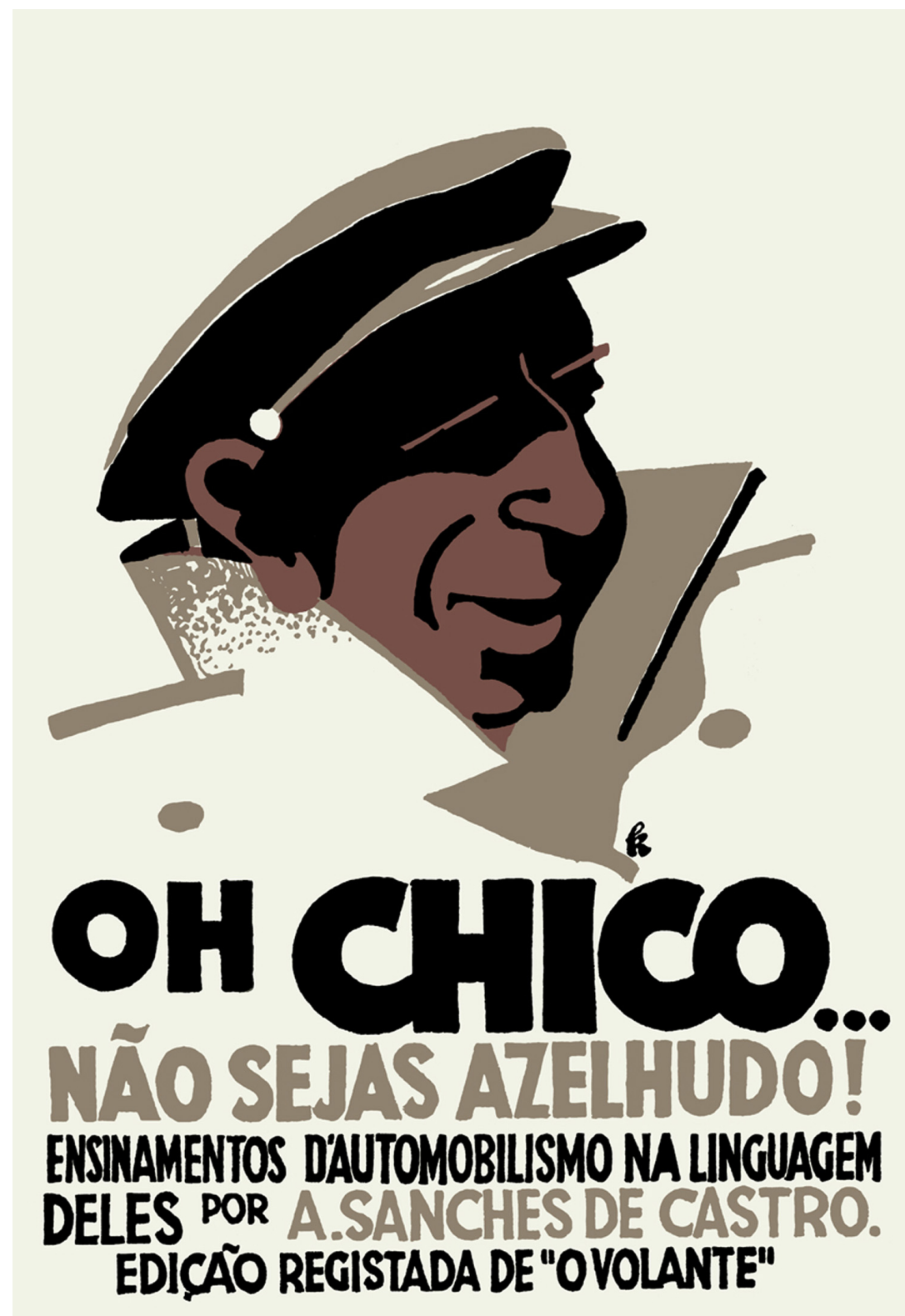

Figura 23. Cartaz publicitário, Fred Kradolfer, 1933 
(ETP), fundado por este, com Bernardo Marques, Thomaz de Melo, Carlos Botelho, Ofélia Marques, Stuart Carvalhais, Carlos Rocha, Selma Rocha, Maria Keil.

A génese do design encontra-se nos artistas plásticos e poetas modernistas "independentes" e pela perceção e entendimento destes, do fenómeno publicitário. António Pedro foi um dos pioneiros através da singular criação gráfica de revistas e capas de livros, bem como os poetas da Orfeu, do Momento e da Presença, como o desenvolvimento e aperfeiçoamento gráficos dos carateres. Este conjunto de factores constituem historicamente o advento do Design que acaba por surgir, pela ação do talento de Fred Kradolfer que já antes tinha contribuído para a evolução sobretudo do grafismo publicitário. Entre outros, José da Rocha e Tomás de Mello -Tom partilham as mesmas ideias de Kradolfer seguindo-o também na Acão até aos anos 50, passando a fazer parte de historia do design Português por mérito próprio.

A actuação era interdisciplinar e transversal pelas diferentes áreas (Design gráfico, expositivo, de equipamento, de interiores, etc.), feita de forma autodidacta, descontraída, aventureira, imprevista, expediente.

Foram sempre muito evidentes as ligações entre as artes plásticas e o design gráfico porque no contexto nacional o design é herdeiro da cultura das artes plásticas e também da arquitectura, pela sua cultura projectual facultando modos de pensar e de projectar.

O design português foi-se desenvolvendo de modo inconsciente e muito antes de haver a palavra "design” a defini-lo já a primeira geração estava consolidada. É na década de 30 que, são criados os primeiros estúdios de design e publicidade casos do Atelier Arta de Artur Soares e Jorge Barradas, do Atelier Íbis de Bernardo e Ofélia Marques e Sarah Afonso, da agencia ETP de José Rocha, do Estúdio MR de Manuel Rodrigues onde irá colaborar 
Sebastião Rodrigues o nome central da segunda geração e o elemento de continuidade, a par de Victor Palla, Fernando Azevedo e Sena da Silva, de onde emergem Paulo Guilherme, António Garcia, António Domingues, Luís Filipe de Abreu, João da Câmara Leme e muitos outros, exemplos que contribuíram para a renovação do Design Português, do seu mercado e dos seus públicos. Participaram com um vasto, variado e relevante legado no património artístico-cultural. Protagonistas de extensa e multifacetada obra tornam-se indubitavelmente agentes na História do Design Português. A esta geração acresce à escola, a aprendizagem mundana, a prática funcional do atelier conjuntamente com a adição das várias experimentas vividas, que no devir proporciona um aprendizado que o próprio academismo das Belas Artes não contemplava.

Com o aparecimento de assaz numero de agencias publicitarias, de onde se destacam a A.P.A. (agencia publicitaria artística) dirigida por Fernando Leitão e a Belarte dirigida por Mário Neves, Araújo Pereira e Roberto Araújo, os artistas tornam-se profissionais nos vários ramos desta área, distinguindo-se: Fred Kradolfer, no Cartaz turístico, Carlos Botelho e Bernardo Marques, na elaboração de livros, folhetos programas, Lucian Donat, Manuel Lapa e Thomaz de Mello-Tom decoração vitrinismo e Alberto Cardoso nos desdobráveis, decoração e na estruturação profissional dos anúncios.

Em 1960 é criado, no âmbito do Instituto Nacional de Investigação Industrial, um núcleo de Design Industrial que em 1979 se torna no Instituto Português de Qualidade.

Frederico George pintor e arquiteto foi o percursor do design industrial (de equipamento mobiliário), Daciano Costa e Sena da Silva foram os seus primeiros colaboradores. No início dos anos 60 Daciano Costa (1930-2005) aplicou a metodologia projectual de 
design na empresa Metalúrgica da Longra. Que com a produção de mobiliário clássico contemporâneo tornou a empresa num caso de grande sucesso devido á conceção e acabamento formal dos produtos.

A associação portuguesa de designers realiza a primeira exposição em 1982 e já nos anos 90 é criado o centro português de design cujo presidente até 1994 é Sena da Silva (1926-2001) e a quem se deve em grande parte a "sede" do design em Portugal.

A escultura foi a arte pouco aberta à modernidade que melhor serviu o discurso nacionalista e conservador do Estado Novo. As obras subjugadas à encomenda pública, ideadas pelas concepções ideológicas dominantes, enalteciam os valores pátrios. Dos escultores mais predominantes destacam-se: Francisco SousaSantos (1855-1955), criou um conjunto de estátuas (públicas) monumentais em que se denota um classicismo austero; Ernesto Canto da Maia, (1890-1891), artista sensível, participou na $1^{\text {a }}$ exposição dos humoristas Portugueses 1912, as suas composições escultóricas $O$ Hino do Amor e o baixo relevo A Família em Portugal, entre outros, chega a ser escultor oficial do regime; António Leopoldo de Almeida, (1890-1981), com intensa actividade artística torna-se uma das melhores expressões da estatuária oficial implementada pelo Estado Novo, contribuindo com estátuas, monumentos de figuras da cultura e da História Portuguesa, com uma figuração do tipo classicizante, visívelna obra O Padrão dos Descobrimentos; Um escultor expressionista com algumas influências de Rodin foi Barata Feyo, (1899-1975), um artista em cuja obra A Almeida Garret concentra um ideal e um tempo marcado por uma ideologia e uma estética nacionalistas.

A partir de 1935 o "regime" vigente confinou a pintura a uma pequena elite. O SPN controlava através das exposições nos salões anuais de arte nacional, impondo temáticas, de cariz cada 
vez mais Nacionalistas e atribuindo os prémios aos seus eleitos. Almada era considerado independente, um símbolo de coragem, apolítico, obtendo reconhecimento pelo SPN. Nas exposições de 41 e 42, coube-lhe nesta ultima um prémio anual.

«A arte moderna era então o SPN, quer dizer Ferro, quer dizer um neoacademismo tranquilo quisessem-no ou não os adversários políticos ou artísticos de António Ferro». ${ }^{68}$

O expressionismo entra rapidamente em todos os quadrantes da atividade criativa desde as artes gráficas (industriais e artesanais), da arquitetura a escultura, á musica, a literatura, á poesia, á coreografia, à cenografia e até á cinematografia, torna-se um verdadeiro projeto artístico. Os temas tratados estão ligados á atualidade e são a denúncia da sociedade portuguesa e da civilização moderna. A imagem é tosca inacabada, deformada, incongruente com o seu significado.

«os pintores de Die Brucke -dos seus aspetos mais negativos: a prostituição, a miséria, a exploração, a opressão, a dor, a injustiça-, mas fazem-no através de uma expressão deformada, e deformante alheia às coordenadas da cultura ocidental. Assim provocam um choque visual, um mal-estar preceptivo, um conflito que transpõe para o interior de mecanismos linguísticos um desconforto e a tragedia- a grande- KRISIS- de que querem falar. ${ }^{69}$

Grandes interpretes do expressionismo também o foram Mário Eloy, Domingues Alvarez, Júlio Reis, Sara Afonso e Rui Mário Gonçalves, pintores satíricos utilizavam cores vivas e elementos decorativos populares persistindo porem a técnica académica. Mário Gonçalves pintor muito importante do expressionismo

${ }^{68}$ FRANÇA , José-Augusto, A arte e a sociedade portuguesa no seculo XX (1910-2000), livros horizonte $\mathrm{Ld}^{\mathrm{a}}$ ano 2000 , p.33

${ }^{69}$ SPROCCATI, Sandro (direc.). Guia Historia da Arte, $4^{\circ}$ edição Lisboa Maio 1999 deposito legal:135020/99, p.148-149 
figurativo em Portugal, pelo modo de apresentação acercou-se no final do surrealismo.

Domingues Alvarez considerava que a arte com a sua ação podia transformar as sociedades, despertar sensibilidades, refletindo estas ideias na representação da sua obra através da expressividade da forma e da cor.

Mário Eloy expôs em Paris e Berlim ao lado de Picasso, Braque, Chagal entre outros. As suas obras cheias de propriedade nela realçam a expressividade da cor, os tons frios e a luz.

Júlio Reis (1902-1983), poeta, ilustrador e pintor português, pertencente á segunda geração dos pintores modernistas, é na década de 20, um dos principais colaboradores da Presença e ilustrador da obra de José Régio, seu irmão. Em 1935 expõe individualmente pela primeira vez na SNBA, em 1936 participa na exposição dos artistas modernos independentes (ao lado de Vieira da Silva, de Almada e de outros) em 1953 expõe no Brasil (São Paulo), em 1958 é lhe atribuído o $1^{\circ}$ premio de desenho no IV Salão de Outubro do Estoril e em 1962 publica a obra Obra poética de Saul Dias aquando da sua estada (em1942) em Évora, torna-se colecionador dos bonecos de Extremoz constituindo uma coleção de 375 peças que se encontra exposta desde 1975 no Museu Municipal de Estremoz. O desenho é marcado pelo expressionismo até 1935, todavia experiencia, durante esta década (30), diferentes tendências através da pintura abstrata e desenhos surrealistas, capitulo enfatizante da sua obra.

Sara Afonso (1899-1983) pintora e ilustradora contemporânea de Ofélia Marques e de Bernardo Marques, viveu em Paris, casou com Almada Negreiros, participa no $1^{\circ}$ Salão dos 


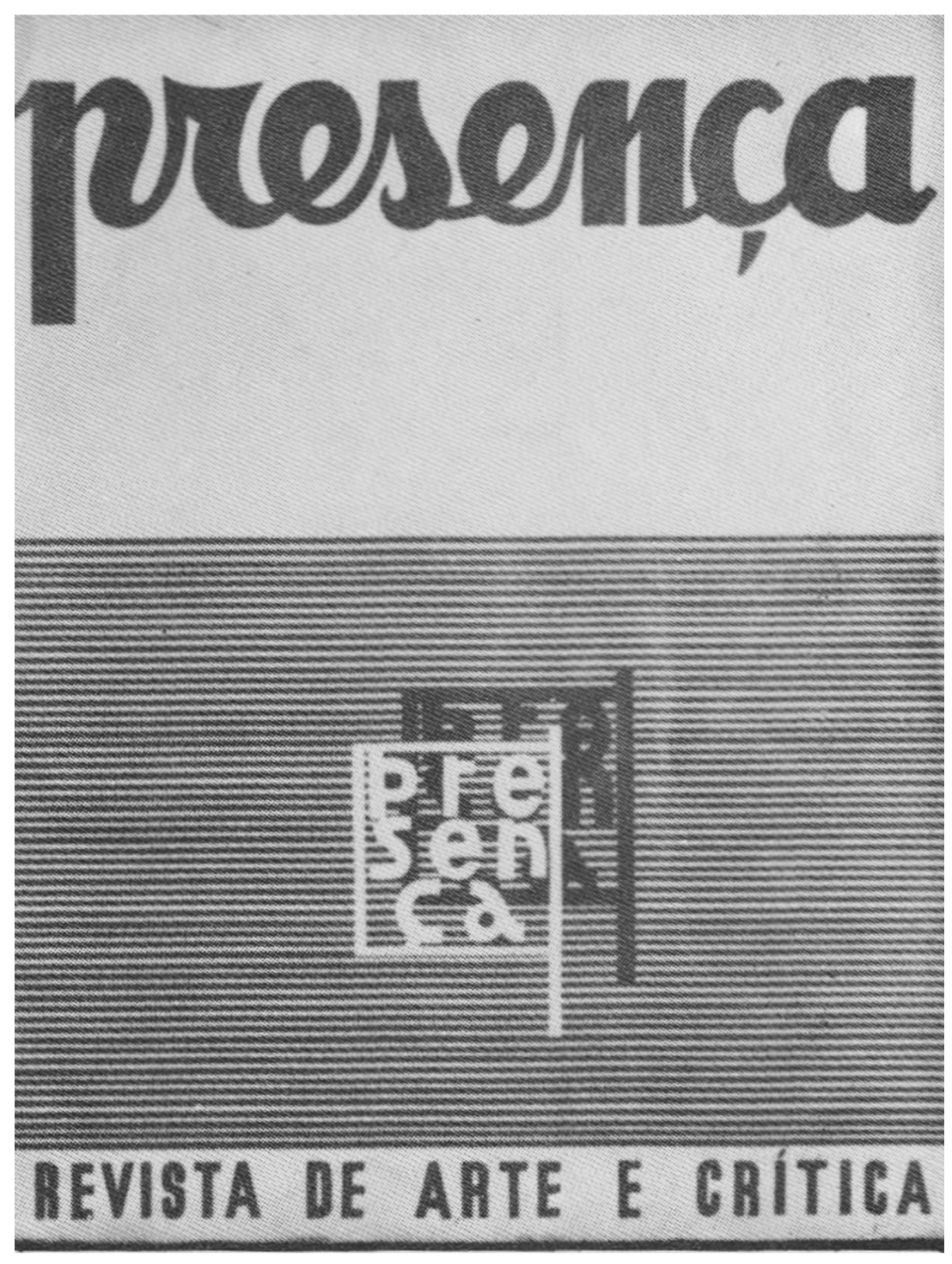

Figura 24. Capa da Revista Presença 
independentes em 1930, na exposição do mundo português em 40, ganhou o Premio de Sousa Cardoso em 1944 e integrou a delegação portuguesa á bienal de São Paulo em 1953. A temática expressa na sua pintura é de forte cariz popular e assenta em festas e tradições portuguesas. Sinteticamente, e de um modo genérico, são características dos seus trabalhosos elementos tradicionais da cultura popular, a qualidade do traço o cromatismo e a narrativa da composição ser implícita no desenho.

\subsubsection{Neo-Realismo / Neo-Realismo}

O Neo-Realismo surgido no final da década de 30 pelos seus ensejos de inspiração marxista, atraía muitos artistas da nova geração "a terceira". sendo o seu introdutor Abel Salazar (1946-1989), Esta nova estética ideológica procurou através da pintura representar o trabalho (campo e fabricas) em total oposição á arte oficial portuguesa, sendo apoiada pelo único jornal de arte publicado em Portugal, Horizonte. Com grande capacidade e qualidade plástica, simplificava as formas, realçando o volume dos corpos utilizando cores escuras e pouco variadas Júlio Pomar (N-1926), Moniz Pereira (1920-1988), e Vespeira (1925-2002) foram os pintores mais proeminentes deste movimento.

Outra vertente dos artistas da geração revelada em meados da década de 40 dedicou-se a uma arte socialmente comprometida, tendo como fundamentos os princípios do materialismo histórico e a sua relação com o desenvolvimento das formas artísticas na sociedade. O principal fundamento do neo- realismo era a ideia de que a arte deve exprimir a realidade viva e humana de uma época, 


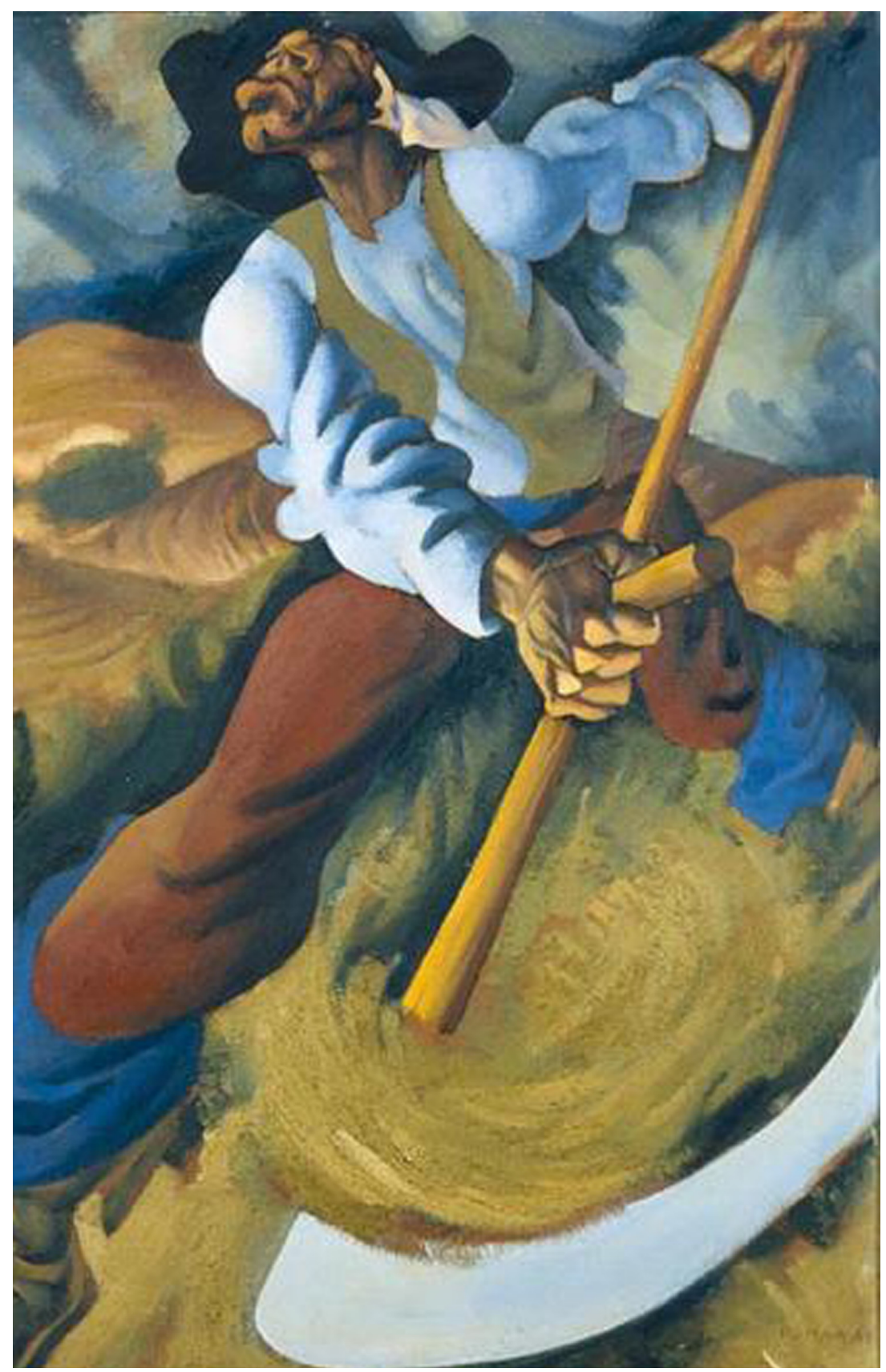

Figura 25. Pintura a óleo de Júlio Pomar, O Gadalheiro, 1945 
manifestar uma tendência histórica progressista, tendo em conta que novas formas podem ter um significado velho, e vice-versa, formas velhas podem conter um significado moderno e progressista. Isto era o que defendia Álvaro Cunhal nas páginas de $O$ Diabo, em 1939. Para Manuel Felipe, Júlio Pomar, Lima de Freitas, Arco (Rui Pimentel), Querubim Lapa, Rogério Ribeiro as realidades sociais compungentes que o país e o mundo do pós-guerra viviam, a par de um entendimento da imagem produzido pelo cinema neorealista, o neo-realismo literário, em que a influência de Alves Redol e Manuel da Fonseca, pelas pinturas dos muralistas mexicanos, com as obras de Orozco, Rivera e Siqueiros, e a obra de Portinari, que se tornou a grande referência dos pintores neorealistas portugueses, assim como o romance realista do século XIX constituíram referências significativas. Por vezes, o movimento neo-realista foi vinculado às teses do realismo socialista, mas tal só ocorreu episodicamente dada a amplitude do espectro de referências dos seus praticantes e das interpretações que delas fizeram.

O neo-realismo surgiu como principal oposição ao modernismo oficial promovido pelo SNI (Secretariado Nacional de Informação), e as Exposições Gerais de Artes Plásticas da SNBA (Sociedade Portuguesa de Belas Artes) foram o principal espaço de apresentação, afirmação, realizadas entre 1945 e 1956. Com críticas de Mário Dionísio, Vespeira, Lima de Freitas e Júlio Pomar o movimento neo-realista entrou em conflito aberto com outros movimentos, como a Abstracção Geométrica ou o Surrealismo, que os acusavam de formalismo, individualismo e defesa "da arte pela arte”.

Manuel Felipe, logo em 1944, realizou alguns trípticos a carvão que denunciavam a exploração do mercado de trabalho através de uma linguagem reportável aos muralistas mexicanos e ao 


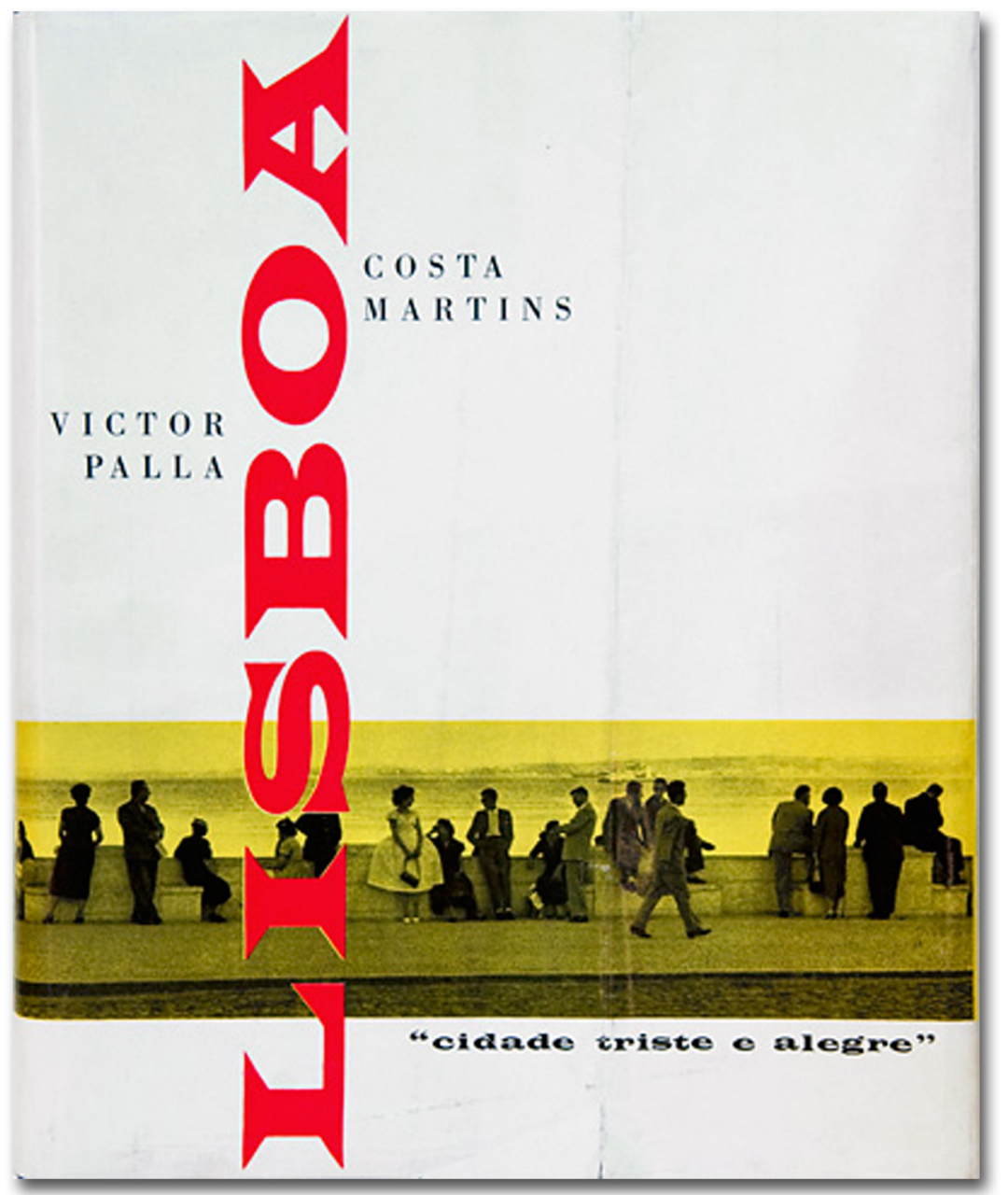

Figura 26. Livro de fotografia, Lisboa Cidade Triste e alegre , 1959 
cinema expressionista alemão. Júlio Pomar, o artista com obra mais complexa do movimento, procurou através de referências americanas, seja a Thomas Bentom, a Tamayo ou Portinari, construir dentro da espacialidade cubista uma linguagem crítica das condições sociais. É também no contexto das Exposições Gerais, que Adelino Lyon de Castro exibiu exemplos duma fotografia mais comprometida com o realismo social, numa fronteira sempre mal esclarecida entre naturalismo e realismo.

O Neo-realismo foi na década de 40 um lugar de encontro de uma prática essencialmente figurativa, que iria encontrar na década de 50 outros desenvolvimentos menos comprometidos socialmente, mas opostos às propostas de outras vanguardas para a modernidade. Os neo-realistas estavam especialmente interessados no assunto das pinturas, da escultura pouco ou nada havia a dizer, também nesta corrente ela era negligenciada.

No ramo da arquitetura desde o inicio foi apresentado maior avanço estético e de confronto com a arquitetura do regime. O neorealismo foi uma corrente estética de intervenção cujas temáticas de cariz revolucionário e libertário, no âmbito social, ético e político, readquire a representação figurativa. Victor Palla e Costa Martins, tiveram uma intervenção muito criativa no campo da fotografia especialmente na obra editada Lisboa Cidade Triste e alegre onde sobressai a índole inovadora. Victor Palla teve também um enorme protagonismo no campo da expressão gráfica, pintura, arquitectura, design e na organização de exposições. Participou em inúmeras edições, com trabalhos que foram veiculados pelo neorealismo.

«O neo-realismo significara então para esses jovens artistas não só uma mais forte e arrojada opção estética face a modernismos academizado da segunda geração, como uma rara oportunidade reflexão humanista que alimentaria a esperança de uma verdadeira 
transformação progressiva da sociedade portuguesa ${ }^{70}$

O neo-realismo com representação na revista vértice, teve grande expressão na literatura portuguesa sendo uma corrente literária de influência Italiana que agrega alguns componentes da literatura Brasileira, baseada na intervenção social (de inspiração marxista: consciência e luta de classes), tanto na prosa como na poesia. Em Portugal esta corrente afirmou-se nos anos 40, muito influenciado por o neorrealista Jorge Amado e sendo o seu principal percursor Ferreira de Castro. Outros nomes adotaram, esta tendência nomeadamente: Alves Redol, Fernando Namora, Manuel da Fonseca, Carlos Oliveira, Romeu Correia entre outros.

«Uma aç̧ão crítica mais animosa e especializada, em camaradagem de geração, deu apoio mais ou menos teórico à pintura neo-realista que vivia também em directa relação com a literatura igualmente empenhada em revistas que mal conseguiam romper as barreiras da censura. Na Vértice, na Seara Nova, como no Mundo Literário e no Horizonte, Jornal das Artes. $\gg^{71}$

A incompatibilidade dos ideais do neo-realismo e o poder politico levou, paralelamente ao aparecimento em 1940 de outra corrente o surrealismo

\footnotetext{
${ }^{70}$ SANTOS, David, Imagens na orla da palavra ensaio, Ilustração \& literatura neo-realista, Museu do Neo-realismo, V.F.Xira 2008, p.26

${ }^{71}$ FRANÇA, José-Augusto. Os 40 anos na arte portuguesa, Fundação Calouste Gulbenkian, Lisboa 1982, p.33
} 


\subsubsection{Surrealismo / Surrealismo}

«Os surrealistas deixaram-nos um amplo e complexo legado de produções artísticas que configuram um universo poético e simbólico dominado pelo desejo, a bela compulsiva e o maravilhoso. Independentemente da qualidade de cada artista, os surrealistas foram responsáveis pela reposição do fio da história, interrompida, durante a política de espírito e o seu modernismo apaziguado. Neste novo plano discursivo traziam questões da modernidade, nada ou escassamente abordadas anteriormente na arte portuguesa: assuntos sobre a identidade do homem moderno, a libertação individual e colectiva, a subversão dos valores da existência, e, no terreno estritamente plástico, um firme e programático anseio de desprendimento do real que questiona o estatuto da arte e a figura do artista como génio criador. $>^{72}$

O surrealismo, movimento de intervenção literário e artístico, influenciado pela teoria da psicanálise de Freud, acentua a acção do inconsciente na actividade criativa, interpreta o universos dos sonhos pelo automatismo psíquico puro, através de uma figuração simbólica e onírica. Das obras dos surrealistas portugueses e quanto aos procedimentos plásticos, na prática, todas se pautam por um lado pelo automatismo e por outro pela fragmentação, quebra de um discurso linear. Entre os seus métodos, nas produções literárias vigora a escrita automática (não linear, descodificada, com saltos temporais) e nas artes plásticas explora-se os mecanismos da colagem e da montagem. As primeiras colagens em Portugal datam 1935 é seu autor António Pedro.

72 ÀVILA, Maria Jesus, Surrealismo em Portugal, Arte Portuguesa do século XIX 1910-1960, MNAC-Museu do Chiado, p. CXIX 


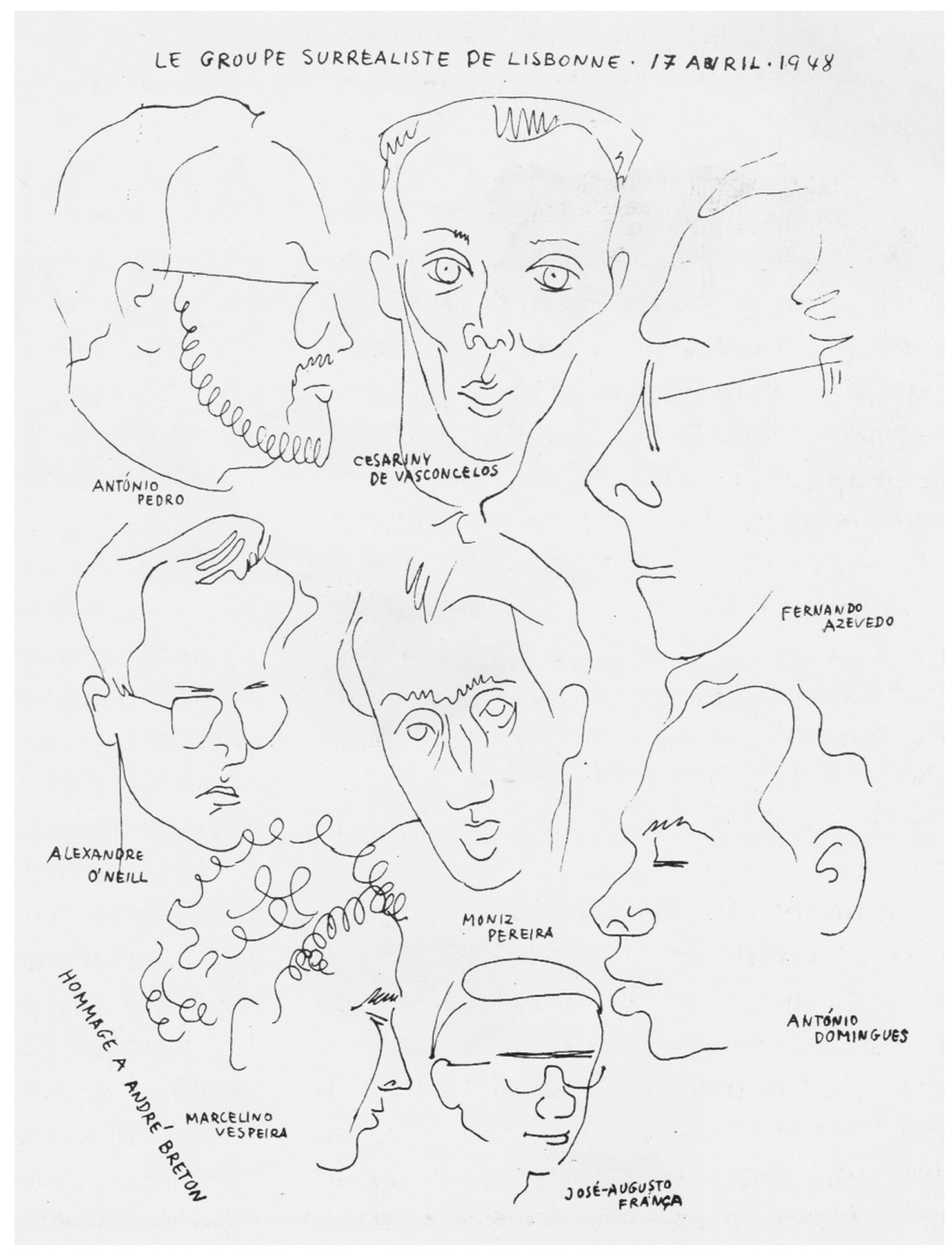

Figura 27. Desenho de António Pedro, O grupo Surrealista de Lisboa 
António Pedro, (1909-1966), independente $1^{\circ}$ critico de arte moderna foi o introdutor do surrealismo em Portugal, (em 1936), defendeu a função contestatária da arte moderna. No mesmo ano organizou a $1^{\text {a }}$ exposição de M.H. Vieira da Silva em 1940, António Pedro conjuntamente com António Dacosta (1914-1990) e com a escultora inglesa Pamela Bodin, organiza uma exposição que seria a $1^{a}$ manifestação surrealista ao passo que o regime Salazarista

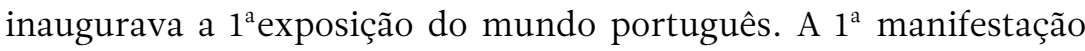
surrealista uma pintura á margem da oficial, um evento que parecia concorrer em certa medida com a grande exposição do mundo português, sem ser ofuscada, antes pelo contrario, era uma exposição original e escandalosa, no panorama artístico nacional. «Mas, ao mesmo tempo, (...) António Pedro (...) e António Dacosta, abriram uma exposiçãoo de obras surrealistas - contrapondo polémica ao discurso patriota de Belém e insólita tomada de consciência de uma realidade histórica pela via do imaginário. Uma pintura agressiva e lírica, espectacular e humorosa, em cenas de catástofre ou de monstruosa ternura entrava assim, subitamente, na arte portuguesa, assinalando uma nova situação modernista muito para além do gosto sobretudo mundano que justificara a primeira, (...). Pintura eminentemente social através de uma mensagem individual exacerbada, o acolhimento que a arte que Pedro e de Dacosta obteve foi de escândalo sem consequências, quer do lado do gosto oficializado em torno de temáticas nacionalistas, quer de outro que então começava a gerar-se (...).> ${ }^{73}$

António Dacosta inicia-se como expressionista mas logo se tornou um criador imagético impar no campo surrealista. Em 1947, por influencia do grupo surrealista parisiense de André Buton, é criado o grupo surrealista de Lisboa, com alguns artista do neo-realismo,

\footnotetext{
${ }^{73}$ FRANÇA, José-Augusto. Os 40 anos na arte portuguesa, Fundação Calouste Gulbenkian, Lisboa 1982, p.25
} 


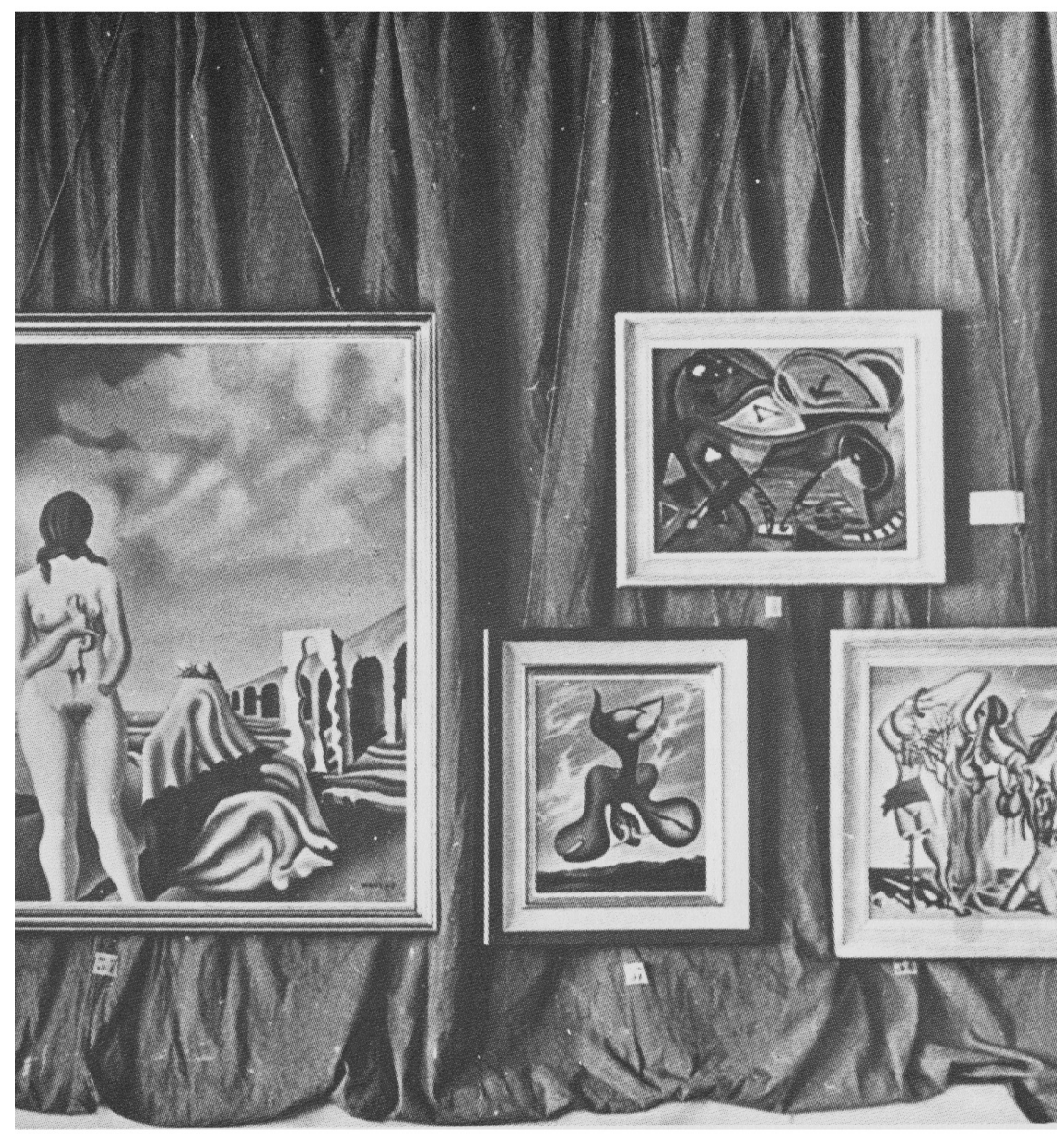

Figura 28. Fotografia da Exposição Surrealista de 1940 
como Vespeira, Moniz Pereira aos quais se juntaram Cruzeiro Seixas (N-1920) e Mário Cesariny (N-1923).

António Maria Lisboa (1928-1953), foi um poeta português, surrealista redator da revista Afixação Proibida (1949) , em colaboração com o seu amigo Mário Cesariny e escreveu o principal manifesto do surrealismo erro próprio com 22 anos de idade (1950) grande parte da sua obra foi publicada depois da sua morte por Luís Pacheco da Editora Contraponto e em 1977 por Mário Cesariny a obra completa reunida num volume organizado por este. São ainda publicações deste, outras obras como: Ossoptico (1952) Isso ontem único (1953), A verticalidade e a chave (1956) exercício sobre o sonho (1958), A vigília de Alfred Jarry (1958), Uma carta: estrela da ilha em puros ministros (1958) e Poesia de António Maria Lisboa (1962). António Lisboa foi contemporâneo de PG. ${ }^{74}$

\title{
3.2.6 Exposición del Mundo Portugués, \\ 1940 / Exposição do Mundo Português, 1940
}

\begin{abstract}
«Exposição do Mundo Português (...) coroava meia dúzia de anos de afirmação e estratégia política - acto de espírito e de arte notavelmente sustentado por uma plêidade de arquitectos, escultores, pintores e decoradores. Com esta realização terminou de modo sistematizado o primeiro "modernismo" da arte nacional, surgido por volta de 1915, arrastado por anos 20 provincianos, perdido e achado na protecção oficiosa das
\end{abstract}

\footnotetext{
${ }^{74}$ PG nutria uma grande amizade e admiração pelo seu amigo António Maria Lisboa.
} 


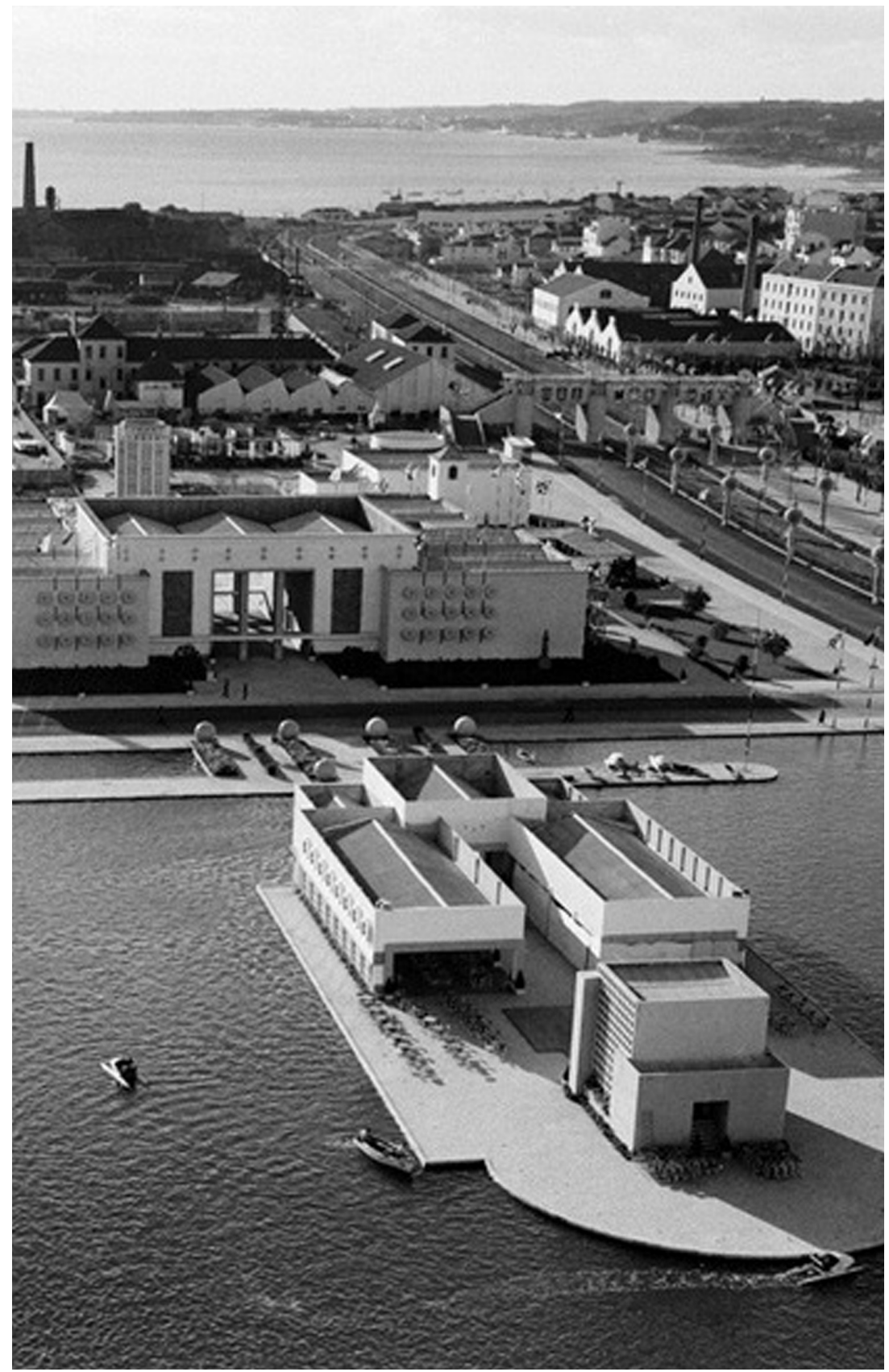

Figura 29. Fotografia lado oeste do Pavilhão dos Portugueses no Mundo 
Exposições de Arte Moderna do S.P.N ${ }^{75}$

Inaugurada a 23 de junho de 1940, a magna exposição do Mundo Português, numa iniciativa politico-cultural, comemorando o duplo centenário, o da independência da Nação (1140) e o da sua restauração (1640). Foi um dos primeiros parques temáticos europeus, uma acção promocional impar no percurso da Nação. O programa da realização direção e planificação dos trabalhos, foi entregue a Cottineli Telmo (1897-1948), artista muito conceituado, principalmente pela sua obra arquitetónica, e contou com a colaboração especial, entre outros, de António Ferro o responsável pelo secretariado da comissão executiva.

«Não era por acaso que Cottineli Telmo estava à frente do Certame. Homem do cinema, ele melhor que ninguém saberia (e soube) interpretar o impulso Hollywoodesco que se queria imprimir ao Certame. Arquitectura efémera, arquitectura de luz, deoremas narrativos, fizeram a originalidade e até o pioneirismo da exposição. ${ }^{76}$

Na conformação da exposição de 600 mil metros quadrados (aproximadamente), fazia parte o Pavilhão de honra e o Pavilhão dos portugueses no mundo de Luís Cristiano da Silva e de Cottineli Telmo, respetivamente, Parque de atrações, o Jardim dos Poetas, Parque Infantil, Pavilhão da vida Popular, representações das aldeias portuguesas, restaurante, estatuaria, diversas figuras históricas, com destaque para o Infante D. Henrique e a estátua da Soberania esculpida por Leopoldo de Almeida, a par de outras infra estruturas criadas como o Aeroporto da Portela. Os Pavilhões temáticos versavam assuntos relacionados com a história de

\footnotetext{
${ }^{75}$ FRANÇA, José-Augusto. Arte Portuguesa anos 40, Fundação Calouste Gulbenkian, Lisboa 1982, p.23

${ }^{76}$ PEREIRA, Paulo, Arte Portuguesa história essencial, Temas e Debates, Círculo de Leitores, 2011, p. 810
} 
Portugal, atividades económicas, cultura regional e território ultramarino, uma seção de etnografia metropolitana.

Esta "mostra" é também um grito para o mundo de independência, porque dela apenas participou um único pais estrangeiro, o Brasil.

Exposição do Mundo Português «fenómeno extremamente importante das actividades estéticas oficiais ao nível da pintura e da escultura tanto quanto da arquitectura ${ }^{77}$

Deste evento pouca estruturação resultou nas artes. A pintura não encontrou novo caminho, a escultura teve outro futuro através da estatuária publica enchendo as praças de Lisboa e da província com monumentais figuras enquanto a arquitectura opta por um formalismo monumentalista de inspiração germânica. Esta exposição pode ser considerada um êxito para o estado novo mas tb um sucesso pessoal de António Salazar.

Foi uma manifestação de vanglória do passado, a confirmar o presente e enfatizar o futuro.

"balanço da nacionalidade, apoteose e auto-retrato do regime..., foi a exacta conclusão da «política do espirito»",78

Aos dias 2 de Dezembro de 1940 encerrou a exposição do Mundo Português.

\footnotetext{
${ }^{77}$ FRANÇA, José-Augusto, Arte e Sociedade do Século XX, Livros Horizonte, 1980, p. 34

${ }^{78}$ Ibidem, p. 37
} 
3.2.7 Abstraccionismo / Abstraccionismo

As origens do abstracionismo ou arte abstrata remontam a Amadeu Sousa Cardoso, Santa Rita, Almada e principalmente a M.H. Vieira da Silva, reaparece em Portugal em 1942 por intermedio de Vespeira, Júlio Resende, Nadir Afonso (N-1920) e principalmente por Fernando Lanhas (N-1927).

«Foi em 1942 que, no Porto, o então estudante de arquitectura Fernando Lanhas realizou as suas primeiras obras abstractas, propondo, assim para uma continuidade significativa uma nova corrente estética que se desenvolveria lentamente em Portugal ao longo da década de 40.» ${ }^{79}$

Não foi calma a implementação em Portugal do abstracionismo. Os movimentos controversos do neo-realismo e do surrealismo, nos anos 40 e princípios dos anos 50 declaradamente rejeitaram o abstracionismo, por raciocínios do foro ideológico ou confundidamente o enquadraram em específicas actuações de imaginário, adoptando o expressionismo em caval rejeição das correntes e dos movimentos geométricos vindo só a desenvolverem-se nos princípios dos anos 50, por Joaquim rodrigo e Jorge Oliveira tendo a sua maior expressão na exposição de 1953 realizado em Lisboa. Em 1950 Fernando Lanhas trouxe às salas do SPN cem quadros abstractos do Salão das Novas Realidades de Paris, contrariamente às opiniões estéticas de AF.

Em 1945 e até ao final da década, cresce uma geração jovem preocupada com um envolvimento profundo nas diferentes vias da modernidade e das suas manifestações de vanguarda. No pós-

${ }^{79}$ AZEVEDO, Fernando de. Arte Portuguesa anos 40, Fundação Calouste Gulbenkian, Lisboa, 1982, p.98 


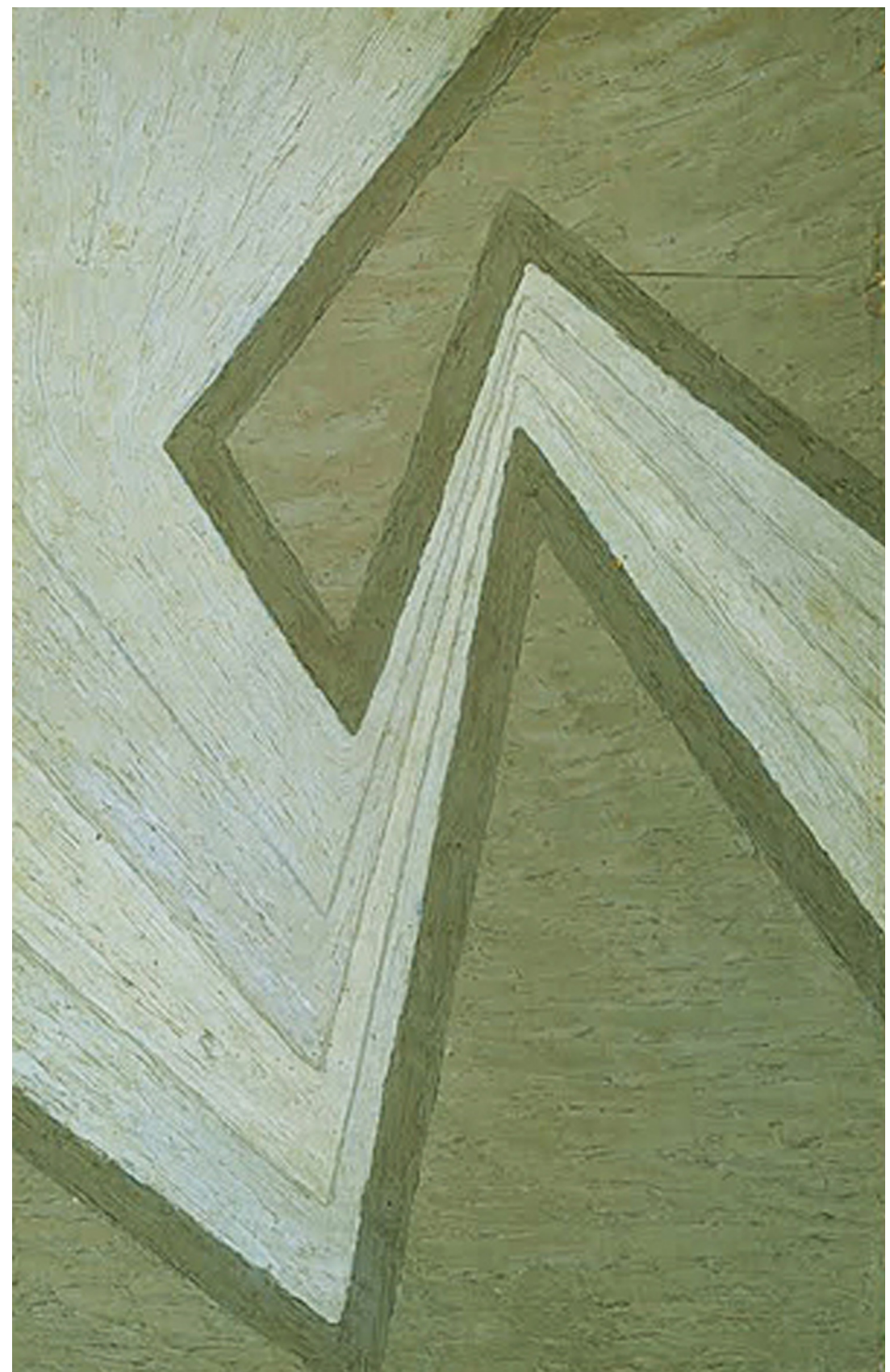

Figura 30. Pintura de Fernando Lanhas, óleo sobre cartão prensado, 1944 
guerra europeu, a prática da abstracção construtivista reconstituiuse como uma vanguarda tendo marcado um papel significativo no contexto português. Pintores abstractos geométricos, como Fernando Lanhas, Nadir Afonso ou Joaquim Rodrigo, resgataram as ligeiras experiencias de António Pedro e a prática vanguardista interrompida, com a morte prematura, de Amadeo de SouzaCardoso. As pesquisas abstraccionistas geométricas debruçavam-se sobre um conhecimento essencialista da pintura e da busca de uma harmonização dos seus elementos constitutivos, na especificidade formal dos seus elementos estruturais.

«(...) em 1954, pareceu possível organizar em Lisboa um I Salão de Arte Abstracta (...). Participaram no salão (...) Vespeira, Jorge Oliveira, Lanhas e Joaquim Rodrigo, todos ali dentro de práticas geométricas, quatro jovens em seus inícios, Bual, Cargaleiro, Bértholo e Paulo-Guilherme, e dois escultores, Jorge Vieira e Margarida de Ávila. ${ }^{80}$

${ }^{80}$ FRANÇA, José-Augusto; História da arte em Portugal, O modernismo; [S. 1.] Editorial Presença, p. 139 


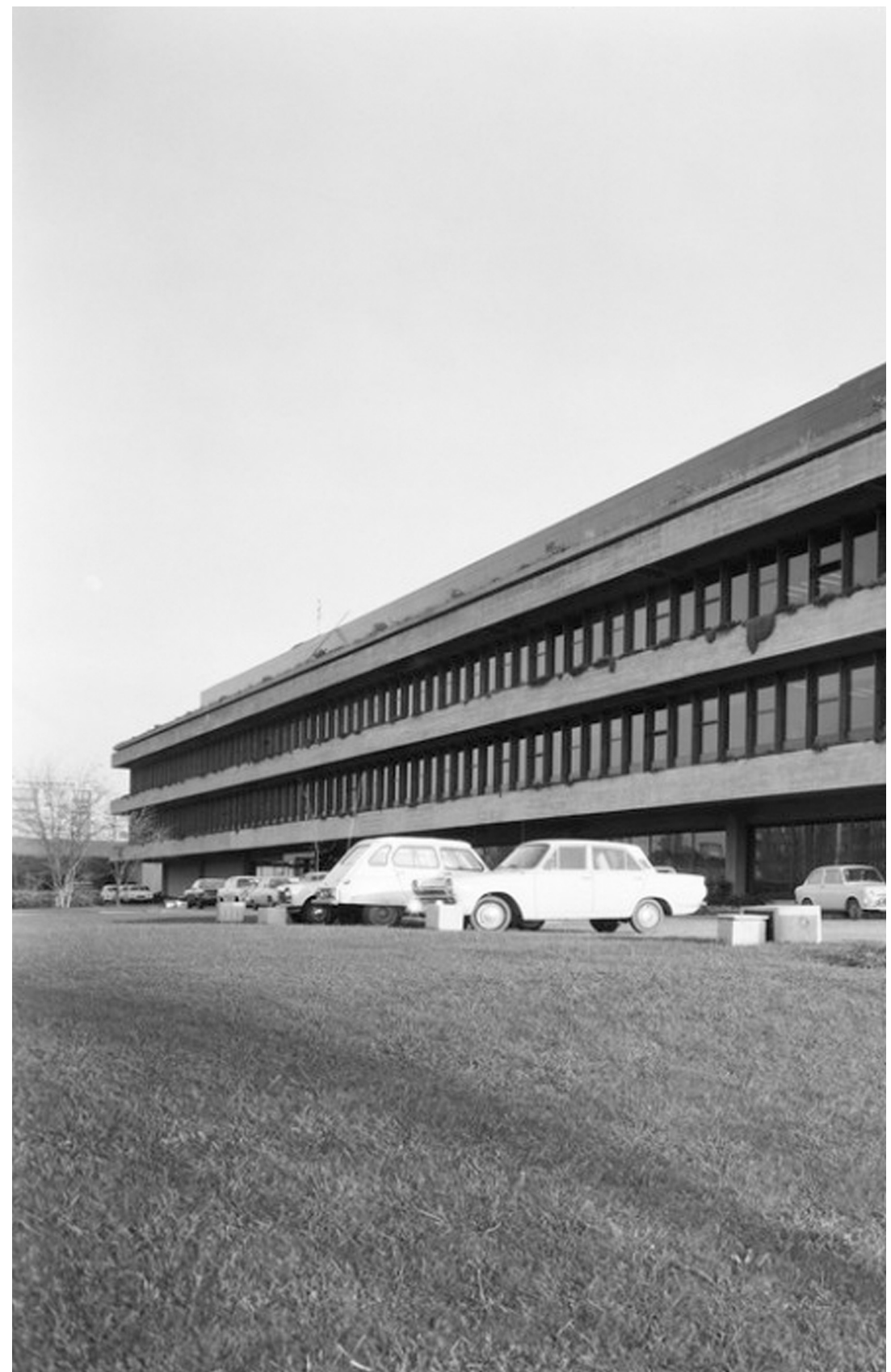

Figura 31. Fotografia Fundação Calouste Gulbenkian, anos 60 


\subsubsection{La Fundación Calouste Gulbenkian / A} Fundação Calouste Gulbenkian

A Fundação Calouste Gulbenkian, gerada por determinação testamentária (1953) do multimilionário Calouste Sarkis Gulbenkian $^{81}$ obteve o estatuto legal e apresenta-se ao publico em 1957, através de uma exposição no domínio das artes plásticas. Esta fundação é um fenómeno pelas dinâmicas de desenvolvimento e progresso que cria em torno da acção preconizadas nos seus estatutos nomeadamente nos domínios da arte, da ciência, da educação, da caridade e pelo contributo excepcional no campo artístico.

«Alem destas exposições de sua própria responsabilidade e organização, a Fundação patrocinava e subsidiava «todas as manifestações desta natureza sempre que elas pudessem constituir um instrumento de desenvolvimento do gosto público por tudo que representasse criação artística, incluindo a arte popular e a arte indígena» ${ }^{82}$

A Gulbenkian substituiu o estado nas acções difusores e promotoras da cultura, através de exposições periódicas permanentes ou itinerantes, das bolsas e prémios atribuídos, na formação de artistas nas várias áreas (música, teatro, etc.), na criação de orquestra de música clássica e dos espetáculos (festivais de música e teatro, etc.)

\footnotetext{
81 «personalidade verdadeiramente superior (...), dotado de faculdades naturais e adquiridas absolutamente invulgares (...), alto espirito e pessoa dotada da mais rara sensibilidade, um dos homens mais notáveis que o historiador de arte Kemeth Clark confessa alguma vez ter conhecido, Gulbenkian constituira uma enorme fortuna, trabalhando sobretudo no domínio financeiro dos petróleos, e com ela soubera dotar-se de uma notável colecção de arte ou de artes, na extensão e variedade dos seus interesses.»in FRANÇA, josé-Augusto. Arte em Portugal no séc.XX 1911-1961, p. 344

${ }^{82}$ FRANÇA, josé-Augusto. Arte em Portugal no séc.XX 1911-1961, Livros Horizonte, 2009, p. 348
} 


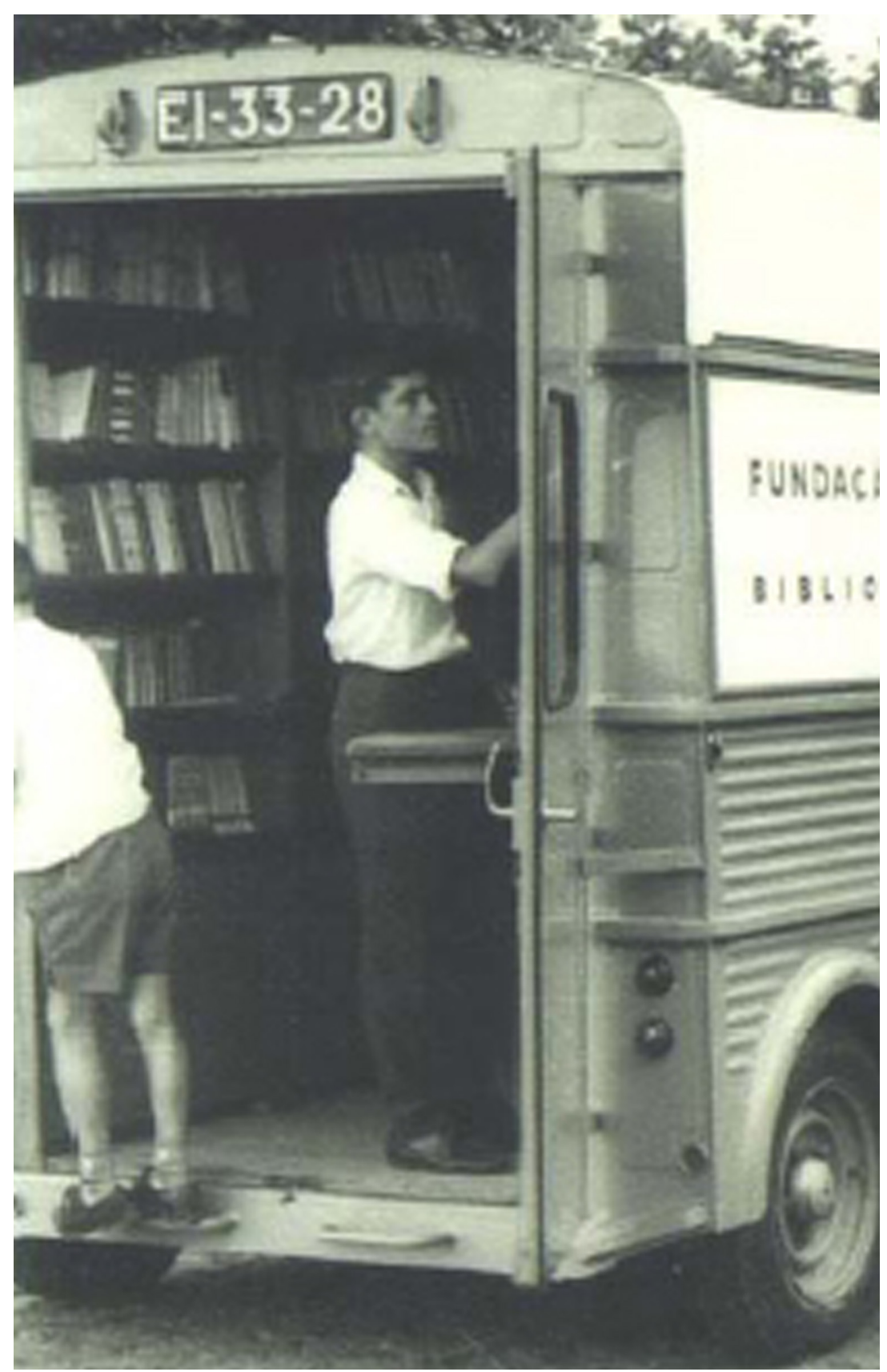

Figura 32. Fotografia da biblioteca itenerante (BNI) 
das bibliotecas e das bibliotecas itinerantes. O serviço das bibliotecas itinerantes (SBI) tinha por objectivos: promover e desenvolver o gosto pela leitura e elevar o nível cultural dos cidadãos, assentando a sua pratica no principio do livre acesso às estantes, empréstimo domiciliário e gratuitidade do serviço sendo o publico alvo o mais carenciado no acesso à cultura e educação das regiões mais desfavorecidas. Em 1958 foram postas a circular pelo país 15 (viaturas) bibliotecas itinerantes e este numero subiu em 1961 para 47, prestando um serviço directo aos cidadãos. Foi o $1^{\circ}$ plano Nacional de leitura, sem o ser, e acaba por ser extinto em 2002.

Do acervo da fundação consta o museu que reúne uma vasta colecção de arte europeia com peças do período do séc. XI até ao séc. XX e da arte oriental e clássica com peças de arte do Japão, da China, Greco-Romana, arte islamica e arte egípcia. Alberga também o centro de arte moderna criado em 1983, salas de conferencias, três auditórios e biblioteca.

«A força das circunstâncias ou do estado a que chegara a própria pintura académica em Portugal, determinou, porém, a orientação do júri a esse «golpe terrível no academismo novecentista», fatal que foi, certamente esclareceu a fundação na sua futura acção, como ela pretendia. Ao Inaugurar a exposição ${ }^{83}$ no Porto, Azevedo Perdigão ${ }^{84}$ teve palavras necessárias e suficientes: «para além de uma estética pragmática, académica, objectiva e estática, criou-se e organizou-se uma nova estética., inconformista (...) essencialmente pessoal (...) revolucionária nos processos e difícil na compreensão, em face da qual haverá, pelo menos, que ter uma atitude esperante (...), compreensiva (...), não admirando que o mundo de hoje tenha uma estética diferente do mundo de ontem. (...) Não tomamos posição, nem tomá-la se justificaria. Mas isto não significa que uma

\footnotetext{
${ }^{83}$ Datada em 1959

${ }^{84}$ Azevedo perdigão era o presidente da Fundação Calouste Gulbenkian.
} 
fundação deva ser, por natureza ou definição, um elemento meramente estabilizador do existente. Ao contrario, às fundações está reservado um grande papel em todas as tarefas que se destinem ao progresso da humanidade, e progredir é, em todos os tempos, fundamentalmente, criar renovando. ${ }^{85}$

A Gulbenkian teve grande desempenho ao nível artístico e cultural através das exposições de artes plásticas, em 1957 e 1961 e dos Salões dos Novíssimos nos quais se apresentam as novas propostas de Arte Contemporânea. Com as sábias decisões da fundação foi possível entrar com certo optimismo nos anos 60.

${ }^{85}$ FRANÇA, josé-Augusto. Arte em Portugal no séc.XX 1911-1961, Livros Horizonte, 2009, p. 346-347 
3.3 El principio del final del “Arte del Régimen” / O início do fim da "Arte do Regime"

Os primeiros cinquenta anos do século $\mathrm{XX}$, não afirmaram as artes plásticas, não sustentaram o seu desenvolvimento, muito pelo situacionismo que manteve o país no isolamento das vanguardas europeias, a par da baixa formação escolar, da doutrina cultural fomentada e da desinformação do povo português.

Em 1958 na sociedade portuguesa manifestou-se uma grave crise politica que foi responsável pelo fosso que separava a criação artística e a aceitação oficial. Os artistas mais conceituados das novas gerações boicotaram a representação na bienal de São Paulo Brasil e a participação Salão Nacional de Arte ambos a cargo do SNI. A comunidade artística é cada vez menos cooperante com o sistema político pela falta de liberdade de expressão e ausência de todo o tipo de apoios principalmente financeiros. O carácter reactivo dos artistas, animados por um espírito de mudança, de rejeição pela ideologia em vigor (fascista), espelha uma maioria silenciosa que poderá ser tido como presságio do que veio a materializar-se em Abril de 74 . 


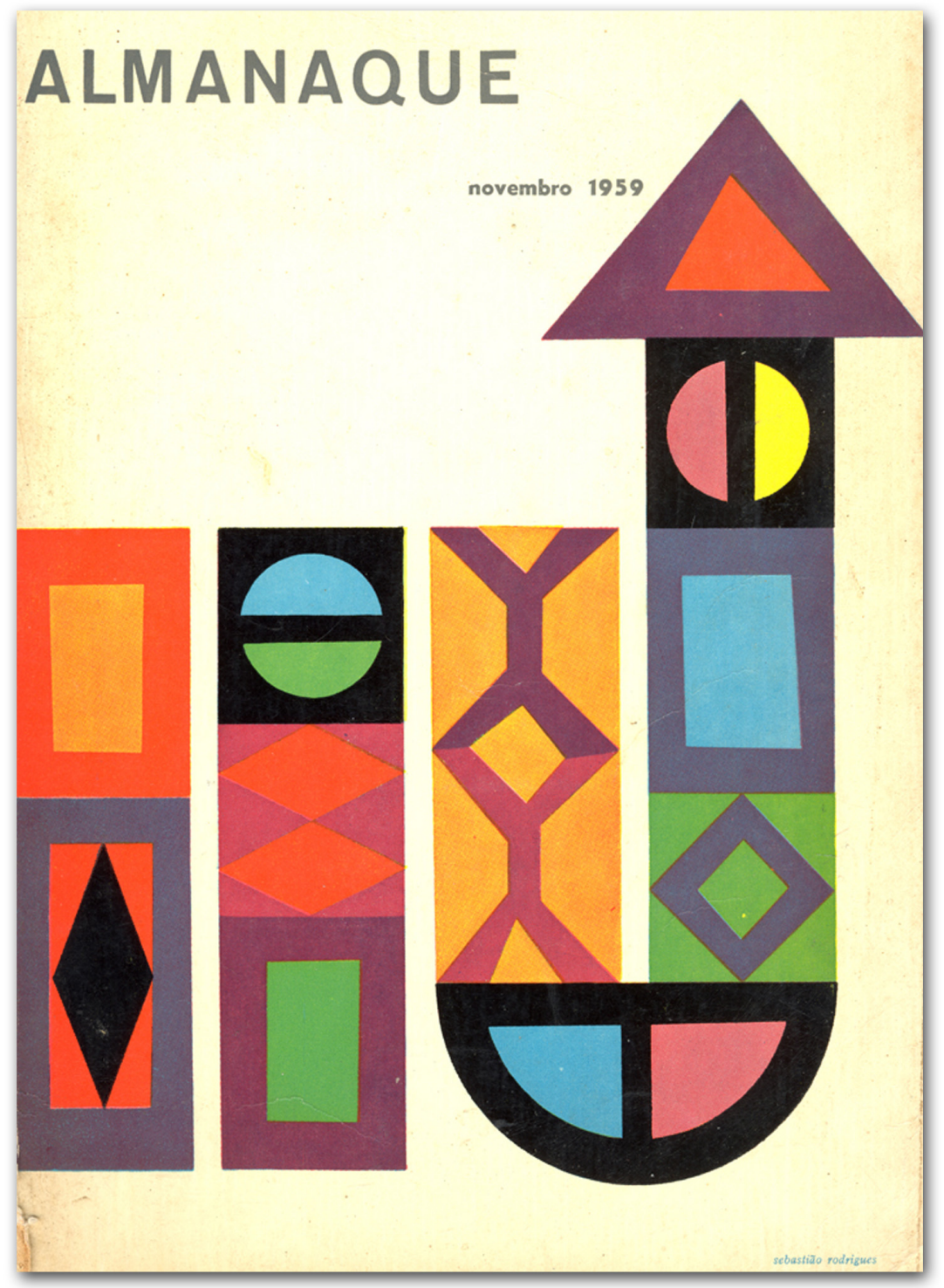

Figura 33. Capa de Sebastião Rodrigues, Revista Almanaque, 1959 


\subsubsection{Años 50 y 60 - nuevos factores / Anos}

50 e 60 - novos factores

Na década de 50 a contextura do modernismo, caraterizou-se pelas soluções estéticas já exploradas, centradas na linguagem figuração/abstração. Muito embora a ação dos artistas emigrados fosse revitalizadora do meio artístico, o modernismo não se sobrepunha ao naturalismo e ao romantismo lírico. O mercado de arte em Portugal, da época, refletia o desenvolvimento sociocultural e o interesse que as artes plásticas despertam no publico em geral. O negócio das "artes" auto-sustentava-se pobremente, apenas quatro galerias (duas em Lisboa e duas no Porto) e uma associação (no Porto) proporcionavam a compra de obras de arte.

Em 1959, foi lançada a revista Almanaque cuja orientação gráfica pertence a Sebastião Rodrigues (1929-1997).Sebastião Rodrigues, António Garcia, Vítor Palla, António Domingos, Luís Filipe Abreu, João da Camara Leme, Sena da Silva, Fernando da Costa, Frederico Jorge, João Machado e Paulo Guilherme, são exemplos, entre outros, que contribuíram para uma renovação do design português, do seu mercado e dos seus públicos. Participaram, com um vasto, diversificado e relevante legado no património artístico-cultural.

Sebastião Rodrigues foi responsável pelo design gráfico da revista Almanaque, onde a fotografia ganha um novo tratamento igualando-se á ilustração deixando o seu significado transpor o seu significante. De 1959 a 1961, guiou esta produção graficamente, tendo sido uma referência, tanto as capas da sua autoria onde 
valorizou a imagem modernista, como nas reportagens fotográficas, com as reproduções a preto e branco de Eduardo Gageiro. Os profissionais preferiam a fotografia a preto e branco pela sua densidade, embora a fotografia a cores atravessasse uma fase de superioridade simultaneamente minorava a estética gráfica. Mais tarde Abel Manta foi seu colaborador. Sebastião Rodrigues é bolseiro da Gulbenkian no biénio 59/60, a sua ação concentra-se na recolha, em todo o território nacional de material gráfico de raiz popular, o qual viria a construir o material e o sucesso do seu trabalho. Sebastião Rodrigues foi a imagem gráfica da fundação Calouste Gulbenkian nos anos 60. Ganhou vários prémios nacionais e internacionais entre eles em 1995, o Presidente da República atribuiu-lhe a medalha de Grande Oficial da ordem de mérito.

«A década de 60 é referida por alguma historiografia como um período de ruptura. É por certo um momento de mudança. Trata-se de uma mudança acompanhada de continuidades mas é, ainda assim, o momento em que os artistas portugueses conseguem, em tempo certo e alinhado com as linguagens internacionais, introduzir pesquisas e formulações estéticas que, ao germinarem, resultariam em trabalhos amadurecidos e percursos individuais amplamente reconhecidos. Desenham-se e projectam-se nestes anos uma série de carreiras de artistas, muitos deles ainda activos, que viriam assumir lugar de destaque no panorama da arte portuguesa contemporânea» ${ }^{86}$

A contestação ao regime, o mau estar social, o estado de estagnação a que o país foi relegado, ocasionaram nos anos 60 também a emigração de um considerável numero de artistas portugueses, que viriam a refletir a necessidade de harmonizar as linguagens estéticas internacionais que virão a sustentar as tendências culturais e artísticas no plano de produção nacional e simultaneamente

${ }^{86}$ MELO, Alexandre, Arte e artistas em Portugal, Editora instituto de Camões, 2007, p.31 
contribuíram para uma nova conjuntura artística e o aparecimento de novos artistas e novos agentes culturais.

Dos mais conceituados artistas que saíram de Portugal para Inglaterra foram: Menez, Paula Rego, João Cutileiro, António Areal, Sá Nogueira, Ângelo Sousa, Mário Cesariny, Bartolomeu Cid, Alberto Carneiro, Ângelo Sousa, Eduarda Batarda, António Sena, Graça Pereira e João Penalva e daqueles que foram para Paris: Rene Bartholo, Costa Pinheiro, Lourdes Castro, João Vieira, Escada, António Dacosta, Júlio Pomar, Manuel Batista e Jorge Martins. Estes e outros fluxos potenciaram o intercâmbio cultural e artístico, o entendimento das vanguardas estrangeiras proporcionando novas formulações no contexto artístico nacional. Também a fundação Gulbenkian fomenta a aproximação á arte internacional através da atribuição de bolsas, do ciclo de exposições "colectivas" iniciado com a Exposição de artes plásticas (1961) e da dinamização do mercado com a abertura de novas galerias.

Frederico George, Daciano Costa, Lagoa Henriques, experienciam as primeiras aprendizagens de ensino do Design em Portugal.

No campo da expressão gráfica emerge uma nova opinião estética, assinalada pela saturação de cores, esquematismos grandes contrastes e pelo sentido de humor.

António Areal, Joaquim Bravo e Álvaro Lapa, desenvolvem a sua actividade artística no desenho pintura e escultura, sendo que foi na escultura que deixaram um legado considerável produzido nos anos 60. António Areal é figura de referência deste período não só pelo desempenho no trabalho escultórico e pictórico mas também pelas observações, comentários e considerações expressos nas obras editadas. Foi principalmente o esforço de renovação, individual ou colectivo dos artistas que aproximaram a arte 


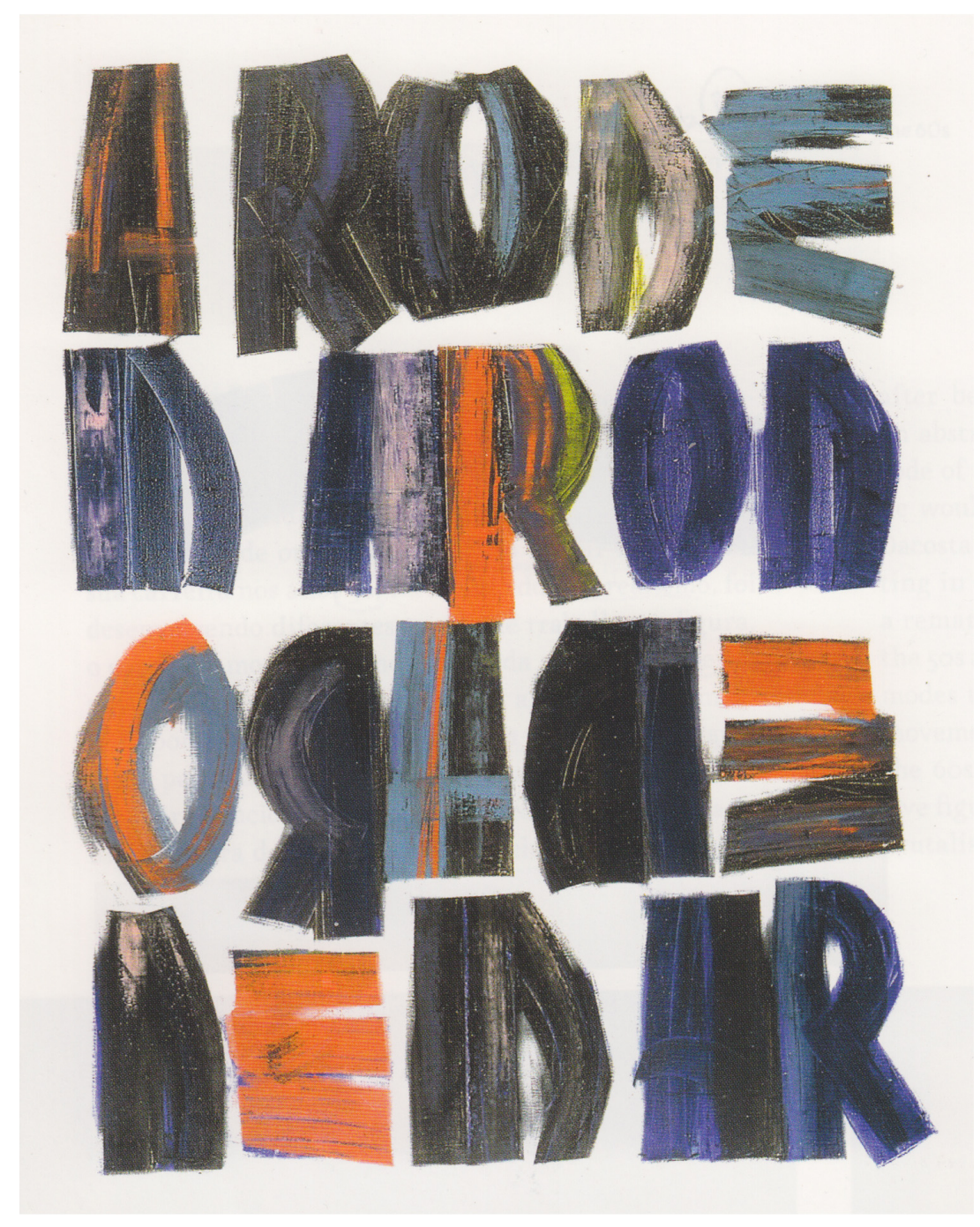

Figura 34. Pintura óleo sobre tela, Uma Rosa É, de João Vieira, 1968 
portuguesa da arte internacional, contudo não se alterava a conjuntura cultural do povo português.

$\mathrm{Na}$ arquitetura desta década eleva-se o feito da exposição retrospectiva de Raul Lino que foi a primeira exposição deste teor em Portugal e na qual suscitava uma nova critica e a participação critica de jovens arquitetos que se insurgiram contra o urbanismo socialmente empobrecidos.

Em 1967 houve um encontro de críticos de arte, onde se produziram algumas observâncias e se reclamava para a arte portuguesa um estudo de caracter e metodologia sociológicas do panorama actual, no concerne a consumos e aspetos informativos e aspetos de produção. Deste encontro foi criada (1969), AICA, Associação Internacional da Criticas d'Arte ${ }^{87}$, e uma representação nacional comité internacional d'historia lárte da unesco. No final da década de 60 Portugal ainda não tem um ensino artístico apropriado, com uma metodologia ultrapassada, fraco apoio bibliográfico (qualitativamente e quantitativamente) e a dotação de verbas quase inexistentes.

Em 1962 é criado o CAPC, Circulo de Artes Plásticas de Coimbra, que tem um grande desempenho na promoção e experienciação de novos comportamentos estéticos. A partir de meados da década (60) o mercado de arte anima-se, novos espaços expositivos e novas galerias são abertos ao publico, nomeadamente em Lisboa a Buchholz e a Dinastia em 1965 e 1968 respectivamente, a Judite Cruz e a S. Mamede, ambas em 1969.

«Nas artes plásticas os anos 60 são um período de experimentação e de confluência de vários movimentos e correntes estéticos.» ${ }^{88}$

\footnotetext{
${ }^{87}$ AICA, foi criada em Portugal em 1948, no âmbito da UNESCO, cuja finalidade é fomentar e auxiliar atividade critica, a partir de 1968 a 1972 conjuntamente com a empresa Soquil premeia as melhores exposições organizadas em Lisboa no campo das artes plásticas com os prémios "Soquil". Em 1981 passa a ser escolhido, anualmente do universo português um artista plástico e um arquitecto merecedores do prémio.

${ }^{88}$ MELO, Alexandre, Arte e artistas em Portugal, Editora instituto de Camões, 2007, p.14
} 


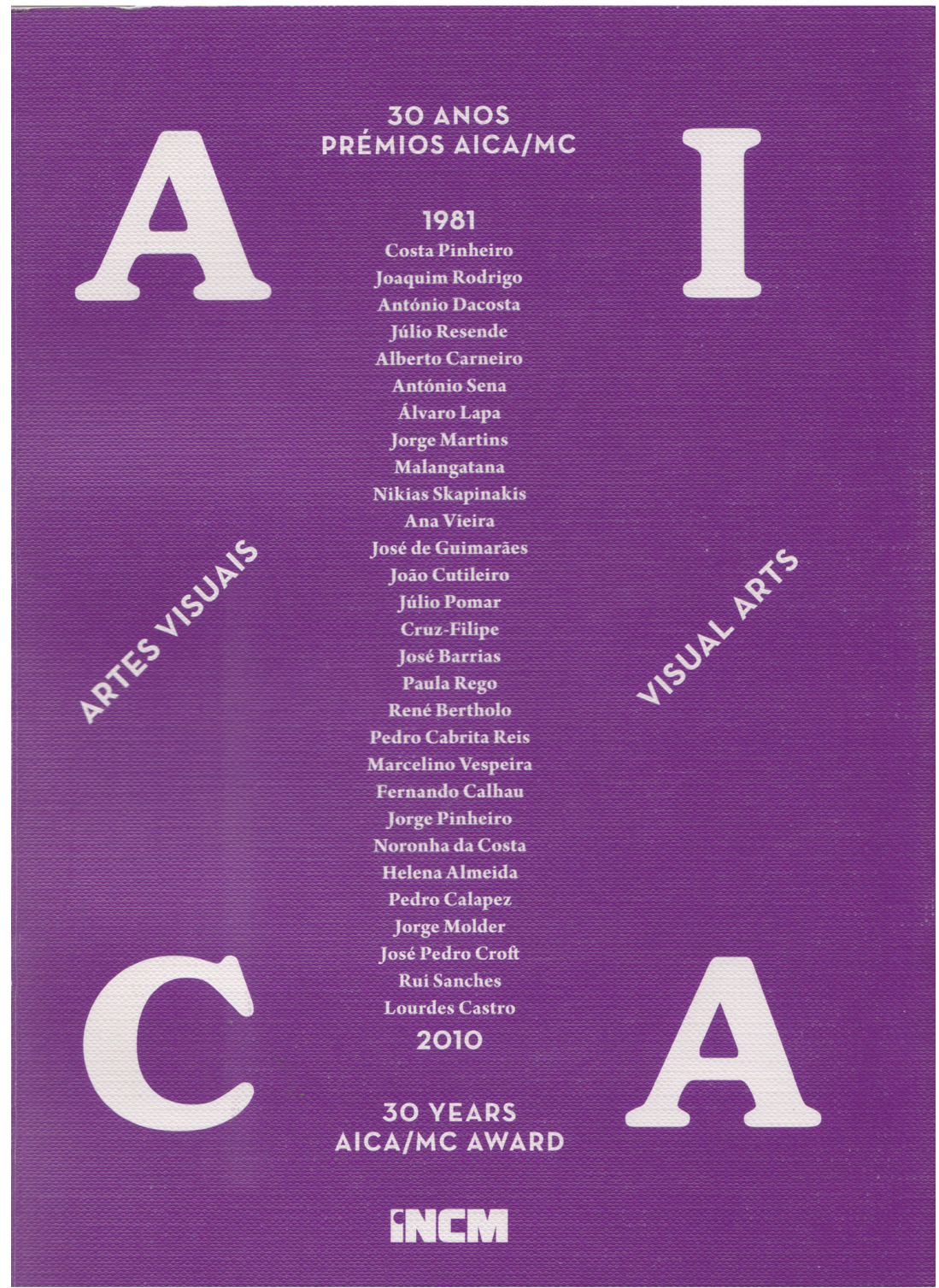

Figura 35. Capa de livro 30 Anos Prémios AICA/MC, INCM 


\subsubsection{El advenimiento de la ruptura - últimas manifestaciones artísticas / $\mathrm{O}$ Advento da Ruptura - últimas manifestações artísticas}

«No que diz respeito ao contexto artístico e, em particular, á realidade das artes plásticas, o período de transição ideológica e política que caraterizou o nosso pais na década de 70 apresenta uma complexa multiplicidade de referências, contribuindo indiretamente para abrir uma nova etapa na atividade artística e cultural. Se é verdade que as reformas empreendidas durante o período marcelista possibilitaram uma maior aproximação à situação internacional, não é menos certo que a política cultural de base traduzia uma ineficácia institucional expressa na falta de museus ou centros de arte contemporânea, na debilidade ou inexistência de mercado e na quase total ausência do apoio do Estado às tendências estéticas contemporâneas. ${ }^{89}$

Nos anos 71 a decoração da «brasileira do chiado» constituiu um sucesso que anima a vida lisboeta, devido à grande intervenção AICA portuguesa. Restituiu-se ao antigo estado repõem-se onze quadros (os quadros vendidos datados de 1925) de onze artistas, mas todo o simbolismo e significado se perdeu e o "café intelectual" o “café da brasileira” degrada-se ao longo dos anos 70.

A AICA tinha criado os prémios Soquil em 1968 que durou até 1972. O premio Soquil (segundo o regulamento) seria atribuído anualmente ao artista plástico que mais se notabilizou em exposições coletivas, individuais ou obras publicas, ao longo do ano anterior.

${ }^{89}$ MELO, Alexandre, Artes e Artistas em Portugal, Editora Instituto Camões Portugal, p. 38 


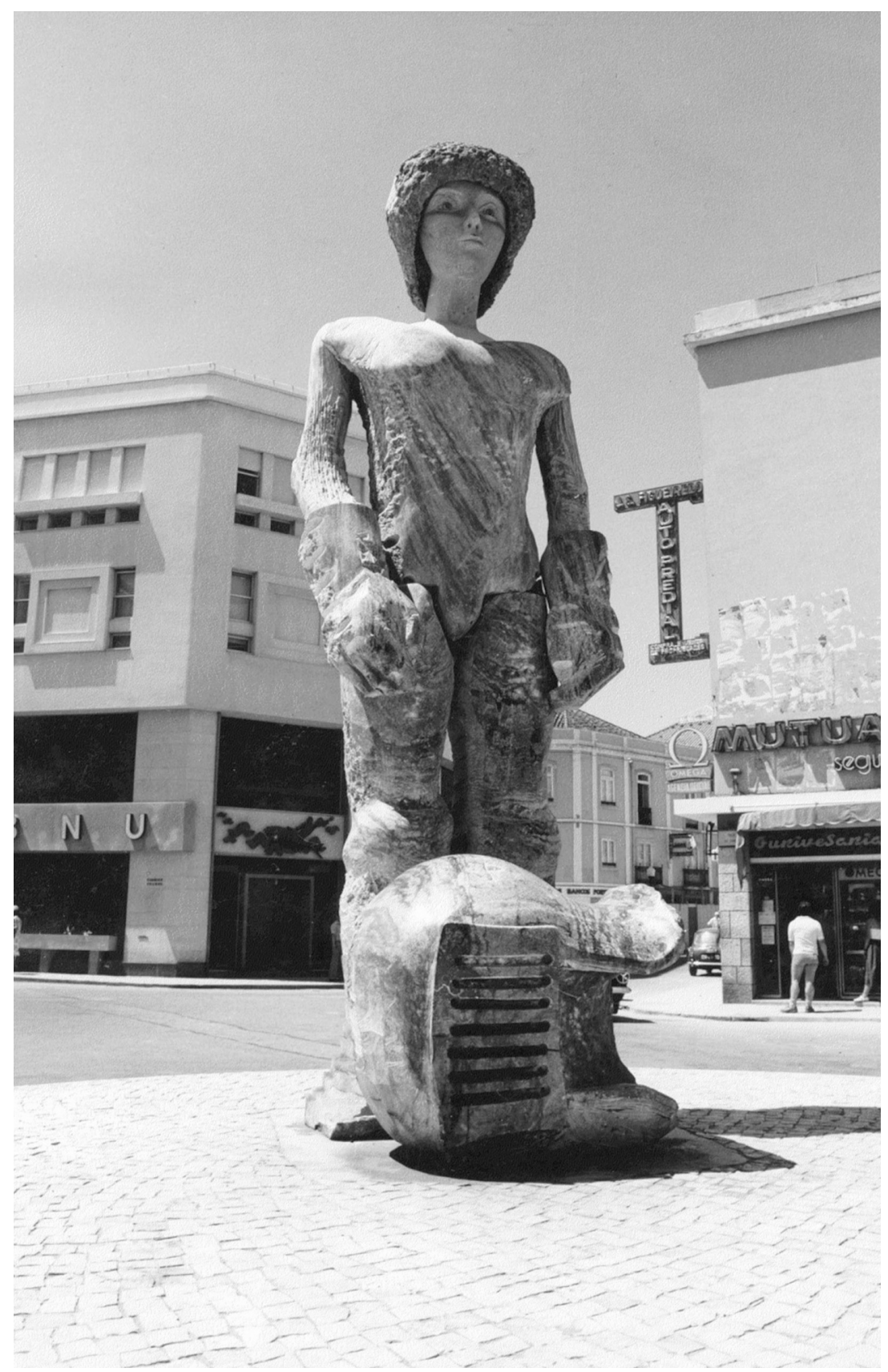

Figura 36. Escultura de João Cutileiro, D.Sebastião, 1973 
A arquitetura dos anos 70 surge impulsionada pelo grande numero de encomendas, privadas e estatais com novas preocupações urbanísticas e de relacionamento com o meio físico, ficando-se a dever em grande parte á recuperação das zonas degradadas e aos programas de apoio das cooperativas de habitação. A escultura portuguesa desta época é influenciada pelas grandes correntes artísticas internacionais (minimalismo, abstracionismo, conceptual, land art, cinetismo, instalação, etc.)

Em 1971 é editada a revista Colóquio - artes (1971-1997) e em 1973 (no Porto) a Revista de artes plásticas sob a direção de José Augusto França. O mesmo antes em 1974 publica A Arte em Portugal no século XX obra de relevo para historiografia artística portuguesa.

Em 1972 a Gulbenkian realiza uma exposição da obra de António Carneiro que assinala um caminho de estudos a analisar, sem qualquer resultado. Ainda em 73 realiza-se um colóquio do comité internacional d'histore de l'arte e em Braga um congresso distinto de arte do século XVIII.

João Cutileiro em 73 inaugura em Lagos uma imagem polemica de D. Sebastião por ser considerada uma imagem heterodoxa. J. Cutileiro contraria assim a tradição da estatuária do governo e dá sentido a um novo começo da escultura portuguesa. 


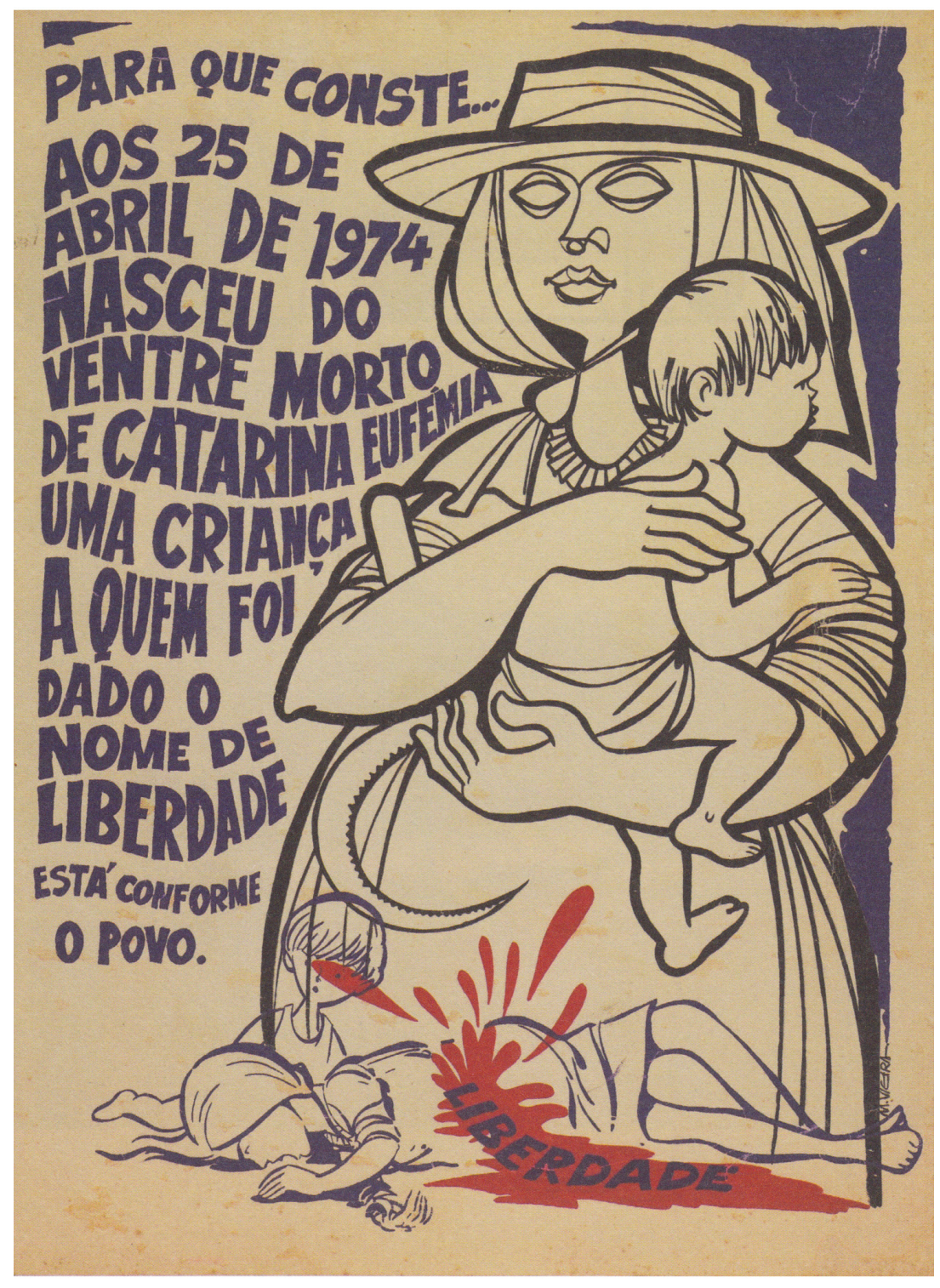

Figura 37. Cartaz de Manuel Vieira, Catarina Eufémia 


\subsubsection{El “Arte del Régimen” Democrático - primeiras asimilaciones / A Arte do Regime Democrático - as primeiras assimilações}

O golpe de estado realizado no 25 de Abril de 1974 liberta o país da ditadura fascista e instaura o regime democrático assente " no estado de direito" que entre outras defende a liberdade e a igualdade, liberto de condicionamento políticos e de censuras... A primeira manifestação "coletiva" acontece a 10 de Junho, dia de Portugal, 48 pintores comemoram este dia, homenageando a revolução, pintando livremente, diante um público e para as camaras da RTP (rádio televisão portuguesa), um grande painel (compartimentado em 48 divisões) cujo tema é a liberdade. Esta obra irregular consegue num amalgamado juntar ao conceptual e ao abstrato a antiga imagem dos anos 40 do neo-realismo. É um evento que não se afirma, não é natural, é um pouco forçado, e não agrada. O painel arde em 1981 conjuntamente com a galeria de arte moderna.

Vivia-se num estado de euforia, nas incertezas do dia-adia, assim foram interrompidas as exposições de artes plásticas.

Os artistas, a arte, bem como outras práticas culturais são instrumentalizados, pelas mais insensatas manifestações ideológicas, são exemplos os pomposos murais do MRPP, Movimento reorganizativo do partido do proletariado, são o novo suporte de comunicação visual de maior visibilidade, de influência maoista, e os cartoons dos artistas: João Abel Manta, Augusto Cid, João Martins, Luís Miranda, Samuel Torres Carvalho, entre outros, reveladores dos valores da revolução, tendo a iconografia recuperado a expressão neo-realista. Na área da fotografia muitos 
foram os anónimos que participaram na cobertura do processo revolucionário. Dos artistas mais conceituados destacam-se: Eduardo Gageiro, Alfredo Cunha, Marcelino Vespeira, Sebastião Rodrigues, M.H. Vieira da Silva, tendo todos eles contribuído para o engrandecimento da expressão visual e da historiografia portuguesa pós revolução.

O património arquitetónico continuou a degradar-se e a própria arquitetura é paupérrima, com a condescendência das autarquias, que vivem culturalmente num estado latente. Promoveram-se algumas mostras temáticas, exposições retrospectiva, muito pela conjuntura política e pela situação social em que o país vivia, destas destacam-se algumas exposições realizadas pelo SNBA (1975), prisão política, tortura e pena de morte. Divulgaram-se artistas, dinâmicas, referencias, estilos, praticas e intenções... Portugal participa numa série de exposições de arte contemporânea: Paris, Roma, Madrid, Londres, Munique, Brasil e Barcelona, este ciclo de exposições, simbolicamente, significa a abertura das portas internacionais (que estavam fechadas ao estado novo), já com a anuência de todos os artistas por não haver conotações politicas. Em 1977, na Galeria Nacional de Arte Moderna em Lisboa foi instalada uma grande exposição na área das artes plásticas, intitulada Alternativa zero, organizada por José Ernesto de Sousa (1921-1988) ${ }^{90}$

«Exposição poética e demagógica, aberta a vários horizontes de vanguarda, ela assimilou, refletiu e propôs o que era e seria possível no Portugal pós 25 de Abril, em lembranças de Kassel. «Alternativa Zero porque não há outra», disse-se na altura, e nessa exposição de contestação e de alegria ( « a coisa mais seria da vida» na citação de

\footnotetext{
${ }^{90}$ José Ernesto de Sousa exerceu uma vasta ação no campo artístico: artes visuais, cinema, teatro, jornalismo, rádio, crítica e ensaio. Como realizador, é reconhecido como um dos fundadores do chamado Novo Cinema (Dom Roberto-1962), filme que inaugura o movimento com Verdes Anos, de Paulo Rocha.
} 
Almada então feita), a exposição foi, ao mesmo tempo, uma espécie de bomba, de agente catalisador e de impasse duma situação incerta. Incerta de si própria e das suas improváveis possibilidades sociais- como verdadeiro e final símbolo do presente vivido na segunda metade dos anos $70 \ldots{ }^{91}$

Proliferavam as publicações humoristas como o olho vivo, riso amarelo ou gaiola aberta, publicações estas de humor viciante, libertino, facilmente interpretadas pelo popular. e também a caricatura política pela mão de alguns artistas como João Abel Manta, José de Lemos, Samuel Torres Carvalho, Vasco Castro, Augusto Cid entre outros caricaturistas.

A I bienal Internacional de Artes Plásticas de Vila Nova de Cerveira em 1978 promoveu e descentralizou e denunciou interessantes assimetrias.

Alguns artistas de continuidade como Júlio pomar, Joaquim Rodrigo, Mário Cesariny, Álvaro Lapa, Eduardo Batarda, José de Guimarães, António Sena e Paula Rego veem o seu trabalho duplamente reconhecido pelo mercado e pela crítica.

Nos anos 70 as actividades de grupo, devido à conjuntura social e política faz presenciar a partilha de objectivos sociais e artísticos e um maior numero de projectos colectivos.

Nesta década inauguram-se seis galerias de grande importância para a formação de artistas, difusão e comercio das artes plásticas. No Porto nasce a Zen em 1970 e a Módulo - Centro Difusor em 1975, em Óbidos em 1970 a Ogiva que tem um papel descentralizador, em ${ }^{91}$ FRANÇA, José-Augusto, Arte e sociedade portuguesa no seculo XX 1910-2000, Livros
horizonte 4 edição-2000, p.66 
Lisboa a Quadro e a Módulo Centro Difusor em 73 e 79 respectivamente.

A Revolução de Abril deixou-nos um notável legado artístico: iconografia partidária, cartoons, cartazes políticos, autocolantes e murais, embora poucos continuem vivos, fazem parte da memória deste povo. 


\section{4 Últimas décadas del siglo $\mathrm{XX}$-implicaciones $\mathrm{y}$}

consolidaciones / Últimas décadas do séc. XX - implicações e consolidações

A massa empresarial e cultural portuguesa adoptam novas dinâmicas no pós-revolução tendo sido os anos 80 fértil no aparecimento de galerias, no despoletar das industrias editoriais, na criação de algumas fundações, casas de cultura e centros culturais dinamizadores da arte e de actividades culturais.

Nas Artes plásticas dá-se o aparecimento e a ascensão de um conjunto de criadores (artistas de diferentes gerações e sensibilidades) e agentes culturais com relevo para a enorme Dinâmica cultural cuja acção foi de grande valia para a difusão e animação da cena artística portuguesa.

A exposição depois do Modernismo (SNBA, 1983) introduz o debate da temática do Pós Moderno. A arte portuguesa na pós modernidade enquadra a fotografia na área das artes plásticas e num contexto histórico artístico, esta afirma-se cada vez mais como uma ferramenta, seja numa orientação sociológica, intimista ou documental. 


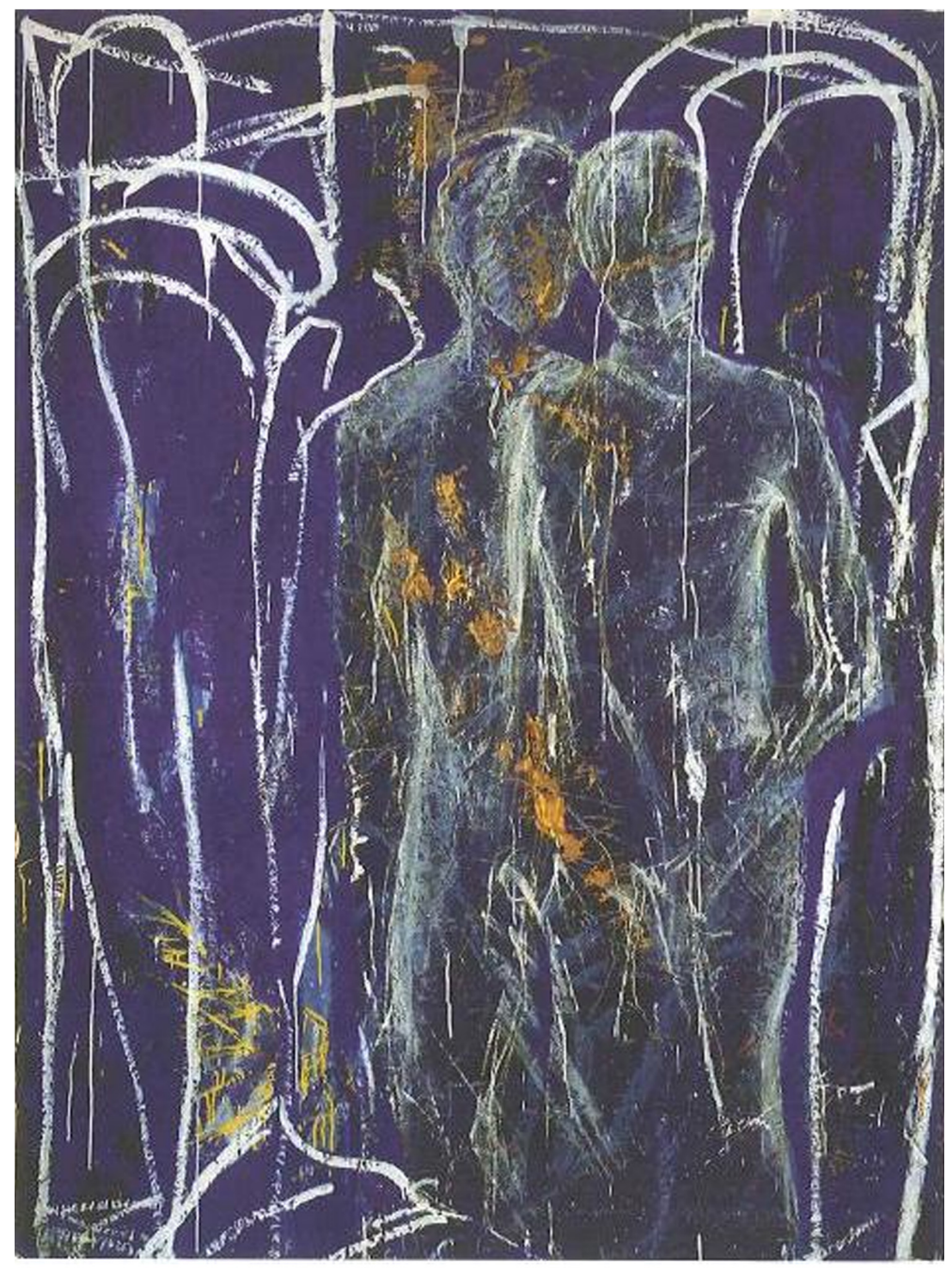

Figura 38. Pintura a óleo sobre tela de António Palolo, 1983 


\subsubsection{Los fenómenos emergentes /}

Fenómenos emergentes

«A rutura democrática do 25 de Abril de 1974 deu lugar, na sociedade portuguesa, a uma nova conjuntura cultural que possibilitou, nos anos $80, \quad \mathrm{o}$ aparecimento e o rápido reconhecimento de uma nova vaga de criadores e agentes culturais. No campo das artes plásticas, esta década caracteriza-se pela emergência de um vasto e diversificado conjunto de artistas com uma forte capacidade de afirmação do seu trabalho e uma presença cultural particularmente dinâmica. Estes artistas foram, por sua vez, acompanhados por uma nova vaga de agentes ligados ás artes plásticas, designadamente galeristas e críticos (como, por exemplo, Alexandre Melo e João Pinharanda), que contribuíram para dar á cena artística um animação e uma capacidade de difusão fora do comum, no que aliás acompanhavam a tendência internacional da década, no sentido de uma crescente popularidade das artes plásticas. ${ }^{92}$

Nos anos 80 inicia-se uma indústria editorial apoiada normalmente pelo mecenato, que acompanha o desenvolvimento do ensino da história de arte, geralmente pautada por interesses comerciais, salvo raras excepções. É lançado um diccionario de arte barroca e uma historia de arte portuguesa, embora uteis, são um tanto irregulares.

Nesta década (80) abrem novas galerias em Lisboa, os Cómicos, a Valentim de Carvalho e a Roma e Pavia, no Porto a Nasoni e a Pedro de Oliveira entre outras, estas são as mais emblemáticas.

${ }^{92}$ MELO Alexandre. Arte e Artistas em Portugal. Instituto de Camões - Portugal 2007 p.61 
O Centro de Arte Moderna é inaugurado em 1983 como já vimos, e foi-lhe atribuído o nome do primeiro presidente da fundação José de Azeredo Perdigão, assim, se designa como acrónimo CAMJAP. Este centro possui a maior colecção de arte em Portugal dos séculos XX e XXI, expõe parte do seu acervo de forma permanente e a partir d'ele organiza exposições temporárias, privilegiando a cultura visual não deixa de abraçar outras iniciativas como a música.

Julião Sarmento (N-1948) participa em 1982 e 1987, na Documenta de Kassel, Alemanha, registe-se que já tinha participado em 1977 na exposição Alternativa Zero, sendo o português que mais se distinguiu, consegue assim, ter uma certa projecção internacional, aliás desde sempre esteve em consonância com as estéticas avançadas da arte internacional.

A exposição do SNBA intitulada Depois do Modernismo (1983), é um evento que marca em certa medida a entrada da arte portuguesa na pós modernidade, importa a discussão pós moderna e a sua temática e na sua realização desenvolve outros actos no campo da arquitectura, moda, musica e dança. Ainda em 1983 a FCG liga-se a exposição XVII do Conselho da Europa, no âmbito dos descobrimentos portugueses do seculo $\mathrm{XV}$, foi um insucesso total tanto a nível de afirmação no quadro europeu como de bilheteira.

A galeria Cómicos inaugurada em 1984, a seguir á exposição Depois do Modernismo é uma marca da década pela afirmação e reconhecimento que obteve a nível internacional e pelo dinamismo artístico que imprimiu. A sua acção ficou relacionada à discussão e a temas no âmbito dos pós modernismo.

Em 1985 realiza-se em Lisboa a exposição Atitudes Laborais e no Porto os Novos Primitivos, têm um denominador comum, ambas participaram na elevação da multiplicidade estética e na promoção do debate teórico. 
A Fundação de Serralves nasceu em 1989 na cidade do Porto e resulta da parceria do Estado Português, instituições públicas e particulares. A fundação Serralves promove e dinamiza actividades que favorecem a cultura e em particular a arte, com especial enfoque no mundo académico dos mais novos. Alem de varias salas de exposições contem também um museu de Arte Contemporânea.

A numismática, à semelhança da filatelia, é um documento histórico e artístico de relevante importância pelas suas imagens, símbolos, divisas que permitem a reconstrução da história e da sua memória.

A execução de moedas exige um trabalho minucioso, moroso, elaborado e uma elevada qualidade técnica do seu desenho capaz de traduzir de imediato o conceito associado e a perpetuação da efígie. Com muita dedicação e criatividade, inúmeros desenhadores, gravadores, pintores, arquitectos, escultores, artistas plásticos contribuíram para a numismática portuguesa: José Simões de Almeida, Francisco dos Santos, Alves do Rego, João da Silva, Marcelino Norte de Almeida, Jaime Martins Barata, Euclides Vaz, Helder Baptista, José Cândido, A. Lucas, João Abel Manta, Armando Matos Simões, José Pedro Roque Gameiro Martins Barata, Dorita Castel-Branco, António M. Trigueiros, Valente de Carvalho, José Manuel Aurélio, Lagoa Henriques, Alberto Gomes, Jerónimo Cabaço, Clara Menéres, Irene Vilar, Isabel Carriço, Fernando Branco, António Marinho, Álvaro França, Alípio Pinto, Raúl de Sousa Machado, Paulo Guilherme d’Eça Leal, Jorge Vieira, Eloísa Byrne, João Duarte, Vitor Santos, José Simão, João Cutileiro, Fernando Conduto, Vítor Nogueira da Silva, Lima de Freitas, Espiga Trigo, José João de Brito, Joaquim Correia, Paula Lourenço e António Vidigal, Arnaldo Lourenço Fragoso, Norte de Almeida, José Rosa, Arnaldo Fragoso e Jerónimo Cabaço, Sousa Machado; Alfredo da Conceição; Helder Batista; Espiga Pinto; Euclides Vaz; Nogueira 


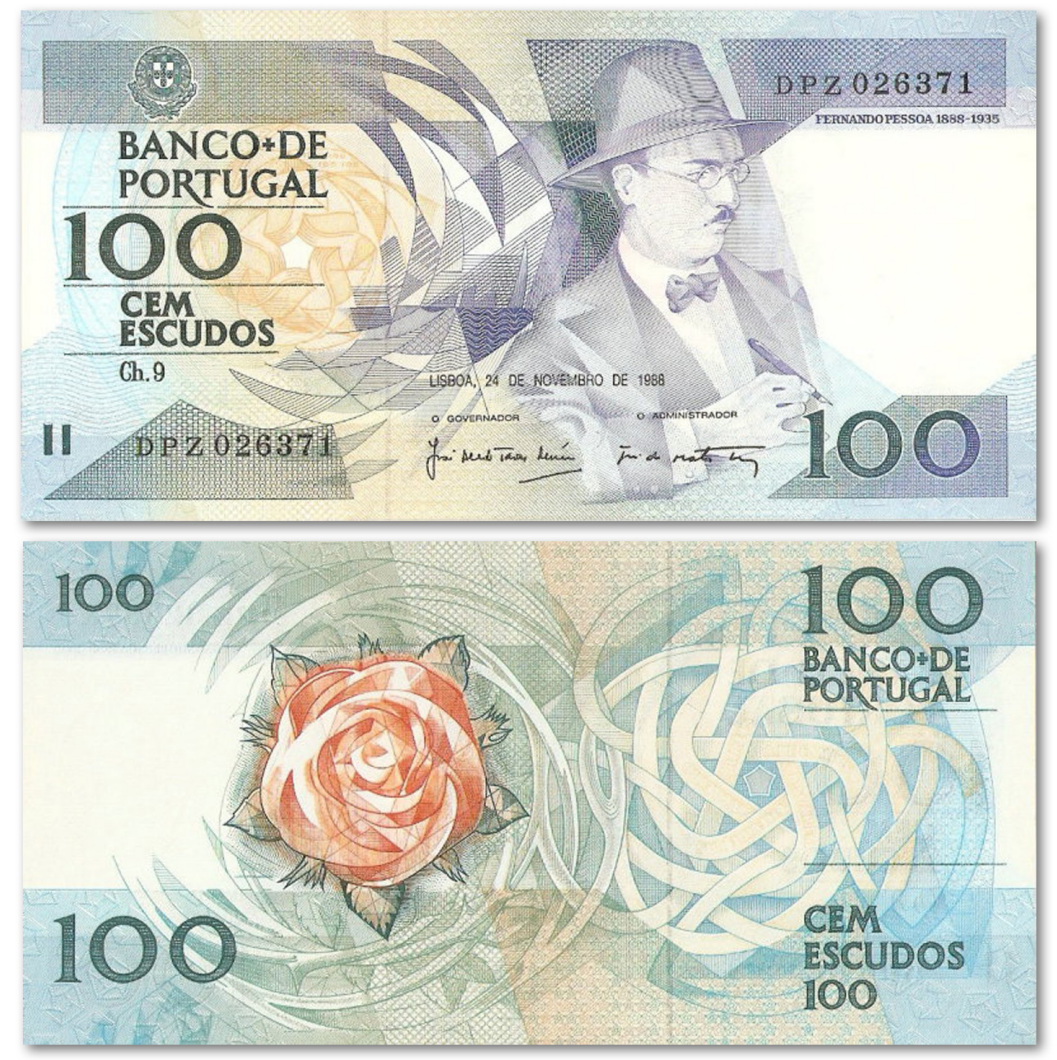

Figura 39. Nota 100 Escudos do Banco de Portugal, por Luís Filipe de Abreu 
da Silva; Alípio Pinto; Álvaro França; José Bandeira; Delgado Nunes; Lima de Freitas; António Cândido, etc.

Em 1998 foi iniciada a construção do centro cultural de belém (CCB), que objectivava a infraestrutura arquitetónica para instalação da presidência portuguesa da União Europeia (em 1992) e simultaneamente conter um núcleo com caracter dinâmico de actividades culturais e lúdicas. A localização da construção recaiu no local da Exposição do Mundo Português de 1940. Também pela carga simbólica associada aos descobrimentos, sendo implantado no lugar dos pavilhões Aldeias portuguesas e Portugueses no mundo. O CCB contém um Museu de Design cujo acervo constam obras desde os anos 30 até à actualidade, a partir de 2006 só funciona em regime temporário para grupos organizados e com pré marcação.

\subsubsection{Fotografía - ruta y participaciones /}

Fotografia - percursos e participações

Desde cedo se percebe que a imagem não só ilustra as palavras como pode ser um elemento narrativo, fenómeno muito bem aproveitado pelos fotógrafos de imprensa nos anos 20. No início do séc. XX, em Portugal, popularizou-se a produção da fotografia devido ao processo tecnológico ser mais simples e mais acessível economicamente. Desenvolve-se no campo fotográfico o amadorismo à semelhança do que se passa no estrangeiro, assente na ocupação dos tempos livres e no ócio. O Estado Novo percepciona desde logo, a importância da imagem como meio mediático privilegiado, para fins propagandísticos, facto que contribui para a evolução da fotografia. 
Ao serviço da propaganda e fazedor de opinião são articulados os domínios do design, da fotografia e das Belas Artes em geral. Para além do fotojornalismo todos os campos no domínio da fotografia eram hipóteses para acção do governo o que cria uma dinâmica de desenvolvimento fundamental para a institucionalização da fotografia em Portugal.

No I Salão dos Independentes de 1930 é por ventura a única mostra ligada ao Modernismo Português, pela obra fotográfica de composições vivas cujos autores são: Branquinho da Fonseca e Edmundo de Bettencourt.

Em 1931 e pelo facto de a fotografia ser enquadrada corporativamente na organização do regime, é criado o Grémio Português da Fotografia (GPF), com bastante relevo na definição dos termos que permite ser portador da carteira profissional, e na articulação de outros aspectos no âmbito da fotografia como o amadorismo.

A acção de AF, secretário do SPN é preponderante na relação da dinâmica cultural e política emergente.

Em 1932 inaugura-se o I Salão Nacional de Arte fotográfica com a participação dos fotógrafos amadores e profissionais. Porém, com a influencia e afirmação dos fotógrafos profissionais no regime, restringe-se o acto expositivo dos fotógrafos amadores ao salão, paradoxalmente, o regime enquadra também a produção fotográfica amadora.

O salonismo pela sua importância transpõe a esfera do estado projecta-se e internacionaliza-se. O salonismo fotográfico manteve-se no topo desde os anos 30 até finais dos anos 60, era praticado por amadores e identificam-se pela corrente ideológica do regime. A obra produzida concursava nos salões numa competição nacional e por vezes internacional. 
O SPN publica o catalogo Portugal 1934, cujas obras, quanto à sua qualidade são consideradas heterogéneas, mas integram muitos recursos da vanguarda artística que lhe concede virtuosismo e complexidade ao produto final.

Acontece também em 1934 a I Exposição Colonial Portuguesa, cuja cooperação fotográfica e o seu sucesso, resulta na prática sistemática da requisição dos fotógrafos pelo poder para semelhantes eventos. O regime organiza também em 1937 o I Salão Internacional de Arte Fotográfica que acaba por ter enorme importância na circulação dos fotógrafos, nas experiências pessoais de cada um e no desenvolvimento das suas obras. Todavia, o verdadeiro empreendimento dá-se em 1940 com a Exposição do Mundo Português, nela se exprime o maior êxito da propaganda editorial, não só pela sua fortificação mas pela coerência das temáticas na construção de uma imagem nacional própria que virá a condicionar a fotografia oficial do estado, como aquelas de cariz mais político.

Em 1946, a I Exposição Geral de Artes Plásticas, advém do panorama cultural do regime no pós guerra, por ter ganho algum relevo e certa inerência.

O Neo-Realismo tem uma maior expressão em 1946, quando os fotógrafos neo-realistas ganham as eleições para a direcção da SNBA, mobilizando-se através das Exposições Gerais das Artes Plásticas (EGAP) procurando demarcar-se dos salões artísticos nacionais.

$\mathrm{Na}$ década de 50 emerge um movimento associativo cultural. Também se manifesta no campo da fotografia com o aparecimento dos foto-Clubes que serão os responsáveis pela obra fotográfica dos anos 50. São criadas três grandes associações em 1949, 50 e 51, Grupo Câmara de Coimbra, Foto-Clube 6x6 de Lisboa e Associação Fotográfica do Porto, respectivamente. A evolução 
destas associações assentou em grande parte na conjuntura cultural do pós-guerra e sua dinâmica, o desfasamento cultural e artístico do governo e a propagação das máquinas fotográficas que elevam o número de usuários. O aparecimento dos foto clubes promove o diálogo em torno da arte fotográfica, os modelos associativo e do salão fotográfico.

Entre 1946 e 1956, a EGAP realiza apenas três exposições com conteúdo fotográfico.

No campo da fotografia Surrealista Fernando Lemos foi o principal protagonista. Desde o pós-guerra que este movimento se vem estabelecendo, mas, só em 1949 é que a sua acção se percebe, quando o neo-realismo entra em rota de rotura. Fernando Lemos obtém através da sua obra uma expressão fotográfica única, com a particularidade e importância de no mesmo acto expositivo agrupar a fotografia com a pintura, tornando o produto mais global e mais próximo do surrealismo, não só pela sua temática mas sobretudo pela metodologia. Fernando Lemos, pela sua obra, corrobora a tese de que os trabalhos mais criativos foram os individuais, fora da esfera do associativismo. As obras individuais foram as mais criativas, não só por estar à margem do associativismo, mas também por não se constituírem no plano geral da fotografia nacional nenhuns movimentos vanguardistas, nem se produzirem pólos que importassem as normas do pensamento fotográfico internacional.

Gerald Castello Lopes (1925-2011) sendo uma figura de destaque, no campo fotográfico, realizou e participou num grande número de exposições individuais e colectivas desde 1956, ano que inicia o seu percurso. Castello Lopes com a Exposição Retrospectiva e inédita, na galeria Ether, em Lisboa, em 1982, conseguiu mudar o panorama nacional fotográfico quanto à circulação e prática da fotografia. 
Victor Palla e Costa Martins editam a obra Lisboa, Cidade Triste e Alegre, em 1959, vindo a ser considerada uma das maiores obras fotográficas portuguesas e o único livro português de fotografia a ter reconhecimento internacional. Este livro contém o registo fotográfico $(\mathrm{P} \& \mathrm{~B})$ da mundanidade dos bairros históricos de Lisboa acompanhado por poesia de grandes autores como Pessoa, Sena, Miguéis, O’Neill, Moura-Ferreira, etc.

Victor Palla foi coevo de Castello Lopes conjuntamente com Costa Martins, Carlos Afonso, Carlos Calvet e António Sena da Silva. António Sena da Silva, foi um fotografo cuja notoriedade e reconhecimento publico só é obtido após a realização da exposição de um conjunto de fotografias relativas aos anos 56/57 na galeria Ether, em Lisboa no ano 1987 e em Serralves no ano 1990.

Os fotógrafos dos anos 70 valorizaram principalmente os aspectos formais derivando daí uma postura artística mais clara e mais empírica. O salonismo foi muito hostilizado por estes artistas.

Nos anos 80 é grande a integração da fotografia na área das artes plásticas, a relação entre a arte e a fotografia cada vez é mais próxima. No campo amador dá-se a massificação das máquinas instantâneas (Polaroid) projectando-se a fotografia de família e ocasional.

O desenvolvimento da arte em Portugal ao longo do seculo $\mathrm{XX}$ teve como adversidades as políticas dos 48 anos de regime ditatorial com o seu disfarçado programa de alfabetização, a censura, os seus "objectivos”, a situação socio económica e cultural do povo português. Porem, a participação dos seus agentes culturais e a contribuição dos artista com o seu labor, a versatilidade, a multidisciplinaridade, o poder criativo participação individual e colectiva, através das suas manifestações e realizações artísticas, o legado que ficou poder-se-á afirmar que a arte esteve sempre 
presente ao longo dos tempos: fluiu, aconteceu, interagiu, formou culturalmente o povo português. 


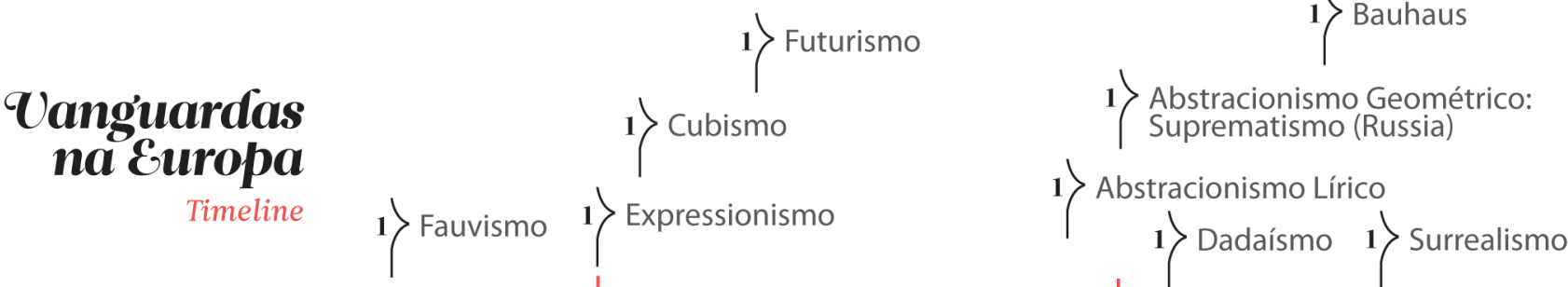

1) Construtivismo

Tordugal
Portas em
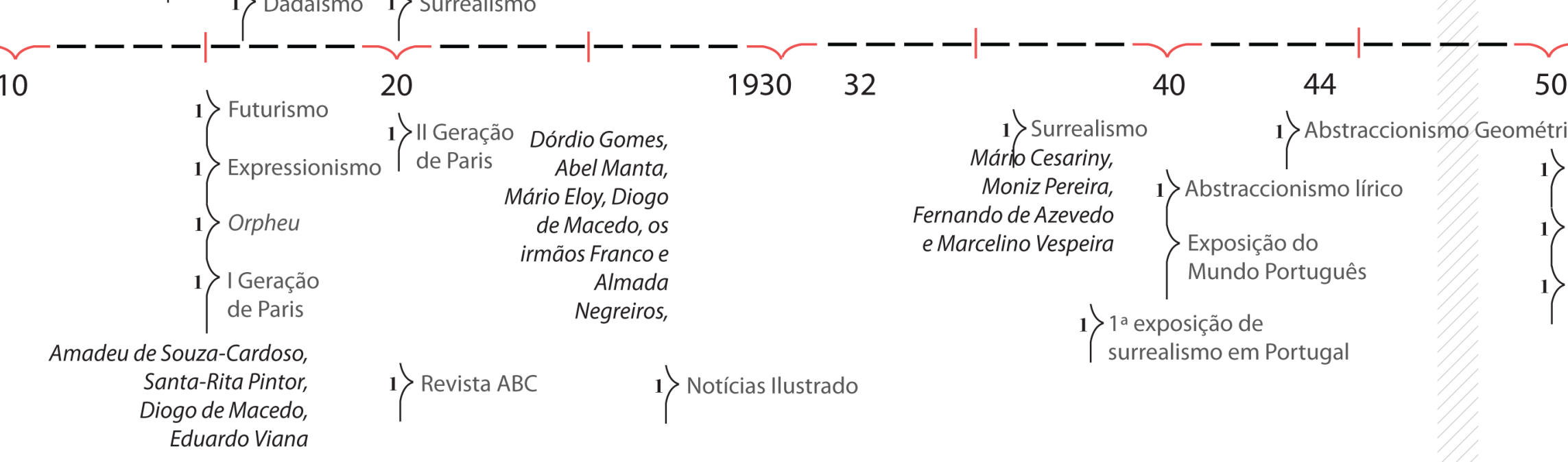

50

20

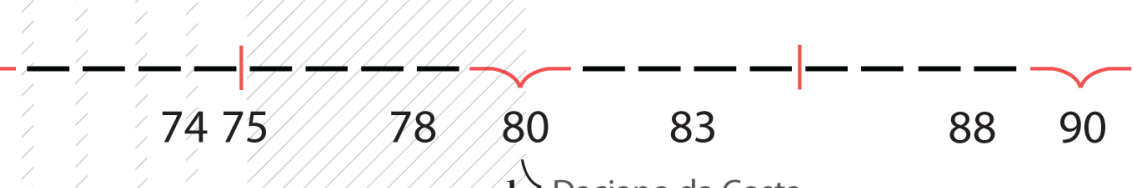

-

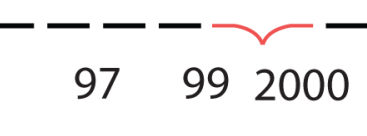

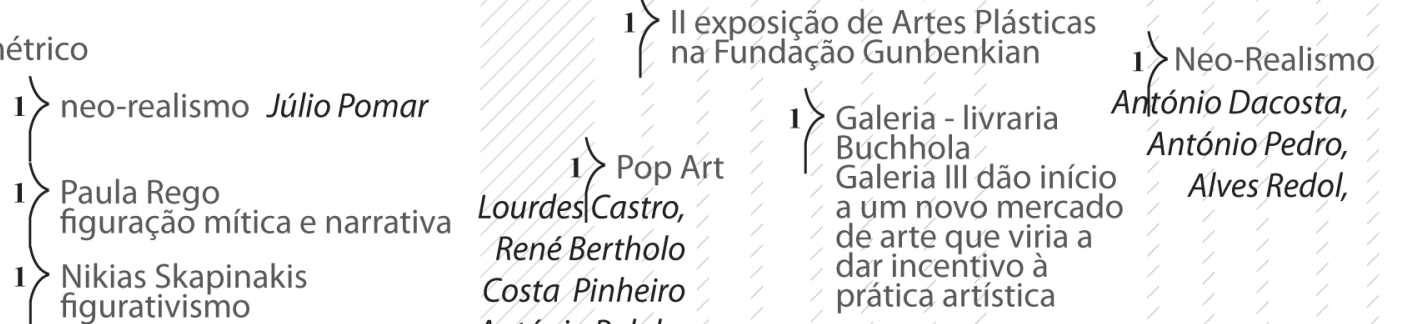

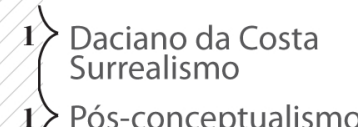

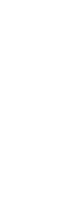

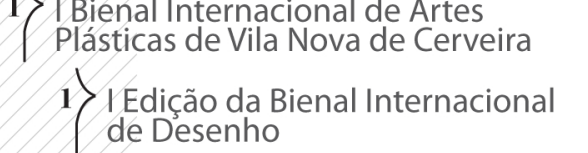

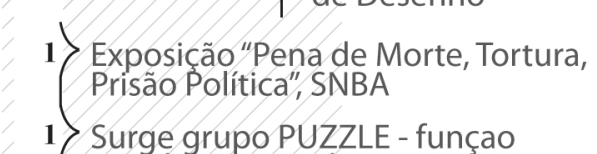 1) Surge grubo puzZZE- funná}

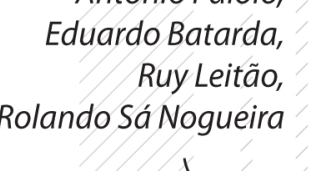

1) "nouveauur realism"
1) op Art Artur Rosá,
1) minimalismo

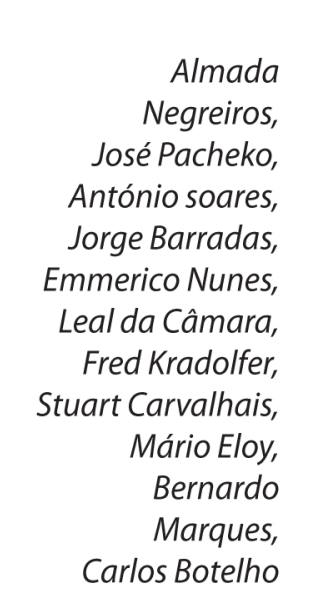

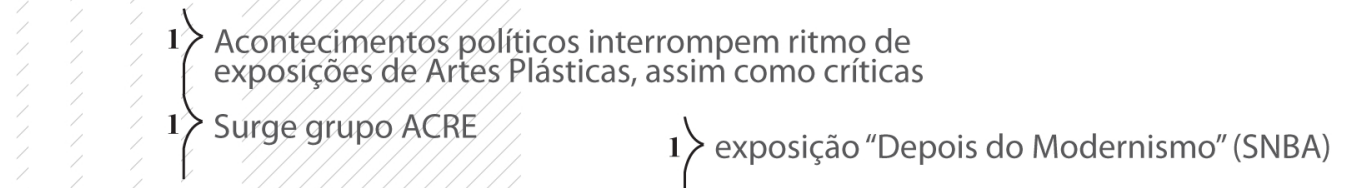

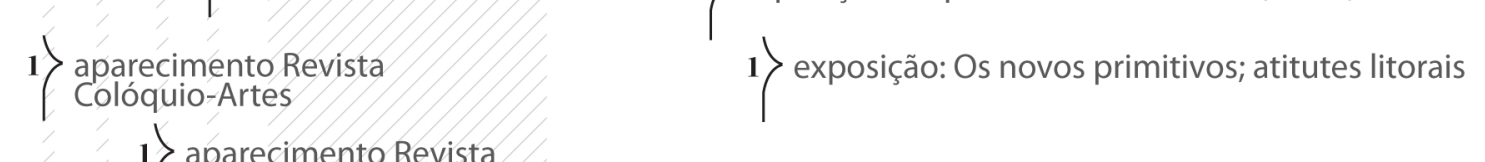
1) aparecimento Revista

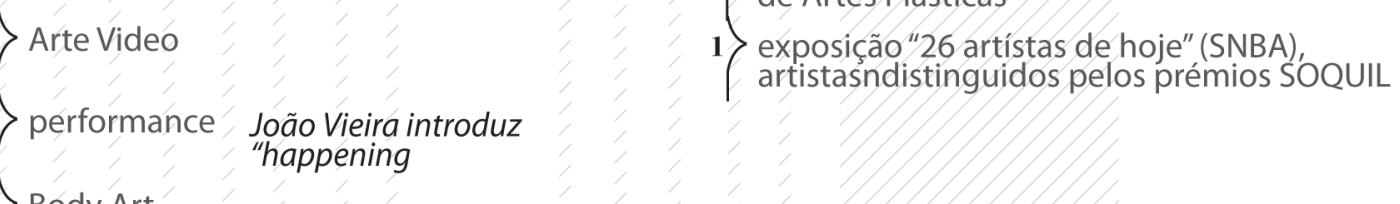




\title{
Capítulo 4: Obra de Paulo- Guilherme D'Eca Leal \\ / Obra de Paulo-Guilherme D’Eça Leal
}

\begin{abstract}
$\ll(\ldots)$ a versatilidade de Paulo-Guilherme começa na sua cabeça para, depois, passar para as suas mãos. Porque, no fundo, PauloGuilherme é um "Faz-Tudo" qualificado que pega na arquitectura, na decoração, na pintura, no desenho, na investigação esotérica, na geometria aplicada, com o ar de quem deita bolas ao ar e as apanha com as mãos com o sorriso de quem se não leva a sério.» ${ }^{93}$
\end{abstract}

Desde muito cedo que PG inicia a sua obra. Com uma obra tão vasta em tão variados domínios e com tantas mudanças geográficas, torna-se difícil organizar cronológica e espacialmente o inventário de toda a sua produção artística. Segue-se uma tentativa de efectuar uma súmula das actividades que desenvolveu na sua vida tão intensa e profícua, o que se infere ser uma tarefa de difícil estruturação lógica. Metaforicamente, é a arrumação de uma casa demasiado grande, mas há que o tentar dentro do possível. Colabora com vários jornais e periódicos de Lisboa, trabalha no Estúdio de Artes Gráficas, Arquitectura e Decoração de Carlos Ribeiro. Dirige gráfica e literariamente jornais como Portugal Ilustrado, Olá, Século de Domingo, Século Ilustrado. Colaborou assim de modo regular com quase todos os jornais diários e periódicos de Lisboa, publica ilustrações bem como elabora inúmeras ilustrações e capas

${ }^{93}$ BAPTISTA, Alçada, "O Universo Plástico de Paulo-Guilherme", Catálogo Paulo-Guilherme D'Eça Leal D'Etecetera e Tal, CML, Lisboa, 2000, p.211 
de livros para diversas editoras, Clássica Editora, Ática, Portugália Editora, Estúdios de Cor, Publicações Europa-América, Editora Ulisseia, Hugin, Arcádia, etc.

Ao longo da sua carreira foi premiado por diversos trabalhos em diferentes áereas: $1^{\circ}$ prémio promovido pelo Secretariado Nacional de Informação do Cartaz Turístico Portugal Welcomes You, (oito vezes consecutivas); $1^{\circ}$ Prémio do Selo de Europa para Portugal, $1^{\circ}$ prémios para o Cartaz para a Ópera de Barcelona, para a Campanha de Vacinação da Cruz Vermelha, para o Jazz de Cascais, Cartaz de Sintra, o Cartaz Concurso Self-Service, para o depliant Évora, para o desenho de estampagem de tecidos Studio Babuíno Roma. Na arquitectura ganha o $1^{\circ}$ prémio do concurso Monumentos aos Pioneiros da Aviação.

Fotografou algumas reportagens internacionais e dedicouse intensamente à fotografia publicitária, podendo destacar-se as extensas campanhas: Sacor - Companhia Portuguesa de Petróleos e Woolmark (importante empresa têxtil).

Durante alguns anos colaborou em vários programas de rádio, produzindo e realizando Uma Vez por Semana.

Tem pinturas, desenhos, tapeçarias e esculturas em dezenas de colecções particulares, em Portugal, Angola, Moçambique, Espanha, França, Itália, Inglaterra, América do Norte e também no Brasil. Neste último salientam-se 16 pinturas de grandes dimensões para as sucursais do Banco Bozanno e Simomsem. No Brasil encontra-se também representado nas colecções particulares de: Afonso P. De Magalhães, Caetano B. Da Veiga, Joacy Goês, Karl Neuman, Carlos Jung, Arthur Campos, Arice Buschman, Victorina Sagboni, José Campos, Nagem Nahas e Winfred Blum.

Realiza vários painéis/murais, tais como: Pintura no átrio do Cinema Paris, Lisboa (6x3m); Pintura na Messe dos Oficiais da GNR (8x4m); Pintura no Hotel Florida (4x2,50m); Biombo pintado 
para o Restaurante Folclore (11x2,50m); Pintura no Casino de Espinho; Pintura na residência de Rita Shmolevitch (6x3m); Pintura em Café em Sintra $(3 \times 3 \mathrm{~m})$; Pintura no Átrio do Hospital de Santarém (7x2m); Pintura na sala de embarque $\left(4^{\circ}\right.$ e $5^{\circ}$ piso $)$ do Aeroporto de Lisboa $(25 \times 3,65 \mathrm{~m})$ e $(60 \times 3,65 \mathrm{~m})$ respectivamente.

Ao longo da vida realizou exposições individuais e colaborou em algumas colectivas.

Paulo Guilherme realizou exposições individuais: Secretariado Nacional de Informação (2 vezes); Junta de Turismo da Costa do Sol, Estoril (2 vezes); Galeria Raymond Duncan em Paris; Estúdio Babuino em Roma; Ilha da Madeira - Funchal; Décor em Lisboa; Sociedade de Belas Artes; Mansarda em Lisboa; no seu próprio estúdio (2 vezes) e colaborou em algumas colectivas: Salões de Artes Plásticas da SNBA; Galeria de Março; Exposição Arte Nova; Salão de Arte Moderna no Secretariado Nacional da Informação. Fez no Rio de Janeiro uma exposição individual na galeria Nouvelle Dezon, outra na galeria Acaiaca, em Curitiba e ainda no museu de arte contemporânea no Panamá. A última foi em 2000 no Palácio Galveias, por iniciativa da Câmara Municipal de Lisboa - exposição retrospectiva de todo o seu trabalho intitulada Paulo-Guilherme, Etecetera e tal.

Trabalhou em feiras comerciais e industriais e colaborou na execução dos vitrais de Almada Negreiros na capela da Marconi.

Fez selos (Europa 1963; X Aniversário da TAP 1963; $1^{\circ}$ Congresso Nacional de Trânsito 1965; Cinquentenário da Força Aérea 1965, etc.); moedas (Descobrimentos Portugueses - Diogo Cão 1988; Navegação Astronómica no Atlântico; Navegações para o Oriente; O milénio do Atlântico (1999), etc.) e medalhas (Congresso Internacional das Casas de Moedas; Fundação do Reino de Portugal - Batalha de Ourique e Almada Negreiros - Centenário de nascimento). 
De forma intensiva, dedicou-se à decoração comercial, onde realizou: boîtes (O Ferro Velho, O caixote, A Coutada, ChequeMate, o Batõ, Lado-a-Lado, Yê-Yê, O Inferninho, O Forno, O Caruncho, La Paloma Grija (Roma), Portinhola, Vip's, Boîte do Casino de Espinho, Café Concerto Cabaretíssimo (de que foi proprietário), Forte Velho, A Nódoa); bares (Borsalino, Três Porquinhos, Snob (de que foi proprietário), On the Rocks) e restaurantes (A copa, A Ronda, O Grilo, O Snobíssimo, de que foi proprietário). Projectou e decorou boutiques: Delfieu, Vanitas, Pompadour do Porto, Pompadour de Cascais e Migacho.

Fez também a decoração de algumas casas particulares, destacando-se entre estas: Moradia de Dr. Manuel Vinhas, em Monsaraz (com Jorge Matos Chaves), Moradia de António Cabrita, Apartamento de Beatriz Elias, Apartamento de João Raposo de Magalhães, etc. Reconstruiu e decorou o Iate Le Coriphéne originalmente pertencente a Alain Lombard e transformado o Dr. António Lereno, administrador do Banco-Franco-Portugais. Decorou o Iate Red-Pirat.

Dirigiu durante alguns anos um gabinete de design de padrões para tapetes da Companhia União Fabril (CUF).

Projectou alguns centros comerciais, tais como: Apolo $70 \mathrm{em}$ Lisboa; Galerias da Praia da Rainha em Cascais, também o Stand N.S.U. e Stand Citröen. Realizou a decoração da Cervejaria Portugália - Cais do Sodré e um grande painel de azulejo para a Cervejaria Portugália no Centro Comercial Colombo. Participou na decoração do Hotel Alvor no Algarve e também no Marina Hotel em Vilamoura. Na obra da decoração do Hotel Alvor do Algarve está também compreendida uma tapeçaria e um relevo em tijolo refractário. Projectou igualmente a ampliação e decoração do PalmBeach em Cascais e do restaurante Bachus em Lisboa. Em 1973 realiza todo o projecto de arquitectura e decoração da Sede do 
Banco Pinto \& Sotto Mayor e entre 1983 e 1993 faz sucessivos projectos de ampliação, volumetria arquitectónica e de decoração no Aeroporto de Lisboa.

Como cenarista, trabalhou em três filmes: Sangue Toureiro, Perdeu-se um Marido, Dois Dias no Paraíso. Realiza perto de uma dezena de filmes de publicidade. Desenha cenários e figurinos para várias peças de teatro: Quem tem medo de Virginia Woolf?, Look Back in Anger, Verão e Fumos, A Taça de Ouro, O Amor, o Dinheiro e a Morte assim como para muitas revistas musicais, tendo produzido em Cascais e no Rio de Janeiro o espectáculo Cabaretíssimo.

Para alguns ballets concebeu cenários e figurinos (Grupo VerdeGaio, Grupo da Fundação Gulbenkian, Grupo de Águeda Sena e Fernando Lima).

Em 1986 produziu e realizou a curta-metragem O Alquimista e, em 1988, o filme de longa metragem Iratan e Iracema, Os Meninos Mais Malcriados do Mundo (Prémio Palma de Ouro do Festival de Cinema da Figueira da Foz).

Realizou uma tapeçaria para os escritórios de Nagem Nahas, São Paulo $(5 \times 2 \mathrm{~m})$, assim como para residência $(1,20 \times 2 \mathrm{~m})$; Sede do Banco Real de S. Paulo (Curitiba) $(2 \times 1,5 \mathrm{~m})$. Realiza muitas outras tapeçarias: Hospital de Santarém; Pantextil; Clube da Marina de Vilamoura; Restaurante Internacional do Aeroporto de Lisboa; 3 Lounge da Ana no Aeroporto de Lisboa; salão Nobre do Aeroporto de Lisboa. Realizou uma série de seis tapeçarias para as sucursais do Banco Mercantil de São Paulo, Brasil; Hotel Alvor no Algarve (3x2m) e um relevo em tijolo refractário (12x6m).

No campo da Literatura, publicou livros como Dilúvio de Quéops (Novas comunicações sobre a antiga ciência egípcia), O segredo, o poder e a chave (um tratado de relações matemáticas e proporções geométricas), o romance As sete portas de Arsenise e 
dois livros de poemas: Ainda é cedo para ser tarde e Depressa que o verso foge. Estes últimos editados em $\mathrm{CD}$, declamados pelo autor. Deixa por terminar um livro já em fase de conclusão Da geometria se faz Pedra e muitos outros projectos que tinha em mente como o livro sobre o seu pai intitulado Um Arlequim chamado Olavo. 
4.1 Ilustración / Ilustração

Começa a "trabalhar semi-profissionalmente" muito cedo: aos 11, 12 anos de idade já tinha muitas ilustrações publicadas.

Aos 12 anos, realiza a sua primeira colaboração regular como ilustrador no Semanário Acção!, o Diário Popular, o Diário de Notícias, O Século.

A ilustração começa de forma natural e incontornável pela prática assídua do desenho. As influências da sua infância, atmosfera artística dos primeiros modernistas, aproximam as suas ilustrações pela pureza do traço e elegância às ilustrações de Almada. Nas ilustrações de PG encontra-se uma manifesta avontade do desenho de traço virtuoso e descritivo.

Em 1971, PG comemorou orgulhosamente as 3 mil ilustrações publicadas. Neste incrível volume de trabalho, encontramos ilustrações inesquecíveis como: as que vivem na colecção Mil e uma noites, editorial Estudios da Cor, de Aquilino Ribeiro. Ilustrações estas que fizeram par com outras de ilustradores relevantes como Alice Jorge, Bartolomeu Cid, Infante do Carmo, Júlio Gil, Luís Filipe de Abreu, Manuel Lapa e Maria Keil; As mil e uma noites da Edição Portugália; As mais Belas Histórias da Medicina da Editora Arcádia; Romance EDA de Eduardo Azevedo com ilustrações a acompanhar cada capitular e páginas preenchidas com desenho tipográficos; a revista brasileira A Moreninha um romace de J.M. de Macedo da Editora Etecetera; História de um quebra-nozes de Alexandre Dumas edições Tempo de Fantasia; etc. 


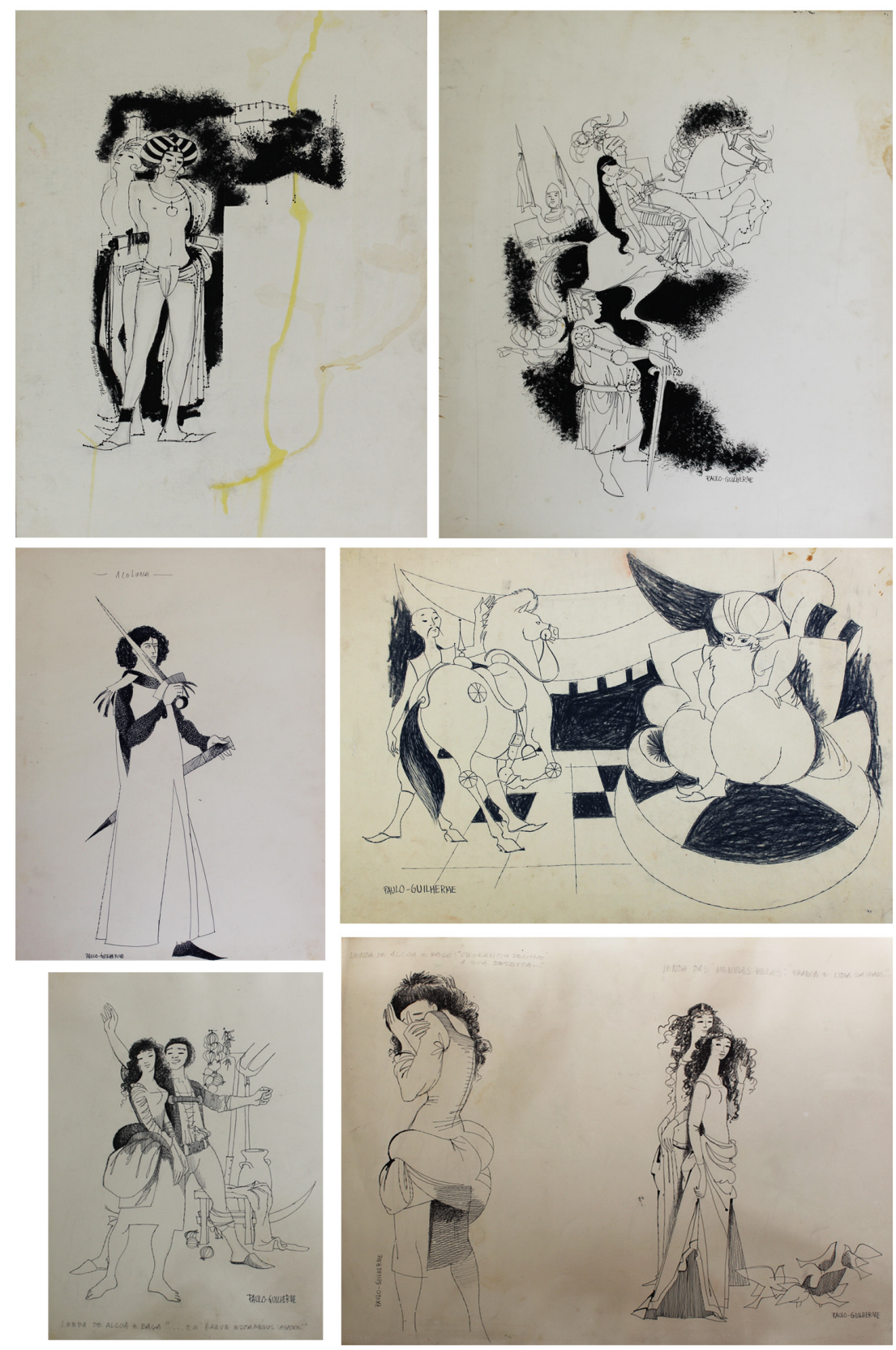

Figura 40. Conjunto de estudos de ilustrações 

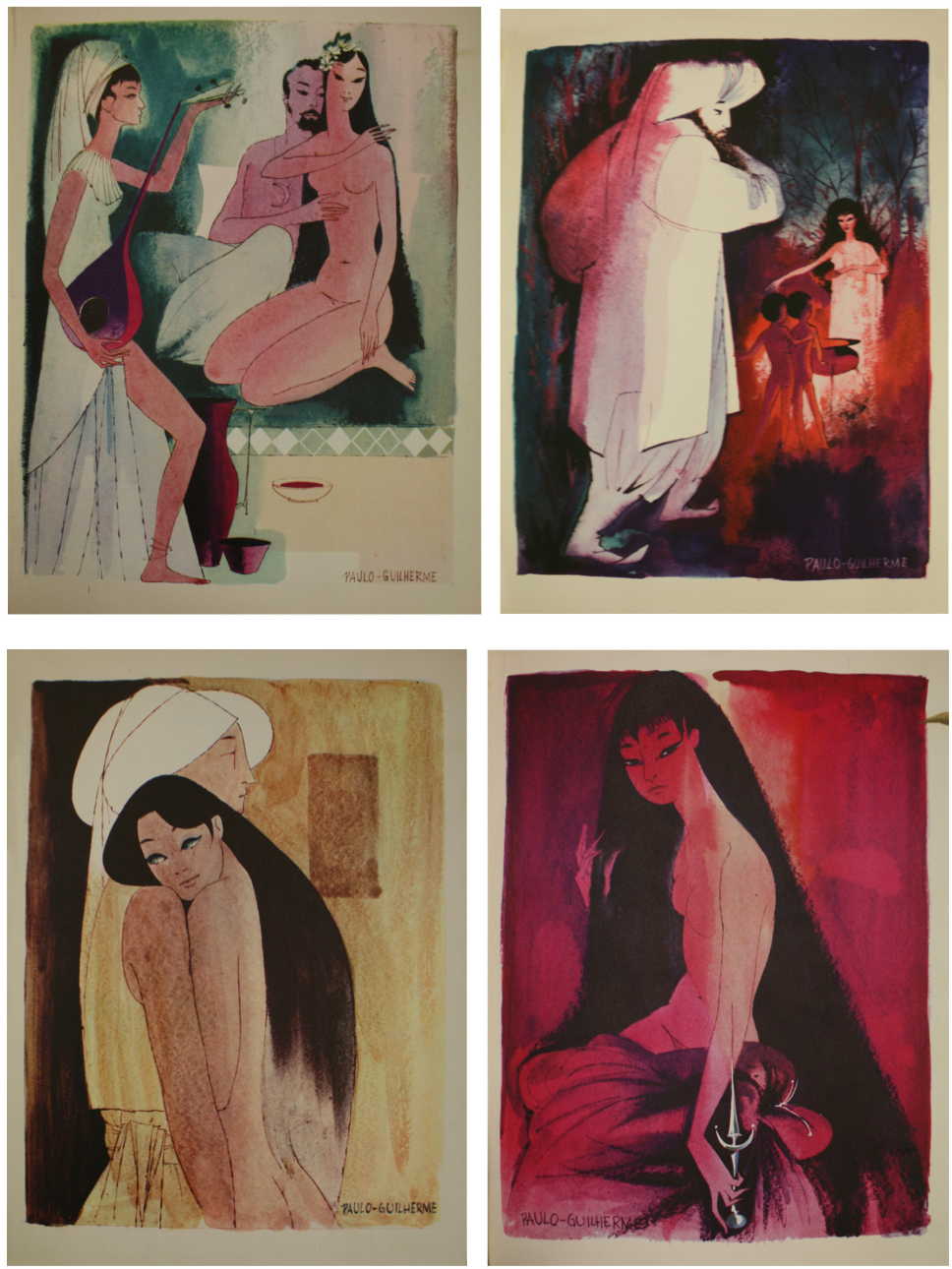

Figura 41. Conjunto de estudos, ilustrações do livro Mil e uma Noites 


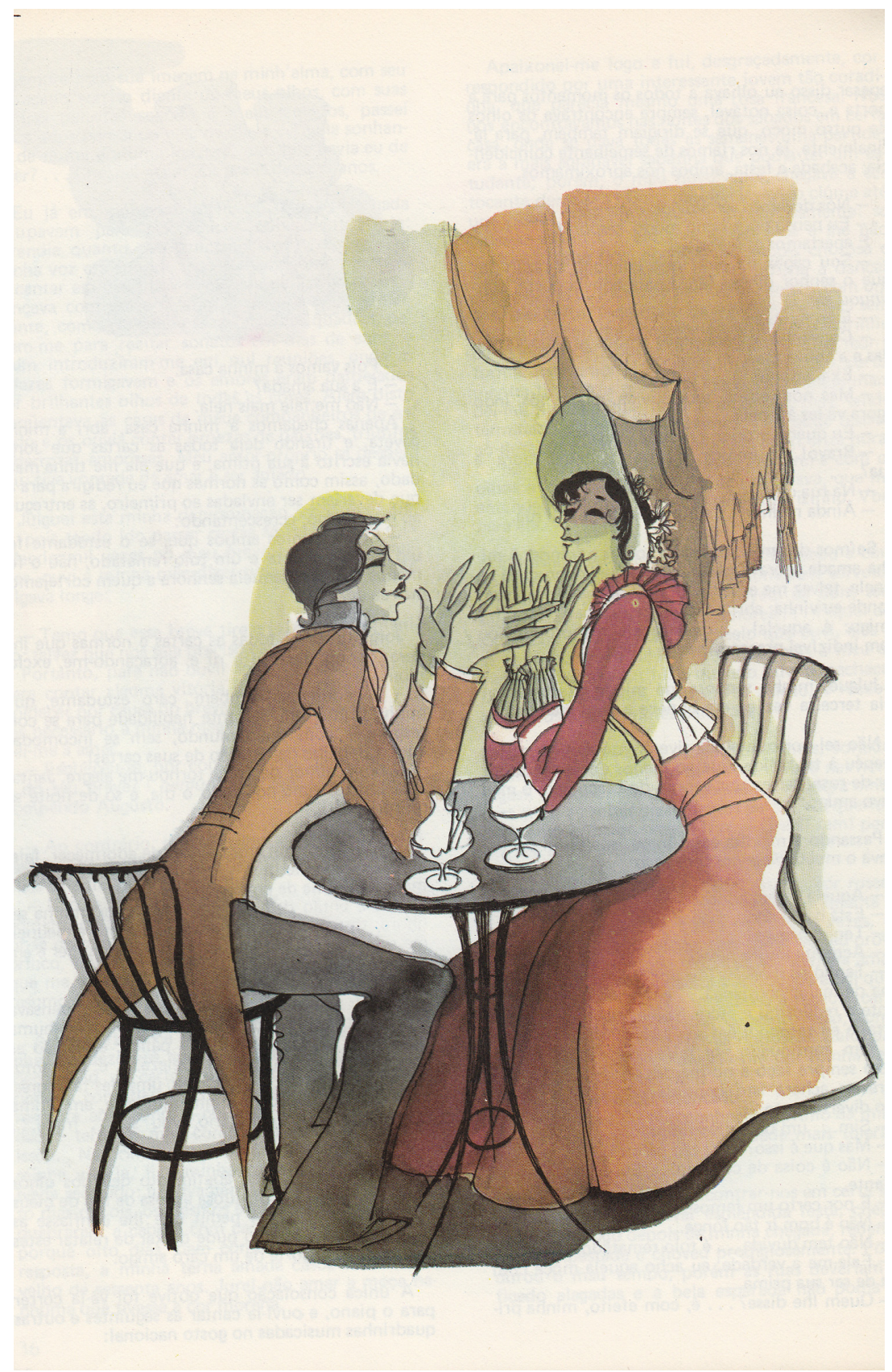

Figura 42. Ilustração, Revista Moreninha, Brasil, 1975 


\subsection{Artes Gráficas / Artes Gráficas}

PG colabora de modo regular com quase todos os jornais diários e periódicos de Lisboa. Dirige gráfica e literariamente jornais como Portugal Ilustrado, Olá, Século de Domingo, Século Ilustrado.

Aprende o ofício das artes gráficas trabalhando no Estúdio de Artes Gráficas, Arquitectura e Decoração de Carlos Ribeiro. Colobora também com agências de publicidade como a APA, PIC realizando muitos anúncios para jornais, cartazes, etc. Faz inúmeros cartazes publicitários para marcas como Linde, Lindola, Lusalite, Marconi, Bel Hair, Natterman, Compal, Companhia de Seguros império, etc, bem como outras peças gráficas tais como desdobráveis, sinalética, capas de Vinis, indentidades corporativas, etc.

«Paulo-Guilherme colaborou intensamente no verdadeiro desígnio nacional em que se tornou a promoção do Turismo, com folhetos, cartazes e publicidade comercial (...) como a Predial Ruicar, a Companhia de Seguros Fidelidade ou o chá Nattermann. A gramática visual de Paulo-Guilherme era variada, desde a rudeza essencial de um Savignac até ao traço virtuoso e descritivo da sua prática de ilustrador editorial.» ${ }^{94}$

O criador do logotipo da Contraponto foi o PG. O Contraponto: Edições e Distribuição foi uma editora criada por Luiz Pacheco, em 1950. Esta editora tinha por objectivo denúnciar a situação política, social e literária, motivada pela luta contra as instituições e pela ideia de combate ao regime em vigor.

\footnotetext{
${ }^{94}$ SILVA, Jorge. Paulo-Guilherme, Colecção D, Silva Designers (coord.) Imprensa NacionalCasa da Moeda, S.A., 1'edição setembro 2012, p.70
} 

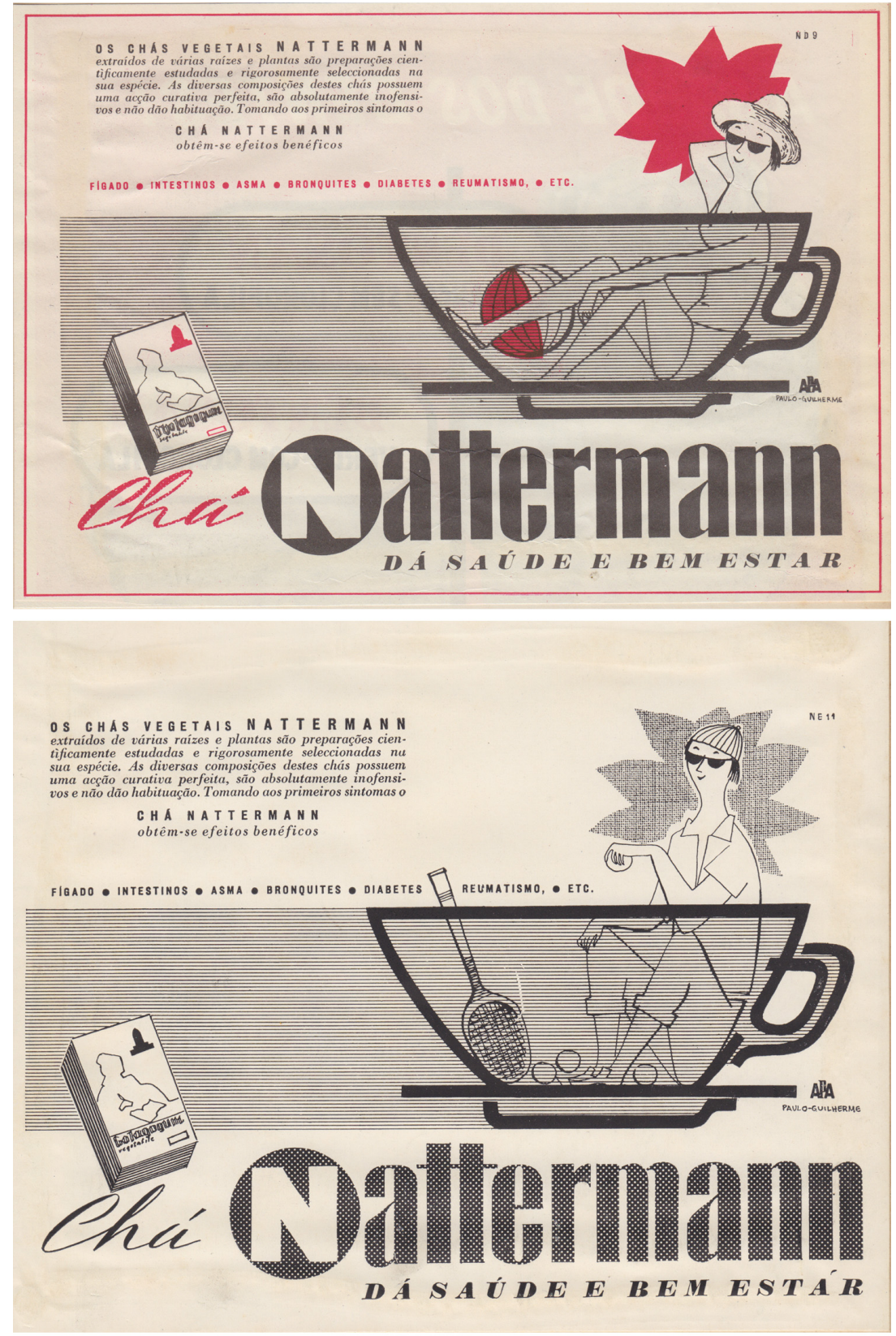

Figura 43. Recortes de jornal, publicidade Chá Nattermann 
PG concebeu outros logotípos como para o restaurante Borsalino, a boîte caixote, bar Snob, teatro capitólio e banco sotto mayor.

Elabora graficamente dezenas de capas de livros para diversas editoras, Clássica Editora, Ática, Portugália Editora, Estúdios de Cor, Publicações Europa-América, Editora Ulisseia, Hugin, Arcádia, etc.

«Paulo-Guilherme foi um extraordinário capista para editoras emblemáticas das décadas de 50, 60 e 70. Paulo-Guilherme usava o seu inesgotável virtuosismo como ilustrador, desde o registo inicial de traço elegante e descritivo das capas da Editorial Organizações, passando pelas poderosas metáforas gráficas de cromatismo intenso na Estúdios Cor e Portugália. Esta viagem começa por uma capa que fez para o primeiro romance do seu pai, Olavo, em 1958.» ${ }^{95}$

Recorre à concepção espacial abstractizada. As figuras geométricas (caso da capa do livro Os Sete minutos, de Irving Wallace), dão um carácter simplificado, de síntese, à composição. Também é interessante constatar que a peça gráfica tenha sido pensada como um todo e a ilustração percorre, lombada, frente, verso, etc. denunciando a preocupação de pensar na tridimensionalidade do objecto.

«Seria na Clássica Editora que Paulo-Guilherme revelaria um maior leque de registos gráficos, afinados com o ar dos tempos. Os anos 60 e 70 mostram-nos um Paulo-Guilherme essencialmente sintético, em poderosas metáforas, quase pictográficas, com que decorou os thrillers de Irving Wallace e Morris West, em composições geométricas que se alongam pela lombada e contracapa.» ${ }^{96}$

\footnotetext{
${ }^{95}$ MOURA, Mário Paulo-Guilherme, Colecção D, Silva Designers (coord.) Imprensa NacionalCasa da Moeda, S.A., $1^{\text {a } e d i c ̧ a ̃ o ~ s e t e m b r o ~ 2012, ~ p .10 ~}$

${ }^{96}$ SILVA, Jorge. Paulo-Guilherme, Colecção D, Silva Designers (coord.) Imprensa Nacional-

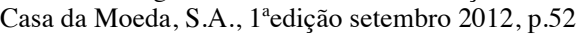




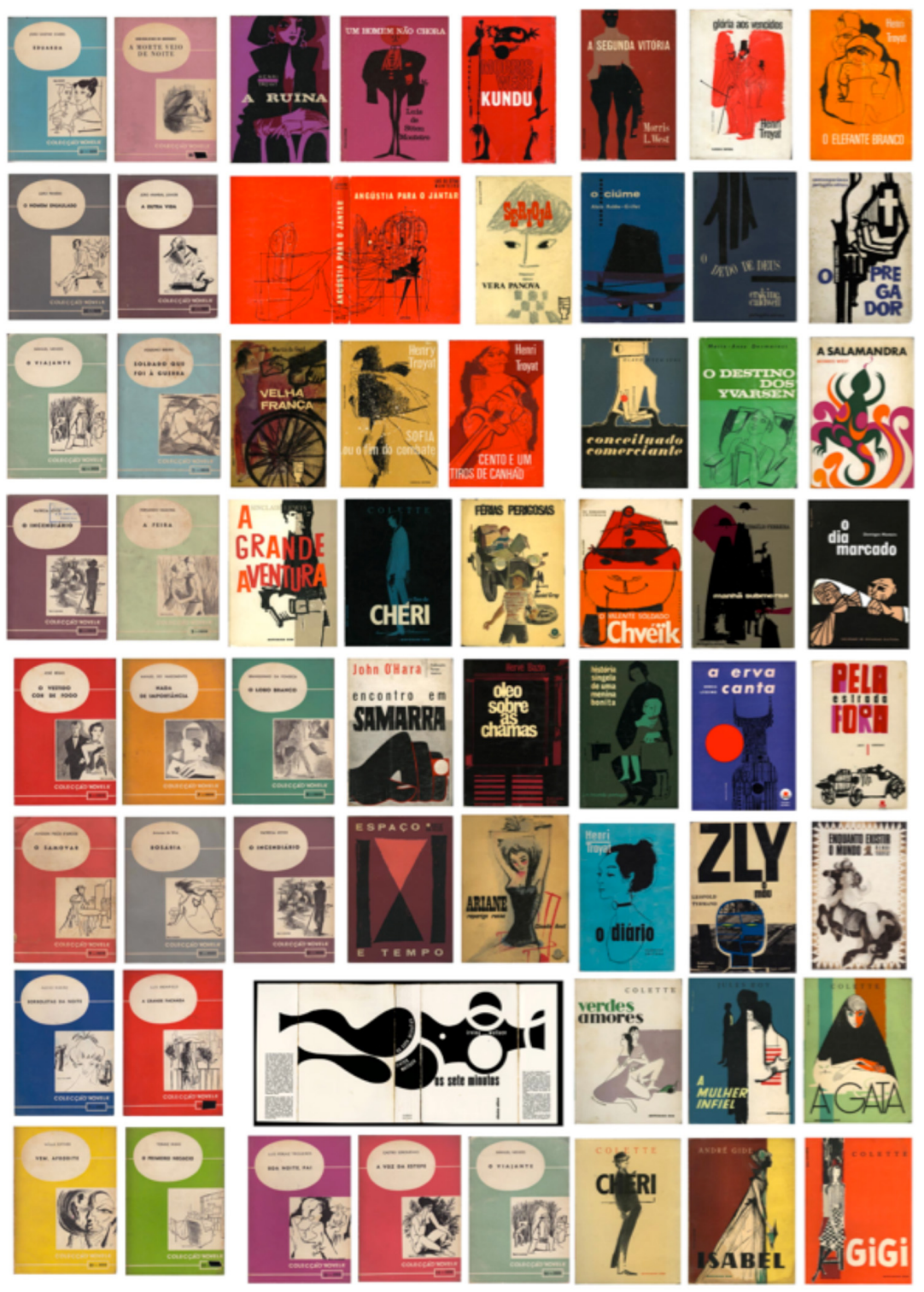

Figura 44. Conjunto de capas de livros 

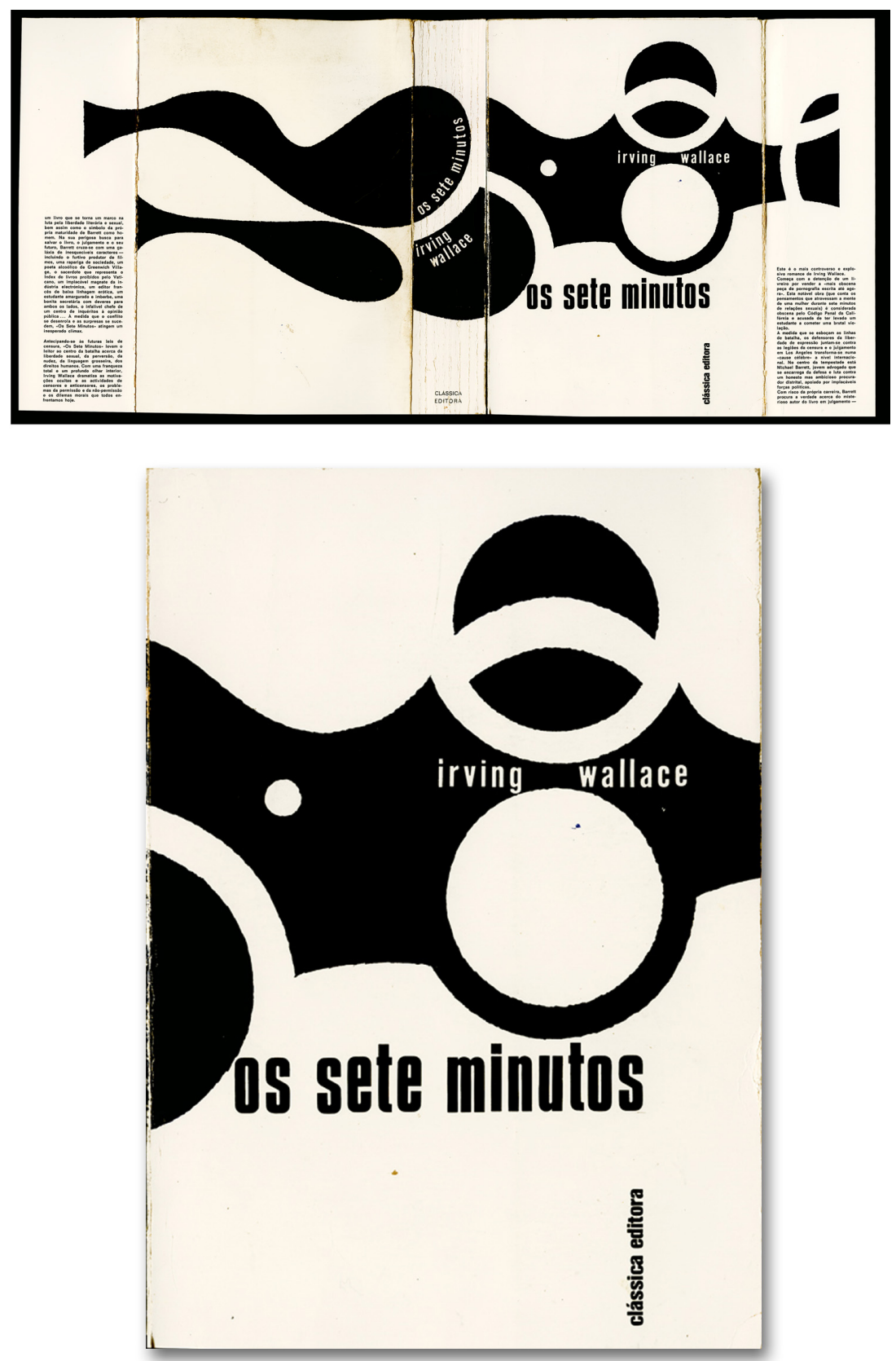

Figura 45. Conjunto de imagens do livro Os sete minutos, Irving Wallace 


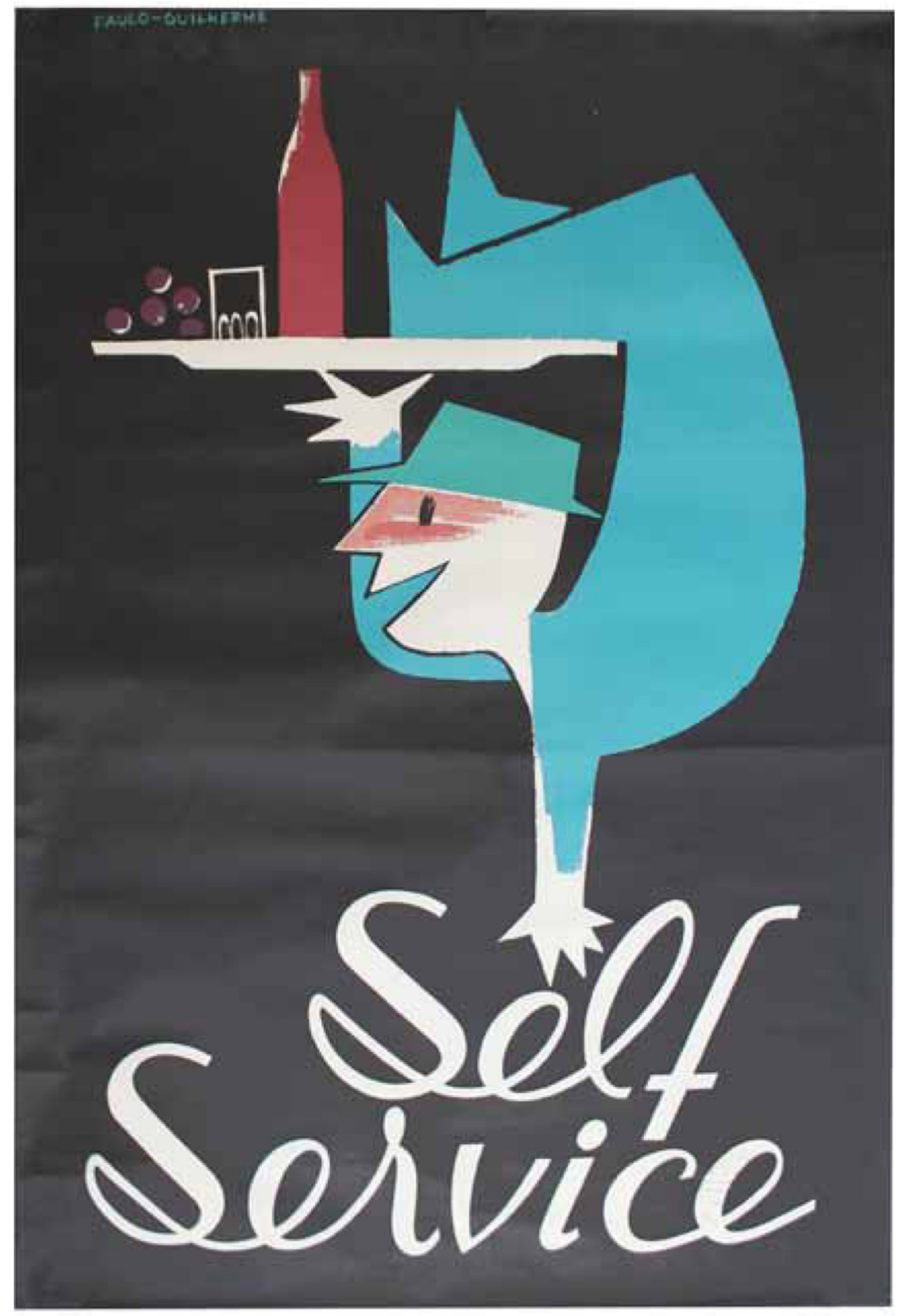

Figura 46. Cartaz Self Service 
$\mathrm{Na}$ sua produção gráfica, cria inesperadas e criativas relações espaciais, de forma, cor e tipográficas, descobrindo novas analogias e discursos.

«As capas de discos de 33 rotações de música para crianças são um tesouro esquecido do design dos anos 60. Como João da Câmara Leme ou Luís Filipe de Abreu, ilustradores/designers seus contemporâneos, Paulo-Guilherme tirava excelente partido da modelação de formas e volumes a partir da cor misturando sabiamente tipografia manual e mecânica.» ${ }^{97}$

$\ll(\ldots)$ o seu trabalho sempre se adaptou com fluência ao estilo da época em que foi feito, sendo possível encontrar situações em que se aproximou dos cartoons publicitários de Savignac, do lirismo abstrato de Lustig, das grandes montagens esbatidas de Bob Peak ou do grafismo delirante dos Push Pin.

Porém, apesar do evidente cosmopolitismo das referências, nunca se tratou de repetir cegamente uma tendência internacional. É possível ver nos seus trabalhos uma delicadeza de desenho capaz de ultrapassar a simples caricatura e entrar no retrato psicológico que o distingue bem de outros ilustradores portugueses da época. As suas capas demonstram esta capacidade para conceber de uma só vez personagens recorrendo às técnicas ilustrativas da altura. ${ }^{98}$

«É esta amplitude de expressão que se torna uma das primeiras características do trabalho de Paulo-Guilherme. E, se existe um conhecimento evidente das tendências e técnicas contemporâneas, se é possível encontrar, aqui e ali, rastos de Saul Bass, Paul Rand ou de Raymond Savignac, estas referências são sempre combinadas com uma verve própria, que se manifesta claramente no à vontade do traço, mas também num conhecimento fluente da interação dos

\footnotetext{
${ }^{97}$ Ibidem, p.60

${ }^{98}$ MOURA, Mário. Paulo-Guilherme, Colecção D, Silva Designers (coord.) Imprensa Nacional-

Casa da Moeda, S.A., $1^{\mathrm{a}}$ edição setembro 2012, p.7
} 

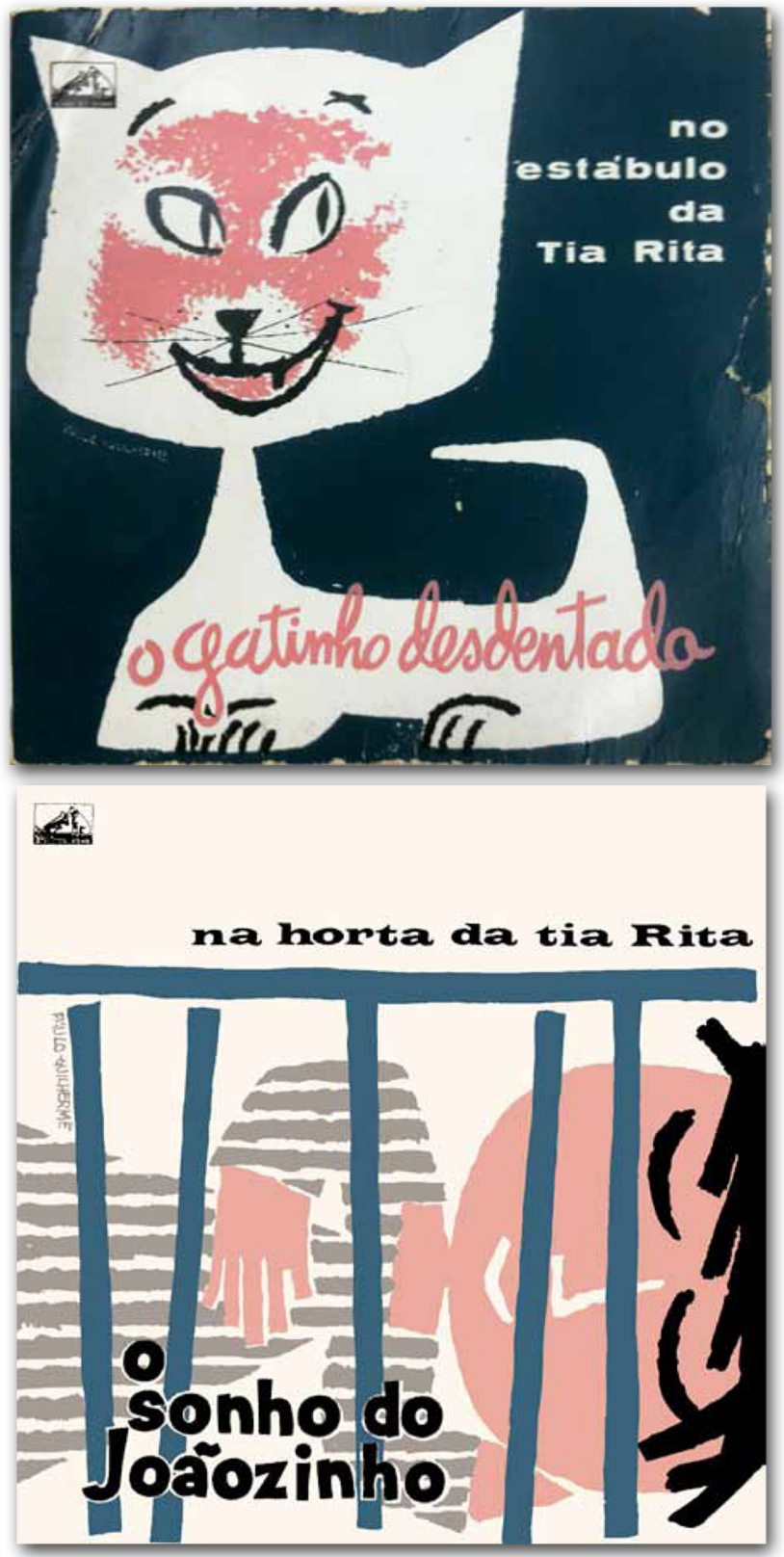

Figura 47. Capas de discos de música de 33 rotações 
materiais, do modo como texturas, padrões e cores se podem combinar para dar uma sensação quase tátil a um anúncio publicitário, uma capa de livro ou o interior de um bar, criando ambiguidades entre desenho e fotografia, objeto e representação, $(\ldots) .{ }^{99}$

«Este domínio do lado físico do design descende evidentemente do programa de ensino da Bauhaus, com a sua ênfase no uso lúdico de ferramentas e materiais que era por sua vez uma sistematização das técnicas inventadas pouco tempo antes pelas vanguardas. É sem dúvida esta modernidade alegre que reencontramos em PauloGuilherme, todo um domínio de referências estéticas e técnicas, usadas com virtuosidade, mas sem o espartilho de um programa, com humor e elegância mas ainda sem a ironia e o pastiche corrosivos do pós-modernismo. Não um modernismo frio, mas uma aplicação pessoal e emotiva, num ponto de equilíbrio entre tendências internacionais e uma estética pessoal.» ${ }^{100}$ Ao longo da sua carreira ganhou múltiplos prémios nas artes gráficas e de publicidade: $1^{\circ}$ prémio promovido pelo Secretariado Nacional de Informação do Cartaz Turístico Portugal Welcomes You, (oito vezes consecutivas); $1^{\circ}$ prémios para o Cartaz para a Ópera de Barcelona, para a Campanha de Vacinação da Cruz Vermelha, para o Jazz de Cascais, Cartaz de Sintra, o Cartaz Concurso Self-Service, para o depliant Évora, para o desenho de estampagem de tecidos Studio Babuíno, Roma.

${ }^{99}$ MOURA, Mário. Paulo-Guilherme, Silva Designers (coord.) Imprensa Nacional-Casa da Moeda, S.A., 1'edição setembro 2012, p.9

${ }^{100}$ Idem 


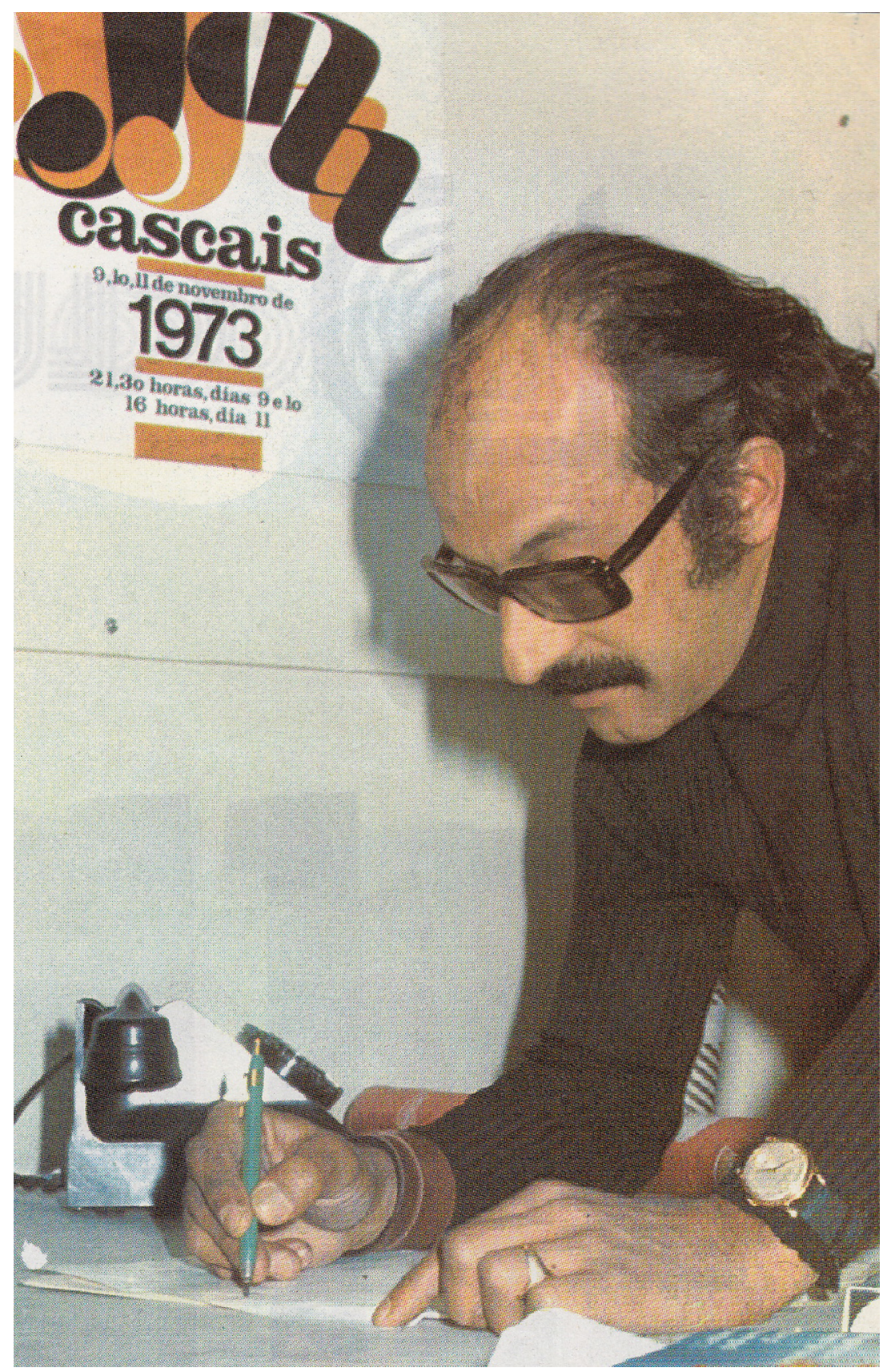

Figura 48. Fotografia de Paulo-Guilherme com cartaz Jazz de Cascais, 1973 
4.3 Filatelia / Filatelia

O selo é irremediavelmente um símbolo de expressão de grande força na sociedade, pelo meio privilegiado em que actua, acessível a todos. Estes símbolos, de mensagens sobre uma região, um acontecimento ou uma personalidade, são denunciadores do tempo, da história, de vivências, de usos e costumes, de esperanças, dos alertas de um País.

Cientes da importância destas peças gráficas os CTT, já nos anos 50/60, privilegiaram seus selos com a qualidade artística de muito designers e ilustradores portugueses, entre os quais encontramos, Cândido da Costa Pinto, Martins Barata, António Lino, Frederico George, Júlio Gil, Almada Negreiros, Álvaro Duarte de Almeida, José de Moura, Álvaro Duarte, Marcelo Morais, José Pedro Roque, Alberto Cardoso, José Pedro Roque, Manuel Rodrigues, Júlio Resende, Guilherme Camarinha, Maria Keil do Amaral, Fred Kradolfer, Artur Bual, Maria Flávia de Monsaraz, João Abel Manta, Sebastião Rodrigues, Luís Filipe de Abreu, António Garcia, PauloGuilheme, etc.

O selo Emissão Europa 1963, teve por base conceptual o Conselho da Europa que é o resultado prático do movimento em prol de uma Europa Unida. Em 1956, pela primeira vez, seis países da Europa Ocidental (França, Bélgica, Holanda, Luxemburgo, Itália e Alemanha), fizeram circular simultaneamente, selos comemorativos e de propaganda do Conselho da Europa, subordinados a um desenho comum. Foi o primeiro passo para a criação do selo europeu, tentando abolir os nacionalismos. O selo Emissão Europa 1963 tem representado o jogo de uniões que simbolicamente forma a pomba da Paz. Sobre papel esmalte, com 

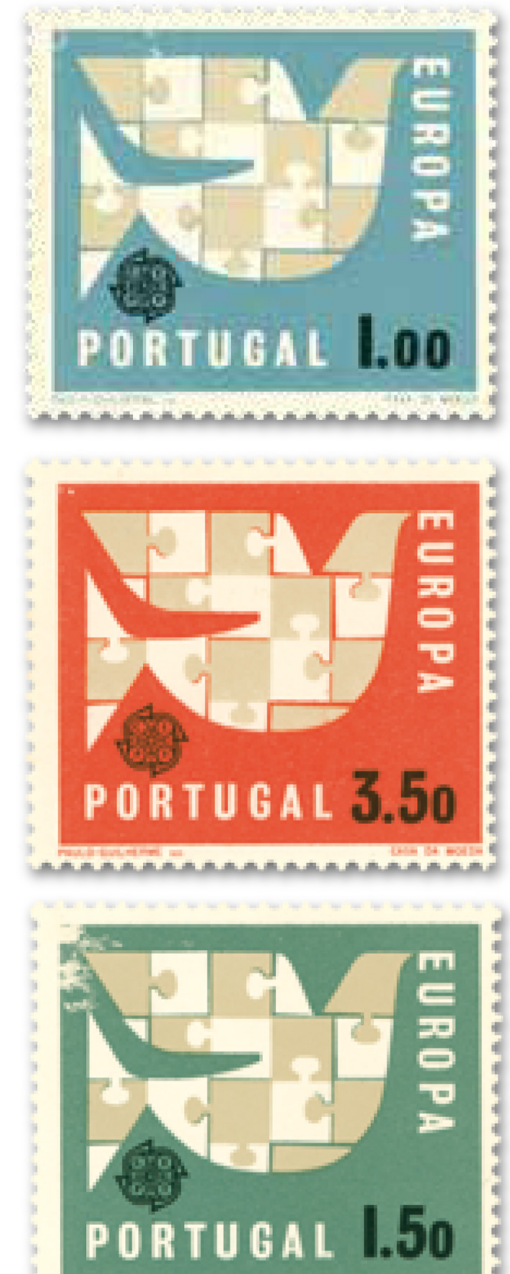

Figura 49. Conjunto de selos Emissão Europa 
dentado, em folhas de 100 selos, a Casa da Moeda em impressão em off-set, emite 6 milhões de selos de $1 \$ 00$ (azul, cinzento e preto); 1,5 milhões de selos de $1 \$ 50$ (verde cinzento e preto) e 1,5 milhões de selos de 3\$50 (vermelho, cinzento e preto). Postos em circulação em 16 de Setembro de 1963 até 30 de Junho de 1965.

A TAP começou com uma frota de dois aviões o Dacota e Skymester, em 1955 adequiriu mais três Super constelation G e em 1962 integra três Caravela Vir, sendo este o mais moderno e rápido avião de médio curso.

Os grandes méritos da TAP, além das ligações internacionais, foram os serviços prestados nas ligações normais para as então, províncias Ultra Marinas e as rápidas pontes aéras, no rebentar da guerra colonial em 1961, assegurando o transporte de tropas e refugiados, tendo recebido o louvor dos poderes públicos pelo serviço prestados.

No âmbito do $5^{\circ}$ aniversário da TAP, PG realizou o selo Emissão Comemorativa do $X$ Aniversário dos Transportes Aéreos Portugueses, 1963. Neste, é apresentando a silhueta dum avião supersónico. Sobre papel liso, com dentado, em folhas de 100 selos, Casa da Moeda em impressão a off-set emite 5 milhões de selos de $1 \$ 00$ (azul escuro e azul), 1 milhão de selos de $2 \$ 50$ (verde escuro e verde) e 1 milhão de selos de $3 \$ 50$ (castanho, vermelho e laranja). Postos em circulação em 1 de Dezembro de 1963 até 30 de Junho de 1965.

A 29 de Setembro de 1951, por decreto, foi fundada a empresa de transporte nacional aéreos, aproximadamente dois anos decorridos mais propriamente em 25 de Abril de 1953, estabelece-se nova sociedade, Transportes Aéreos Portugueses (TAP), 1953.

Promovido pelo Automóvel Clube de Portugal, I Congresso Nacional de Transito realizou-se em Lisboa de 15 a 19 de Fevereiro de 1965, dedicado a todos os aspectos ligados à legislação e 

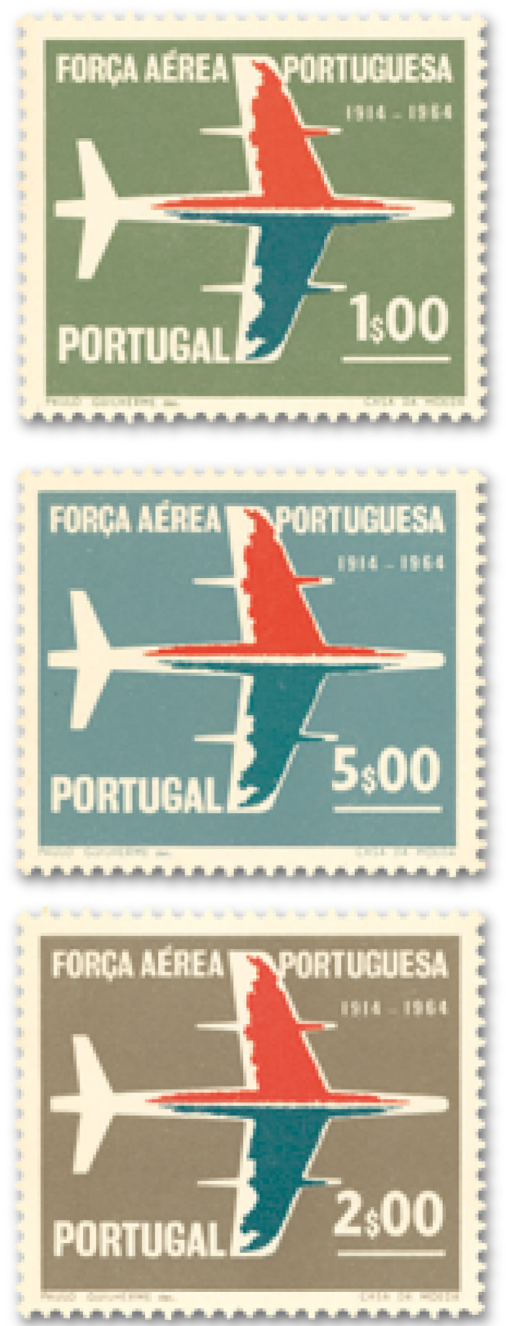

Figura 50. Selos Cinquentenário da Força Aérea 
administração, circulação, estacionamentos, sinalização e prevenção e segurança rodoviária. No selo Emissão Comemorativa do I Congresso Nacional de Transito, 1965 é apresentando alegoricamente um semáforo em cruzamento de vias. Sobre papel liso, com dentado, em folhas de 100 selos, a Casa da Moeda em Impressão a off-set emite 9 milhões de selos de 1\$00 (amarelo, vermelho e verde), 1 milhão de selos de $3 \$ 50$ (verde, vermelho e amarelo) e 1,5 milhões de selos de $3 \$ 50$ (vermelho, amarelo e verde). Postos em circulação a 15 de Fevereiro de 1965.

A Escola Militar de Aeronáutica foi fundada em 14 de Maio de 1914 e em 1916 é inaugurada a Escola de Aeronáutica em Vila Nova da Rainha. Foi no final da guerra 1914-1918 que se criou a aviação militar na qual se enquadra a força aérea, denominada como a $5^{\text {a }}$ arma do regime. Em 1952 é reconhecida a autonomia da Aeronáutica sendo a Força Aérea incluida num subsecretariado de Estado. Em 1961, a força aérea participou na guerra colonial em Angola com elogiados serviços pelo regime. Do efectivo de 100 homens da inicial escola regista-se na actualidade um corpo de 20 mil homens.

A memória do cinquentenário da Força Aérea, foi eternizado através de uma estampilha comemorativa da autoria de PG. O selo Emissão Comemorativa do Cinquentenário da Força Aérea, 1965, foi impresso a off-set pela Casa da Moeda sobre papel liso, em folhas de 100 selos com denteado. Foi posto em circulação a 20 de Outubro de 1965. Foram emitidos 9 milhões de selos de $1 \$ 00$ (verdecinzento, verde e vermelho), 1 milhão de selos de $2 \$ 00$ (castanhocinzento, verde e vermelho), e 500 mil selos de $5 \$ 00$ (azul-claro verde e vermelho). A Revolução de 28 de Maio de 1926 ou simplesmente "Revolução Nacional", resulta da revolta militar de índole nacionalista e anti-parlamentar que pôs fim à primeira 

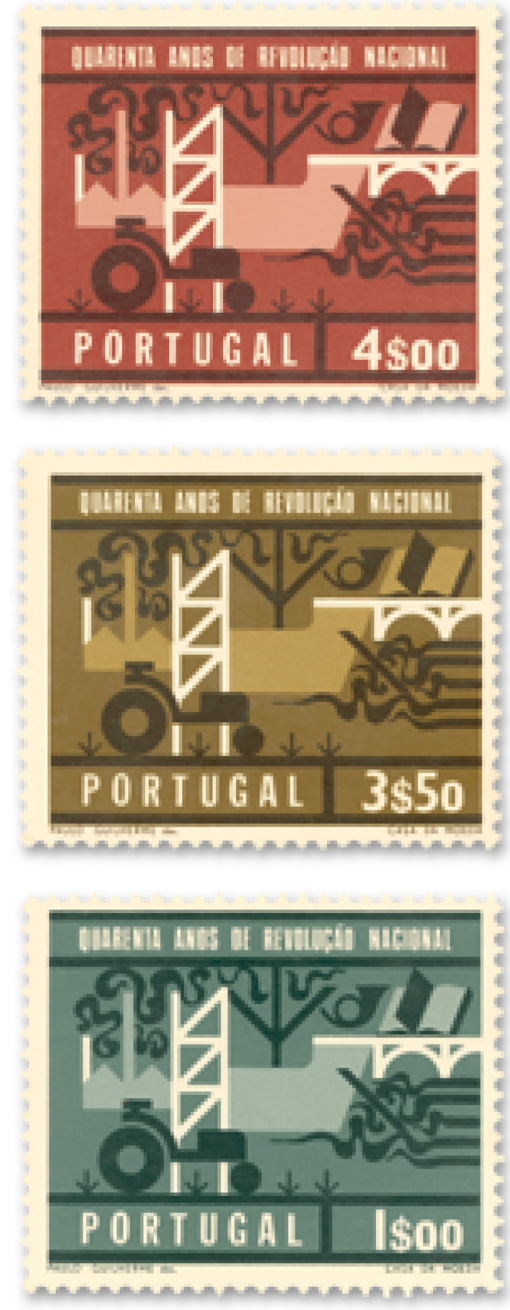

Figura 51. Selos Revolução Nacional 
república originando a implementação da auto-denominada Ditadura Nacional. No ano de 1933, aprovada por Constituição instaurou-se o Estado Novo vindo a governar Portugal até ao golpe militar de 25 de Abril de 1974.

No âmbito das comemorações promovidas pelo Estado Novo, PG realizou o selo Emissão Comemorativa do $40^{\circ}$ Aniversário da Revolução Nacional, 1966. Foi impresso a off-set pela Casa da Moeda sobre papel liso, em folhas de 100 selos com dentado carrega um desenho alegórico das obras do Estado Novo. Destes selos foram emitidos 9 milhões de selos de $1 \$ 00$ (azul-cinzento), 1 milhão de selos de 3\$50 (castanho-amarelo), e 1 milhão se selos de $4 \$ 00$ (castanho-vermelho), sendo postos em circulação a 28 de Maio de 1966.

«Mesmo com o programa de emissões filatélicas alinhado pelas efemérides e propaganda do Estado Novo, em séries como o Cinquentenário da Força Aérea ou o $40^{\circ}$ Aniversário da Revolução Nacional, os selos de Paulo-Guilherme revelavam a pureza formal e geométrica do International Style que contagiava o design gráfico europeu da época. Um clássico desta virtuosa síntese são os selos Europa que aqui se revelam em vários estudos alternativos para a série de 1963, sempre em apurada estilização conceptual e sóbria paleta cromática. ${ }^{101}$

Foi premiado com $1^{\circ}$ Prémio do Selo de Europa para Portugal.

${ }^{101}$ SILVA, Jorge, Paulo-Guilherme, Colecção D, Silva Designers (coord.) Imprensa Nacional-

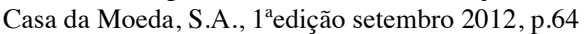



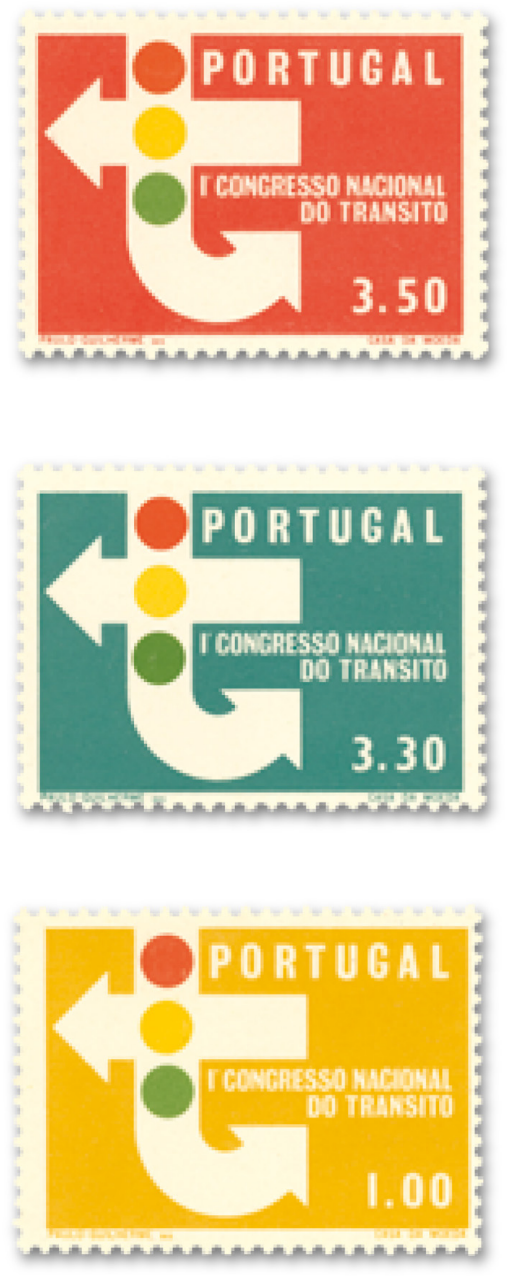

Figura 52. Selos I Congresso Nacional de Transito 
4.4 Pintura y dibujo / Pintura e desenho

O ambiente dos primeiros anos vividos entre artistas e intelectuais na casa paterna (anos 30), o respirar do Figurativo de Almada e Abel Manta torna essa a sua formação base de forma natural e incontornável. As excitantes experiências e as descobertas da mocidade boémia, a rigidez do curso de Belas Artes, tudo está substanciado na pintura de PG. Das memórias de pintores pertencentes à École de Paris e do próprio cubismo analítico anexado ao seu academismo resulta na sua obra um rigor de composição que denota a atenção cuidada do tratamento do desenho afirmando-o nas suas produções, um equilíbrio de formas e volumes.

A pintura foi evoluindo de aguadas suaves para aguarelas de cores fortes. Lentamente a paleta foi reduzida na sua policromia com contrastes dominantes no claro e escuro. Acompanhando esta evolução a perferencia no formato desenvolvia-se numa questão de “escala" cada vez maior.

«Em sua pintura deixa transparecer um saudosismo pelo clima "belle époque", da nobreza Salazarista, que se esvai - fundindo um evidente "art nouveau" às reminiscências estruturais cubistas; às linhas forças futuristas; aos contrastes simultâneos do orfismo; ao raionismo russo, que, segundo Barr, se apoia numa frase de seu avô italiano Leonardo da Vinci: "O ar está cheio de infinito numero de linhas radiantes, rectas, que se cruzam sem jamais coincidir por completo; elas representam a verdadeira forma da razão de ser de cada objecto» ${ }^{102}$

102 ARAÚJO, Adalice, “D’Eça, um Gauguin à Portuguesa,” Jornal Diário do Paraná, secção das Artes, 1978, p.11 


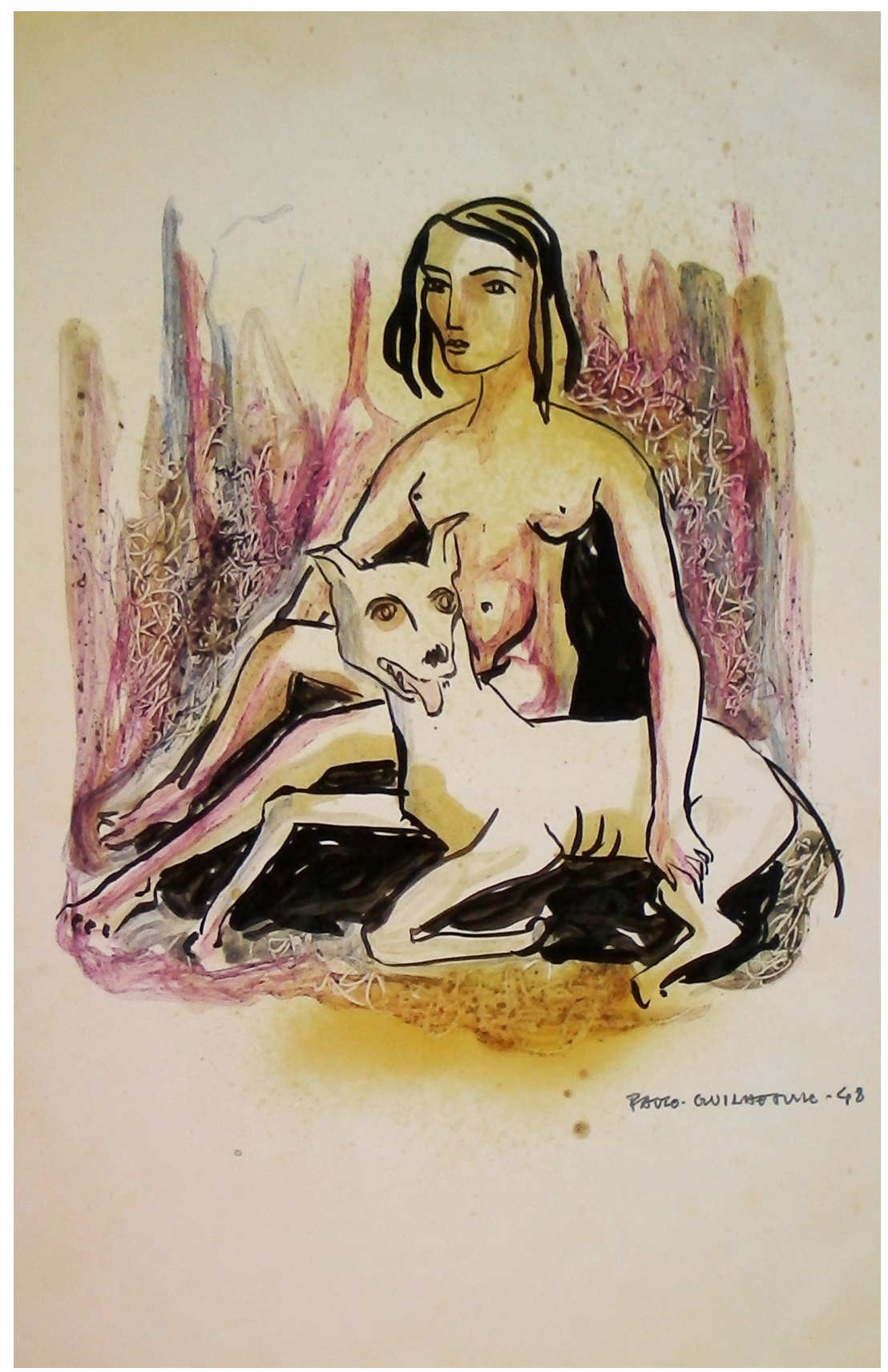

Figura 53. Desenho técnica mista, 1948 
PG admite que, no princípio, foi influenciado por todos os pintores que viu; todos eles tinham qualquer coisa, absorveu: os desenhos de Rodin, Daumier, Bernardo Marques, António da Costa, Almada Negreiros, Fragonard, Dufy, Klee, Kandinsky, Larionov, Dewasne, Pillet, Vazarely, Vieira da Silva. E sobre todas as fases e evoluções as sombras constantes de Picasso e de seu Pai.

Esta intenção sistemática e a característica marcante Art Deco da sua pintura, por vezes parecem perigosamente próxima da ilustração, talvez como resultado dos longos anos em que trabalhou como ilustrador de jornal e cenógrafo. Salienta-se que a estrutura geométrica é forte resultado da sua formação de arquitecto e de decorador.

A sua pintura tinha por base, elementos naturais e as figuras humanas. Estas, com o natural desenvolvimento e evolução descaracterizam-se, eram envolvidos numa complicada construção geométrica que se tornava quase dominante na sua pintura. Os elementos basilares progrediam numa sucessão de espirais e círculos que se entrecortam e crescem. Teve uma extensa fase figurativa, seguindo o abstrato durante muitos anos e regressa alegremente - ao figurativo.

«Por infuência de Delaunay, o círculo chega, muitas vezes, a gerar uma expansão em linhas forças esféricas, em todo o campo visual, rigorosamente calculado. Por outro, sendo um círculo uma forma cinética, sua estrutura arquitectónica faz com que as forças fluam em ondulações, dando ao todo o movimento dos espectáculos musicais que tanto D’Eça gosta de encenar e dirigir.» ${ }^{103}$

$\mathrm{Na}$ sua pintura deixa clara a manifesta intenção de produzir arte alegre e optimista não apresentando nenhum comentário psicológico ou social. No início a temática centraliza-se, em generalidade, na mulher encantadora e superficial. Contudo a sua

${ }^{103}$ Idem 

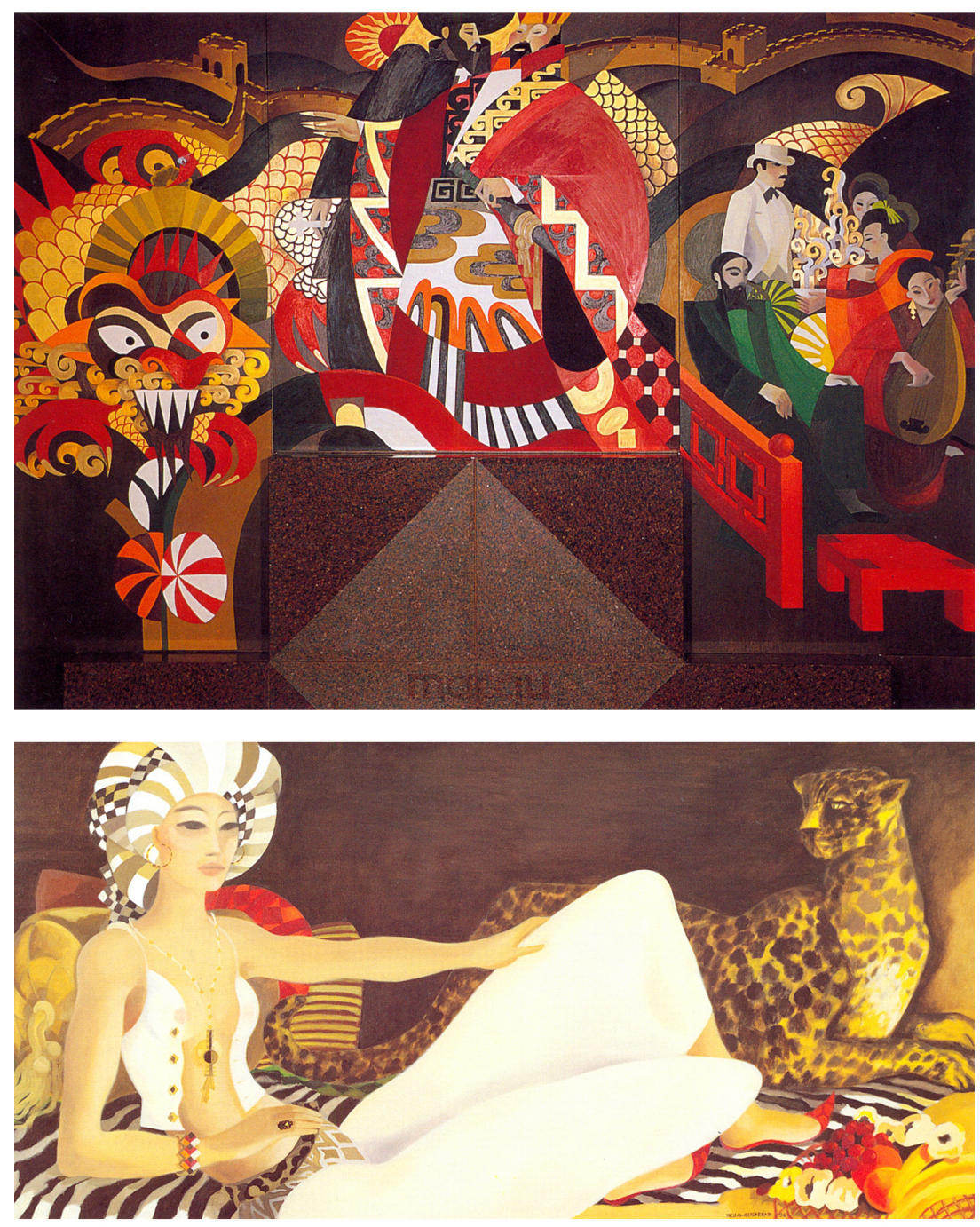

Figura 54. Conjunto de pinturas 
obra tinha os mais diversos motivos, estilizados com apurado gosto, atraem pela elegância do arabesco e pela harmoniosa distribuição cromática e o encanto precioso e vibrátil característico da BelleEpoque.

$\ll(\ldots)$ experimentei febrilmente todas as formas de arte conhecidas e adquiri, pelo menos, uma grande experiência. (...)

Sempre tive a tendência de pintar o lado alegre da vida. Influenciado, talvez, por personagens e ambientes requintados e elegantes em que sempre circulei (e procurei), a minha pintura reflecte facilmente esse modo e viver. Gosto de pintar gente e situações agradáveis e calmas. Alem disso, a luz e a cor (para mim elementos vitais da alegria de viver) estão sempre presentes. ${ }^{104}$

A pintura de PG caracteriza-se também pela síntese formal e unidade cromática e pela existência e abundancia de elementos estáveis. A cor, a forma e a luz - criadora de tudo - são os materiais de construção. Os negros dilatam as fronteiras das cores. A presença constante do negro é por outro lado, explicado por PG, como um contraponto para tornar os tons mais intensos e luminosos; Acreditava que se utilizasse cores claras elas se auto-destruiriam e que a cor possuia a sua carga emocional própria. PG tinha por habito só pintar quando havia sol, de preferência de tarde, porque pela manhã a luz ainda é cinzenta. À noite só tem lugar o desenho. Se não houver sol, PG não insiste na pintura porque afirma que tudo lhe sai mal. Sempre que surgisse um novo material considerava-o, experimentava-o e estudava-o. Não renunciava de modo nenhum aos meios, acreditava que seria desprezar armas. Em PG reside a importância da renovação, a exploração da inquietude que nele habita.

$\ll(\ldots)$ a certa altura, estava na idade, comecei a fazer pintura de

${ }^{104}$ Idem 

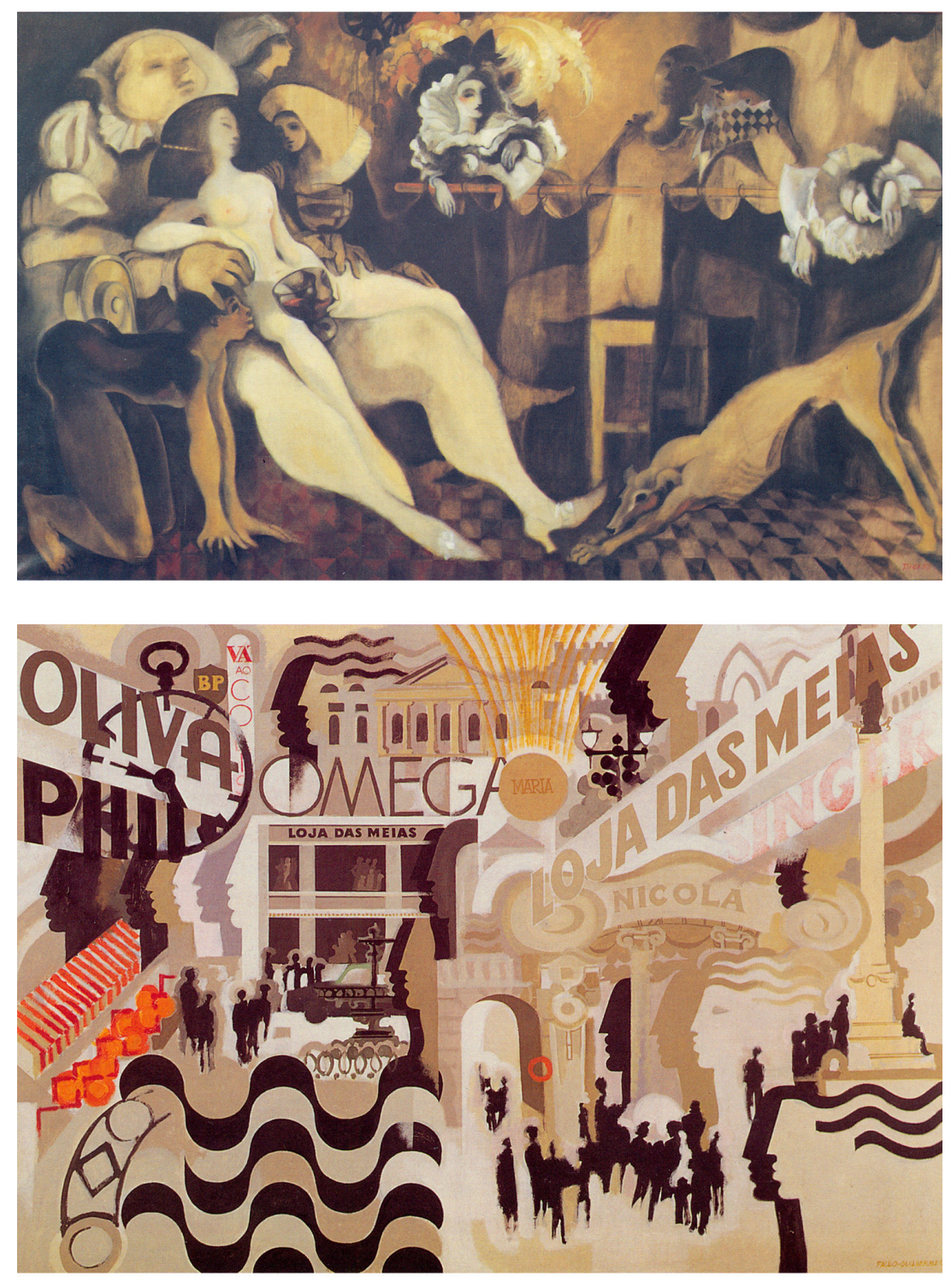

Figura 55. Conjunto de quadros, pintura a óleo 
intenções sociais; homens magros acorrentados, arames farpados e coisas parecidas. Ganhei alguns amigos que me davam palmadas nas costas e me diziam que tinha futuro no neo-realismo. Mas a minha auto-crítica dizia-me que as minhas pinturas não convenciam ninguém quanto às misérias deste mundo. Parti repentinamente para outra via: Klee, Kandinsky, Vassaleri e por aí fora. Foi óptimo: Perdi amigos neo-realistas e ganhei outros novos. Nessa altura dos acontecimentos, era inevitável, evoluí e mergulhei cegamente no cegamente abstracto pesado. Aconteceu de novo a mesma coisa: lá se foram mais uns tantos amigos que tinham apostado na fase anterior ela vieram outros novos.» ${ }^{105}$

«A minha pintura não é nem mais nem menos que um dos meus variados modos de expressão. Mas não compliquemos as coisas. Essa Expressão é igual a mim mesmo, variada, conforme o dia me corre ou conforme o lugar ou objectivo a que se destina. É uma expressão principalmente estética, e, como eu, alegre, bem disposta e mais ou menos escorreita.» ${ }^{106}$

PG acreditava que há momentos, no dia a dia, em que tudo parece enquadrar-se numa harmónica arquitectura universal, que o fascinava. Quando pintava procurava ou até mesmo fazia para que esses momentos acontecessem; o braço da mulher que coincide com a linha do horizonte ou ele mesmo é o horizonte; as cotas da cadeira forma um todo, circular, com o ombro do modelo; O tampo da mesa completa-se num triângulo exacto de sol projectado na parede; etc. Daí a presença constante de uma forte composição geométrica que quase sempre impunha ostensivamente.

Enganosa impressão de encantadoras trivialidades impõe-se no desenho. Com poder de síntese transfigura o decorativo, tirando partido das diagonais nos traços excitados e expressivos. Controla

\footnotetext{
${ }^{105}$ BRANDÃO, A. Almeida, “Paulo-Guilherme: Um Equilíbrio Conquistado do Interior”, Revista Artes Plásticas, nº15, Janeiro 1992, p. 64

${ }^{106}$ Ibidem, p.66
} 

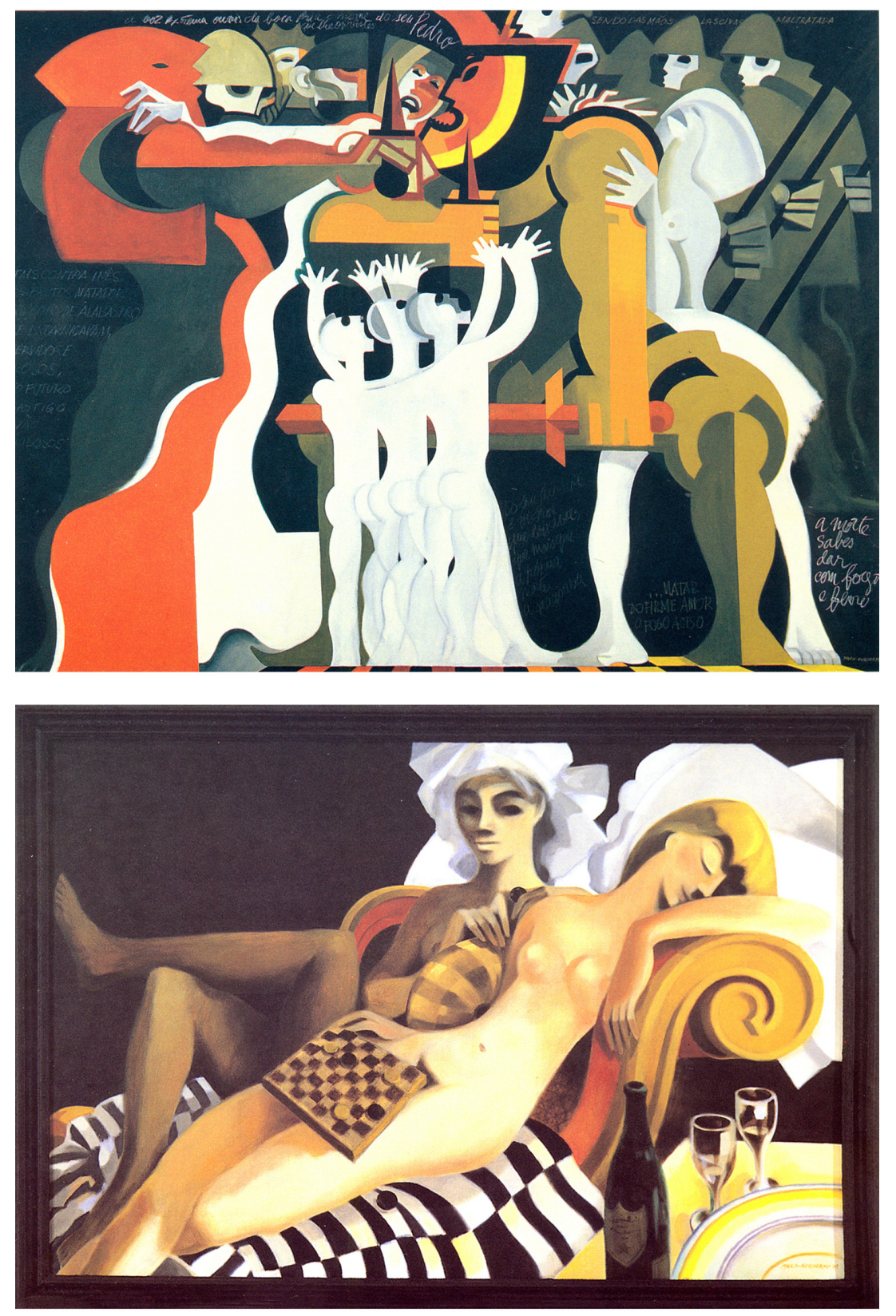

Figura 56. Conjunto de quadros, pintura a óleo 
rigorosamente a espontaneidade inicial do desenho, sacrificando-a até, através de modificações contínuas, em benefício, de um bom efeito final.

«Em toda a pintura de Paulo-Guilherme, há uma constante de sedução deliberada, que não se envergonha do recurso ao virtuosismo - por vezes ingénuo - nem a certos clichés 'retro' que testemunham as suas memorias de menino.» ${ }^{107}$

É necessário reflectir que a evolução da sua pintura também de certo modo se deve ao seu grave problema de visão, que se foi agravando com o passar dos anos. Nota-se a evolução das aguadas leves e variadas para uma pintura de grandes contrastes, também uma consequente redução da paleta, traço torna-se mais grosso, as machas mais largas. Não esquecendo o gosto pelas grandes dimensões e a necessidade de uma boa luz, a luz solar.

Tem um grande volume de pinturas e desenhos em dezenas de colecções particulares, em Portugal, Angola, Moçambique, Espanha, França, Itália, Inglaterra, América do Norte e também no Brasil. Neste último salientam-se 16 pinturas de grandes dimensões para as sucursais do Banco Bozanno e Simomsem, e as colecções particulares de: Afonso P. De Magalhães, Caetano B. Da Veiga, Joacy Goês, Karl Neuman, Carlos Jung, Arthur Campos, Arice Buschman, Victorina Sagboni, José Campos, Nagem Nahas e Winfred Blum.

Realizou vários painéis/murais, tais como: Pintura no átrio do Cinema Paris, Lisboa (6x3m); Pintura na Messe dos Oficiais da GNR (8x4m); Pintura no Hotel Florida (4x2,50m); Biombo pintado para o Restaurante Folclore(11x2,50m); Pintura no Casino de Espinho; Pintura na residência de Rita Shmolevitch $(6 \times 3 \mathrm{~m})$; Pintura em Café em Sintra (3x3m); Pintura no Átrio do Hospital de Santarém

${ }^{107}$ SILVA, António Sena da, 2Modo de usar as Artes", Catálogo de exposição, Paulo-Guilherme D’Eça Leal D’etecetera e tal 2000, Palácio Galveias 2000, Câmara Municipal de Lisboa , Novembro de 1999 , p.243 

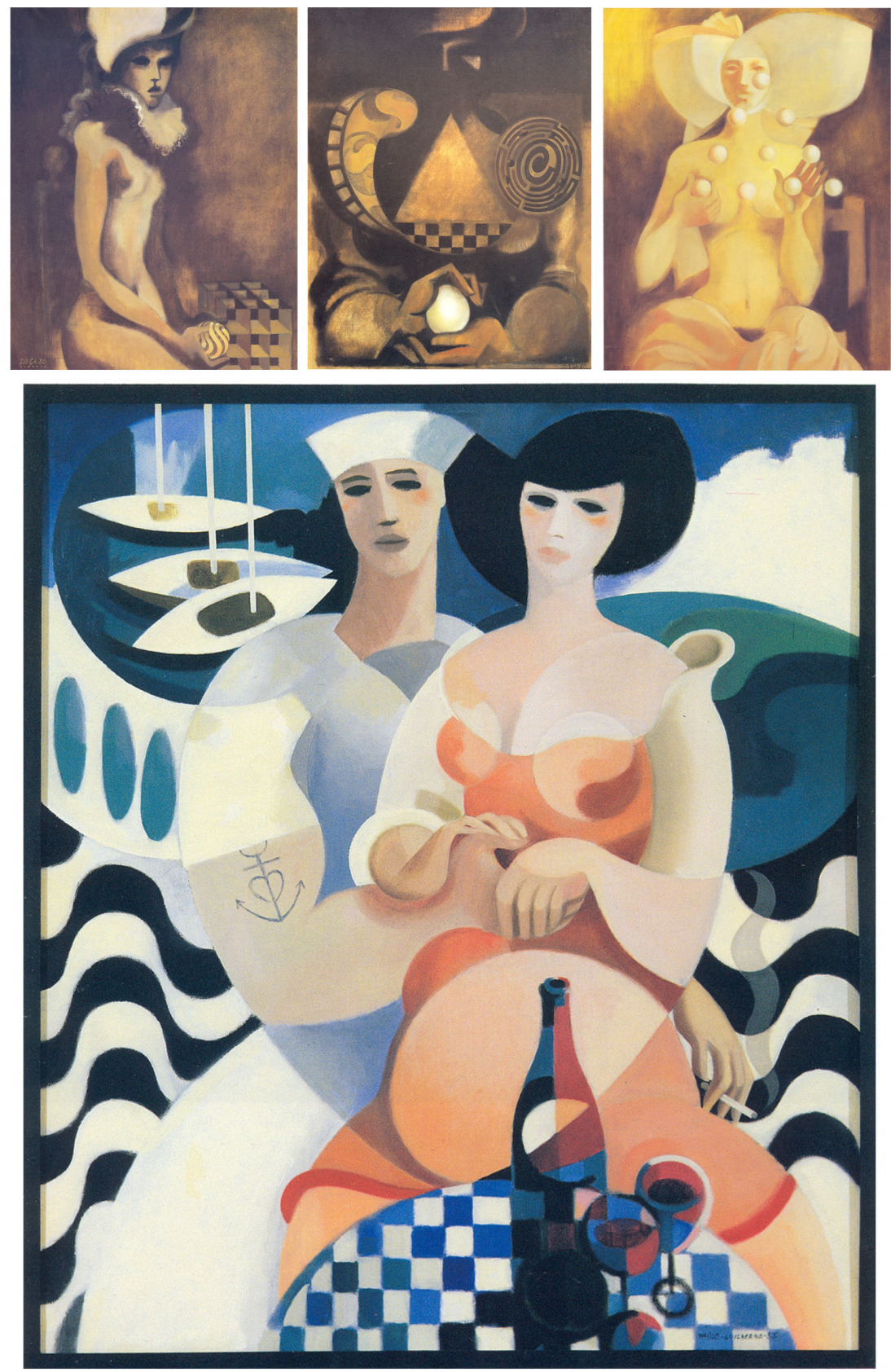

Figura 57. Conjunto de quadros, pintura a óleo 
(7x2m); Pintura na sala de embarque $\left(4^{\circ}\right.$ e $5^{\circ}$ piso $)$ do Aeroporto de Lisboa $(25 \times 3,65 \mathrm{~m})$ e $(60 \times 3,65 \mathrm{~m})$ respectivamente.

PG fez várias exposições particulares e participou em muitas colectivas, contudo no anos 80 estas foram reduzindo de forma visível até desaparecerem por completo. As pinturas de PG voltaram a aparecer ao público sob o formato de uma grande exposição retrospectiva em 2000, intitulada Paulo-Guilherme D’Eça Leal, etecetera e Tal no palácio de Galveias.

«Da sua pintura começou por se dizer que era figurativa e isolada e desse facto creio que em parte derivou a forma discreta que ao longo destes últimos anos se distanciou de qualquer divulgação pública. Todavia, se dificuldade nela há (ou houve) para que o seu trabalho pictórico tivesse estado arredio do meio, quer em termos de ligações com Galerias de Arte, quer com a realização de exposições de pintura, importa assinalar que é a Obra da sua própria pintura, do interior da qual o autor, sem qualquer concessões à ligeireza com que o seu trabalho fosse encarado normalmente, o procurou interrogar e dar a ver no que ele tem, digamos, de essencial. Expor com regularidade não significa que possamos ser profissionais de ofício, que possamos ter mais (ou menos) valor que outro artista que esteja em contacto permanente com o público que acompanha ou visita galerias ou vê exposições.

(...) Traduzir o universo pictórico na obra de Paulo-Guilherme não é, pois, tarefa fácil, pela concentração e precisão de traço, ambiências, formas, alguma metáfora, riqueza de cores, harmonia, volumes e temas. Trata-se de uma pintura que projecta a visão de um espaço sugestivo que escapa aos limites do regionalismo, para alem dos domínios de um questionamento capaz de envolver todos os homens, de todas as épocas e latitudes. ${ }^{108}$

${ }^{108}$ BRANDÃO, A. Almeida, "Paulo-Guilherme: Um Equilíbrio Conquistado do Interior", Revista Artes Plásticas, nº15, Janeiro 1992, p. 65 

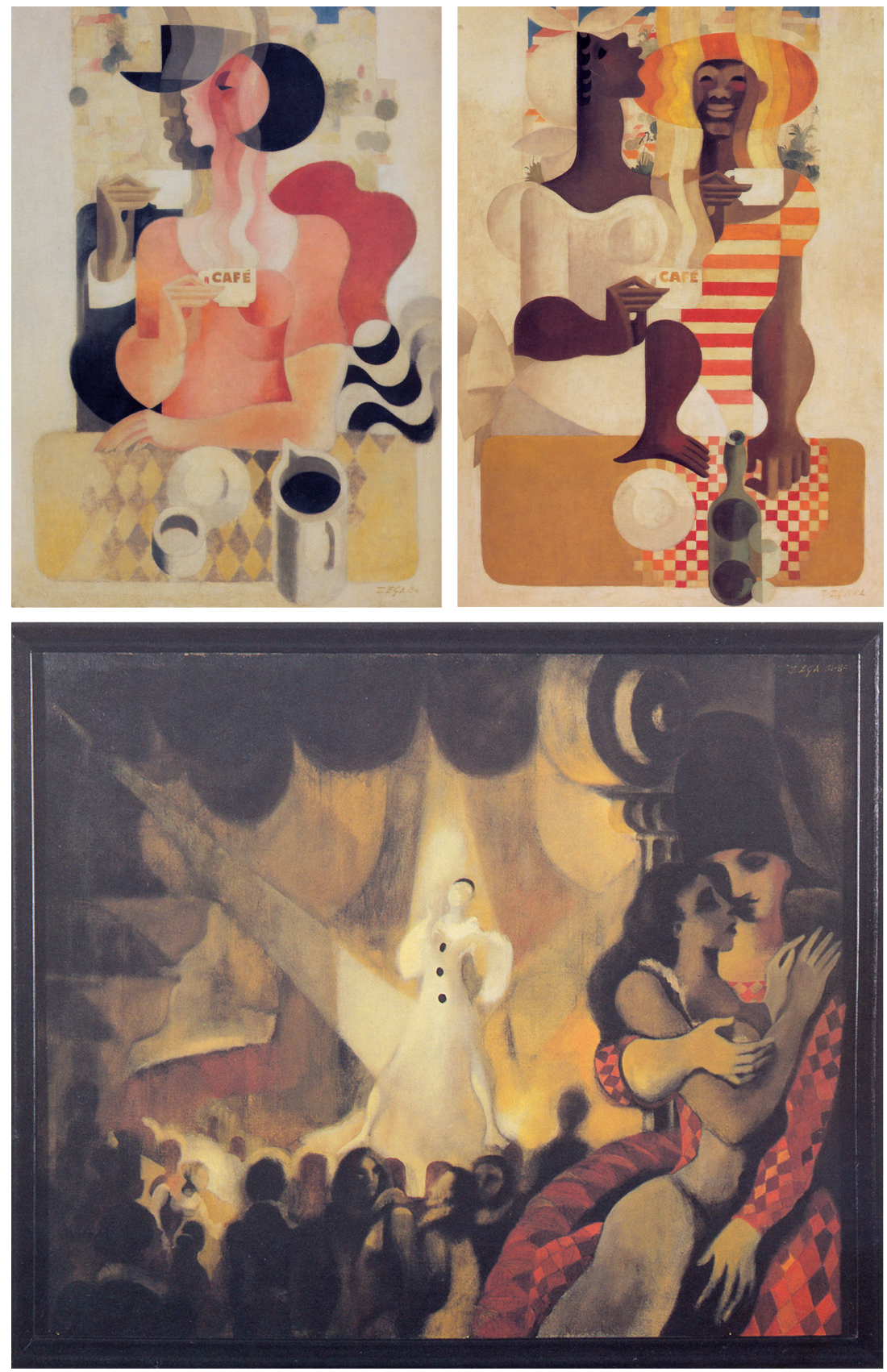

Figura 58. Conjunto de quadros, pintura a óleo 
4.5 Escultura y tapices / Escultura e tapeçaria

PG tem tapeçarias e esculturas em dezenas de colecções particulares, Portugal, Angola, Moçambique, Espanha, França, Itália, Inglaterra, Brasil e América do Norte. No Brasil, PG, chega a fazer uma exposição apenas com as suas esculturas e tapeçarias, contudo, o campo escultórico não foi o mais trabalhado. A sua intervenção nesse campo foi fugaz o que não se pode dizer do campo da tapeçaria. PG realizou tapeçarias para: os escritórios de Nagem Nahas, São Paulo $(5 \times 2 m)$, assim como para residência $(1,20 \times 2 m)$; Sede do Banco Real de S. Paulo (Curitiba) (2x1,5m); o Hospital de Santarém; Pantextil; o Clube da Marina de Vilamoura; o Restaurante Internacional do Aeroporto de Lisboa; 3 Lounge da Ana no Aeroporto de Lisboa; o salão Nobre do Aeroporto de Lisboa. Realizou também uma série de seis tapeçarias para as sucursais do Banco Mercantil de São Paulo, Brasil; Hotel Alvor no Algarve $(3 \mathrm{x} 2 \mathrm{~m})$.

As esculturas que expôs com as tapeçarias no MAC, têm como "elemento-base" o círculo que se identifica como o ponto primordial. Desta figura geométrica ele tira as mais diversas manifestações formais, nada foi subtraído, nada foi adicionado, apenas foram feitos cortes e dobras. O círculo tem significado simbólicos, extremamente peculiares: ausência de divisão, a perfeição; O movimento conseguido nas esculturas simbolizam o tempo, a continua sucessão dos instantes. Explica PG que no princípio era a esfera e que embora sendo o circulo uma projecção da esfera, não passa de uma abstracção inventada pelo homem. Trabalha nas suas obras com metal, dando ênfase ao círculo, como suporte adopta o ferro niquelado, cromado e pintado. Na sua escultura cresce a importância do sentido cinético. 

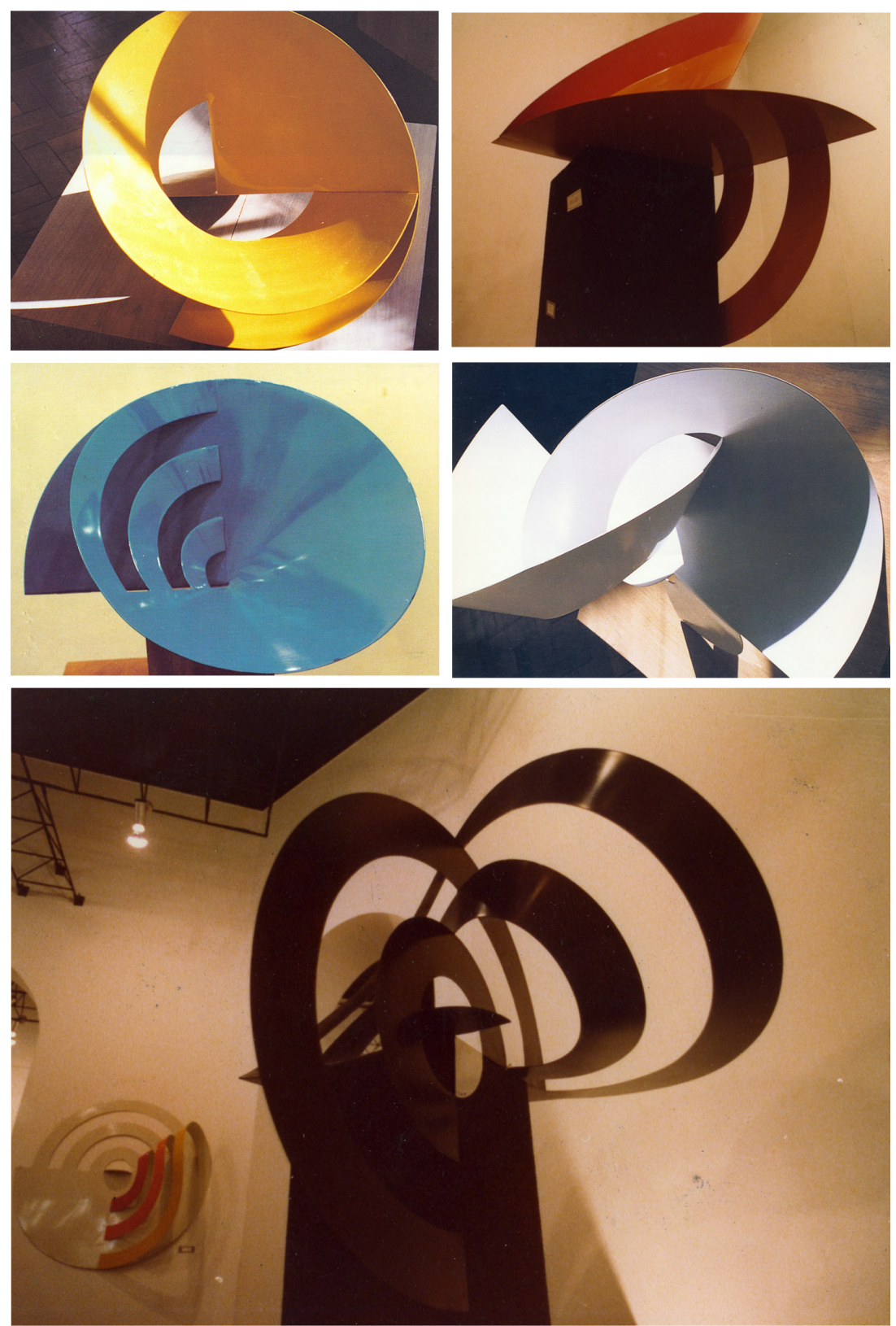

Figura 59. Conjunto de fotografias de esculturas 
«Agora, veio revelar-nos o Escultor, aceitando desafio do espaço, com o seu inerente mistério de indefinição, vacuidade e abstração. No princípio era a esfera, desde sempre conectada com o princípio, o começo, a sacralidade originária. O zero e o infinito - temas fundamentais da metafísica Indu que levaram - quem sabe!, os portugueses na demanda do Prestes João das Índias.

Em todas as esculturas que D'Eça Leal ora nos apresenta está presente a problemática do círculo. A partir dele toda a criação é possível por cisão, desdobramento, reentrância, super - posição, multifacetamento - numa fantástica desmultiplicação de possibilidades que a cada passo nos coloca toda a temática do espaço onde existe e porventura se move: O vazio, a divisão do espaço em parte irreais, inexistentes a não ser pelos objectos que nele se situam.

Uma constante porém se repete em todas elas: sua virtualidade de reconstituição original, de que ele círculo, zero, infinito, em nada foi afectado na sua essência pelas sucessivas máscaras ou ardis com que o artista - ator pretende criar em nós a ilusão da multiplicidade; todas elas contêm em si a potencialidade do regresso as origens. Talvez uma forma, porventura inconsciente, do artista expressar, à sua maneira estética - metafísica, o seu sentimento de SAUDADE.» ${ }^{109}$

«Coloridas, com vazados que lhes ressaltam o aspecto de leveza e que sugerem ricos espaços e de formas elegantes e diversas, embora partindo de uma única, revelam-se-nos abstractas. Elas propõe, no entanto, o ideal de se poder chegar, partindo do círculo - à semelhança dos mestres renascentistas, que tinham nessa figura a melhor das formas - à esfera, símbolo perfeito da harmonia

109 ARAÚJO, Adalice. “Balanço D’Eça esculturas e tapeçarias no MAC”, Jornal Diário do Paraná, Secção das Artes, 1978, p.23 

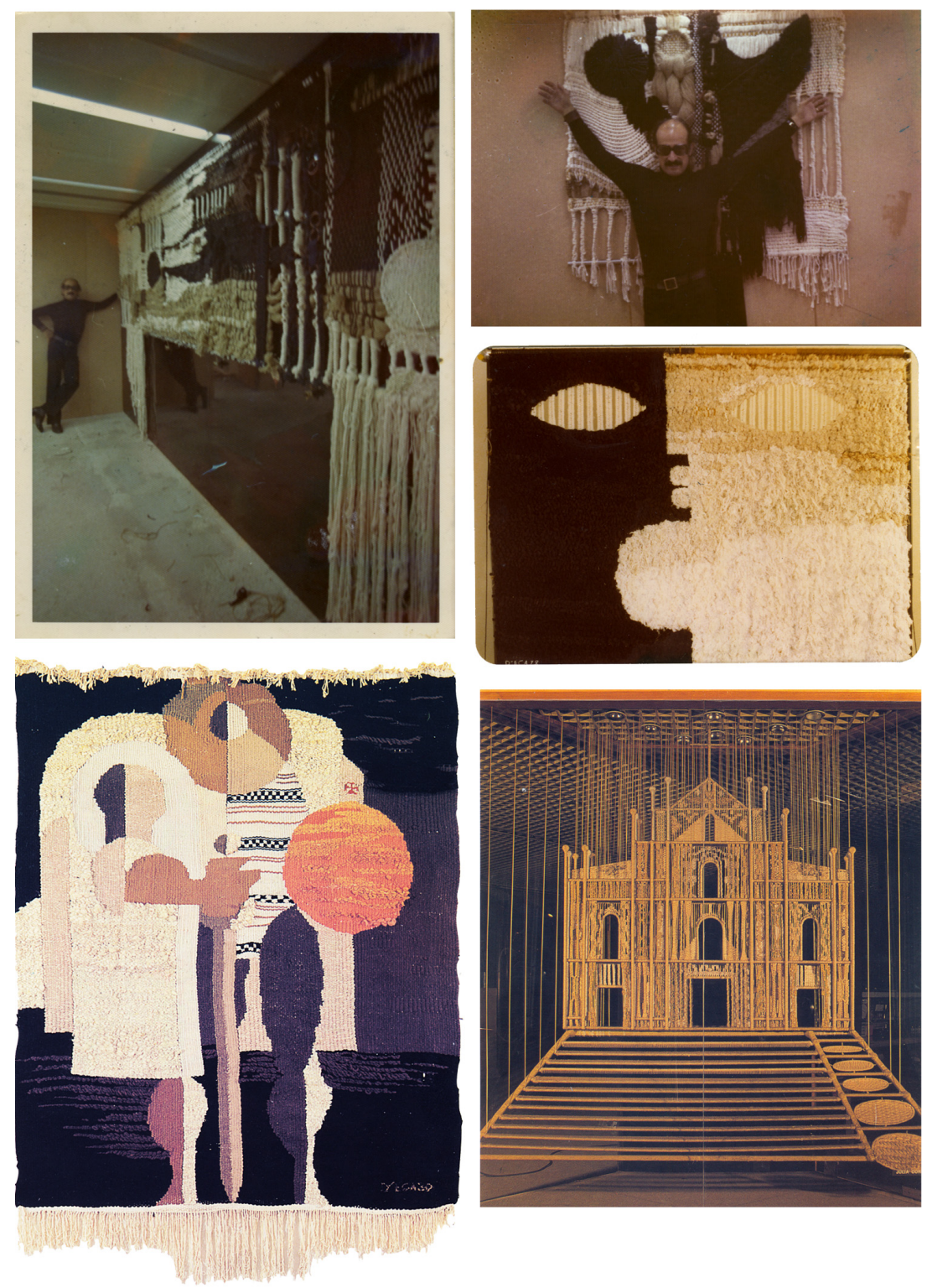

Figura 60. Conjunto de fotografias de tapeçarias 
universal.» ${ }^{110}$

«(...)numa fantástica desmultiplicação de possibilidades que a cada passo nos coloca toda a temática do espaço onde existe e porventura se move: o vazio, a divisão do espaço em partes irreais, inexistentes a não ser pelos objetos que nele se situam.» ${ }^{111}$

A tapeçaria tecida é uma técnica de confecção artesanal de um tecido. Normalmente ganha corpo com o cruzamento de fios de fibras têxteis, como lã, algodão etc. que com diversas cores e por diversas técnicas de entrelaçamento tornam possível incorporar as mais complexas figuras.

PG utilizava esta técnica como base principal à construção de tapeçarias decorativas de parede. A sua técnica não é rigorosa nas suas regras, evidentemente que há pormenores mais ou menos rígidos (como é o caso dos diferentes nós p.e conhecidos desde sempre) mas esta flexibilidade permite uma grande liberdade de execução, possibilitando trabalhos de grande riqueza e de variedade quanto à sua textura. A tapeçaria de PG parte sempre de um desenho original, transporta para a obra onde ganha uma nova identidade, nova face, uma nova originalidade pela composição intrínseca dos materiais e pela técnica usada para traduzir o modelo inicial. Assim é ultrapassado o problema da mera transposição para um outro suporte e a diferenciação de escala.

$\mathrm{Na}$ tapeçaria de PG prevalece o sentido construtivo, obtendo um trabalho mais compulsivo, forte e puro, visceralmente integrado às raízes da terra e à memoria dos seus mistérios. Os materiais são extraídos da natureza, nada sofisticados, adoptados no seu estado natural: algodões, jutas, lã virgem, etc. No seu trabalho são visíveis diversas técnicas da tapeçaria tecida como o entrançar, entrelaçar,

\footnotetext{
${ }^{110}$ CARNEIRO, Fernando. "Esculturas e Tapeçarias", Desdobrável de exposição - Museu de arte contemporânea do Paraná, Brasil, 1978

${ }^{111}$ GONÇALVES, Alberto Pinto. "Esculturas e Tapeçarias”, Desdobrável de exposição - Museu de arte contemporânea do Paraná, Brasil, 1978
} 
enrolamentos, suspensões, nós (Rya), nó de Beiriz, Gobelin, aplicações, trama interrompida, borboto, incrustações, torções, ténicas mistas etc. bem como técnicas da tecelagem, tafetá, tafetá riscas, tafetá xadrez, cetim e sarja.

$\mathrm{Na}$ tapeçaria, PG sai do espírito linear da tapeçaria procurando efeitos através de relevos num mundo abstratizante. 
4.6 Interiores y decoración / Interiores e decoração

«A década foi também assinalada pela aventura de PauloGuilherme em empresas decorativas mundanas e cosmopolitas, mais ou menos comerciais - como a decoração das boîtes O Ferro Velho ou O Caruncho, da escadaria, e salões de estar, jogos e recepção do Hotel Alvor - Praia (em colaboração com Eduardo Medeiros), para onde concebeu tapeçarias e relevos murais, ou da boutique Delfieu, verdadeiro marco da evolução do gosto e dos hábitos de consumo que colminaria no projecto de centros comerciais como o celebrado Apolo 70, com notável interior de restaurante, hoje infelizmente desfigurado. Na transição para os anos 70, esta vertente mundana acentuou-se, manifestando-se um gosto decorativo que acertou, com extrema elegância, com os revivalismos estilizados da Art Nouveaux e Art Déco internacionalizados: primeiro, o bar Snob, lembrado de «pub» inglês e, ainda hoje, um dos mais acolhedores bares lisboetas, depois o Snobíssimo, que surpreendeu a «Jeunesse dorée» cascaense pelo requinte da sua estilização interior «fin-de-siècle» - e, como proprietário de ambos, Paulo-Guilherme viu-se convertido em barista, «restaurateur» e animador de tertúlias. De certo modo, a experiencia repercutiu-se no desenho e, desde então o seu traço especializou-se numa estilização modernista essencialmente decorativa, de lembrança Art Déco, que lhe ficou perdurando no papel e alastrou, até hoje, para a pintura e para trabalhos como painéis decorativos em madeira pintada ou com embutidos, em recuperação de artesanias quase perdidas. ${ }^{112}$

\footnotetext{
${ }^{112}$ SANTOS, Rui Afonso. “Paulo-Guilherme D’Eça Leal D’Etecetera e Tal”, Revista Artes
} Ibérica, $\mathrm{n}^{\circ} 34$, Abril 2000, ISSN 0873-5700, p.27 

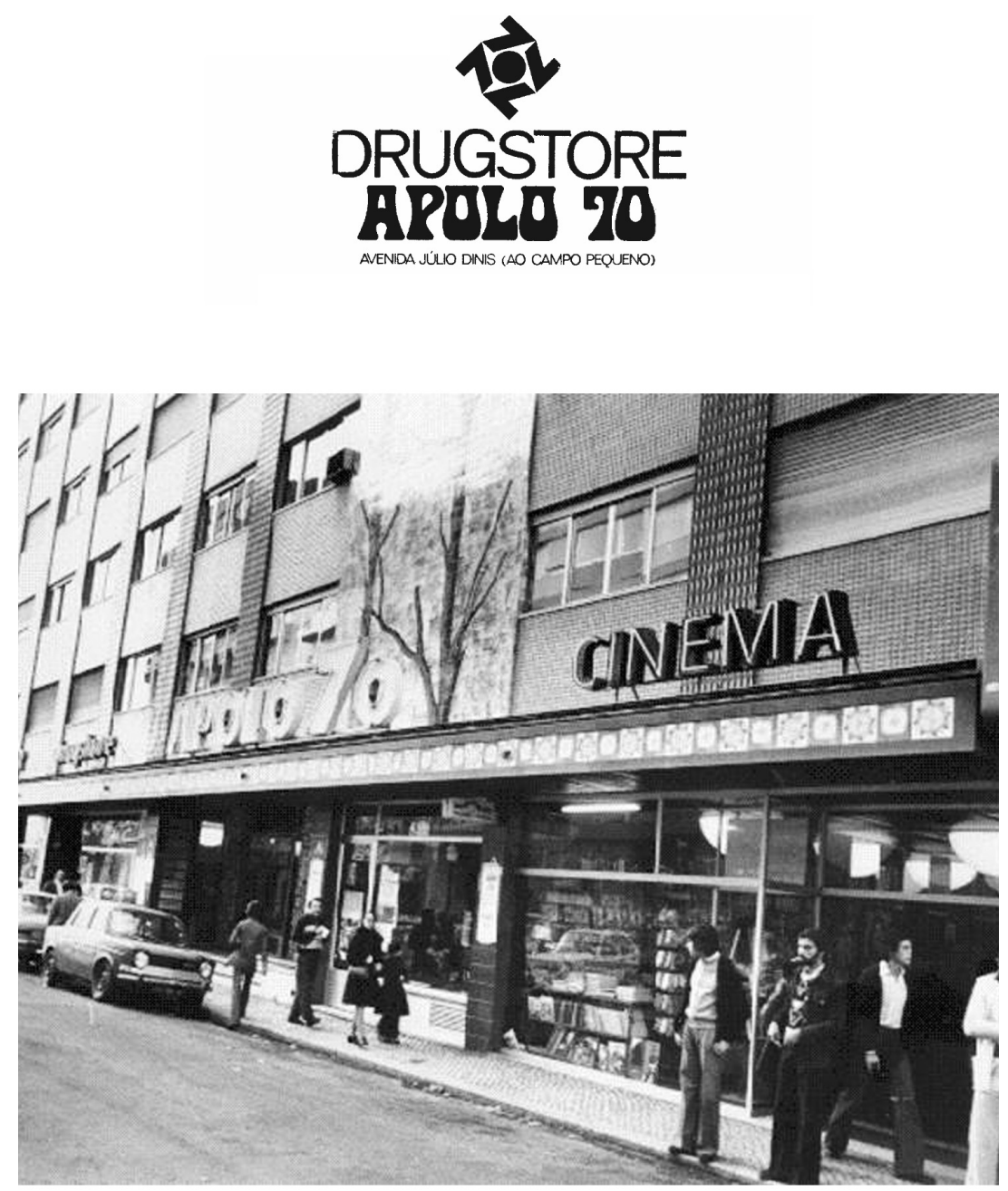

Figura 61. Centro comercial Apolo 70 
Nos anos 60, PG, dedicou-se à criação de ambientes noctívagos, decorando imensos clubes noturnos, que faziam a noite em Portugal. Intitulavam-se por boîtes. A decoração de PG era bastante desejada e requisitada, pois conseguia ambientes bastante singulares, exuberantes e únicos.

O Ferro Velho; O Caixote, em Cascais, atrás do cinema S.José; Cheque-Mate, no Porto; Lado-a-Lado, propriedade do cantor romantico Toni de Matos, que contava com a presença habitual de Simone de Oliveira; Yé-Yé; O Inferninho; O Forno; Portinhola, Cascais; Vip's, Cascais; Boîte do Casino de Espinho; Café-Concerto Cabaretíssimo, Cascais; A Nódoa, Cascais no Monte Estoril; O Ex; A Ronda; O Caruncho, Lisboa; $O$ Batô, em Leça da Palmeira e a $A$ Coutada, no Porto.

A discoteca Batô foi inaugurada em 1971 sendo uma das discotecas mais antigas da cidade do Porto. A decoração a cargo de PG conseguiu incorporar no seu interior, uma réplica da embarcação Varna naufragada nos anos 60, na foz do Porto. O Batô ainda mantem a mesma decoração e mantem-se actualizada apesar dos seus quarenta e um anos de vida.

Com uma lareira na parte central, A Coutada, em Leça da Palmeira, era um ambiente distinto, próprio para grandes celebrações. Única em Portugal até na decoração, pela originalidade e extravagante utilização de animais embalsamados, que meticulosamente colocados the conferiam uma

atmosfera fora de comum mas ao mesmo tempo envolvente. As comemorações das grandes datas (aniversários, Reveillons, etc.), eram em tom solene, geralmente jantares de gala, com o traje obrigatório e a rigor, que também se obrigava a vestir em grandes espetáculos e que contava com grandes nomes entre outros: Patxi Andión, Vinícius de Moraes, Toquinho, Ivon Curi, Carlos do Carmo, etc. 

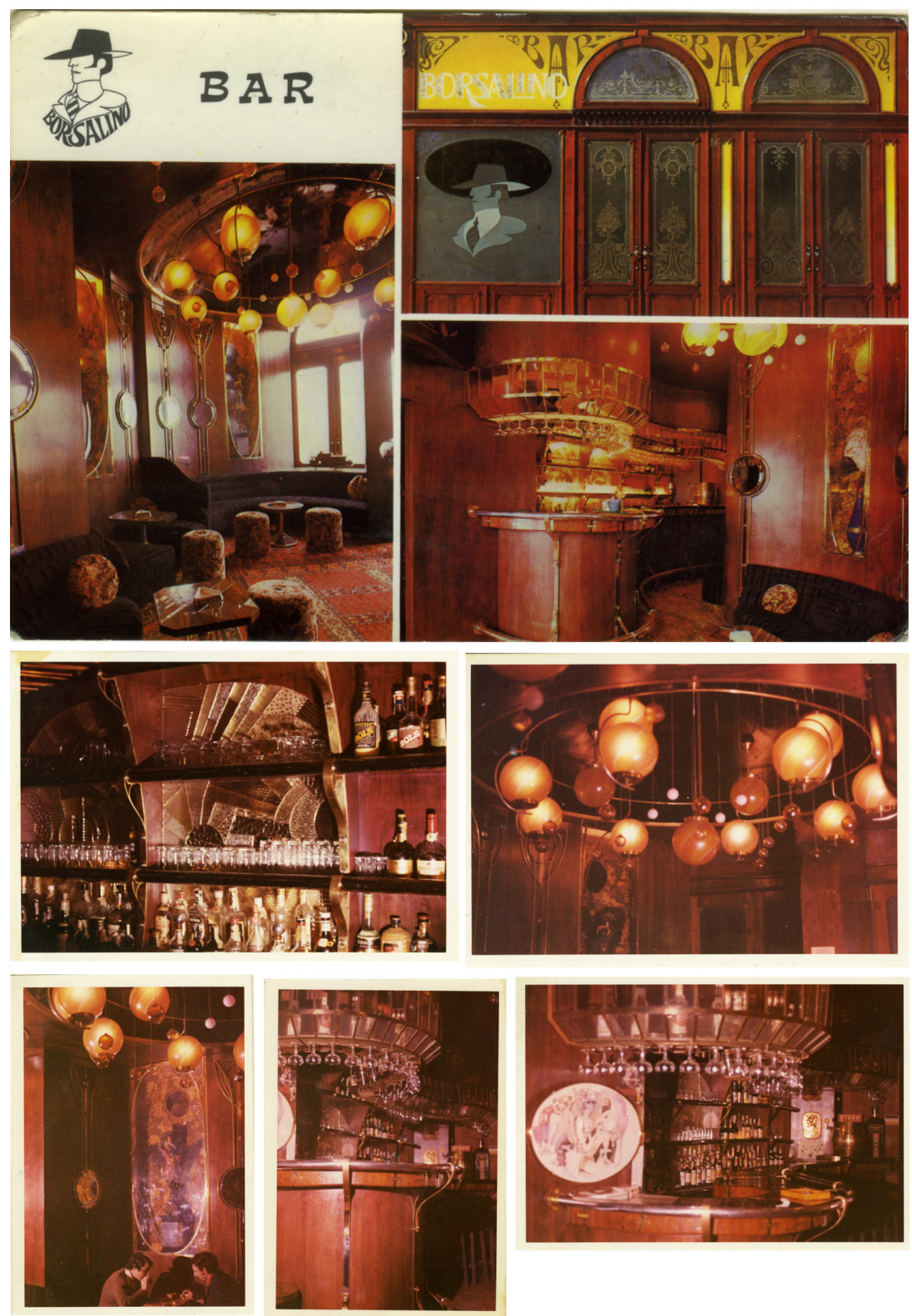

Figura 62. Conjunto de imagens do Borsalino 
Entre os vários bares concebidos por PG emerge nos anos setenta o Borsalino, sito em Cascais, em que além da decoração a criação da imagens corporativa foi também da responsabilidade de PG.

«Entre as soluções expeditas adoptadas para o Forte Velho (com as paredes e as abobadas forradas a papel de jornal) e o refinamento da pormenorização do Bar Borsalino, revela-se uma mesma objectividade da abordagem de situações diversas de fruição do espaço» ${ }^{113}$

Nos bares decorados pelo PG, evidencia-se o Snob, $\mathrm{n}^{\circ}$ 178, da Rua do Século em Lisboa. Corria o ano de 1963 quando PG jornalista de $O$ Século e Alberto Nunes de Carvalho compraram a um artesão a oficina de latoaria. Sob fortes influencias de bares ingleses, a 16 de Novembro de 1964, abre portas o bar Snob. Num ambiente londrino dos anos 60, candeeiros à meia-luz, cinzeiros enormes em cima das mesas de tampo de veludo verde acolhe tertúlias e muita animação (fora de horas).

«Snob, um dos mais famosos locais de peregrinação para jornalistas e políticos da nossa praça. (...) o Snob tinha o destino marcado no seu código genético: a maior parte das redacções dos jornais da época situava--se no bairro Alto, bem perto do pequeno bar. Jornalistas de O século, Diário Popular ou da Agencia de Notícias ANOP afluíam depois da hora de fecho para beber um copo e comentar a história do dia. Dois anos depois da sua abertura, Adriano Oliveira, antigo director do cabaré Maxim, compra a casa a Eça Leal e herda a sua clientela. $»^{114}$

«É assim o Snob Bar, ponto de encontro histórico de jornalistas e

\footnotetext{
${ }^{113}$ SILVA, António Sena da, 2Modo de usar as Artes", Catálogo de exposição, Paulo-Guilherme D'Eça Leal D'etecetera e tal 2000, Palácio Galveias 2000, Câmara Municipal de Lisboa , Novembro de 1999, p. 242,243

${ }^{114}$ SIMÕES, Humberto. “Snob”, Revista Focus 201/2003, p. 23
} 

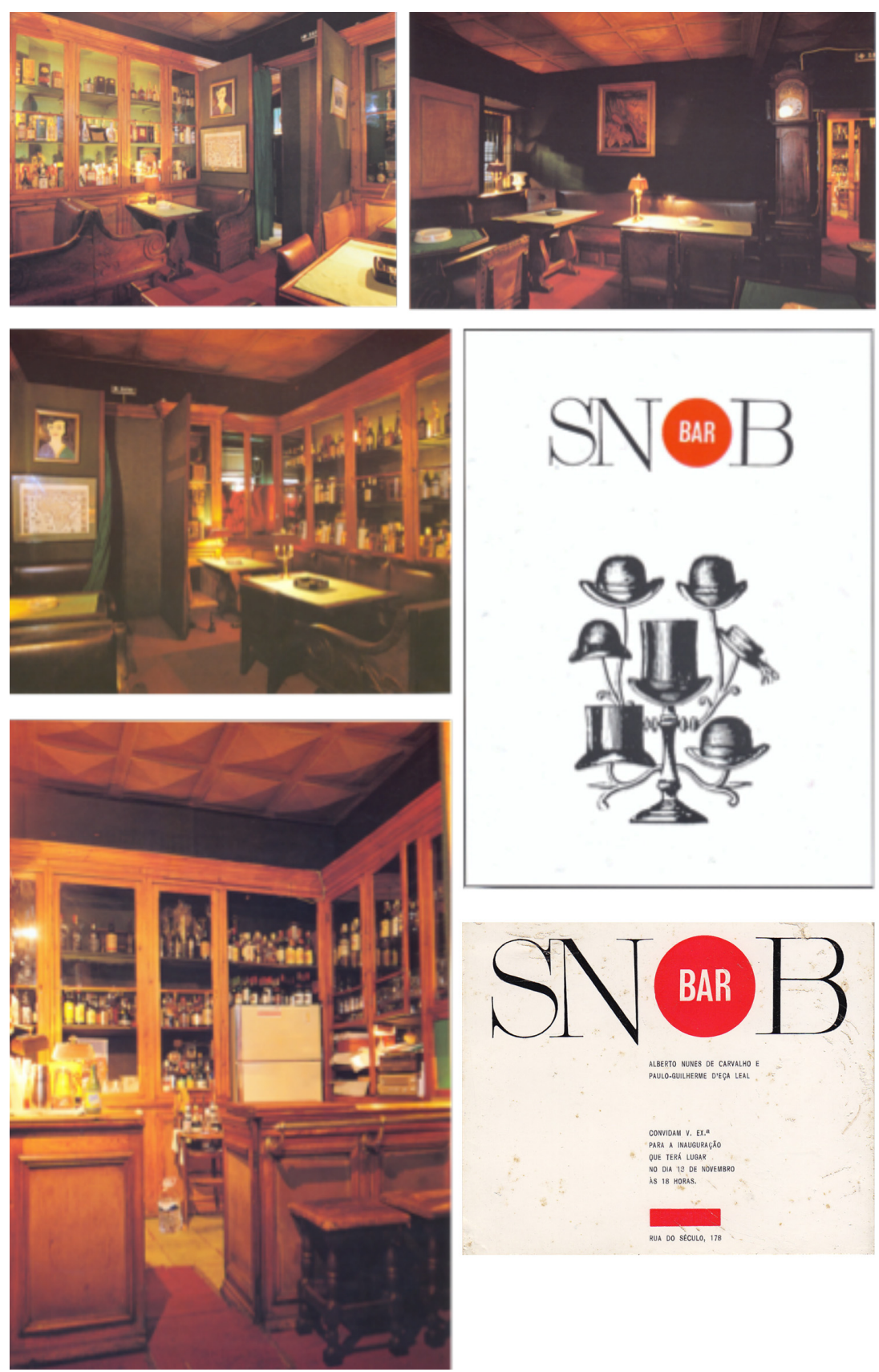

Figura 63. Conjunto de imagens do bar Snob 
políticos, médicos e advogados, actores e artistas plásticos, músicos e cineastas. Eles entram, ocupam as mesas, as cadeiras e os sofás em tons de castanho-terra e esperam que os acepipes sejam servidos. Tudo ali é intimista, obscuro, quase a roçar o sedutor.» ${ }^{115}$

$\mathrm{Na}$ área da restauração arquitecta a decoração de espaços como Bachus em Lisboa, A Ronda no Monte Estoril, A Copa em Cascais, o Grilo, Restaurante Eduardo VII, Bebedouro em Curitiba, La Bohéme, também em Curitiba (do qual foi proprietário) e obviamente responsável pela sua imagem corporativa.

Autor da decoração do espaço cervejaria Portugália Rio, no Cais do Sodré (1997) e de um painel de azulejo, de grandes dimensões, para a Cervejaria Portugália no Centro Comercial Colombo (1997). A Cervajaria Portugália foi lugar comum durante três décadas (30/40/50), de políticos, artistas e desportistas. Lugar elegido pela ambiência criada, própria para a boémia, convívio e descontracção. Desta celebridade selecionou Cotinelli Telmo a sua esplanada para a cena final do filme A Canção de Lisboa, em 1933, com a adaptação aos novos tempos, novos conceitos surgiram, e em 1997 transpos-se com a mesma gênese para uma cadeia de restaurantes pautada pelo serviço, sabores e ambientes da cervejaria que nos seus 80 anos de vida conquista e fideliza o público, entre o qual lembra-se nomes como Raúl Solnado, Vasco Santana ou Amália Rodrigues. A cervejaria Portugália Rio foi inaugurada a 10 de Junho de 1997 e tinha por objectivo «manter a tradição da Portugália, mas apostando na modernidade para captar a juventude ${ }^{116}$ como afirma Manuel Vinhais, um dos administradores. Esta cervejaria ocupa uma área de cerca de 500 metros quadrados, distribuídos apenas por um piso. O espaço foi imaginado pelo arquitecto Gastão Cunha

\footnotetext{
${ }^{115}$ PAGO, Ana, "Bifes e tertúlias com 40 anos de vida “, Diário de Notícias, 21 Novembro 2004, [disponível em: http://www.dn.pt/inicio/interior.aspx?content_id=590021] [consultado em 20/10/10, 10:30:00]

${ }^{116}$ GANHÃO, Mafalda. “As novas casas da Portugália”, Expresso, n¹274, 28 Março 1997, p.9
} 

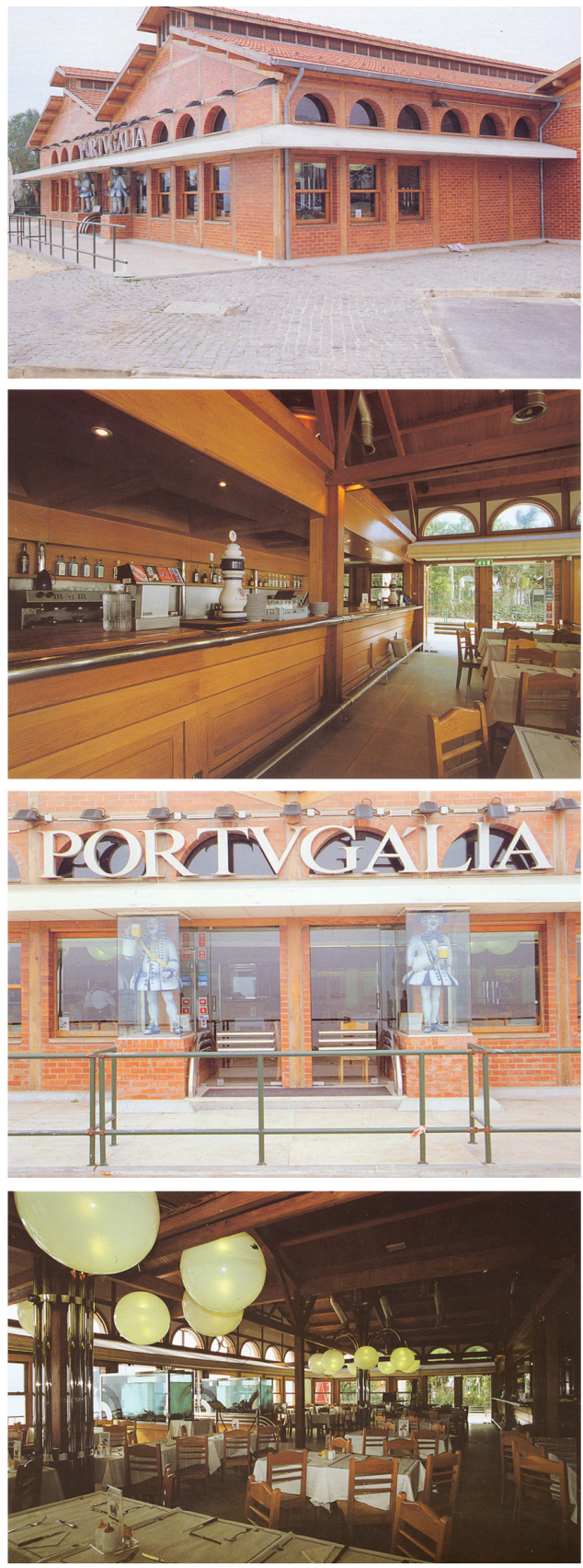

Figura 64. Conjunto de fotografias da cervejaria Portugália-Rio 
Ferreira e decorado por PG. Inclui uma área para cerca de 50 mesas e uma esplanada para o rio.

«(...) o Snobíssimo e o Borsalino são casos exemplares de acolhimento "quente" (...) Ele é capaz de receber bem as pessoas através do calor das formas e dos materiais (caso do Snobíssimo e do Borsalino, em que o bem estar vem do calor das madeiras, dos tecidos, dos livros e das imagens "art noveau" que hoje funcionam quase unicamente como elementos de humor) (...).» ${ }^{117}$

O Snobíssimo, restaurante de PG em Cascais, mostra como o seu proprietário habilmente o pensa e o projecta. Retirando-o de um lugar comum dota-o de outras valências simultânea e aquele ambiente acolhedor, intimista e burlesco permitam ao mesmo tempo degustar uma boa refeição e assistir a um espetáculo de qualidade também de PG, o Caberetíssimo.

«(...) Do Snob e do Snobíssimo, já se tem falado bastante, mas referir apenas a "decoração" seria incorrecto. Aqui é o cenário que escolhe os protagonistas e os figurantes, condicionando gentilmente os papeis que eles podem desempenhar. No entanto, se insistirmos em atribuir a designação de design para abranger todo o trabalho de Paulo-Guilherme, corremos o risco de uma interpretação redutora. Talvez seja preferível limitarmo-nos a classificá-lo como um mutante de "homem do Renascimento" que, graças a uma capacidade de trabalho prodigiosa, consegue acumular experiências e realizações que continuam a incomodar os críticos bem-pensantes e várias corporações de artistas bem-comportados. ${ }^{118}$

\footnotetext{
117 BAPTISTA, António Alçada, "O universo plástico de Paulo-Guilherme", Catálogo de exposição, Paulo-Guilherme D’Eça Leal D'etecetera e tal 2000, Palácio Galveias 2000, Câmara Municipal de Lisboa, 1999, p. 210

${ }^{118}$ SILVA, António Sena da, "Modo de usar as Atres", Catálogo de exposição, Paulo-Guilherme D'Eça Leal D'etecetera e tal 2000, Palácio Galveias 2000, Câmara Municipal de Lisboa, 1999, p.243
} 

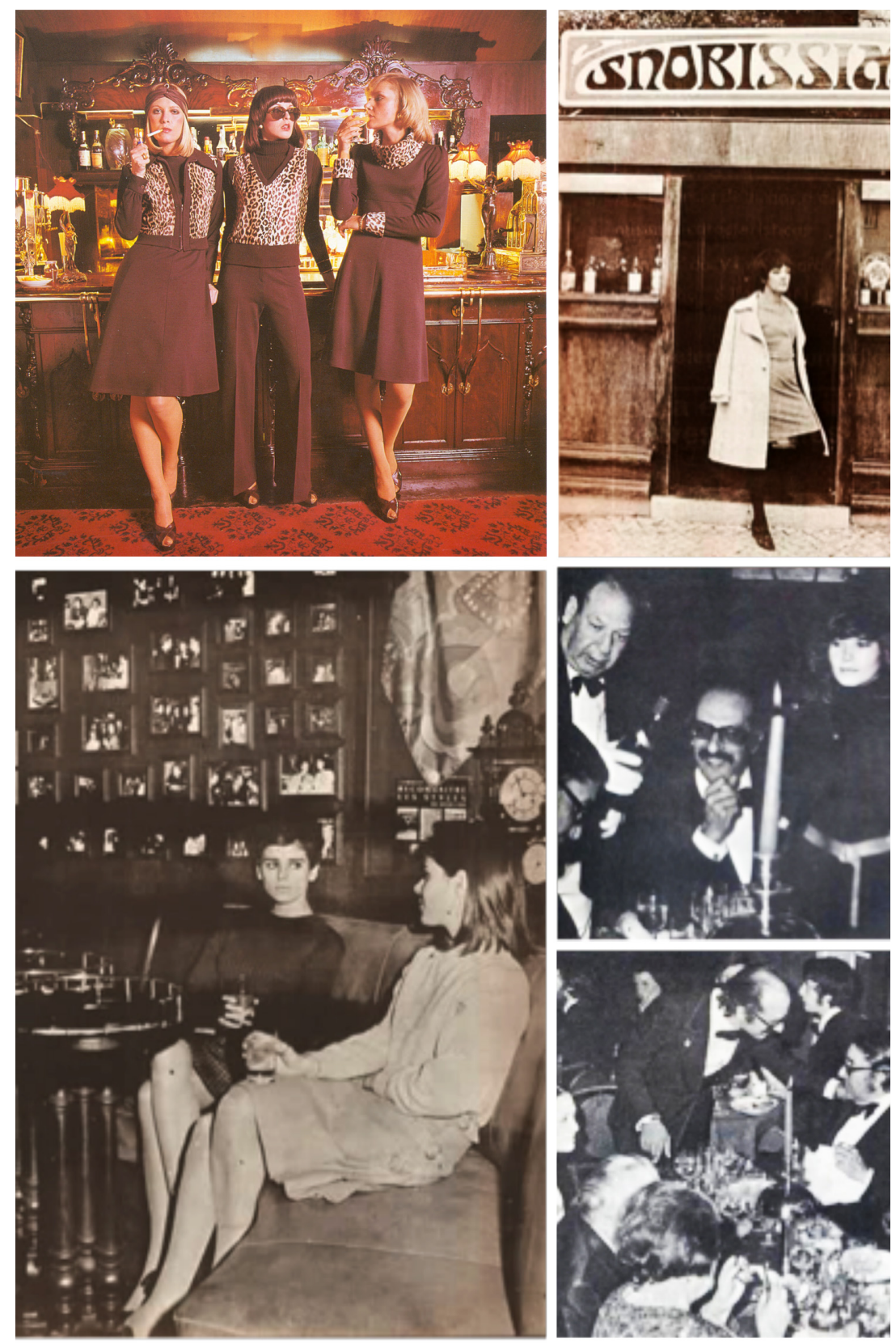

Figura 65. Conjunto de fotografias do Snobíssimo 
PG em 1968, participa na decoração do Marina Hotel em Vilamoura e também no Hotel Alvor, ambos no Algarve.

Em meados da década de 60, e pela conjuntura de desenvolvimento turístico de algarve, neste âmbito, foi mandado construir o Hotel Alvor Praia, pela Sociedade de Investimentos Hoteleiros SARL. O projecto de arquitectura foi da responsabilidade de Alberto Cruz e a arquitectura paisagística foi confiado a Gonçalo Ribeiro Telles. Este empreendimento luxuoso contou com a colaboração de António Garcia e José Espinho, concebendo o design de interiores, mobiliário e decoração dos quartos, sala de jantar do bar e sala de estar; PG, Eduardo Medeiros e João Alcobia tiveram a incumbência dos salões e da escadaria principal. A arquitectura de interiores ficou a cargo de Daciano Dacosta.

Na obra da decoração do Hotel Alvor do Algarve está também compreendida uma tapeçaria $(3.00 \times 2.00 \mathrm{~m})$ e um relevo em tijolo refractário $(12.00 \times 6.00 \mathrm{~m})$ realizada por PG.

Decorou algumas casas particulares: Dr. Manuel Vinhais em Monsaraz (com Jorge Mattos Chaves); António Cabrita; Beatriz Elias; João Raposo Magalhães; Mário de Oliveira; Rita Smhmolevitch; Francisco Mata; Ruy Guedes; Henrique Lima. Reconstruiu e decorou o Iate Le Coriphéne originalmente pertencente a Alain Lombard e transformado para o Dr. António Lereno, administrador do Banco-Franco-Portugais. Foi-lhe entregue também a decoração de um outro iate, Iate Red-Pirat.

Dedicou-se intensamente à projecção e decoração comercial como são exemplos os prontos-a-vestir Delfieu, Vanitas, Migacho e Pompadour (Porto e Cascais). Estas lojas, como outras (A Maçãa, as lojas Tara, 007, A Outra Face da Lua, Porfírios, Cenoura, etc.) emergiram nas décadas de 60/70, como sinal de modernidade. Vieram a substituir rápidamente as modistas ou mesmo as roupas que se faziam em casa. 


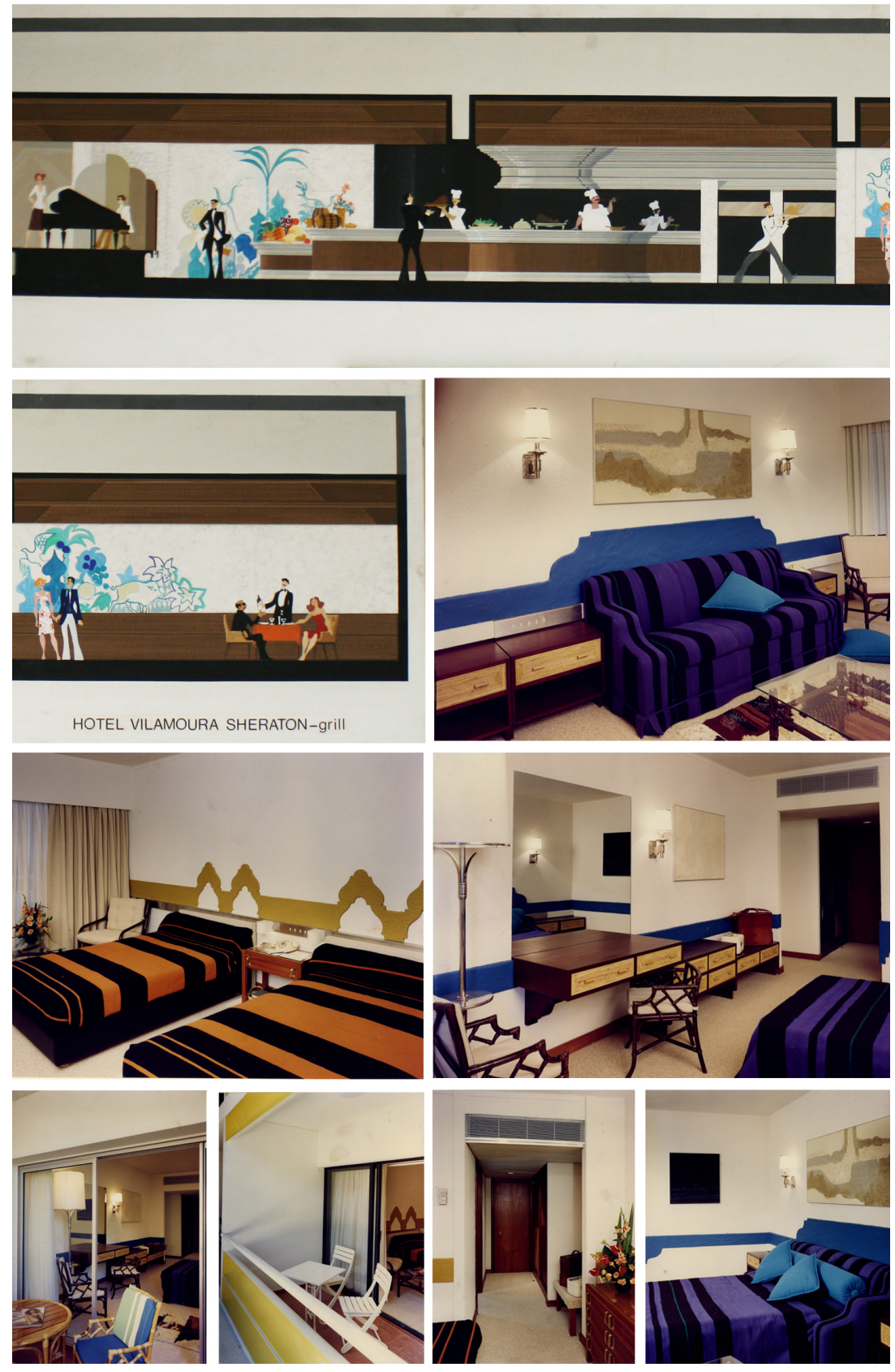

Figura 66. Conjunto de imagens do Vilamoura Hotal Sheraton 


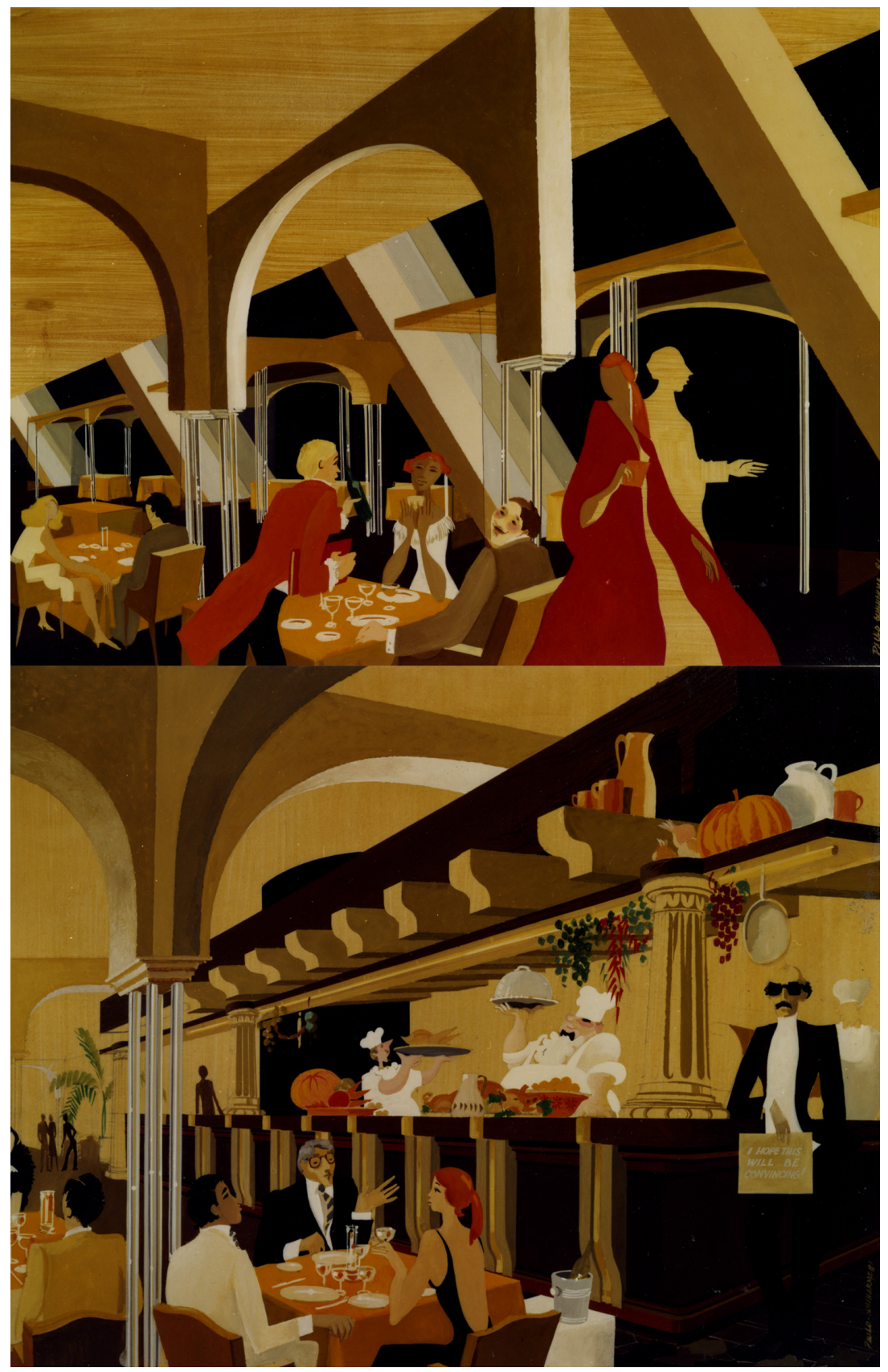

Figura 67. Maquetas do interior do Vilamoura Hotal Sheraton 

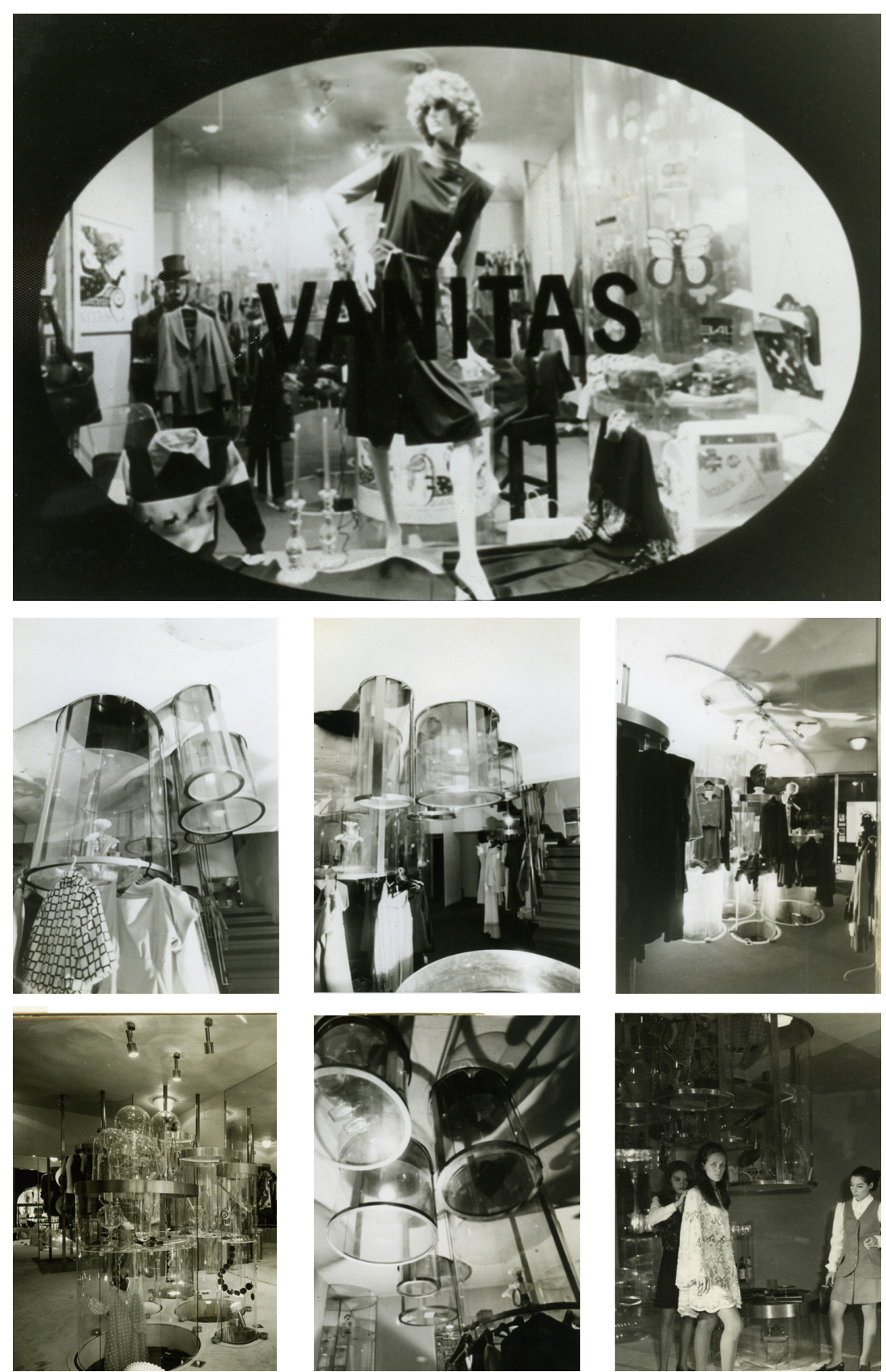

Figura 68. Conjunto de fotografias da loja Vanitas 
4.6.1Restaurante Bachus / Restaurante Bachus

O restaurante Bachus, pensado por PG nos anos 80, recriava a atmosfera Art Deco, das décadas de 1920 e 30. O edifício assenta nas fundações que remontam ao período anterior ao terramoto de 1755 e foi inaugurada em 1983. Foi uma casa das mais frequentadas em Lisboa, situada numa movimentada rua do Chiado, com diversos acessos ao Bairro Alto, envolvência boémia que torna este espaço especial e diferente.

$\ll(. .$.$) o ambiente desta luxuosa casa é digno de figurar em qualquer$ película de cinema, ou série televisiva, dada a fidelidade com que reproduz o gosto dos "loucos anos 20" na Europa e o modo como nos transporta para outro tempo.» ${ }^{119}$

Cria este espaço com a filosofia de honrar a vinha e o vinho, homenageando o Deus Baco, Deus do Vinho. Este ambiente luxuoso dividia-se por dois pisos, ligados entre si por uma elegante escada em caracol. O piso superior, equipado com requintado mobiliário, com vista privilegiada e nas paredes com azulejos portugueses pintados à mão que se estendem até à sala privativa. $\mathrm{O} 1^{\circ}$ andar têm luz natural e uma vista magnífica sobre o rio Tejo. No piso de baixo, enquadradas com vitrinas, várias colunas pintadas com parras e uvas esculpidas sustentam o primeiro andar. Cada peça foi elaborada individualmente, desde os candeeiros de tecto às mesas com revestimento a cobre. A madeira, o couro e latão são os seus materiais nobres eleitos. À entrada, um pequeno hall abre caminho ao conforto do bar provido de bancos altos em pele. Neste espaço totalmente revestido a madeira tinha lugar a distinção, a

${ }^{119}$ NEVES, Patrick. "Restaurante "Bachus"”, [disponível em http://revistanectar.wordpress.com/tag/restaurante/], [consultado em 18/02/11, 16:00:00] 

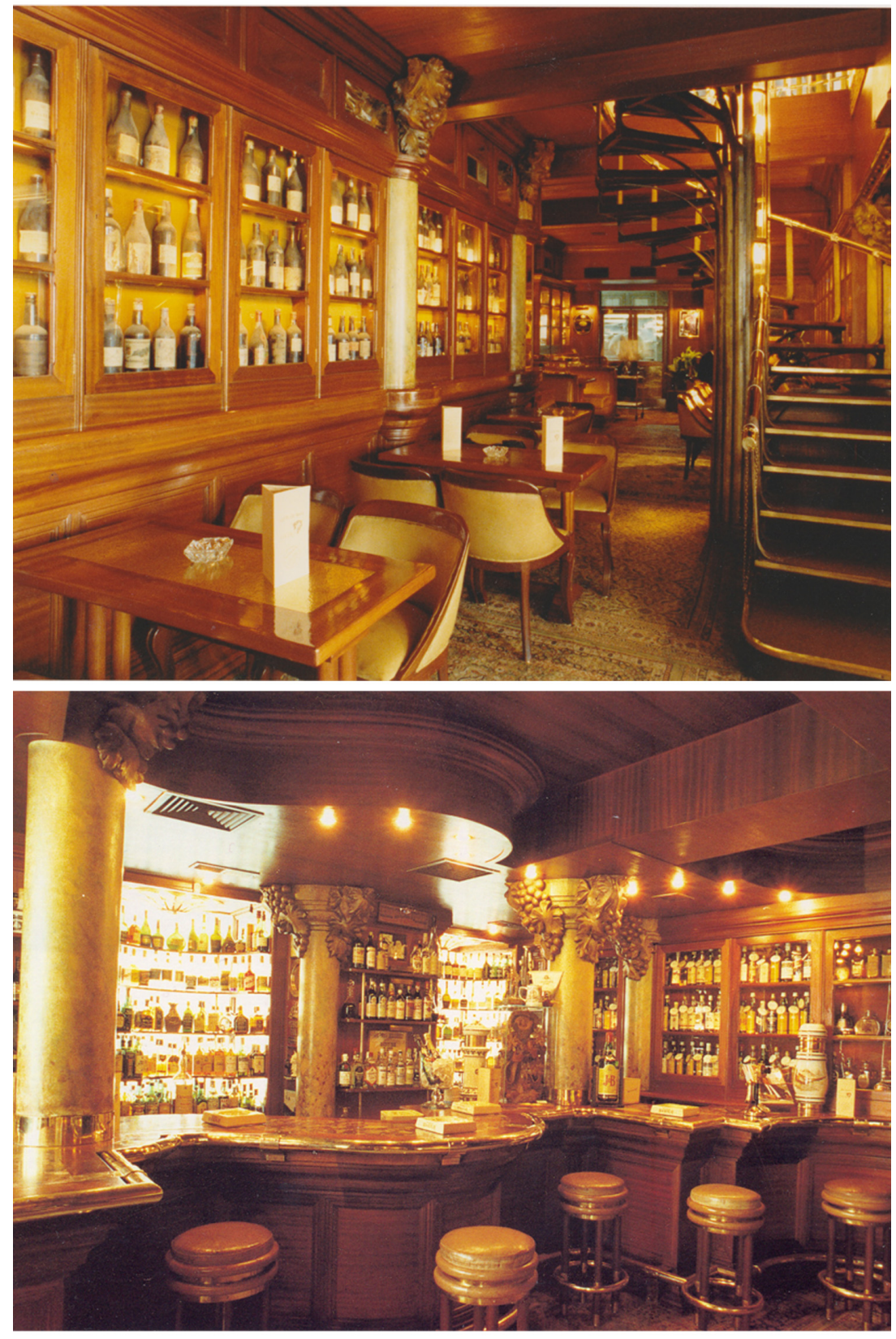

Figura 69. Conjunto de fotografias do Restaurante Bachus 

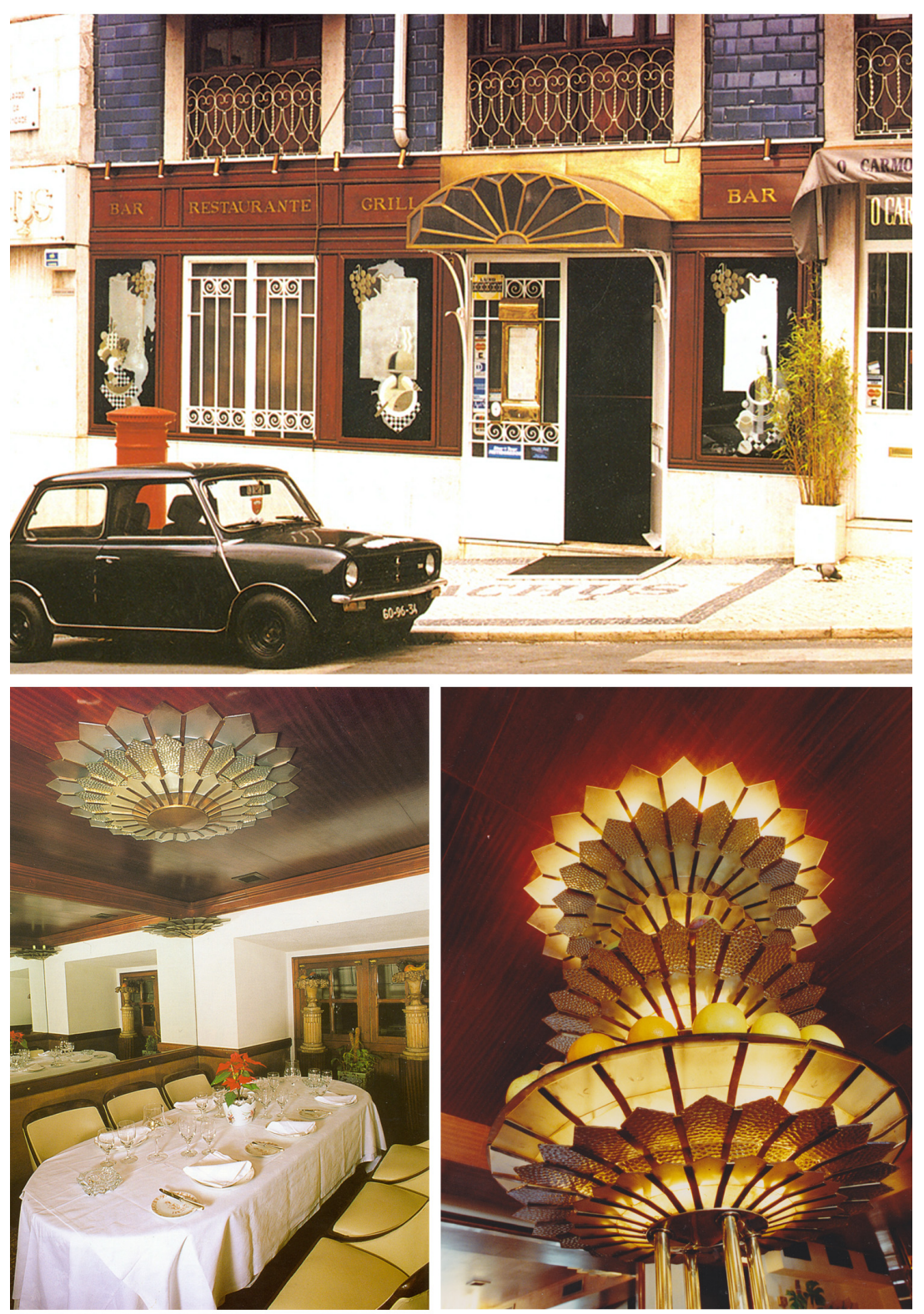

Figura 70. Conjunto de fotografias do Restaurante Bachus 

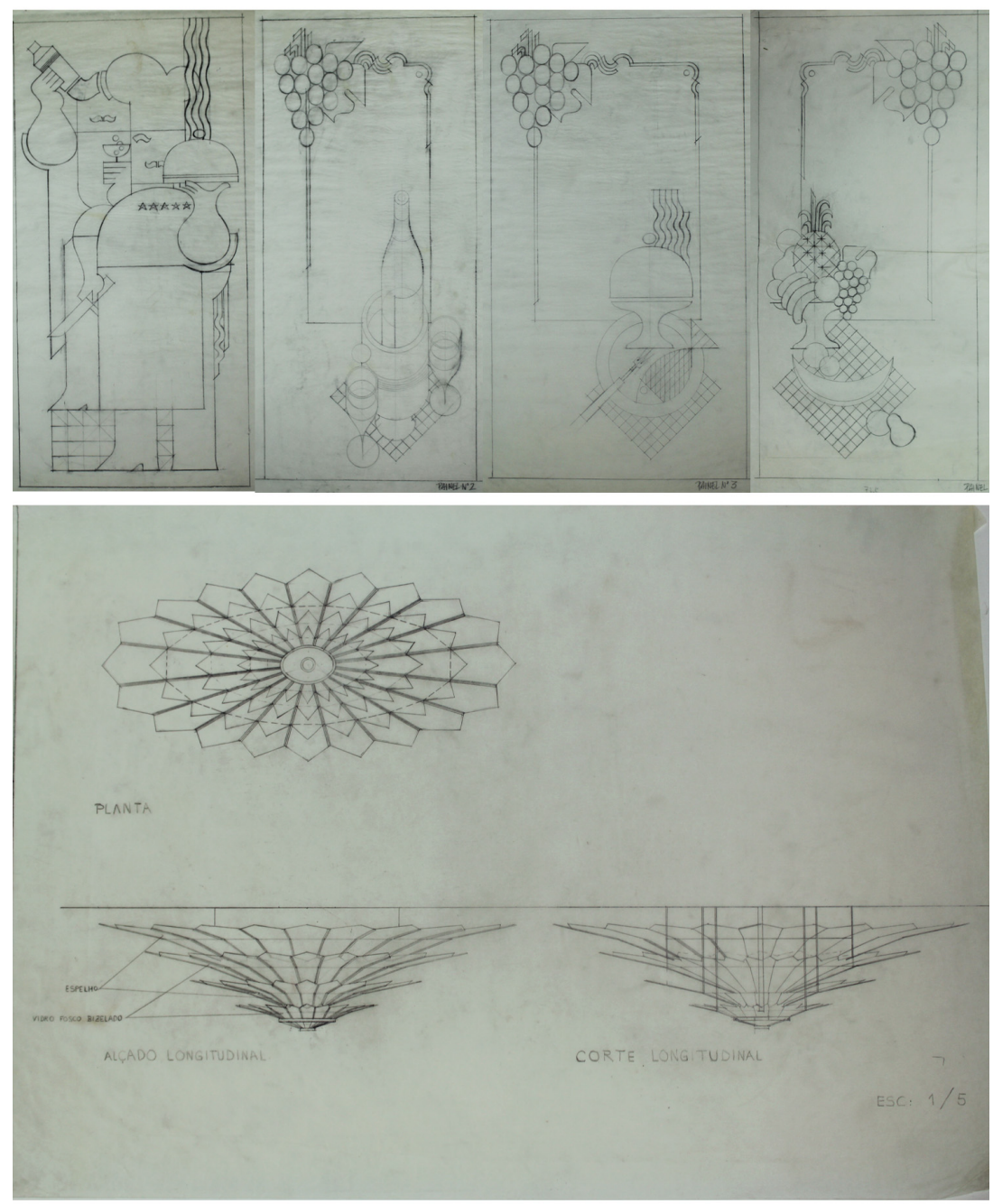

Figura 71. Estudos do projecto Restaurante Bachus 
sofisticação, a classe. Na frontaria do restaurante exibem-se quatro painéis, todos com o mesmo registo a mesma narrativa e do mesmo material a "pedra". Estas obras são baixos relevos e resultam da combinação ou associação de variados tipos de pedra, plana, formando um conjunto de onde ressalta um desenho figurativo com carácter geometrizante. À excepção de todo o resto, estes paineis ainda fazem parte do imóvel e em bom estado de conservação.

4.6.2 Misión de Macau / Missão de Macau

O edifício Centro Científico e Cultural de Macau, à data da criação, encontrava-se em avançado estado de deterioração necessitando uma total remodelação. A reconstrução esteve a cargo da Direç̧ão Geral dos Edifícios e Monumentos Nacionais e a arquitectura de interiores foi entregue a PG.

O Edifício da Missão de Macau em Lisboa, edifício de cinco pisos, outrora situado na Rua da Junqueira $n^{\circ} 30$. Deu ao público uma noção geral da presença portuguesa em Macau e dos Benefícios do Intercâmbio cultural entre a China e Portugal.

$\ll O$ Museu do Oriente define-se como uma unidade museológica permanente, aberta ao público, tutelada pela Fundação Oriente, tendo por missão a valorização dos testemunhos quer da presença portuguesa na Ásia quer das distintas culturas asiáticas.

Trata-se de um museu de âmbito territorial internacional e de carácter transdisciplinar, que procura, através do cruzamento de pontos de vista emergentes dos campos temáticos da História, da Arte e da Antropologia, proporcionar aos Portugueses e aos que nos 

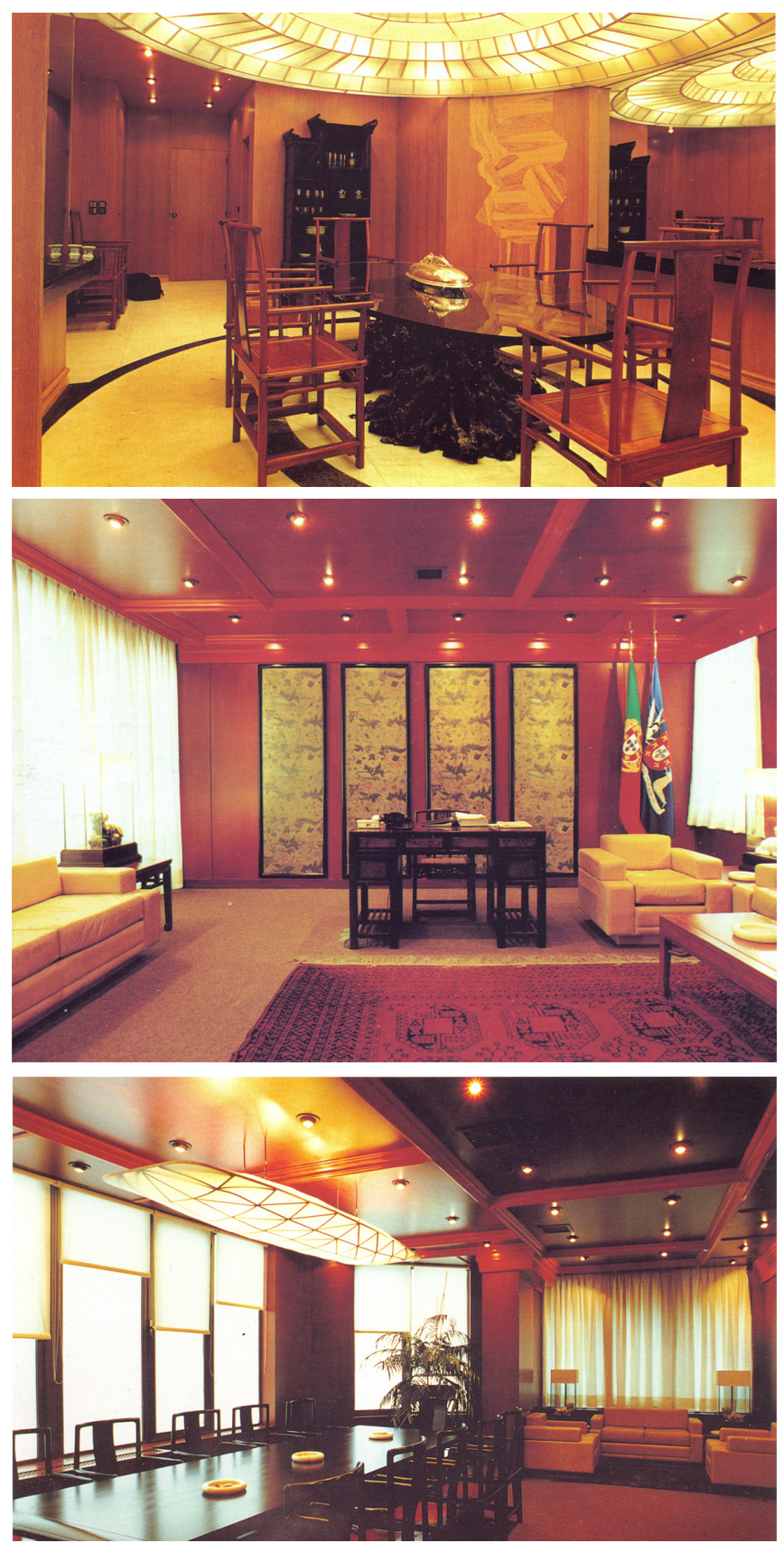

Figura 72. Conjunto de fotografias da Missão de Macau 
visitam uma memória viva e actuante das culturas asiáticas e da relação secular que foi estabelecida entre o Oriente e o Ocidente, principalmente através de Portugal.

A esses campos temáticos corresponde um diversificado património cultural de interesse histórico, artístico, documental, etnográfico e antropológico relacionado tanto com a cultura popular e as religiões orientais como com os mais variados aspectos da presença portuguesa na Ásia ao longo de cinco séculos.» ${ }^{120}$ Nesse sentido, além da exposição de artefactos e documentos manteve-se um ritmo de exposições temporárias e de conferências a que o público se habituou na acção da missão de Macau, em Lisboa.

O Jardim, entrada obrigatória do museu, descretamente orientalizado de modo a desde logo introduzir o visitante no ambiente que virá a encontrar no museu. Além disso, dada a localização particularmente recatada desta área em relação à rua, é eventualmente cenário de pequenos concertos, festejos tradicionais, ou simples reuniões comemorativas.

O percurso da entrada sublinhado por três pórticos chineses que conduziram o visitante para a entrada do museu.

Sem alterar a fachada proposta pelo arquitecto da direcção geral dos Edifícios e Monumentos Nacionais e antes pelo contrário partindo desse traçado, na entrada é construída uma antecâmara munida de portas automáticas de modo a proteger o ar condicionado do interior.

A antecâmara é ladeada de dois pequeníssimos corpos laterais. Todo esse conjunto, inteiramente em vidro tomará o aspecto de mini jardim de inverno que se integra no ambiente do próprio jardim. Serve também de suporte ao lettring do nome do Museu. Os pequenos corpos laterais contêm o balcão de venda de

${ }^{120}$ FUNDAÇÂO MUSEU DO ORIENTE, [disponível em: http://www.museudooriente.pt/209/omuseu.htm,] [consultado em 21/07/12, 22:12:00] 

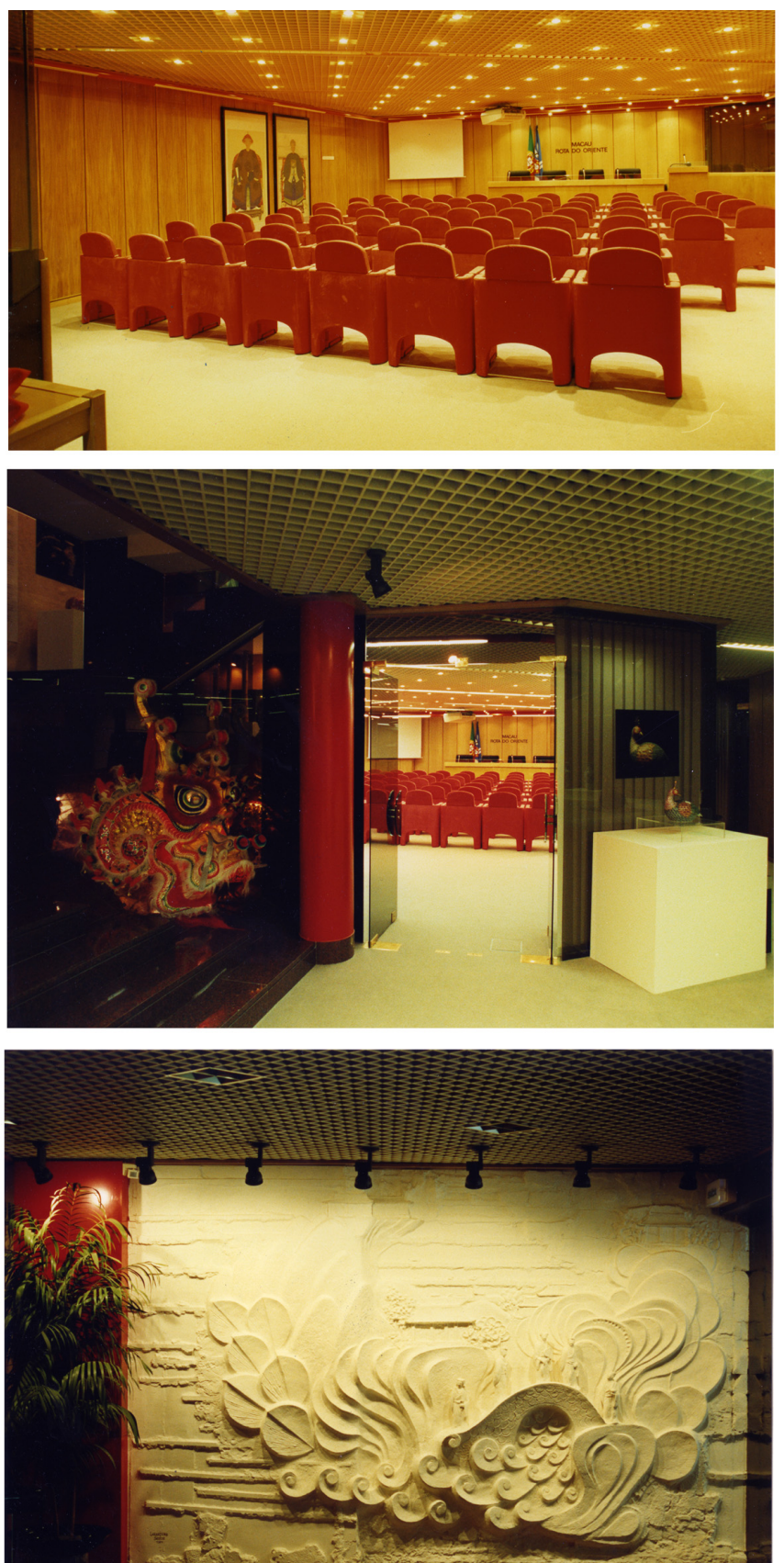

Figura 73. Conjunto de fotografias da Missão de Macau 
entradas e de pequenas peças, postais e livros.

O núcleo duro do museu desenvolve-se nos dois primeiros pisos ( $\mathrm{R} / \mathrm{C}$ e $1^{\circ}$ andar) cuja unidade é criada por uma escada entre os dois pisos. A área do R/C é profusamente equipada periféricamente, de vitrines tao espaçosas quanto possível para permitirem uma fácil exposição das peças que constituiem o acervo do museu. Para tal, é inclusivamente aproveitados os vãos de algumas das janelas. A traça destas é no entanto respeitada embora as vitrines nelas inseridas se integrem no conjunto.

O auditório, numa das paredes, contém um painel de embutidos de madeira. Aliás, todas as peças decorativas e de arte agora existentes foram inteiramente aproveitadas na ambientação do projecto. O mesmo se passou com o equipamento técnico de escritório e móveis.

A peça principal desta zona é uma larga escadaria de inspiração asiática, construida em madeiras vermelhas que conduz directamente ao piso superior através da abertura existente no espaço compreendido entre as quatro colunas centrais. Esta escada inteiramente ladeada por um conjunto de vitrines de alto a baixo que contém todas as maquetes dos edificios de Macau. São estas em número suficiente distribuidas densamente por todo o espaço contido pelos vidros. Deste modo a simples utilização da escada mostra ao visitante o tipo de arquitectura característico de Macau.

Ainda no piso térreo é localizado um pequeno bar que tem como decoração principal vitrines, em toda a superficie das paredes, que contêm objectos de Macau para venda ao público, assim como livros, especiarias e outros artigos. O pavimento desta área é totalmente em pedra branca de Estremoz polida. As lajes têm uma dimensão fora do vulgar cerca de $2 \mathrm{~m} \times 1 \mathrm{~m}$ com

$0,25 \mathrm{~m}$ de espessura. Este pavimento é enriquecido com um largo ornato em pedra preta embutida logo após a entrada. As quatro 

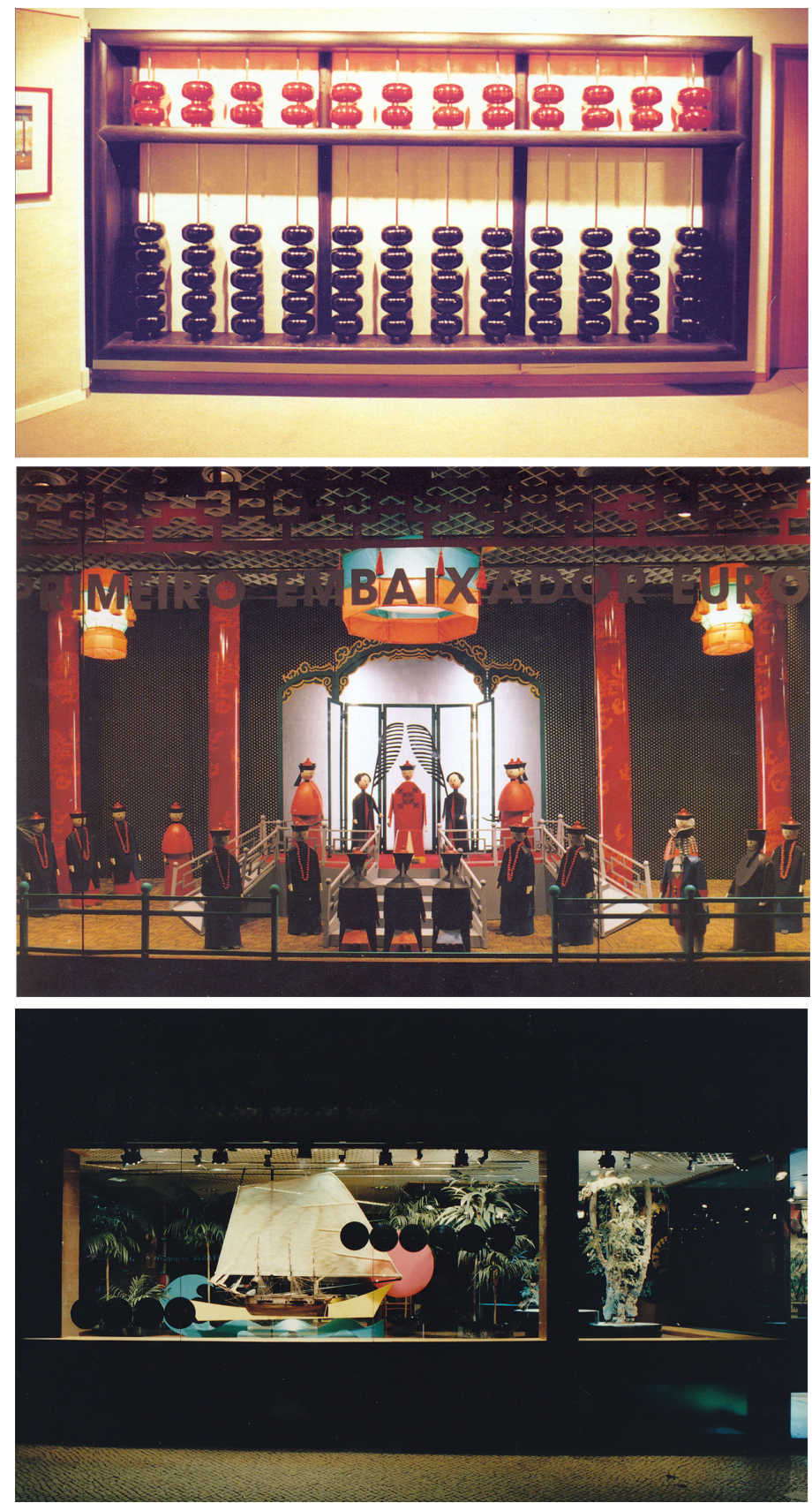

Figura 74. Conjunto de fotografias da Missão de Macau 
colunas centrais, neste piso e em todos os seguintes são lacadas a vermelho. As paredes são de cor branca e o tecto é forrado com madeira clara em placas tipo Junkers.

O interior das vitrines é revestido a tecido de cor próxima do tom ocre acinzentado, que sendo neutro de grau médio, valoriza todas as cores que se lhe aponham.

Em sequência natural do $\mathrm{R} / \mathrm{C}$, o $1^{\circ}$ piso tem todos os acabamentos identicos no que se refere a pavimento, paredes, tecto e vitrines. Será suplementarmente equipado com vitrines baixas tipo mesa, redondas, que permite enfatizar pequenos objectos: caixas; leques; joias e outros. Neste piso localiza-se também um pequeno gabinete com zona para secretária e pequena sala de espera, para o responsável directo pela direcção do Museu.

$\mathrm{O} 2^{\circ}$ piso era principalmente vocacionado para exposições temporárias e conferências. O pavimento muda para alcatifa vermelha que formará conjunto com as cadeiras de uma zona de auditório que enfrenta um estrado que contém uma mesa de conferências. Na parede por detrás desse estrado havia um painel de sistema intermutável que permitia o uso quer de um ecran de projecção quer de um quadro escriturável de apoio às conferências. Esta zona era eventualmente também utilizada para concertos tendo a possibilidade de muito rapidamente ser mudado o arrumo das cadeiras.

Toda a superfície desse pisso pode ser organizada de modo sempre diferente e livre pois todos os seus componentes são móveis. O $3^{\circ}$ piso era constituído por: um armazém directamente servido pelo monta cargas exterior; uma sala de expediente e um balcão de atendimento; uma sala de arquivo que comportava máquina fotocopiadora, fax e central telefónica; um gabinete secundário; um gabinete de secretária; uma sala de reuniões; um gabinete principal; um gabinete de secretaria e uma sala de espera. De um modo geral 
os acabamentos desta zona eram: pavimento geral, com excepção do armazém, madeira; o pavimento do armazém em mosaico hidraulico; tectos, apenas nas zonas publicas, no gabinete principal e na sala de reuniões, em madeira tipo junkers e paredes e restantes tectos tinham uma pintura branca.

A sala de espera, a sala de reuniõs e o gabinete principal foram alvo de uma decoração especial.

$\mathrm{O} 4^{\circ}$ piso foi preparado para o atendimento ao público com um salão de chá e refeições ligeiras e serviço de bar, concebidos de modo a manter a tónica do ambiente chinês. O tecto, no centro tinha uma clarabóia tratada decorativamente no mesmo sentido. Os tectos do pequeno bar e os pisos de exposições temporárias e do restaurante tiveram um tratamento semelhante aos tectos do $4^{\circ}$ andar da Missão (sala de reuniões) com sancas vermelhas moldadas. 
4.7 Arquitectura / Arquitectura

«A criação dos seus espaços surge assim como se fosse uma imposição metafísica de quem quer pôr, peça a peça, um mundo em harmonia com a raiz da natureza e talvez o reino do fazer do reino do ser, fronteira que não lhe apetece atravessar.» ${ }^{121}$

Com o conhecimento de decorador e já com uma carreira consolidada em vários domínios (artista gráfico, ilustrador, pintor e decorador), PG aventura-se no plano da arquitectura. Trabalha numa sociedade Galhardo Leal \& Medeiros que posteriormente seria apenas Leal \& Medeiros com o arquitecto Eduardo Medeiros onde realizam vários projectos. PG aprende e adapta-se facilmente a qualquer ofício e a arquitectura é mais um deles. Deixa o seu cunho pessoal em vários espaços públicos como as Galerias On the Rocks da Praia da Rainha em Cascais e o Palm Beach projecto de ampliação e decoração. Palm Beach era um empreendimento turístico localizado no topo da Praia da Conceição, em Cascais, que englobava um restaurante panorâmico, esplanada sobre o mar, um pub e uma boîte. É de relevar o centro comercial Apolo 70, situado na Avenida Júlio Dinis em Lisboa. Este espaço, com uma área de $3000 \mathrm{~m} 2$, tinha dois pisos, com uma oferta diversificada e acessível em 41 lojas. Foi o primeiro Centro Comercial em Portugal e único, durante muitos anos, possuía também um arrojado bar, um bowling de 4 pistas, e uma farmácia que se constituía caso original e único em Portugal. Continha também um cinema, cuja sala era forrada a napa branca e rodeada por poltronas encostadas às paredes. Na

121 BAPTISTA, Alçada, “O Universo Plástico de Paulo-Guilherme”, Catálogo Paulo-Guilherme D'Eça Leal D'Etecetera e Tal, CML, Lisboa, 2000, p.211 


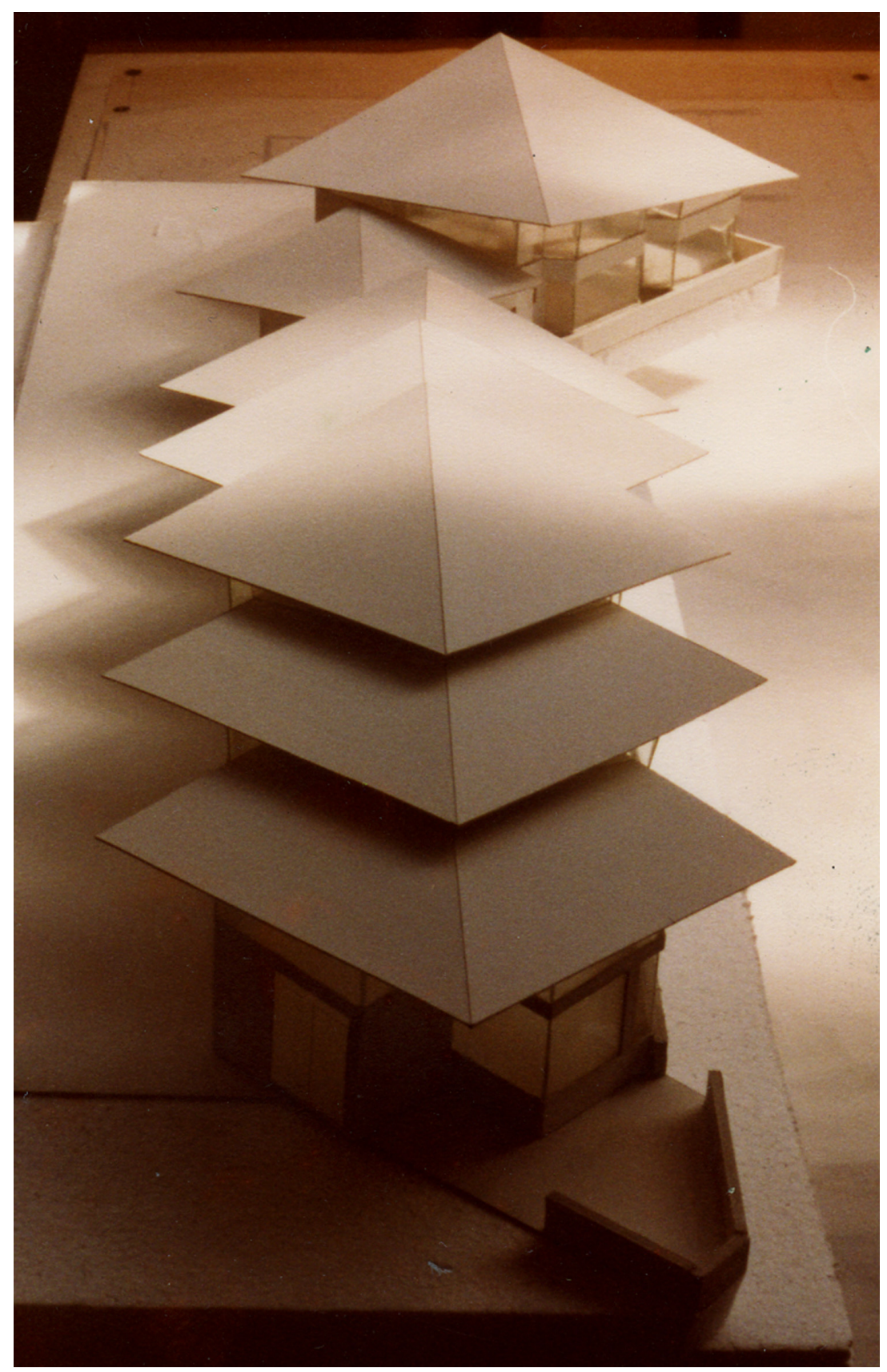

Figura 75. Maqueta do Palm Beach 
época tornou-se portanto, num espaço excepcional e um acontecimento incontornável para a vida lisboeta. Mesmo com a evolução dos tempos e com o aparecimento das novas grandes superfícies comerciais, o Centro Comercial Apolo 70 conseguiu sobreviver até aos dias.

Em 1973 realizou todo o projeto de arquitetura e decoração da Sede do Banco Pinto \& Sotto Mayor, no Porto. Neste projecto desenvolveu sete pisos: sub-cave, cave, piso de entrada e mais quatro andares, mantendo apenas a fachada original do edifício. Contrariando todos os conceitos clássicos de arquitetura, abre novos caminhos na concepção arquitectónica, na articulação espacial e volumétrica. A cor dominante em todo o edifício era o branco e os materiais mais utilizados eram o aço, vidro, madeira e fibra de vidro. Na entrada tinha lugar um banco talhado num único bloco de mármore e um enorme lustre de 380 lâmpadas definindo assim um espaço esférico. O acesso aos andares superiores fazia-se por uma escadaria transparente que rodeava uma coluna de cristal. Essa coluna, envergava o elevador unindo a cave ao quarto andar. Todo o sentido decorativo desta obra encontra a sua origem na própria construção, marcada pelo rigor na realização tanto dos espaços como dos pormenores. A arquitetura interior é resultado de uma grande simplicidade do desenho e da montagem dos diferentes elementos que a constituem. O conjunto toma então um aspecto preciso, puro e claro, determinantemente marcado pela transparência, símbolo de organismo aberto.

Enquanto arquitecto foi vencedor do primeiro prémio do concurso Monumento aos Pioneiros da Aviação (1980), uma homenagem aos pioneiros desaparecidos aqueles que tanto contribuíram para a expansão da aeronáutica portuguesa.

«O Monumento será a consagração e a homenagem, embora tardia, a quem muito fez pelo seu País, não pouco contribuindo para o 


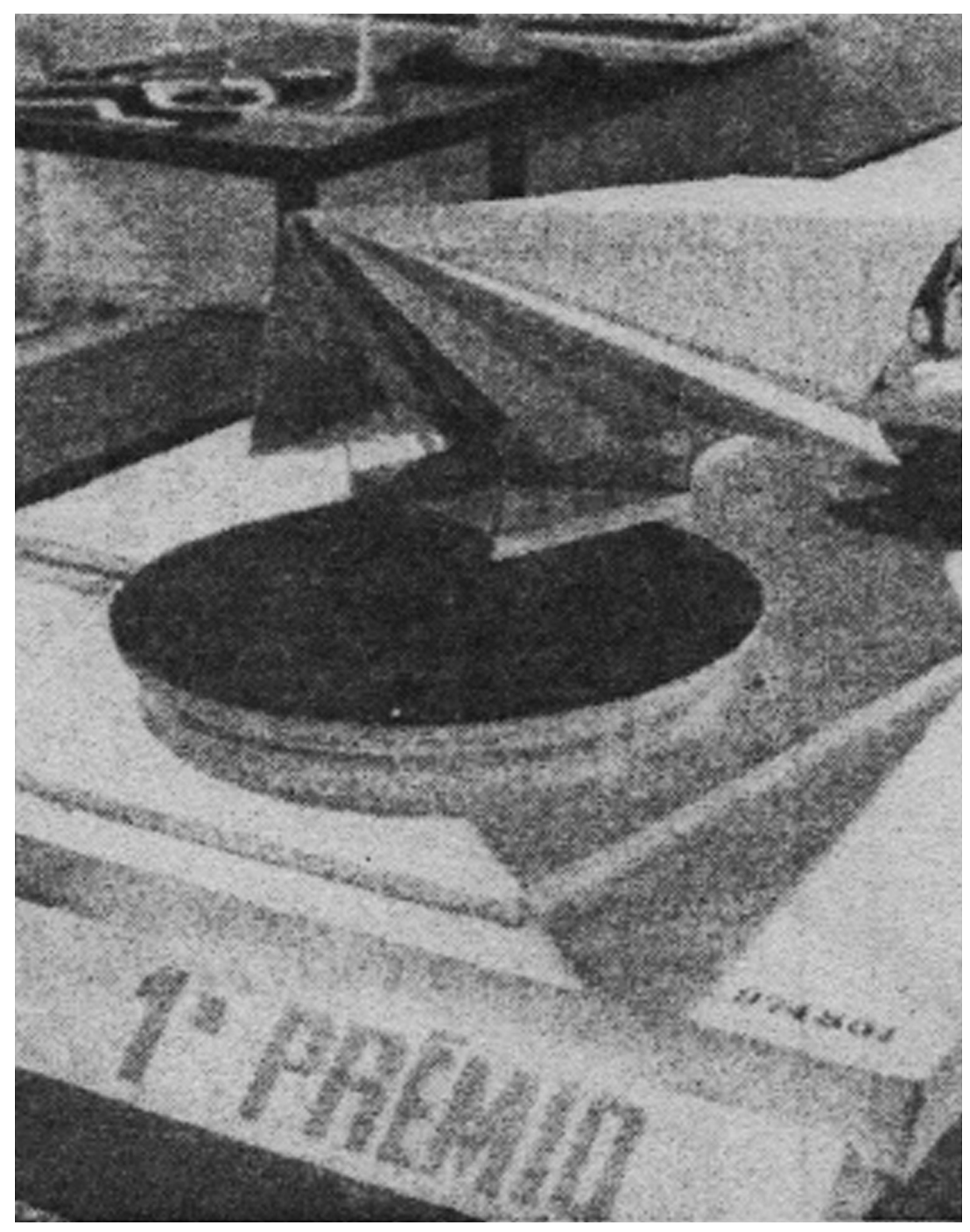

Figura 76. Maqueta do Monumento aos Pioneiros da Aviação 
progresso na comunicação entre os homens. Homenagem que adquire uma dimensão nacional, por duas ordens de razões: primeiro, por abranger todos os pioneiros (incluindo os maiores: Coutinho e Sacadura), e não apenas os que saíram da Amadora; segundo, pelo próprio nível artístico e dimensão do monumento sem paralelo (dentro do tema, e ano âmbito que se propões abranger) em todo o mundo.

À escala mundial, os voos dos portugueses dos anos 20 e 30 - pese embora certos juízos «históricos» de trazer por casa que têm constituído regra no que se tem dito e escrito sobre o tema - não constituíram (excepção feita à Travessia do Atlântico Sul por Gago Coutinho e Sacadura Cabral, e ao voo nocturno sobre o mesmo oceano, de Beires e Castilho) feitos excepcionais. Apenas os métodos de Navegação de Coutinho trouxeram de facto algo de inovador e de muito válido para o progresso da Aviação.

O Monumento - e isto é opinião meramente pessoal - excede portanto o valor dos feitos que consagra. Porém, o conjunto de equipamento social e cultural que vem proporcionar à cidade tem um valor inestimável, não facilmente realizável de uma outra forma. ${ }^{122}$ A escolha do projecto a ser edificado na cidade da Amadora, fora resultante de um concurso público por um júri constituído pelo Presidente da Câmara Municipal, pelo arquitecto Fernando Pinto Coelho, pela chefe de secretária Judite Catana, pelo professor Emanuel Costa Correia, da Faculdade de Letras, pelo escultor Lagoa Henriques, da Escola Superior de Belas-Artes de Lisboa, pelo escultor Carlos Amado, da Sociedade Nacional de Belas-Artes, pelo arquitecto Jorge de Brito Abreu, da Direç̧ão Geral de Edifícios e Monumentos Nacionais e por João Francisco Barahona, representante do Aero-Clube de Portugal.

${ }^{122}$ PEIXOTO, M.Lemos, “O tema é: Os pioneiros da aviação “, Notícias da Amadora, 1980, p. 7 
Entre nove concorrentes, Paulo Guilherme vence com um projecto original que prevê: um átrio de entrada; um salão monumental de 500 metros quadrados para exposições, festas, reuniões, conferências e festivais; um grande restaurante de forma circular, uma sala de cinema com 154 lugares, instalações amplas para serviços respeitantes à aviação civil e uma plataforma exterior que poderá servir para exposições ao ar livre.

$\mathrm{Na}$ cidade da Amadora, chegou a ser lançada a primeira pedra do monumento dedicado aos Pioneiros da Aviação, no mesmo dia (18 de Outubro de 1980) em que se celebrava o 60 ${ }^{\circ}$ aniversário da tentativa da primeira viagem aérea entre a Amadora e o Funchal, com o célebre avião Cavaleiro Negro, tripulado por Sarmento de Beires e Brito Pais. O acto de lançamento foi executado por Humberto da Cruz, o mais antigo precursor do desenvolvimento da aviação em Portugal. Contudo este monumento de interesse local e cultural nunca foi construído face a constrangimentos financeiros.

Entre 1983 e 1993 faz sucessivos projectos de ampliação, volumetria arquitectónica e de decoração no Aeroporto de Lisboa. A intervenção de Paulo-Guilherme no Aeroporto de Lisboa passa maioritariamente pelo espaço das "Partidas", que foi pensada a uma escala compatível com as grandes movimentações das multidões e com as próprias exigências de conforto e de funcionalidade que um espaço destes requer. Esta arquitetura é fortemente determinada pelas diferenciadas volumetrias e pelos seus volumes opacos e envidraçados. Envolve-se assim, no Aeroporto de Lisboa durante dez anos da sua vida, em sucessivos projetos de ampliação, volumetria arquitectónica e decoração. 


\subsubsection{Banco Sotto Mayor / Banco Sotto Mayor}

Realizou todo o projecto de arquitectura e decoração da Sede do Banco Pinto \& Sotto Mayor (1973), no Porto, encomenda pessoal de António Champalimaud.

«Num país tão ligado as suas tradições como Portugal, a nova sede do Banco Pinto e Sotto Mayor teve um efeito bombástico. Rompendo radicalmente com a arquitectura tradicional lusitana, este edifício não deixa de constituir uma etapa importante tanto a nível técnico como estético.» ${ }^{123}$

Este imóvel, outrora situado no Passeio das Cardosas (hoje Praça da Liberdade), o mais importante centro cívico da capital nortenha, cuja traça original externa não podia, por razões de estética urbana, ser alterada.

Além deste condicionalismo, outros desafios se colocaram à equipa de técnicos chefiada por PG. Foi confrontada e obrigada a superar um elevado número de problemas pela complexidade do projecto na agregação de vários materiais além dos preceitos implícitos para toda a construção nomeadamente: alinhamentos, cérceas, estrutura do imóvel, resistência de matérias, etc.

O velho edifício foi completamente escavado e despojado do seu recheio original, para receber as bem feiturias de uma nova articulação espacial e volumétrica e ganhar um novo nome Banco Pinto \& Sotto Mayor.

${ }^{123}$ tradução livre da autora. No original «Dans un pays aussi attaché à ses traditions que le Portugal, le nouveau siège de la Banco Pinto et Sotto Mayor fait l'effet d'une véritable bombe. Rompant radicalement avec l'architecture lusitanienne traditionnelle, ce bâtiment n'en constitue pas moins une étape importante tant au niveau technique qu'esthétique.» in Banco Pinto et Sotto Mayor, architecture intérieure,SICOB 73, 1973 

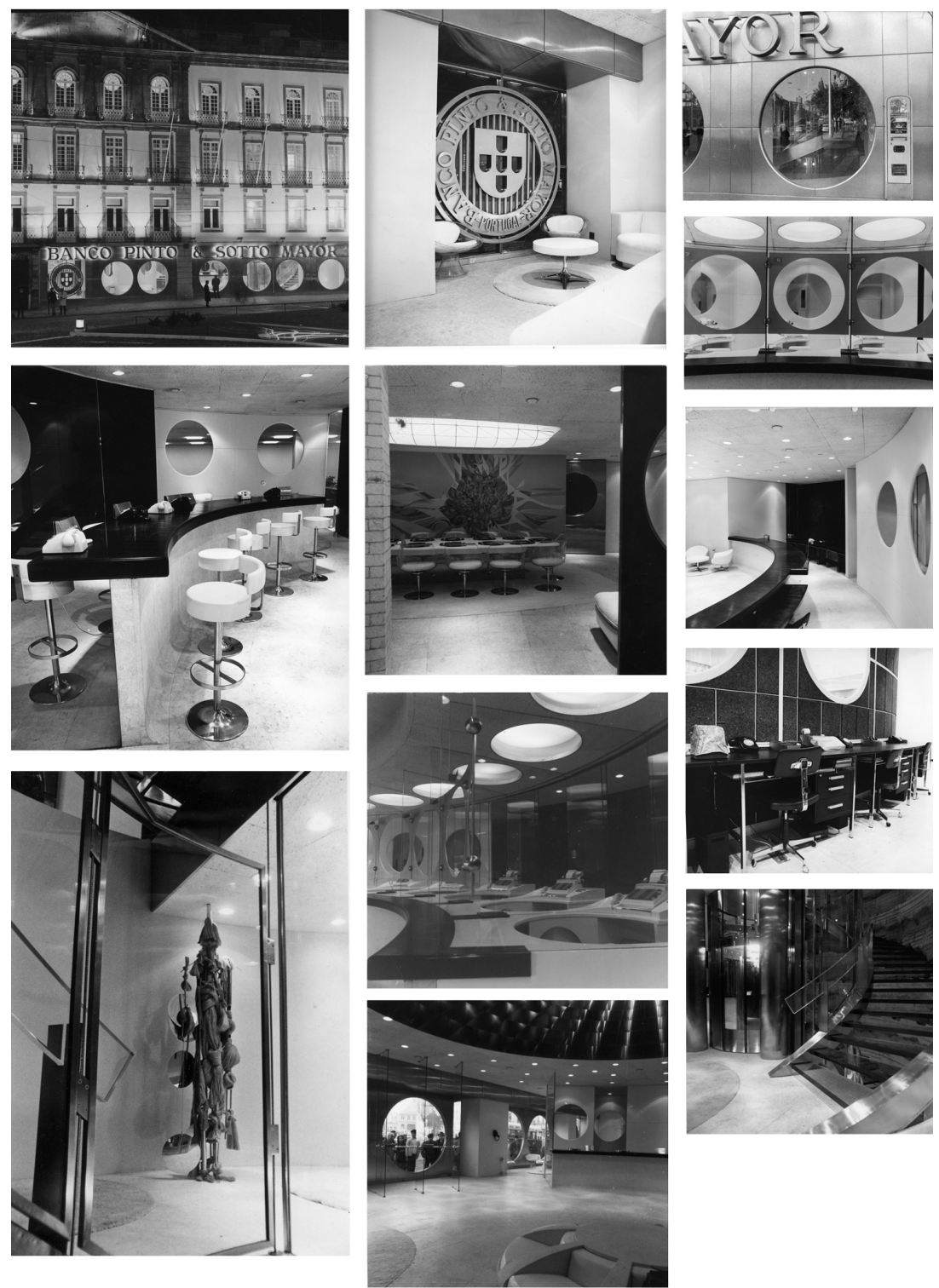

Figura 77. Conjunto de fotografias do Banco Pinto \& Sotto Mayor 
Do aço fosco fez os painéis da fachada do edifício, os painéis interiores que suportam os vidros e as letras identificativas do imóvel na fachada, que sobressaiem também pelo seu relevo e pela sua volumetria. A missão era árdua, conjugar as especificidades técnicas com o tema proposto pela empresa que assentava na criação de um banco "aberto", apelativo, de óbvia leitura interpretativa de toda a "máquina de trabalho" que aquela organização bancária à inteira disposição dos seus clientes. A principal premissa deste projecto estabelecia estritamente um esquema funcional.

Esta proposta, inteiramente inovadora em Portugal, cuja ousadia é em absoluto contrário aos cânones, foi a motivação principal do grande desafio estético que Paulo Guilherme desencadeou. Registe-se que foram abolidos de todos os conceitos tidos como certos e rentáveis no meio bancário, no que se refere a instalações para o público: madeiras escuras, mármores, apainelados, para definirem uma atmosfera grave e taciturna (na grande maioria dos casos) ou então meramente funcional e neutra. O novo edifico da filial do Banco Pinto \& Sotto Mayor no Porto - é sintomático que seja o Porto a abrir o caminho em novas concepções de arquitectura - é o contrário de todos esses conceitos clássicos. Este projecto pedia assim um carácter funcionalista, prático e simplista. A cor dominante em todo o edifico era o branco e os materiais mais utilizados eram o aço, vidro, madeira e fibra de vidro. A cor dominante era contraposta à cor incisiva de aço polido que aparece frequentemente, não apenas como suporte de uma determinada solução funcional, mas antes pela sua presença estética decididamente moderna.

«(...) trata-se de uma das mais notáveis obras de arquitectura empresarial realizados no País, e a ela temos que nos referir com justificada alegria, pelo avanço que demonstra no sector de 

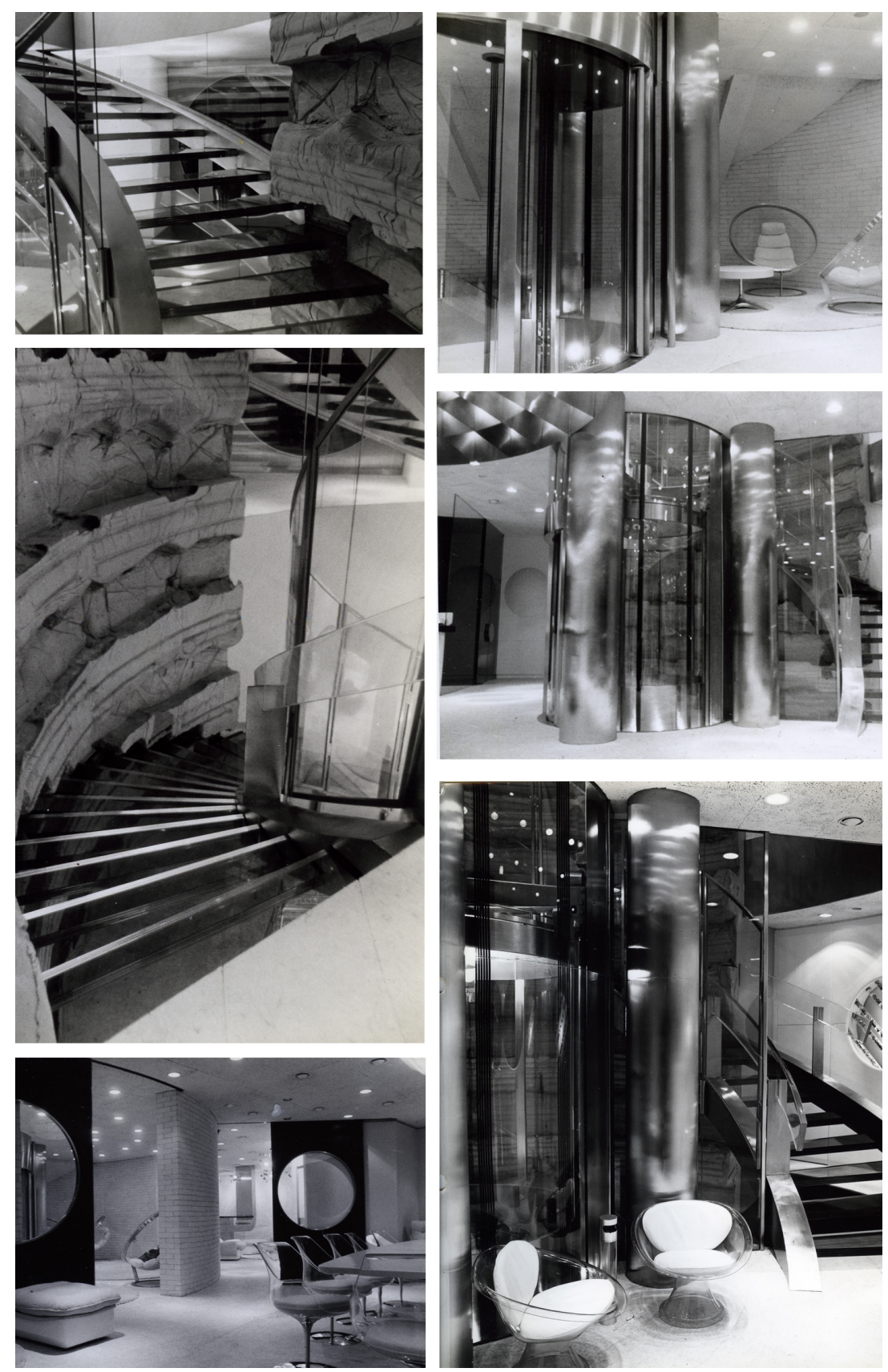

Figura 78. Conjunto de fotografias do Banco Pinto \& Sotto Mayor 
actividade $(\ldots) \gg .{ }^{124}$

As instalações do Banco desenvolvia-se em sete pisos: subcave, cave, piso de entrada e mais quatro andares.

$\mathrm{Na}$ entrada exibia-se um banco talhado num único bloco de mármore e um enorme lustre de 380 lâmpadas definindo assim um espaço esférico.

$\mathrm{O}$ acesso aos andares superiores fazia-se por uma escadaria transparente que rodeava uma coluna de cristal. Essa coluna envergava o elevador unindo a cave ao quarto andar. A escada principal é essencialmente composta por degraus em vidro apoiados sobre vigas de aço. Com o elevador, atravessa-se todo o edifício, à excepção do subsolo, seguindo depois ao longo de um muro de cimento decorado de um lado e de vidros abaulados e suportados pela estrutura metálica da escada do lado oposto.

O espaço do hall para o público (no segundo andar) é definido por uma mesa circular, também com o tampo de cristal, e cujo envolvimento, através de lâmpadas e discos metálicos dispostos em «mobile» lhe dá o aspecto de uma escultura dinâmica que ocupa o vão central tecto-chão.

O elevador é envolvido pela escada. Sabemos que a caixa do ascensor, por norma, é o eixo por onde unem os lances e patamares da escada principal de um imóvel, é raro vermos (pelo menos nos anos 70 e em Portugal) uma transposição estética desta premissa funcional. Uma escada transparente em torno de uma coluna de cristal.

A visão parcial dos serviços foi harmonizada através de um conjunto de divisórias, de modo a impedir a desordem própria, inerente, de um local de trabalho, proporcionando a visão de uma empresa em plena laboração.

${ }^{124}$ BURNETT, Leo. “O banco Pinto \& Sottomayor no Porto", Revista Casa \& Decoração, nº21, Maio/Junho p. 9 

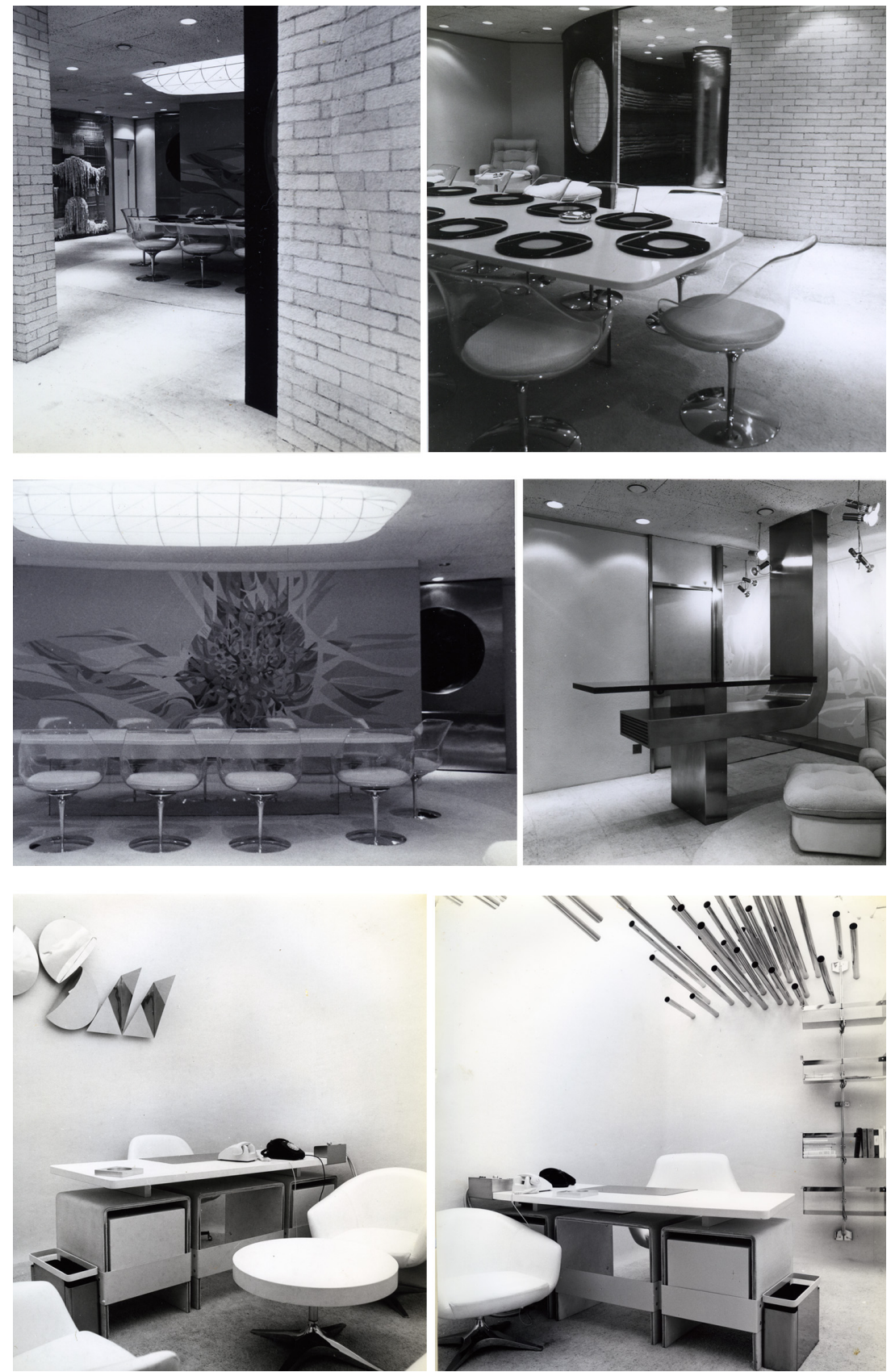

Figura 79. Conjunto de fotografias do Banco Pinto \& Sotto Mayor 
As estruturas mecânicas e eléctricas, nomeadamente as redes de televisão em circuito fechado e os mecanismos dos elevadores foram construídos de forma a serem visíveis, mais um exemplo que torna a transparência nem aspecto dominante deste projecto.

«Todo o sentido decorativo desta obra encontra a sua origem na própria construção, marcada por um maior rigor na realização tanto dos espaços, como dos pormenores. A arquitectura interior, extremamente aperfeiçoada é resultado de uma grande simplicidade do desenho e da montagem dos diferentes elementos que a constituem. O conjunto reveste então um aspecto preciso, puro e claro.» ${ }^{125}$

As caixas são essencialmente feitas por uma só peça moldada em fibra artificial de vidro, com alvéolos, previstos para receber televisão, máquinas de calcular, caixas de segurança, telefones... As divisórias metálicas são constituídas por um esqueleto de ferro revestido de um metal pintado (preto ou branco) do lado dos clientes no oposto lado dos funcionários, é revistada por corticite, fixado por lingotes aparafusados ao chão. Os gabinetes de trabalho obedecem sempre ao mesmo tema, embora nunca se repitam. Evidencia-se o facto de que PG, trabalhando voluntariamente dentro de uma gama muito restrita de materiais e de cores, tenha sido tão bem sucedido na criação dos vários ambientes na mesma unidade.

Os tectos são formados por uma aparente armadura em aço polido que suporta placas unidas e moldadas em vidro acrílico opalino, atrás das quais se propaga uma iluminação uniforme.

\footnotetext{
${ }^{125}$ tradução livre da autora. No original «Tout le sens décoratif de cet ouvrage trouve sa source dans la construction elle-même, marquée par la plus grande rigueur dans la réalisation des volumes comme celle des détails. L'architecture intérieure, extrêmement épurée a été obtenue par une três grande simplicité dans le dessin et dans le montage des différents éléments la composant. L'ensemble revêt alors un aspect précis, pur et clair.» in Banco Pinto et Sotto Mayor, architecture intérieure,SICOB 73, 1973
} 

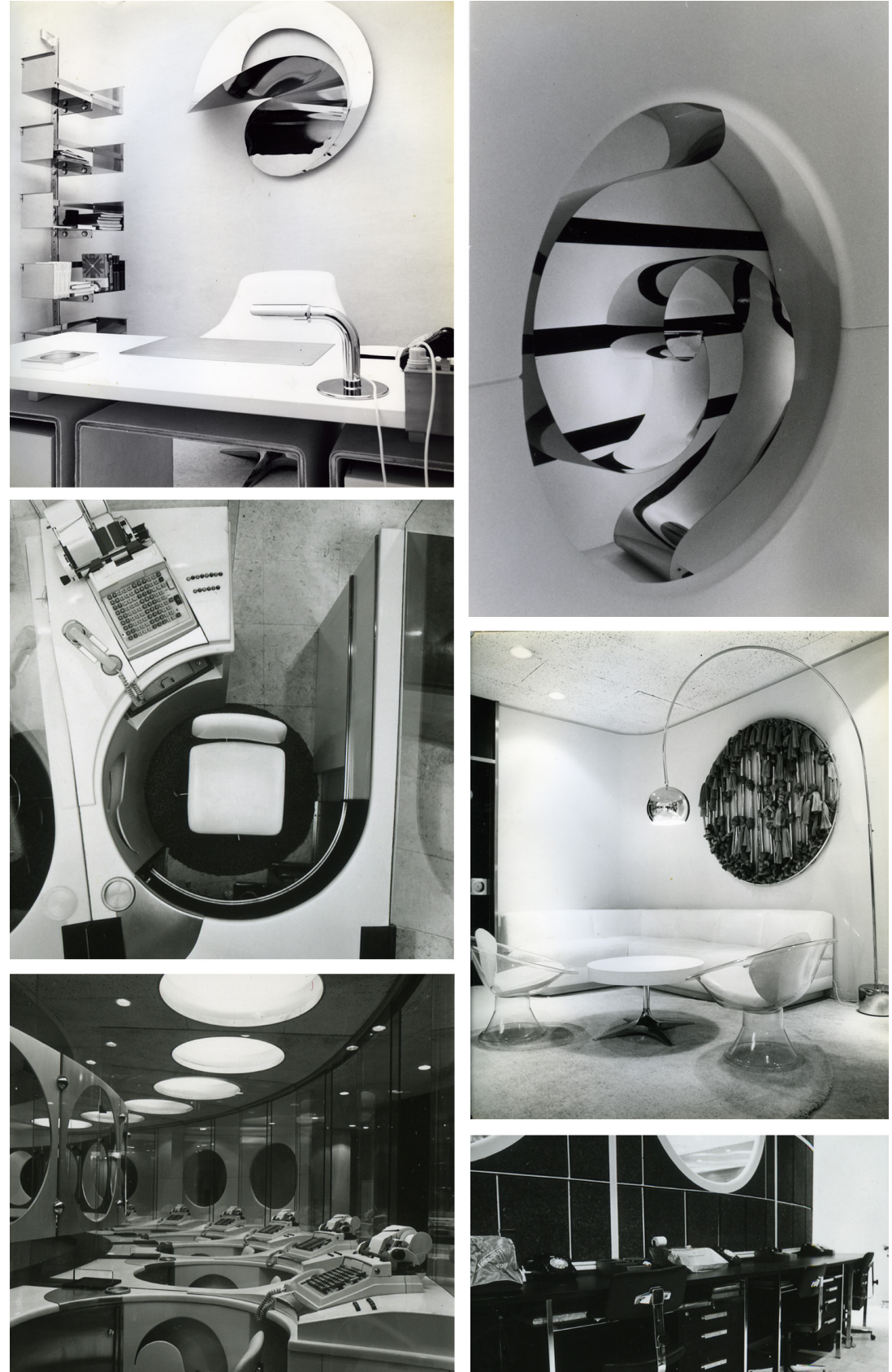

Figura 80. Conjunto de fotografias do Banco Pinto \& Sotto Mayor 
Toda a atenção do decorador foi voltada para a sala do conselho, situada no $2^{\circ}$ piso. Chão, muros e tecto são revestidos por painéis de estanho moldado, que recebem esferas de aço inoxidável. O mesmo acontece no primeiro andar com a sala de onde se domina, o cofre principal cujo muro no qual se insere é totalmente revestido por uma placa de aço, em que foi estampado um molde com a forma da porta do cofre. Esta, aberta, vem alojar-se naturalmente neste alvéolo. Embora seja assim nos espaços reservados aos funcionários, nos locais de atendimento ao público ou nos reservados à direcção, o arquitecto preocupou-se não só com os espaço mas também com a criação de um ambiente. O mobiliário era de linhas modernas, simples, depurados, desprovidos de ornamentação.

Os elementos dominantes da decoração estão na parede, lateral, uma escultura metálica semelhante a um ramo de espiral que se desprende, alada.

Ao fundo, um painel constituído por uma trama onde se encastram, a intervalos desiguais, rolos, cordas, fibras têxteis de espessuras diferentes e que tecem, uma bela mancha plástica.

O bar de apoio e a sala de refeições que se situam no último piso do imóvel co-habitam intrinsecamente de um modo que as soluções forçadamente funcionais se disfarçam em soluções estéticas e vice-versa. De forma engenhosa e original foi aproveitada a conduta do ar condicionado, esta serve de suporte à placa de vido que define o bar.

PG assina ainda as peças decorativas do dorso da escada moldado em cimento, das paredes em relevos moldados em estanho e aço, Esculturas em aço, Móveis especiais, Elementos de decoração luminosa Das tapeçarias foram responsáveis Flávia Monsaraz, Ana Maria de la Paz e Luís Filipe de Abreu. Este ultimo também responsável pelo painel mural na sala de jantar da Direcção. A pintura de quadros entregue a Júlio Resende. 

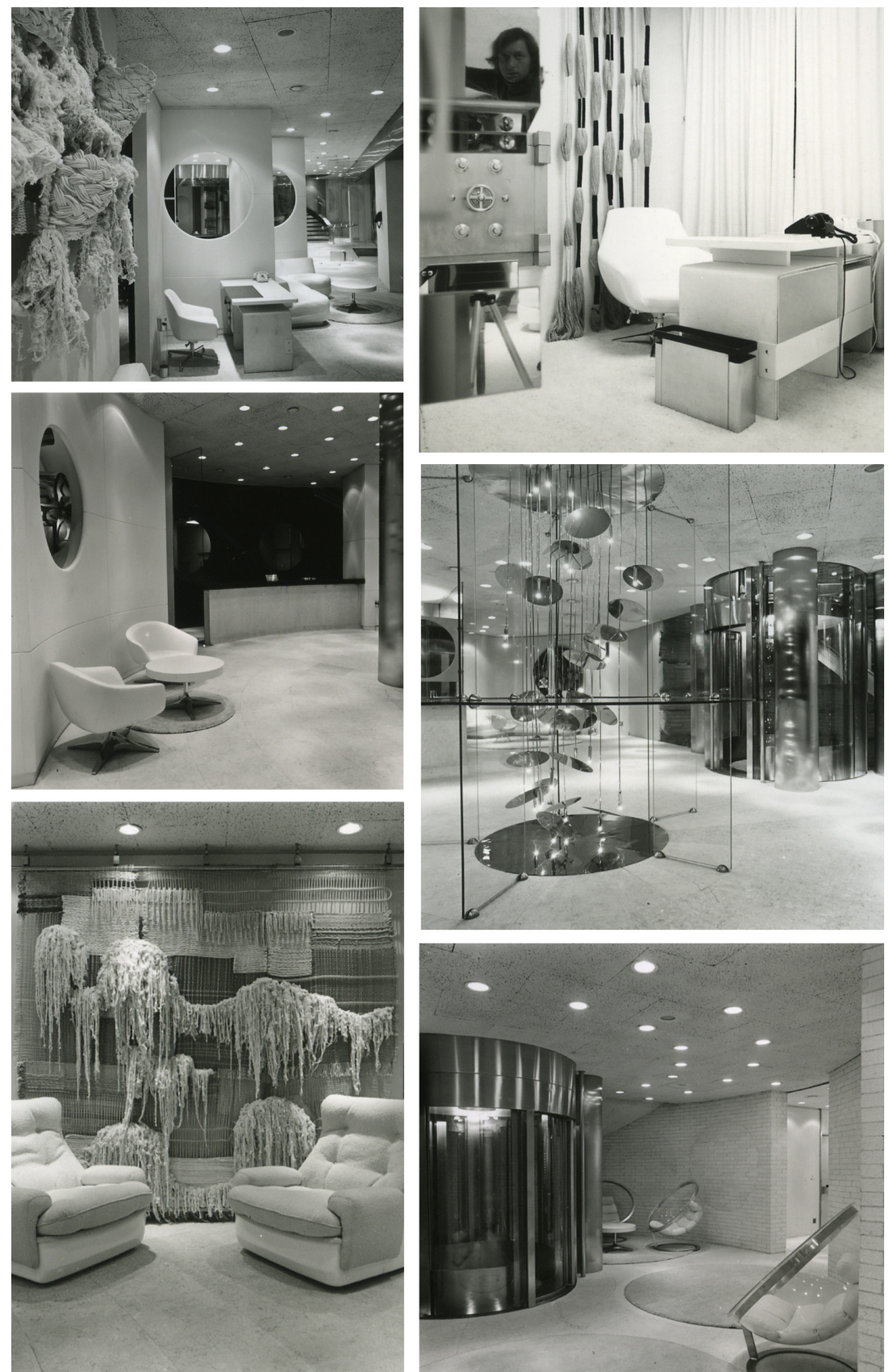

Figura 81. Conjunto de fotografias do Banco Pinto \& Sotto Mayor 
«(...) a importância exemplar daquele espaço de cinco andares que constitui uma unidade plástica harmoniosa em que as audácias nos aparecem com grande naturalidade por causa da solidez como foram concebidas e executadas. ${ }^{126}$

«(...) a Filial do Banco Pinto \& Sotto Mayor, no Porto (...): é a busca conseguida dum acolhimento construído sobre a harmonia dum espaço plasticamente unificado. Ele é capaz de receber bem as pessoas (...) pela harmonia que vem do uso incolor das formas. ${ }^{127}$

${ }^{126}$ BAPTISTA, Alçada, "O Universo Plástico de Paulo-Guilherme", Catálogo Paulo-Guilherme D'Eça Leal D'Etecetera e Tal, CML, Lisboa, 2000, p. 210

${ }^{127}$ Idem 


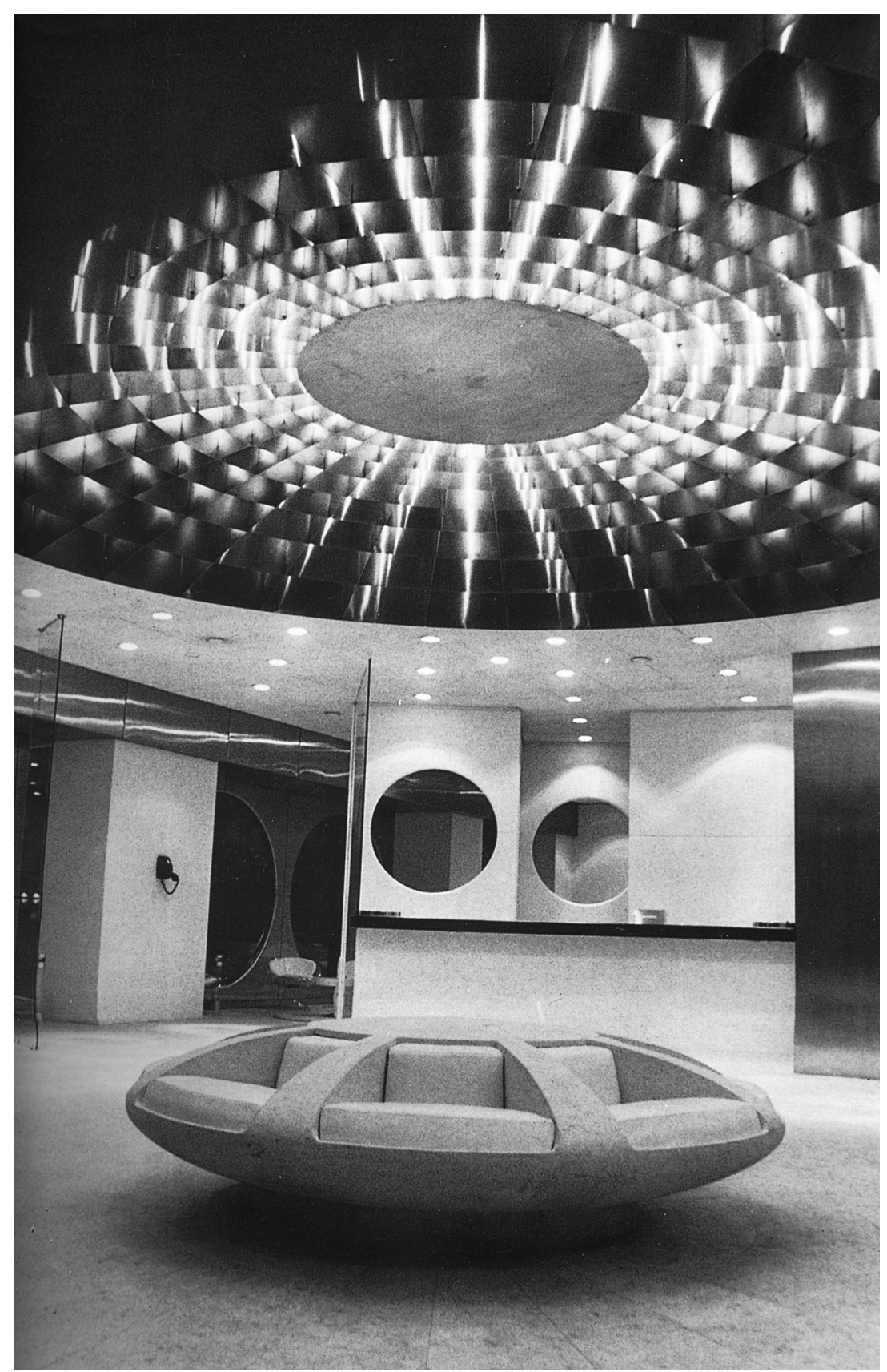

Figura 82. Fotografia hall do Banco Pinto \& Sotto Mayor 


\subsection{El aeropuerto de Portela - ANA Aeropuertos / Aeroporto Portela - ANA Aeroportos}

O Aeroporto Internacional da Portela situa-se na Portela de Sacavém, $7 \mathrm{~km}$ a noroeste do centro da cidade de Lisboa, com uma área total de aproximadamente 495 hectares. O Aeroporto da Portela encontra-se rodeado por áreas residenciais e comerciais. As zonas residenciais concentram-se mais a leste e a sul, enquanto o desenvolvimento comercial é mais intenso a nordeste do aeroporto.

A ANA é o operador do Aeroporto da Portela, sendo responsável pelas operações aeroportuárias e pela manutenção e actualização dos movimentos de aeronaves no aeroporto. Para além das instalações que pertencem à ANA e cuja manutenção é efectuada por esta empresa, existem ainda outros locatários nas instalações no Aeroporto da Portela.

O primeiro edifício do Aeroporto da Portela foi projectado por Keil do Amaral na década de 40. Cinquenta anos depois, o Aeroporto exigia obras de ampliação e decoração que fizessem frente às novas exigências impostas pelo tempo.

«A empresa pública ANA, criada em 1978 com a missão de estudar, planear, construir, explorar e desenvolver infra-estruturas aeroportuárias e de navegação aérea, ao assumir nesse ano a gestão do aeroporto de Lisboa, deparou-se com estruturas envelhecidas e equipamentos inadequados face à acelerada evolução da aviação civil e do transporte aéreo de carga e passageiros, ao ponto de «ser reconhecido oficialmente terem aqueles decaído a um nível próximo da degradação». Um programa imediato foi elaborado para modernizar e «obter elevados standards de segurança para aviões e 

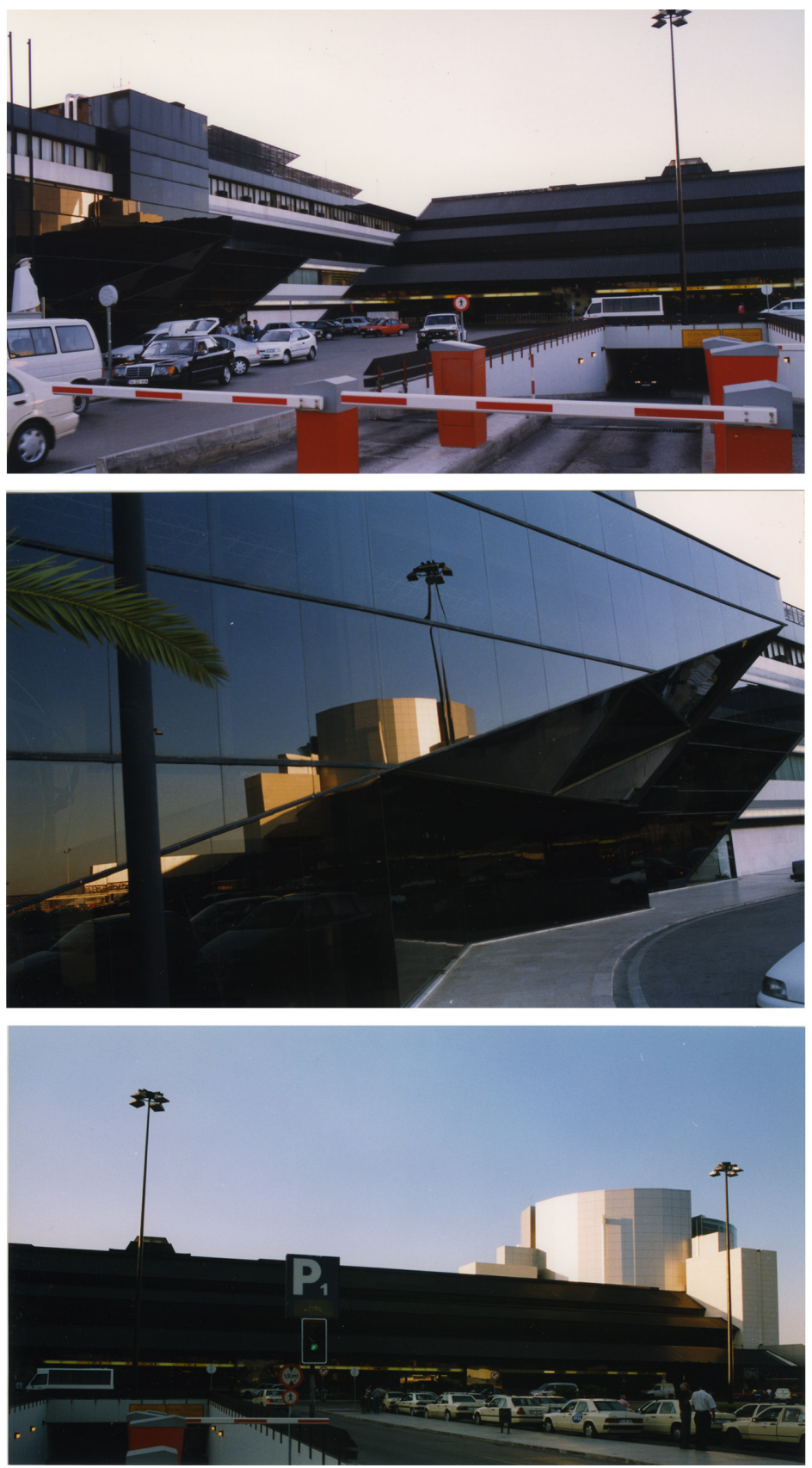

Figura 83. Conjunto de fotografias do Aeroporto de Lisboa 
passageiros, criar instalações adequadas às actividades do transporte aéreo, renovar a gama de serviços prestados e melhorar a sua qualidade. ${ }^{128}$

«Era uma arquitectura amena e "perene", compatível com as exigências de um tráfego pacífico previsível a médio prazo. (...) Viajar de avião era, nessa época, privilégio de algumas elites - não exclusivamente as mais endinheiradas... - que eram tratadas com desvelo pelo pessoal de terra e de bordo, (...).» ${ }^{129}$

Com o chamariz da Expo 98, a ideia de uma afluência avultada de passageiros, tornou imperativo remodelar a fundo o Aeroporto de Lisboa.

A intervenção de Paulo Guilherme no Aeroporto de Lisboa passa essencialmente pelo espaço das "Partidas", que foi pensada a uma escala compatível com as grandes movimentações das multidões e com as próprias exigências que um espaço destes requer.

«As primeiras obras de remodelação iniciaram-se em Janeiro de 1983 no corpo norte C, estendendo-se depois para a zona das Partidas, com coberturas de novas lojas, bares e restaurantes, um Lounge de primeira classe, salas para crianças e abrangendo ainda nova instalação electrica, som e ar condicionado, novo sistema informativo baseado em displays, e facilidades para passageiros deficientes. Em Outubro de 1984 começou a renovação da zona do Check-in. $\gg^{130}$

Esta arquitectura é fortemente determinada pelas diferenciadas volumetrias e pelos seus volumes opacos e envidraçados. Encontram-se graciosos pormenores de design nos

\footnotetext{
${ }^{128}$ MOREIRA, José Guardado, Aeroporto de Lisboa 1942-1992 Ana aeroportos e navegação aérea, Edições INAPA, p.182

${ }^{129}$ SILVA, António Sena, "Modo de usar as Artes", Catálogode exposição, Paulo-Guilherme D'Eça Leal D'etecetera e tal 2000, Palácio Galveias 2000, Câara Municipal de Lisboa ; Novembro de 1999, p.24

${ }^{130}$ MOREIRA, José Guardado, Aeroporto de Lisboa 1942-1992 Ana aeroportos e navegação aérea, Edições INAPA, p.150
} 

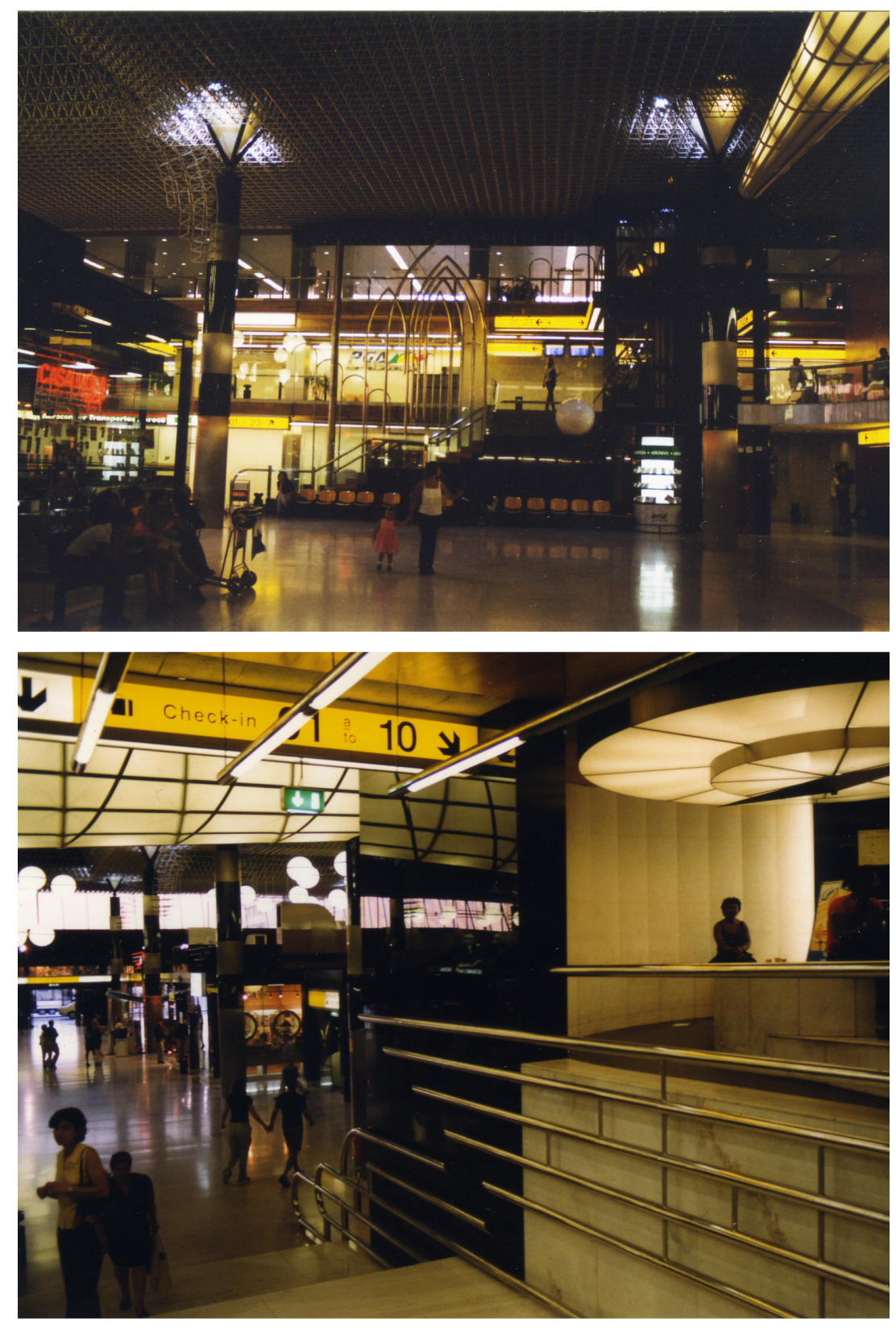

Figura 84. Conjunto de fotografias do Aeroporto de Lisboa 
corrimãos de escadas, explorando originalmente diferentes alturas, a animação do espaço contempla superfícies de espelho negro, adereços ogivais em aço polido e candeeiros esféricos.

Construiu-se uma nave com aproximadamente 60 x 60 x 21 $\mathrm{m}$ de altura, toda ela compreendido no ex parque de automóvel, algo megalómano ao gosto de Paulo-Guilherme. Projectou também a sala VIP, a sua decoração ia desde os quadros feitos por medida, tapeçarias a esculturas. As salas de espera, os jardins em frente das Partidas, as chegadas, a entrada principal, as mangas de acesso do avião para as salas, sala das mangas, as "colmeias" do tecto, a escadaria que dá para os voos domésticos, foram também traçados por PG.

Os degraus das escadas são construídos em grandes blocos de madeira maciça, que se repetem, em lanços de cinco degraus cada um. Estas escadas, inseridas na nave, eram acompanhadas por uma forma de carácter escultórico, feitas em enormes pedaços de aço polido $(9 \mathrm{x} 14 \mathrm{~m})$. De inspiração no jerónimos, constroem-se cinco grandes abóbadas, suportadas por arcos. Arcos estes são feitos em materiais modernos, sendo a sua estrutura parcialmente em alumínio.

O chão, tem um pavimento feito em lajes de pedra com dimensões invulgares, nunca menos de $1,2 \times 2 \mathrm{~m}$. O tecto alberga uma trama geométrica em alumínio e uns grandes candeeiros esféricos dispostos de forma assimétrica.

As casas de banho feitas em grandes pedras mármore tinham a loiça dissimulada por ser de igual material que as paredes.

O restaurante do Aeroporto foi pensado e desenhado ao pormenor como é apanágio de PG, desde uma fruteira esculpida em pedra, o design dos cardápios à sinalética das casas de banho.

Para a ampla entrada da Aeroporto foram pensados e desenhados várias esculturas da autoria do escultor Laranjeira 

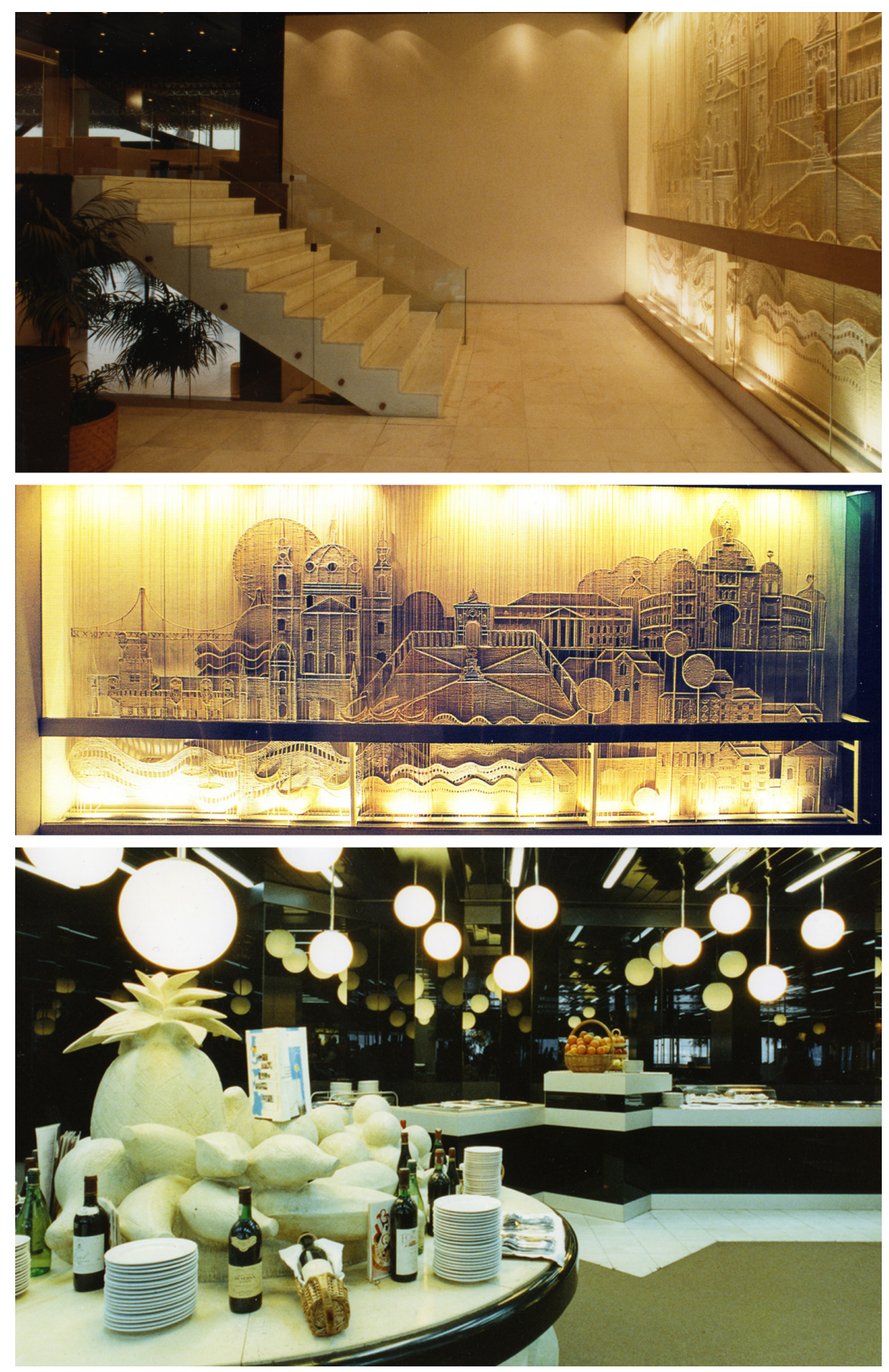

Figura 85. Conjunto de fotografias do Aeroporto de Lisboa 

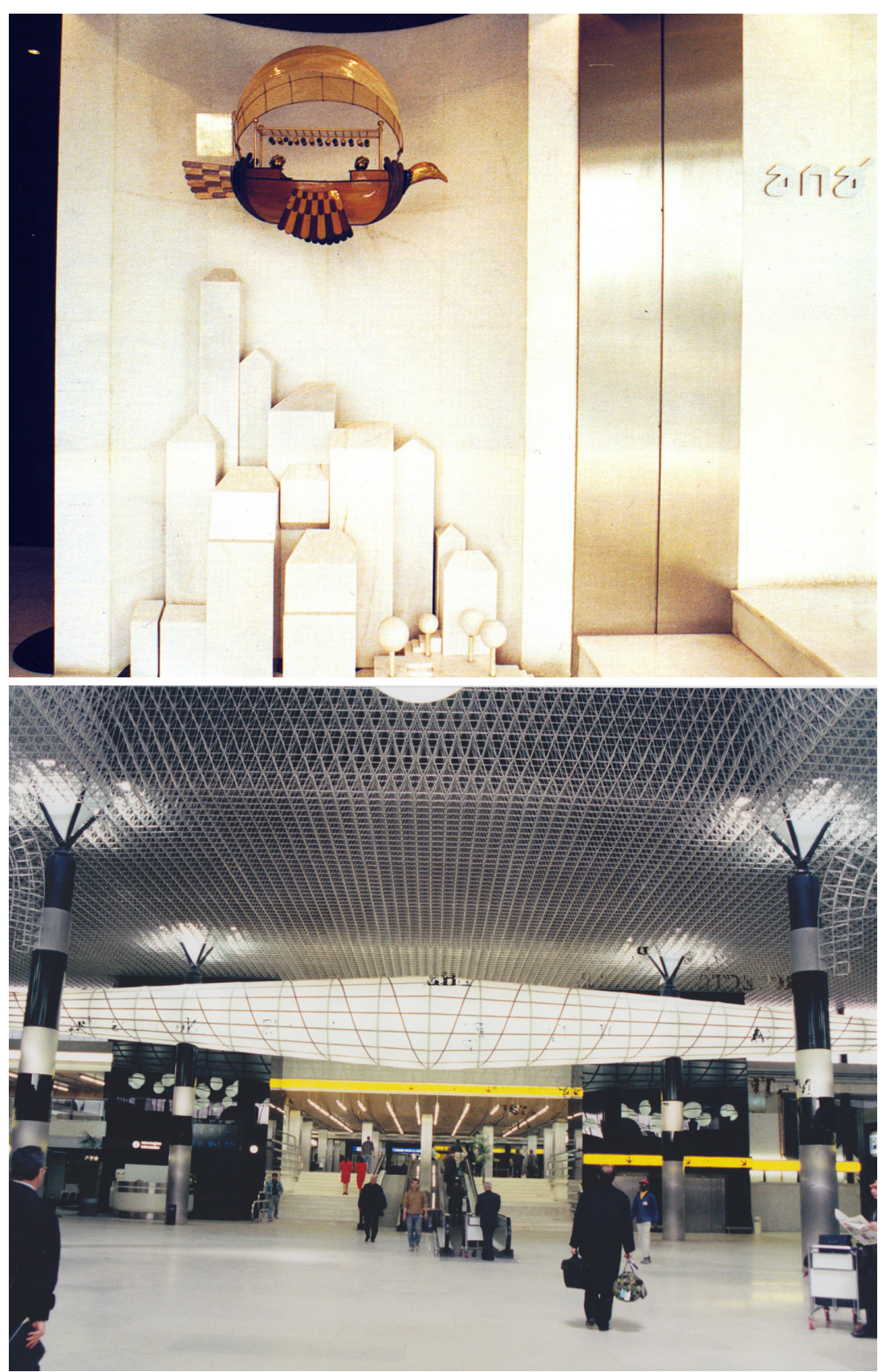

Figura 86. Conjunto de fotografias do Aeroporto de Lisboa 

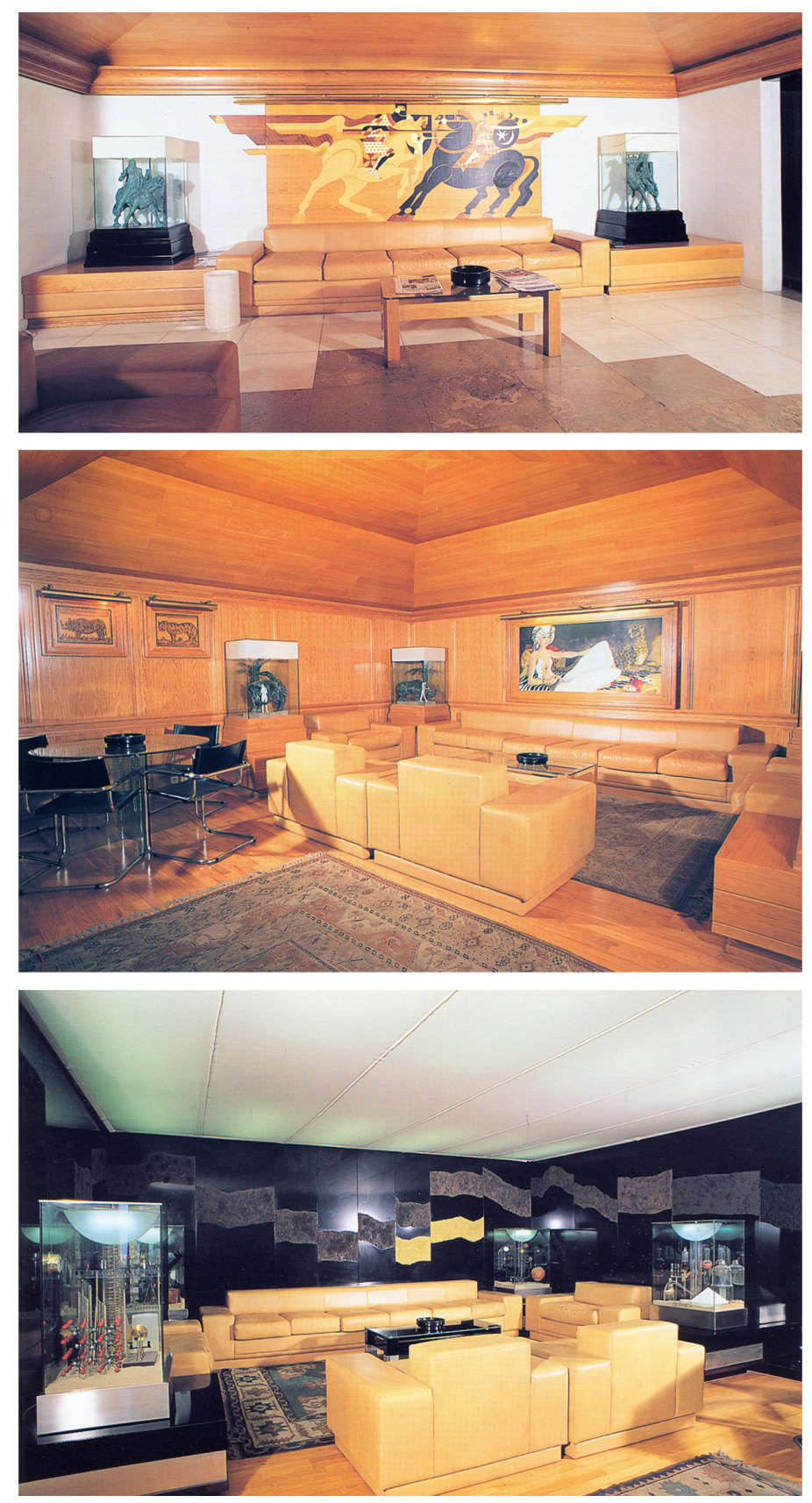

Figura 87. Conjunto de fotografias das Salas VIP 
Santos e também um grande painel em tapeçaria (10x5m), em 3 planos desenhado por PG e realizado por Júlia Correia. Para o exterior das Partidas PG projectou num relógio de sol todo ele feito em pedra.

«O novo serviço de check-in, com um novo balcão destinado aos passageiros não portadores de bagagem de porão, entrou em funcionamento em Agosto de 1990. O balcão situa-se à entrada do terminal 1 (antigo terminal internacional) e destina-se a suprir as necessidades de cerca de $20 \%$ dos passageiros com destino a outros países europeus. Os check-in dos voos polulares da TAP-Air Portugal, domésticos e internacionais, são feitos no terminal 1, enquanto o terminal 2 (antigo terminal doméstico) são feitos agora os check-in dos voos charter, nacionais e estrangeiros.» ${ }^{131}$

«No início de 1992 entraram em funcionamento três das seis pontes telescópias, as conhecidas «mangas», que permitiam o acesso directo dos passageiros ao interior do avião, e foi posto em acção o novo serviço de check-in, com 54 posições. Nos finais, de 1991 o Público titulava «Portela duplica e moderniza visual» $(\ldots){ }^{132}$ «O ano de 1992 vai ficar indelevelmente gravado na história do aeroporto de Lisboa. A sua capacidade de acolhimento de passageiros passa a ser de oito milhões por ano, com dez novas salas de embarque e desembarque. ${ }^{133}$

Numa altura avançada do projecto pronto a iniciar-se "Chegadas" do Aeroporto de Lisboa por razões de incompatibilidade PG rompe com a direç̧ão do Aeroporto, abandonando o compromisso, termina a sua participação de ampliação, decoração e volumetria arquitectónica do Aeroporto de Lisboa em 1993. Em jeito de represália o nome de PG foi retirado da história do Aeroporto.

\footnotetext{
${ }^{131}$ MOREIRA, José Guardado, Aeroporto de Lisboa 1942-1992 Ana aeroportos e navegação aérea, Edições INAPA, p.161

${ }_{132}$ Ibidem, p. 181

${ }^{133}$ Ibidem, p. 182
} 


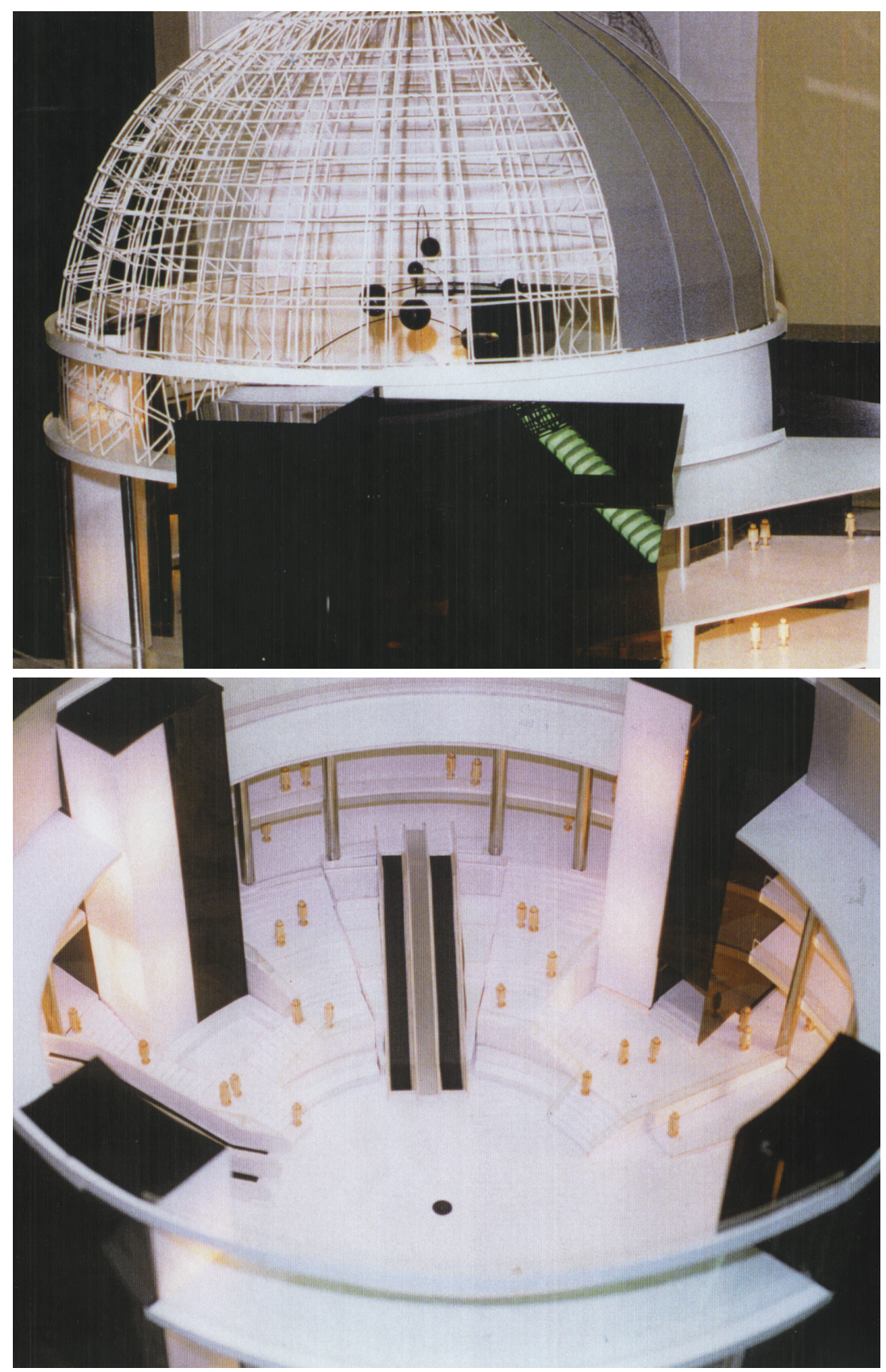

Figura 88. Conjunto de fotografias da maqueta das Chegadas 
«Cinquenta anos depois da sua entrada em funcionamento, o aeroporto de Lisboa modernizou-se a ponto de estar muito longe da imagem idílica que apresentava nos primeiros anos da década de 1940.» ${ }^{134}$

4.8 Espetáculo y exposiciones / Espectáculos e exposições

Desenha cenários e figurinos para várias peças de teatro: Quem tem medo de Virginia Woolf?, Look Back in Anger, Verão e Fumos, A Taça de Ouro, O Amor, o Dinheiro e a Morte, e também para alguns ballets designadamente: Grupo Verde-Gaio, Grupo da Fundação Gulbenkian, Grupo de Águeda Sena e Fernando Lima. Como cenarista, trabalha em três filmes: Sangue Toureiro, Perdeuse um Marido, Dois Dias no Paraíso. Produz o Cabaretíssimo, um espectáculo music hall estreou em Julho de 1974 no café - concerto Cabaretíssimo, em Cascais. Três meses depois, foi para o Teatro Monumental de Lisboa. Após uma temporada no Sá da Bandeira, no Porto, voltou à capital e dali foi posto em cena no Brasil. Ao longo da sua vida realiza muitas exposições individuais e colaborou em algumas colectivas. Contudo é no ano 2000, no Palácio Galveias por iniciativa da Câmara Municipal de Lisboa que elabora uma grande exposição. Exposição retrospectiva de todo o seu trabalho intitulada Paulo-Guilherme, Etecetera e tal.

${ }^{134}$ Ibidem, p. 181 

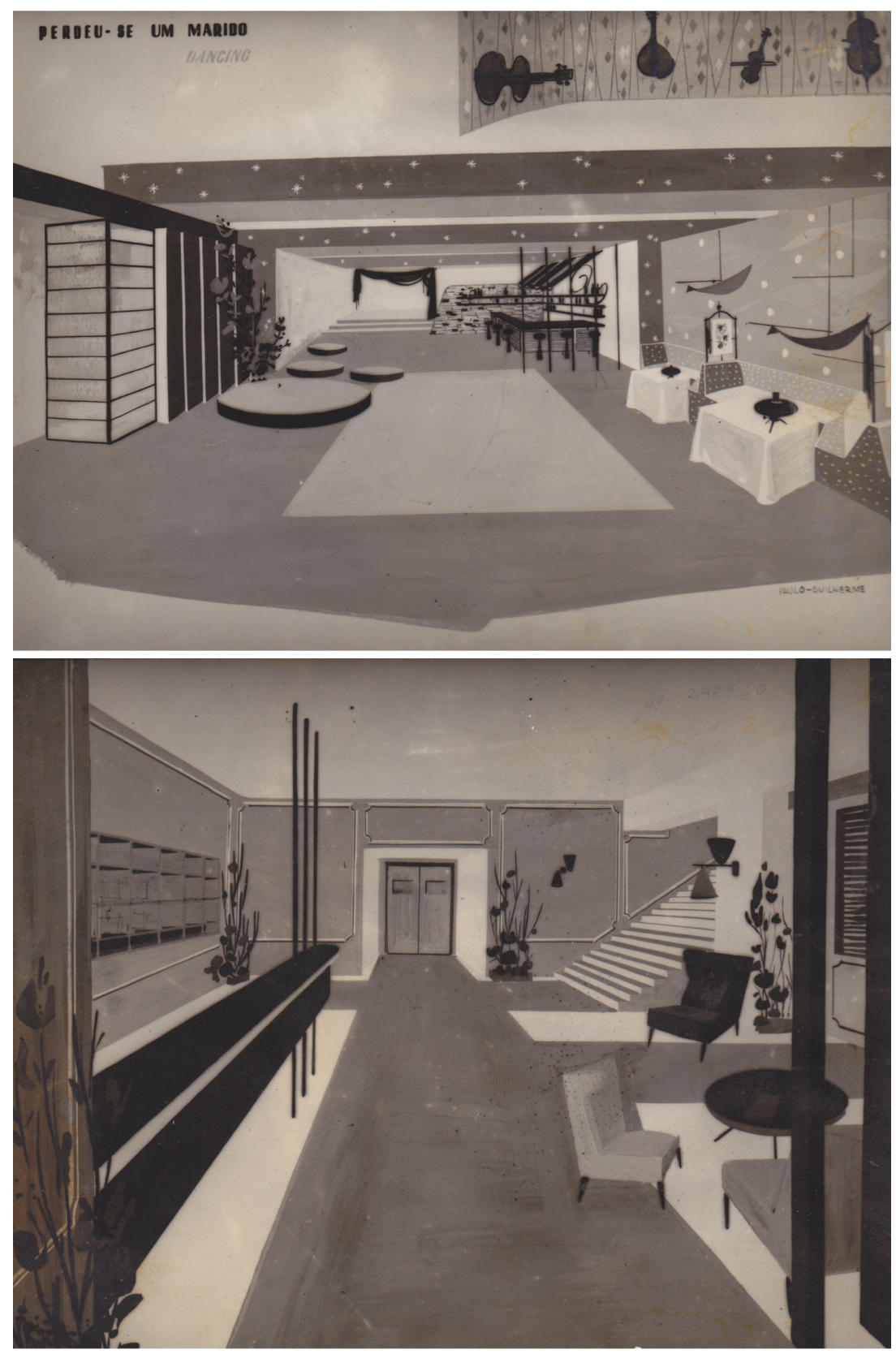

Figura 89. Desenhos do cenário, Perdeu-se um Marido 


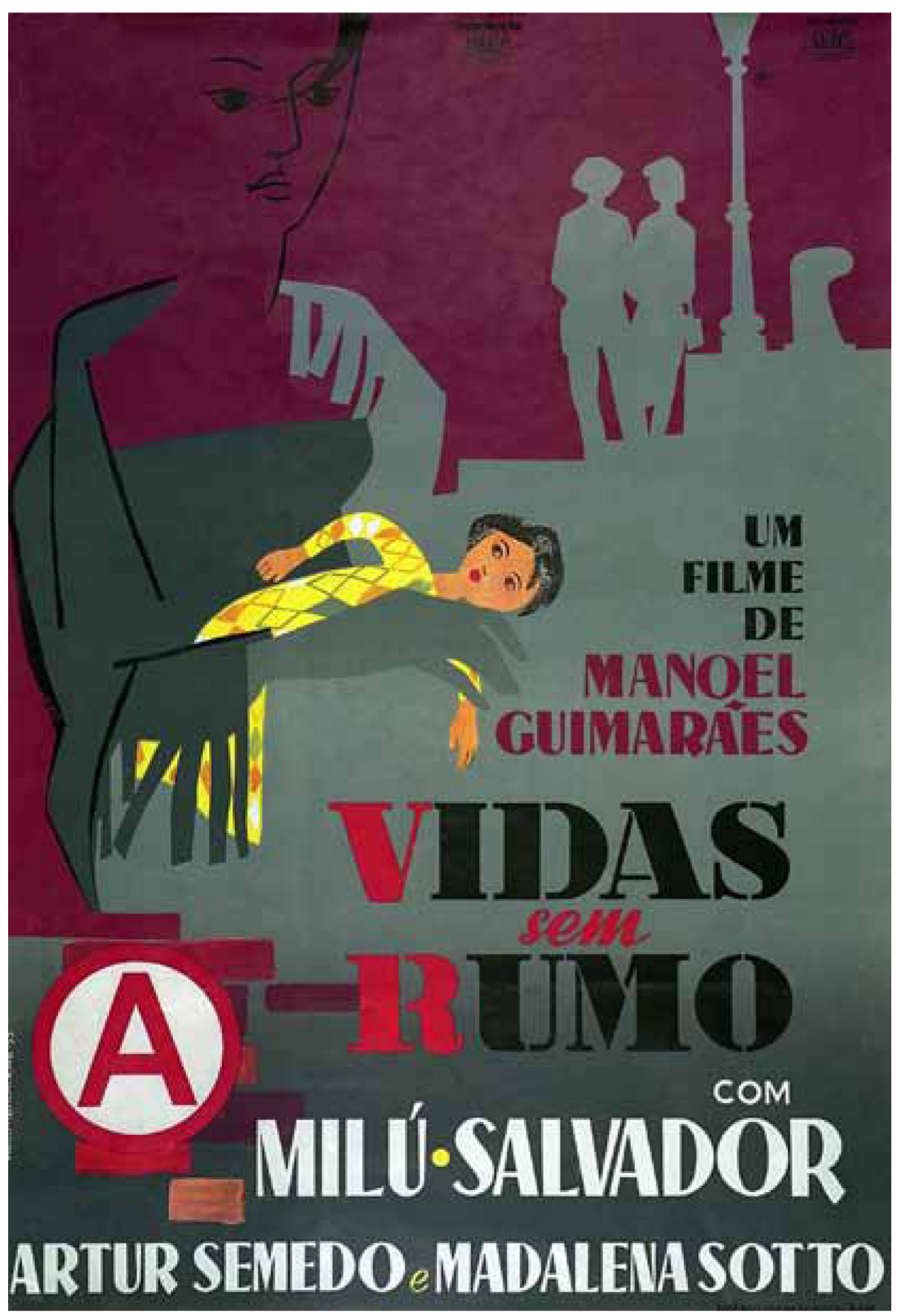

Figura 90. Cartaz do filme, Vidas sem Rumo 


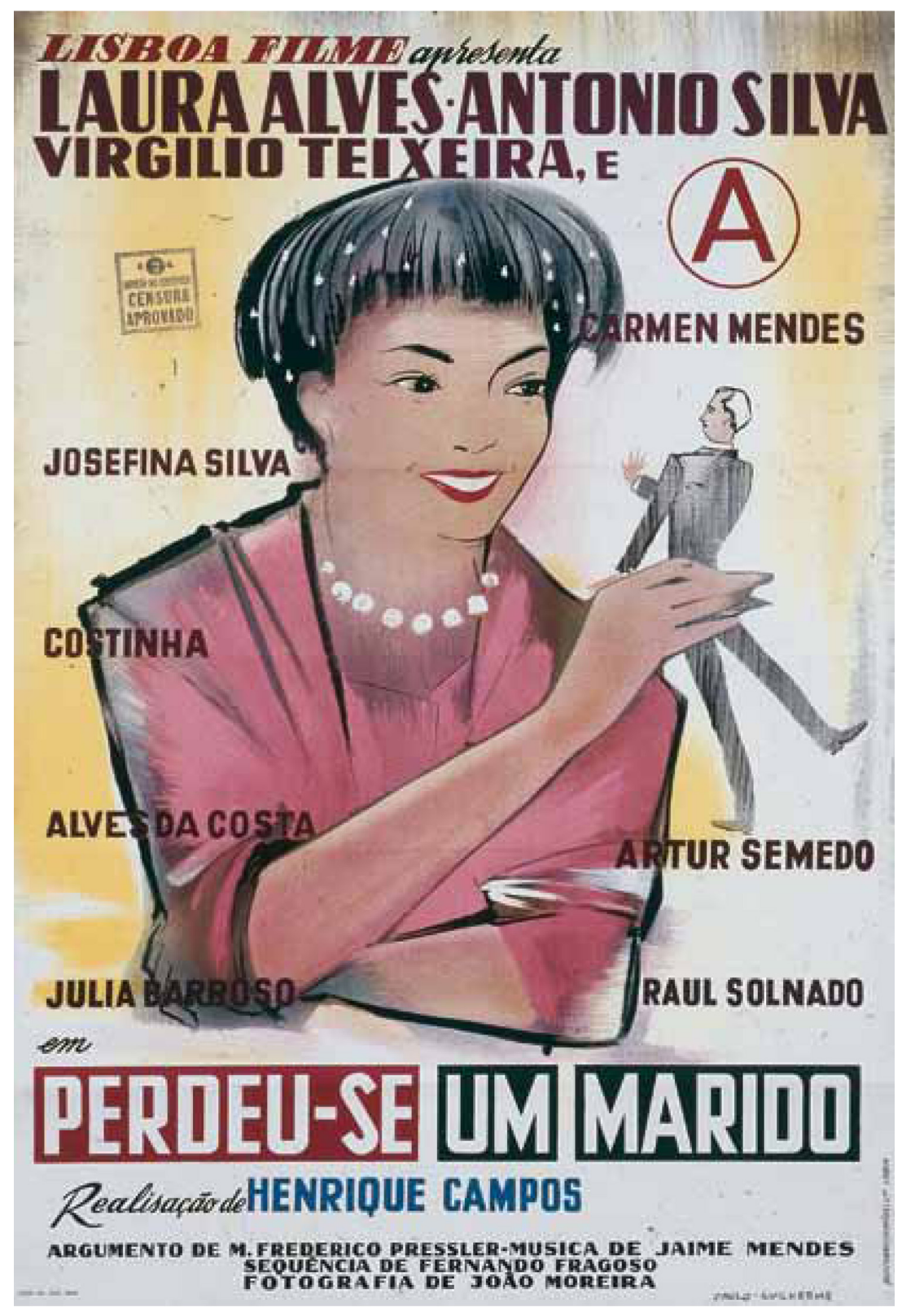

Figura 91. Cartaz do filme, Perdeu-se um marido 
4.8.1 Cabaretíssimo / Cabaretíssimo

«Decorado com base em elementos dos anos 30, de muito bom gosto, o Cabaretíssimo é uma sala de dimensões reduzidas - 180 pessoas - , com um palco a condizer, onde o espectáculo e espectadores formam um todo indivisível, de um "show" de duas horas e um quarta, sem qualquer interrupção. E, convenhamos, nada que não seja de qualidade se aguenta divertidamente durante tanto tempo... ${ }^{135}$

Dois meses após o 25 de Abril, Paulo-Guilherme faz uma revolução na noite de Lisboa com Cabaretíssimo. Trata-se dum espectáculo music hall alternativo e arrojado de duas horas e meia, inédito em Portugal.

«O "Cabaretíssimo" faz ruptura na pacata marginalidade alfacinha sedenta, nesses tempos gloriosos, de promiscuidade revolucionária.» ${ }^{136}$

A decoração do café-concerto é, evidentemente, de PG. Atmosfera é anos 30, demarcadamente Art Deco. O espaço continha muitos espelhos, luzes no palco, cortinas, mesas redondas com toalhas vermelhas e até passarela até o público. As cores principais eram os pretos, laranjas e vermelhos.

Os actores do espetáculo serviam também os clientes num clima de intimidade levando assim o espectador a tornar-se participante. PG e António Bardis (o coreógrafo, ex-bailarino do Alária, encenador, ensaiador e artista) trabalharam uma banda sonora original, construindo, sobre ela, um espectáculo de Playback juntamente com um trabalho de luminotécnica e de

\footnotetext{
${ }^{135}$ PLANTIER, Carlos, "Cabaretíssimo: uma grande festa”, O Seculo Ilustrado, 1974 , p.48 ${ }^{136}$ Idem
} 

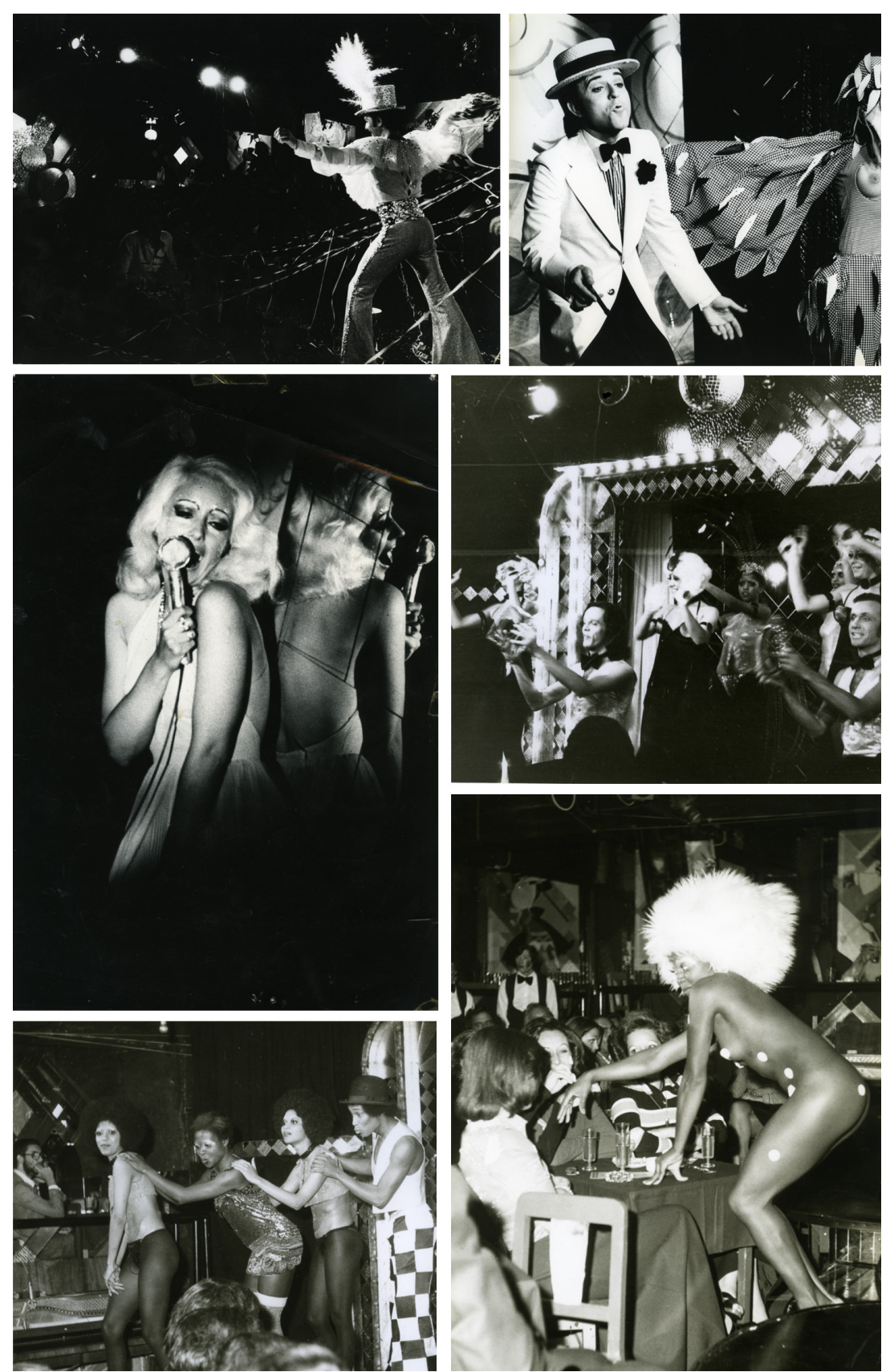

Figura 92. Conjunto de fotografias do Cabaretíssimo 

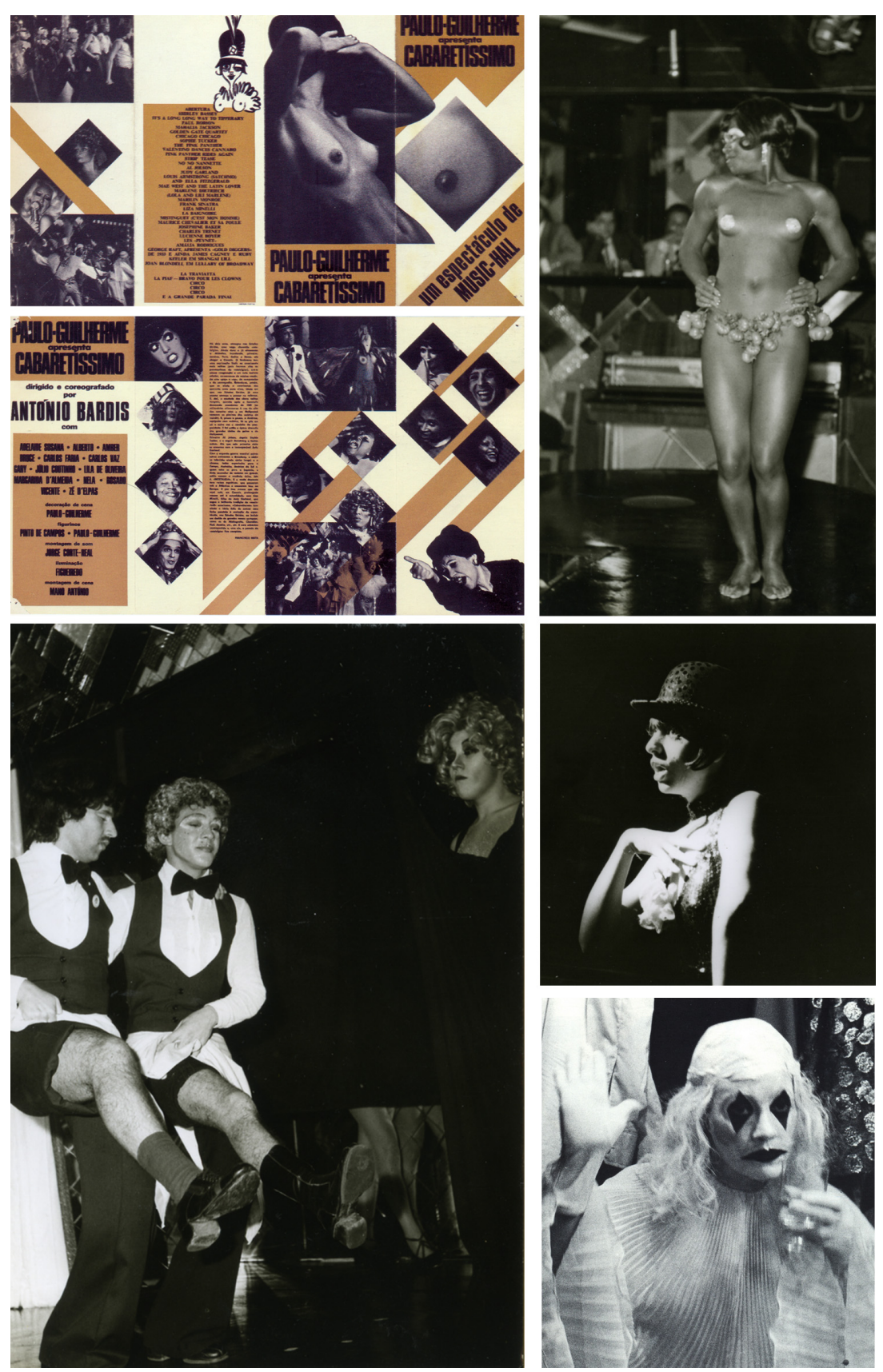

Figura 93. Conjunto de imagens do Cabaretíssimo

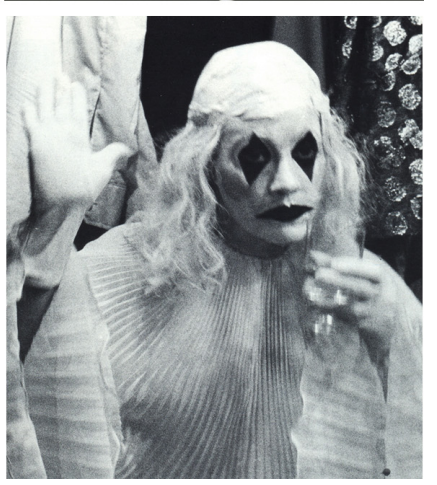




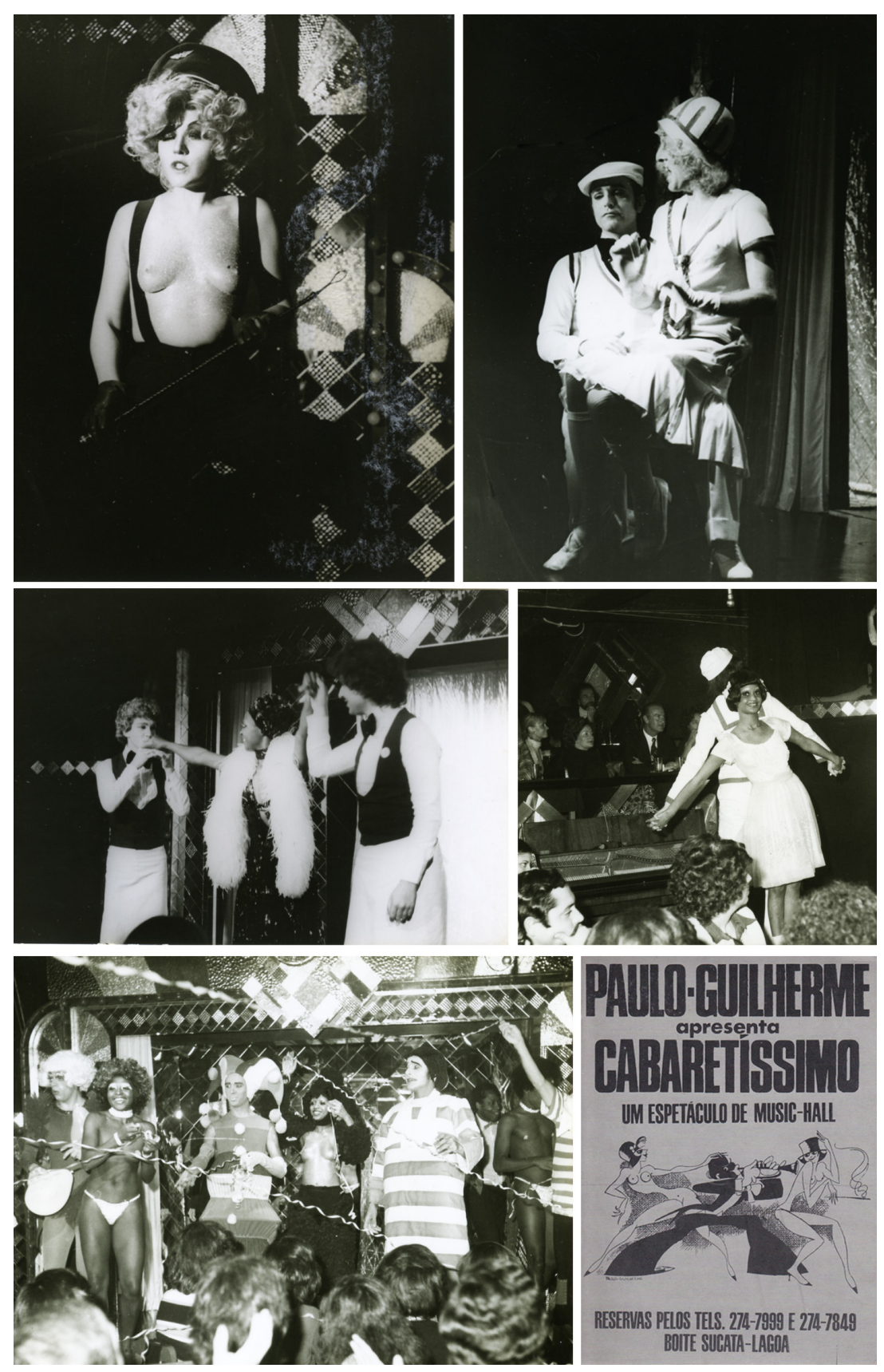

Figura 94. Conjunto de imagens do Cabaretíssimo 
sonoplastia. Espectáculo com nus, travestis, músicas dos anos 20 a 40 - em gravações originais -, mímica, imitações e muito humor.

$\ll(.$.$) as músicas, que os artistas acompanham dançando,$ representando, reivindicando, estão primorosamente montadas e escolhidas, numa selecção original onde os melhores não foram esquecidos, e os menos conhecidos ficaram mais recordados; comenta a jornalista Maria João Avillez. As presenças eram: em primeiro lugar, os "travestis", José Manuel Rosado, magnífico em "Mae West", "Mistinguette" e "Opera"; Carlos Faria, em "No, No, Nanette" e "Lucienne Boyer"; Paulo e Júlio Coutinho, " Casa da Mariquinhas”, na pele de Amália Rodrigues. Depois, António Bardis em "Guerra de 14", "Sinatra" e "Maurice Chevalier"; Margarida de Almeida "vestindo-se" de "Judy Garland", "Marlene" e "Clown"; Lila de Oiliveira em "Liza Minelli"; Bruce vivendo "Paul Robenson" e "Louis Armstrong" e, ainda, a escultural Adelaide Suzana, muito bem em "Shirley Basey", "Sarah Vaughan" e "Josephine Baker" » ${ }^{137}$ Nas imitações, o ponto forte, aparecem Marléne, Chevalier, Mae West. Al Jolson. Marylin. Sophie Tucker, Lucienne Boyer, Charles Trenet, Josephine Baker, Mistinguette. George Raft, Judy Garland, Ginger Rogers, Fred Astaire, Frank Sinatra, Louis Armstrong, Lisa Minelli, Charles Aznavour, Edith Piaff, Maurice Chevalier, Marlene Dietrich e Amália.

Nomes célebres do mundo da música e da canção eram interpretados por um grupo de artistas, habitualmente figuras apagadas do palco. Os artistas eram: Margarida d' Almeida, Adelaide Suzana, Georges Laverny (cantores), Wanda, José Manuel Marques, Álvaro Rodrigues, Brenda, Colo, Theresa, Geraint, Williams, Bruce Mac Stoddard, José Manuel Rosa Alberto Guerra Machado, Carlos Faria, Carlos Alberto Silva Vaz, Fernando Paulo, Lila Oliviera, Claudia Martins, António Barros, Júlio Coutinho

\footnotetext{
${ }^{137}$ PLANTIER, Carlos, "Cabaretíssimo: uma grande festa”, O Seculo Ilustrado, 1974 , p.49
} 
(travestis), Rui Guedes (pianista), entre outros. O trabalho do guarda-roupa, é de Paulo Guilherme e Pinto de Campos; Som: Jorge Corte-Real. Luzes: João Figueiredo. Há um trabalho de conjunto, com enorme vontade de bem fazer, de fugir da vulgaridade estagnante. Trabalho que fica um ano em actuação em Portugal e o enorme êxito repete no Brasil. O Cabaretissimo, na carioca boîte Sucata é auxiliado na coreografia pela inglesa Bernardette, que simultaneamente é uma das bailarinas. O elenco - de aproximadamente 15 pessoas - inclui duas brasileiras e uma inglesa, Brenda Wicar.

«O êxito é tanto que se repete no Brasil, na Carioca Boîte "Sucata" onde "Cabaretíssimo" faz uma carreira de oito meses em cena, só interrompida por uma cheia que inundou o rio e, claro está, a "Sucata". Carlos Faria a estrela máxima do espetáculo, uma noite atravessou a sala a nado, mas a chuva tudo levou... ficando para sempre este original e único artista, generoso amigo e inconsolável português, que como Almada fez de tudo e bem, até teatro, com generosidade, génio e revolta de ser português (...).» ${ }^{138}$ ${ }^{138}$ FÉRIA, Filipe la. Catálogode exposição, Paulo-Guilherme D'Eça Leal D'etecetera e tal
2000, Câara Municipal de Lisboa ; Novembro de 1999, p.289 


\subsubsection{Exposicione Paulo-Guilherme D'Eça Leal etcétera y tales, 2000 / Exposição Paulo- Guilherme D’Eça Leal etecetera e tal, 2000}

«...Sempre inquieto, criativo e ousado, abriu novos espaços à comunicação das artes plásticas, da fotografia e da decoração. A sensualidade, a cor, o mistério, o esotérico, o desconhecido, o inatingível são temas marcantes da obra, seja qual for o suporte escolhido para ela. A presente exposição é uma viagem pela sua vida, pelo seu imaginário, pelas suas utopias, pelos seus afectos, pelas suas realizações, pelas suas perturbações. Como elemento de convívio, o espaço do edifício do Campo Pequeno onde ela se encontra, apresenta ao visitante zonas de estar, de tertúlia, de lazer. "Alquimista das Ideias" lhe chamou, num imponente catálogo editado pela Câmara Municipal de Lisboa, Pedro Bandeira Freire. $\gg^{139}$

Paulo-Guilherme D’Eça Leal etecetera e tal, 2000 foi uma grande exposição retrospectiva, realizada por PG no Palácio Galveias, Campo Pequeno de Março a Abril do ano 2000. Esta exposição, de entrada gratuita, contou com uma enorme quantidade de quadros, maquetas, plantas, painéis, trabalhos estes de todas as vertentes que PG actou, inclusive a visualização de seus próprios filmes. As paredes do Palácio das Galveias ficaram literalmente forradas com trabalhos do PG conseguindo sem dificuldade preencher as oito salas que lhe foram disponibilizadas. A acompanhar esta exposição, PG deu algumas palestras sobre as suas investigações e a Câmara Municipal de Lisboa editou um catálogo de exposição. O grande catálogo, de 403 páginas, embarga imagens da

${ }^{139}$ BRÁS, José António. “Alquimista das Imagens”, Visão 7,n³67, 23 a 29 de Março, p.34 


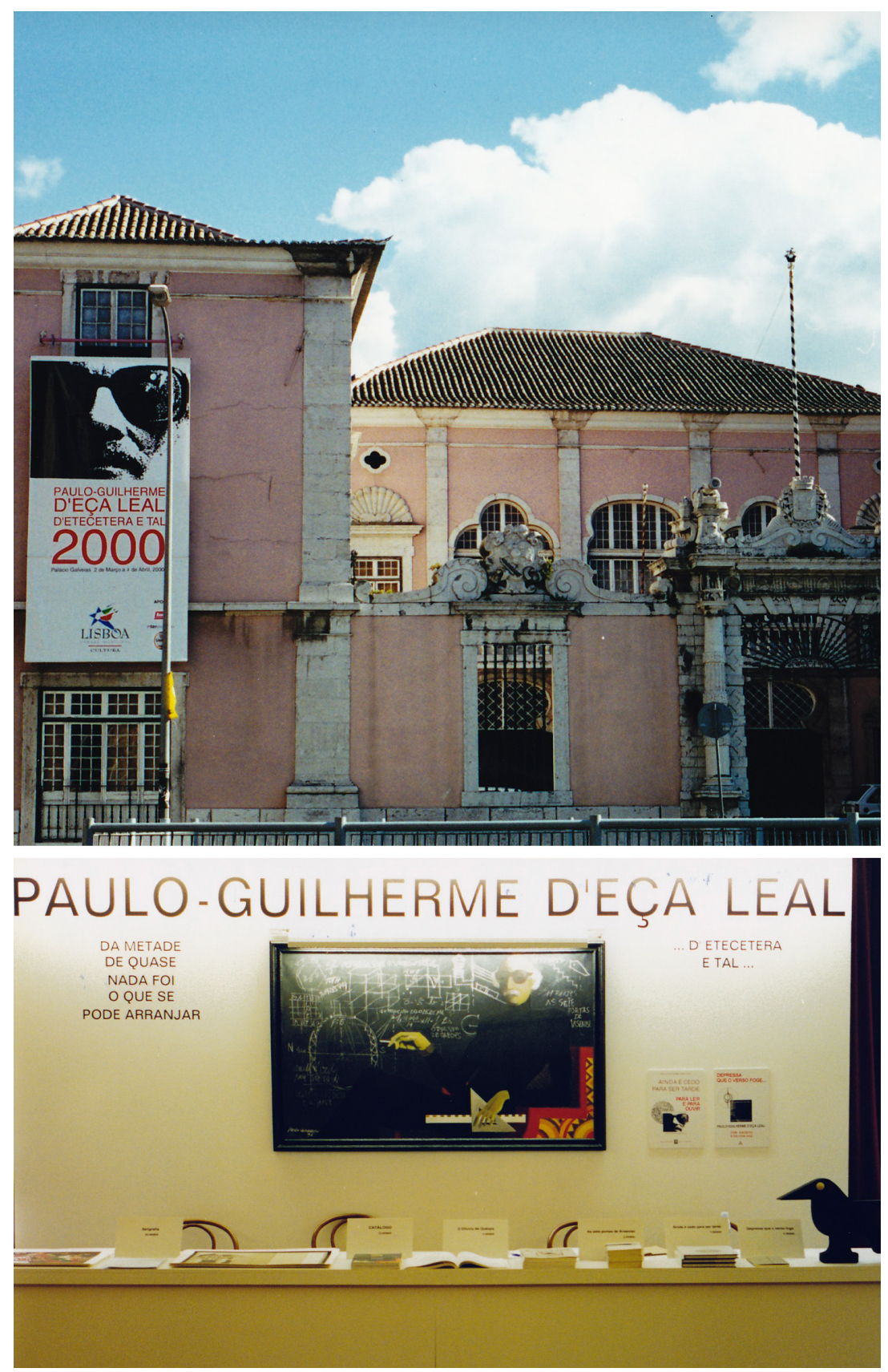

Figura 95. Conjunto de fotografias da exposição em Galveias 


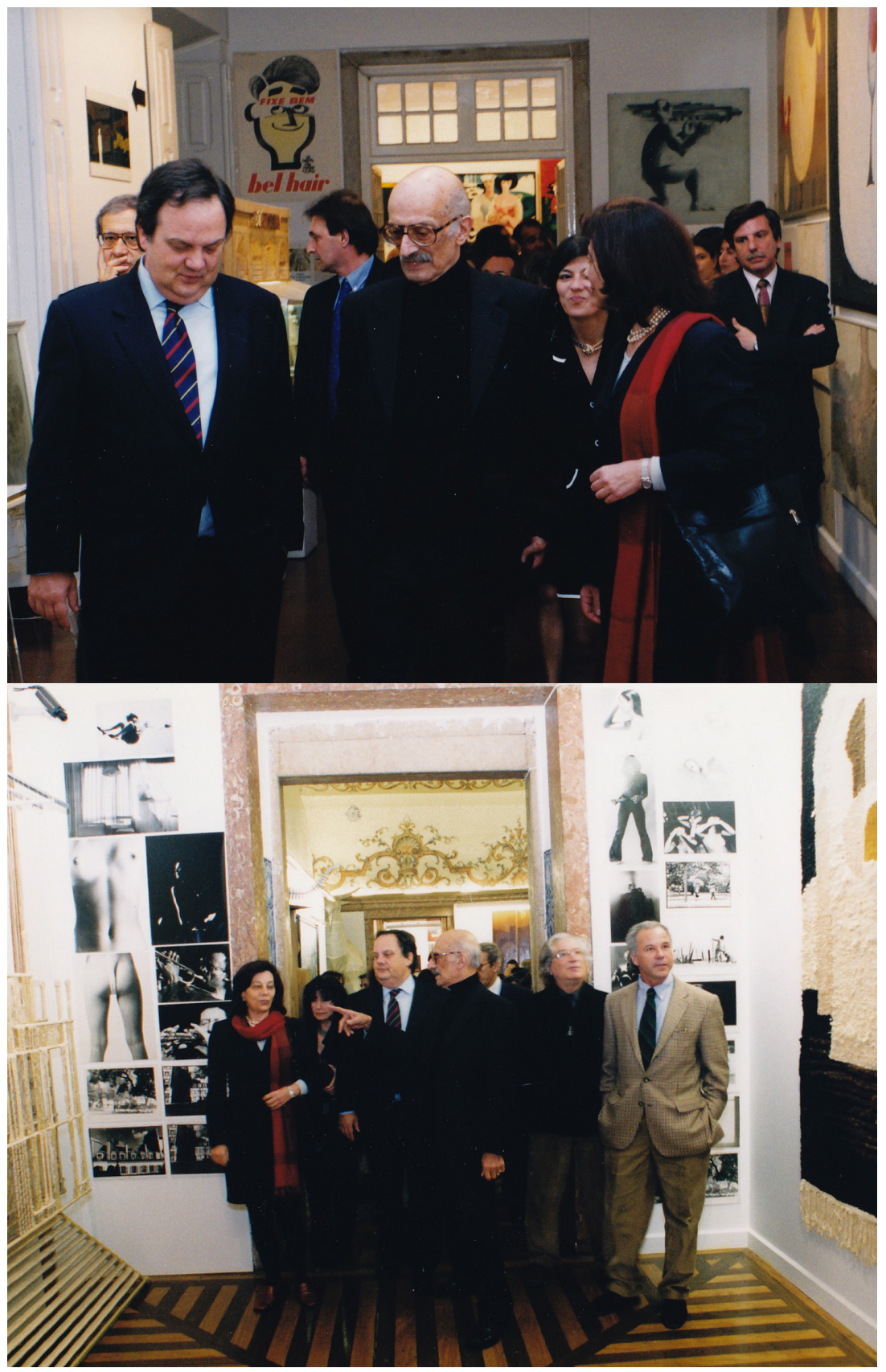

Figura 96. Conjunto de fotografias da exposição em Galveias 


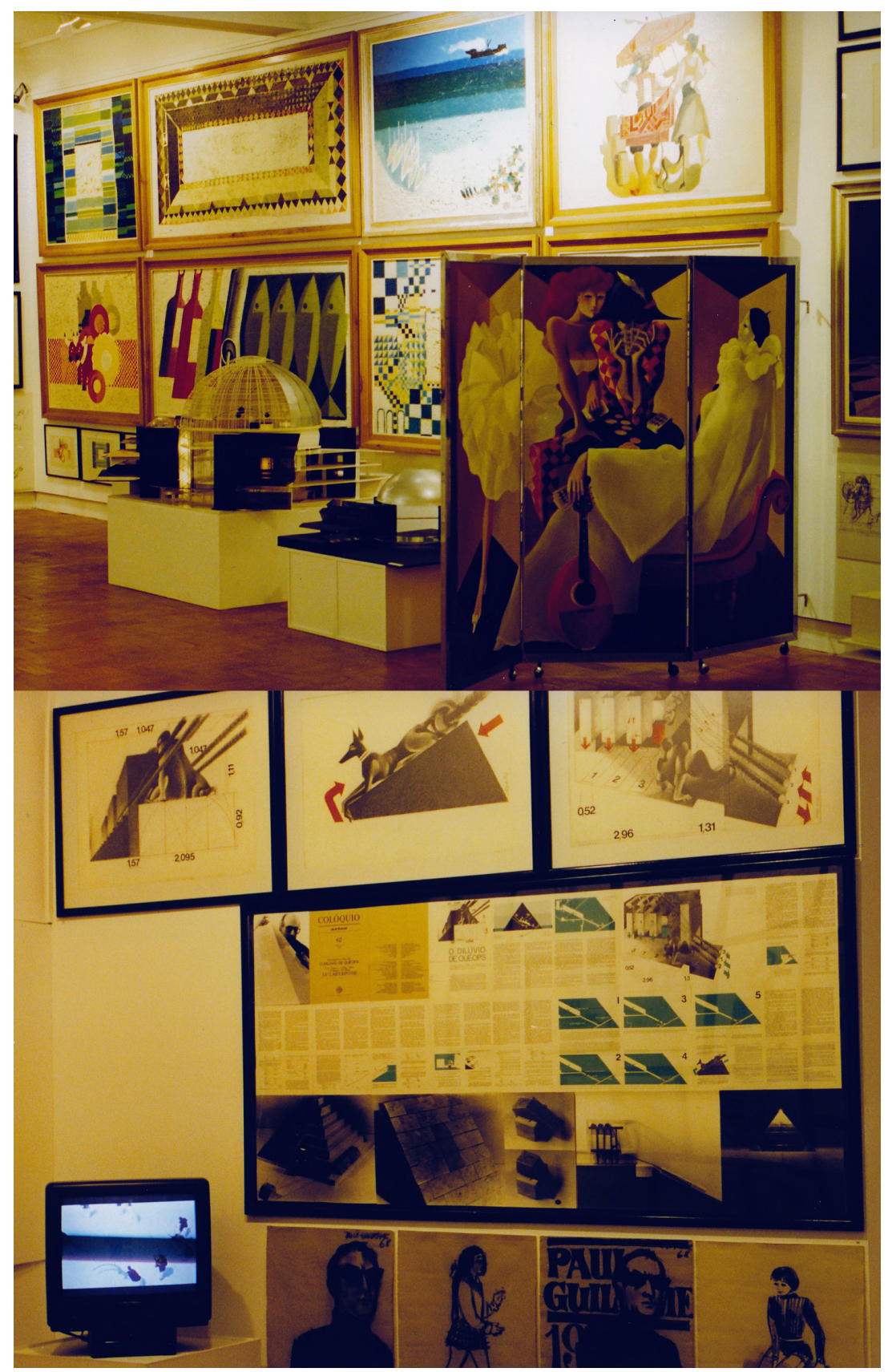

Figura 97. Conjunto de fotografias da exposição em Galveias 
obra de PG em diferentes domínios e contou com vários textos de vários autores: João Soares, José-Augusto França, PauloGuilherme, Cruzeiro Seixas, Homem Cardoso, António Alçada Baptista, António Sena da Silva, Pedro Bandeira Freire, Filipe La Féria, Carlos Calvet e Fernado Dacosta.

«De Paulo Guilherme, em carta aberta com remetente carimbado de Jarzé, José Augusto França fala de um coleccionador de impossíveis e de absurdos com registo e implicações em seis, sete ou oito carreiras nos caminhos transversais, que são os da verdadeira criação, e saúda-lhe os passes mágicos, em verónicas às marrações desta terra ingrata.

Já Cruzeiro Seixas rebusca a primeira fala com Paulo Guilherme, nos idos anos quarenta, quando os dinossauros (antes de se deixarem aprisionar como animais domésticos nos "Casos de Direito Galáctico" de Mário Henrique Leiria) se passeavam ainda nas ruas daquela Lisboa, que então se confundia com as aguarelas de Botelho, que acolhia ainda há pouco na mesma mesa de café o pai Olavo d'Eça Leal e Pessoa, para deixar escorregar para novo parágrafo "Que país este! Do grande naufrágio, apenas se salvava o mar...", e em metáfora recorrente apelar à fadiga a água "que já nem ouve o que lhe grito".

E que acrescentar a António Alçada Baptista, no seu olhar o universo plástico de Paulo Guilherme, "um faz-tudo qualificado que pega na arquitectura, na decoração, na pintura, no desenho, na investigação isotérica, na geometria aplicada, com ar de quem deita bolas ao ar e as apanha com as mãos com o sorriso de quem não se leva a sério..."

Talvez lembrar o "enterteiner" que o próprio Paulo se reclama, como Picasso ou Strawinsky, lista a que António Sena da Silva acrescenta Mozart ou Moliere, Watteau ou Louis Amstrong, para lhe admitir a sensação de boa companhia, já que estão excluídos vestígios de 

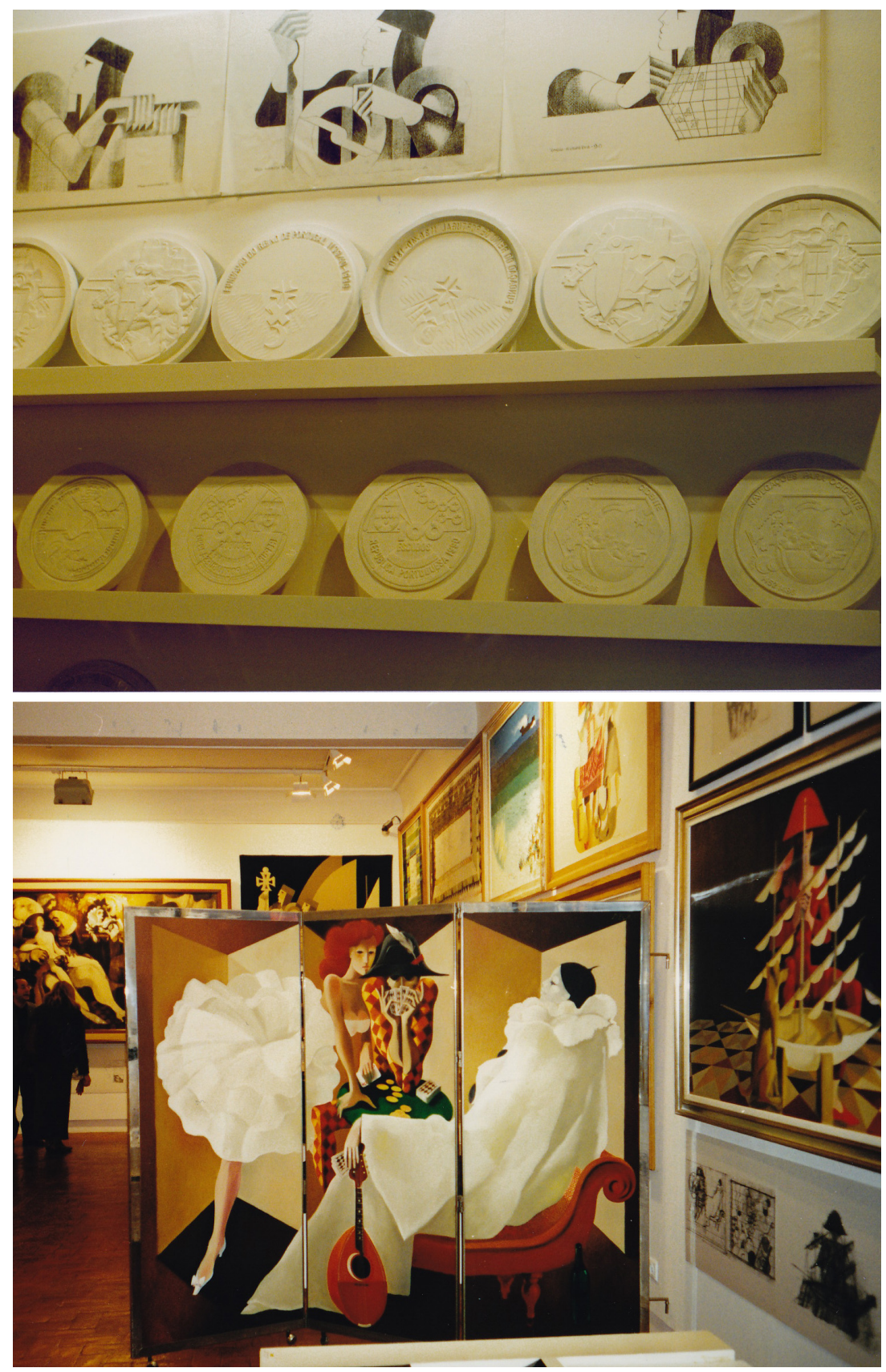

Figura 98. Conjunto de fotografias da exposição em Galveias 


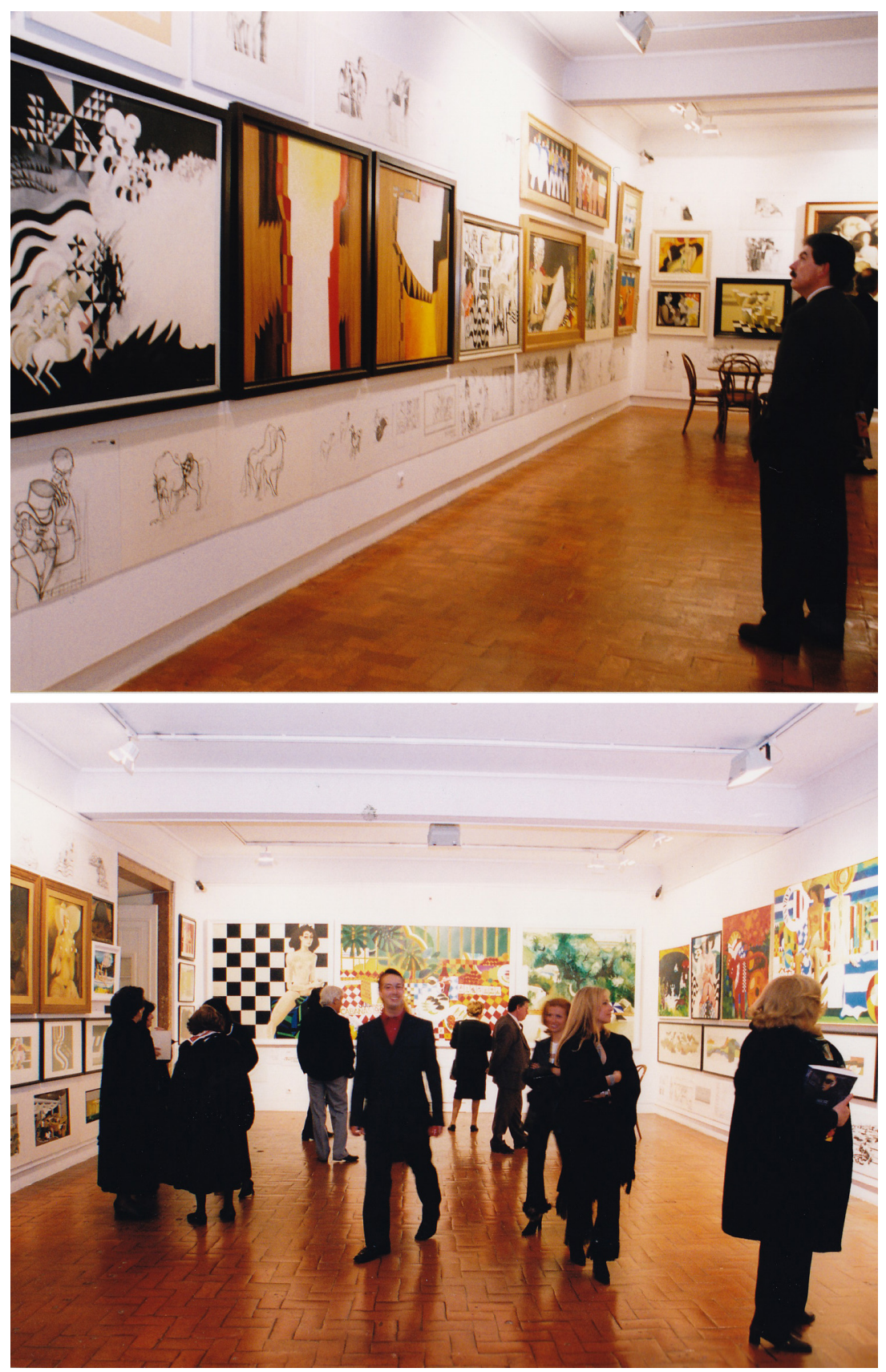

Figura 99. Conjunto de fotografias da exposição em Galveias 
modéstia, um vício que Paulo Guilherme ignora.

Ou o alquimista, segundo Pedro Bandeira Freire, ou a dúvida de António Homem Cardoso entre o poeta e o cineasta, o designer ou o decorador, o arquitecto ou o pintor, ou ainda o escritor de que Filipe La Féria diz ter merecido melhor sorte, e talvez o seu fado não o deixasse fugir para o alto das pirâmides do Egipto, e concluir com o grito que sobre Almada, que fez de tudo e bem, até teatro, com generosidade, génio e revolta de ser português: "que desgraça ter nascido em Portugal".

À pirâmide de Kheops, ao pi e aos côvados reias egípcios recorre Carlos Calvet, que vai buscar a Napoleão o fascínio de quarenta séculos de segredos matemáticos que nos contemplam do alto da maior Pirâmide que também seduziram o investigador $\mathrm{e}$ piramidologista Paulo Guilherme, o mesmo Paulo Guilherme que leva Fernando Dacosta a discorrer sobre os autores que atravessam elipticamente a cultura, flutuando pelo lugares, géneros, tempos e públicos. Uma espécie de corpos mestiços, feitos de muitos sangues, alegrias, inquietações, memórias, mistérios, fascínios e deslumbramentos. $\gg^{140}$

${ }^{140}$ BRÁS, José António. “Alquimista das Imagens” Visão 7,n³67, 23 a 29 de Março, p.35 


\subsection{Realización / Realização}

No campo da realização PG tivera, no início, com o seu pai e posteriormente a título individual experiencias no campo da publicidade televisiva. Efectou dezenas de anúncios televisivos para marcas como a Nestlé, Ovomaltine (produtos alimentares), Tissot (marca de relógios), entre outros. Estes anúncios eram realizados de um modo rápido, prático e expedito, chegando num só dia a fazer 2 ou 3 anúncios. Os modos e os meios de realização eram precários e necessitavam de grande imaginação para fazer face às dificuldades. Valeu-lhe a experiencia na concepção de cenários e figurinos para teatro bem como decorador.

Ainda assim, outros ficaram por fazer como foi o caso de um projecto televisivo Diletante ma non troppo, uma série de programas com variadíssimos assuntos dirigido e apresentados por PG que chegou a ser anunciado ao grande público.

«Em princípio, vai ser um programa bem disposto, leve, embora muitas vezes eu trate de assuntos sérios, porque não acredito nada em falar das coisas sérias, com aquele ar sisudo, erudito e complicado. Não sei se consigo essa simbiose. Vou procurar falar dos assuntos, de modo a prender o espectador. Não sei se o vou conseguir de qualquer modo, é uma experiência nova e eu gosto imenso de fazer coisas que não sei fazer, porque alem de normalmente não me sair muito mal, tenho a vantagem de as aprender e de se tornarem mais uma mala na minha bagagem. Será um programa a sério que não se leva a sério mas quando dá para brincar, brinca-se a sério.» ${ }^{141}$ Explica PG numa entrevista.

Em 1986 produziu e realizou a curta-metragem $O$

\footnotetext{
${ }^{141}$ NEVES, Berta,’Diletante ma non troppo", revista Tv em Directo, p.6-7
} 


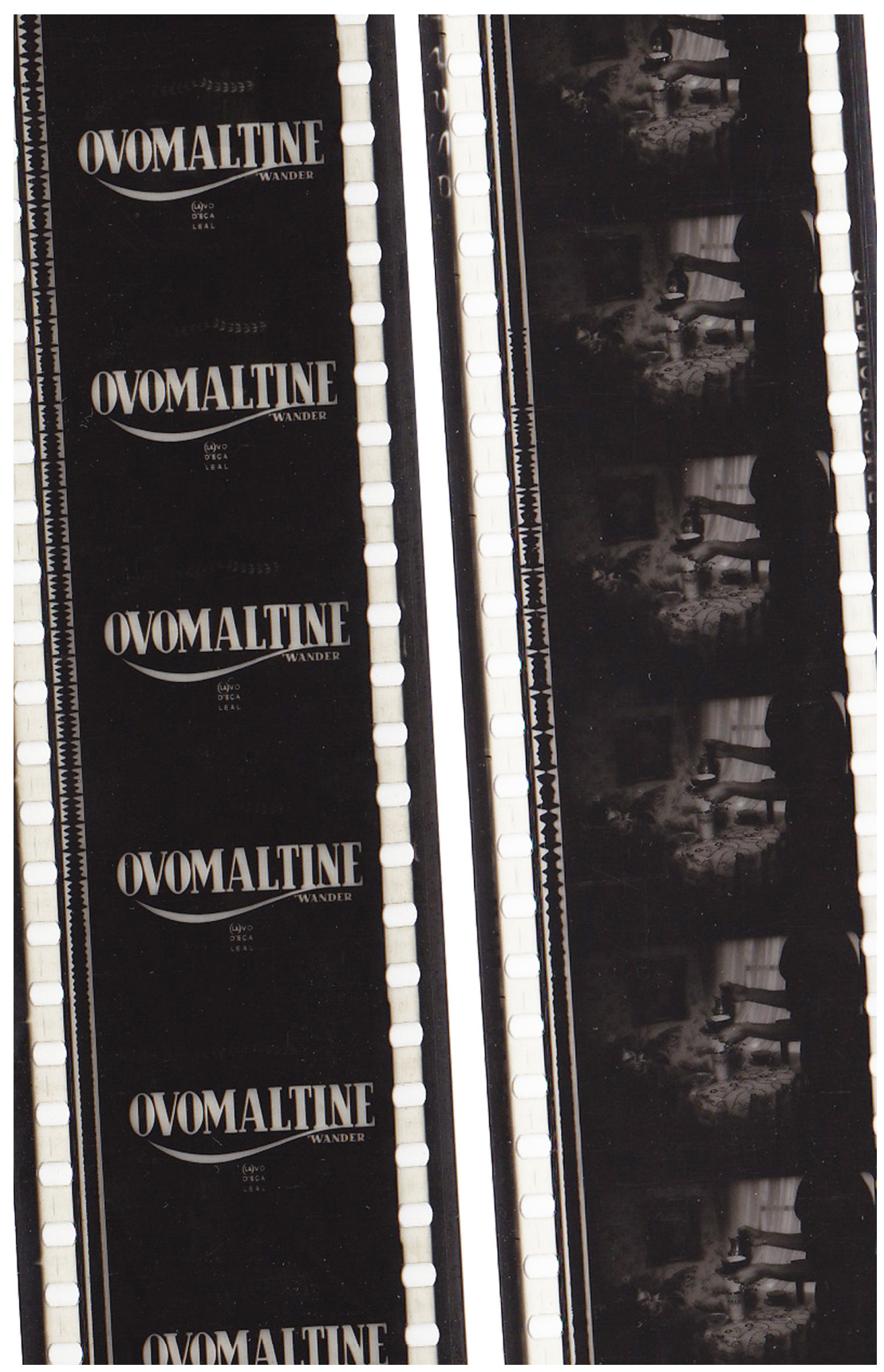

Figura 100. Película do anúncio Ovomaltine 
Alquimista e, em 1988, o filme de longa metragem Iratan e Iracema, Os Meninos Mais Malcriados do Mundo (Prémio Palma de Ouro do Festival de Cinema da Figueira da Foz).

\subsubsection{OAlquimista / O Alquimista}

«É alquimista porque esse é o título da sua primeira obra de cinema, uma curta metragem que é uma pequena pérola barroca e onde um homem, o alquimista Paulo-Guilherme, procura a perfeição na "pessoa" de uma bola de ouro que, à custa de ser tratada e limada, acaba por ficar convertida no mais celeste dos grãos de poeira que acabará por se perder no éter. ${ }^{142}$

A curta-metragem intitulada o O Alquimista, 1986, de 14 minutos de duração foi estreada no Fantasporto nesse mesmo ano. A realização e argumento desta película $16 \mathrm{~mm}$ (159 mt), a cores devese a PG, produção de Jaime Cruz e Natércia Machado, fotografia de Mário de Carvalho e interpretação/personagem simplesmente a um indivíduo, o próprio PG.

Um alquimista verifica quão pouco realizou depois de ter chegado ao ponto mais elevado, mais intenso da sua maturidade. Propõe-se, assim, realizar algo de definitivo: algo perfeito! Após reflectir sobre o que haveria de efectuar chega à conclusão que «fosse o que fosse que fosse perfeito» ${ }^{143}$ seria o suficiente para alcançar um feito

\footnotetext{
${ }^{142}$ FREIRE, Pedro Bandeira, Catálogo de exposição, Paulo-Guilherme D'Eça Leal D'etecetera e tal 2000, Palácio Galveias 2000, Câmara Municipal de Lisboa, p. 278

${ }^{143}$ D'EÇA LEAL, Paulo-Guilherme (Director) (1986). O Alquimista [film] Portugal. 13.58 min., 3:01
} 


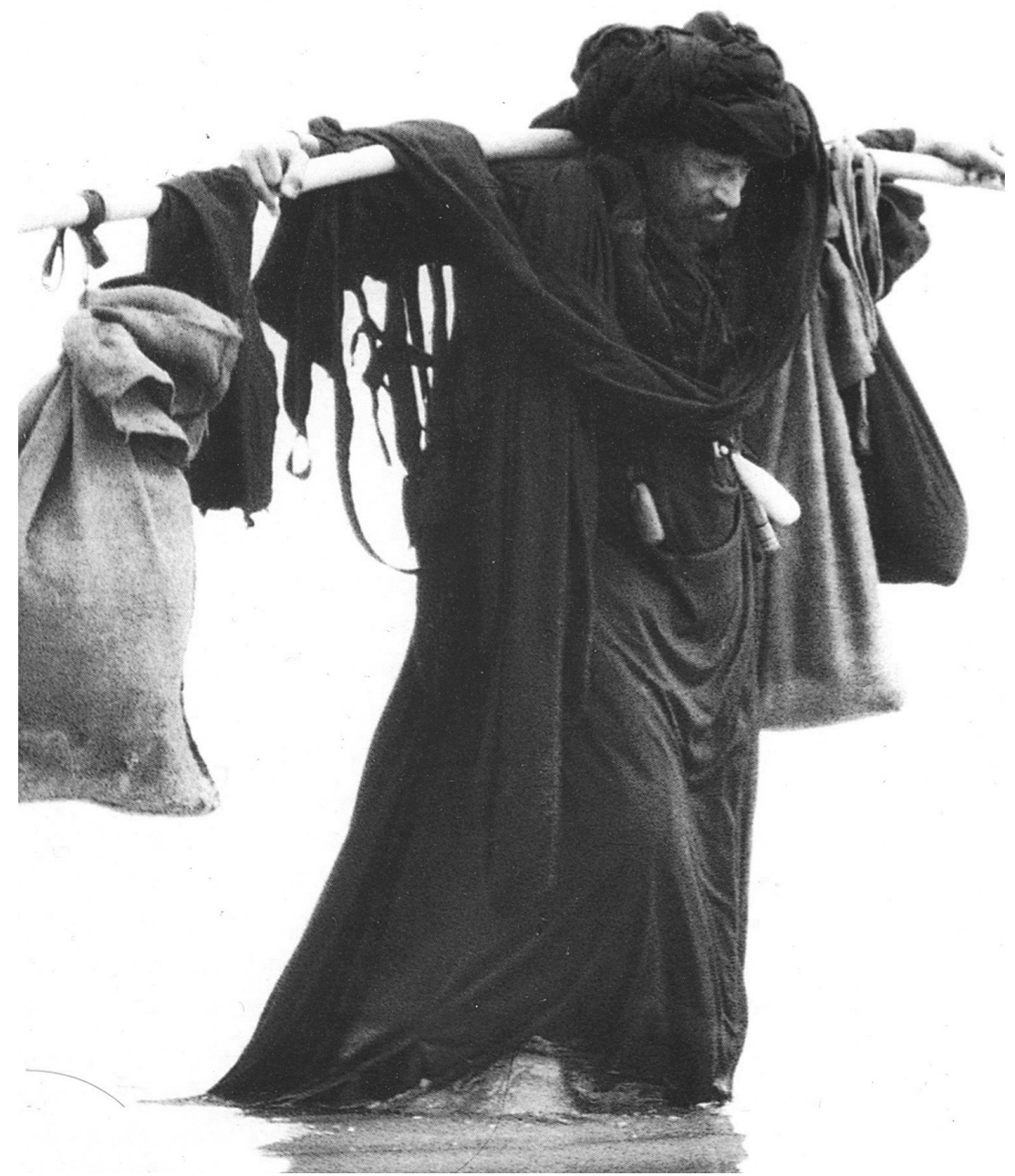

Figura 101. Imagem do filme Alquimista 

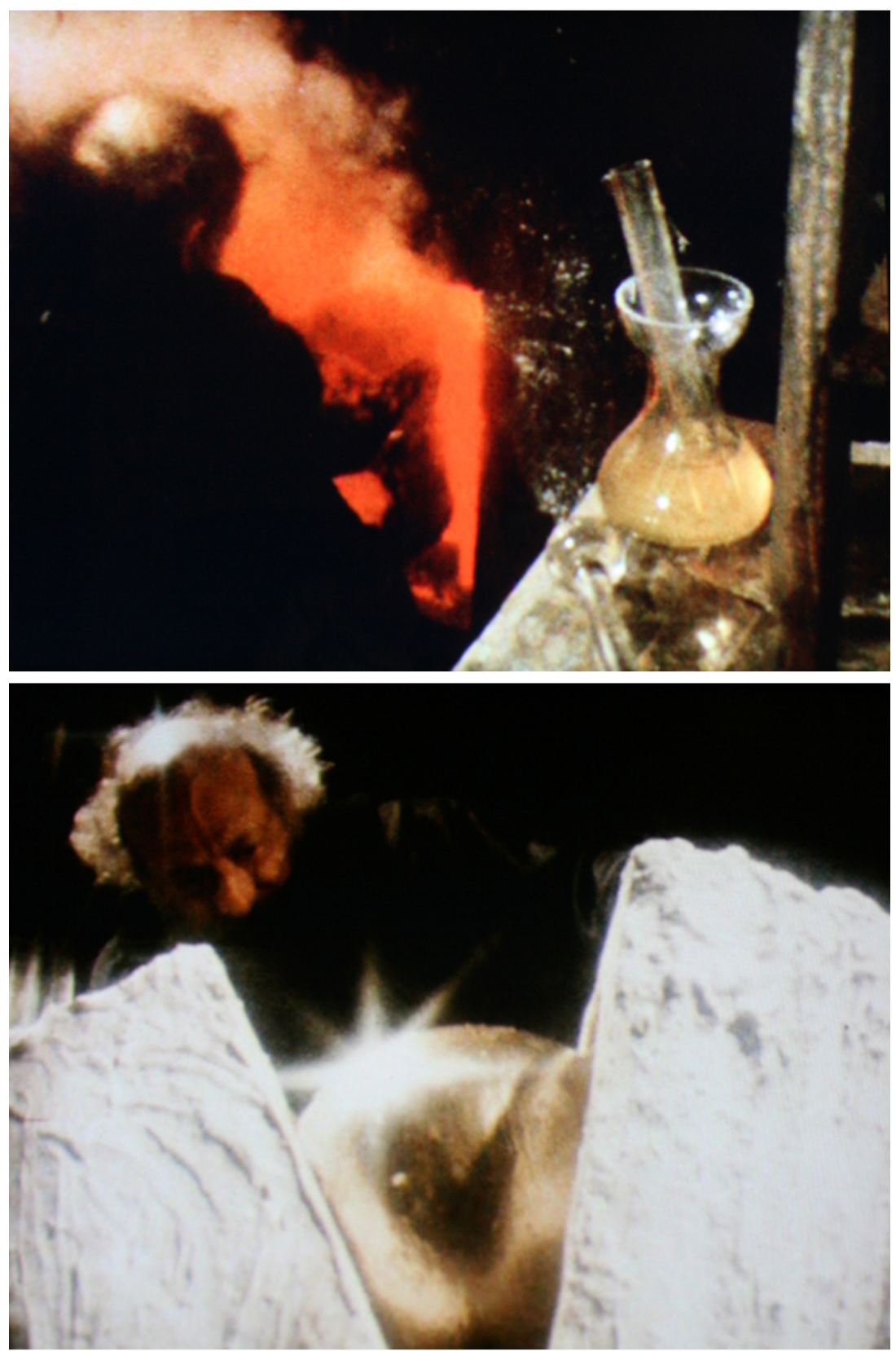

Figura 102. Conjunto de imagens do Alquimista 


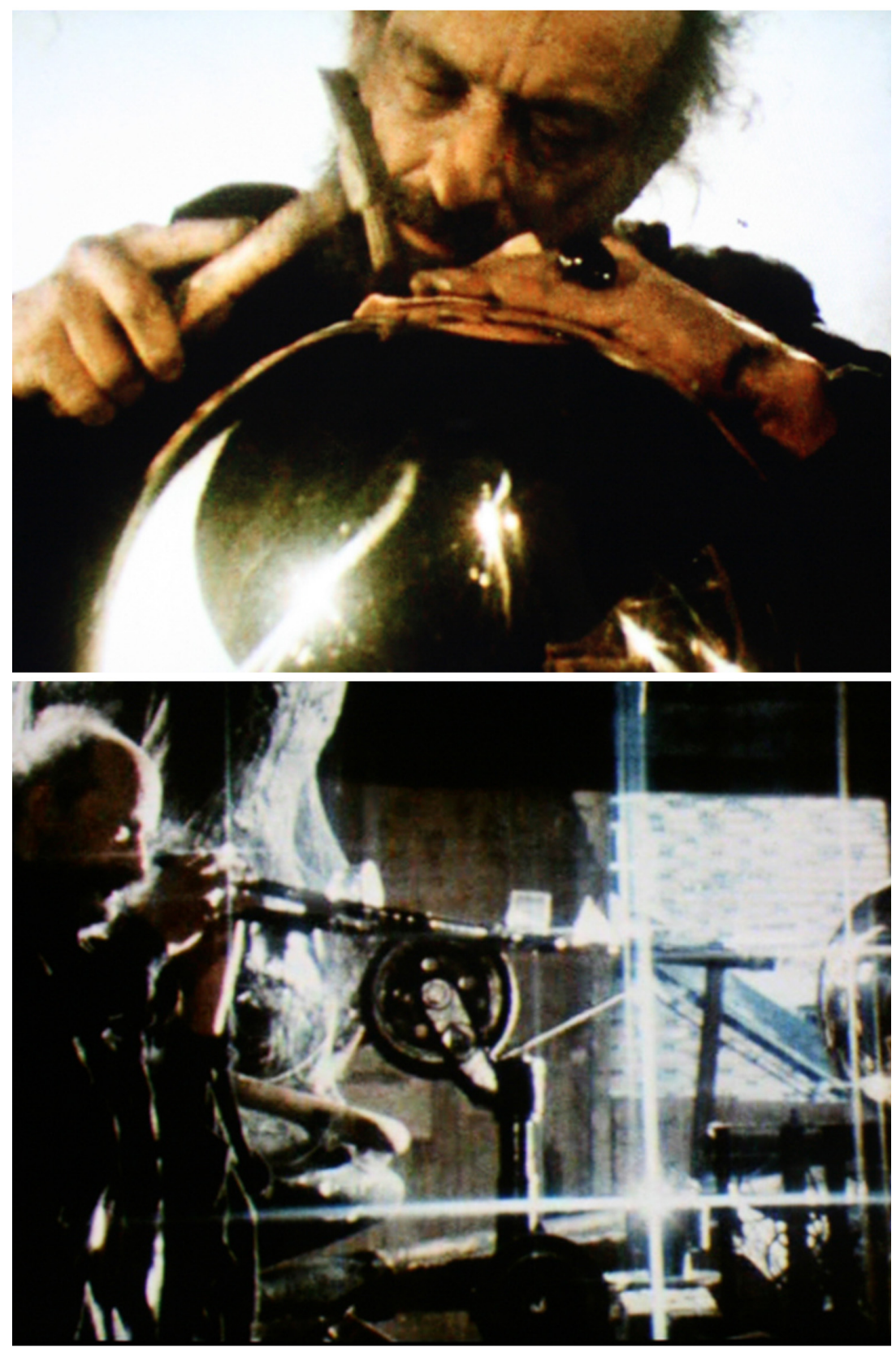

Figura 103. Conjunto de imagens do Alquimista 
inédito e valioso. Por uma dedução lógica chega a uma esfera em ouro, sem defeitos. Num cenário totalmente esotérico, obscuro e esquecido passam-se anos após anos, sobre uma narrativa lenta o Alquimista busca a perfeição.

O figurino, adereços e os cenários saíram do traço de PG conseguindo a atmosfera e ambientes propícios a esta narrativa. Com uma história de simplicidade desarmante consegue colocar o espectador numa curiosidade constante para o desenlace. 


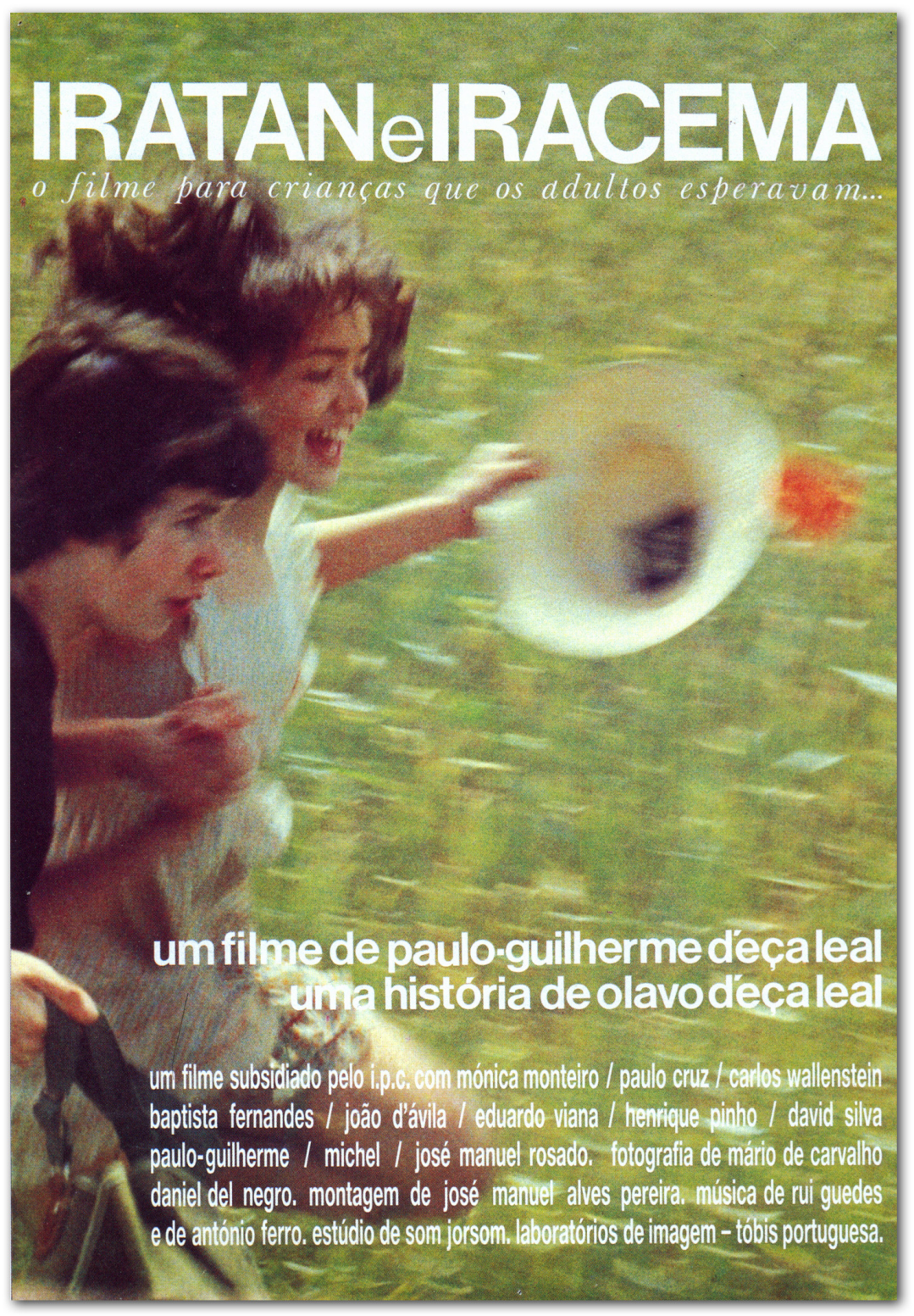

Figura 104. Cartaz do filme, Iratan-Iracema 


\subsubsection{Iratan e Iracema, los chicos más traviesos del mundo / Iratan e Iracema, os meninos mais mal criados do mundo}

«(...) filho retoma a obra do pai para elaborar sobre ela um filme que é, simultaneamente, a exposição de uma dívida formativa e a assunção de uma autonomia criativa num outro médium.

É na esquiva e refinada poeticidade desta relação que se encontra muito do encanto, do fascínio artístico do filme. E, naturalmente (last but not least), no próprio valor artístico dos dois objectos em causa, obra literária e obra cinematográfica.

Do livro diga-se a hábil reflexão do mundo infantil, isenta de preconceitos psicanalíticos paternalistas, sobre a vitalidade da imaginação fluida das crianças, e a elegante manipulação das palavras - das obscuras e densas relações entre as palavras.

Do filme diga-se a preocupação de encontrar o modo mais adequado à captação visual (uma nova arquitectura) desse universo imaginativo riquíssimo, o risco (calculado?) de articular (e sonda) dois mundos aparentemente contrários, o real e o onírico.

(...)

E como é difícil capturar esses intrincados e fugazes revérberos que os mecanismos imaginativos da (in)consciência infantil fabricam! Se, para Jean-François Lyotard, o filme industrial representa uma maneira insidiosa de multiplicar os efeitos de realidade, aquilo que denomina "fantasias do realismo", IRATAN e IRACEMA... poderá ser considerado um filme que gera o oposto disto, a multiplicação 

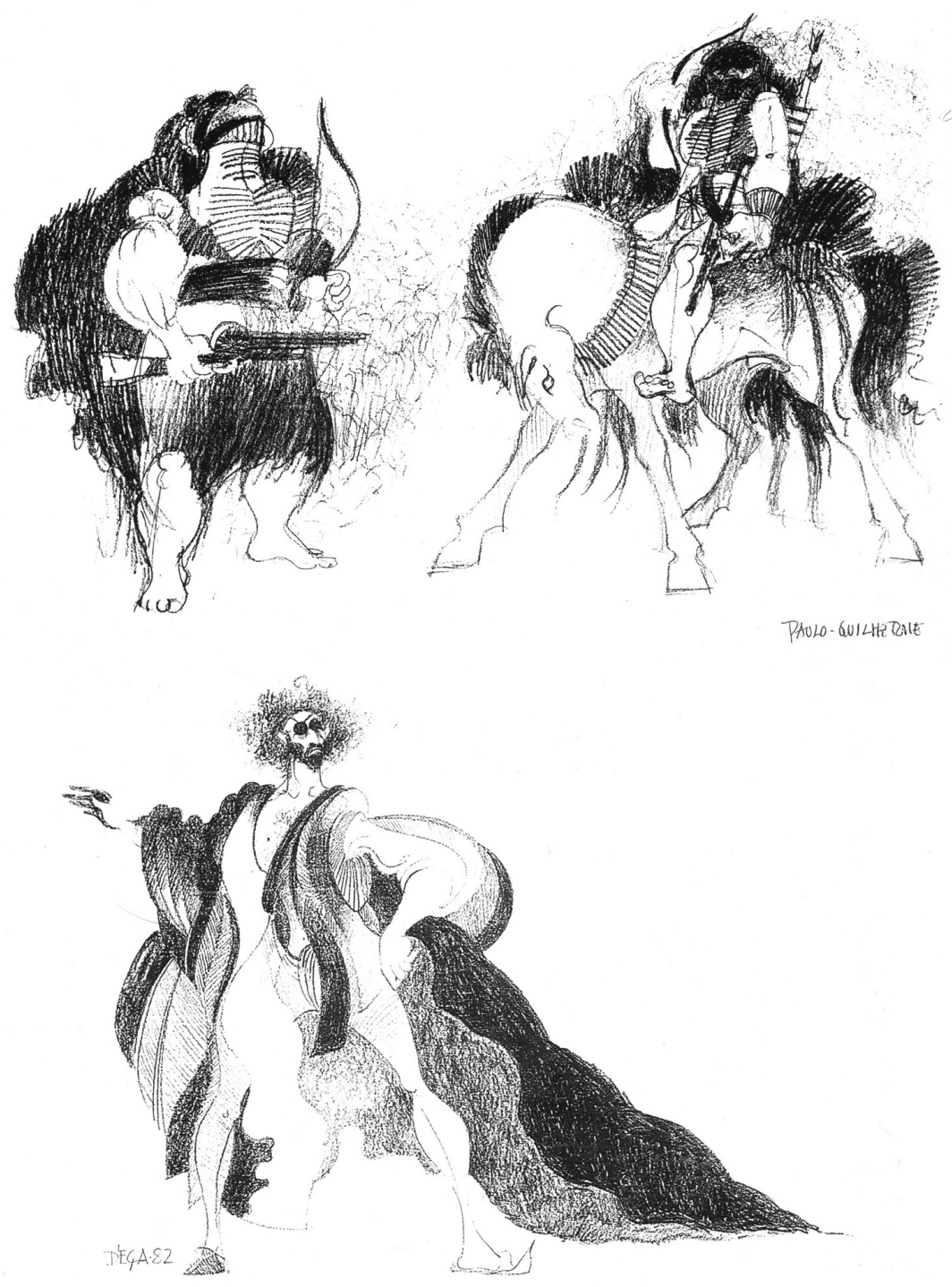

Figura 105. Desenho das personagem da longa-metragem 

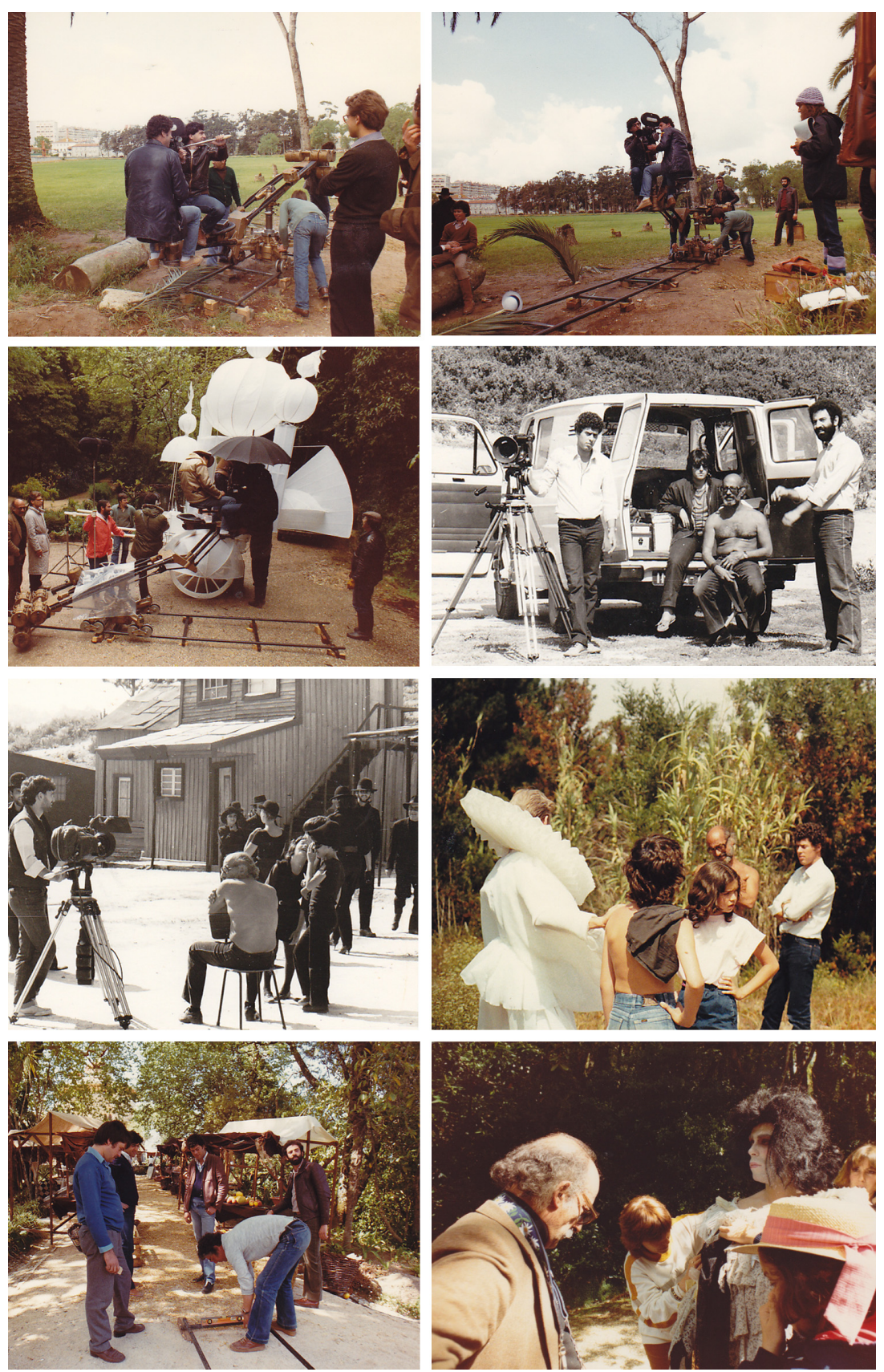

Figura 106. Conjunto de fotografias do making-of 

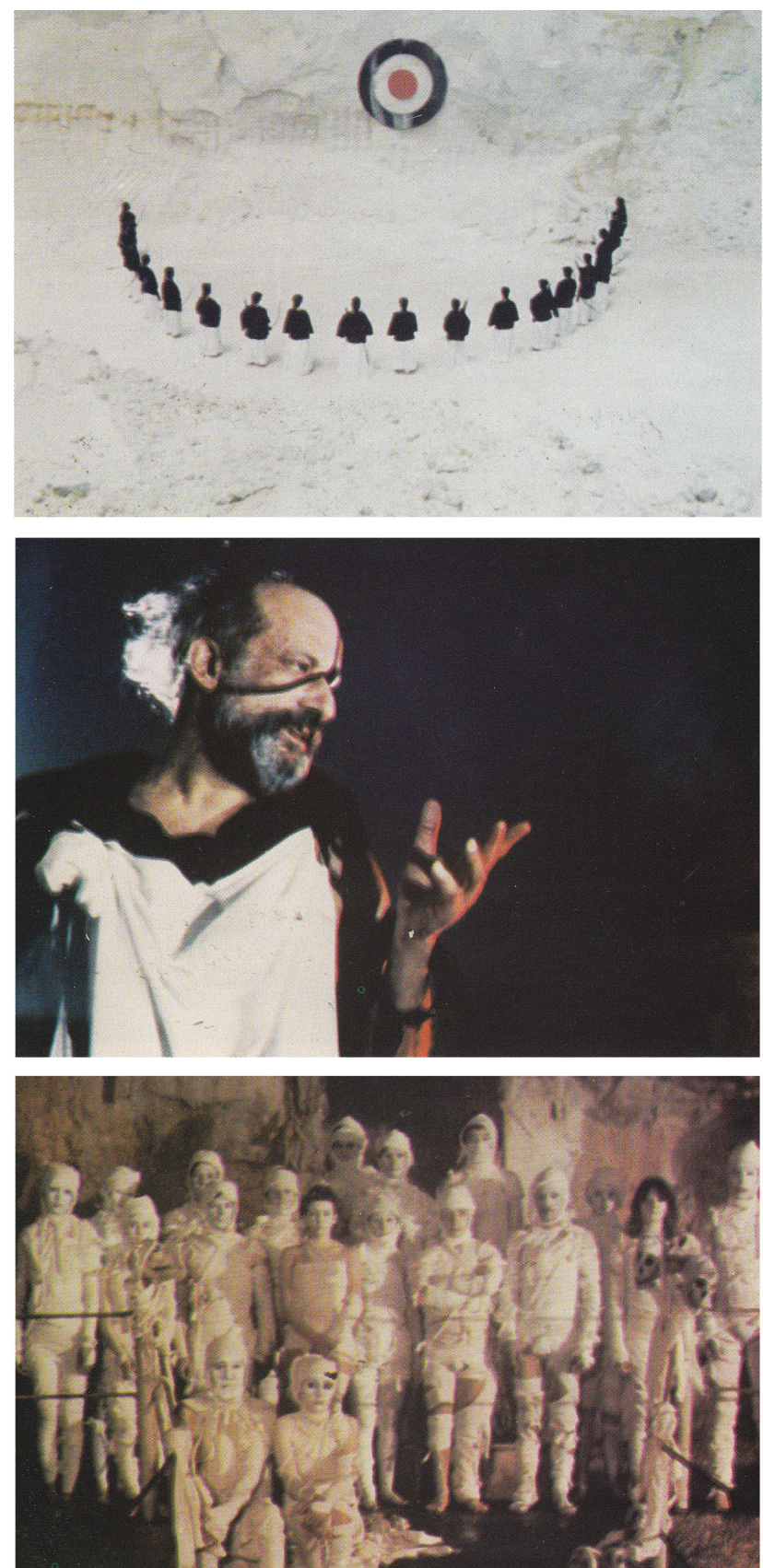

Figura 107. Conjunto de imagens do filme de longa-metragem 
dos efeitos da irrealidade, o realismo da fantasia. $\gg^{144}$

Com o projecto da realização do filme Iratan e Iracema, os Meninos Mais Mal Criados do Mundo desde 1974, PG aos cinquenta anos candidata-se no plano de 1981 a um subsídio do IPC, o qual lhe foi atribuído. Este projecto adveio de uma obra de seu pai, publicada pela primeira vez em 1939 e galardoada com o Prémio Maria Amália Vaz de Carvalho desse ano. Com base no livro Iratan e Iracema, os meninos mais mal criados do mundo, PG realiza uma longametragem, 1984-87, género ficção/fantástico, 35mm, duração 109 minutos, a cores. PG foi director, produtor, realizador, argumentista, guionista e actor desempenhando o papel de faquir. Contou com uma grande equipa de filmagem e elenco: Alváro Faria [intérprete] Príncipe Ivan; Amílcar Bonança [intérprete] Menino de Pedra; António Ferro [Música]; Baptista Fernandes [intérprete] desconhecido; Carlos Alberto Lopes [Sonoplastia]; Carlos Machado [intérprete] Rei; Carlos Wallenstein [intérprete] Criada Velha e Mordomo; Daniel Del Negro [direcção de fotografia]; David Silva [intérprete] Homem Vermelho; Diana [intérprete] Bruxa; Eduardo Viana [intérprete] Naúfrago; Francisco Baião [Música]; Henrique Pinho [intérprete] $1^{\circ}$ Ministro e Pai do príncipe; Jacinto Ramos [intérprete]; João [intérprete] Condessa; João d'Ávila [intérprete] Conde; João Lagarto [intérprete] Pássaro Bisnau; João Malaquias [intérprete] Primo; José Manuel Alves Pereira [Montagem]; José Manuel Rosado [intérprete] Rainha dos Sonhos; Ladislau Ferreira [intérprete] pai; Mário Alberto [direcção de arte]; Mário de Carvalho [Direcção de fotografia]; Michel [intérprete] Vendedor de Memórias; Mizé [intérprete] Bruxa; Mónica [intérprete] Bruxa; Mónica Monteiro [intérprete] Iracema; Paulo Cruz [intérprete] Iratan; Paulo-Guilherme [Faquir]; Paulo-Guilherme [Produção]; Paulo-Guilherme [Argumento]; Pedro Caldas [Sonoplastia]; Rita

${ }^{144}$ FREIRE, Pedro Bandeira, Catálogo de exposição, Paulo-Guilherme D'Eça Leal D'etecetera e tal 2000, Câmara Municipal de Lisboa, 1999, p. 279 
Rodrigues [intérprete] prima; Rui Guedes [Música].

«Sempre que a realidade os aborrece, o que acontece muitas vezes, dois irmãos - Iratan e Iracema, no limiar da adolescência transformam-na, pela fantasia, em algo mais interessante, mais excitante. A ilusão e o sonho são, para eles, ferramentas de precisão - com que manipulam o quotidiano, obtendo resultados inesperados e fascinantes. Eis a história que eles - os meninos mais malcriados do mundo - nos contam... $\gg^{145}$

Em 1988, PG ganha o Troféu de Ouro no festival de Cinema dos Países de Língua Oficial Portuguesa, em Aveiro.

${ }^{145}$ MATOS-CRUZ, José, "Sessenta Cartazes Cinema Português", Revista de Cinema, Estrofio Publicações Lda, Abril, 1989, p.232 


\subsection{Literatura / Literatura}

No campo da Literatura explorou vários géneros literários em cinco livros editados. Utiliza esta prática social para transmitir/incitar sentimentos, ideias, descobertas, novas relações sobre o mundo e as coisas, propondo ao leitor entre o entretenimento à reflexão.

Publicou livros como Dilúvio de Quéops (Novas comunicações sobre a antiga ciência egípcia), O segredo, o poder e a chave (um tratado de relações matemáticas e proporções geométricas), o romance As sete portas de Arsenise e dois livros de poemas: Ainda é cedo para ser tarde e Depressa que o verso foge. Estes últimos editados em CD, declamados pelo autor.

Desde o início da sua escrita manteve a preocupação de ser entendido, pretendendo que o que escrevia fosse acessível a qualquer leitor. Prova disso, são os livros editados desde o género da ficção, à poesia, terminando nas investigações com uma escrita simples e directa. O caminho da investigação nasce no Brasil com a proposta de escrever um artigo sobre as Sete maravilhas do Mundo. É no campo da investigação que PG explora o seu fascínio pelo entendimento global, pela descoberta de mistérios, do oculto. Não negam a marcada influência e fascínio pela $1^{\mathrm{a}}$ geração de Modernistas, tal como Almada Negreiros que também demonstra o fascínio sobre os mistérios dos Painéis de São Vicente de For de Nuno Gonçalves.

Qualquer livro de Paulo-Guilherme é actualmente uma autentica raridade pois estão praticamente extintos do mercado tendo apenas lugar em alfarrabistas. Nunca foram traduzidos para outras línguas, não explorando assim o mercado internacional, embora fosse um desejo do autor. 


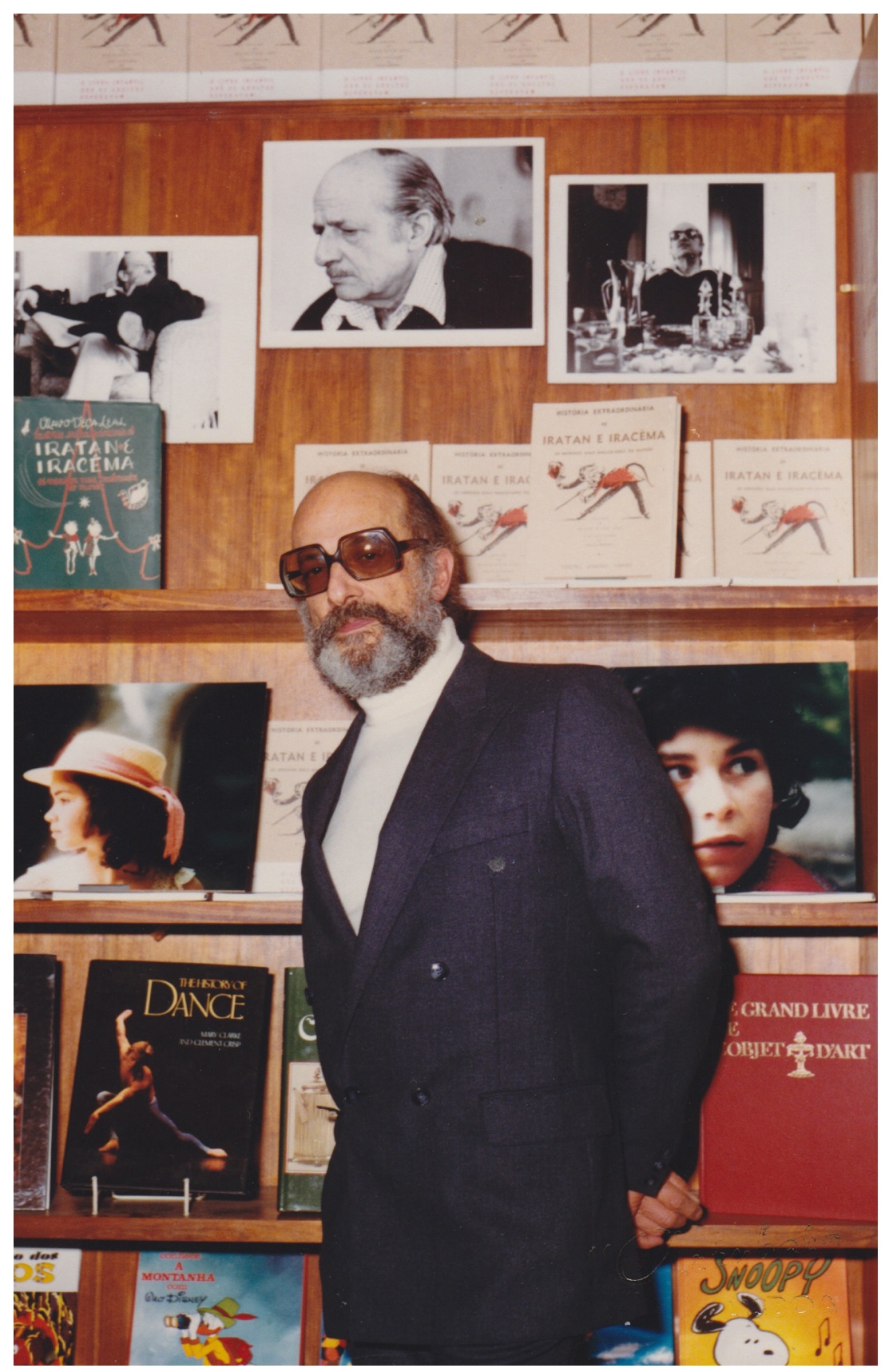

Figura 108. Fotografia de Paulo-Guilherme 
4.10.1 La ficción y la poesía / Ficção e poesia

Em 1995 PG edita, pela Bertrand Editora, o livro As Setes Portas de Arsenise. As Setes Portas de Arsenise não é autobiográfico nem documental, têm recordações da infância, da juventude e uma fantasia excêntrica. Neste livro PG junta as coisas que são e que não são, incluindo as personagens (ora podem ou não existir). A base do livro foi o facto real de Arsenise procurar PG porque o seu avô, Arsène Lupin, conhecera o avô Tomás D’ Eça Leal (avô de PG), em casa de Jacinto de Tormes, no 212 do Champs Elysées. Aqui PG revela o seu gosto pelo insólito mas um insólito com lógica, tratando de criar relações entre as partes. Neste romance que se desenrola, no Mosteiro dos Jerónimos, PG combina o suspense da descoberta de uma arca de esmeraldas, os Templários e a arquitectura sagrada e narra como os materiais primitivos da alquimia, o ouro e a prata, foram ocultados nos pilares que sustentam o Mosteiro. O segredo do Tesouro originário de Tomar, foi transmitido de rei para rei.

«Texto de difícil classificação, As Sete Portas de Arsenise oscila entre a simples crónica sequencial de factos, que o autor afirma, a aparência de ficção que a disfarça e o empolgamento de um romance de aventuras. Aventuras do espírito, que não deixam por isso de ser arriscadas. Não só nas feras do mato, ou nas brutalidades da guerra, se encontra o perigo. É por entre pistas dos segredos dos cavaleiros Templários, dos mistérios e ameaças das antigas tradições que se desenvolve a acção (...)» ${ }^{146}$

Ainda é cedo para ser tarde é outro livro de PG, em verso e prosa simultaneamente. Este livro foi editado pela Bertrand Editora e lançado no Centro Cultural de Belém, em 1997.

\footnotetext{
${ }^{146}$ FELGUEIRAS, Fernando. As Sete Portas de Arsenise, Bertrand Editora Lda.,1995, Aba da capa
} 

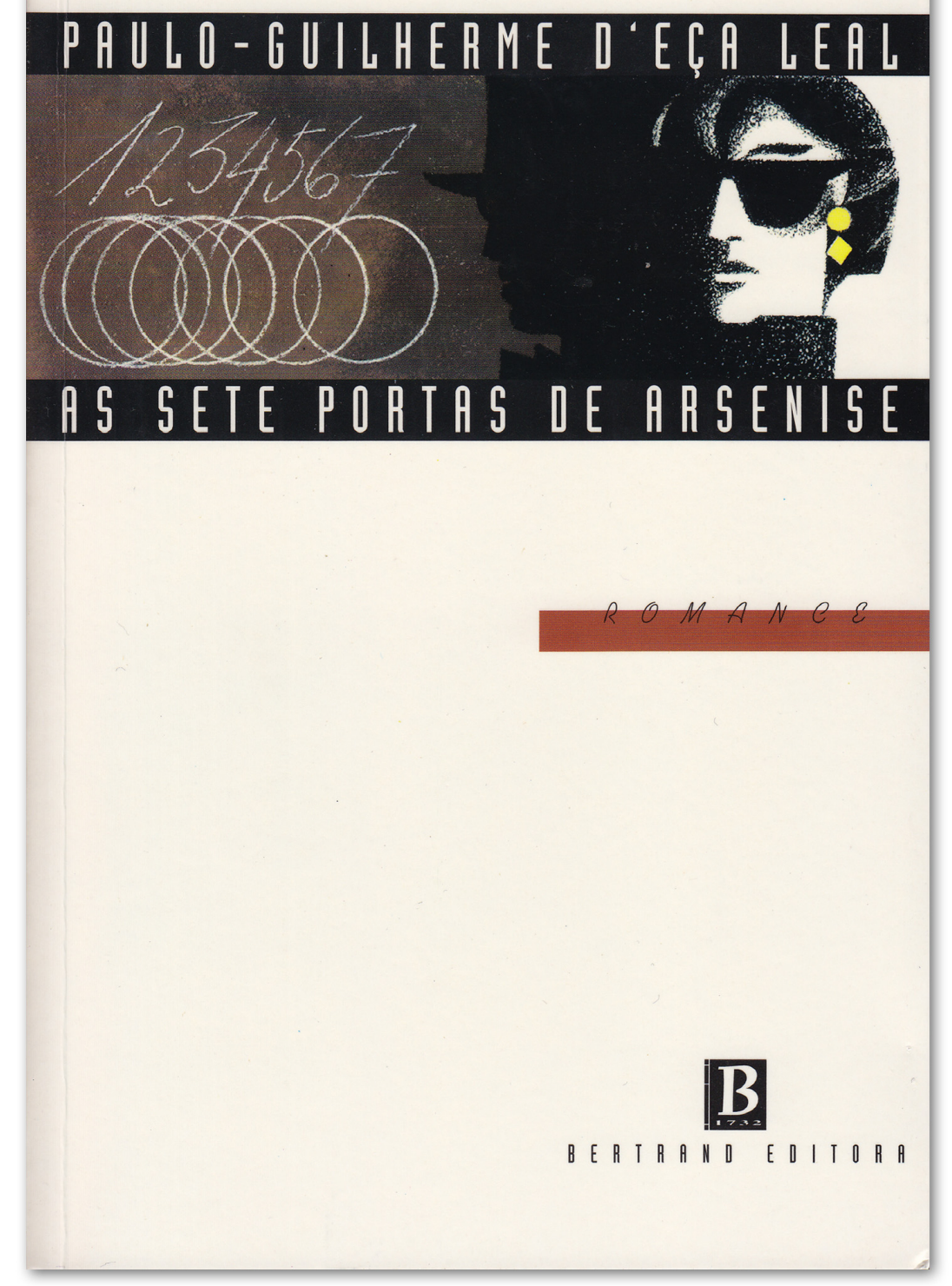

Figura 109. Capa do livro, As sete portas de Arsenise 
«Recordações verdadeiras e inventadas preenchem o último livro de Paulo-Guilherme, (...) a obra integra-se num percurso de outras invenções do autor,(...) "Viagem ao fundo de Lisboa, com incursões (habituais) em Paris, assim se poderá sintetizar o livro de PauloGuilherme. Nele se cruzam os seus amigos, e, também, os amigos do seu pai, Olavo D'Eça Leal, que se distribuíam dos anos 20 aos anos 60 entre o Marino da Arcada e a Brasileira do Chiado: Carlos Queirós e Bernardo Marques, Fernando Pessoa e Almada, Estrela Faria e Ofélia, José Gomes Ferreira e Ramada Curto, Eduardo Anahory e Jorge Matos Chaves, António Ferro e Fernanda de Castro, Tomaz Ribeiro Colaço e Henrique Galvão, Manuela Porto e Roberto de Araújo, Merícia de Lemos e António Duarte, Eduardo Viana e Mário Eloy...

Uma das singularidades reside na intemporalidade das situações referidas no texto. «Antes de ter nascido já eu era pintor e poeta e vivia na encosta para o Tejo, entre a Camões e São Bento, num atelier simpático que cheirava a tintas Lefranc, compradas em Paris, e a café na cafeteira.»

Ou então: «Quando morreu [Fernando Pessoa], eu tinha três anos, mas gosto de imaginar que de vez em quando ia ter com ele ao Martinho da Arcada, ao fim da tarde, e que o atazanava com perguntas incómodas, insolentes e indiscretas.»

O mesmo acontece em relação a Florbela Espanca, evocada num longo poema que reconstitui a presença da mulher, o poeta e a sua audácia, os traços vivos de uma época da sociedade e da cultura portuguesa. Mas, a par das ficções, Paulo-Guilherme concilia as associações, num jogo lúdico de sinestesias: «Tenho uma mesa enorme cheia de tubos misturados. São um bom retrato meu e das minha aventuras [...]. Uma quantidade razoável de amarelos cromo lembram-me, quando em Paris, no meu quartinho no Hotel Rolin, me esforçava por reproduzir a luz do sol de Cascais, que eu 


\section{PAULO-GUILHERME D’EÇA LEAL \\ AINDA É CEDO PARA SER TARDE}

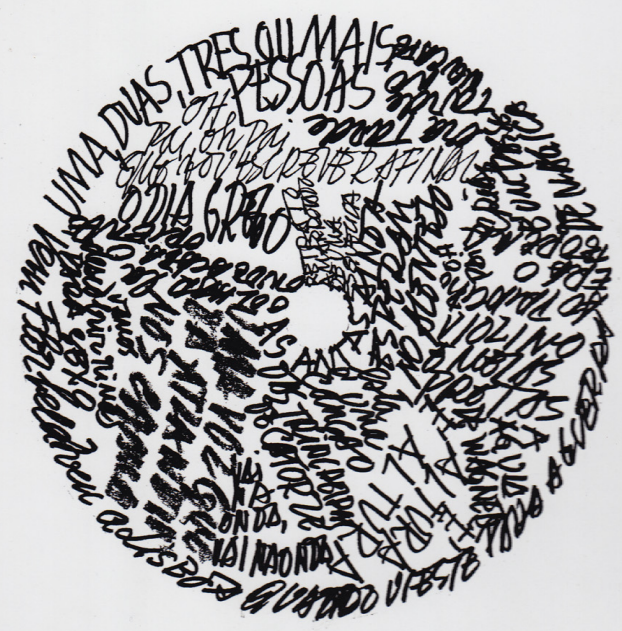

BERTRANDEDITORA

Figura 110. Capa do livro, Ainda é cedo para ser tarde 
deixara havia mais de um ano [...]. Vou abrir aquele azul cerúleo e cheirá-lo como se faz ao vinho. Lembra-me o Algarve: ela era morena e muito nova. E eu também. Talvez seja preferível o ocre: era forte e bonita e foi minha colega na escola de Belas Artes. » ${ }^{147}$

Ilustrado pelo próprio Paulo-Guilherme, este livro abre um mundo de um homem que «gostava de ser isto, aquilo e aqueloutro: físico, matemático, general, rei ou presidente de qualquer coisa, ou música. Gostava de ser tudo isto e o mais que fosse» ${ }^{148}$. Com a particularidade de tanto poder ser lido como ouvido pois faz-se acompanhar de um $\mathrm{CD}$, onde o autor declama as memórias com músicas de fundo. Restituiu-nos assim «um tempo em que havia mais tempo» e «as conversas tinham toda a vantagem em não darem coisa nenhuma, sobre o perigo de perderem a graça», nota o autor.

Em 1999 edita uma autobiografia poética, intitulado Depressa que o verso Foge. A apresentação desta obra, teve lugar no Hotel Avenida Palace, em Lisboa, e foi feita pelo pelo escritor e jornalista Fernando Dacosta. Usaram, também, da palavra Luís Miguel Rosa Dias e Mário Máximo, para se referirem aos múltiplos aspectos dos talentos de PG.

Editado pela Hugin, o livro revela, em sucessivos poemas, o que Paulo Guilherme pensa de si próprio e dos amigos e até dos que não quer como amigos. Neles inclui alguns protagonistas da cena política e partidária.

«(...)fez também reviver, mais uma vez, e com este livro no cenário belle époque do Avenida Palace, a memória de seu pai Olavo d'Eça Leal, que foi no seu tempo e na sua geração. - a que se segue à Fernando Pessoa e de Almada Negreiros -, outra figura fascinante da cultura que se repartiu em inúmeras, actividades e na boémia de

${ }^{147}$ VALDEMAR, António, "Lisboa e Paris em memorias de Paulo-Guilherme", Jornal Diário de Notícias, Arte e Multimédia, Dezembro 1997, p. 43

${ }^{148}$ D’EÇA LEAL, Paulo-Guilherme, Ainda é cedo para ser tarde, Bertrand Editora 1997, p.135 


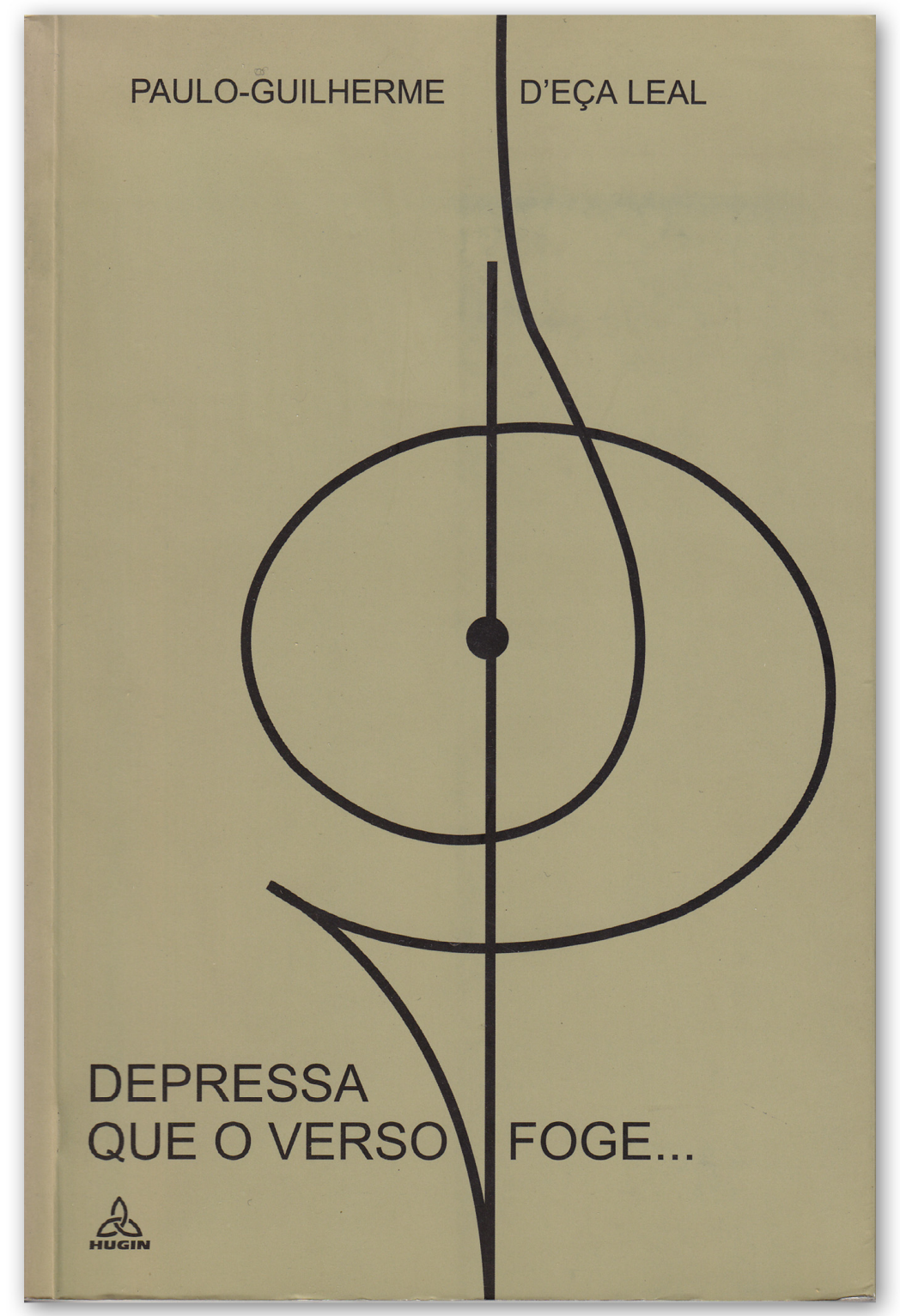

Figura 111. Capa do livro, Depressa que o verso foge... 
espírito das tertúlias do Chiado.

Estamos portanto em face de uma visão retrospectiva, com um toque futurista, da literatura e da arte da Lisboa dos anos 20 e 30, projectada numa geografia sentimental, até aos nossos dias.» ${ }^{149}$

Esta edição da Hugin tem também a particularidade de tanto poder ser lida como ouvida pois o livro Depressa que o verso Foge faz-se acompanhar por um $\mathrm{CD}$, onde o autor declama seus poemas com músicas de fundo. Aqui revela quem é e o que faz, como se verifica na nota de contra-capa:

«E aqui estou... com a lucidez de quem faz poemas mas não é poeta, de quem pinta mas não é pintor, de quem escreve mas não é escritor ${ }^{150}$. PG não assistiu ao lançamento por se encontrar hospitalizado.

149 VALDEMAR, António, "Paulo Guilherme retratado em versos dele próprio", Diário de Notícias, Artes \& Multimédia , 20 de Dezembro 1999

${ }^{150}$ D’EÇA LEAL, Paulo-Guilherme, Depressa que o verso foge, Hugin Editora 1999, contracapa 


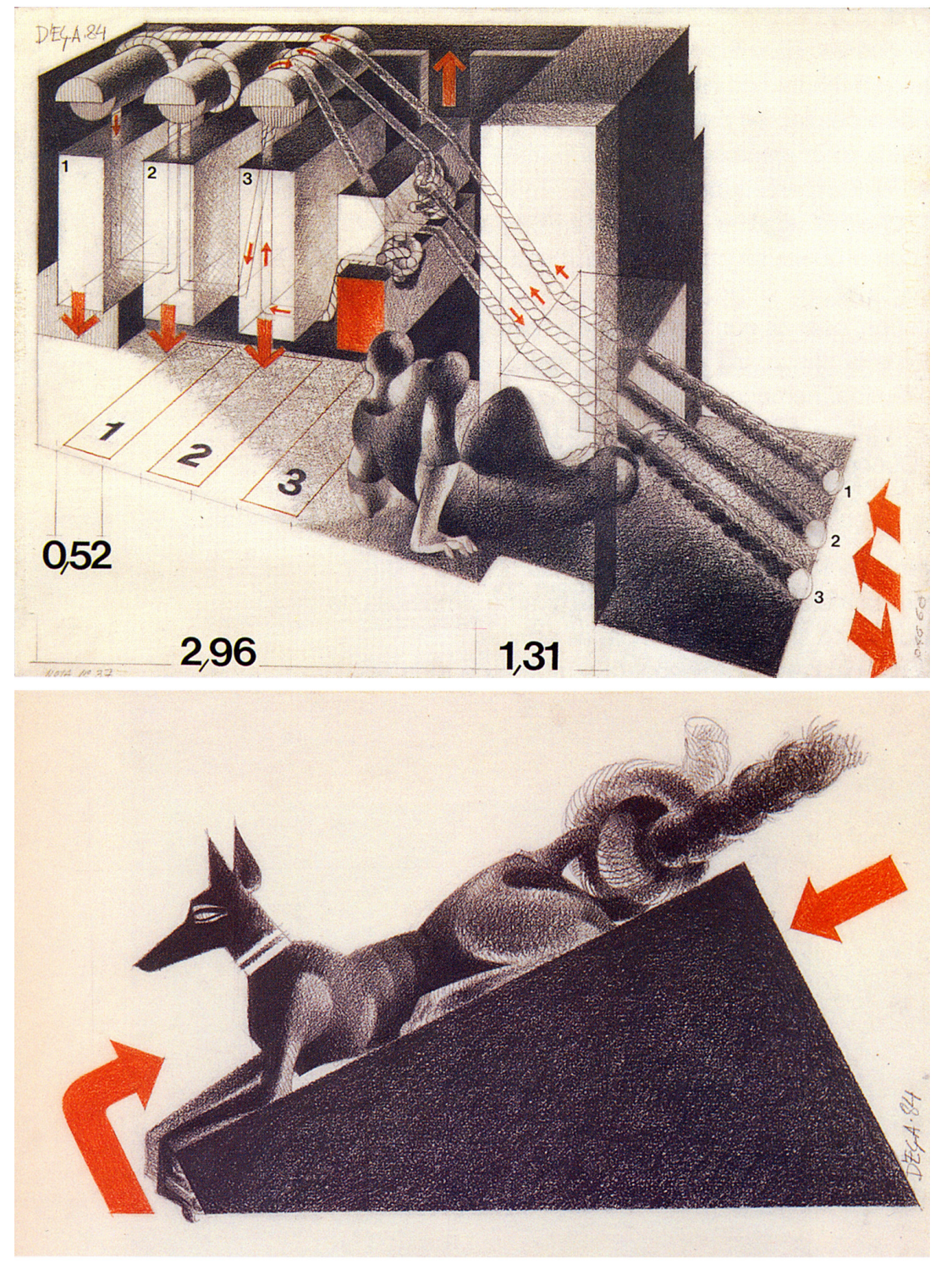

Figura 112. Desenhos do livro, O dilúvio de Quéops 


\subsubsection{Investigación / Investigação}

Ao fim de 16 anos de investigação, PG diz com toda a simplicidade que sabe como a grande pirâmide de Quéops foi construída. Resultante desta longa investigação é o livro O Dilúvio de Quéops, Novas Comunicações Sobre a Esquecida Ciência Egípcia, editado pela Livros Horizonte em 1993.

«Escrever sobre matérias da imprecisa zona de fronteira da ciência oficial e das ciências herméticas é já de si um risco a que poucos autores se atrevem. Se cumulativamente se opta por uma abordagem numa perspectiva da primeira, mas sem cariz de desprezo pelas "superstições ignaras", e se recusa a falsa facilidade tão em voga de teorias pseudo-herméticas com base em vagas filosofias orientais mal entendidas e dados de difícil ou impossível verificação da parte do leitor, as dificuldades, para o autor, crescem de forma assustadora. Se, finalmente, se aborda um tema sobre que centenas de livros já foram escritos, a empresa agiganta-se em dificuldade. Paulo-Guilherme, consciente de todos estes riscos e dificuldades abalançou-se a esta hercúlea tarefa, motivado por uma longa paixão (de 15 anos) pela matéria, e alicerçado numa das vias mais puras da investigação, a experimentação.

Das dificuldades que o autor teve, pode o leitor atento aperceber-se, quando perante uma afirmação que o seu espírito põe em causa, numa primeira análise, verificar passadas poucas linhas, que o autor vem refutar aquela dúvida, com reflexo apropriada. Também por este meio pode verificar a maturidade, no que respeita ao tema, atingida pelo autor.

As vias rigorosas da experimentação e da geometria não irão por certo agradar nem a gregos nem a troianos, sendo uns os 


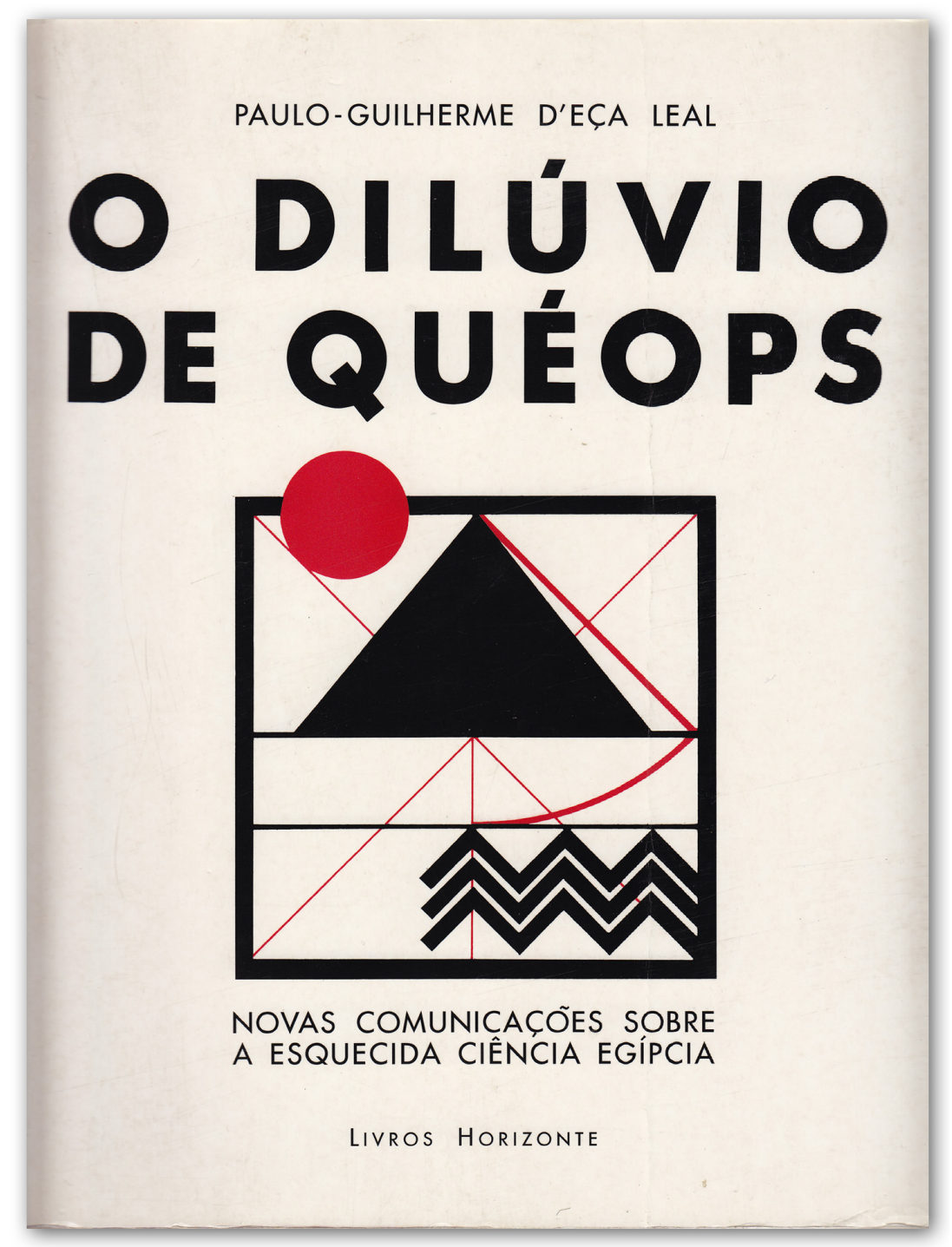

Figura 113. Capa do livro, O dilúvio de Quéops 
"académicos" que considera desprezível o tratamento destes temas, e os outros os que se confortam com uma fantasia sem regras nem bases. Uns e outros porém não poderão recusar a originalidade das muitas ideias apresentadas e da sua executabilidade prática. ${ }^{151}$

Teve início quando PG foi convidado, no Brasil, para escrever uma série de artigos sobre as sete maravilhas do Mundo. Começou pelo artigo da pirâmide de Quéops e ao fazer algumas pesquisas começou a desenvolver uma "tese". Isto foi em 1975 e a partir daí nunca mais largou a pirâmide de Quéops. Mais do que as facetas históricas, aflorou a geometria e a matemática da pirâmide.

A Pirâmide de Quéops é um enigma que sempre provocou a curiosidade de todos e sempre desafiou o conhecimento dos eruditos e dos estudiosos. Todos esforçados em descortinar o sentido e a formúla da misteriosa construção, usando os mais rigorosos instrumentos de medida. Porém PG acredita que a todos eles lhe faltou: pensar do mesmo modo que os construtores da pirâmide, um pensar à "egípcia".

$\ll$ O caminho da obra de Paulo-Guilherme tem a originalidade de não se apoiar em dados históricos e os seus cálculos matemáticos apenas servem de apoio para a sua teoria da razão da Pirâmide de Quéops ter sido construída oferecendo-nos um sumário de conhecimentos geométrico-astronómicos a ser redescobertos após um futuro dilúvio. (...) Depois de Almada creio que não se terá escrito nenhuma mítica geométrica como a que Paulo-Guilherme nos apresenta com a agravante de o herói da sua história criar e preservá-lo da mortalidade no previsto novo dilúvio.» ${ }^{152}$

Esta gigantesca construção, em toda a sua plenitude e em tudo o que ela encerra, o secreto saber da antiga ciência egípcia,

\footnotetext{
${ }^{151}$ GRAÇA, J. G. Charrua, Desdobrável de divulgação de palestra de Paulo-Guilherme D’Eça Leal, Calouste Gulbenkian, 1993

${ }^{152}$ PORTUGAL, José Blanc de, Desdobrável de divulgação de palestra de Paulo-Guilherme D’Eça Leal, Calouste Gulbenkian, 1993
} 


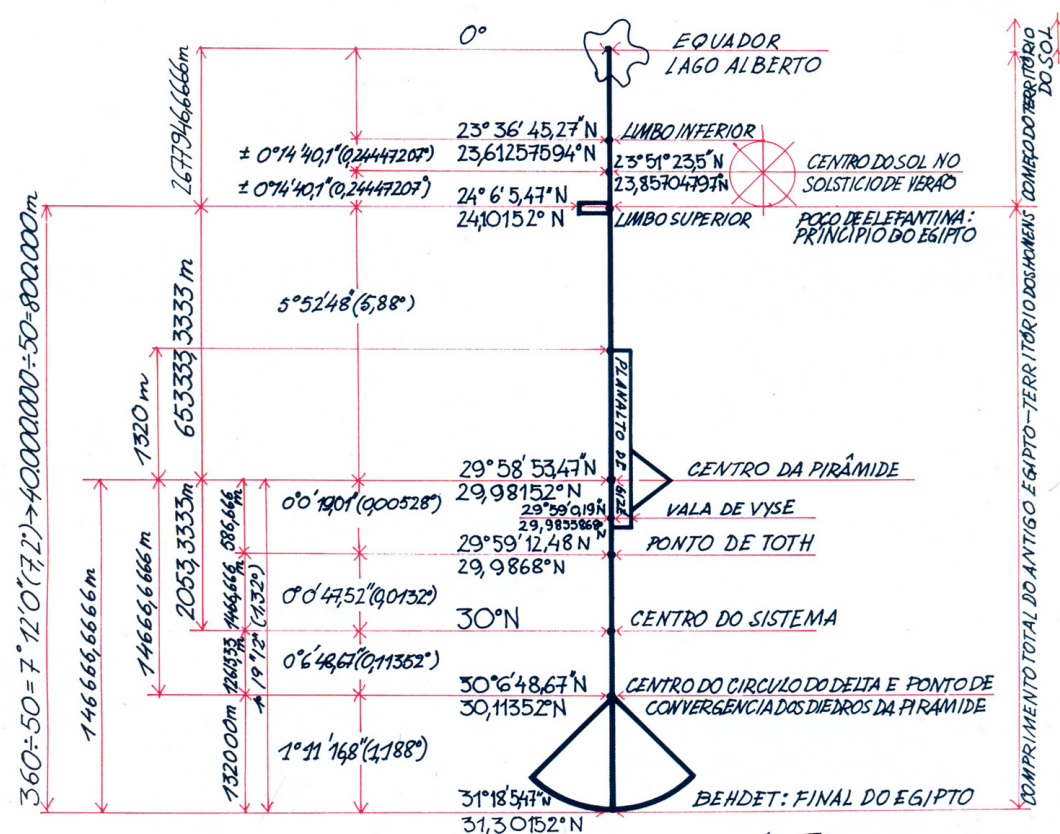

TODAS AS MEDIDAS CONSTANTES DESSTE GRA'FICO SAOO DIVISIVEIS POR 4,4444/m= $\left.=\frac{22}{7} \times \sqrt{2}\right)$ OCOM EXCEPCAOO DA

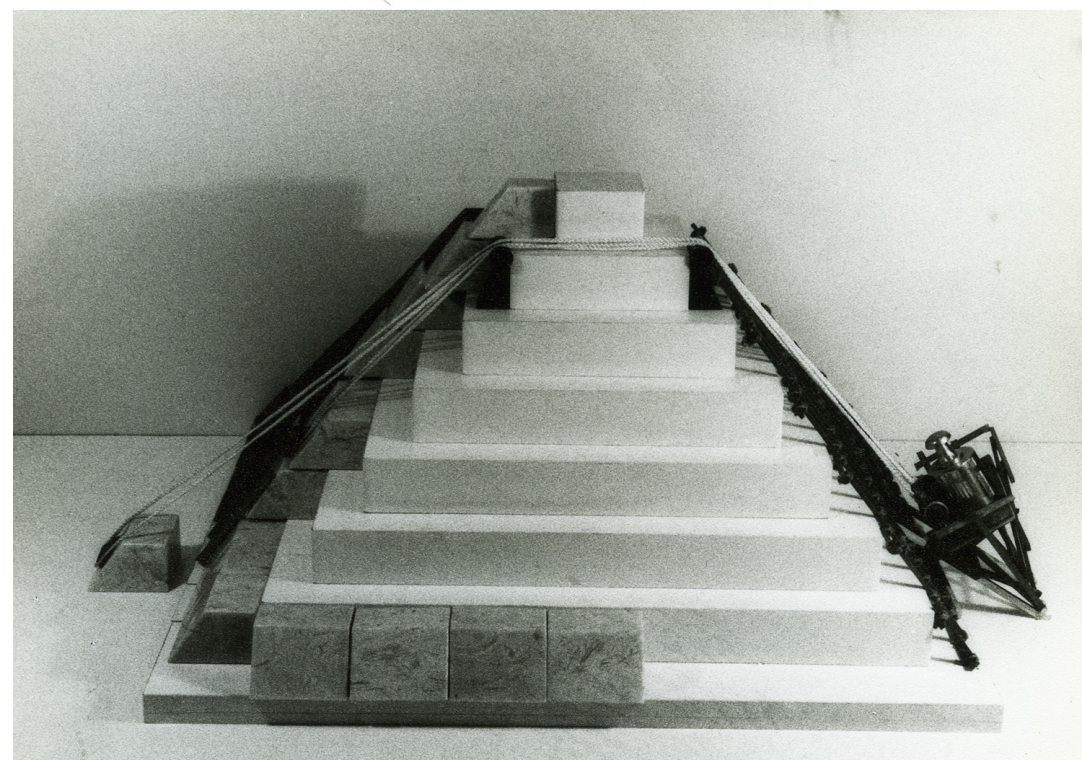

Figura 114. Cálculos do estudo da pirâmide 
ocultada pelos enigmáticos religiosos, torna cada vez mais importantes as análises, que porventura, quisá, permitirá recuperarmos conhecimentos perdidos e uma nova consciência daquilo que nos envolve. PG partiu do princípio que os egípcios não faziam nada por acaso. Tenta resolver os problemas construtivos, matemáticos que a pirâmide contém, que por vezes têm uma simplicidade desarmante. Os princípios que regeram as soluções de PG foram de uma simplicidade liceal.

A pirâmide de Quéops é uma máquina que foi um dia construída para que um homem, um único homem, pudesse sobreviver a um hipotético dilúvio. A história fictícia que PG engendrou serve apenas para que os leitores mais facilmente possam seguir o funcionamento que encontrou na Pirâmide de Quéops. Um livro que explique a construção da grande pirâmide ao comum dos mortais. Ciência que vai de construção em construção, atravessando as épocas, transmitida de mestre para mestre que a certa altura o saber perdeu-se. PG defende que homens como Afonso Domingues, arquitecto da Batalha, teriam que ser possuidores desse conhecimento, para conseguir inventar toda aquela geometria.

«(...) verificado a sua extrema preocupação em ver por dentro o pensamento matemático que a gerou, não se perdendo no labirinto por vezes confuso das meditações, hipóteses e especulações que uma pletora de investigadores e curiosos tem abundantemente produzido, mas procurando com persistente entusiasmo estabelecer o máximo de correspondências e concordâncias que possam ser extraídas das variadas dimensões que se encontram na prodigiosa Construção, as quais se fundamentam nos números 11 e 14, por sua vez intimamente relacionados com a razão 22/7, o Pi egípcio, também conhecido por Pi de Arquimedes (mas Arquimedes veio dos 

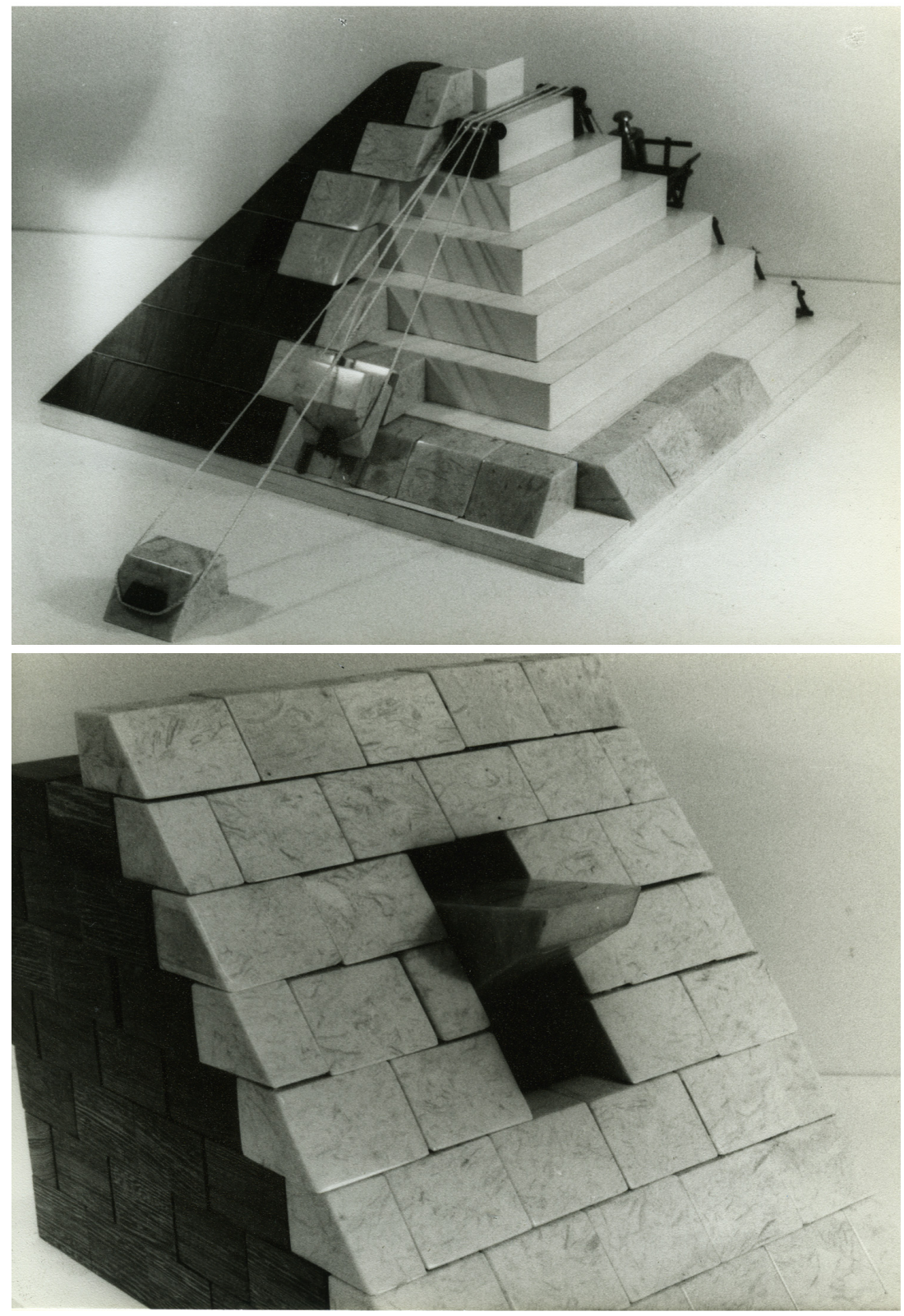

Figura 115. Conjunto de fotografias da maqueta da piramide 
egípcios...) $\gg^{153}$

«Não esqueçamos que a sua matemática e a sua tecnologia iam muito além do que é geralmente admitido pelos piramidologistas mais conservadores. E outra coisa não seria de pensar acerca desses antigos sábios que, para dar um exemplo simples, conseguiram implantar perfeitamente paralelos entre si os dois lados basais das duas maiores pirâmides, a de Khéops e a de Kéfren, separadas por mais de $1 \mathrm{~km}$, e orientá-los rigorosamente a Norte com uma exactidão que iguala ou mesmo excede a orientação do Observatório de Paris, realizada milhares de anos mais tarde com aperfeiçoados instrumentos modernos.

Este sistema matemático mostra bem a sua coerência quando nos dá, por vezes, resultados que constituem agradáveis surpresas.

Conto um episódio curioso: recentemente, estava conversando com o Paulo-Guilherme sobre as medidas da Grande Pirâmide e a dada altura perguntei-lhe qual seria a largura original da plataforma superior que lhe truncava o vértice e na qual seria se erigia o piramidon, hoje ambos desaparecidos. Segundo os seus cálculos respondeu-me - essa largura teria de ser 2,8221574 metros (é indiferente dar medidas em metros ou em côvados reais egípcios, pois o côvado e metro são comensuráveis com alta precisão: 1 côvado $=11 / 21$ metros. Comensurabilidade que, aliás, também dá que pensar...). Ocorreu-me, então, multiplicar esse número por 11, um dos números básicos da pirâmide, tendo obtido o valor de 31, 943731, o qual me pareceu imediatamente aparentar-se com o cubo de Pi. Tirei-lhe a raiz cúbica e surgiu-nos como resultado exactamente o famoso Pi egípcio: 22/7. Assim, o sistema continuava a funcionar com impecável rigor! ${ }^{154}$

Numa necessária condensação dos vários assuntos e a indispensável

${ }^{153}$ CALVET, Carlos, "O sábio olhar de Khéops", Catálogo de exposição, Paulo-Guilherme D’Eça Leal D'etecetera e tal 2000, Câmara Municipal de Lisboa, 28 de Janeiro de 1993, p. 310

${ }^{154}$ Ibidem, p. 311 
leveza do seu tratamento para seu entendimento, PG disponibiliza ao público uma síntese de um longo e profundo estudo de todos os dados conhecidos sobre a Pirâmide de Quéops e apresenta soluções lógicas e absolutamente inéditas. O fascínio da sua investigação não é pequeno, pois organiza comunicações publicas para dissecar sobre o pensamento dos sábios sacerdotes que construíram a grande pirâmide do Egipto. Fê-lo em duas conferencias proferidas, uma na Gulbenkian onde o anfiteatro para 140 pessoas recebeu cerca de 400 e na Missão de Macau onde o furor foi semelhante.

Foi autor do livro O segredo o poder e a chave da Hugin editora, em 2003. O fascínio pelos painéis de Nuno Gonçalves surgira desde infância alimentado por conversas que ouvia a seu pai com os amigos. Este livro debruça-se sobre os célebres painéis de Nuno Gonçalves, pintura enigmática, intrigante já estudada e interpretada de várias maneiras e por várias pessoas, entre os quais Almada Negreiros. Contudo PG, experimenta um novo caminho, tenta uma nova interpretação, de um ponto de vista matemático, geométrico aliado com intuição.

«Escrever sobre matérias da imprecisa zona de fronteira da ciência oficial e das ciências herméticas é já de si um risco a que poucos autores se atrevem. Se cumulativamente se opta por uma abordagem numa perspectiva da primeira, mas sem cariz de desprezo pelas "superstições ignaras", e se recusa a falsa facilidade tão vaga de teorias pseudo-herméticas com base em vagas filosofias orientais mal entendidas e dados de difícil ou impossível verificação da parte do leitor, as dificuldades, para o autor, crescem de forma assustadora.

Se, finalmente, se aborda um tema sobre que centenas de livros já foram escritos, a empresa agiganta-se em dificuldades.

Paulo-Guilherme, consciente de todos estes riscos e dificuldade, abalançou-se a esta hercúlea tarefa, motivado por uma longa paixão 
(de 15 anos) pela matérias, e alicerçado numa das vias mais puras da investigação, a experimentação.

Das dificuldades que o autor teve pode o leitor atento aperceber-se, quanto perante uma afirmação que o seu espírito pões em causa, numa primeira análise, verificar passadas poucas linhas, que o autor vem refutar aquela dúvida, com reflexão apropriada. Também por este meio pode verificar a maturidade, no que respeita ao tema, atingido pelo autor.

As vias rigorosas da experimentação e da geometria não irão por certo agradar nem a Gregos nem a Troianos sendo uns os académicos que consideram desprezível o tratamento deste tema, e outros os que se confrontam com uma fantasia sem regras nem bases. Uns e outros porém não poderão recusar a originalidade das muitas ideias apresentadas e da sua exacutabilidade prática.» ${ }^{155}$

PG relaciona aqui os painéis de Nuno Gonçalves com uma obra igualmente estanque, a Igreja e Mosteiro de Santa Maria da Vitória, a "Batalha". Resultante de uma proposição única que as interliga, as completa, as define e acima de tudo que as explica de forma assertiva e detalhada.

«Para mim, os painéis de Nuno Gonçalves são um retrato dos intervenientes na batalha de Alfarrobeira. Tinha de haver uma razão para ligar na pintura 60 personagens. (...) Conheço a sua geometria, a sua integração arquitectónica, o seu tamanho e o local para onde estavam destinados: a Batalha, mas não no sítio proposto por Almada Negreiros." 156

"Paulo-Guilherme (...) mediu cada centímetro do monumento e analisou ao pormenor os mais íntimos detalhes. A análise exaustiva

\footnotetext{
155 GRAÇA, José Gabriel Charrua Graça, "O prefácio de um homem das ciências aplicadas", revista Olá!, p.11

${ }^{156}$ GASTÃO, Ana Marques, “Entrevista Paulo - Guilherme D’ Eça Leal: Aplauso ou café da manhã”, Artes \& Multimédia, 2003, p.6
} 


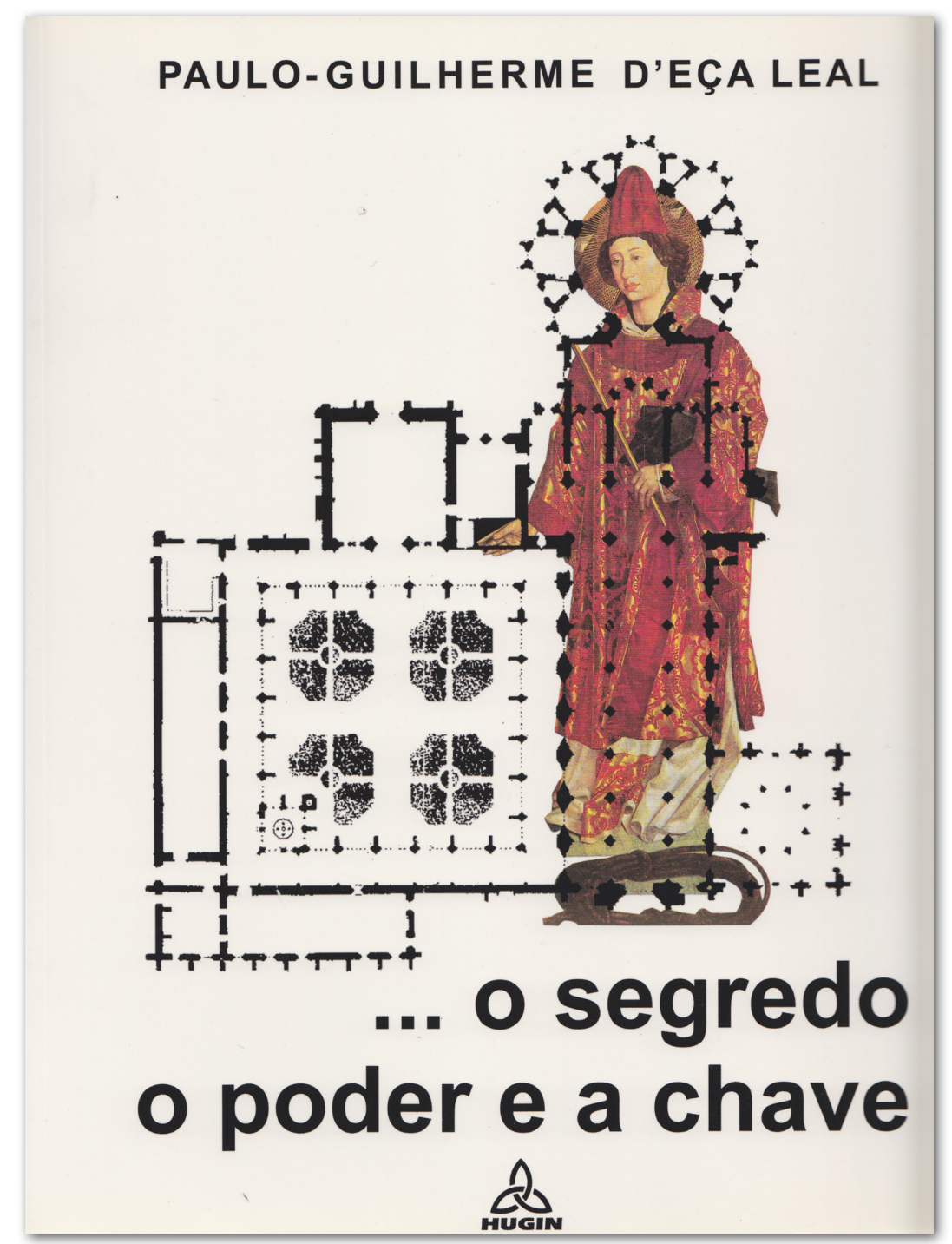

Figura 116. Capa do livro, O segredo, o poder e a chave 
dos painéis e do mosteiro levaram Paulo-Guilherme a concluir que a obra de arte foi pintada numa parede da Batalha. Descobriu que o reflexo desenhado no capacete de um dos cavaleiros era provocado nada mais nada menos do que por uma janela do próprio mosteiro. "Há ali uma vara numa certa posição, com uma certa dimensão. E isso é geometria. É um recado que, com uma formula matemática, me leva à planta da Batalha.

Foram essas análises da geometria que levaram Paulo-Guilherme a desconfiar da existência de uma cripta debaixo de um conjunto de pilares das capelas cabeceiras do mosteiro. Mas nem sempre é fácil convencer os outros de teorias tão pouco ortodoxas. Levou algum tempo a encontrar quem pagasse o estudo do Laboratório Nacional de Engenharia Civil para averiguar se havia ou não ali uma cavidade. (...) Os resultados das ressonâncias magnéticas ao edifício comprovaram que, naquele local, está um buraco com três metros de altura e cinco de largo.» ${ }^{157}$

PG sentiu imensas dificuldades em conseguir autorizações para concluir esta investigação contudo foi revitalizante a descoberta de uma cripta no subsolo do Mosteiro da Batalha que, por si só, é digna de nota. Interessado, não num possível tesouro dos Templários, mas na possibilidade de consultar eventuais documentos que lá pudessem estar, respostas para toda aquela arquitectura maravilhosa que encontrou. Porém, nem mesmo com uma descoberta a este nível, esta investigação foi facilitada. Não obteve mais autorizações enterrando assim de novo o mistério.

«Não acredito que esteja lá o ouro dos Templários - mas se estiver tanto melhor; o que me interessa é consultar os eventuais documentos que lá possam encontrar e que poderão ser a resposta à

${ }^{157}$ LEAL, Paulo Guilherme D'Eça, cit in GARCIA,RITA. “O caçador de Templários”, Revista Focus, ${ }^{\circ} 278,9$ a 15/2/2005, p.78 
arquitectura maravilhosa que aqui encontrei.» ${ }^{158}$

Esta investigação ocupou 8 anos de estudo - A descoberta da chave geométrica e do recado que contem os painéis de Nuno Gonçalves que culmina num livro e também em diversas palestras públicas.

Após uma palestra no próprio lançamento do livro e posteriores contactos com PG, o jornalista Frederico Valarinho comenta «Descobri que ele acreditava naquilo que escrevia e passei eu próprio, céptico jornalista de ideologias perdidas em incontáveis artigos escritos a metro, a acreditar que poderia haver um fundo de verdade naquilo que Paulo-Guilherme defendia.

Visitei a Batalha, para ver com os meus olhos se seria possível que ele tivesse razão. Não medi ao milímetro, como ele fez. Não tive conhecimentos de pintura e arquitectura que ele teve para poder analisar profundamente um dos mais importantes monumentos religiosos portugueses. Verifiquei, contudo, que muito daquilo que ele tinha escrito era verdade e isso despertou-me a curiosidade. $\mathrm{E}$ esse é um dos grandes méritos de Paulo-Guilherme : desperta a curiosidade.» ${ }^{159}$

${ }^{158}$ LEAL, Paulo Guilherme D’Eça, cit in GARCIA,RITA. "O caçador de Templários", Revista Focus, n' $329 / 2006$, p.42

${ }^{159}$ VALARINHO, Frederico, “O que esconde a Batalha?”, Revista Focus, n³29/2006, pág.42 
4.11 Otros trabajos / Outros trabalhos

Foi fotografo de algumas reportagens internacionais e dedicou-se intensamente à fotografia publicitária, podendo destacar-se as extensas campanhas: Sacor - Companhia Portuguesa de Petróleos e Woolmark.

Em colaboração com a INCM, PG fez parte dos escultores que participaram na série Descobrimentos Portugueses iniciada em 1987.

$\mathrm{Na}$ I Série dedicada às Navegações e Descobrimentos da Costa Ocidental Africana, colaborou com a moeda dedicada a Diogo Cão. Em 1990, na II Série cujo tema era as Navegações e Descobrimentos dos Arquipélagos Atlânticos, participou com a moeda Navegação Astronómica. Na III Série de 1991, dedicada à Descoberta da América, criou a moeda Navegações para Ocidente. Após um interregno voltou a colaborar com a INCM com as moedas Milénio do Atlântico em 1999 e em 2000 com o Centenário da morte de Eça de Queirós.

Na medalhística a INCM produziu três medalhas criadas pelo artista, a comemorativa do Centenário do Nascimento de João Gaspar Simões, a dos 850 Anos da Batalha de Ourique e Almada Negreiros. 

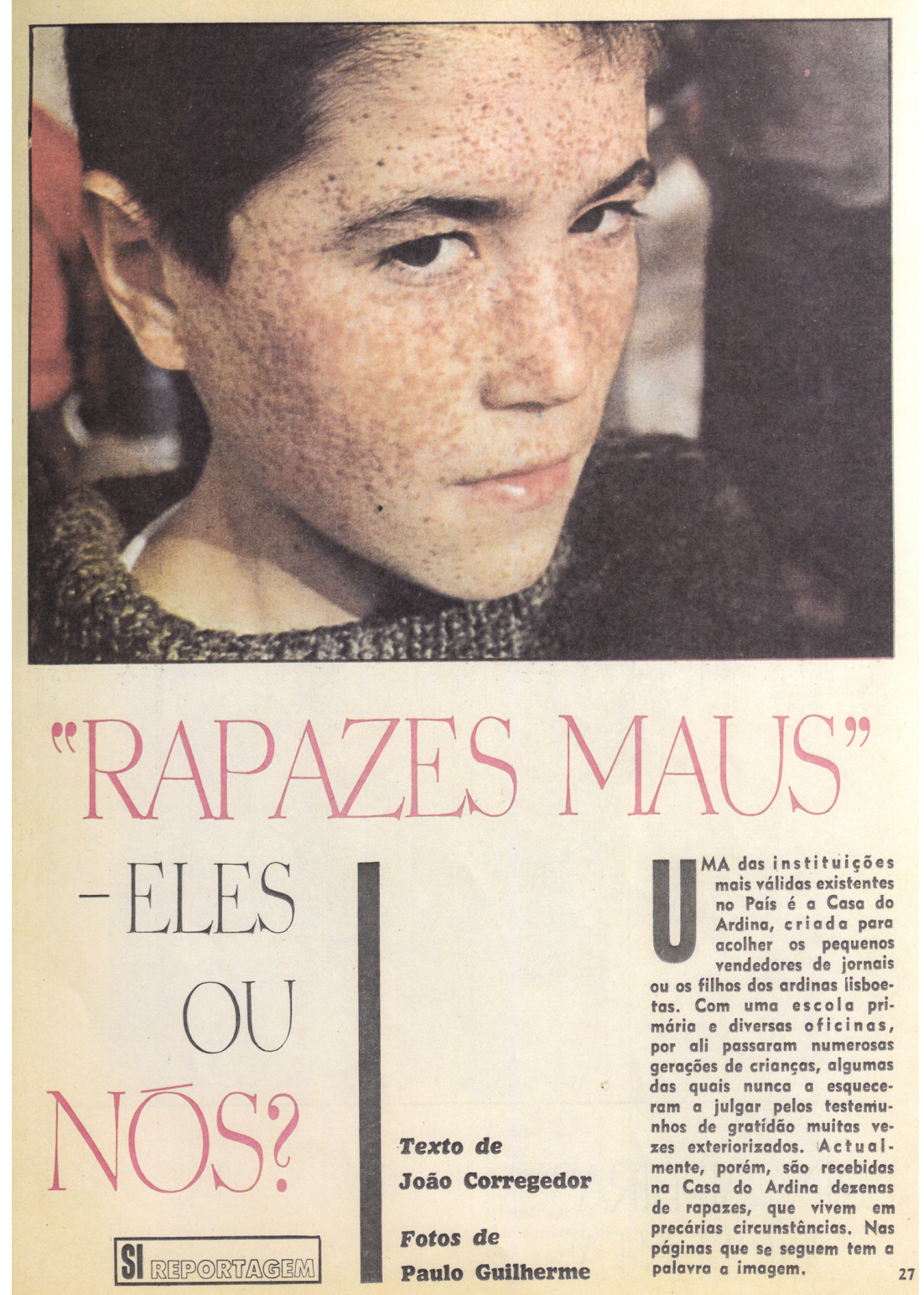

Figura 117. Página do Século Ilustrado, n¹626, 1969 

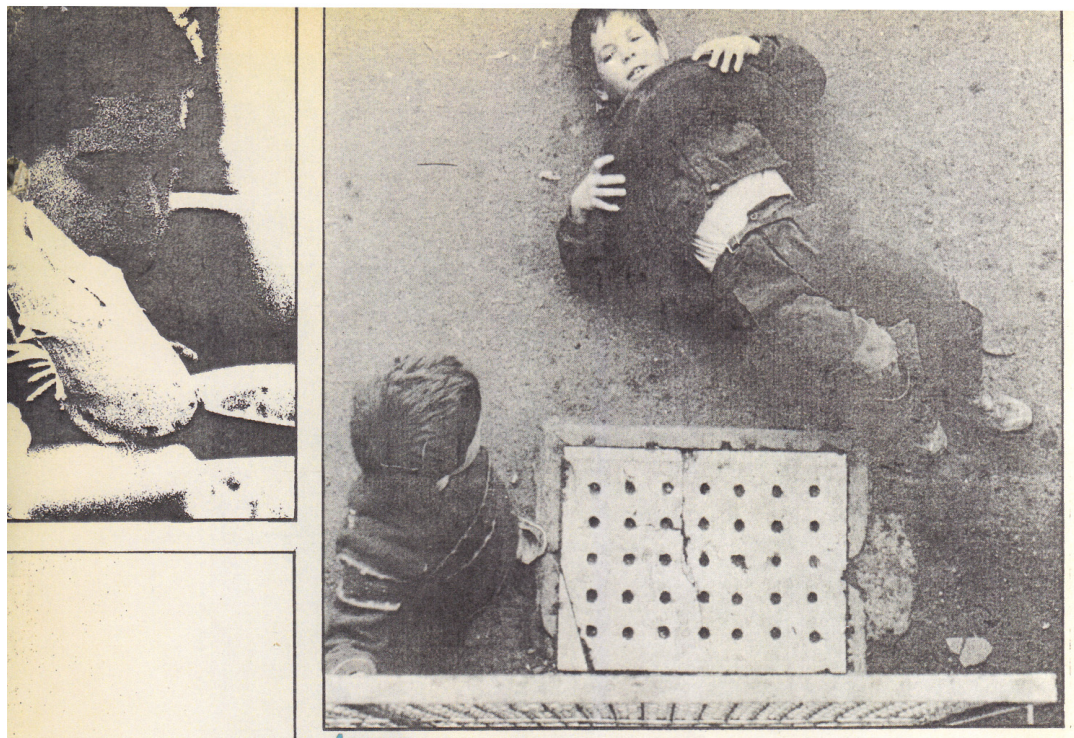

\section{Apesul}

das dificuldades

de toda $\boldsymbol{a}$ ordem

que

sobrecarregam

a obra levada

a efelto ma Casa

do Ardinat, navo tie ai

drivida due que,

pouco e pouco,

ali acolhidos

comecam a sentin

mais alegria

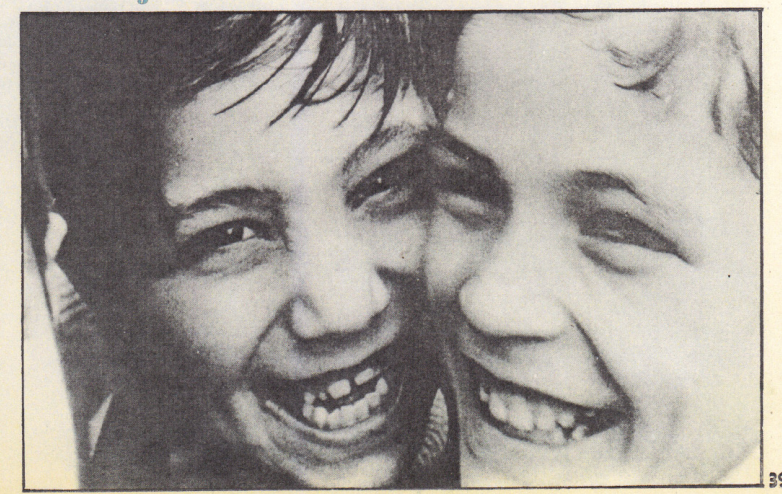

Figura 118. Página do Século Ilustrado, n¹626, 1969 


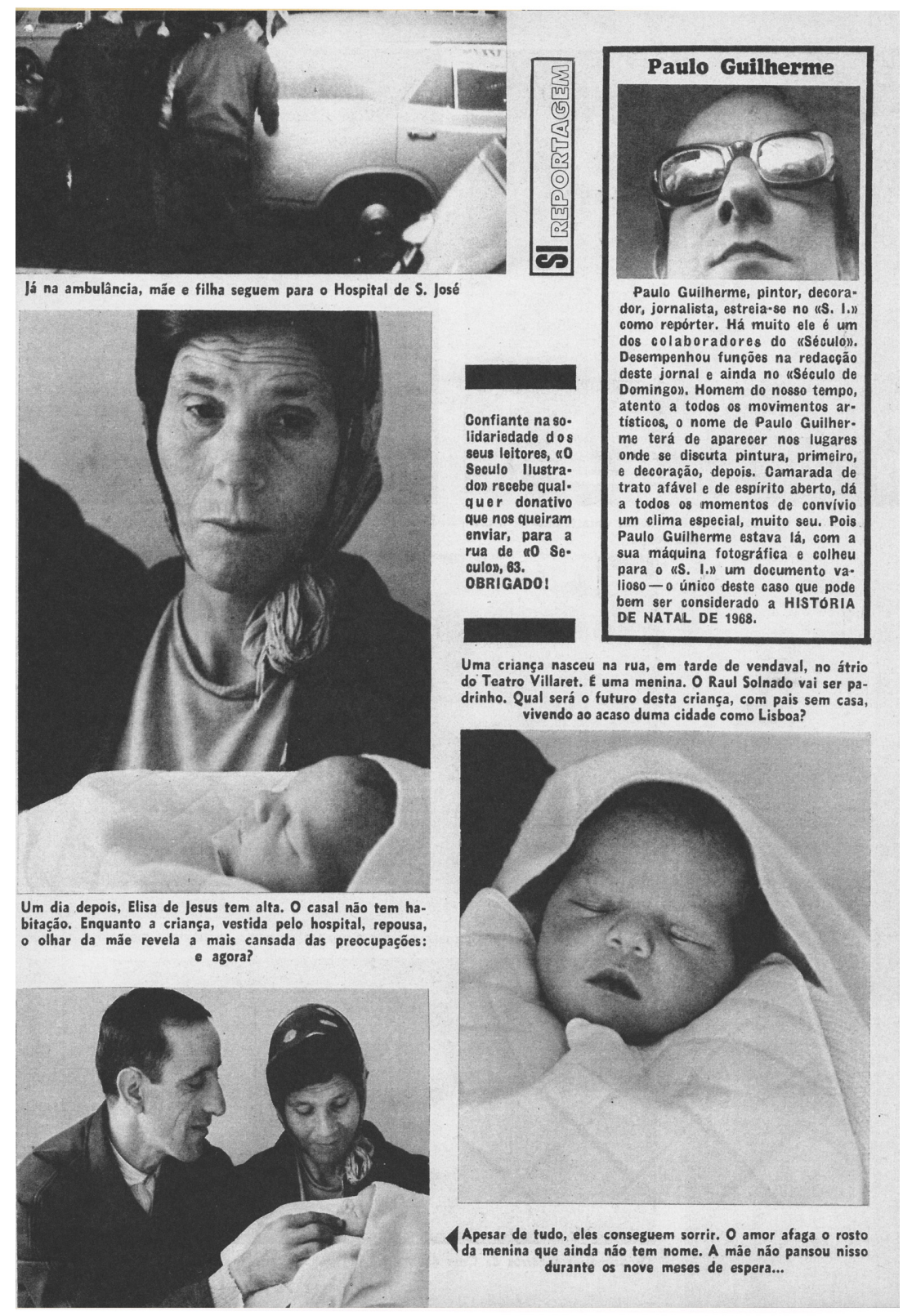

Figura 119. Página do Século Ilustrado, n¹617, 1968 
4.11.1 Numismática / Numismática

Na sua colaboração com a INCM, PG fez parte dos escultores que participaram na série Descobrimentos Portugueses iniciada em 1987. Na I Série dedicada às Navegações e Descobrimentos da Costa Ocidental Africana, colaborou com a moeda dedicada a Diogo Cão, 1988. Em 1990, na II Série cujo tema era as Navegações e Descobrimentos dos Arquipélagos Atlânticos, participou com a moeda Navegação Astronómica, 1990. Na III

Série de 1991, dedicada à Descoberta da América, criou a moeda Navegações para Ocidente. Elabora moedas Milénio do Atlântico em 1999, e em 2000 a do Centenário da morte de Eça de Queirós.

Na medalhística a INCM produziu três medalhas criadas pelo artista, a comemorativa do Centenário do Nascimento de João Gaspar Simões 2003, a dos 850 Anos da Batalha de Ourique e Almada Negreiros, 1993.

No anverso da moeda I Série dos Descobrimentos, Navegações e Descobrimentos da Costa Ocidental Africana Diogo Cão, 1987 tem uma cercadura dentada interrompida pela numeração "22", "13" e "6". E junto a esta, circularmente, exibe as inscrições "República Portuguesa", "100 Esc." e o desenho de três cruzes dos Descobrimentos, duas juntas separando "República" de "100" e uma outra isolada que separa "Esc." de "Portuguesa”. Tem representado um astrolábio formado por um circulo e um ponteiro colocado ao centro da moeda. No canto superior direito a presenta o Escudo Nacional, que sobrepõe parte do astrolabo a partir do centro e junto ao circulo do astrolabo a inscrição da data "1987". Evidencia um campo quadripartido, nos quadrantes inferior equerdo e inferior direito são visíveis três linhas, em cada um que 

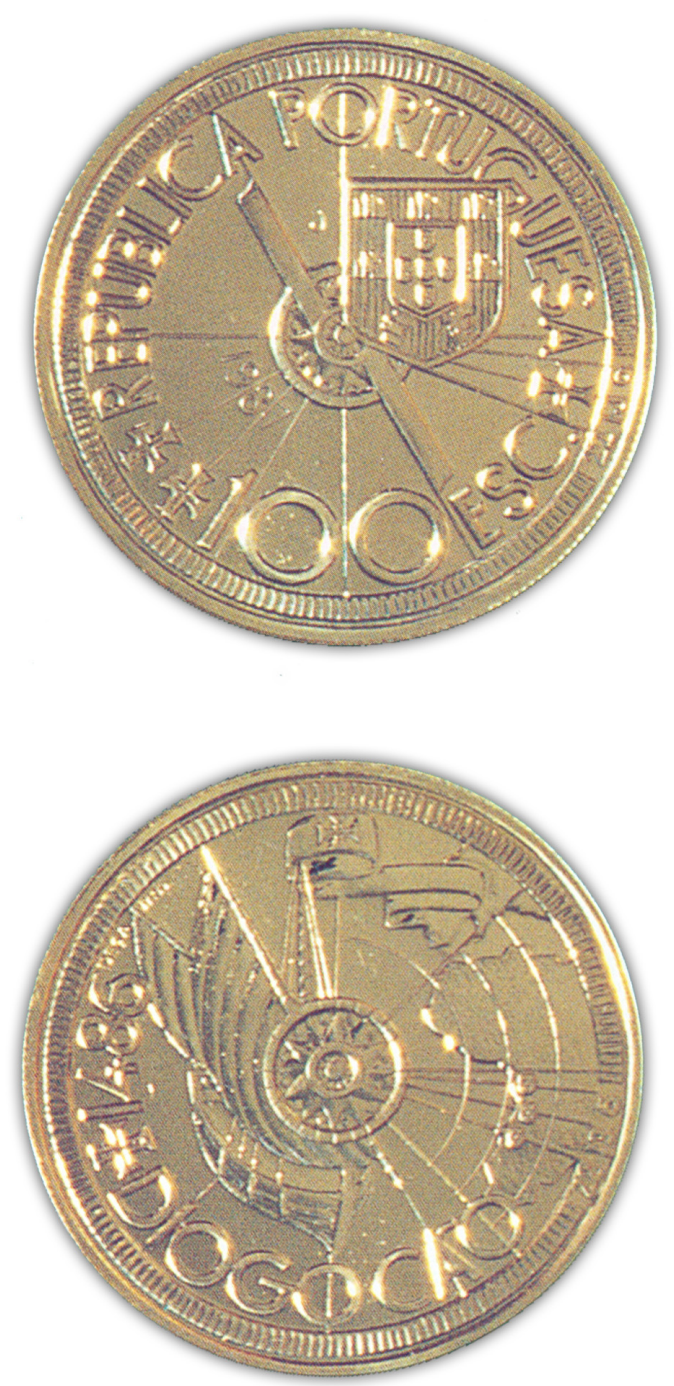

Figura 120. Moeda Diogo Cão 
geometricamente correspondem ao raio em representação do mapa cartográfico. Figura também uma linha oblíqua correspondente ao diâmetro.

No verso a mesma cercadura dentada, interrompida pela mesma inscrição numérica, "22", "13" e "6". Ao centro um circulo de tamanho igual ao do astrolabo (anverso), com o desenho da rosa dos ventos, que se sobrepõe a uma caravela, com uma grande bandeira que contem o desenho da cruz dos Descobrimentos. Circularmente mostra as inscrições "Diogo Cão" e a data "1486", separadas pela cruz dos Descobrimentos. É visível o mapa do continente Africano e várias linhas que geometricamente são diâmetros, raios e circunferências concêntricas em representação do mapa cartográfico.

Metal: Cupro-Ní-quel

Composição: Cu 750 - Ni 250

Peso: $16,5 \mathrm{gr}$

Diâmetro: $33,5 \mathrm{~mm}$

Bordo: Serrilhado

Autor/Escultor: Paulo Guilherme

No âmbito da Navegação Astronómica (II Série dos Descobrimentos, Navegações e Descobrimentos dos Arquipélagos Atlânticos - Navegação Astronómica, 1990) cuja ciência foi usada para fins de orientação, proporcionando ao navegador a posição exacta das estrelas como se estivessem fixas no céu, que com conhecimento da altura das estrelas em relação ao horizonte, o navegador pode ter a percepção, de forma estimada, da sua posição. Tal conhecimento permite navegar em função da longitude e da latitude e inferir o desenvolvimento natural da arte de bem navegar, tal como os feitos das "Descobertas" em tal área. Daí toda a justificativa para trazer à 

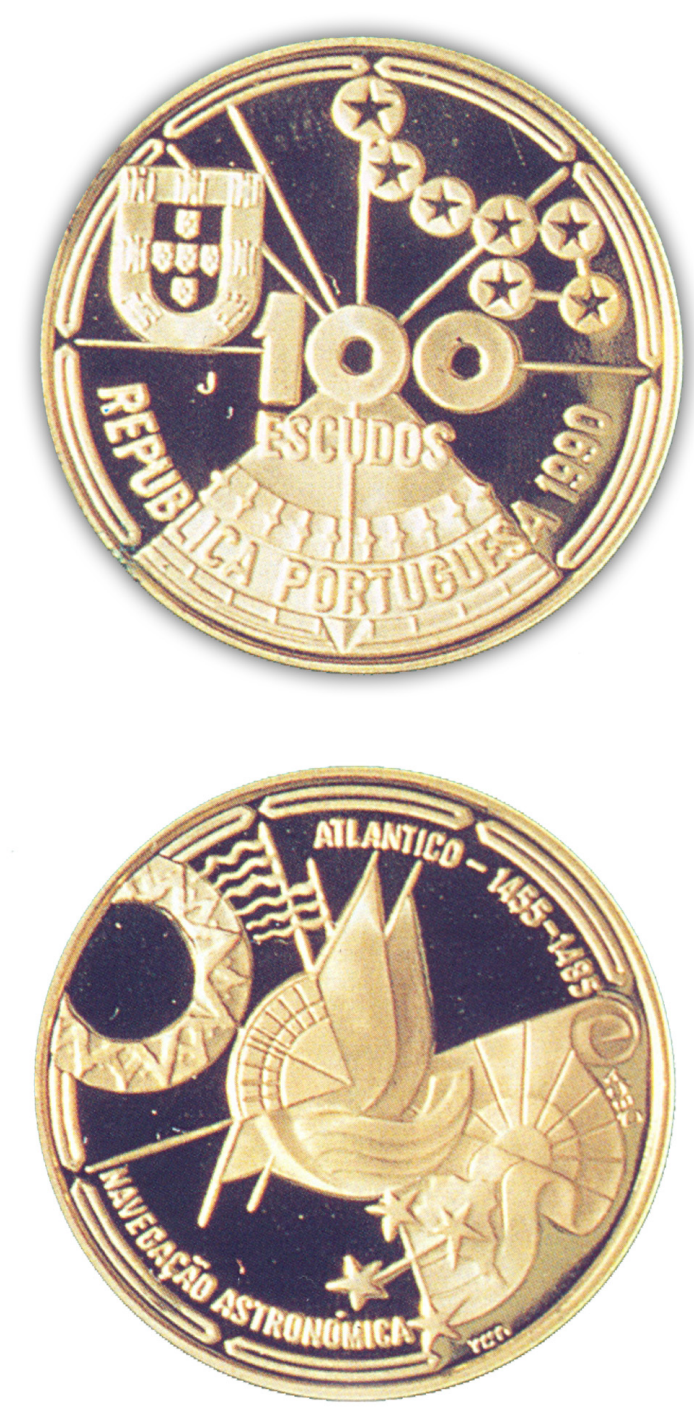

Figura 121. Moeda Navegação Astronómica 
memória as varolorosas rotas marítimas através da recordação numismartica.

A moeda série II dos Descobrimentos Portugueses Milénio do Atlântico, 1990 expõe no centro da face o valor de "100 escudos”, coincidente com o centro dum campo quadripartido. Na parte superior direita figura a "constelação lusa maior" com a "Estrela Polar" e na parte superior esquerda mostra o escudo das armas nacionais. Na parte inferior diametralmente oposta ao escudo e à estrela, exibe-se a legenda circular "República Portuguesa", 1990, inscrita parcialmente sobre o desenho representativo do quadrante náutico a toda a volta apenas interrompida por este desenho contém justaposta ao rebordo, uma orla de elementos de escala cartográfica.

No verso inclui: concentricamente a um campo tripartido uma caravela latina. Na parte inferior a inscrição "Navegação Astronómica" e na parte superior a inscrição "Atlantico/14551485". No lado esquerdo um elemento de um aparelho de medida de registo da altura solar e no lado direito uma representação cartográfica estando parcialmente sob uma figura representativa da constelação Cruzeiro do Sul. Na parte superior e inferiores existe uma cercadura de elementos de escala cartográfica e no lado esquerdo esta é parcialmente interrompida.

Metal: Cupro-Ní-quel

Composição: Cu 750 - Ni 250

Peso: $16,5 \mathrm{gr}$

Diâmetro: $33,5 \mathrm{~mm}$

Bordo: Serrilhado

Autor/Escultor: Paulo Guilherme

Ano: 1990

Valor Facial: 100 escudos

A face da moeda III Série dos Descobrimentos, A Descoberta da América - Navegações para Ocidente, 1991 ostenta um hexágono 

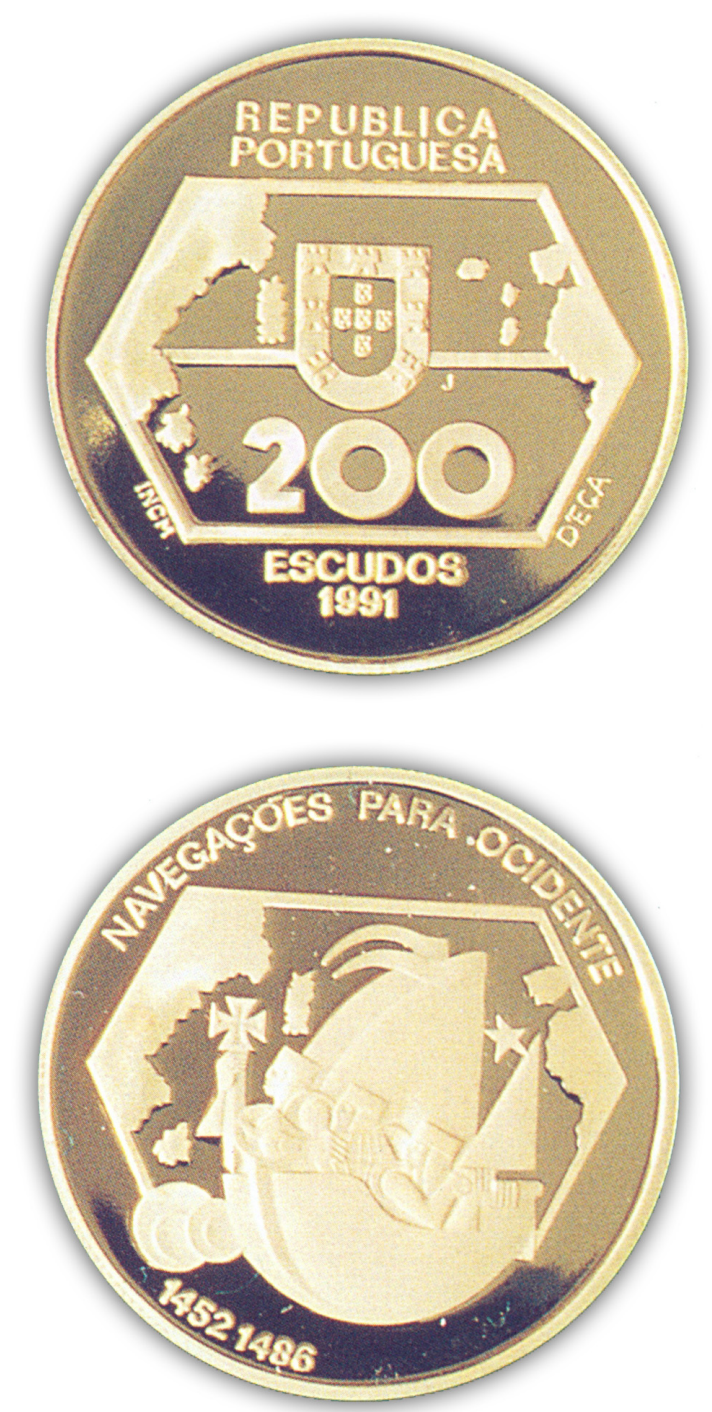

Figura 122. Moeda A Descoberta da América - Navegações para Ocidente 
regular, dividido por um eixo de simetria, entrecortado por o escudo Nacional sobrepondo o centro da moeda e com mais incidência para a parte superior direita. Ainda dentro do hexágono, a inscrição "200" que está colocada entre o escudo e a linha inferior do hexágono e o desenho de elementos de representaçãoo cartográfico. Fora do hexágono na parte superior em duas linhas paralelas, a inscrição "Républica”, "Portuguesa” e na parte inferior em duas linhas paralelas as inscrições "Escudos”, “1991”. Do lado inferior direito uma linha oblíqua e paralela à linha do lado do hexágono a inscriçãoo “D’Eça” e no lado inferior esquerdo do mesmo modo a inscrição "INCM".

No verso da moeda o mesmo hexágono irregular, entrecortado, por uma caravela com duas velas, contendo três personagens em figuração da tripulação um padrão, uma bandeira e uma estrela de cinco pontas. Dentro do hexágono, figuram os mesmo desenhos de representação cartográfica da face só que em menor número. Na parte exterior do hexágono junto ao rebordo e em linha circular, duas inscrições "Navegações para Ocidente" e em lado oposto "1452 1486".

Metal: Cupro-Ní-quel

Composição: Cu 750 - Ni 250

Peso: 21 gr

Diâmetro: $36 \mathrm{~mm}$

Bordo: Serrilhado

Autor/Escultor: Paulo Guilherme

No anverso da moeda, Milénio Atlântico, é visível ao centro o logotípo da Expo 98, com ascendencia para a parte superior, sobrepondo um pouco a linha inferior do desenho do escudo nacional. Este escudo colocado junto ao rebordo entrecorta as inscrições "Republica" e "Portuguesa", inscritas circularmente. Todo este registo se desenvolve na metade, (mais ou menos) do 

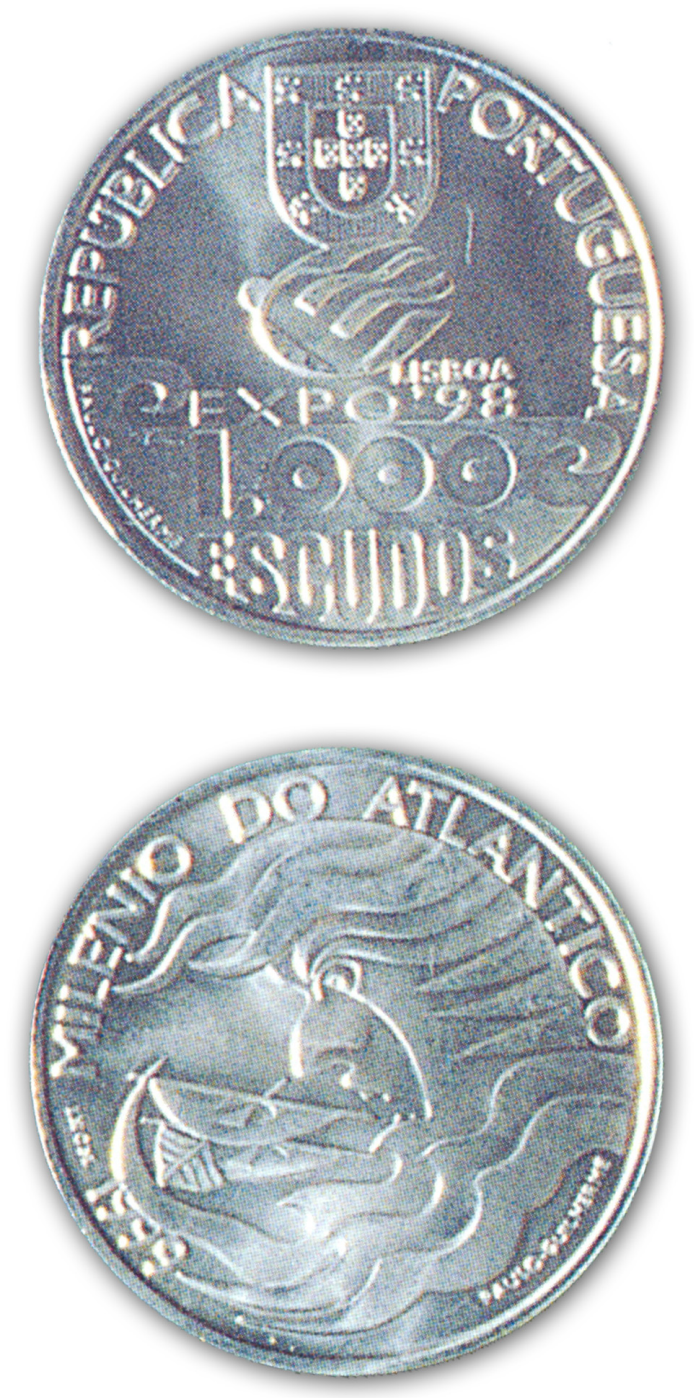

Figura 123. Moeda Milénio Atlântico 
circulo superior, na outra metade (circulo inferior), expõe-se uma forma organica, na qual na linha superior pode ler-se as inscrições "Expo 98" e por cima desta a inscrição "Lisboa". Dentro da dita forma organica, as inscrições "1.000" sobrepondo a palavra "escudos", registada irregularmente, por a parte inferior desta desenvolver-se paralelamente ao rebordo. A parte inferior esquerda contém o nome "Paulo-Guilherme" escrito em forma circular e junto ao rebordo.

No verso circularmente, exibe as inscrições "Milénio do Atlântico" na parte superior, na parte inferior direita a inscrição "Paulo-Guilherme" e na parte inferior esquerda "INCM", "1999". No desenho gravado é visivel a cara do Adamastor, uma caravela com as cruzes dos Descobrimentos nas velas e as ondas do mar.

Série: Datas e Figuras da História de Portugal

Ano: 1999

Valor Facial: 1.000 escudos

Metal: prata $500 \%$

Acabamento: normal

Diâmetro: $40 \mathrm{~mm}$

Peso: $27 \mathrm{~g}+/-1 \%$

Bordo: serrilhado

Eixo: horizontal

Tiragem: 500.000

Escultor: Paulo Guilherme

Legislação: Decreto-Lei n ${ }^{\circ}$ 314/99, de 11 de Agosto

José Maria D’Eça de Queiroz (1845-1900), licenciou-se em direito, chegou a ser diplomata e foi um dos grandes romancistas portugueses. Das suas obras destacam-se o Crime do Padre Amaro como o melhor romance realista português do séc. XX e os Maias. A Relíquia e o Mistério da Estrada de Sintra e a Ilustre Casa de Ramires entre outros. Eça foi amigo de Camilo Castelo Branco e de Antero de Quental, tendo participado com estes em Coimbra, nas publicações avulsas da revista Gazeta de Portugal que mais tarde 
foram reunidas em colecção e publicados em livro, postumamente. Durante a sua vida colaborou em jornais nomeadamente no Diário de Notícias e revistas. Foi director do periódico O Distrital de Évora e fundador da Revista Portugal. A sua obra mereceu a tradução para cerca de vinte idiomas.

A incumbência de realização da medalha em prata, comemorativa do centenário da morte de Eça de Queiroz, recaiu em PG (Eça de Queirós - Centenário da Morte, 2000).

$\mathrm{O}$ anverso da moeda tem uma expressiva imagem de Eça de Queiroz singularmente desenhada e notavelmente geométrica e as inscrições de "Eça de Queiroz”, “1900-2000”. No reverso figura as inscrições "República Portuguesa", "Centenário da Morte de Eça de Queiroz" o seu valor "500 escudos" e patenteia o Escudo Nacional e dois ramos de louro.

Série: Datas e Figuras da História de Portugal Ano: 2000

Valor Facial: 500 escudos

Metal: prata $500 \%$

Acabamento: normal

Diâmetro: $30 \mathrm{~mm}$

Peso: $14 \mathrm{~g}+/-1 \%$

Bordo: serrilhado

Eixo: horizontal

Tiragem: 500.000

Escultor: Paulo Guilherme d'Eça Leal 

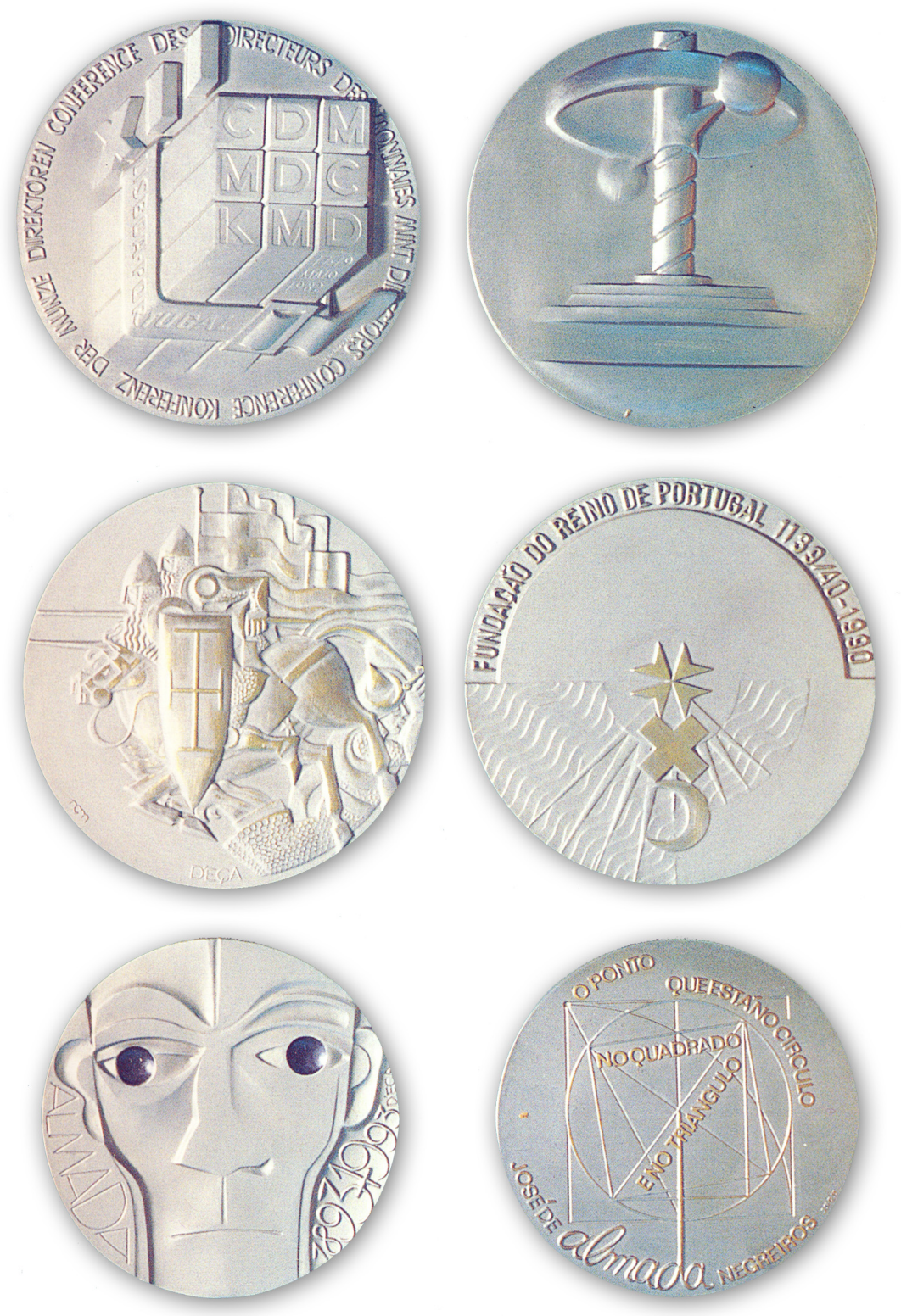

Figura 124. Conjunto de medalhas comemorativas 

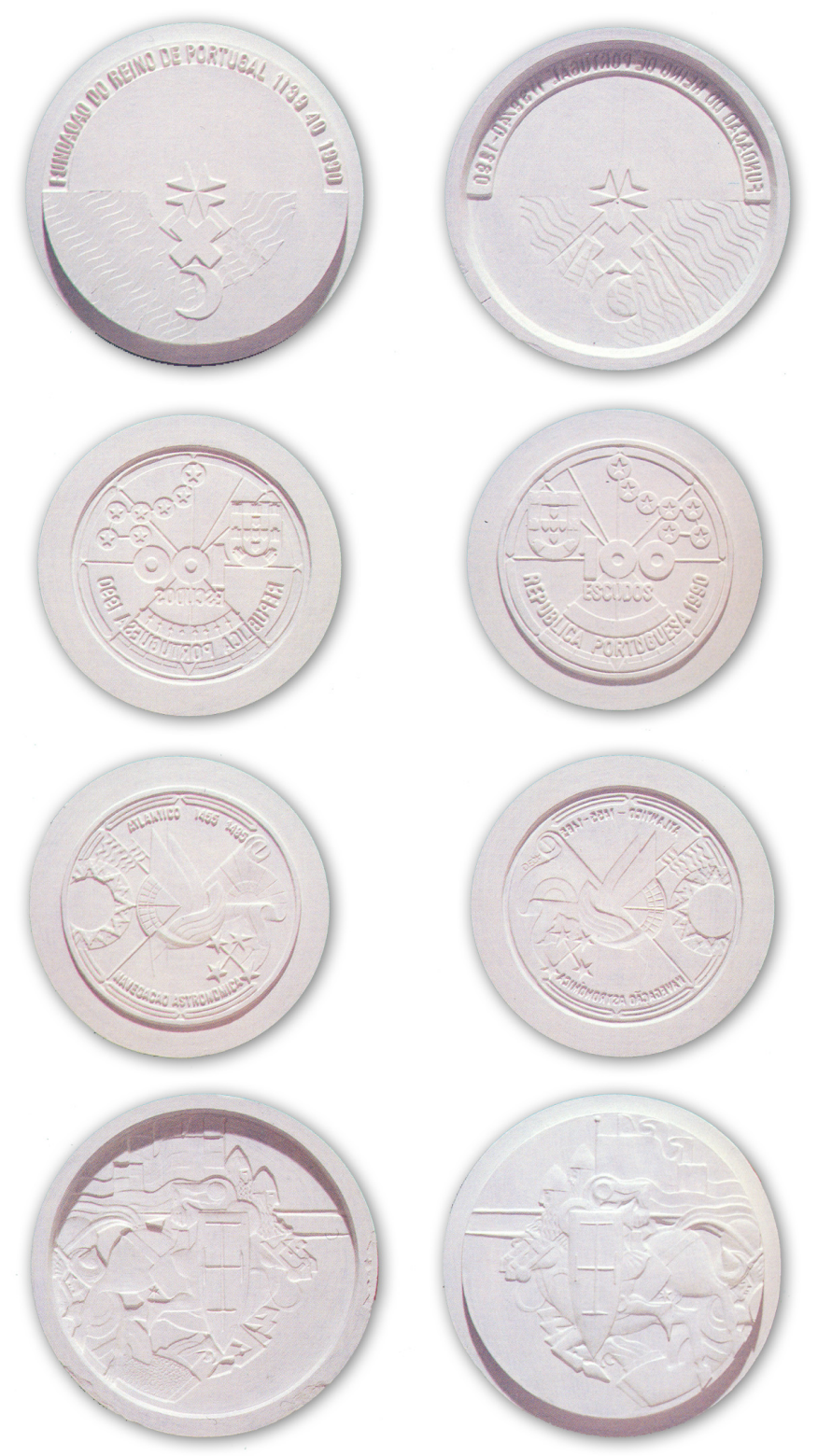

Figura 125. Conjunto de matrizes de moedas em gesso 


\subsubsection{Fotografía / Fotografia}

A sua actividade começa com o fotojornalismo produzindo trabalhos para jornais e periódicos, durante mais de uma década, periodo que lhe proporcionara uma larga experiencia no campo de fotografia. Nesse campo valeu-lhe a sensibilidade, o instinto, a rapidez e a sua curiosidade. E à semelhança de todas as áreas em que trabalhou, PG foi um exemplar auto-didacta, desenvolvendo as suas técnicas a partir de bibliografia temática associada à sua inteligência resolve os problemas de forma prática, expediente. Desenvolveu assim a sua capacidade de avaliar as situações de modo rápido e de aproveitar o melhor momento. Admirador de Henri CartierBresson, afirma que foi uma das suas grandes influências. O trabalho fotográfico de PG é de uma surpreendente variedade inconformista, constituído por temáticas como o quotidiano, o retrato, mas essencialmente a figura feminina. O seu enorme e conhecido gosto pelo corpo feminino fá-lo alargar a sua actividade para o universo da moda, tornando-se responsável por vários bockets de modelos. As fotografias valorizavam a indumentária mas essencialmente a postura corporal e a essencia da figura fazendo sobressair a beleza das suas modelos, relativizando o papel do cenário. Embora tenha sido uma área a que PG muito se dedicou, a fotografia é uma área que se dilui em todo o seu trabalho. Hoje encontra-se completamente dispersa e de difícil acesso porém teve o seu espaço e o seu tempo e indubitavelmente contribuiu, através das noticias e artigos que ilustrou para a memória colectiva portuguesa.

«O Paulo é fotógrafo? É, é um grande fotógrafo» ${ }^{160}$

${ }^{160}$ CARDOSO, Homem,"O Paulo-Guilherme é fotografo?", Catálogo de exposição, PauloGuilherme D'Eça Leal D'etecetera e tal 2000, Câmara Municipal de Lisboa, 28 de Janeiro de 1993, p. 189 

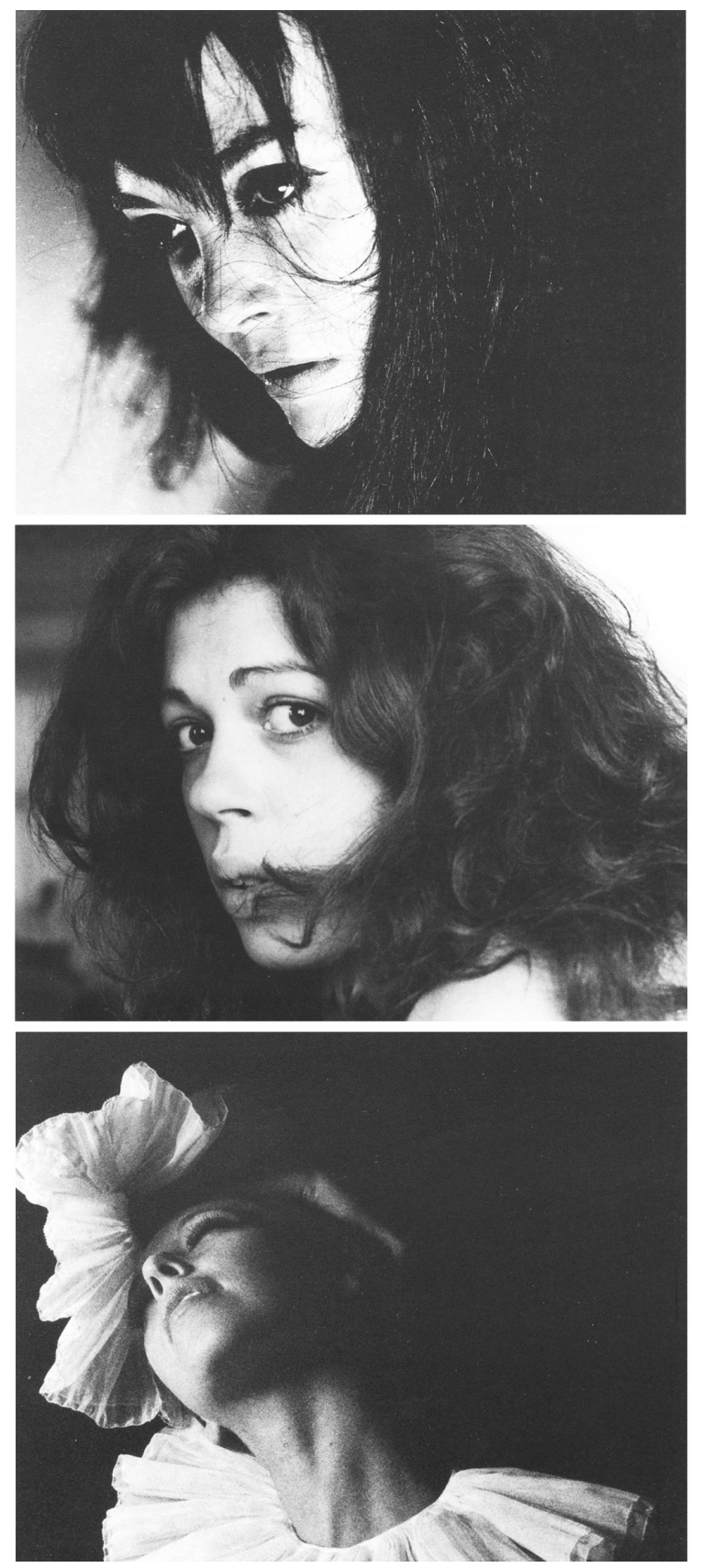

Figura 126. Conjunto de fotografias de Paulo-Guilherme 

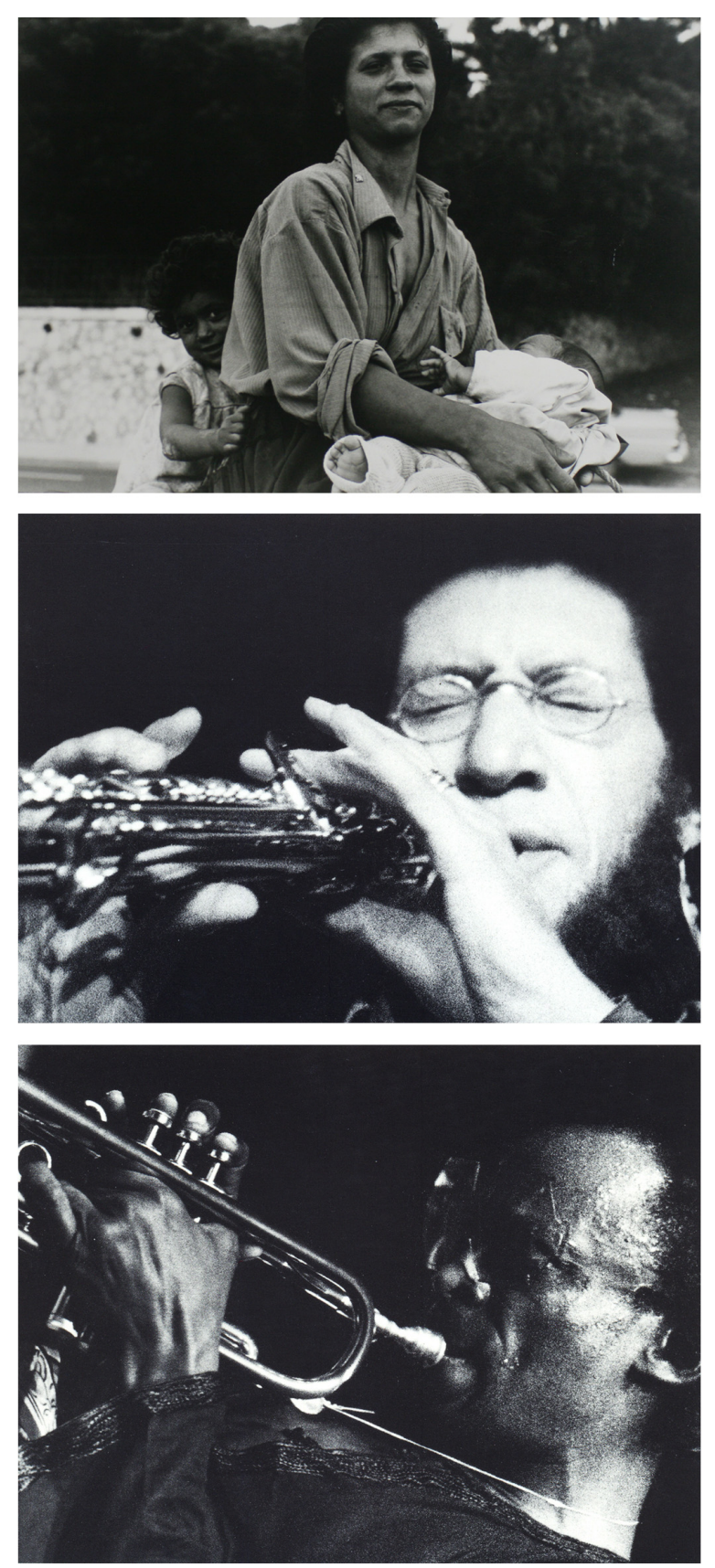

Figura 127. Conjunto de fotografias de Paulo-Guilherme 

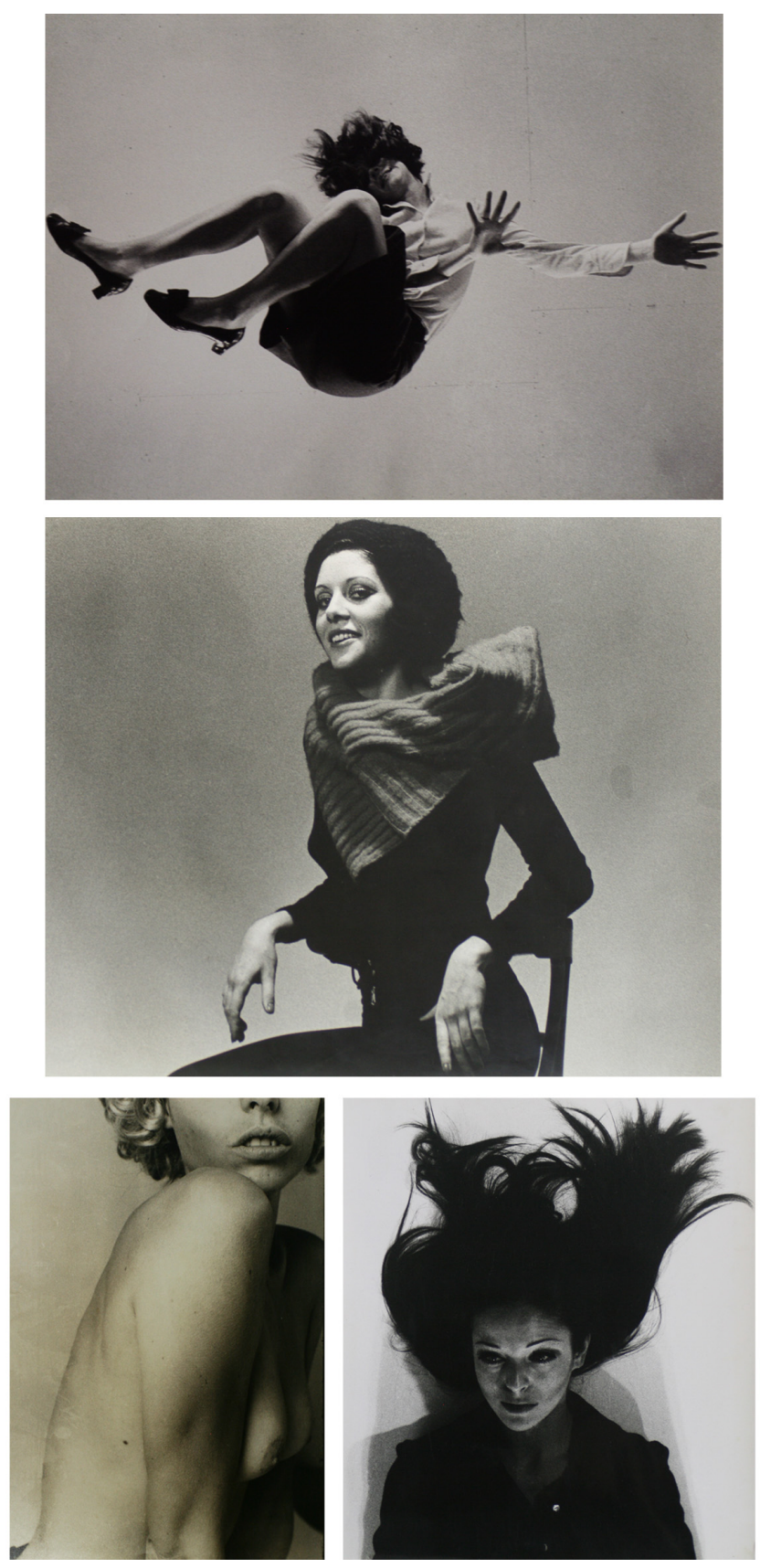

Figura 128. Conjunto de fotografias de Paulo-Guilherme 


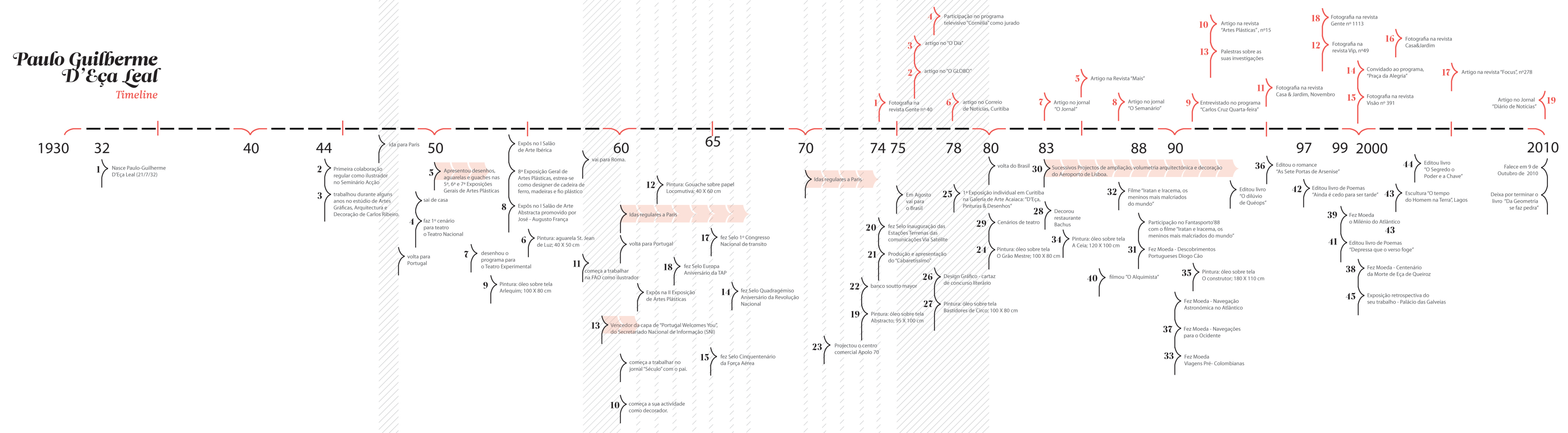




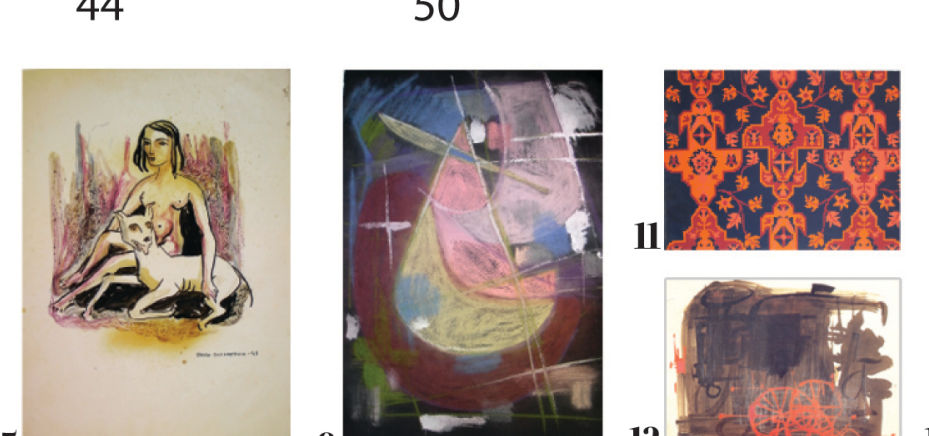

60

70

$7475 \quad \underset{78}{80} 83$

$88 \quad 90$

,

rent
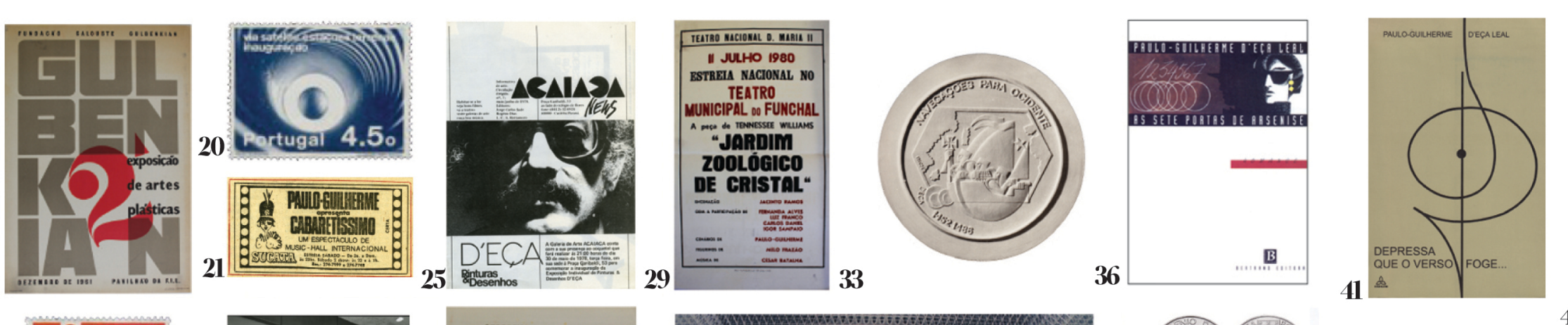

$97 \quad 992000$
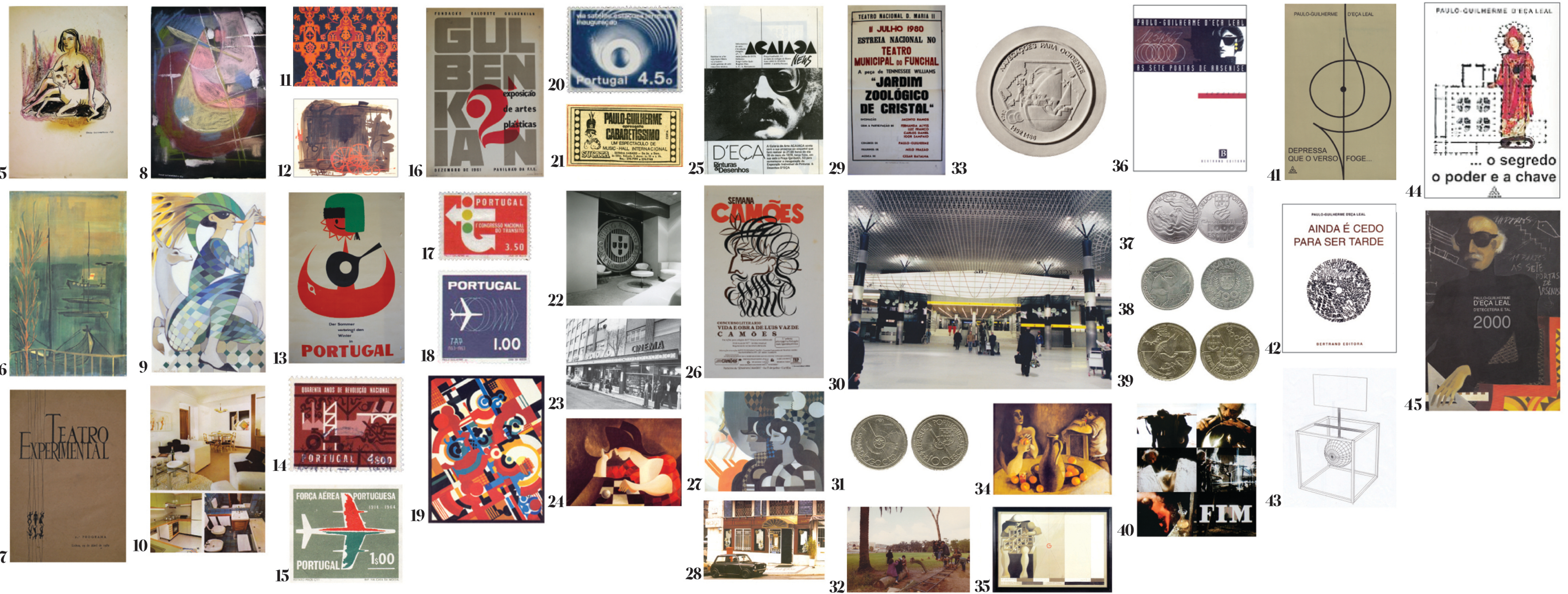


\section{Conclusiones}

El siglo XX, en Portugal, fue de grandes convulsiones políticas, económicas y sociales, factores que contribuyeron a la inestabilidad social y al poco desarrollo con las evidentes repercusiones a nivel cultural. La inestabilidad generada por la crisis política, la dictadura de Salazar, la guerra colonial y la revolución de abril, con la instauración de la democracia de un modo repentino y inesperado, fueron factores determinantes para el desequilibrio social y cultural del pueblo portugués. Así, en un entorno político/cultural desfavorable, la modernización se convierte en un proceso complejo, lento y en algunos aspectos, retrógrado, con sus consecuentes perjudiciales repercusiones a todos los niveles, en particular en lo que se refiere a las prácticas artísticas. Sin embargo, paradójicamente, la producción artística en Portugal a lo largo de ese tiempo fue prolifera y de una calidad estimable, fruto de la acción, compromiso y la calidad de algunos de sus artistas.

«El único agente visible en la historia es el individuo. Podemos en realidad considerar a la sociedad como la verdadera matriz de eventos históricos y hacer de la importancia social de estos, el criterio de su relevancia para la historia. (...) El comportamiento del individuo está condicionado no sólo por un plan psicológico, y no todo lo que logra se hace en su propio interés. El individuo está siempre en una situación social histórica y se comporta de acuerdo a los requerimientos, sin a menudo entenderlos o sin la intención de respetarlos. (...) La persona que habla en nombre y en interés del grupo al que pertenece; es su portavoz y no sólo expresa las aspiraciones y los intereses 
individuales. $\gg^{161}$

Siguiendo este criterio, podría decirse que los autores y protagonistas de nuestra historia son los agentes importadores de las nuevas propuestas internacionales, la élite de artistas que vivían en el extranjero, y que en contacto con los movimientos vanguardistas, eran permeables a la renovación de sus lenguajes. Personajes con peso cultural, con una gran capacidad creativa y de innovación, de una formación teoría estimable, etc., autores de acciones y obras de indudable valor cultural y artístico.

Entre estos personajes, emerge un «Inteligente, firme, autoritario, prestable, educado, seguro, escrupuloso, leal, perseverante, sensible, discreto, tímido, ardiente, imaginativo, seductor, generoso pero egocentrista, es cómo podríamos clasificar en una introducción rápida, este polifacético artista que la mayoría del público no conoce cómo debe de ser ${ }^{162}$. Se trata de Paulo Guilherme D' Eça Leal, un artista del que hemos aspirado a mostrar en el presente estudio, su perfeccionismo, su versatilidad, su inusual destreza manual y mental, cuyas motivaciones para la acción y eficiencia productiva revelaron, en su fértil recorrido productivo multidisciplinar, su capacidad de adaptación y adecuada respuesta a cuantas exigencias le plantearon los retos artísticos a lo que se enfrentó. La cuidadosa preparación, la espontaneidad sometida a lo que tenía en mente, lo hacía ser diferente y singular en una época, que le tocó vivir, de cambio, de desafíos desiguales, de exigencia, competitividad y también, de vulgaridad.

La sociedad aceptaba bien el profesionalismo ecléctico y tenía respeto por los artistas multifacéticos, con los que confiaba a la hora de que solucionasen rápidamente y con efectividad, necesidades

\footnotetext{
${ }^{161}$ Traducción libre de: HAUSER, Arnold. Teorias da Arte, Editorial Presença. Lda, $2^{\text {a }}$ Edição Lisboa, 1988, p.174

${ }_{162}$ Traducción libre de: BRANDÃO, A. Almeida. "Paulo-Guilherme: Um Equilíbrio

Conquistado do Interior", Artes Plásticas, n 15, Janeiro 1992, p.64
} 
que aparecían de los nuevos problemas que surgían. El gusto desmedido por la novedad y la posibilidad de superar las carencias del momento, convierten a PG en un artista de espíritu ecléctico y vocación pluridisciplinar, cuyo talento va a ponerse de manifiesto a lo largo y ancho de un extensa la trayectoria artística y vital.

«Hijo de Olavo D' Eça Leal, artista polifacético que durante muchos años fue un inolvidable animador de la vida cultural portuguesa, D' Eça es también un hombre renacentista con la capacidad de múltiples creaciones.» ${ }^{163}$ PG contribuyó de manera significativa a la cultura visual portuguesa a través de una gran variedad de trabajos y obras realizadas desde ámbitos y disciplinas artísticas tan diversas como el dibujo, las artes gráficas, ilustration, la pintura, la escultura, la decoración, la escenografía, la producción teatral, el cine, la fotografía y la arquitectura, siendo reconocido también como escritor, poeta, e investigador.

Entendemos que el perfil más destacable de su producción sea, posiblemente, el hecho de la calidad media del conjunto de su obra en base a la variedad de orígenes disciplinarios de los que proviene.

En el área de Artes Gráficas, la obra de PG será una de las más difundidas y reconocidas, pues por sus característica propias, estas "piezas gráficas" de fácil e inmediata comprensión, llegan fácilmente al público portugués. Este factor es determinante para valorar el trabajo y la producción de PG pues, no en vano, se trata de un medio privilegiado, que se amolda y proyecta fácilmente a la cultura visual portugués. Su colaboración regular en casi todos los diarios y periódicos de Lisboa, su participación en campañas de distintas agencias de publicidad, su participación en la mayor parte de editoras portuguesas de importancia, sus miles de ilustraciones

${ }^{163}$ Traducción libre de: VINHAS, Manoel. “D’Eça, Paulo-Guilherme D’Eça Leal”, Desdobrável Exposição Nouvelle Dezon Galeria d'Arte, 24Maio-7Junho, 1975 
publicadas, portadas de libros, trabajos en identidades corporativas y los muchos reconocimientos y premios en el área de las artes graficas, lo convierten, al margen del reconocimiento público de la calidad gráfica que PG imprimía en sus trabajos, en un protagonista relevante de las Artes Gráficas en Portugal.

No se puede dejar de resaltar su faceta de reportero gráfico en la información nacional e internacional, un trabajo muy visible en periódicos y revistas. Pues bien, la obra fotográfica se muestra inconformista y de una variedad sorprendente, desde temas cotidianos y retratos, hasta -y esencialmente-, la figura femenina, PG trabajó también para la moda y la publicidad. También, su destreza y virtuosismo como ilustrador, le lleva a ser el escenógrafo de tres películas ${ }^{164}$, revistas musicales, algún ballet y varias obras de teatro, para los que, incluso, diseña vestuario.

«Esta es la amplitud de la expresión que se convierte en una de las primeras características de la obra de Paulo-Guilherme. Y si hay una comprensión clara de las tendencias y técnicas contemporáneas, si se puede encontrar aquí y allá, evidencias de Saul Bass, Rand Paul o de Raymond Savignac, estas referencias se combinan siempre con un brío propio, que se manifiesta claramente en la destreza del trazo, pero también en el conocimiento de la interacción de los materiales, del modo en como texturas, padrones y colores se pueden combinar para dar una sensación casi táctil a un anuncio publicitario, una portada de libro o al interior de un bar, creando ambigüedad entre el dibujo y la fotografía, objeto y representación ${ }^{165}$

\footnotetext{
${ }^{164}$ Destaca amplias campañas: Sacor - La petrolera portuguesa e Woolmark.

${ }^{165}$ Traducción libre de: MOURA, Mário. Paulo-Guilherme, Colecção D, Silva Designers (coord.) Imprensa Nacional-Casa da Moeda, S.A., 1 1aedição setembro 2012, p.9
} 
La filatelia se afirmó como un interesante y curioso medio de comunicación para PG, de hecho, puede formar parte de su trabajo. A PG le atrae poderosamente, cómo una imagen tan pequeña, puede simultáneamente, proyectarse hacia horizontes históricos y culturales. La fuerza visual del mensaje filatélico refuerza toda una cultura que se apoya y difunde en la cultura visual de un pueblo. El sello es, efectivamente, en su momento, un medio de expresión gráfica de gran fuerza en la sociedad al ser un medio privilegiado por su accesibilidad y difusión. Se convierten en símbolos de mensajes sobre una región, un acontecimiento o una personalidad, son reveladores del transcurso del tiempo, historia, experiencias, usos y costumbres de los pueblos.

Consientes de la importancia de estas piezas gráficas, los CTTCorreios de Portugal, en los años 50/60, dieron a sus sellos, en millones de ejemplares, la calidad artística de los diseñadores e ilustradores portugueses. Paulo-Guilherme también se expresó en esta área participando con varios trabajos acentuando sus sellos con una modernidad alegre, de poderosas metáforas en composiciones geométricas, en el que la síntesis es una característica obvia de sus composiciones gráficas, contribuyendo así valiosamente en el desarrollo artístico filatélico, ampliando la gama de registros gráficos, reforzando y ampliando la cultura visual de Portugal.

También, como documento histórico, la moneda es una fuente confiable que contiene datos sobre las personas que la acuñaron, en sus diversos aspectos organizativos: como la religión, idioma, situación económica, etc. Así la numismática tiene un papel destacado en el estudio de la historia de la humanidad. Su registro gráfico, así como sus tipos ayudan también al desarrollo artístico/cultural, ayudando a comprender a los propios pueblos. Sin embargo, se le pueden reconocer otros atributos en el campo del coleccionismo que en conjunto con otras disciplinas también 
desarrollo en la búsqueda de una mejor comprensión de su legado histórico/artístico. Al igual que en las artes gráficas, escenografía, ilustración y filatelia, PG contribuyó con su delicado dibujo de trazo elegante y descriptivo, grafismos creativos llenos de simbolismo en sus composiciones de fuerte carácter geométrico. Colocó toda su experiencia al servicio del engrandecimiento de la numismática portuguesa a través de un trabajo de reconocida calidad en este campo.

En diversas áreas y también en la pintura, Paulo-Guilherme nunca se sometió a los intereses comerciales, evitando curadores o galeristas, consiguientemente pone su pintura fuera del mercado. Por lo tanto, no podemos situar su obra en los circuitos comerciales de la pintura portuguesa. Sin embargo, su pintura la encontramos en casi todas, si no en todas, las miles de decoraciones privadas que realizó. Con ella, Paulo-Guilherme, conseguía una unidad en sus decoraciones porque pintaba en función de la decoración y los espacios que le ofrecía el cliente, por lo que la integración era completa en favor de la atmosfera que pretendía crear, lo que daba un toque particular y personal a decoraciones.

Su pintura, tenía como base, elementos naturales y figuras humanas, en general, la mujer encantadora y superficial, con la clara y manifiesta intención de producir una arte alegre y optimista, sin presentar ningún comentario psicológico o social. Motivos estilizados con exquisito gusto, que atraen por la elegancia del arabesco y por la armoniosa distribución de colores transmitiendo una nostalgia por la belle époque, junto con un evidente art nouveau hasta las reminiscencias estructurales cubistas. Tuvo una extensa fase figurativa seguida de lo abstracto durante muchos años, para regresar a lo figurativo.

En los diseños de tapicería que realiza Paulo-Guilherme prevalece el 
sentido constructivo, consiguiendo así un trabajo más compulsivo, fuerte y puro, integrando visceralmente las raíces de la tierra y la memoria de sus misterios. Los materiales son extraídos de la naturaleza, poco sofisticados, adoptados en su estado natural: algodón, yute, lana, etc. En su trabajo son visibles muchas técnicas de tapicería tejida así como técnicas de telar. En esta campo, PauloGuilherme sale del espíritu linear de la tapicería, buscando nuevos efectos a partir de relieves en un mundo abstracto.

«Sus esculturas, por lo menos, son verdaderas poesías (...) Sus tapices, aunque desprovistos de color son extremadamente vibrantes (...) verdaderos tesoros.» ${ }^{166}$ Las tapicerías que desarrollo, excepto las que integran las exposiciones realizadas en Brasil (una individual en la Galería Nouvelle Dezon; y otra en la Galería Acaiaca, en Curitiba y en el Museo de arte contemporánea de Panamá) fueron creadas como elementos para sus decoraciones, así como sus esculturas cuya intervención fue fugaz.

Se dedicó algún tiempo a la creación de ambientes nocturnos, decorando muchos clubes que hacían parte de la noche en Portugal. Se puso de moda y estaba muy solicitado llegando a ser un diseñador y decorador de gran prestigio. La decoración de PauloGuilherme fue deseada y solicitada porque conseguía crear ambientes muy singulares, exuberantes y únicos, así que la alta burguesía se esforzaba para que sus decoraciones tuvieran su firma. Fue también responsable por la decoración de espacios públicos como restaurantes, bares, stands, tiendas o centros comerciales.

En sus decoraciones estaban algunas veces, pormenores de la Belle Époque, del Art Nouveau, como en el restaurante Bachus, Snobíssimo o de modernismo con formas más geométricas puras,

${ }^{166}$ Traducción libre de: CARNEIRO, Fernando. “D’Eça, Paulo-Guilherme D’Eça Leal”, Desdobrável Exposição Nouvelle Dezon Galeria d'Arte, 24Maio-7Junho, 1975 
por ejemplo en la tienda Vanitas o Stand de la Citroen. Independientemente de los diferentes estilos que Paulo-Guilherme usara, lo que prevalecía en sus decoraciones era lo extravagante, lo original.

El carácter único de las decoraciones de Paulo-Guilherme era la forma de pensar global y única para un determinado espacio. La decoración era hecha hasta el más mínimo detalle y no dejaba nada a la suerte. Pensaba en el espacio como un todo y sus preocupaciones iban desde la lámpara de techo, los muebles, los cuadros, hasta los tapices de pared. Todos los elementos que constituían el espacio, que creaban la atmósfera, eran pensados y proyectados con el mismo propósito. Daba mucha importancia a la luz y trabajaba los espacios como un todo, es decir, el proyecto era pensado globalmente hasta el más mínimo detalle, nada estaba descoordinado. Conseguía así espacios muy bien conjugados, armoniosos y con un gran sentido estético. Se convirtió en un decorador de prestigio con una carrera consolidada durante tres décadas.

La intervención de Paulo-Guilherme en la arquitectura portuguesa fue sobresaliente no sólo por las obras de gran envergadura e importancia para la sociedad como es el Aeropuerto de Lisboa, si no también por lo enfoque único daba a sus trabajos. Su intervención en el Aeropuerto de Lisboa fue esencialmente en el espacio de la zonas de salida de la terminal, pensado en una escala compatible con los movimientos de grandes masas de gente y con los requisitos que un espacio así requiere. Esta arquitectura está fuertemente determinada por los diferentes volúmenes opacos y trasparentes en cristal. Pueden encontrarse inesperados detalles de diseño en los pasamanos de las escaleras, explorando diferentes alturas; la animación del espacio incluye superficies de espejo negro, accesorios ojivales de acero pulido y lámparas esféricas. 
Incompatibilidades de la grandeza conceptual y sus costos, degradaran la relación con la gestión de los aeropuertos hasta tal punto que se refleja también en los detalles, que conducen a un colapso total cuando se iniciaba el proyecto de llegadas. Estos eventos llevaron a que el nombre de Paulo-Guilherme fuera borrado de la historia constructiva del aeropuerto, imposibilitando el reconocimiento público.

En el estilo de PG, tal y como venimos insistiendo, es notorio su eclecticismo. En el Banco Pinto \& Sotto Mayor (1973), que se situaba en Oporto, es evidente la influencia del Modernismo, su abordaje a través del funcionalismo trajo nuevas formas rompiendo con lo tradicional y conservador. Esta propuesta, totalmente innovadora en Portugal, cuya audacia es absolutamente contraria a los cánones, fue la motivación principal de ese gran desafío estético que PauloGuillerme desencadenó. Cabe señalar, que fueron suprimidos de todos los conceptos considerados correctos y rentables en el medio bancario, en lo que se refiere a instalaciones para el público: madera oscura, mármol, paneles, para definir un ambiente severo y taciturno (en la mayoría de los casos) o puramente funcional y neutro. El edificio de la filial del Banco Pinto \& Sotto Mayor en Porto abre el camino a nuevas concepciones de la arquitectura cortando con todos los conceptos clásicos. Trabajó en el edificio como un todo logrando una unidad y armonía en todos los elementos, estos coexisten intrínsecamente de modo que las soluciones forzadamente funcionales se disfrazan en soluciones estéticas y viceversa. Trabajó la transparencia e innovó en varios aspectos como el caso, entre muchos otros, de la escalera hecha totalmente en vidrio (una novedad para la época) o una barra de apoyo lograda de una forma ingeniosa y original, aprovechando un conducto del aire.

En el campo de la producción, Paulo-Guilherme realizo decenas de 
anuncios de televisión, produjo y dirigió el cortometraje «El Alquimista» (1986) y el largometraje «Iratan e Iracema, los niños más traviesos del mundo» (1988), este último con el reconocimiento público de la Palma de Oro Premio Film Festival en Figueira da Foz y el Trofeo de Oro en el Festival de Cine de los países de lengua portuguesa de Aveiro. Sin embargo, no fueron debidamente difundidos; el largometraje fue transmitido en episodios en la televisión portuguesa (RTP) y fue proyectado en la Bedeteca pero nunca salió en los cines. Una vez más PauloGuilherme se niega a someterse a los intereses comerciales, por lo tanto imposibilita al público, en general, acceder a su trabajo.

Al contrario de sus realizaciones cinematográficas, su producción teatral dejo marcas provocando una revolución en la noche de Lisboa: «Cabaretíssimo rompe con la tranquila marginal lisboeta sedienta de aquellos tiempos gloriosos de promiscuidad revolucionaria.» ${ }^{167}$ El espectáculo fue un music hall alternativo y audaz de dos horas y media, inédito en Portugal. Este éxito fue llevado a Brasil donde estuvo ocho meses en escena. Se dijo: «Es un espectáculo absolutamente nuevo en Brasil. Pero no vale solo por ser una novedad: Caberetíssimo es uno de los mejores musicales presentados en Europa en los últimos dos años y su creador, PauloGuilherme, recibió las mejores elogios de la crítica de Portugal y España, que pasó de adjetivos como "magnífico", "fascinante", "fabuloso", "extraordinario", etc ... » 168

Es en el campo de la investigación, Paulo-Guilherme explora su fascinación por la comprensión global, por el descubrimiento de los misterios, por lo oculto. Desde el principio de su escritura tuvo la

${ }^{167}$ Traducción libré de: PLANTIER, Carlos. "Cabaretíssimo: uma grande festa", O Seculo Ilustrado, 1974 , p.48

${ }^{168}$ ALMEIDA, Margarida de. "Beleza e a fúria, de Cabaretíssimo”, Jornal O dia, 21 Março 1976 , p. 28 
preocupación por poder ser entendido, pretendiendo que lo que escribía fuera accesible a cualquier lector. Prueba de eso, son los libros editados de ficción y poesía, de escritura simple y directa. Sin embargo, escribir de materias que no tienen una frontera precisa entre la ciencia oficial y las especulaciones esotéricas es ya por si un riesgo al que pocos autores se atreven.

Tiene que reconocerse la originalidad de muchas de sus ideas, las soluciones lógicas absolutamente inéditas y con ellas los descubrimientos, un ejemplo de eso, es el estudio sobre el Monasterio da Batalla que fue noticia en un artículo de periódico titulado «¿Qué esconde la Batalla?» (revista FOCUS nº329/2006) revelando resultados prácticos de las predicciones de su libro (descubrimiento de la existencia de una cripta). Hizo públicas sus deducciones y soluciones, no solo con la publicación de sus libros, sino también con dos conferencias, una en la Fundación Gulbenkian, donde el anfiteatro para 140 personas recibió cerca de 400 y en la Misión de Macau donde el interés y la expectación fueron semejantes.

Paulo-Guilherme, experimenta un nuevo camino en la descodificación de los célebres paneles de Nuno Gonçalves que reúne en un libro (El secreto, el poder y el clave), desde la intuición y con una nueva interpretación desde un punto de vista matemático.

«Tal vez sea preferible limitarnos a clasificarlo como un mutante "hombre del Renacimiento" que, gracias a una prodigiosa capacidad de trabajo, consigue acumular experiencias y logros que siguen incomodando a los críticos bien-pensantes y diversas corporaciones de artistas de buen comportamiento»169

169 Traducción libre de: SILVA, António Sena da, "Modo de usar as Artes”, Catálogo de exposição, Paulo-Guilherme D'Eça Leal D'etecetera e tal 2000, Câmara Municipal de Lisboa, 28 de Janeiro de 1993, p. 243 
Por sus planteamientos, deducciones y conjeturas formalistas, Paulo-Guilherme se sitúa al lado de grandes artistas como Almada Negreiros y Lima de Freitas; su vertiente como geómetra, por su originalidad, no puede pasar desapercibida. «Paulo-Guilherme fue, tal vez, el último de los tres geómetras portugueses (...) Almada, Lima de Freitas e Paulo-Guilherme» ${ }^{170}$

La obra de Paulo-Guilherme es el resultado de medio siglo de trabajo en una actividad profesional artística, creativa, interdisciplinar y transversal, que lo convierte en uno de los máximos exponentes del eclecticismo como forma de acción. Seleccionado, cotejado y estudiado su legado artístico, sobresalen principalmente cuatro áreas: la arquitectura, la decoración, las artes gráficas (ilustración, escenografía, filatelia, a la que añadimos la numismática) y la literatura. Estas áreas se distinguen de las otras porque sus enfoques inéditos y atrevidos tuvieron mayor difusión pública, y en consecuencia, mayor visibilidad por lo que constituyen un legado más reconocible y con mayor impacto en la historia artística y cultural portuguesa.

La presente investigación a través de una compilación inédita de toda la obra de Paulo-Guilherme, con la dificultad añadida de su dispersión, desclasificación y desorganización, ha pretendido contribuir de forma significativa al esclarecimiento, enriquecimiento y preservación de la memoria visual portuguesa. Entendemos que es un objetivo futuro, optimizar los resultados de este estudio y difundirlos con la finalidad de hacerlos accesibles a todo el público, algo que podremos iniciar a través de la película documental Paulo-Guilherme, el alquimista de ideas, que adjuntamos al presente documento como anexo, y que hemos realizado paralelamente a la presente investigación.

${ }^{170}$ Traducción libre de: FERNANDES, Nuno Nazareth. Paulo-Guilherme O alquimista das Ideias [film] Portugal. 109 min. PINTO, Rute Bastardo (Prod.) (2012). in Adjunto 
Este trabajo que hemos realizado ya ha permitido un nuevo posicionamiento PG en la cultura visual portuguesa, a través de la edición de un fascículo enteramente dedicado a este artista incluido en la Colecção D patrocinado por la imprenta de la Casa da Moneda que se ocupa del Diseño Gráfico Portugués, colocándolo junto a otros grandes nombres de diseño gráfico portugués como R2, Victor Palla, Pedro Falcão, etc.

En todos los campos temáticos, Paulo-Guilherme expresó su competencia artística, con un gran rendimiento y versatilidad. Su obra es rica y reúne un conjunto de contenidos que permitirán en base a su aprendizaje, un conocimiento capaz de proporcionar una visión más amplia y comprensiva de las manifestaciones estéticas del pasado.

Los premios que ganó, las exposiciones que se han realizado, las numerosas referencias que hemos encontrado sobre él, las entrevistas que hemos revisado en los medios de comunicación, los resultado de las conferencias que impartió a lo largo de los años, y cuantos testimonios hemos recogido, dan sobradas garantías de valor e interés de su trabajo, su condición intelectual y su talento artístico. Entendemos que con los visto y mostrado, la obra de PG es, definitivamente, significativa y relevante en el contexto del patrimonio artístico y visual portugués, valorada por cuantos la conocen, aspiramos a que sea reconocida como debe con la modesta pretensión de haber contribuido a ello con la presente investigación. 


\section{Conclusão}

O séc. XX em Portugal foi prolífero em convulsões politicas, económicas e sociais, factores que contribuíram para a instabilidade social e um fraco desenvolvimento com as evidentes repercussões a nível cultural. A inconstância gerada pelas crises politicas, pela ditadura de Salazar, a Guerra Colonial e a Revolução de Abril com a implantação da democracia de modo repentino e inesperado, foram aspectos determinantes para o desequilíbrio social e cultural do povo português. Assim, numa conjuntura político/cultural desfavorável, torna a modernização num progresso complexo, moroso e em alguns aspectos retrógrado, havendo repercussões nefastas a todos os níveis em particular no desenvolvimento das práticas artísticas. Paradoxalmente, a produção artística em Portugal desse tempo foi em número e de uma qualidade estimável , fruto da acção, empenho e da qualidade de alguns de seus artistas.

«O único agente visível na história é o indivíduo. Podemos na realidade considerar a sociedade como a verdadeira matriz dos acontecimentos históricos e fazer da importância social destes o critério da sua pertinência para a história. (...) O comportamento do indivíduo não é condicionado apenas por um plano psicológico, e nem tudo o que é realizado por ele é feito no seu próprio interesse. $O$ individuo encontra-se sempre numa determinada situação histórico-social e comporta-se de acordo com as exigências, sem muitas vezes as compreender ou tencionar respeitá-las. (...) O indivíduo fala em nome e actua no interesse do grupo a que pertence; é o seu porta-voz e não exprime apenas interesses e 
aspirações individuais. ${ }^{171}$

Seguindo este critério, poderia dizer-se que os autores e protagonistas de nossa história são os agentes importadores das novas propostas internacionais, a elite de artistas que viviam no estrangeiro e que em contacto com os movimentos vanguardistas, eram permeáveis à renovação de suas linguagens. Personagens com peso cultural, com uma grande capacidade criativa e de inovação, de uma formação teórica estimável, etc. autores de acções e obras de indubitável valor cultural e artístico.

Entre estas personagens, emerge um «Inteligente, firme, autoritário, prestável, educado, confiante, escrupuloso, leal, perseverante, sensível, pacífico, discreto, tímido, ardente, imaginativo, sedutor, generoso mas egocentrista, eis como poderíamos classificar, em termos de introdução rápida, este Artista multifacetado que a maioria do público não conhece como deve ser.» ${ }^{172}$ Trata-se de Paulo-Guilherme D’Eça Leal, um artista que pretendemos mostrar neste estudo, seu perfeccionismo, versatilidade, sua incomum destreza manual e mental, cujas motivações relativas à acção e eficiência produtiva revelaram, em seu fértil curso produtivo multidisciplinar, sua capacidade de adaptação e adequada resposta às inúmeras exigências que se lhe apresentaram nos demais desafios artísticos que enfrentou.

A elaboração primorosa, a espontaneidade subjugada ao que tinha em mente, tornava-o diferentemente singular, numa época, que lhe tocou viver, época de mudanças, de desafios dispares, tempos de exigência e competitividade e também de vulgaridade.

A sociedade aceitava bem o profissionalismo eclético e nutria certo respeito por artistas multifacetados, confiava naqueles que

${ }^{171}$ HAUSER, Arnold. Teorias da Arte, Editorial Presença. Lda, 2a Edição Lisboa, 1988, p.174

${ }^{172}$ BRANDÃO, A.Almeida. "Paulo-Guilherme: Um Equilíbrio Conquistado do Interior", Artes Plásticas, nº15, Janeiro 1992, p.64 
solucionassem rapidamente e com eficácia as necessidades de novos problemas emergentes. O gosto desmedido pelo novo e a possibilidade de superar as carências do momento, convertem Paulo-Guilherme num artista de espírito eclético e de vocação pluridisciplinar, cujo talento vai manifestar-se em grande amplitude numa extensa trajectória artística e de vida.

«Filho de Olavo D'Eça Leal, artista plurifacetado que durante muitos anos foi inesquecível animador da vida cultural portuguesa, D’Eça é também homem de renascença na capacidade múltipla das várias criações. ${ }^{173}$

PG contribuiu de maneira significativa para a cultura visual portuguesa, através de uma grande variedade de trabalhos e obras realizadas em âmbito e disciplinas artísticas tão diversas como o desenho, artes gráficas, ilustração, pintura, escultura, decoração, cenografia, produção teatral, cinema, fotografia e a arquitectura, sendo reconhecido também como escritor, poeta e investigador.

Entendemos que o perfil más notável de sua produção é, possivelmente, a qualidade média do conjunto da sua obra tendo por base a variedade proveniente das origens disciplinares.

$\mathrm{Na}$ área das Artes Gráficas, a obra de Paulo-Guilherme será uma das mais difundidas e reconhecidas, dado às características próprias destas "peças gráficas”, de fácil e imediata compreensão, chegam facilmente ao público português. Este factor é determinante para valorar o trabalho e a produção de Paulo-Guilherme pois, não é em vão, trata-se de um meio privilegiado, que se molda e projecta facilmente na cultura visual portuguesa.

A partir da sua colaboração de modo regular em quase todos os jornais diários e periódicos de Lisboa, da sua colaboração em

${ }^{173}$ VINHAS, Manoel.'D’Eça, Paulo-Guilherme D'Eça Leal”, Desdobrável Exposição Nouvelle Dezon Galeria d'Arte, 24Maio-7Junho, 1975 
campanhas distintas em várias agências de publicidade, da sua participação na maior parte das Editoras Portuguesas importantes, milhares de ilustrações publicadas, capas de livros, trabalhos em identidades corporativas e os muitos reconhecimentos e prémios na área das artes gráficas que se convertem no reconhecimento público da qualidade gráfica que PG imprimia nos seus trabalhos, e o tornam um protagonista relevante nas Artes Gráficas em Portugal.

Não podendo deixar de frizar a sua faceta como fotojornalista em reportagens nacionais e internacionais, trabalho muito visível em jornais e revistas. Pois bem, a obra fotográfica revela-se inconformista e de uma variedade surpreendente, desde temas quotidianos e retratos, até e essencialmente, a figura feminina, Paulo-Guilherme trabalhou igualmente a moda e a publicidade ${ }^{174}$. Também a sua destreza e virtuosismo como ilustrador leva-o a ser cenógrafo de três filmes, revistas musicais, alguns ballets e várias obras de teatro para os quais desenha o vestuário.

«É esta amplitude de expressão que se torna uma das primeiras características do trabalho de Paulo-Guilherme. E, se existe um conhecimento evidente das tendências e técnicas contemporâneas, se é possível encontrar, aqui e ali, rastos de Saul Bass, Paul Rand ou de Raymond Savignac, estas referências são sempre combinadas com uma verve própria, que se manifesta claramente no à vontade do traço, mas também num conhecimento fluente da interação dos materiais, do modo como texturas, padrões e cores se podem combinar para dar uma sensação quase tátil a um anúncio publicitário, uma capa de livro ou o interior de um bar, criando ambiguidades entre desenho e fotografia, objeto e representação, $(\ldots) . \gg^{175}$

\footnotetext{
${ }^{174}$ Destaca-se as extensas campanhas: Sacor - Companhia Portuguesa de Petróleos e Woolmark ${ }^{175}$ MOURA, Mário. Paulo-Guilherme, Colecção D, Silva Designers (coord.) Imprensa Nacional-Casa da Moeda, S.A., $1^{\text {a }}$ edição setembro 2012, p.9
} 
A filatelia afirmou-se como um interessante e curioso meio comunicacional para PG, de facto, pode formar parte de seu trabalho. A PG atrai poderosamente este espaço imagético, como uma imagem tão pequena, pode simultaneamente projectar horizontes históricos e culturais. A força da mensagem visual filatélica reforça toda uma cultura diversa que se apoia e difunde na cultura visual de um povo. O selo é efectivamente, em seu momento, um meio de expressão gráfica de grande força na sociedade, por ser um meio privilegiado, acessível e bastante difundido. Estes símbolos convertem-se, em mensagens sobre uma região, um acontecimento ou uma personalidade, são denunciadores do curso do tempo, da história, experiências, de usos e costumes, dos povos.

Cientes da importância destas peças gráficas os CTT- Correios de Portugal, já nos anos 50/60, privilegiaram seus selos, em milhões de exemplares, com a qualidade artística de muito designers e ilustradores portugueses. Paulo-Guilherme também nesta área se expressou tendo participado com vários trabalhos vincando os seus selos com uma modernidade alegre, de poderosas metáforas em composições geométricas, em que a síntese é característica evidente das suas composições gráficas, dando assim um contributo válido no desenvolvimento artístico filatélico ampliando o leque de registos gráficos, reforçando e engrandecendo a cultura visual de Portugal.

Também, como um documento histórico, a moeda é uma fonte confiável que contem dados sobre as pessoas que a cunharam, em seus diversos aspectos organizativos: como a religião, situação económica, etc. Assim a numismática tem um papel destacado no estudo da história da humanidade. O seu registo gráfico, assim como seus tipos relegam-nos também para desenvolvimento artístico/cultural, podendo ajudar a inferir a compreensão desses 
mesmos povos. Contudo outros atributos podem lhe ser atribuídos como no campo do coleccionismo que servindo-se de outras disciplinas também as desenvolve, na procura do melhor entendimento de todo o seu legado histórico /artístico. À semelhança de disciplinas como as artes gráficas, cenógrafia, ilustração e filatelia, PG contribuiu com o seu desenho delicado de traço elegante e descritivo, grafismos criativos carregados de simbolismo em composições de forte pendor geométrico. Colocou toda a sua competência também ao serviço do engrandecimento da numismática Portuguesa através de um trabalho de reconhecida qualidade.

Nos vários campos e também no campo da pintura, PG nunca se subjugou a interesses comerciais, evitando curadores ou galeristas que consequentemente situaram a sua pintura fora dos mercados. Portanto não podemos colocar a sua obra nos circuitos comerciais da pintura portuguesa. Contudo, encontramos sua pintura em quase todas, se não todas, as milhares de decorações que realizou. Com ela, PG conseguia uma unidade em suas decorações pois pintava em função da decoração e dos espaços proposto pelo cliente, pelo que a integração era completa em favor da atmosfera que pretendia criar e que dava um toque particular e pessoal a essas decorações.

A sua pintura, tinha por base, elementos naturais e as figuras humanas, na generalidade, na mulher encantadora e superficial, com clara e manifesta intenção de produzir arte alegre e optimista não apresentando nenhum comentário psicológico ou social. Motivos estilizados com apurado gosto, atraem pela elegância do arabesco e pela harmoniosa distribuição cromática deixando transparecer um saudosismo pelo clima belle époque, fundindo um evidente art nouveau às reminiscências estruturais cubistas. Teve uma extensa fase figurativa, seguindo o abstrato durante muitos anos e regressa ao figurativo. 
Nos desenhos de tapeçaria de PG prevalece o sentido construtivo, obtendo um trabalho mais compulsivo, forte e puro, visceralmente integrado às raízes da terra e à memoria dos seus mistérios. Os materiais são extraídos da natureza, nada sofisticados, adoptados no seu estado natural: algodões, jutas, lã virgem, etc. No seu trabalho são visíveis diversas técnicas da tapeçaria tecida bem como técnicas da tecelagem. Na tapeçaria, PG sai do espírito linear da tapeçaria procurando efeitos através de relevos num mundo abstratizante.

«As suas esculturas, pelo menos, são verdadeiras poesias. (...) As suas tapeçarias, embora desprovidas de colorido conseguem ser extremamente vibrantes (...) verdadeiras preciosidades.» ${ }^{176}$

As tapeçarias que elaborou exceptuando as que integraram nas exposições realizadas no Brasil (numa exposição individual na galeria Nouvelle Dezon; outra na galeria Acaiaca, em Curitiba e ainda no museu de arte contemporânea no Panamá) foram criadas como elementos em prol das suas decorações, bem como as suas esculturas cuja intervenção foi fugaz.

Dedicou-se algum tempo à criação de ambientes noctívagos, decorando imensos clubes noturnos, que faziam a noite em Portugal. Tornou-se moda e foi muito procurado tornando-se um designer e decorador de grande prestígio. A decoração de PG era bastante desejada e requisitada, pois conseguia ambientes bastante singulares, exuberantes e únicos, assim as altas burguesias empenhavam-se para que as suas decorações tivessem a sua assinatura. Foi também responsável pela decoração de espaços públicos como restaurantes, bares, stands, lojas ou centros comerciais.

${ }^{176}$ CARNEIRO, Fernando. “D’Eça, Paulo-Guilherme D’Eça Leal”, Desdobrável Exposição Nouvelle Dezon Galeria d'Arte, , 24Maio-7Junho, 1975 
Nas suas decorações estava por vezes presente revivalismos da Belle Époque, da Arte Nova, casos como o restaurante Bachus, Snobíssimo ou o modernismo com formas mais geométricas e puras como a loja Vanitas e o stand da Citroen. Independentemente das aspirações de diferentes estilos que PG recorresse o que imperava nas suas decorações era o extravagante e o original. A unicidade das decorações de PG era a forma de pensar global e única para aquele espaço. A decoração era feita ao mais ínfimo pormenor e nada era deixado ao acaso, PG pensava no espaço como um todo e as suas preocupações iam desde o candeeiro de tecto, ao mobiliário, às telas que haveriam de habitar naquele espaço às tapeçarias de parede. Todos os elementos que constituíam o espaço, que faziam a atmosfera eram pensados e projectados no mesmo propósito. Dava muita importância à integração da luz e trabalhava os espaços como um todo, isto é, o projecto era pensado globalmente ao mais ínfimo pormenor, nada era descorado. Conseguia assim PG espaços muito bem conjugados, harmoniosos e com grande sentido estético. Tornou-se um decorador de prestígio com carreira consolidada durante três décadas.

A intervenção de PG na arquitectura portuguesa foi preponderante não só pelas obras de grande envergadura e importância para a sociedade como é o exemplo aeroporto de Lisboa mas também pela abordagem única que PG lhes imprimiu. A intervenção de PG no Aeroporto de Lisboa passa essencialmente pelo espaço das "Partidas", pensado a uma escala compatível com as grandes movimentações das multidões e com as próprias exigências que um espaço destes requer. Esta arquitectura é fortemente determinada pelas diferenciadas volumetrias e pelos seus volumes opacos e envidraçados. Encontram-se inesperados pormenores de design nos corrimãos de escadas, explorando originalmente diferentes alturas, a animação do espaço contempla superfícies de espelho 
negro, adereços ogivais em aço polido e candeeiros esféricos. Incompatibilidade da grandeza conceptual e seus custos, degradam a relação com a direcção do aeroporto a tal ponto que se reflectiu também em pormenores levando à ruptura total quando iniciava o projecto das Chegadas. Acontecimentos estes que levaram a que o nome de Paulo-Guilhereme fosse retirado da história da construção do Aeroporto, impossibilitando o reconhecimento público.

No estilo de PG, como temos vindo a insistir, é notório o seu ecletismo. No Banco Pinto \& Sotto Mayor (1973), outrora situado na cidade do Porto, é evidente a influência do Modernismo, a sua abordagem pelo funcionalismo trouxe novas formas cortando com o tradicional e conservador. Esta proposta, inteiramente inovadora em Portugal, cuja ousadia é em absoluto contrário aos cânones, foi a motivação principal do grande desafio estético que Paulo Guilherme desencadeou. Registe-se que foram abolidos de todos os conceitos tidos como certos e rentáveis no meio bancário, no que se refere a instalações para o público: madeiras escuras, mármores, apainelados, para definirem uma atmosfera grave e taciturna (na grande maioria dos casos) ou então meramente funcional e neutra. O edifico da filial do Banco Pinto \& Sotto Mayor abre o caminho em novas concepções de arquitectura cortando com todos os conceitos clássicos. Trabalhou o edifício como um todo conseguindo uma unidade e harmonia em todos os elementos, estes co-habitam intrinsecamente de um modo que as soluções forçadamente funcionais se disfarçam em soluções estéticas e vice-versa. Trabalhou a transparência e inovou em vários aspectos como é o caso de muitos outros, a escadaria feita totalmente em vidro (uma novidade para a época) ou o bar de apoio conseguido de forma engenhosa e original aproveitando a conduta do ar.

No campo da realização PG efectuou dezenas de anúncios televisivos, produziu e realizou a curta-metragem "O Alquimista" 
(1986) e o filme de longa metragem "Iratan e Iracema, Os Meninos Mais Malcriados do Mundo" (1988) este ultimo com o reconhecimento público do prémio Palma de Ouro do Festival de Cinema da Figueira da Foz e Troféu de Ouro no festival de Cinema dos Países de Língua Oficial Portuguesa, em Aveiro. Contudo não foram devidamente difundidos, a longa metragem ainda passou em episódios na RTP e foi exibido na Bedeteca mas nunca passou para os cinemas. Mais uma vez PG recusa subjugar-se a interesses comerciais comprometendo o acesso da sua obra ao grande público.

Mas contrário às suas realizações cinematográficas, a sua produção teatral deixa marcas provocando uma revolução na noite de Lisboa.

«O "Cabaretíssimo" faz ruptura na pacata marginalidade alfacinha sedenta, nesses tempos gloriosos, de promiscuidade revolucionária.» ${ }^{177}$

Espetáculo Cabaretíssimo foi um music hall alternativo e arrojado de duas horas e meia, inédito em Portugal. Este êxito foi levado para o Brasil onde faz uma carreira de oito meses em cena.

«É um espetáculo absolutamente novo no Brasil. Mas não vale apenas pela novidade: «Caberetíssimo» é um dos melhores musicais apresentados na Europa nos últimos dois anos e seu criador, Paulo-Guilherme, recebeu os maiores elogios da critica de Portugal e Espanha, que caiu de adjetivos como «magníficos», «fascinante», «fabuloso», «extraordinário» etc... $»^{178}$

É no campo da investigação que Paulo-Guilherme explora o seu fascínio pelo entendimento global, pela descoberta de mistérios, do oculto. Desde o início da sua escrita manteve a preocupação de ser entendido, pretendendo que o que escrevia fosse acessível a

\footnotetext{
177 PLANTIER, Carlos, “Cabaretíssimo: uma grande festa," O Seculo Ilustrado, 1974 , p.48 178 A ALMEIDA, Margarida de. "Beleza e a fúria, de Cabaretíssimo", Jornal O dia, 21 Março 1976 , p.28
} 
qualquer leitor. Prova disso, são os livros editados que desde o género da ficção e poesia, tem uma escrita simples e directa. Contudo escrever sobre matérias que não têm uma fronteira precisa entre a ciência oficial e as especulações esotéricas é já de si um risco a que poucos autores se atrevem. Porém tem que se reconhecer a originalidade das muitas ideias apresentadas, as soluções lógicas absolutamente inéditas e com elas as descobertas, exemplo disso é o caso dos estudos sobre o Mosteiro da Batalha que fizeram notícia em um artigo intitulado "O que esconde a Batalha?" (revista FOCUS $\left.\mathrm{n}^{\circ} 329 / 2006\right)$ revelando resultados práticos das previsões de seu livro (descoberta da existência de uma cripta).

Tornou publico as suas deduções e soluções, não só com a publicação dos seus livros, mas também em duas conferencias proferidas, uma na Gulbenkian onde o anfiteatro para 140 pessoas recebeu cerca de 400 e outra na Missão de Macau onde o interesse e expectativa foram semelhantes. Paulo-Guilherme, experimenta um novo caminho na descodificação dos célebres painéis de Nuno Gonçalves que reúne no livro O segredo o poder e a chave, com uma nova interpretação de um ponto de vista matemático, geométrico aliado à intuição.

«Talvez seja preferível limitarmo-nos a classificá-lo como um mutante de "Homem do Renascimento" que, graças a uma capacidade de trabalho prodigiosa, consegue acumular experiencias e realizações que continuam a incomodar os críticos bem-pensantes e várias corporações de artistas bem-comportados. ${ }^{179}$

Pela sua abordagem, deduções e conjunturas formalistas, PauloGuilherme situa-se ao lado de grandes artistas como Almada Negreiros e Lima de Freitas na vertente de Geómetra que não pode

${ }^{179}$ SILVA, António Sena da, "Modo de usar as Artes", Catálogo de exposição, Paulo-Guilherme D’Eça Leal D'etecetera e tal 2000, Câmara Municipal de Lisboa, 28 de Janeiro de 1993, p. 243 
pela sua originalidade passar despercebido.

«Paulo-Guilherme era talvez o último dos três geómetras portugueses , (...) Almada, Lima de Freitas e PG. $\gg^{180}$

A obra de PG é resultado de meio século de trabalho, numa actividade profissional artística, criativa, interdisciplinar e transversal, que o converte num dos expoentes máximos do eclétismo como forma de acção. Seleccionado, reunido e estudado o seu legado artístico sobressaem principalmente quatro áreas: arquitectura, decoração, artes gráficas (ilustração, cenografia, filatelia, a que juntamos a numismática) e a Literatura. Estas áreas distinguem-se das outras pelo facto destas abordagens inéditas e arrojadas terem tido maior divulgação pública, e em consequência, maior visibilidade pelo que constituíram um legado mais reconhecível e com maior impacto na história artística e cultural portuguesa.

A presente investigação através de uma compilação inédita de toda a obra de Paulo-Guilherme, com a dificuldade acrescida por se encontrar totalmente dispersa, desorganizada e por classificar, tem como pretensão dar um contributo significativo para o esclarecimento, enriquecimento e preservação da memória visual portuguesa.

Entendemos que é objectivo futuro optimizar os resultados deste estudo e difundi-los com a finalidade de os tornar acessível a todo público, algo que poderemos iniciar através do filme documental: Paulo-Guilherme, O alquimista das Ideias, que juntamos ao presente documento como anexo, que realizámos paralelamente à presente investigação.

Esta investigação realizada já permitiu um novo posicionamento de

180 FERNANDES, Nuno Nazareth. Paulo-Guilherme O alquimista das Ideias [film] Portugal. 109 min.PINTO, Rute Bastardo (Prod.) (2012)., em Anexo. 
Paulo-Guilherme na cultura visual portuguesa, através da edição do fascículo inteiramente dedicado a Paulo-Guilherme inserido na Colecção D promovida pela Imprensa Casa da Moeda que versa o Design Gráfico Português, colocando-o a par de outros grandes nomes do Design Gráfico Português como R2, Victor Palla, Pedro Falcão e etc.

Em todos os campos temáticos, PG manifestou a sua competência artística, com amplo desempenho e versatilidade. A sua obra é rica e reúne um conjunto de conteúdos que permitirão no fundo a sua aprendizagem, um conhecimento capaz de proporcionar uma visão mais ampla e compreensiva das manifestações estéticas do passado.

Os prémios que arrecadou, as exposições realizadas, as várias referências que encontramos sobre ele, as entrevistas analisadas nos meios de comunicação, os resultados das conferencias que participou ao longo de vários anos, e os testemunhos recolhidos, dão garantias de sobra do valor e interesse do seu trabalho, da sua condição intelectual e seu talento artístico. Entendemos que com o visto e mostrado, a obra de Paulo-Guilherme é, definitivamente, significativa e relevante no contexto do património artístico e visual português, valorado por quantos a conhecem, aspiramos que seja reconhecida como deve e que tenhamos, com a modesta pretensão, contribuído para tal com a presente investigação. 


\section{Bibliografia / Bibliografia \\ libros Impresos / Livros impressos:}

AA.VV. O Grafismo e ilustração nos anos 20. Catálogo editado pela Fundação Calouste Gulbenkian / Centro de Arte Moderna, Lisboa, 1986

AA.VV. Victor Palla. Fundação Calouste Gulbenkian / Centro de Arte Moderna, Lisboa, 1992

AA.VV. X Exposição Geral de Artes Plásticas 1945-1956, Sociedade Industrial de Tipografia, LDA, Lisboa, 1956

AFONSO, Lígia. Victor Palla in Um Tempo e um Lugar. Dos anos quarenta aos anos sessenta. Dez exposições gerais de artes plásticas, Vila Franca de Xira: Museu do Neo-Realismo / Câmara Municipal de Vila Franca de Xira, 2005

ALBERGARIA, Manuel \& Santaclara (coord.). Aeroporto de Lisboa $50^{\circ}$ aniversário 1942/1992. Edições ANA aeroporto e navegação aérea - EP, 1992

ARNHEIM, Rudolf. El pensamiento visual, Paidós Estética, Barcelona, 1986

BENJAMIN, Walter. Sobre arte, técnica, linguagem e política. Relógio D’Água Editores, Lisboa, 1992

CAMBOTAS, Manuela; MEIRELES Fernanda; PINTO, Ana Lídia Pinto. Arte Portuguesa, Porto Editora, 2010

CAMPOS, Kika da Costa (Org.). Quarenta Homens na cozinha. Edições ASA, Lisboa, 1994

CHAVES, Norberto. El oficio de diseñar. Propuestas a la conciencia crítica de los que comienzan, Gustavo Gili (Col. Hipótesis), Barcelona, 2001

COELHO, Jacinto do Prado. Dicionário de Literatura, Figueirinhas, Porto, 1979 
COSTA, Daciano da ; SOUTO, Maria Helena ; GEORGE Frederico. Ver pelo Desenho, Livros Horizonte, Lisboa, 1993

COSTA, João Benard da. História do Cinema, IN-CM, Lisboa, 1991

COTRIM, João Paulo \& GASPAR, Luis Manuel. El Alma de Almada el impar: obra gráfica, 1926-1931. Catálogo Galeria Palácio Galveias, Campo Pequeno, Bedeteca Lisboa, 2004

COUTINHO, Bárbara \& MARTINS, João Palla. Silva Designers (coord.), Victor Palla, Imprensa Nacional-Casa da Moeda, S.A., Lisboa, 2011

DAUCHER, Hans, Visión artística y visión racionalizada, Gustavo Gili (Col. Comunicación Visual), Barcelona, 1978

DIAS, Fernando Rosa. Ecos Expressionistas na pintura Portuguesa Entre-Guerras (1914-1940), Edição Campo da Comunicação, Lisboa, 2011

ENEL, F., El cartel. Lenguaje, funciones, retórica. Fernando Torres Editores, Valencia, 1974

ESTRELA, Rui. A Publicidade no Estado Novo, Volume I (1932/1959), Colecção Comunicando $\mathrm{n}^{\circ} 1$, Simplesmente Comunicando - Edição de Revistas Lda., 2004

ESTRELA, Rui. A Publicidade no Estado Novo, Volume II (1960/1973), Colecção Comunicando $\mathrm{n}^{\circ} 2$, Simplesmente Comunicando - Edição de Revistas Lda., 2005

AA.VV. Exposição Retrospectiva de 45 anos na Obra de Thomaz de Mello. TOM, impresso nas Oficinas Gráficas da Secretaria de Estado da Informação e Turismo, Lisboa, 1973

FERRO, António. Teatro e Cinema, SNI, Lisboa, 1953

FIALHO, Maria de Lurdes. Tecelagem tapeçaria, Secretaria Geral Núcleo de Coordenação Editorial, 1976

FRANÇA, José-Augusto. A Arte e a Sociedade Portuguesa no Século XX 1910-2000. Edições Livro Horizonte, Lisboa, 2000

FRANÇA, José-Augusto. A Arte em Portugal no século XX 19111961, Livros Horizonte, Lisboa, 2009 
FRANÇ, José-Augusto. Almada o Português sem mestre, Editora Estúdio Cor, Lisboa, 1974

FRANÇA, José-Augusto. História da Arte em Portugal - O Modernismo, Editorial Presença, Lisboa, 2004

FUNDAÇÃO CALOUSTE GULBENKIAN. Almada compilação das comunicações apresentadas no Colóquio sobre Almada Negreiros, Fundação Calouste Gulbenkian ACARTE, Lisboa, 1985

FUNDAÇÃO CALOUSTE GULBENKIAN. Sebastião Rodrigues: designer, Fundação Calouste Gulbenkian, Lisboa, 1995 FUNDAÇÃO CALOUSTE GULBENKIAN. Sena da Silva, Fundação Calouste Gulbenkian, Lisboa, 2009

GALINDO CÁCERES, Jesús (coor.), Técnicas de investigación en sociedad, cultura y comunicación, Editor M.A. Calderón Reyes, Edamsa Impresores, México, 1998

GALINDO, Inocencio \& MARTIN, José Vte., Imagen $y$ conocimiento, Editorial UPV, Valencia, 2008

GEORGEL, Jacques. O Salazarismo, Publicações D.Quixote, Lisboa, 1985

GERMANI-FABRIS, Fundamentos del proyecto gráfico, Ed. Don Bosco, Barcelona, 1973

HAUSER, Arnold. Teorias da Arte, Editorial Presença. Lda, Lisboa, 1988

JOLY, Martine. A imagem e a sua interpretação, Edições 70, Lda., Lisboa, 2002

KANIZSA, Gaetano. Gramática de la visión, Paidós Comunicación, Barcelona, 1986

KULLBERG, Carlos. Selos de Portugal- Vol. III (1954/1970), Clube Nacional de Filatelia, 2003

LAPA, Pedro. et al. Arte Portuguesa do Século XX, MNAC-Museu do Chiado Leya, Lisboa, 2011

LEAL, Olavo D’Eça. História de Portugal para Meninos Preguiçosos, Livraria Tavares Martins, Lisboa, 1943

LEAL, Paulo-Guilherme D’Eça. Ainda é cedo para ser tarde, Bertrand Editora, Lisboa, 1997 
LEAL, Paulo-Guilherme D'Eça. As sete portas de Arsenise, Bertrand Editora, Lisboa, 1995

LEAL, Paulo-Guilherme D'Eça. Depressa que o verso foge, Hugin Editora, Lisboa, 1999

LEAL, Paulo-Guilherme D'Eça. O dilúvio de Quéops, Novas comunicações sobre a esquecida ciência egípcia, Livros Horizonte, Lisboa, 1993

LEAL, Paulo-Guilherme D'Eça. O segredo, o poder e a chave, Hugin Editora, Lda., Lisboa, 2003

AA.VV. Paulo-Guilherme d'Eça Leal d'Etcetera e Tal 2000, Arte ibérica, Lisboa, 2000

LLOVET, Jordi. Ideología y metodología del diseño, Ed. Gustavo Gili, Barcelona, 1979

LOBO, Theresa. Cartazes Publicitários, Colecção da Empreza do Bulhão, Inapa, Lisboa, 2001.

MARTINS, João Paulo (Org.). Daciano Dacosta Designer, Fundação Calouste Gulbenkian, Lisboa, 2001

MELLO, Thomaz. Catálogo da Exposição Falando do Ofício, Sociedade Tipográfica, 1986

MIRANDA, José A. Bragança de. Teoria da Cultura, Edições Século XXI, Lda., Lisboa, 2002

MOREIRA, José Guardado, Aeroporto de Lisboa 1942-1992 Ana aeroportos e navegação aérea, Edições INAPA, Lisboa, 1992

MOURA, Mário. Design em tempos de crise, Braço de Ferro Centro Português de Design, 1992

MUNARI, Bruno. Diseño y comunicación visual, Ed. Gustavo Gili, Barcelona, 1974

NOGUEIRA, Isabel. Teoria da Arte no Século XX, Edição Imprensa da Universidade de Coimbra, 2012

Ó, Jorge Ramos do. Os anos do Ferro, Editorial Estampa, Lisboa, 1999 
ORTIGÃO, Ramalho. O Culto da Arte em Portugal, Esfera do Caos Editora Lda, 2006

PEREIRA, Paulo. Arte Portuguesa História Essencial, Círculo de Leitores e Temas e Debates, Lisboa, 2011

PINA, Luis de. História do cinema português, Publicações EuropaAmérica, Mem Martins, 1986

QUINTERO, Alejandro Pizarroso. História da Propaganda, Planeta Editora, 1993

RODRIGUES, António (coord.). História de Portugal em datas, Temas e Debates - Actividades Editoriais , Lda., Lisboa, 2007

ROSAS, Fernando ; BRANDÃO, J.M. Dicionário de História do Estado Novo, Círculo de Leitores, Lisboa, 1996

SANTOS, David. Ilustração \& Literatura Neo-Realista, Museu do Neo-Realismo, V.F. XIRA, 2008

SARAIVA, José Hermano. História concisa de Portugal, Colecção Saber - Publicações Europa-América, 2011

SILVA, Manuela ; TAMEN, M.Isabel (coord.). Sistema de Ensino em Portugal, Fundação Calouste Gulbenkian, Lisboa, 1981

SOUSA, Jorge Pais de. O fascismo catedrático de Salazar, das origens na I Guerra Mundial à intervenção militar na Guerra Civil de Espanha 1914-1939, Imprensa da Universidade de Coimbra, 2011

SOUTO, Maria Helena, História do Design em Portugal I Reflexões, Edições IADE, Lisboa, 2009

SOUTO, Maria Helena, Portugal nas Exposições Universais. 18511900, Ed. Colibri/IHA-FCSHUNL, 2010

SPROCCATI, Sandro (coord.), et al. Guia de História da Arte, Editorial Presença, Lisboa, 1999

TORGAL, Luís (coord.). O cinema sob o olhar de Salazar, Temas e Debates, Lisboa, 2001

TRINDADE, Luís. Primeiras páginas O Século XX nos jornais portugueses, Tinta da China Edições, 2006

VIEIRA, Joaquim, Portugal Século XX - Crónica em Imagens 1950- 
60, Bertrand Editora Lda, Lisboa, 2006

VILCHIS, Luz del Carmen. Diseño: universo de conocimiento (investigación de proyectos en la comunicación gráfica), Centro Juan Acha, México, 2002

VILCHIS, Luz del Carmen. Metodología del diseño, Editorial Claves Latinoamericanas, México, 1997

VILCHIS, Luz del Carmen. Relaciones dialógicas en el diseño gráfico, Escuela Nacional de Artes Plásticas, México. 2006

WALKER, John A. \& CHAPLIN, Sara, Una introducción a la cultura visual, Octaedro EUB, 2002

WONG, Wucius, Fundamentos del diseño bi- y tri-dimensional, Gustavo Gili, Barcelona, 1981

Artículos en Periódicos / Revistas / Artigos em

Jornais/Revistas:

AZEVEDO, Agostinho. "Estão na forja 13 filmes portugueses". Correio da Manhã, Junho 1983

AZEVEDO, Agostinho. "Monumento aos pioneiros da aviação". Correio da Manhã, Outubro, 1980

CEGONHO, Pedro. "Um bairro à imagem de Montmartre". Santo condestável, Julho a Dezembro, 2008

ESTEVES, António. "Inauguração da Portugália no Cais do Sodré". VIP, $\mathrm{n}^{\circ} 49,1988$

FALCÃO, Maria Armanda. "Cabaretíssimo: Nervossismo em Cascais”. Diário Popular, Junho, 1974

GARCIA, Rita. “O Caçador de Templários”. Focus, Fevereiro, $\mathrm{N}^{\circ} 278,2005$ 
GASTÃO, Ana Marques. “Aplauso ou um café da manhã”. Diário de Notícias, 1999

GANHÃO, Mafalda. “As novas casas da Portugália”. Expresso $n^{\circ} 1274,1997$

GONÇALVES, Santos. "Centenário de Eça de Queirós assinalado com moeda”. Correio da Manhã, Maio, 2000

GRAÇA, José Gabriel Charrua. "Paulo-Guilherme A extraordinária re-construção da Pirâmide de Quéops”. Olá!/Semanário, 1993

JUNG, Carlos. "D’Eça N'Acaica diz Carlos Jung”. Acaica News, nº7, 1978

LEAL, Paulo-Guilherme D’Eça. “O Dilúvio de Quéops”. Colóquio das Artes, $\mathrm{n}^{\circ}$ 62, 1984

LEAL, Paulo-Guilherme D’Eça. “Um decorador não se faz às pressas”. Casa \& Decoração, n ANO V, 1980

LORENÇO, Basílio. “Mosteiro da Batalha Paulo-Guilherme”, Focus, $\mathrm{n}^{\circ} 329,2006$

LOURENÇO, Basílio. “Paulo-Guilherme D’Eça Leal”. Nova Gente, $\mathrm{n}^{\circ} 404,2003$

MACHADO, José Sousa. “Paulo-Guilherme D’Eça Leal D’Etecetera e Tal”. Arte Ibérica, $\mathrm{n}^{\circ}$ 33, 2000

MARINHO, Roberto. "Lançamento do Livro «Interiores»". Casa $\mathcal{E}$ Jardim, $\mathrm{n}^{\circ} 212,1995$

MARQUES, Pedro Piedade. “Modernidade Alegre”. Revista Ler, $\mathrm{n}^{\circ} 112,2012$

MATOS-CRUZ, José de. "Sessenta Cartazes Cinema Português". Revista de Cinema, Estrófico Publicações Lda. , Abril, 1989

MELO, Cláudia. “Tudo é Geometria”. Notícias Sábado’211, Janeiro, 2010

MESQUITA, Mário. “Amadora ergue monumento aos pioneiros da aviação". Diário de Notícias, Outubro, 1980 
MESTRE, João. "Portugal ilustrado". Magazine,

Novembro/Dezembro, 2011

MONTEIRO, Carlos. "História de Olavo em Cinema". O Jornal, Fevereiro 1983

NOBREGA, José Manuel da. "Longa (e chata!) como o peixeespada”. Se7e, Junho, 1983

PASSO, Horácio de. "Empreendimento turístico bloqueado pela rodoviária”. Correio da Manhã, 30 Agosto, 1983

PEIXOTO, M. Lemos. “O tema é: Os pioneiros da aviação”. Notícias da Amadora, SARL, 1980

PINHEIRO, Paula Moura. “Paulo Guilherme D’Eça Leal”. Elle, $\mathrm{n}^{\circ} 138,2000$

PINTO, Ferreira. "Vivó Luxo!”. Tal \& Qual, Outubro, 1989

PLANTIER, Carlos. "Cabaretíssimo: uma grande festa”. O Século Ilustrado, n 485, 1974

REICHENBACH, Carlos Oscar. "Um andar na quinta das freiras". Casa \& Jardim, $\mathrm{n}^{\circ} 55,1982$

REIS, Mário. “O segredo de Quéops”. Fim de semana, Outubro, 1980

RODRIGUES, Miguel Urbano. "Edificação do monumento aos pioneiros da aviação foi ontem simbolicamente iniciada". O Diário, $\mathrm{n}^{\circ} 1479,1980$

SABBA, Jecthel. "Cabaretíssimo". Gazeta de Notícias, Março, 1976

SANTOS, Rui Afonso. “Paulo Guilherme D’Eça Leal D’Etecetera e Tal”. Arte Ibérica, ${ }^{\circ} 34,2000$

SARAIVA, Carlos. "Paulo Guilherme D’Eça Leal 7 Artes \& Oficios7”. Espaços, 2000

SECRETARIADO PROPAGANDA NACIONAL. "Prémios anuais do SPN". O figueirense, Julho, 1944

SECRETARIADO PROPAGANDA NACIONAL. "Prémios literários e artísticos do SPN”. Diário de Notícias, Julho, 1943 
SILVA, Sena. "Paulo Guilherme D’Eça Leal”. Cadernos de Design, $\mathrm{n}^{\circ}$ Ano 2, 1993

SIMÕES, Humberto. “Snob”. Focus, n²01, 2003

SOARES, F. Ribeiro. “Paulo-Guilherme D'Eça Leal Algures entre a ficção e a realidade”. Mais, Maio, 1985

SOUTO, Maria Helena. "O design moderno em Portugal". Cadernos de Design, Junho de 1992

VALDEMAR, António. "Lisboa e Paris em Memórias de PauloGuilherme”. Diário de Notícias, Dezembro, 1997

VALDEMAR, António. "Paulo-Guilherme retratado em versos dele próprio”. Diário de Notícias, Dezembro, 1999

VELLOSO, Fernando. “D’Eça”. Acaica News, nº7, 1978

VILARINHO, Frederico. "Quem é Paulo-Guilherme?”. Focus, $\mathrm{n}^{\circ} 329,2006$

ZANATTI, Ana. "Que as Pedras Levitem. Os meus Livros”, Julho, 2005

\section{Tesis / Teses:}

DANIEL, André Filipe Martins. Design de identidades corporativas do designer Carlos Rocha, Faculdade de Arquitectura da Universidade Técnica de Lisboa, Lisboa, 2011

FRAGOSO, Ana Margarida. Formas e expressões da comunicação visual em Portugal, contributo para o estudo da cultura visual do sec. XX, através das publicações periódicas, Faculdade de Arquitectura - Universidade Técnica de Lisboa, 2010

HENRIQUES, Ana Rita. Fred Kradolfer : Designer Gráfico influenciador e influenciado em Portugal, Faculdade de Arquitectura - Universidade Técnica de Lisboa, 2011

PALLA, João. ; MARTINS, Carmo Reinas. Victor Palla (1922-2006) Um levantamento crítico, IADE Instituto de Artes Visuais, Design e Marketing - Escola Superior de Design, 2006 
REDOL, Ana Catarina de Oliveira. A influência do abstraccionismo geométrico no Design Gráfico nos anos 60. Para uma abordagem em Portugal, Escola Superior de Design do IADE, 2008

RIBEIRO, Carla Patrícia Silva. O "Alquimista de Sínteses”: António Ferro e o Cinema Português, Universidade do Porto - Faculdade de Letras, 2010

SARMENTO DE MATOS, Ana Sofia Ramires Ferro da Costa Pessoa. Zeitgeist - O Espírito do Tempo António Garcia - Design e Arquitectura nas décadas de 50-70 do século XX. Depois da obra, o futuro, Universidade de Lisboa - Faculdade de Belas Artes, 2006

\section{Los artículos electrónicos / Artigos electrónicos:}

BÁRTOLO, José; O Estado do Design: Reflexões sobre teoria do design em Portugal, [disponível em: http://artecapital.net/ opinioes.php?ref=30] [consultado em 15/08/09, 14:10:00]

Exposição do Mundo Português. In Infopédia [Em linha]. Porto: Porto Editora, 2003-2012. [disponível em: www: <URL: http://www.infopedia.pt/\$exposicao-do-mundoportugues>].[Consult. 2012/06/19, 17:15:00]

LAPA, Pedro; Arte Moderna em Portugal: de Amadeo a Paula Rego, [disponível em: http: / www.museudochiadoipmuseus.pt/pt/node/686? page=2] [consultado em 16/03/11, 10:40:00]

MARQUILHAS, Maria Beatriz; O Declínio da Arte: Morte e Transfiguração (II), [disponível em:

http://www.artecapital.net/opinioes.php? $\mathrm{ref}=115$ ] [consultado em 20/06/12, 18:18:00]

PAGO, Ana, Bifes e tertúlias com 40 anos de vida, Diário de Notícias, 21 Novembro 2004, [disponível em: http://www.dn.pt/inicio/interior.aspx?content_id=590021] [consultado em 20/10/10, 10:30:00] 


\section{Sitios Web / Websites:}

http://almanaquesilva.wordpress.com/

http://coloquio.gulbenkian.pt/

http://cvc.instituto-camoes.pt/index.php

http://pedromarquesdg.wordpress.com/

http://reactor-reactor.blogspot.pt/

http://ressabiator.wordpress.com/

http://tipografos.net/livro-meios.html

http://www.bnportugal.pt/

http://www.cpd.pt/

\section{Audiovisuales / Audiovisuais:}

ALEXANDRE, Paulo. (Prod.) (2002). Artes e Letras [video VHS]. RTP2

CRUZ, Carlos. (Prod.) (25/12/1991). Carlos Cruz Quarta-feira [video VHS]. RTP

D'EÇA LEAL, Paulo-Guilherme (1990). Ciclo de palestras [video VHS]

D’EÇA LEAL, Paulo-Guilherme (1991). Ciclo de palestras Fundação Caloust Gulbenkian [video VHS]

D’EÇA LEAL, Paulo-Guilherme (Director) (1986). O Alquimista [film] Portugal. 13.58 min.

D’EÇA LEAL, Paulo-Guilherme (Director) (1987). Iratan e Iracema, os meninos mais mal criados do mundo [film] Portugal. 109 min.

LETRIA, Joaquim. (Prod.) (1993). Joaquim Letria [video VHS]. RTP2

MOUTINHO, Vera (Editor) (2011). Vem aí a História da Ilustração Portuguesa [film] Portugal. 4 min., [disponível em: http://videos.sapo.pt/UrgjzvUpbPt8EZBBZCBd] [consultado em 20/06/12, 21:30:00] 
QUEIRÓZ, Álvaro. (Prod.) (1995). Paulo-Guilherme [video VHS]. Acervo pessoal de Álvaro Queiróz

RANGEL, Emídio. (Prod.) (1998). Conversas Secretas [video VHS]. SIC

SOBREIRO, Daniel (Director) (2011). Documentário - Sebastião

Rodrigues [film] Portugal. 38 min., [disponível em:

http://vimeo.com/17399044 ] [consultado em 15/06/12, 19:30:00]

\section{Listas de figuras / Índice de Figuras}

Figura 1. Fotografia de Paulo-Guilherme, $1991 \ldots 58$

Figura 2. Fotografia de Paulo-Guilherme, 1995________________________ 60

Figure 3. Retrato de Paulo-Guilherme por Eduardo Malta, 1932_____ 62

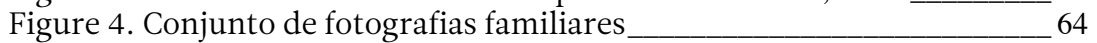

Figura 5. Fotografia de Paulo-Guilherme, 1991__________________________ 66

Figura 6. Fotografia de Paulo-Guilherme e Olavo, 1974 ____________ 68

Figura 7. Desenhos de Paulo-Guilherme, 1948 ______________ 70

Figura 8. Fotografia de Paulo-Guilherme no atelier em Brasil, 1975____ 76

Figura 9. Conjunto de imagens da vida social de Paulo-Guilherme______ 80

Figura 10. Cartaz de Alamda Negreiros para o SPN, 1934__________ 90

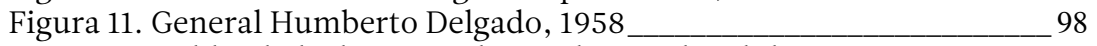

Figura 12. Publicidade da marca de Combustível Móbil,1957____ 100

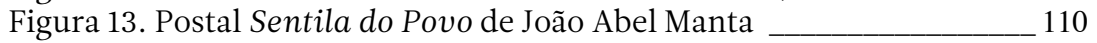

Figura 14. Capa de livro, ilustrado por Fred Kradolfer, 1943____________________ 118

Figura 15. Fotografia I ${ }^{\circ}$ Salão dos Humoristas ___ 120

Figura 16. Pintura óleo sobre tela de Amadeu Sousa Cardozo, 1917_____ 124

Figura 17. Dois trípticos de Almada Negreiros,1948_________________ 128

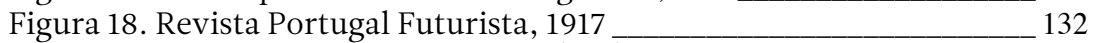

Figura 19. Cartaz de Paulo-Guilherme (SNI), $1963 \ldots 134$

Figura 20. Conjunto de fotografias de Olavo D’Eça Leal______________ 138

Figura 21. Conjunto de capas do livros de Olavo D'Eça Leal ___________ 142

Figura 22. Fotografia de Olavo na Emissora Nacional,anos 40. _____ 144

Figura 23. Cartaz publicitário, Fred Kradolfer, 1933_______________________________

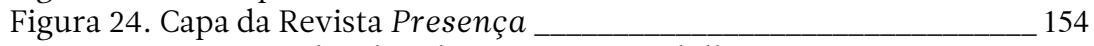

Figura 25. Pintura a óleo de Júlio Pomar, O Gadalheiro, 1945

Figura 26. Livro de fotografia, Lisboa Cidade Triste e alegre , 1959____ 158

Figura 27. Desenho de António Pedro, O grupo Surrealista de Lisboa __ 162

Figura 28. Fotografia da Exposição Surrealista de $1940 \ldots$

Figura 29. Fotografia lado oeste do Pavilhão dos Portugueses no Mundo 166 
Figura 30. Pintura de Fernando Lanhas, óleo sobre cartão prensado, 1944

Figura 31. Fotografia Fundação Calouste Gulbenkian, anos 60____ 172

Figura 32. Fotografia da biblioteca itenerante (BNI) ______ 174

Figura 33. Capa de Sebastião Rodrigues, Revista Almanaque, 1959 __ 178

Figura 34. Pintura óleo sobre tela, Uma Rosa É, de João Vieira, 1968 __ 182

Figura 35. Capa de livro 30 Anos Prémios AICA/MC, INCM __ 184

Figura 36. Escultura de João Cutileiro, D.Sebastião, $1973 \ldots 186$

Figura 37. Cartaz de Manuel Vieira, Catarina Eufémia____________ 188

Figura 38. Pintura a óleo sobre tela de António Palolo, $1983 \ldots 194$

Figura 39. Nota 100 Escudos do Banco de Portugal, por Luís Filipe de Abreu

Figura 40. Conjunto de estudos de ilustrações

Figura 41. Conjunto de estudos, ilustrações do livro Mil e uma Noites _ 215

Figura 42. Ilustração, Revista Moreninha, Brasil, 1975 _________ 216

Figura 43. Recortes de jornal, publicidade Chá Nattermann____ 218

Figura 44. Conjunto de capas de livros _____________________ 220

Figura 45. Conjunto de imagens do livro Os sete minutos, Irving Wallace

Figura 46. Cartaz Self Service 222

Figura 47. Capas de discos de música de 33 rotações 224

Figura 48. Fotografia de Paulo-Guilherme com cartaz Jazz de Cascais, 1973

Figura 49. Conjunto de selos Emissão Europa __________ 228

Figura 50. Selos Cinquentenário da Força Aérea 230

Figura 51. Selos Revolução Nacional ____________ 232

Figura 52. Selos I Congresso Nacional de Transito_____ 234

Figura 53. Desenho técnica mista, $1948 \_236$

Figura 54. Conjunto de pinturas_____________________________________ 238

Figura 55. Conjunto de quadros, pintura a óleo ___ 240

Figura 56. Conjunto de quadros, pintura a óleo __________ 242

Figura 57. Conjunto de quadros, pintura a óleo _ 244

Figura 58. Conjunto de quadros, pintura a óleo ____________________ 246

Figura 59. Conjunto de fotografias de esculturas __________ 248

Figura 60. Conjunto de fotografias de tapeçarias ___ 250

Figura 61. Centro comercial Apolo 70__________________ 254

Figura 62. Conjunto de imagens do Borsalino _____________ 256

Figura 63. Conjunto de imagens do bar Snob ___ 258

Figura 64. Conjunto de fotografias da cervejaria Portugália-Rio ___ 260

Figura 65. Conjunto de fotografias do Snobíssimo______________ 262

Figura 66. Conjunto de imagens do Vilamoura Hotal Sheraton____ 264

Figura 67. Maquetas do interior do Vilamoura Hotal Sheraton ____ 265

Figura 68. Conjunto de fotografias da loja Vanitas ___ 266

Figura 69. Conjunto de fotografias do Restaurante Bachus _____ 268

Figura 70. Conjunto de fotografias do Restaurante Bachus ___ 269

Figura 71. Estudos do projecto Restaurante Bachus__________ 270

Figura 72. Conjunto de fotografias da Missão de Macau_____ 272

Figura 73. Conjunto de fotografias da Missão de Macau _____ 274 
Figura 74. Conjunto de fotografias da Missão de Macau__________ 276

Figura 75. Maqueta do Palm Beach______ 280

Figura 76. Maqueta do Monumento aos Pioneiros da Aviação _____ 282

Figura 77. Conjunto de fotografias do Banco Pinto \& Sotto Mayor ____ 286

Figura 78. Conjunto de fotografias do Banco Pinto \& Sotto Mayor_____ 288

Figura 79. Conjunto de fotografias do Banco Pinto \& Sotto Mayor____ 290

Figura 80. Conjunto de fotografias do Banco Pinto \& Sotto Mayor______ 292

Figura 81. Conjunto de fotografias do Banco Pinto \& Sotto Mayor _____ 294

Figura 82. Fotografia hall do Banco Pinto \& Sotto Mayor ___________ 296

Figura 83. Conjunto de fotografias do Aeroporto de Lisboa________________ 298

Figura 84. Conjunto de fotografias do Aeroporto de Lisboa ___ 300

Figura 85. Conjunto de fotografias do Aeroporto de Lisboa _____ 302

Figura 86. Conjunto de fotografias do Aeroporto de Lisboa __________ 303

Figura 87. Conjunto de fotografias das Salas VIP _____________ 304

Figura 88. Conjunto de fotografias da maqueta das Chegadas________ 306

Figura 89. Desenhos do cenário, Perdeu-se um Marido__________ 308

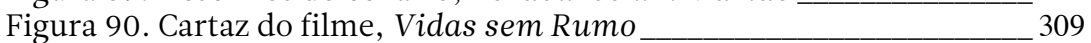

Figura 91. Cartaz do filme, Perdeu-se um marido _______ 310

Figura 92. Conjunto de fotografias do Cabaretíssimo ____ 312

Figura 93. Conjunto de imagens do Cabaretíssimo _______________ 313

Figura 94. Conjunto de imagens do Cabaretíssimo __________ 314

Figura 95. Conjunto de fotografias da exposição em Galveias________ 318

Figura 96. Conjunto de fotografias da exposição em Galveias________ 319

Figura 97. Conjunto de fotografias da exposição em Galveias____ 320

Figura 98. Conjunto de fotografias da exposição em Galveias______________ 322

Figura 99. Conjunto de fotografias da exposição em Galveias______ 323

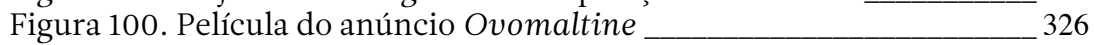

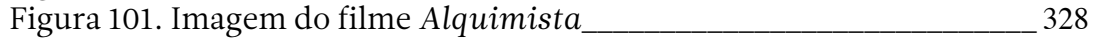

Figura 102. Conjunto de imagens do Alquimista_________________________________ 329

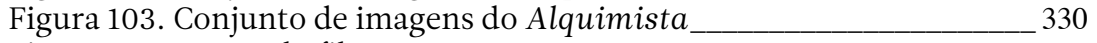

Figura 104. Cartaz do filme, Iratan-Iracema_________________ 332

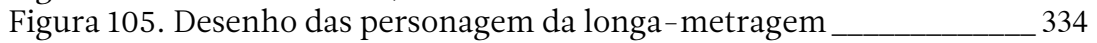

Figura 106. Conjunto de fotografias do making-of_________________ 335

Figura 107. Conjunto de imagens do filme de longa-metragem____ 336

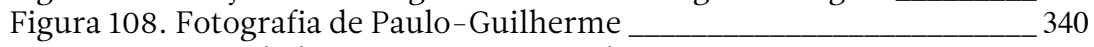

Figura 109. Capa do livro, As sete portas de Arsenise______ 342

Figura 110. Capa do livro, Ainda é cedo para ser tarde________________ 344

Figura 111. Capa do livro, Depressa que o verso foge..._______________ 346

Figura 112. Desenhos do livro, O dilúvio de Quéops____________________ 348

Figura 113. Capa do livro, O dilúvio de Quéops___________________ 350

Figura 114. Cálculos do estudo da pirâmide ____ 352

Figura 115. Conjunto de fotografias da maqueta da piramide __________ 354

Figura 116. Capa do livro, O segredo, o poder e a chave __________ 358

Figura 117. Página do Século Ilustrado, $\mathrm{n}^{\circ} 1626,1969$

Figura 118. Página do Século Ilustrado, $\mathrm{n}^{\circ} 1626,1969$

Figura 119. Página do Século Ilustrado, ${ }^{\circ} 1617,1968$

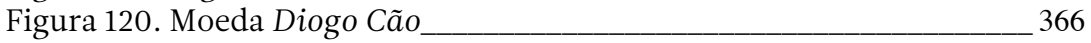

Figura 121. Moeda Navegação Astronómica_______________________________ 368 
Figura 122. Moeda A Descoberta da América - Navegações para Ocidente

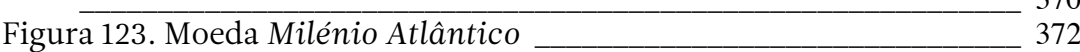

Figura 124. Conjunto de medalhas comemorativas_______________ 375

Figura 125. Conjunto de matrizes de moedas em gesso________ 376

Figura 126. Conjunto de fotografias de Paulo-Guilherme_______ 378

Figura 127. Conjunto de fotografias de Paulo-Guilherme____ 379

Figura 128. Conjunto de fotografias de Paulo-Guilherme_______ 380

\title{
V. Siglas y abreviaturas / Acrónimos e abreviaturas
}

\author{
$\mathrm{AF}$ _ António Ferro
}

AICA_ Association Internationale des Critiques d'Art

ANA_ Aeroportos e Navegação Aérea

CDS_ Centro Democrático e Social

CPC_ Centro Português de Cinema

CUF _ Companhia União Fabril

D.G.S_ Direcção Geral de Segurança (1969 por Marcelo Caetano)

ETP_ Estúdio Teórico de Publicidade

F.A_ Forças Armadas

FAO_ Organização para a Alimentação e Agricultura das Nações Unidas

FP-25_ Forças populares 25 de Abril

FUP_ Força de Unidade Popular (partido Fundado por Otelo)

GNR_ Guarda Nacional Republicana

IPC_ Instituto Português do Cinema

LP_ Legião Portuguesa

MDPCDE_ O Movimento Democrático Português - Comissão

Democrática Eleitoral

MFA_ Movimento Forças Armadas

MP_ Mocidade Portuguesa

MPLA_ Movimento Popular de Libertação de Angola 
MUD_ Movimento União Democrática

PAIGC_ Partido Africano para a Independência da Guiné e Cabo

Verde

PCP_ Partido Comunista Português

PG_Paulo-Guilherme

PIDE_ Polícia Internacional e de Defesa do Estado (45/69)

PS_ Partido Socialista

PSD_ Partido Social Democrata

PVDE_ Policia de Vigilância e Defesa de Estado

RTP_ Rádio Televisão Portuguesa

SBI_ Serviço Biblioteca Itinerante

SNBA_ Sociedade Nacional de Belas Artes

SNI_ Secretariado Nacional de Informação

SPN_ Secretariado Propaganda Nacional

UPA_ União Povo Africano 